Министерство образования и науки Российской Федерации

Федеральная служба

государственной статистики

(I) В НЫСШАЯ ШКО АА ЭКОНОМИКИ
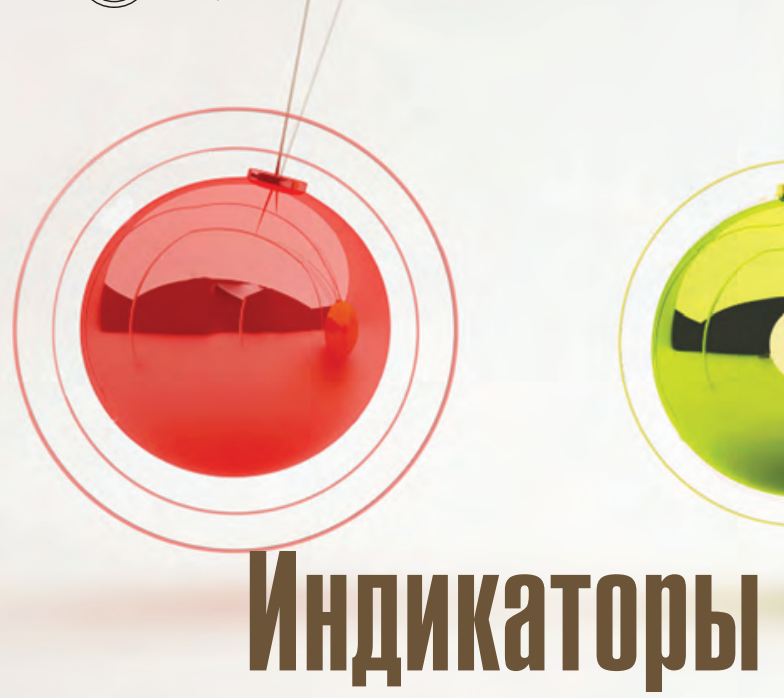

0бр

бразования: 2017

Статистический сборник

$\overbrace{\text { Лет }}^{\substack{\text { институт статистических } \\ \text { исследований и экономики } \\ \text { знаний Ниу вшэ }}}$ 
Министерство образования и науки

Российской Федерации

Федеральная служба

государственной статистики

(P) ВЫСШАЯ ШКОАА ЭКОНОМИКИ

НАЦИОНАЛЬНЫЙ ИССЛЕДОВАТЕЛЬСКИЙ УНИВЕРСИТЕТ

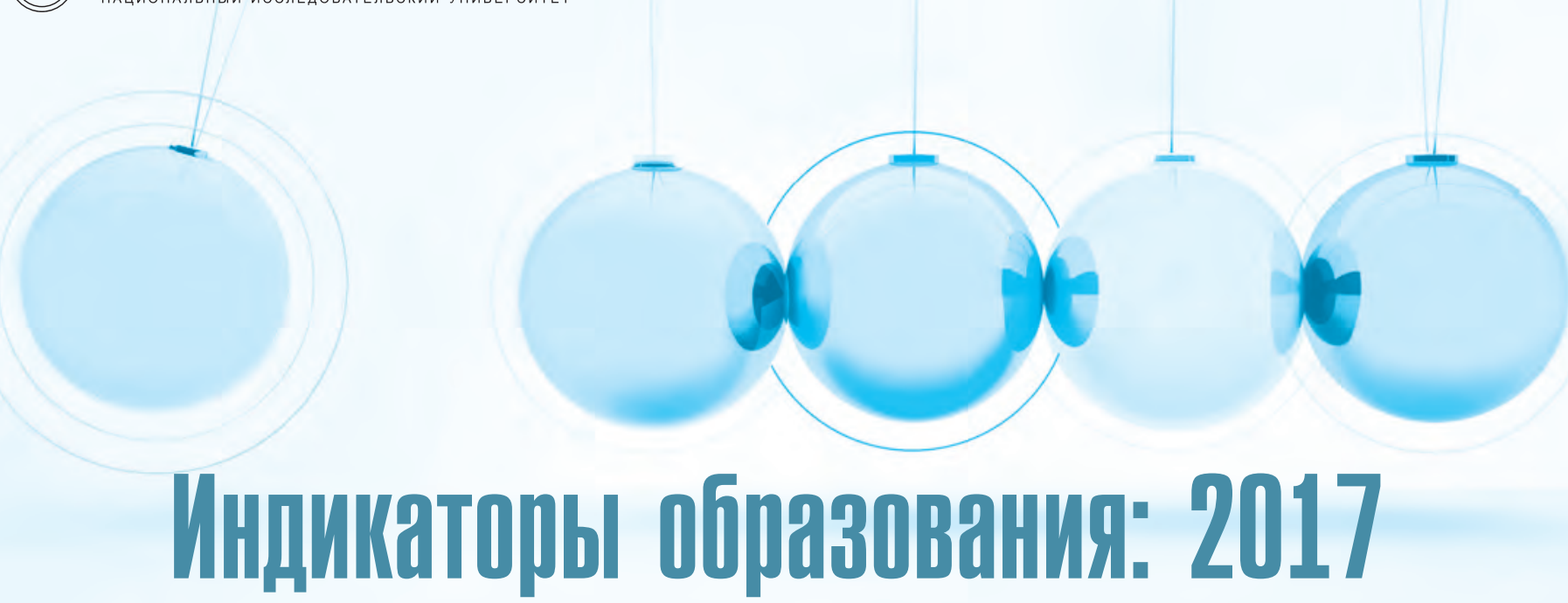

\section{Статистический сборник}

Москва 2017 
удК $37(470+571)(083.41)$

ББК $74(2 \mathrm{PoC})$ я2

И60

Редакционная коллегия: Л. М. Гохберг, Н. В. Ковалева, Я. И. Кузьминов

Авторы: Н. В. Бондаренко, Л. М. Гохберг, И. Ю. Забатурина, Н. В. Ковалева, В. И. Кузнецова, О.К. Озерова, М. А. Пинская, О.А. Подольский, А.А. Пономарева, Е.Д. Рылько, Н.Б. Шугаль

В подготовке материалов принимали участие специалисты Росстата: 3. Ж. Зайнуллина, Н. В. Коновка, В. И. Кузнецов, М.А. Рязанова, М. А. Сабельникова, Т. Н. Савостьянова, Е. Б. Фролова, В. Ж. Чумарина

Индикаторы образования: 2017 : статистический сборник / Н. В. Бондаренко, Л. М. Гохберг, И. Ю. Забатурина и др.; Нац. исслед. ун-т И60 «Высшая школа экономики». - М.: НИУ ВШЭ, 2017. - 320 с. - 300 экз. - ISBN 978-5-7598-1580-8 (в обл.).

В настоящем сборнике, подготовленном Институтом статистических исследований и экономики знаний Национального исследовательского университета «Высшая школа экономики», представлены данные, отражающие уровень и динамику основных индикаторов образования в Российской Федерации. Сборник содержит сведения об организациях, осуществляющих образовательную деятельность. Отдельные разделы посвящены оценке образовательных достижений обучающихся, связи образования с рынком труда, финансирования образования, состава обучающихся, персонала, условий обучения; представлены международные сопоставления.

В публикации использованы данные Федеральной службы государственной статистики, Министерства образования и науки Российской Федерации, Федерального казначейства, Организации экономического сотрудничества и развития, а также собственные методологические и аналитические разработки Института статистических исследований и экономики знаний НИУ ВШЭ.

Публикация подготовлена по итогам работы в рамках Программы фундаментальных исследований Национального исследовательского университета «Высшая школа экономики» (НИу ВШЭ) и с использованием средств субсидии в рамках государственной поддержки ведущих университетов Российской федерации «5-100».

Editorial Board: Leonid Gokhberg, Natalia Kovaleva, and Yaroslav Kuzminov

Authors: Natalia Bondarenko, Leonid Gokhberg, Irina Zabaturina, Natalia Kovaleva, Vera Kuznetsova, Olga Ozerova, Marina Pinskaya,

Oleg Podolskiy, Alena Ponomareva, Ekaterina Rylko, and Nikolay Schugal

With contributions by Rosstat experts: Zifa Zaynullina, Nadezhda Konovka, Vasily Kuznetsov, Marina Ryazanova, Marina Sabelnikova,

Tatyana Savostyanova, Elena Frolova, and Venera Chumarina

Indicators of Education in the Russian Federation: 2017 : Data Book / N. Bondarenko, L. Gokhberg, I. Zabaturina, et al.; National Research University Higher School of Economics. - Moscow: HSE, 2017.

The publication was prepared within the framework of the Basic Research Programme at the National Research University Higher School of Economics (HSE) and supported within the framework of a subsidy by the Russian Academic Excellence Project '5-100'.

ISBN 978-5-7598-1580-8 (c) Национальный исследовательский университет «Высшая школа экономики», 2017 При перепечатке ссылка обязательна 


\section{СОДЕРЖАНИЕ}

Система образования в Российской Федерации

1. Образовательный потенциал населения

1.1. Уровень образования населения в возрасте 15 лет и старше: 2015.

1.2. Уровень образования населения в возрасте 25-64 лет по возрастным группам: 2015

1.3. Средняя ожидаемая продолжительность обучения в течение предстоящей жизни для детей в возрасте 6 лет

1.4. Коэффициенты выпуска специалистов (квалифицированных рабочих, служащих) с профессиональным образованием

1.5. Оценка грамотности 15-летних российских обучающихся.

1.6. Распределение 15-летних обучающихся России и стран ОЭСР по уровням естественнонаучной грамотности

1.7. Удельный вес 15-летних обучающихся, показавших низкий и высокий уровни естественнонаучной грамотности, в их общей численности по странам: 2006 vs 2015

1.8. Распределение 15-летних обучающихся России и стран ОЭСР по уровням читательской грамотности

1.9. Удельный вес 15-летних обучающихся, показавших низкий и высокий уровни читательской грамотности, в их общей численности по странам: 2009 vs 2015
1.10. Распределение 15 -летних обучающихся России и стран 0ЭСР по уровням математической грамотности .

1.11. Удельный вес 15-летних обучающихся, показавших низкий и высокий уровни математической грамотности, в их общей численности по странам: 2012 vs 2015 .

1.12. Грамотность населения в возрасте $16-65$ лет в области чтения по уровню образования и странам

1.13. Математическая грамотность населения в возрасте 16-65 лет по уровню образования и странам .

1.14. Грамотность населения в возрасте 16-65 лет в области чтения по занятости и странам.

1.15. Грамотность населения в возрасте 16-29 лет со средним профессиональным и высшим образованием в области чтения по странам

1.16. Участие населения в непрерывном образовании

1.17. Участие населения России и европейских стран в непрерывном образовании по видам

Методологические комментарии . .46

2. Образование и рынок труда

2.1. Уровень занятости и безработицы в зависимости от уровня образования населения: 2015

2.2. Занятые по уровню образования

2.3. Уровень занятости населения по уровню образования и возрастным группам: 2015

2.4. Безработные по уровню образования 
2.5. Уровень безработицы по уровню образования и возрастным группам: 2015

2.6. Средняя продолжительность безработицы по уровню образования

2.7. Длительная безработица по уровню образования и полу: 2015

2.8. Уровень участия в рабочей силе населения, имеющего высшее образование, по специальностям и направлениям подготовки по диплому: 2015

2.9. Уровень участия в рабочей силе населения, имеющего среднее профессиональное образование по программам подготовки специалистов среднего звена, по специальностям по диплому: 2015

2.10. Уровень участия в рабочей силе населения, имеющего среднее профессиональное образование по программам подготовки квалифицированных рабочих, служащих, по профессиям по диплому: 2015.

2.11. Уровень участия в рабочей силе выпускников, окончивших профессиональные образовательные организации и образовательные организации высшего образования в 2012-2014 гг.: 2015.

2.12. Связь основной работы с полученной профессией (специальностью) занятых по уровню профессионального образования.

2.13. Потенциальная рабочая сила по уровню образования..............63

2.14. Средняя заработная плата работников по уровню образования и полу.

2.15. Соотношение средней заработной платы работников по уровню образования .65
2.16. Средняя заработная плата работников по группам занятий и уровню образования: 2015

2.17. Выпуск квалифицированных рабочих, служащих (очная форма обучения)

2.18. Выпуск бакалавров, специалистов, магистров государственными и муниципальными образовательными организациями высшего образования (очная форма обучения)

2.19. Численность выпускников образовательных организаций, зарегистрированных в органах государственной службы занятости

Методологические комментарии

3. Финансирование образования 71

3.1. Расходы на образование в Российской Федерации .................72

3.2. Расходы на образование в Российской Федерации в процентах к валовому внутреннему продукту

3.3. Государственные расходы на образование по уровням бюджетной системы

3.4. Динамика государственных расходов на образование.

3.5. Удельный вес расходов на образование в общих расходах консолидированного бюджета Российской Федерации и бюджетов государственных внебюджетных фондов .

3.6. Государственные расходы на образование в процентах к валовому внутреннему продукту по отдельным уровням бюджетной системы

3.7. Государственные расходы на образование по подразделам классификации расходов бюджетов 
3.8. Государственные расходы на образование в процентах к валовому внутреннему продукту по подразделам классификации расходов бюджетов

3.9. Государственные расходы на образование в расчете на одного обучающегося по подразделам классификации расходов бюджетов

3.10. Инвестиции в основной капитал, направленные на развитие образования

3.11. Структура инвестиций в основной капитал, направленных на развитие образования,

по источникам финансирования

3.12. Структура инвестиций в основной капитал, направленных на развитие образования, по формам собственности

3.13. Объем платных услуг населению в системе образования.

3.14. Расходы домашних хозяйств на оплату услуг образования.

3.15. Расходы домашних хозяйств на оплату услуг образования по 10-процентным группам населения с различным уровнем среднедушевых доходов

3.16. Объем средств дошкольных образовательных организаций по источникам финансирования

3.17. Объем средств общеобразовательных организаций по источникам финансирования

3.18. Объем средств образовательных организаций дополнительного образования, реализующих дополнительные общеобразовательные программы для детей, по источникам финансирования
3.19. Объем средств образовательных организаций, реализующих образовательные программы среднего профессионального образования, по источникам финансирования: 2015 .

3.20. Объем средств образовательных организаций высшего образования по источникам финансирования

3.21. Средние потребительские цены на отдельные виды услуг образования.

3.22. Индексы потребительских цен на отдельные виды услуг образования.

3.23. Численность студентов, обучающихся по образовательным программам среднего профессионального образования - программам подготовки квалифицированных рабочих, служащих, прием на обучение и выпуск квалифицированных рабочих, служащих по источникам финансирования

3.24. Численность студентов, обучающихся по образовательным программам среднего профессионального образования - программам подготовки специалистов среднего звена, прием на обучение и выпуск специалистов среднего звена по источникам финансирования.

3.25. Численность студентов, обучающихся по образовательным программам высшего образования - программам бакалавриата, программам специалитета, программам магистратуры, прием на обучение и выпуск бакалавров, специалистов, магистров по источникам финансирования 


\subsection{6. Среднемесячная номинальная начисленная} заработная плата работников образования

3.27. Реальная начисленная заработная плата в образовании и экономике.

3.28. Среднемесячная номинальная начисленная заработная плата работников образования по формам собственности организаций

3.29. Среднемесячная номинальная начисленная заработная плата работников образования

3.30. Среднемесячная номинальная начисленная заработная плата работников образования в процентах к заработной плате

в экономике в целом

3.31. Средняя заработная плата педагогических работников государственных и муниципальных образовательных организаций

Методологические комментарии

4. Контингент обучающихся

4.1. Динамика численности обучающихся по отдельным образовательным программам

4.2. Численность воспитанников организаций, осуществляющих образовательную деятельность по образовательным программам дошкольного образования, присмотр и уход за детьми

4.3. Численность воспитанников организаций, осуществляющих образовательную деятельность по образовательным программам дошкольного образования, присмотр и уход за детьми, по группам: 2015.
4.4. Численность воспитанников организаций, осуществляющих образовательную деятельность по образовательным программам дошкольного образования, присмотр и уход за детьми, по полу и возрасту: 2015.

4.5. Посещаемость организаций, осуществляющих образовательную деятельность по образовательным программам дошкольного образования, присмотр и уход за детьми

4.6. Численность воспитанников, посещающих группы кратковременного пребывания.

4.7. Численность обучающихся в общеобразовательных организациях

4.8. Охват детей и подростков образовательными программами начального, основного и среднего общего образования.

4.9. Численность обучающихся в общеобразовательных организациях (без вечерних (сменных) общеобразовательных организаций) по полу и возрасту: 2015/2016

4.10. Численность обучающихся в общеобразовательных организациях (без вечерних (сменных) общеобразовательных организаций) по группам классов

4.11. Численность лиц с ограниченными возможностями здоровья, детей-инвалидов, инвалидов, обучающихся в общеобразовательных организациях 
4.12. Численность лиц с ограниченными возможностями здоровья, детей-инвалидов, инвалидов, обучающихся в классах общеобразовательных организаций

(без вечерних (сменных) общеобразовательных организаций), не являющихся отдельными классами для обучающихся по адаптированным основным общеобразовательным программам

4.13. Численность лиц с ограниченными возможностями здоровья, детей-инвалидов, инвалидов, обучающихся индивидуально на дому

4.14. Численность обучающихся в государственных

и муниципальных отдельных общеобразовательных организациях и классах для обучающихся с ограниченными возможностями здоровья

4.15. Выпускники общеобразовательных организаций 123

4.16. Численность детей и подростков в возрасте 7-18 лет, не обучающихся в образовательных организациях по различным причинам

4.17. Распределение детей и подростков в возрасте 7-18 лет, не обучающихся в образовательных организациях, по полу и возрасту: 2015 .

4.18. Численность учащихся образовательных организаций дополнительного образования, реализующих дополнительные общеобразовательные программы для детей.

4.19. Численность студентов, обучающихся по образовательным программам среднего профессионального образования программам подготовки квалифицированных рабочих, служащих
4.20. Охват молодежи образовательными программами среднего профессионального образования программами подготовки квалифицированных рабочих, служащих.

4.21. Численность студентов, обучающихся по образовательным программам среднего профессионального образования программам подготовки квалифицированных рабочих, служащих, по возрасту

4.22. Численность лиц с ограниченными возможностями здоровья, детей-инвалидов, инвалидов, обучающихся по программам среднего профессионального образования - программам подготовки квалифицированных рабочих, служащих

4.23. Прием на обучение по образовательным программам среднего профессионального образования программам подготовки квалифицированных рабочих, служащих.

4.24. Выпуск квалифицированных рабочих, служащих по профессиям

4.25. Численность студентов, обучающихся по программам среднего профессионального образования - программам подготовки специалистов среднего звена

4.26. Охват молодежи образовательными программами среднего профессионального образования программами подготовки специалистов среднего звена по полу

4.27. Численность студентов, обучающихся по образовательным программам среднего профессионального образования программам подготовки специалистов среднего звена, по полу и возрасту 
4.28. Структура численности студентов, обучающихся по образовательным программам среднего профессионального образования - программам подготовки специалистов среднего звена, по формам обучения: 2015/2016...

4.29. Численность лиц с ограниченными возможностями здоровья, детей-инвалидов и инвалидов, обучающихся по образовательным программам среднего профессионального образования - программам подготовки специалистов среднего звена: 2015/2016

4.30. Численность иностранных студентов, обучающихся по образовательным программам среднего профессионального образования - программам подготовки специалистов среднего звена

4.31. Прием студентов на обучение по образовательным программам среднего профессионального образования -программам подготовки специалистов среднего звена .

4.32. Выпуск специалистов среднего звена 137

4.33. Выпуск специалистов среднего звена по укрупненным группам специальностей: 2004-2013

4.34. Выпуск специалистов среднего звена по укрупненным группам специальностей: 2014, 2015

4.35. Численность студентов, обучающихся по образовательным программам высшего образования - программам бакалавриата, программам специалитета, программам магистратуры

4.36. Охват молодежи образовательными программами высшего образования - программами бакалавриата, программами специалитета, программами магистратуры по полу
4.37. Численность студентов, обучающихся по образовательным программам высшего образования - программам бакалавриата, программам специалитета, программам магистратуры, по полу и возрасту

4.38. Численность студентов, обучающихся по образовательным программам высшего образования

4.39. Структура численности студентов, обучающихся по образовательным программам высшего образования программам бакалавриата, программам специалитета, программам магистратуры, по формам обучения: 2015/2016.

4.40. Численность лиц с ограниченными возможностями здоровья, детей-инвалидов, инвалидов, обучающихся по образовательным программам высшего образования программам бакалавриата, программам специалитета, программам магистратуры

4.41. Численность иностранных студентов, обучающихся по образовательным программам высшего образования программам бакалавриата, программам специалитета, программам магистратуры

4.42. Структура численности иностранных студентов из стран дальнего зарубежья, обучающихся по образовательным программам высшего образования - программам бакалавриата, программам специалитета, программам магистратуры, по гражданству: 2015/2016

4.43. Прием студентов на обучение по образовательным программам высшего образования - программам бакалавриата, программам специалитета, программам магистратуры 
4.44. Прием студентов по образовательным программам высшего образования .

4.45. Прием на обучение по образовательным программам высшего образования - программам бакалавриата, программам специалитета, программам магистратуры по укрупненным группам специальностей и направлений подготовки

4.46. Выпуск бакалавров, специалистов, магистров.

4.47. Структура выпуска по уровню полученных дипломов 154

4.48. Подготовка научно-педагогических кадров в аспирантуре

4.49. Численность аспирантов по полу и возрасту

4.50. Выпуск из аспирантуры по отраслям наук

4.51. Удельный вес лиц, защитивших диссертации в период подготовки, в общем выпуске из аспирантуры

по отраслям наук: 2015 .

Методологические комментарии

5. Персонал образовательных организаций

5.1. Среднегодовая численность занятых по видам экономической деятельности

5.2. Удельный вес занятых в образовании в общей численности занятых в экономике

5.3. Удельный вес женщин в общей численности занятых в экономике и в образовании

5.4. Распределение занятых в экономике и в образовании по уровню образования: 2015.

5.5. Средний возраст занятых в экономике и в образовании ..........166

5.6. Среднегодовая численность работников образования
5.7. Численность работников организаций, осуществляющих образовательную деятельность по образовательным программам дошкольного образования, присмотр и уход за детьми, по категориям.

5.8. Численность педагогических работников организаций, осуществляющих образовательную деятельность по образовательным программам дошкольного образования, присмотр и уход за детьми, по должностям.

5.9. Численность женщин в составе педагогических работников организаций, осуществляющих образовательную деятельность по образовательным программам дошкольного образования, присмотр и уход за детьми, по должностям....

5.10. Уровень образования педагогических работников организаций, осуществляющих образовательную деятельность по образовательным программам дошкольного образования, присмотр и уход за детьми

5.11. Уровень образования педагогических работников организаций, осуществляющих образовательную деятельность по образовательным программам дошкольного образования, присмотр и уход за детьми, по должностям: 2015

5.12. Структура численности педагогичесих работников организаций, осуществляющих образовательную деятельность по образовательным программам дошкольного образования, присмотр и уход за детьми, по возрастным группам. 
5.13. Структура педагогического персонала организаций, осуществляющих образовательную деятельность по образовательным программам дошкольного образования, присмотр и уход за детьми, по должностям и возрастным группам: 2015 .

5.14. Численность воспитанников в организациях, осуществляющих образовательную деятельность по образовательным программам дошкольного образования, присмотр и уход за детьми, в расчете на одного воспитателя

5.15. Численность работников общеобразовательных организаций по категориям

5.16. Численность работников общеобразовательных организаций (без вечерних (сменных) общеобразовательных организаций) по категориям

5.17. Численность педагогических работников общеобразовательных организаций по должностям

5.18. Укомплектованность штатов педагогических работников общеобразовательных организаций: 2015

5.19. Численность педагогических работников общеобразовательных организаций (без вечерних (сменных) общеобразовательных организаций) по должностям

5.20. Численность женщин в составе педагогических работников общеобразовательных организаций по должностям

5.21. Численность женщин в составе педагогических работников общеобразовательных организаций (без вечерних (сменных) общеобразовательных организаций) по должностям
5.22. Уровень образования педагогических работников общеобразовательных организаций.

5.23. Уровень образования педагогических работников общеобразовательных организаций (без вечерних (сменных) общеобразовательных организаций)

5.24. Уровень образования педагогических работников общеобразовательных организаций по должностям: 2015

5.25. Структура численности педагогических работников общеобразовательных организаций по возрастным группам

5.26. Структура численности педагогических работников общеобразовательных организаций по должностям и возрастным группам: 2015.

5.27. Численность учителей общеобразовательных организаций по специальностям

5.28. Укомплектованность штатов педагогических работников общеобразовательных организаций учителями по специальностям: 2015

5.29. Численность женщин в составе учителей общеобразовательных организаций по специальностям.

5.30. Уровень образования и возрастной состав учителей общеобразовательных организаций по специальностям: 2015

5.31. Численность обучающихся в общеобразовательных организациях в расчете на одного учителя

5.32. Общая характеристика учителей и директоров ......................196

5.33. Средний возраст учителей и директоров .............................198

5.34. Общая недельная нагрузка учителей .................................. 198 
5.35. Распределение времени учителей и директоров

по видам деятельности

5.36. Потребность учителей в профессиональном развитии

5.37. Барьеры профессионального развития учителей

5.38. Последствия оценки качества работы учителей.

5.39. Численность работников образовательных организаций дополнительного образования, реализующих дополнительные общеобразовательные программы для детей, по категориям.

5.40. Численность педагогических работников образовательных организаций дополнительного образования, реализующих дополнительные общеобразовательные программы для детей, по должностям.

5.41. Укомплектованность штатов педагогических работников образовательных организаций дополнительного образования, реализующих дополнительные общеобразовательные программы для детей: 2015 ....

5.42. Численность женщин в составе педагогических работников образовательных организаций дополнительного образования, реализующих дополнительные общеобразовательные программы для детей, по должностям

5.43. Уровень образования педагогических работников образовательных организаций дополнительного образования, реализующих дополнительные общеобразовательные программы для детей
5.44. Уровень образования педагогических работников образовательных организаций дополнительного образования, реализующих дополнительные общеобразовательные программы для детей, по должностям: 2015.

5.45. Структура численности педагогических работников образовательных организаций дополнительного образования, реализующих дополнительные общеобразовательные программы для детей, по возрастным группам ...

5.46. Структура численности педагогических работников образовательных организаций дополнительного образования, реализующих дополнительные общеобразовательные программы для детей, по должностям и возрастным группам: 2015

5.47. Численность работников профессиональных образовательных организаций, реализующих образовательные программы среднего профессионального образования - программы подготовки квалифицированных рабочих, служащих, по категориям

5.48. Численность педагогических работников профессиональных образовательных организаций, реализующих образовательные программы среднего профессионального образования - программы подготовки квалифицированных рабочих, служащих, по должностям 
5.49. Укомплектованность штатов педагогических работников профессиональных образовательных организаций, реализующих образовательные программы среднего профессионального образования - программы подготовки квалифицированных рабочих, служащих, по должностям: 2015

5.50. Численность женщин в составе педагогических работников профессиональных образовательных организаций, реализующих образовательные программы среднего профессионального образования - программы подготовки квалифицированных рабочих, служащих, по должностям

5.51. Уровень образования педагогических работников профессиональных образовательных организаций, реализующих образовательные программы среднего профессионального образования - программы подготовки квалифицированных рабочих, служащих

5.52. Уровень образования педагогических работников профессиональных образовательных организаций, реализующих образовательные программы среднего профессионального образования - программы подготовки квалифицированных рабочих, служащих, по должностям: 2015

5.53. Структура численности педагогических работников профессиональных образовательных организаций, реализующих образовательные программы среднего профессионального образования - программы подготовки квалифицированных рабочих, служащих, по возрастным группам.
5.54. Структура численности педагогических работников профессиональных образовательных организаций, реализующих образовательные программы среднего профессионального образования - программы подготовки квалифицированных рабочих, служащих, по должностям и возрастным группам: 2015

5.55. Численность преподавателей профессиональных образовательных организаций, реализующих образовательные программы среднего профессионального образования - программы подготовки квалифицированных рабочих, служащих

5.56. Численность мастеров производственного обучения профессиональных образовательных организаций, реализующих образовательные программы среднего профессионального образования - программы подготовки квалифицированных рабочих, служащих, имеющих производственную квалификацию на уровне и выше установленной для выпускников.

5.57. Численность студентов профессиональных образовательных организаций, реализующих образовательные программы среднего профессионального образования - программы подготовки квалифицированных рабочих, служащих, в расчете на одного преподавателя (включая мастеров производственного обучения)

5.58. Численность работников образовательных организаций, реализующих образовательные программы среднего профессионального образования - программы подготовки специалистов среднего звена, по категориям 
5.59. Численность педагогических работников образовательных организаций, реализующих образовательные программы среднего профессионального образования - программы подготовки специалистов среднего звена, по должностям.

5.60. Численность женщин в составе педагогических работников образовательных организаций, реализующих образовательные программы среднего профессионального образования - программы подготовки специалистов среднего звена..

5.61. Численность женщин в составе педагогических работников образовательных организаций, реализующих образовательные программы среднего профессионального образования - программы подготовки специалистов среднего звена, по должностям: 2015/2016.

5.62. Уровень образования педагогических работников образовательных организаций, реализующих образовательные программы среднего профессионального образования - программы подготовки специалистов среднего звена...

5.63. Уровень образования педагогических работников образовательных организаций, реализующих образовательные программы среднего профессионального образования - программы подготовки специалистов среднего звена, по должностям: 2015/2016.

5.64. Численность преподавателей образовательных организаций, реализующих образовательные программы среднего профессионального образования программы подготовки специалистов среднего звена
5.65. Численность женщин в составе преподавателей образовательных организаций, реализующих образовательные программы среднего профессионального образования - программы подготовки специалистов среднего звена.

5.66. Численность преподавателей образовательных организаций, реализующих образовательные программы среднего профессионального образования - программы подготовки специалистов среднего звена, имеющих ученую степень, ученое звание

5.67. Численность преподавателей образовательных организаций, реализующих образовательные программы среднего профессионального образования программы подготовки специалистов среднего звена, прошедших повышение квалификации и (или) профессиональную переподготовку ....

5.68. Структура численности преподавателей образовательных организаций, реализующих образовательные программы среднего профессионального образования - программы подготовки специалистов среднего звена, по возрастным группам

5.69. Численность работников образовательных организаций высшего образования по категориям

5.70. Численность профессорско-преподавательского состава образовательных организаций высшего образования

5.71. Численность профессорско-преподавательского состава образовательных организаций высшего образования по должностям.

5.72. Численность женщин в составе профессорскопреподавательского состава образовательных организаций высшего образования 
5.73. Численность женщин в составе профессорскопреподавательского состава образовательных организаций высшего образования по должностям: 2015/2016

5.74. Численность профессорско-преподавательского состава образовательных организаций высшего образования, имеющего ученую степень, ученое звание

5.75. Численность профессорско-преподавательского состава образовательных организаций высшего образования, прошедшего повышение квалификации и (или) профессиональную переподготовку

5.76. Структура профессорско-преподавательского состава образовательных организаций высшего образования по возрастным группам.

Методологические комментарии

6. Условия обучения

6.1. Основные фонды образования 246

6.2. Индексы физического объема основных фондов образования.

6.3. Ввод в действие основных фондов образования, коэффициенты их обновления и выбытия

6.4. Ввод в действие мощностей образовательных организаций.

6.5. Динамика числа образовательных организаций 248

6.6. Число организаций, осуществляющих образовательную деятельность по образовательным программам дошкольного образования, присмотр и уход за детьми 249
6.7. Число мест в организациях, осуществляющих образовательную деятельность по образовательным программам дошкольного образования, присмотр и уход за детьми

6.8. Средний размер групп в организациях, осуществляющих образовательную деятельность по образовательным программам дошкольного образования, присмотр и уход за детьми: 2015

6.9. Площадь помещений дошкольных образовательных организаций.

6.10. Удельный вес арендованной площади в общей площади помещений дошкольных образовательных организаций

6.11. Техническое состояние и благоустройство зданий дошкольных образовательных организаций.

6.12. Дошкольные образовательные организации, использующие персональные компьютеры и интернет: 2015

6.13. Общеобразовательные организации

6.14. Общеобразовательные организации (без вечерних (сменных) общеобразовательных организаций)

6.15. Вечерние (сменные) общеобразовательные организации

6.16. Средний размер класса в общеобразовательных организациях (без вечерних (сменных) общеобразовательных организаций)

6.17. Сменность занятий в общеобразовательных организациях (без вечерних (сменных) общеобразовательных организаций) 
6.18. Удельный вес обучающихся в две-три смены

в общей численности обучающихся

в общеобразовательных организациях

(без вечерних (сменных) общеобразовательных

организаций)

6.19. Численность обучающихся в государственных

и муниципальных общеобразовательных

организациях в группах продленного дня

(без вечерних (сменных) общеобразовательных

организаций)

6.20. Учебная площадь общеобразовательных организаций

(без вечерних (сменных) общеобразовательных

организаций)

6.21. Учебная площадь общеобразовательных организаций

(без вечерних (сменных) общеобразовательных

организаций) в расчете на одного обучающегося

6.22. Техническое состояние зданий общеобразовательных организаций (без вечерних (сменных)

общеобразовательных организаций)

6.23. Благоустройство зданий общеобразовательных

организаций (без вечерних (сменных)

общеобразовательных организаций)

6.24. Обеспеченность обучающихся в общеобразовательных организациях (без вечерних (сменных)

общеобразовательных организаций)

горячим питанием ....

6.25. Наличие персональных компьютеров

в общеобразовательных организациях

(без вечерних (сменных) общеобразовательных

организаций)
6.26. Число персональных компьютеров, используемых в учебных целях, в расчете на 100 обучающихся в общеобразовательных организациях (без вечерних (сменных) общеобразовательных организаций) .

6.27. Общеобразовательные организации (без вечерних (сменных) общеобразовательных организаций), имеющие доступ к интернету, адрес электронной почты, веб-сайт.

6.28. Образовательные организации дополнительного образования, реализующие дополнительные общеобразовательные программы для детей

6.29. Техническое состояние и благоустройство зданий организаций дополнительного образования, реализующих дополнительные общеобразовательные программы для детей

6.30. Профессиональные образовательные организации, реализующие образовательные программы среднего профессионального образования - программы подготовки квалифицированных рабочих, служащих

6.31. Профессиональные образовательные организации, реализующие программы среднего профессионального образования - программы подготовки специалистов среднего звена .

6.32. Филиалы профессиональных образовательных организаций, реализующих программы среднего профессионального образования - программы подготовки специалистов среднего звена.

6.33. Площадь зданий профессиональных образовательных организаций, реализующих программы среднего профессионального образования: 2015 
6.34. Распределение площади зданий профессиональных образовательных организаций, реализующих программы среднего профессионального образования, по форме владения, пользования: 2015 .274

6.35. Техническое состояние зданий профессиональных образовательных организаций, реализующих программы среднего профессионального образования: 2015.

6.36. Использование площади учебно-лабораторных зданий профессиональных образовательных организаций, реализующих программы среднего профессионального образования: 2015

6.37. Обеспеченность обучающихся в профессиональных образовательных организациях, реализующих программы среднего профессионального образования, общежитиями: 2015

6.38. Обеспеченность студентов профессиональных образовательных организаций, реализующих программы среднего профессионального образования, сетью общественного питания: 2015

6.39. Наличие персональных компьютеров, используемых в учебных целях, в профессиональных образовательных организациях, реализующих программы среднего профессионального образования: 2015 .

6.40. Число персональных компьютеров, используемых в учебных целях, в профессиональных образовательных организациях, реализующих программы среднего профессионального образования, в расчете на 100 студентов

6.41. Образовательные организации высшего образования .280
6.42. Филиалы образовательных организаций высшего образования, реализующие программы бакалавриата, специалитета, магистратуры

6.43. Площадь зданий образовательных организаций высшего образования

6.44. Распределение площади зданий образовательных организаций высшего образования по форме владения, пользования: 2015.

6.45. Техническое состояние зданий образовательных организаций высшего образования

6.46. Использование площади учебно-лабораторных зданий образовательных организаций высшего образования

6.47. Обеспеченность обучающихся в образовательных организациях высшего образования общежитиями: 2015

6.48. Обеспеченность студентов образовательных организаций высшего образования сетью общественного питания

6.49. Наличие персональных компьютеров, используемых в учебных целях, в образовательных организациях высшего образования

6.50. Число персональных компьютеров, используемых в учебных целях, в расчете на 100 студентов.

6.51. Организации, осуществляющие подготовку научнопедагогических кадров в аспирантуре

Методологические комментарии

7. Международные сопоставления 293

7.1. Уровень образования взрослого населения в России и странах ОЭСР: 2015 
7.2. Удельный вес взрослого населения, имеющего высшее образование (МСК0 6, 7 и 8), в его общей численности в России и странах 0ЭСР по возрастным группам: 2015

7.3. Удельный вес взрослого населения, имеющего основное общее образование и ниже (МСКО 0, 1 и 2), в его общей численности в России и странах ОЭСР по возрастным группам: 2015

7.4. Занятость и безработица по образованию в России и странах 0ЭСР: 2015

7.5. Уровень занятости лиц, имеющих среднее профессиональное образование по программам подготовки специалистов среднего звена и высшее образование (МСКО 5, 6, 7 и 8), в России и странах 0ЭСР по предметным областям: 2012

7.6. Государственные расходы на образование в России и странах 0ЭСР в процентах к валовому внутреннему продукту: 2015.

7.7. Государственные расходы на образование в России и странах 0ЭСР в процентах от общих государственных расходов: 2015
7.8. Охват образованием населения в возрасте 5-29 лет в России и странах 0ЭСР: 2015

7.9. Удельный вес иностранных студентов и аспирантов в их общей численности в России и странах ОЭСР: среднее профессиональное по программам подготовки специалистов среднего звена и высшее образование (МСКО 5, 6, 7 и 8), 2015

7.10. Распределение выпускников, получивших среднее профессиональное образование по программам подготовки специалистов среднего звена и высшее образование впервые, в России и странах ОЭСР по уровню образования: 2015 .

7.11. Удельный вес женщин в общей численности учителей (преподавателей) в России и странах ОЭСР: 2015

7.12. Численность обучающихся в расчете на одного учителя (преподавателя) в России и странах ОЭСР: 2015

7.13. Средний размер класса в России и странах 0ЭСР: 2015 313

Методологические комментарии

Условные обозначения:

... нет данных,

- явление отсутствует,

0.0 незначительная величина.

В отдельных случаях небольшое расхождение итогов

с суммой слагаемых объясняется округлением данных. 


\section{1. Образовательный потенциал населения}




\section{1. УРОВЕНЬ ОБРАЗОВАНИЯ НАСЕЛЕНИЯ В ВОЗРАСТЕ 15 ЛЕТ И СТАРШЕ: 2015*}

(в расчете на 1000 человек населения соответствующей возрастной группы, указавших уровень образования)

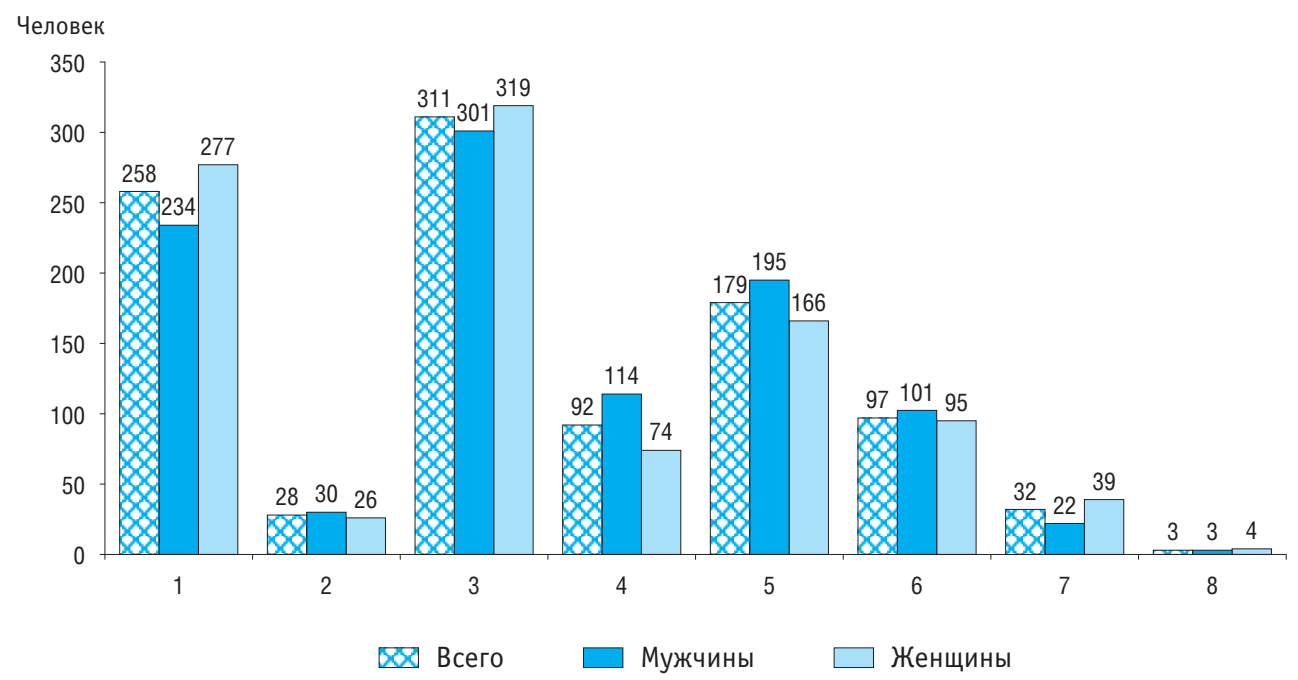

Имеют образование:

1 - высшее

2 - неполное высшее профессиональное

3 - среднее профессиональное по программам подготовки специалистов среднего звена

4 - среднее профессиональное по программам подготовки квалифицированных рабочих, служащих

5 - среднее общее

6 - основное общее

7 - начальное общее

8 - не имеют начального общего образования

* По данным микропереписи населения 2015 г. 
1.2. УРОВЕНЬ ОБРАЗОВАНИЯ НАСЕЛЕНИЯ В ВОЗРАСТЕ 25-64 ЛЕТ ПО ВОЗРАСТНЫМ ГРУППАМ: 2015* (в расчете на 1000 человек населения соответствующей возрастной группы, указавших уровень образования)

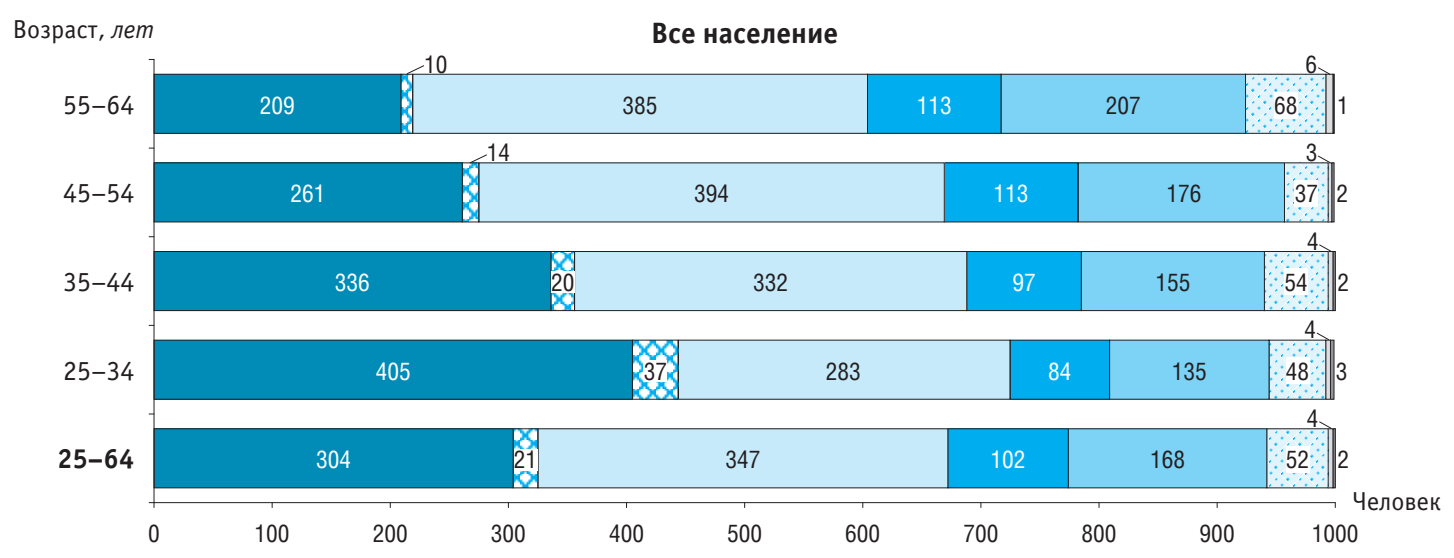

Имеют образование:

высшее

но неполное высшее профессиональное

среднее профессиональное по программам подготовки специалистов среднего звена

$\square$ среднее профессиональное по программам подготовки квалифицированных рабочих, служащих

* По данным микропереписи населения 2015 г.

среднее общее

основное общее

начальное общее

не имеют начального

общего образования 


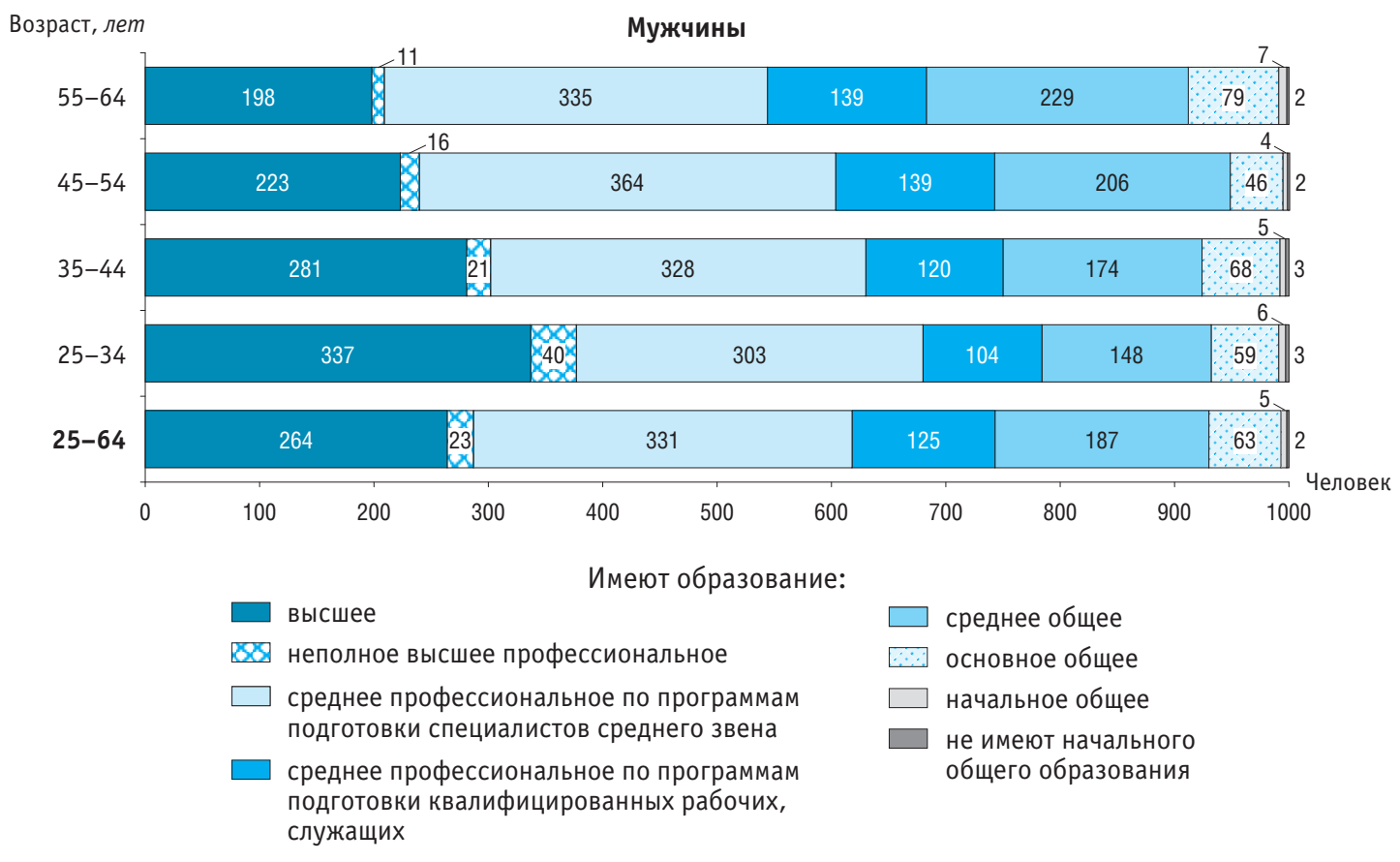




\section{(окончание)}

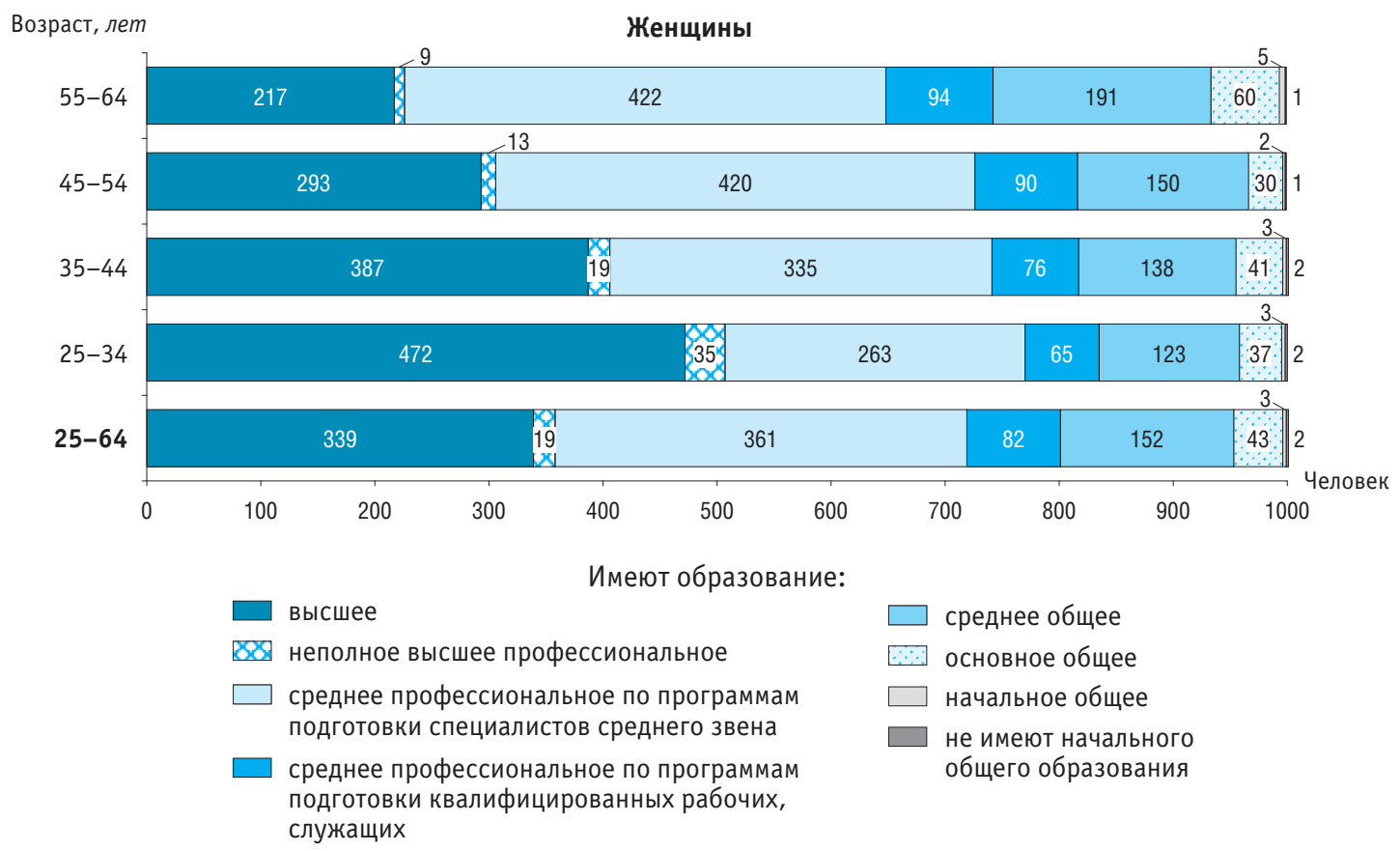


1.3. СРЕДНЯЯ ОЖИДАЕМАЯ ПРОДОЛЖИТЕЛЬНОСТЬ ОБУЧЕНИЯ В ТЕЧЕНИЕ ПРЕДСТОЯЩЕЙ ЖИЗНИ ДЛЯ ДЕТЕЙ В В0ЗРАСТЕ 6 ЛЕТ

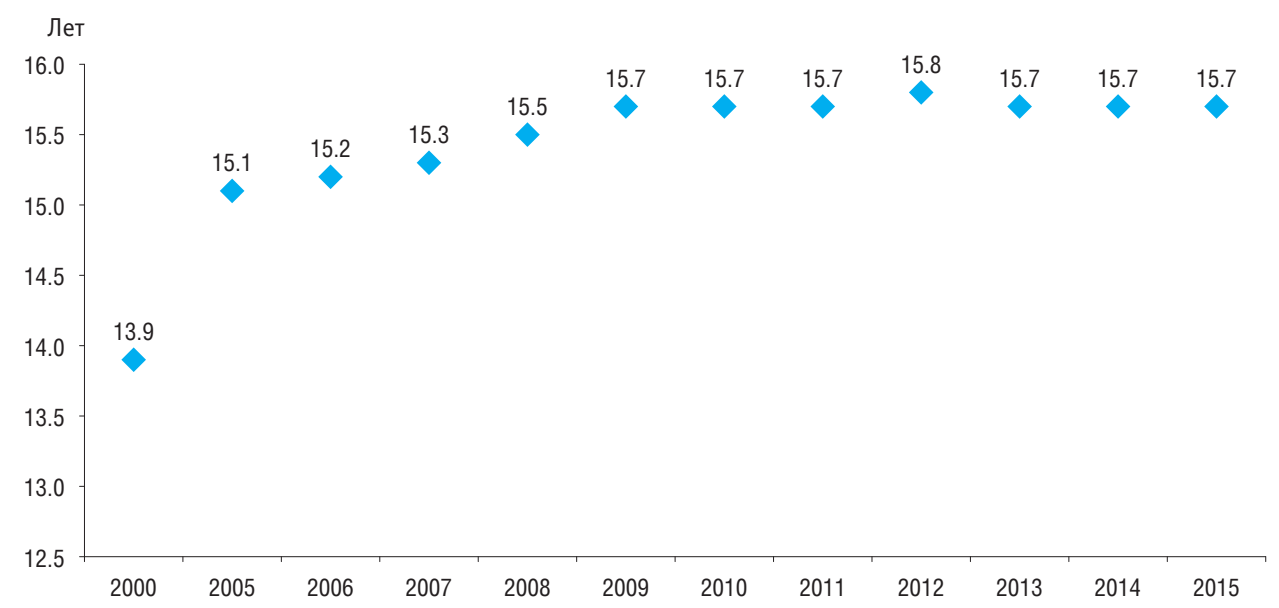




\section{4. КОЭФФИЦИЕНТЫ ВЫПУСКА СПЕЦИАЛИСТОВ (КВАЛИФИЦИРОВАННЫХ РАБОЧИХ, СЛУЖАЩИХ) С ПРОФЕССИОНАЛЬНЫМ ОБРАЗОВАНИЕМ}

(отношение численности выпускников, обучавшихся по программам профессионального образования, к численности населения в возрасте, теоретически соответствующем окончанию образования на определенной ступени*)

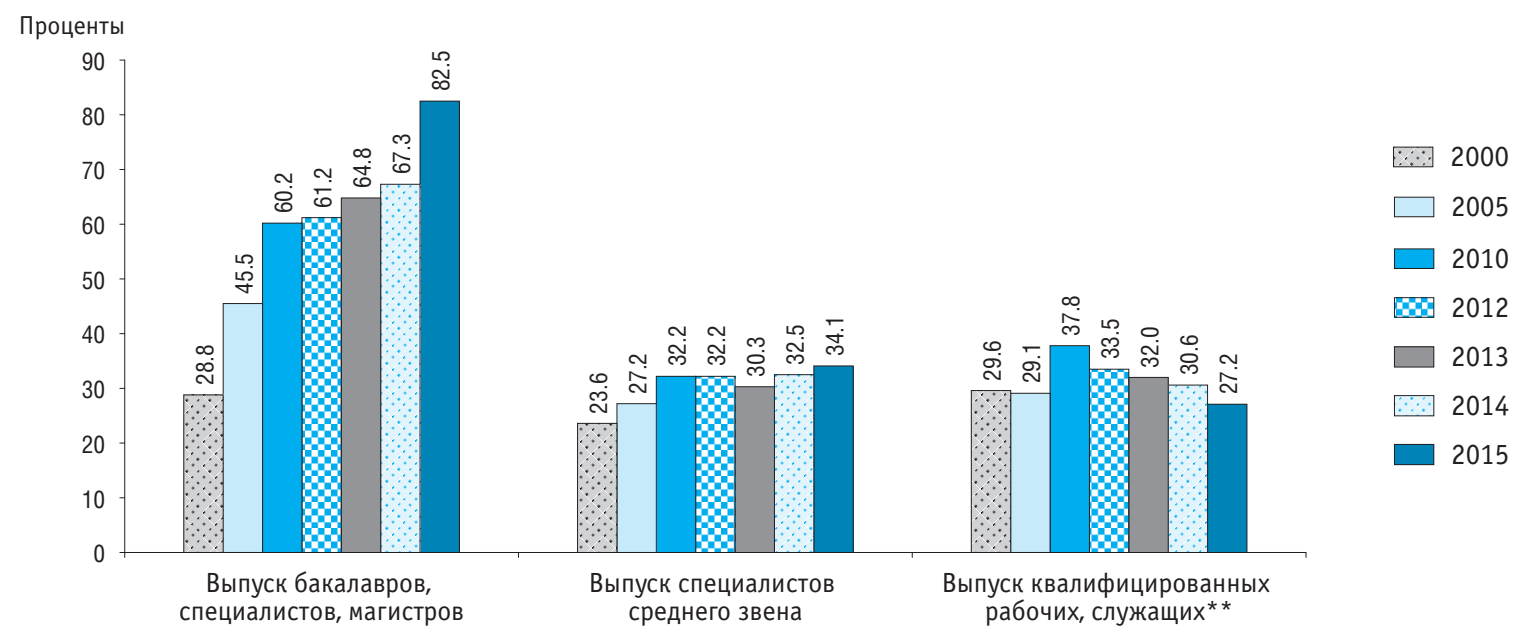

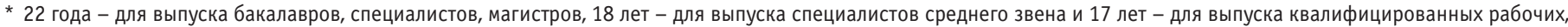
служащих.

** С 2010 г. - включая выпускников, обучавшихся на договорной основе, но без учета краткосрочно (менее 500 часов) обученных. 


\section{5. ОЦЕНКА ГРАМОТНОСТИ 15-ЛЕТНИХ РОССИЙСКИХ ОБУЧАЮЩИХСЯ*}

(средний балл по международной 1000-балльной шкале)

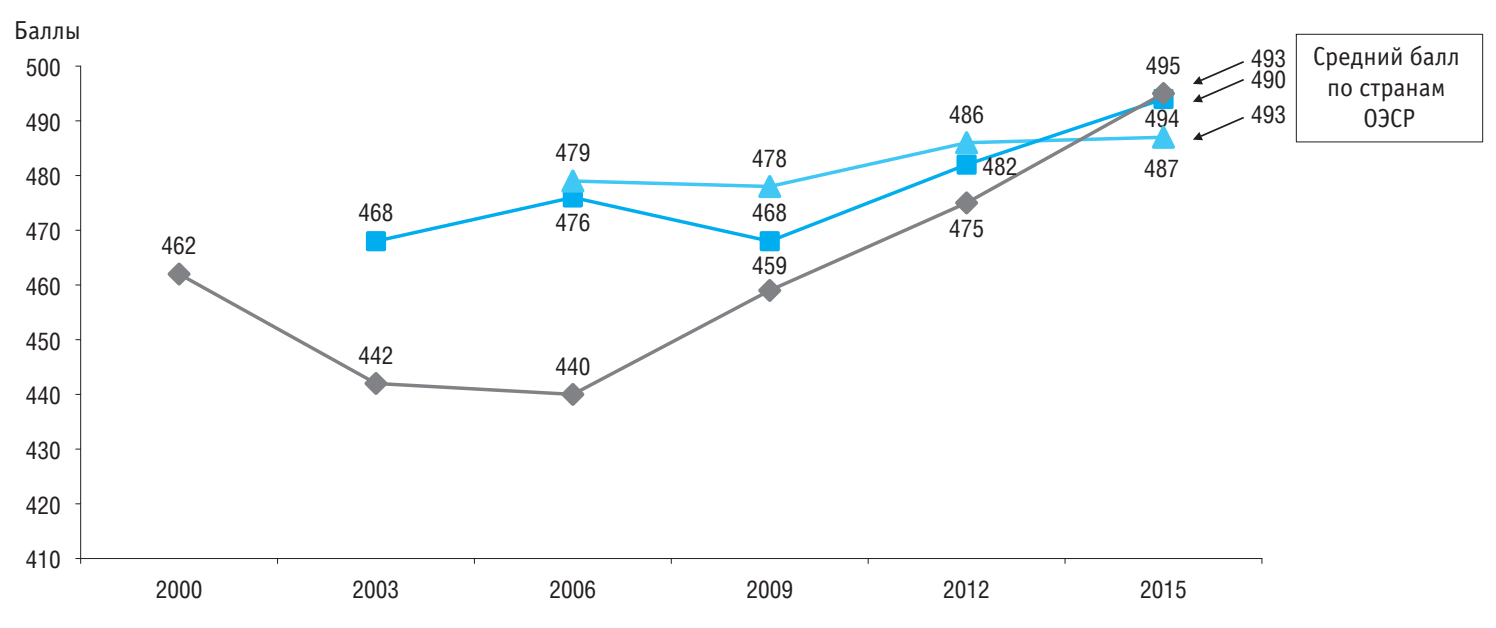

\footnotetext{
—— Читательская грамотность

-_ Математическая грамотность

- Естественнонаучная грамотность
}

* По результатам международного исследования образовательных достижений обучающихся PISA; среднее значение по странам 0ЭСР приведено по числу стран, принимавших участие в исследовании в соответствующем году. 


\section{6. РАСПРЕДЕЛЕНИЕ 15-ЛЕТНИХ ОБУЧАЮЩИХСЯ РОССИИ И СТРАН ОЭСР ПО УРОВНЯМ}

\section{ЕСТЕСТВЕННОНАУЧНОЙ ГРАМОТНОСТИ *}

Проценты

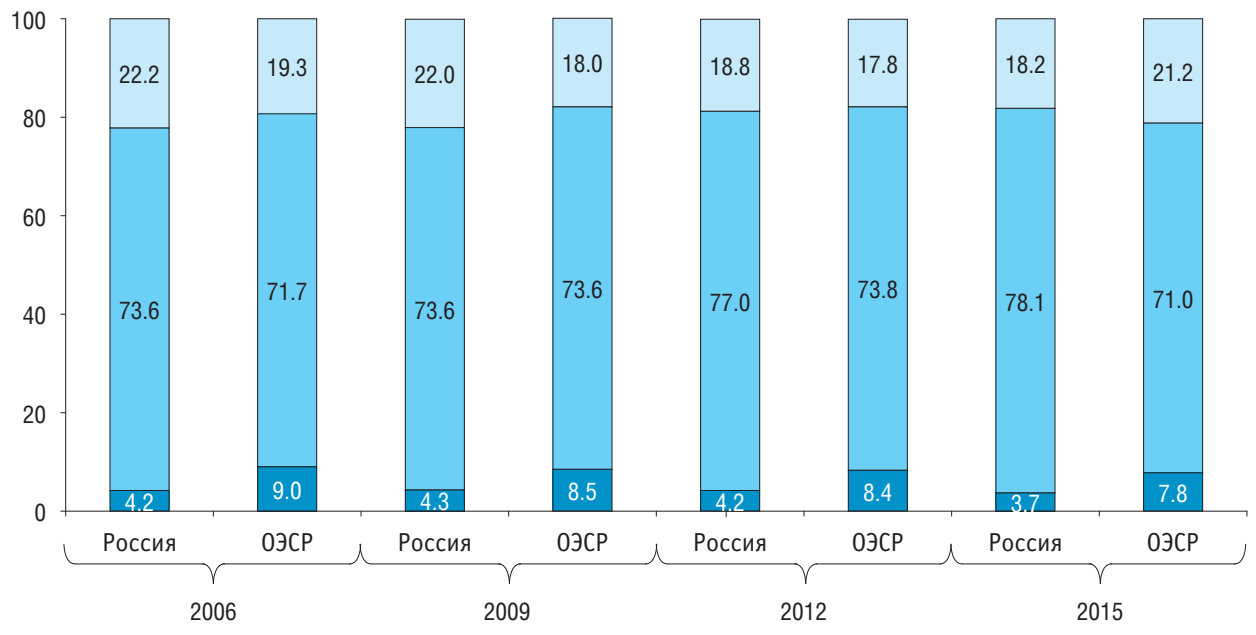

Уровни:

$\square$ 5-6-й (633 балла и более)

$\square$ 2-4-й (от 410 до 633 баллов)

$\square$ 1-й и ниже (менее 410 баллов)

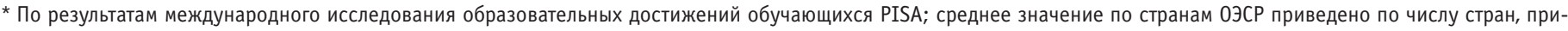
нимавших участие в исследовании в соответствующем году. 
1.7. УДЕЛЬНЫЙ ВЕС 15-ЛЕТНИХ ОБУЧАЮЩИХСЯ, ПОКАЗАВШИХ НИЗКИЙ И ВЫСОКИЙ УРОВНИ ЕСТЕСТВЕННОНАУЧНОЙ ГРАМОТНОСТИ, В ИХ ОБЩЕЙ ЧИСЛЕННОСТИ ПО СТРАНАМ: 2006 VS 2015*

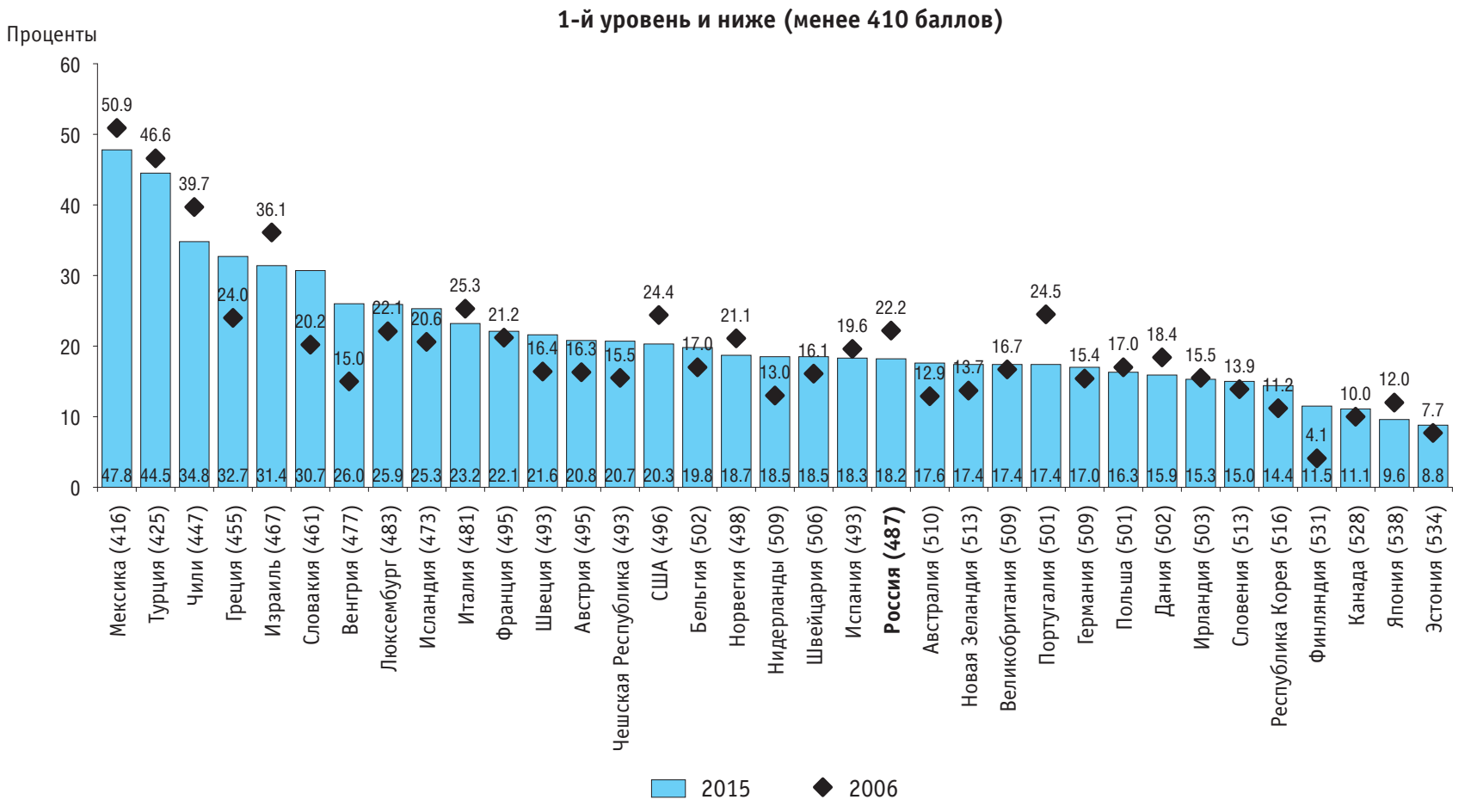

* По результатам международного исследования образовательных достижений обучающихся PISA; по каждой стране в скобках указан средний балл по 1000-балльной шкале (2015). 
(окончание)

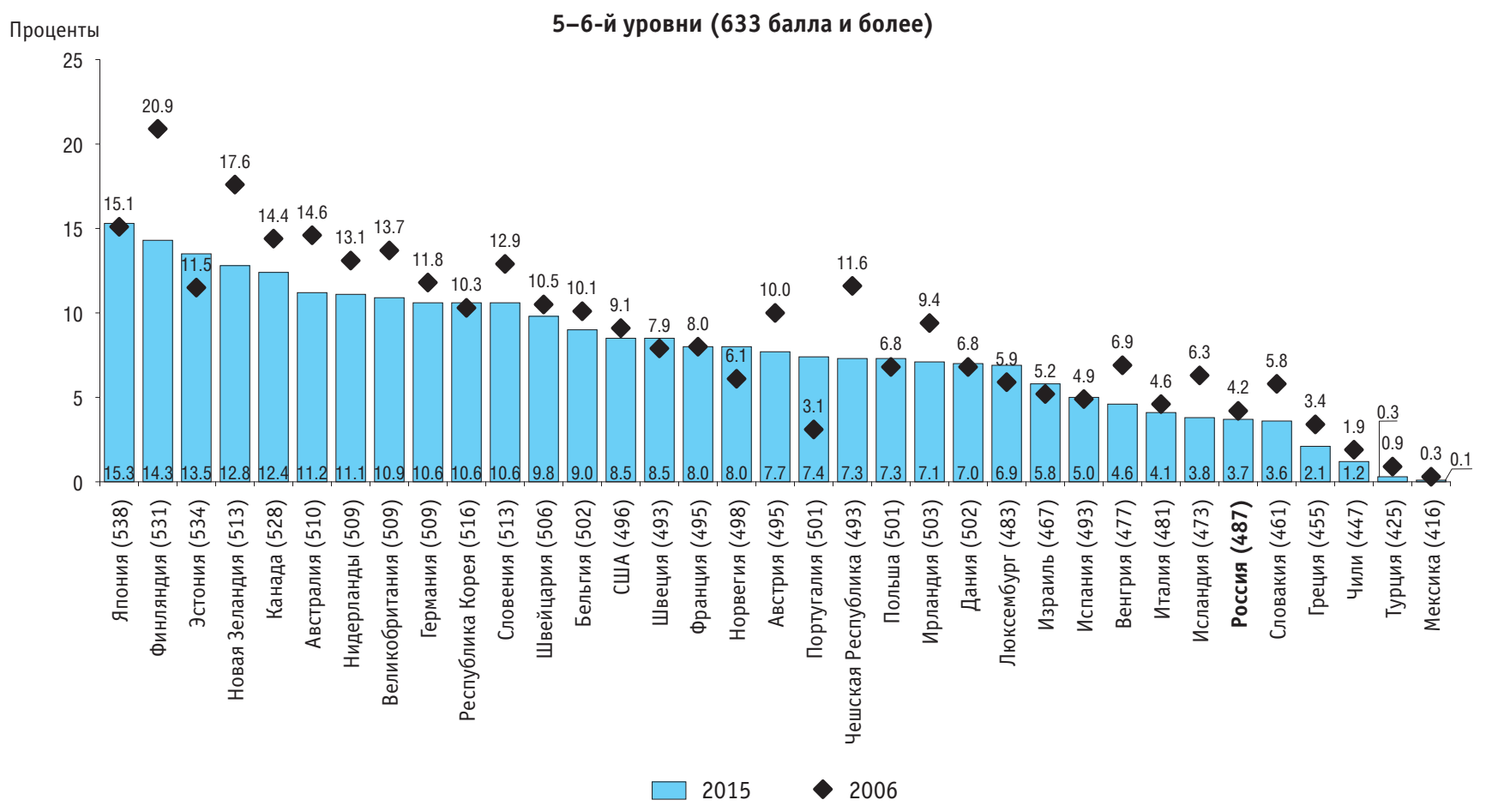




\section{8. РАСПРЕДЕЛЕНИЕ 15-ЛЕТНИХ ОБУЧАЮЩИХСЯ РОССИИ И СТРАН ОЭСР ПО УРОВНЯМ} ЧИТАТЕЛЬСКОЙ ГРАМОТНОСТИ*

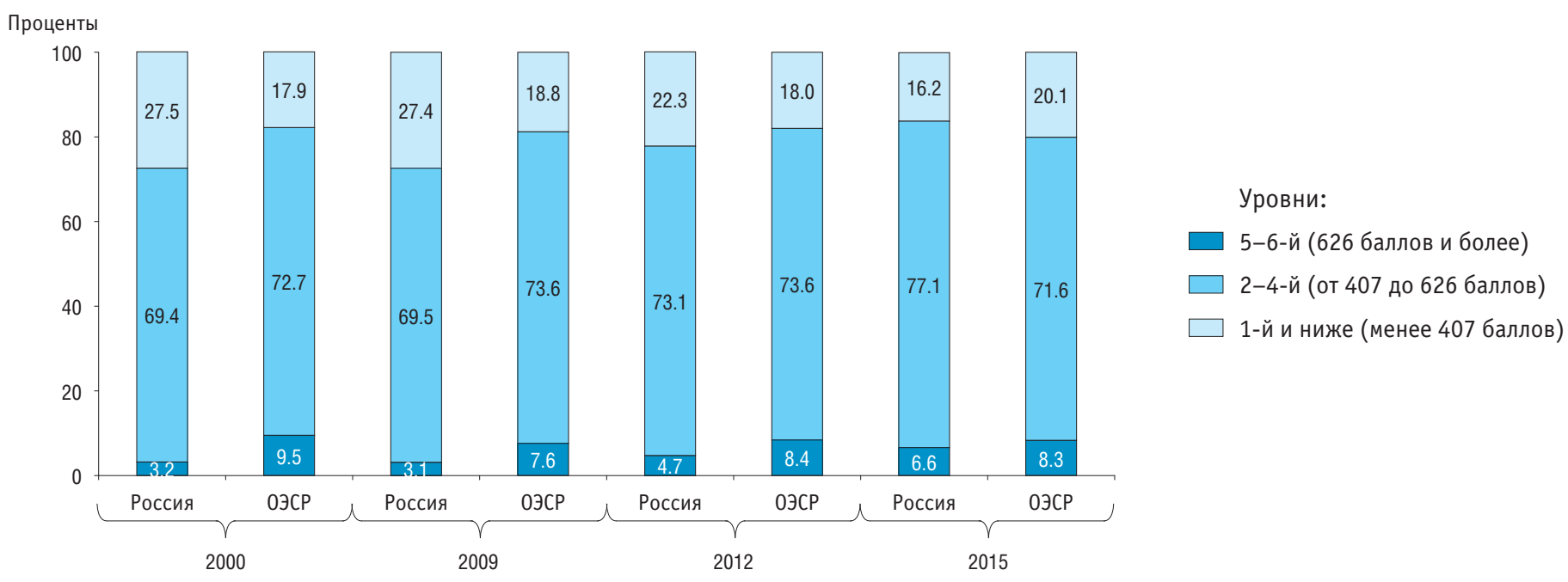

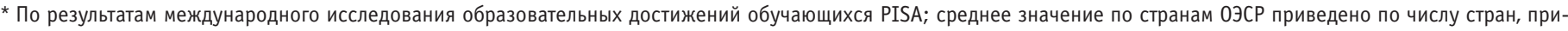
нимавших участие в исследовании в соответствующем году. 
1.9. УДЕЛЬНЫЙ ВЕС 15-ЛЕТНИХ ОБУЧАЮЩИХСЯ, ПОКАЗАВШИХ НИЗКИЙ И ВЫСОКИЙ УРОВНИ ЧИТАТЕЛЬСКОЙ ГРАМОТНОСТИ, В ИХ ОБЩЕЙ ЧИСЛЕННОСТИ ПО СТРАНАМ: 2009 VS 2015*

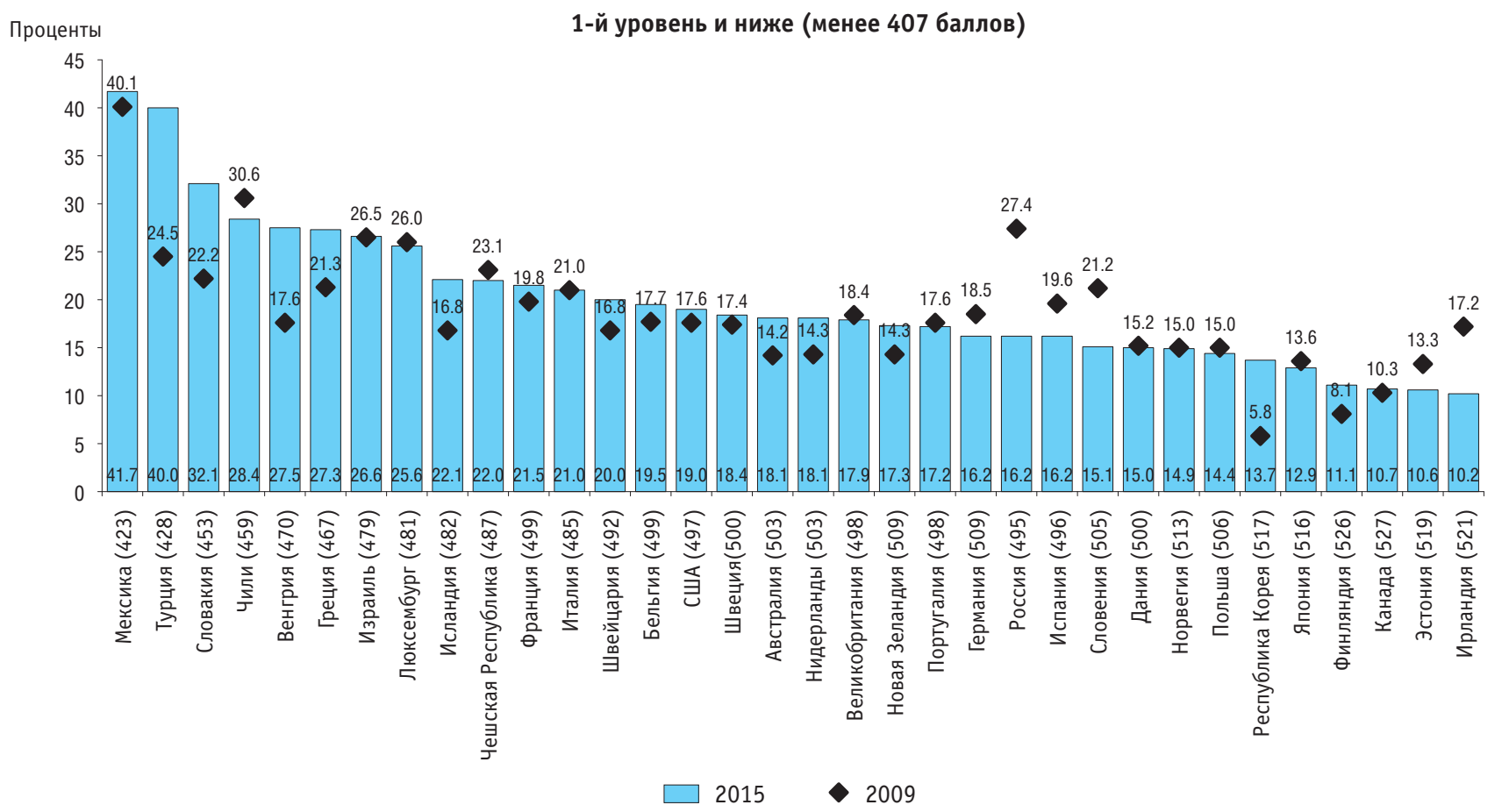

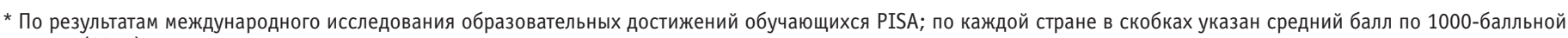
шкале (2015). 
(окончание)

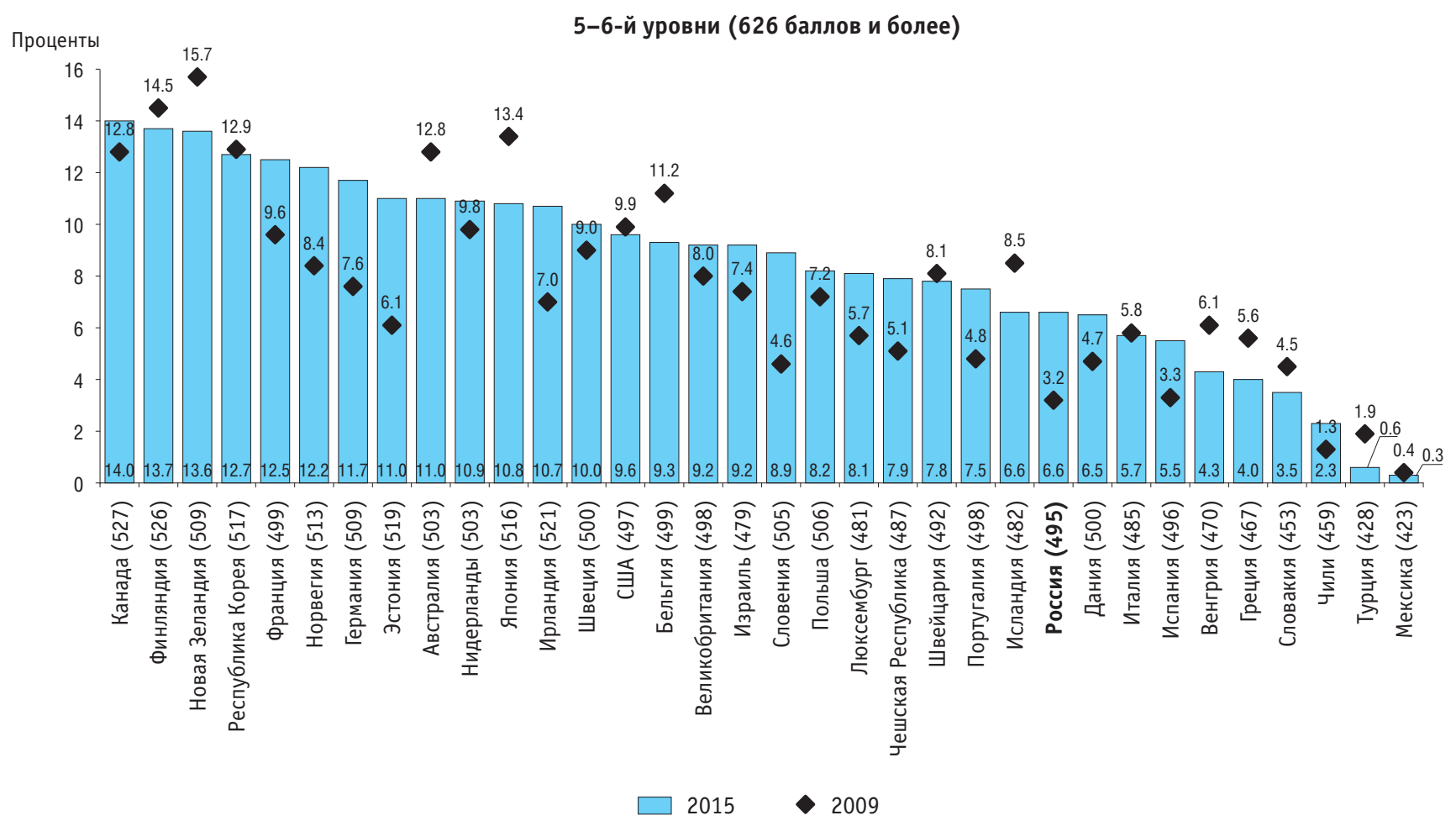




\subsection{0. РАСПРЕДЕЛЕНИЕ 15-ЛЕТНИХ ОБУЧАЮЩИХСЯ РОССИИ И СТРАН ОЭСР ПО УРОВНЯМ МАТЕМАТИЧЕСКОЙ ГРАМОТНОСТИ *}

Проценты

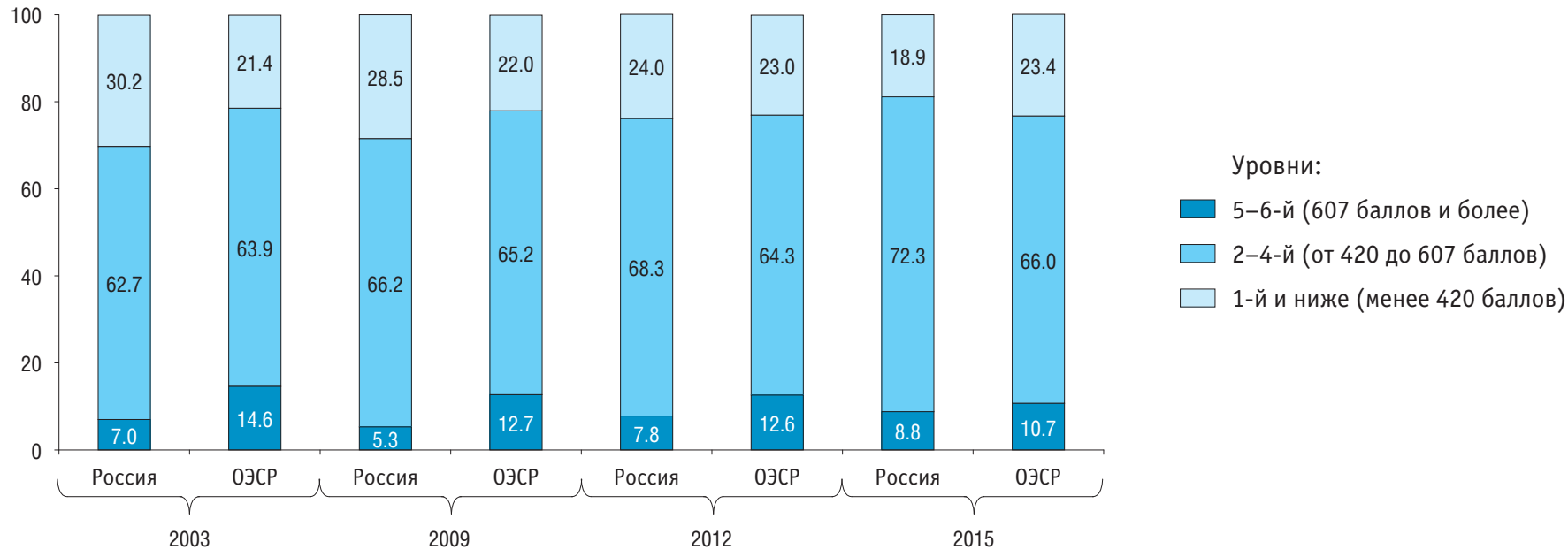

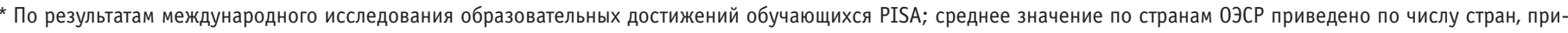
нимавших участие в исследовании в соответствующем году. 
1.11. УДЕЛЬНЫЙ ВЕС 15-ЛЕТНИХ ОБУЧАЮЩИХСЯ, ПОКАЗАВШИХ НИЗКИЙ И ВЫСОКИЙ УРОВНИ МАТЕМАТИЧЕСКОЙ ГРАМОТНОСТИ, В ИХ ОБЩЕЙ ЧИСЛЕННОСТИ ПО СТРАНАМ: 2012 VS 2015*

\section{Проценты}

60

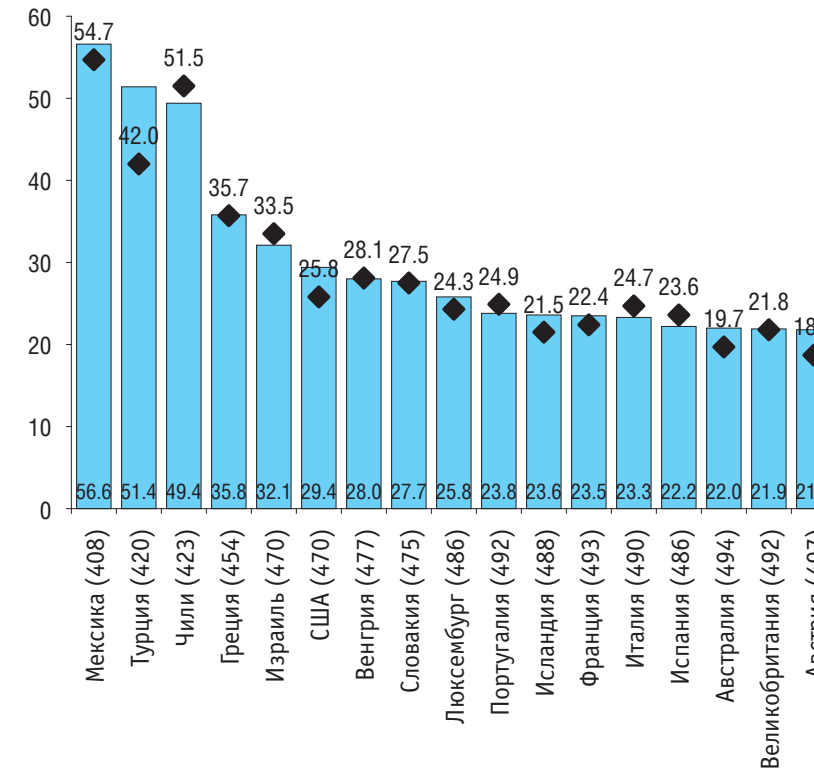

\section{1-й уровень и ниже (менее 420 баллов)}

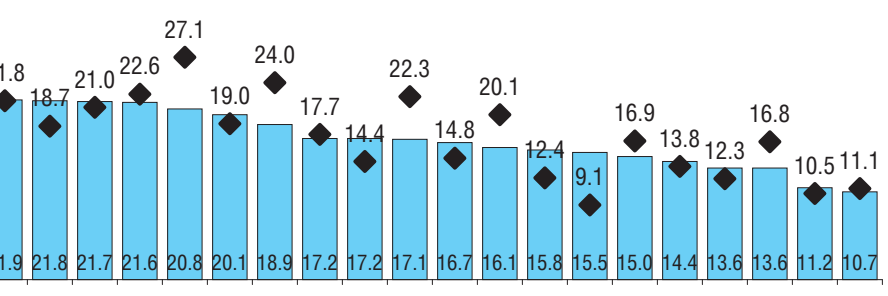

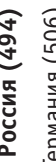

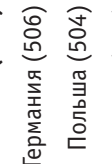

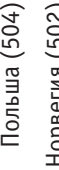

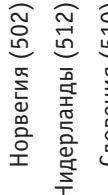

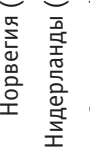

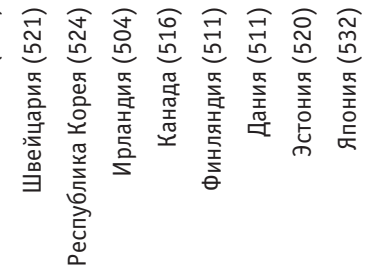




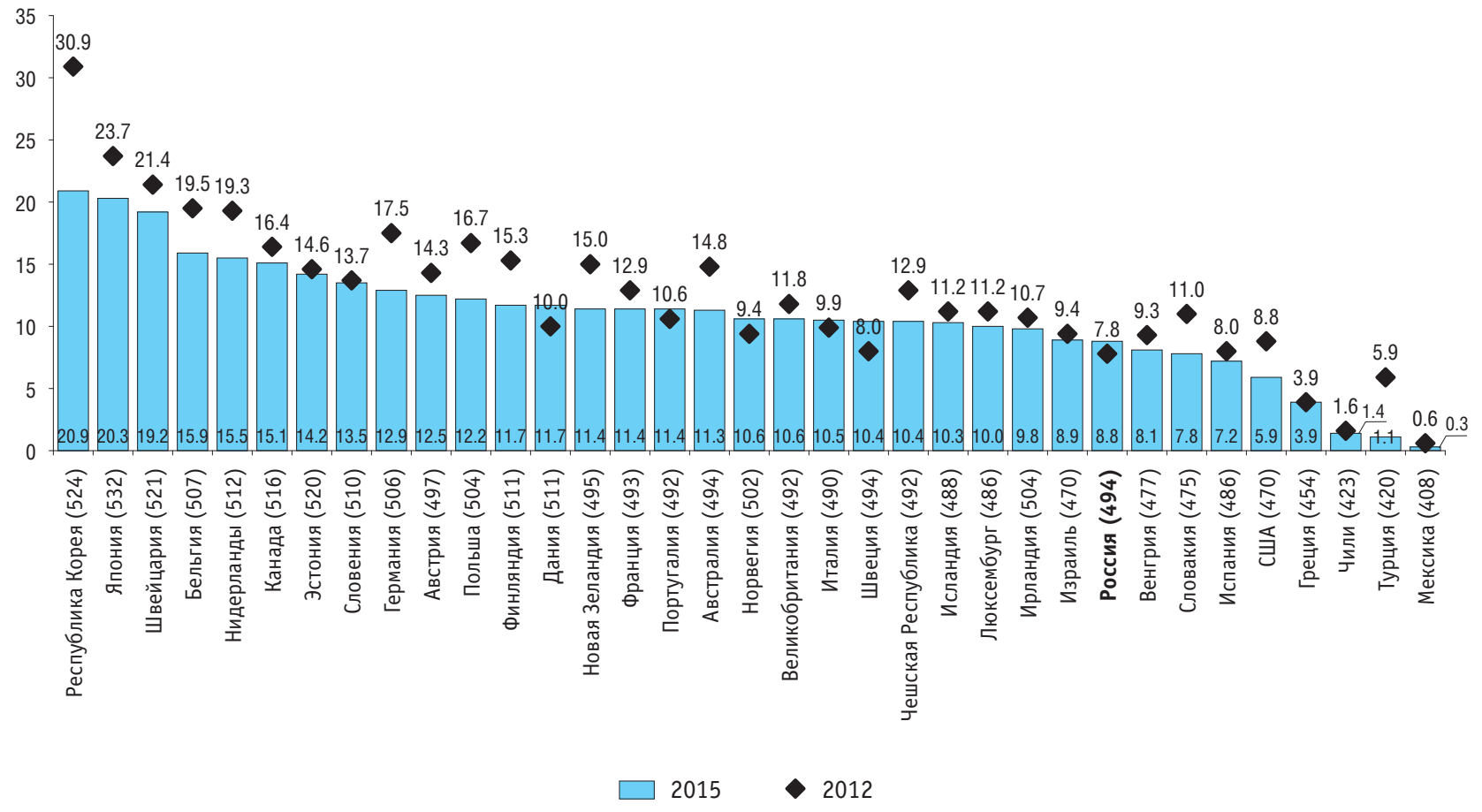

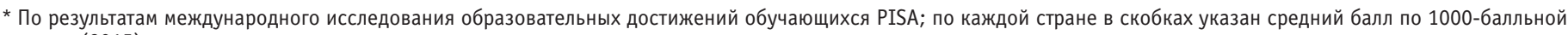
шкале (2015). 


\subsection{2. ГРАМОТНОСТЬ НАСЕЛЕНИЯ В ВОЗРАСТЕ 16-65 ЛЕТ В ОБЛАСТИ ЧТЕНИЯ ПО УРОВНЮ ОБРАЗОВАНИЯ И СТРАНАМ*} (средний балл по 500-балльной шкале)

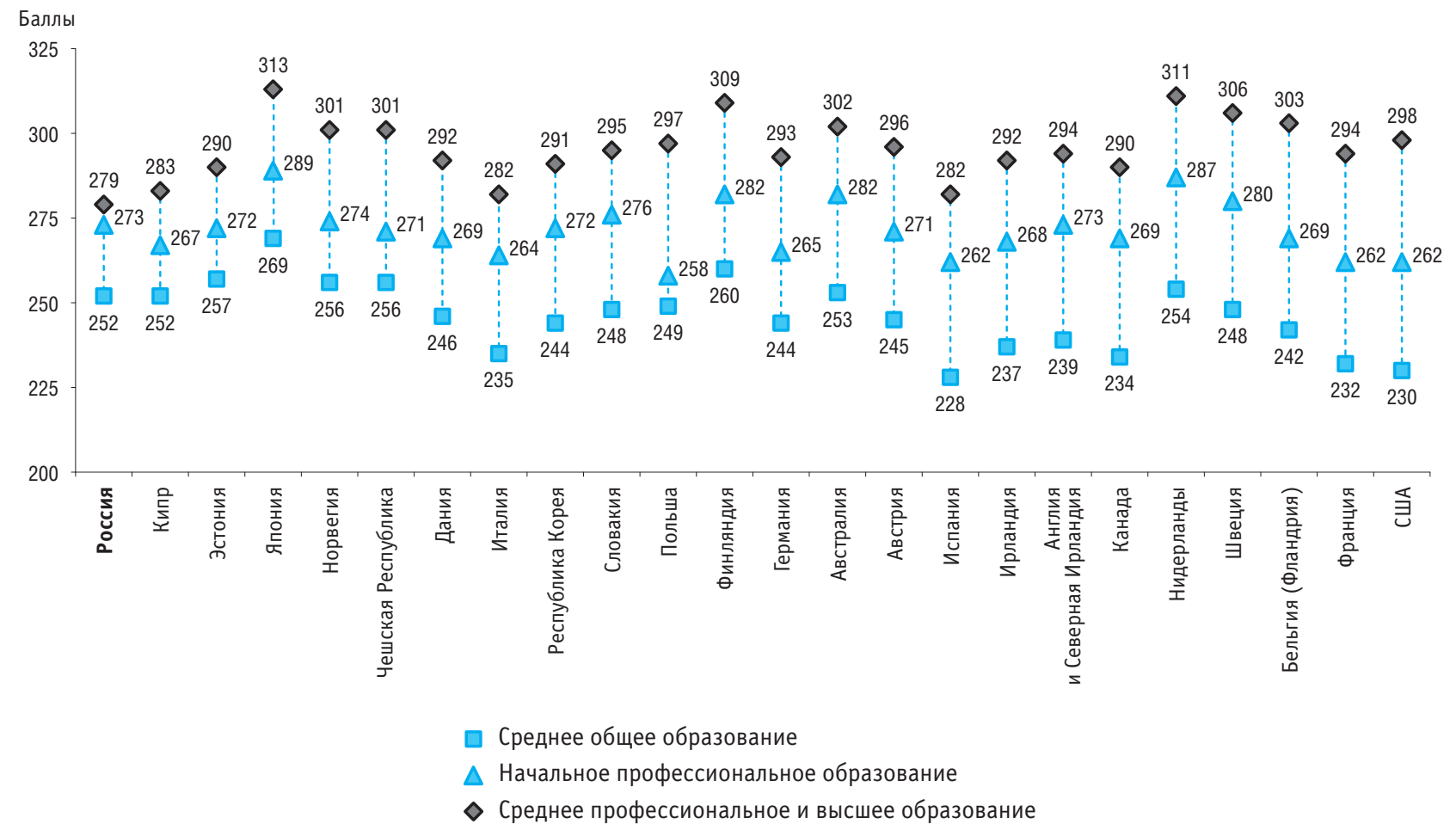

* Здесь и далее (рис. 1.13-1.15) - по результатам международного исследования компетенций взрослых (PIAAC) (2012). 
1.13. МАТЕМАТИЧЕСКАЯ ГРАМОТНОСТЬ НАСЕЛЕНИЯ В ВОЗРАСТЕ 16-65 ЛЕТ ПО УРОВНЮ ОБРАЗОВАНИЯ И СТРАНАМ (средний балл по 500-балльной шкале)

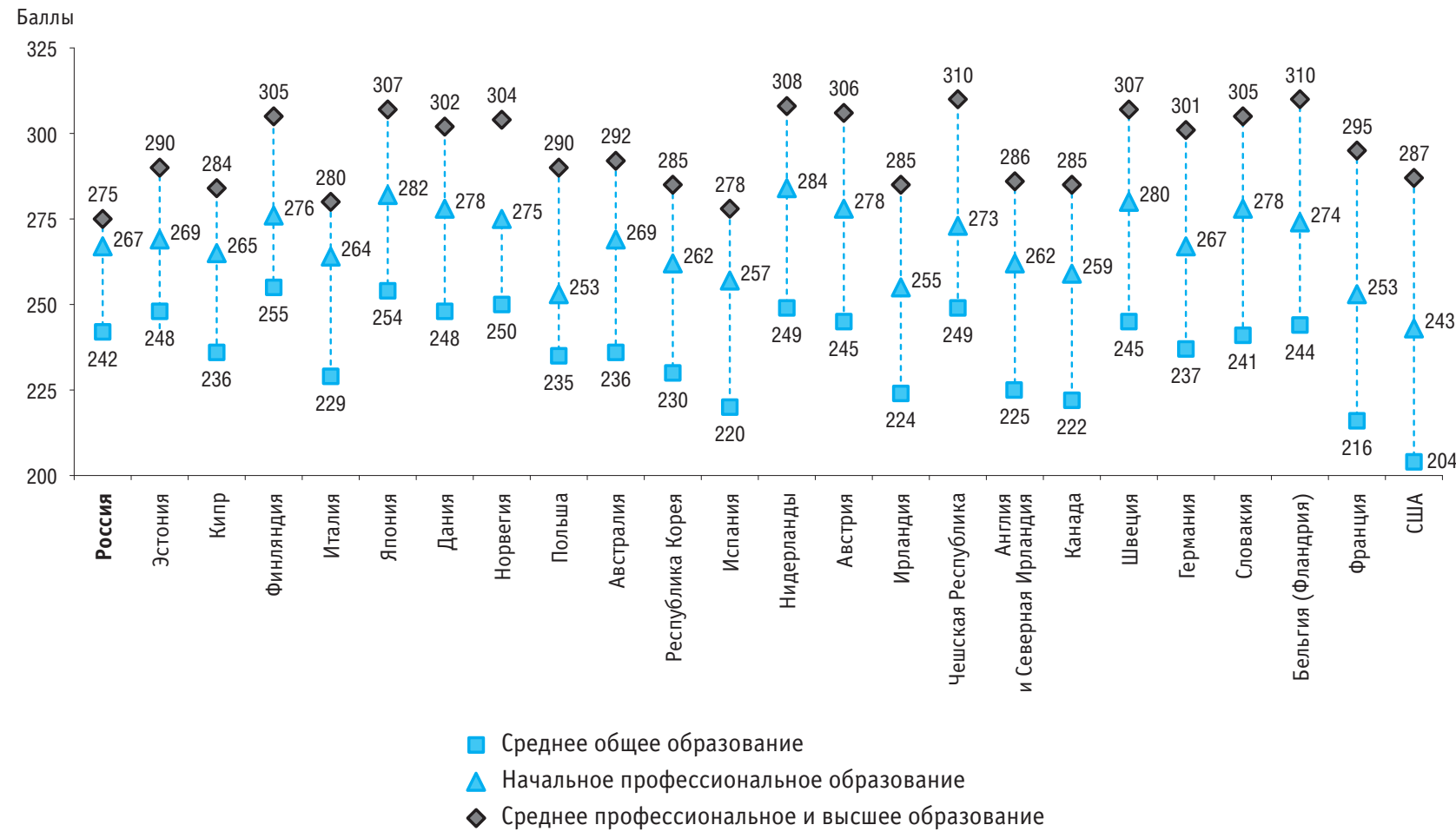


1.14. ГРАМОТНОСТЬ НАСЕЛЕНИЯ В ВОЗРАСТЕ 16-65 ЛЕТ В ОБЛАСТИ ЧТЕНИЯ ПО ЗАНЯТОСТИ И СТРАНАМ (средний балл по 500-балльной шкале)

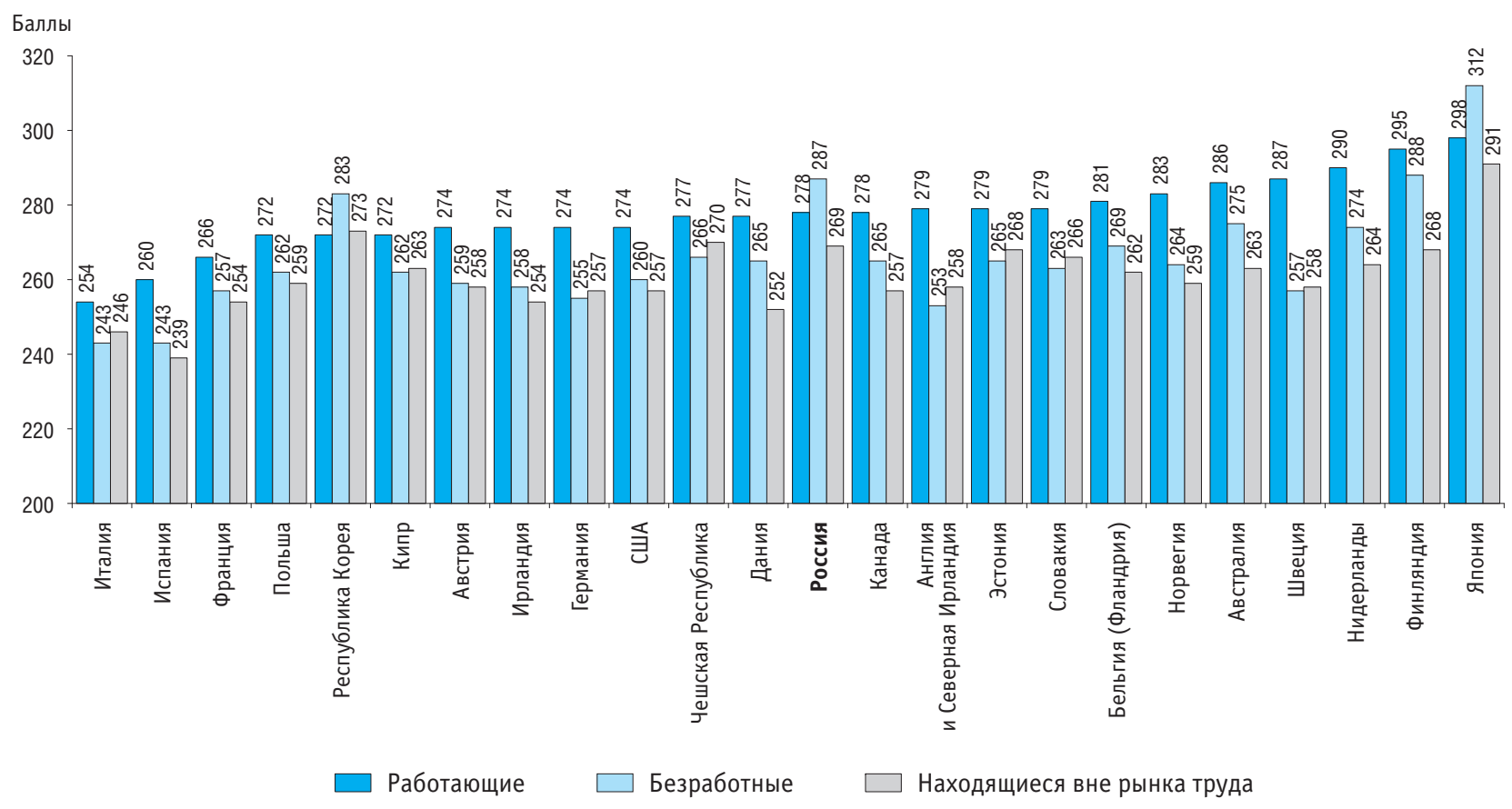




\subsection{5. ГРАМОТНОСТЬ НАСЕЛЕНИЯ В ВОЗРАСТЕ 16-29 ЛЕТ СО СРЕДНИМ ПРОФЕССИОНАЛЬНЫМ И ВЫСШИМ ОБРАЗОВАНИЕМ В ОБЛАСТИ ЧТЕНИЯ ПО СТРАНАМ \\ (средний балл по 500-балльной шкале)}

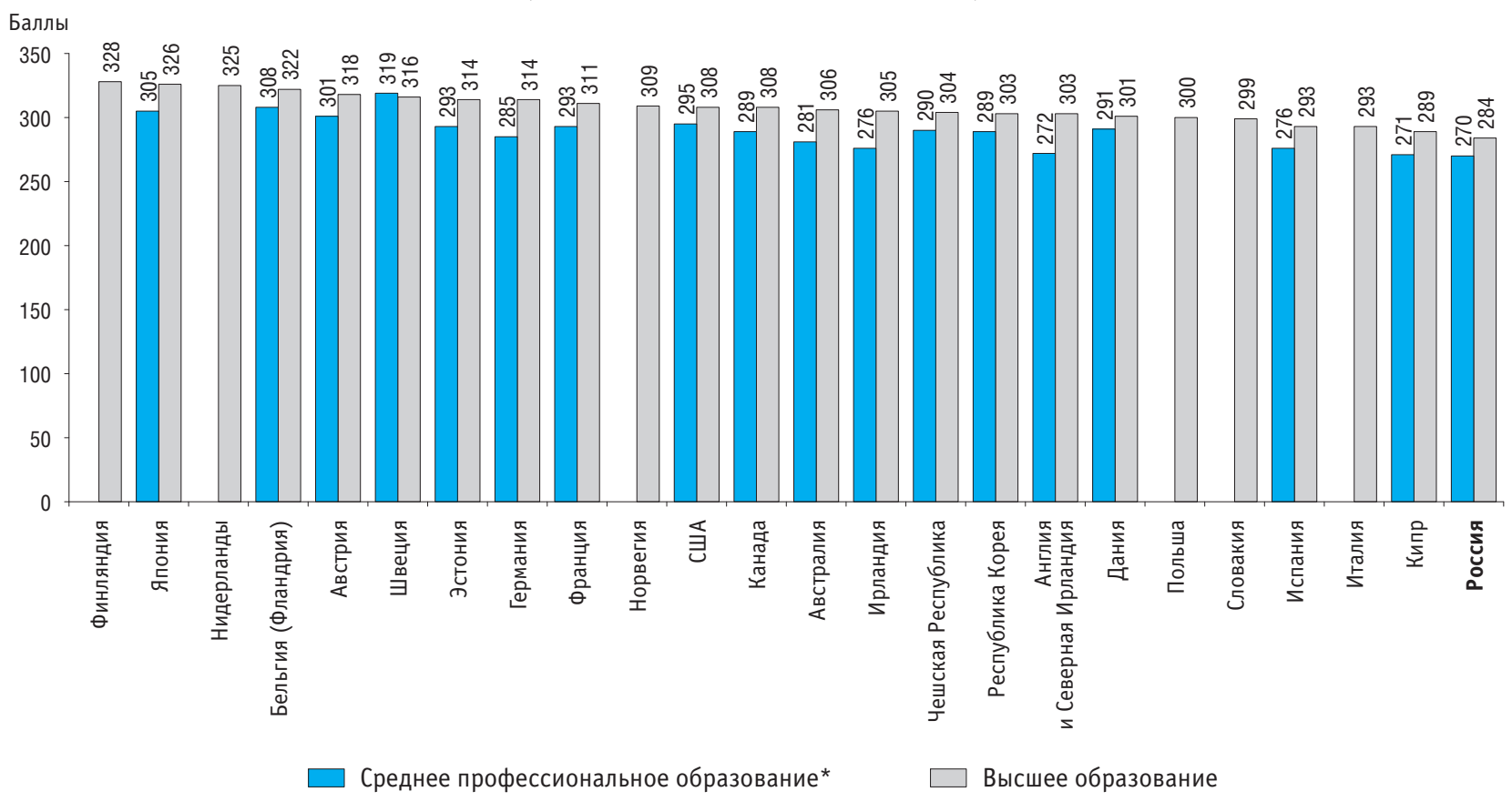

* По Нидерландам, Норвегии, Польше, Словакии, Италии данные отсутствуют. По Финляндии данные были сняты. 


\subsection{6. УЧАСТИЕ НАСЕЛЕНИЯ В НЕПРЕРЫВНОМ ОБРАЗОВАНИИ \\ (в процентах от численности респондентов в возрасте 25-64 лет)}

\begin{tabular}{|c|c|c|c|c|c|c|c|}
\hline & 2006 & 2008 & 2010 & 2012 & 2013 & 2014 & 2015 \\
\hline Всего участвовали за последние 12 месяцев* & 22.4 & 24.8 & 30.4 & 27.3 & 29.2 & $27.0^{* *}$ & $24.0^{* \star}$ \\
\hline \multicolumn{8}{|l|}{ В том числе по видам непрерывного образования: } \\
\hline формальное образование & 4.5 & 2.7 & 2.4 & 2.7 & 2.5 & 1.9 & 7.5 \\
\hline аспирантура, докторантура & 0.2 & 0.2 & 0.1 & 0.2 & 0.3 & 0.2 & 0.5 \\
\hline высшее - программы бакалавриата, специалитета, магистратуры & $2.3^{\star * *}$ & $1.4^{* * *}$ & $1.8^{\star \star *}$ & 1.8 & 2.0 & 1.3 & 2 \\
\hline \multicolumn{8}{|l|}{ среднее профессиональное - программы подготовки специалистов } \\
\hline среднего звена & 1.3 & 0.4 & 0.3 & 0.1 & 0.1 & 0.3 & 3.3 \\
\hline \multicolumn{8}{|l|}{ среднее профессиональное - программы подготовки квалифицированных } \\
\hline рабочих, служащих & 0.3 & 0.4 & 0.1 & 0.8 & 0.2 & 0.1 & 2 \\
\hline дополнительное образование & 8.0 & 12.1 & 14.8 & 13.5 & 12.4 & $14.1^{* *}$ & $12.2^{\star *}$ \\
\hline \multicolumn{8}{|l|}{ вуз по программе второго высшего образования или магистратура } \\
\hline по другому профилю & $\ldots$ & $\ldots$ & $\ldots$ & 0.6 & 0.5 & 0.5 & 0.9 \\
\hline курсы повышения квалификации & 4.6 & 5.4 & 8.2 & 6.3 & 5.8 & 5.4 & 4.5 \\
\hline профессиональные конференции, семинары, тренинги на регулярной основе & 1.5 & 1.4 & 3.2 & 3.7 & 3.5 & 3.9 & 2.2 \\
\hline \multicolumn{8}{|l|}{ единовременные (разовые) профессиональные лекции, конференции, } \\
\hline семинары, тренинги & 1.1 & 3.2 & 2.8 & 4.7 & 3.1 & 3.7 & 1.4 \\
\hline любительские курсы (домоводства, кройки и шитья, водительские и т.п.) & 0.9 & 2.3 & 1.8 & 2.1 & 2.1 & 1.5 & $1.3^{* * * *}$ \\
\hline профессиональные курсы (для получения новой профессии) & 1.6 & 1.6 & 2.0 & 1.3 & 1.4 & 0.7 & 0.5 \\
\hline частные уроки с преподавателем, инструктором & $\ldots$ & $\ldots$ & 0.3 & 1.4 & 0.5 & 0.6 & 0.3 \\
\hline MBA & 0.0 & 0.0 & 0.2 & 0.5 & 0.1 & 0.2 & 0.3 \\
\hline стажировка & $\ldots$ & $\ldots$ & $\ldots$ & $\ldots$ & $\ldots$ & $0.5^{\star *}$ & $0.7^{\star *}$ \\
\hline обучение на рабочем месте в форме наставничества & $\ldots$ & $\ldots$ & $\ldots$ & $\ldots$ & $\ldots$ & $1.3^{* *}$ & $1.0^{* *}$ \\
\hline \multicolumn{7}{|l|}{ курсы целевого назначения (обучение для изучения новой техники, технологии, } & $1.4^{\star *}$ \\
\hline \multicolumn{8}{|l|}{ курсы обучения управлению транспортными средствами различных } \\
\hline 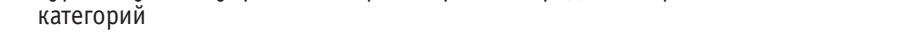 & $\ldots$ & $\ldots$ & $\ldots$ & $\ldots$ & $\ldots$ & $\ldots$ & $1.5^{\star *}$ \\
\hline \multicolumn{8}{|l|}{ обучение технике безопасности, пожарной безопасности, на курсах } \\
\hline по гражданской обороне, охране труда и т.п. & $\ldots$ & $\ldots$ & $\ldots$ & $\ldots$ & $\ldots$ & $\ldots$ & $1.1^{\star *}$ \\
\hline
\end{tabular}


(окончание)

\begin{tabular}{|c|c|c|c|c|c|c|c|}
\hline & 2006 & 2008 & 2010 & 2012 & 2013 & 2014 & 2015 \\
\hline самообразование & 17.4 & 20.9 & 24.4 & 24.4 & $28.7^{* *}$ & $24.6^{* *}$ & $20.4^{\star \star}$ \\
\hline $\begin{array}{l}\text { занимались самообразованием с использованием печатных материалов } \\
\text { (профессиональных книг, журналов и т.п.) }\end{array}$ & 12.7 & 12.8 & 13.6 & 15.4 & 17.4 & 12.3 & 10.3 \\
\hline $\begin{array}{l}\text { ходили на экскурсии в музеи, по культурно-историческим, природным } \\
\text { и промышленным объектам }\end{array}$ & $\ldots$ & $\ldots$ & 2.8 & 5.2 & 5.9 & 3.5 & 3.8 \\
\hline $\begin{array}{l}\text { слушали/смотрели учебные передачи по радио, ТВ } \\
\text { осваивали полезные навыки (например, по работе с компьютерными } \\
\text { программами, вождению автомобиля, шитью, вязанию и т.п.) }\end{array}$ & 2.0 & 3.1 & 3.8 & 4.3 & 5.5 & 3.1 & 3.7 \\
\hline под руководством друзей или членов семьи & $\ldots$ & $\ldots$ & 5.6 & 5.1 & 5.3 & 2.7 & 3.7 \\
\hline обучались под руководством наставников, коллег на своем рабочем месте & 3.7 & 5.6 & 5.1 & 4.2 & 5.1 & 2.4 & $3.9^{* \star \star * *}$ \\
\hline обучались с использованием компьютера, включая онлайн-обучение & 0.8 & 2.1 & 7.9 & 4.6 & 3.6 & 2.6 & 3.3 \\
\hline обучались с использованием аудио- и видеозаписей & 2.9 & 3.1 & 2.1 & 3.6 & 2.2 & 0.8 & 1.9 \\
\hline посещали центры обучения, включая библиотеки & 6.3 & 4.4 & 2.8 & 2.8 & 1.8 & 1.4 & 1.7 \\
\hline получали консультации на тематических форумах в интернете & $\ldots$ & $\ldots$ & $\ldots$ & $\ldots$ & $3.8^{\star *}$ & $2.8^{* *}$ & $2.6^{* *}$ \\
\hline $\begin{array}{l}\text { занимались самообразованием по подкастам или онлайн-приложениям } \\
\text { для мобильных телефонов, планшетов и т.п. (курсы или отдельные лекции, } \\
\text { мастер-классы для скачивания) }\end{array}$ & $\ldots$ & $\ldots$ & $\ldots$ & $\ldots$ & $0.9^{* *}$ & $2.0^{* *}$ & $0.9^{\star *}$ \\
\hline $\begin{array}{l}\text { занимались самообразованием по онлайн-трансляциям лекций/выступлений, } \\
\text { вебинаров }\end{array}$ & $\ldots$ & $\ldots$ & $\ldots$ & $\ldots$ & $0.5^{\star \star}$ & $0.6^{* *}$ & $1 * *$ \\
\hline занимались самообразованием по другим материалам, найденным в интернете & $\ldots$ & $\ldots$ & $\ldots$ & $\ldots$ & $6.1^{* *}$ & $7.4^{* *}$ & $4.8^{\star *}$ \\
\hline посещали публичные лекции, семинары, выступления в парках, кафе, музеях и т.п. & $\ldots$ & $\ldots$ & $\ldots$ & $\ldots$ & $2.3^{* *}$ & $1.8^{* *}$ & $1.6^{\star *}$ \\
\hline посещали клубы для изучения иностранных языков & $\ldots$ & $\ldots$ & $\ldots$ & $\ldots$ & $0.5^{* *}$ & $0.2^{* *}$ & $0.4^{\text {** }}$ \\
\hline посещали открытые мастер-классы, воркшопы & $\ldots$ & $\ldots$ & $\ldots$ & $\ldots$ & $0.4^{* *}$ & $0.7^{* *}$ & $1.4^{\star * *}$ \\
\hline
\end{tabular}

* За 12 месяцев респонденты могли проходить обучение как в сфере формального образования, так и на курсах дополнительного образования, а также заниматься самообразованием. Так, в 2014 г. в формальном и дополнительном образовании (хотя бы в одной из их форм) участвовали $15.4 \%$ респондентов.

** Показатели рассчитаны по расширенному списку видов образовательной деятельности.

*** В опросах 2006, 2008, 2010 гг. в позиции «высшее образование» учитывалось обучение по программам второго высшего образования и магистратуры по другому профилю. В данных 2012-2015 гг. эти позиции учтены в структуре дополнительного образования.

**** С 2015 г. - без учета курсов вождения (они выведены в отдельную строку).

***** С 2015 г. - «освоение производственных навыков на рабочем месте (самостоятельно или при участии коллег, исключая наставничество)». 


\subsection{7. УЧАСТИЕ НАСЕЛЕНИЯ РОССИИ И ЕВРОПЕЙСКИХ СТРАН В НЕПРЕРЫВНОМ ОБРАЗОВАНИИ ПО ВИДАМ} (в процентах от численности респондентов в возрасте 25-64 лет)

\section{Формальное и (или) дополнительное образование}

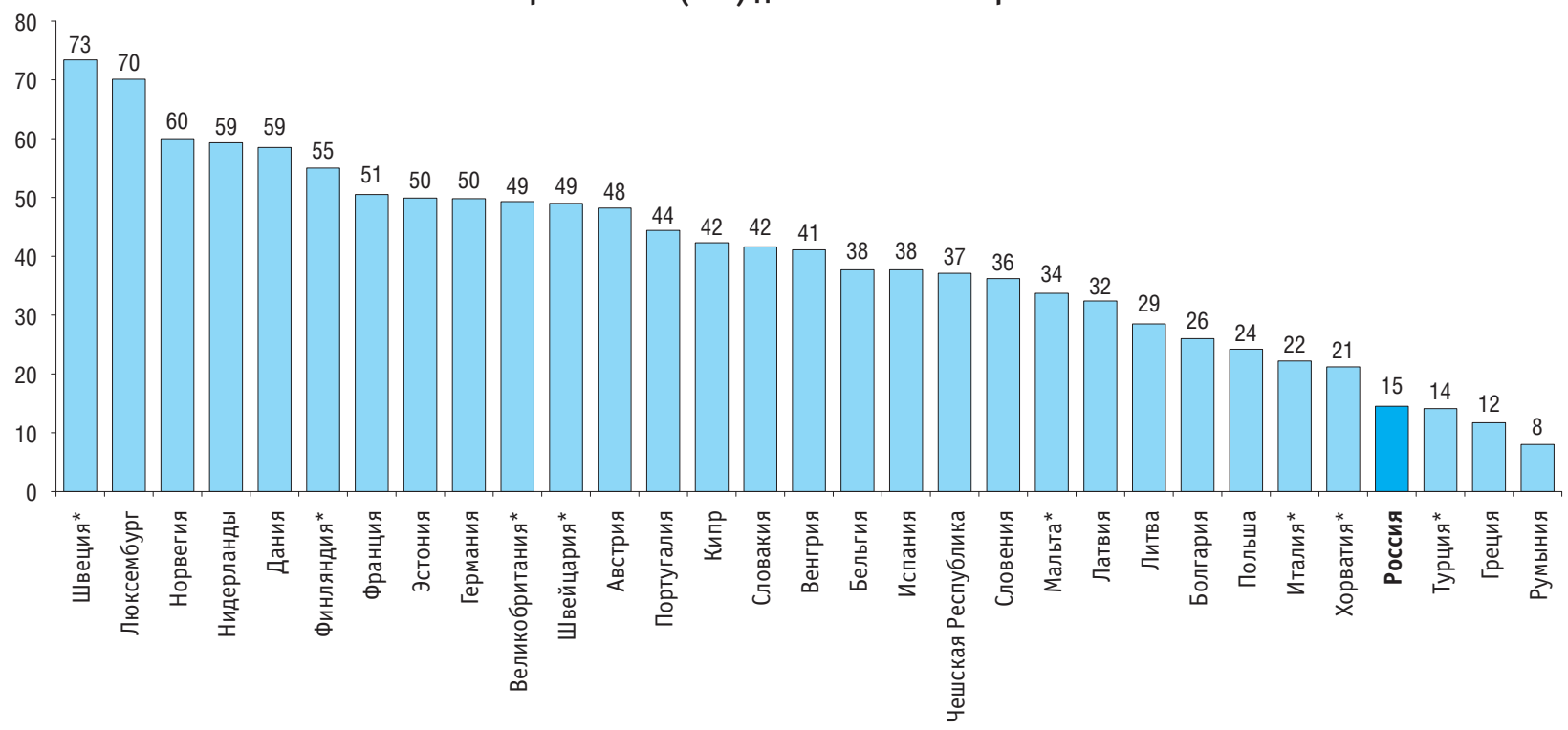

* Данные по отмеченным странам - за 2007 г., по остальным европейским странам - за 2011 г. Данные по России - за 2015 г. 
(продолжение)

\section{Формальное образование}

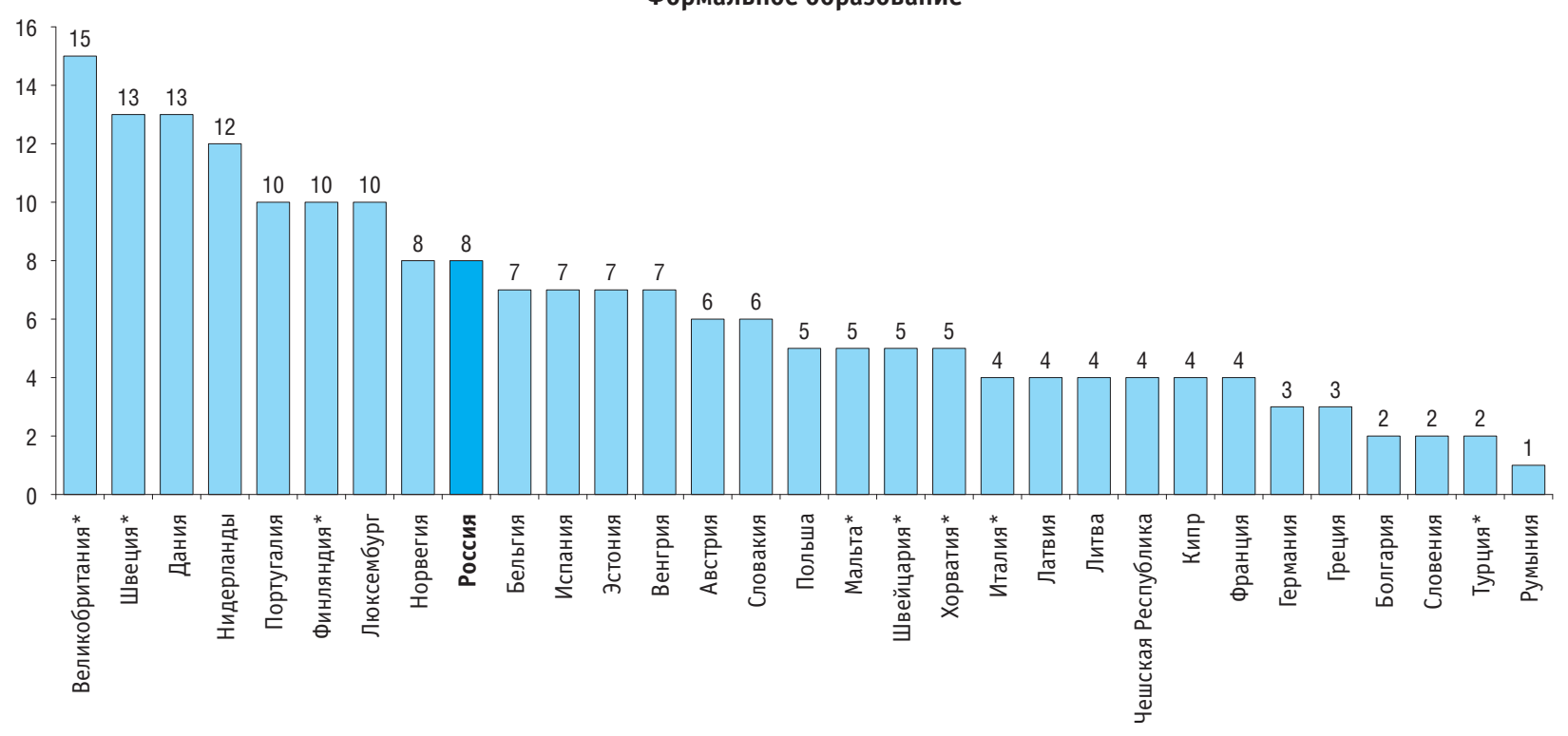


(продолжение)

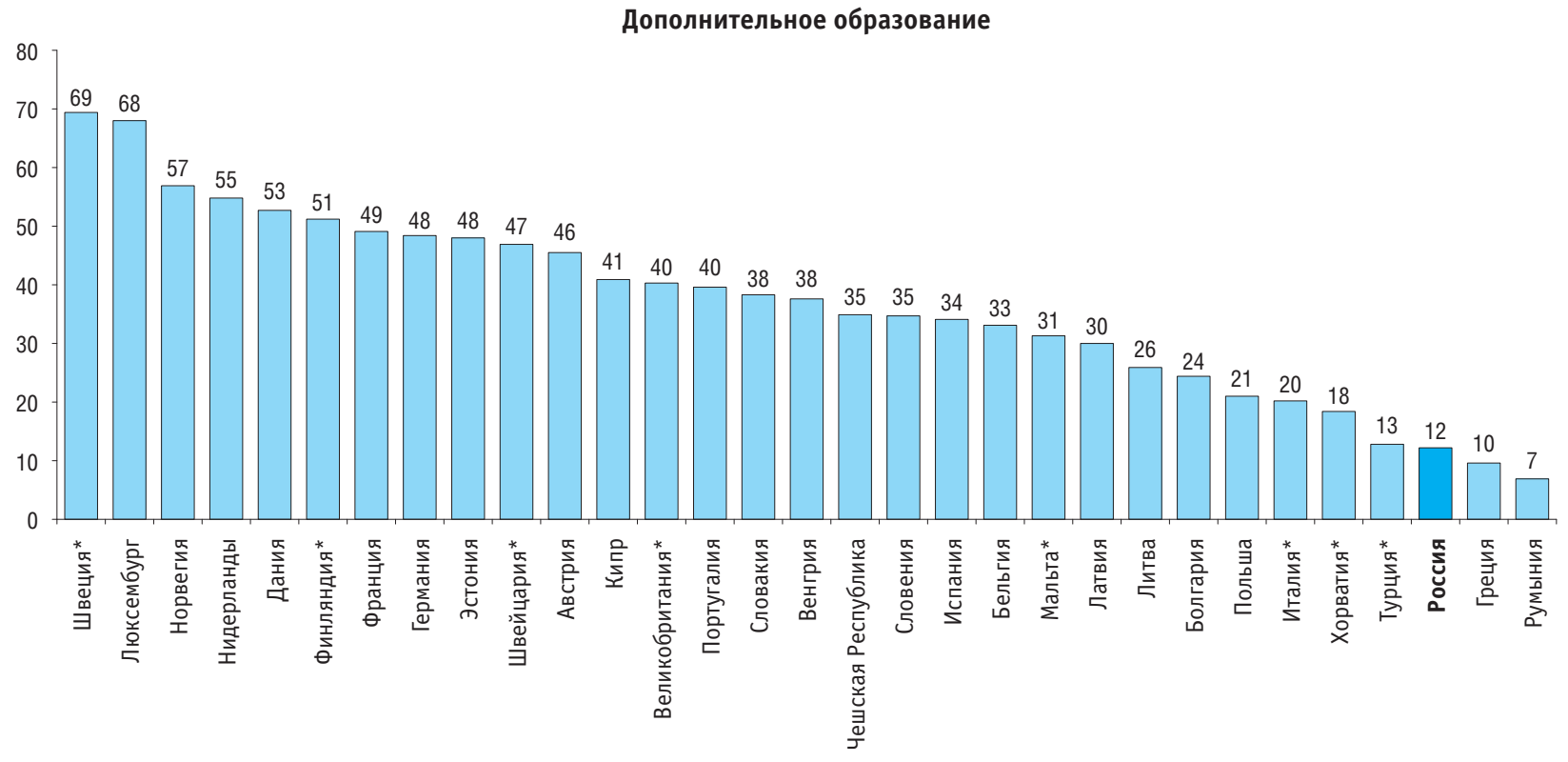




\section{(окончание)}

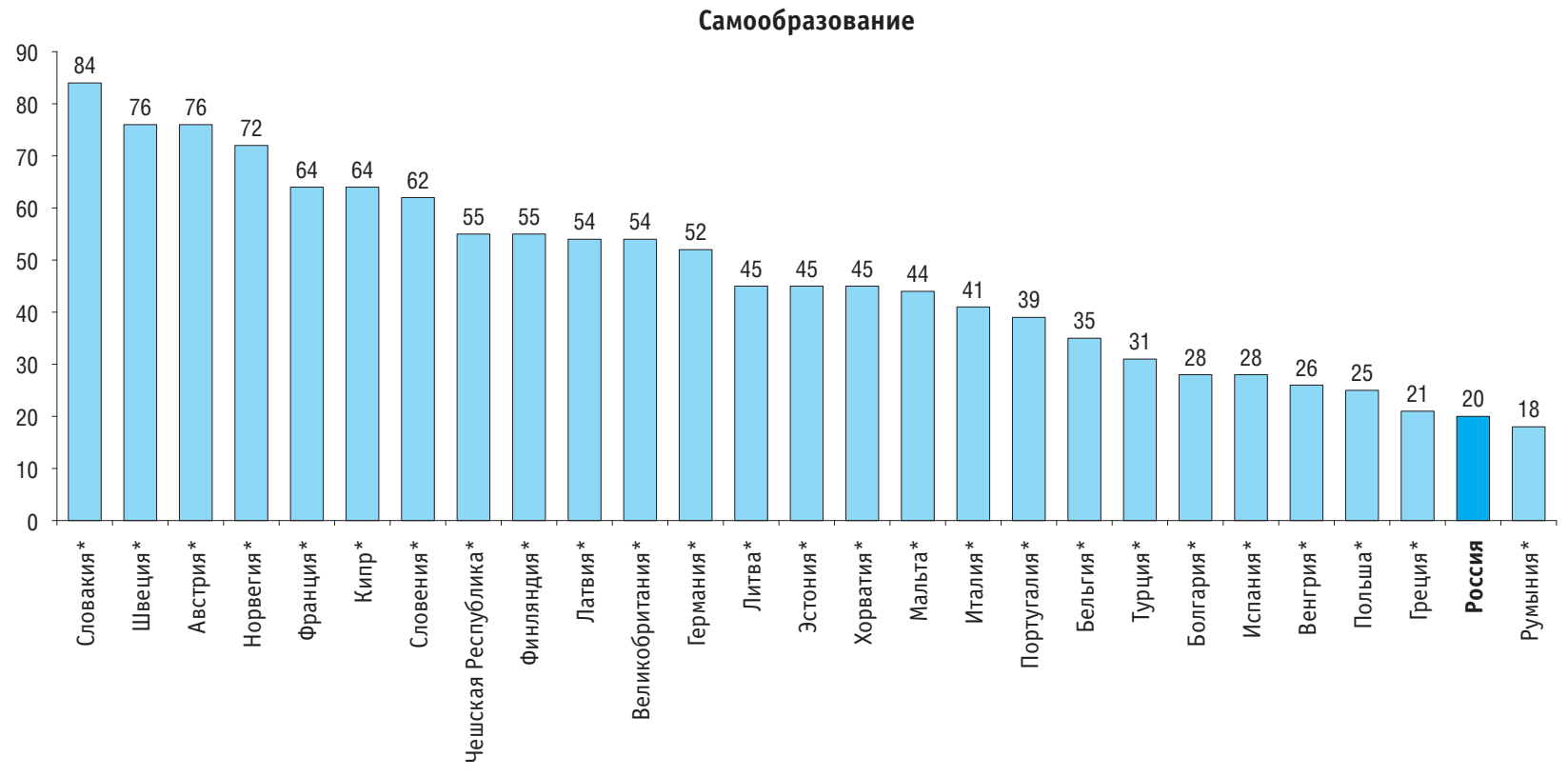




\section{МЕТОДОЛОГИЧЕСКИЕ КОММЕНТАРИИ}

Первоисточником получения сведений об уровне образования населения являются переписи населения. Перепись населения - процесс сбора демографических, экономических и социальных данных, характеризующих каждого жителя страны или территории по состоянию на определенный момент времени. С 1 по 31 октября 2015 г. была проведена микроперепись населения во всех субъектах Российской Федерации, охватившая 2154.2 тыс. человек (1.5\% численности населения России на 01.01.2016 г.).

Средняя ожидаемая продолжительность обучения в течение предстоящей жизни для детей в возрасте 6 лет - число лет, которое человек в возрасте 6 лет может потратить на обучение на всех ступенях образования при существующем уровне охвата обучением и с учетом его потенциальной образовательной траектории. Определяется путем суммирования коэффициента охвата обучением детей соответствующего возраста на каждом году жизни, начиная с 6 лет.

Международная программа по оцениванию образовательных достижений обучающихся (Programme for International Student Assessment - PISA), реализуемая 0ЭСР, ориентирована на оценку образовательных достижений обучающихся 15-летнего возраста и их умения применять полученные знания в жизни. Источник данных по странам - OECD (http://www.oecd.org/pisa)/. В рамках данного обследования используются следующие понятия:

- читательская грамотность - способность человека понимать и использовать письменные тексты, размышлять о них и заниматься чтением для того, чтобы достигать своих целей, расширять свои знания и возможности, участвовать в социальной жизни;

- математическая грамотность - способность человека определять и понимать роль математики в окружающем мире, высказывать хорошо обоснованные математические суждения и использовать математику так, чтобы удовлетворять в настоящем и будущем потребности, присущие созидательному, заинтересованному и мыслящему гражданину;

- естественнонаучная грамотность - способность человека осваивать и использовать естественнонаучные знания для постановки вопросов, освоения новых знаний, объяснения естественнонаучных явлений и формулирования основанных на научных доказательствах выводов, затрагивающих естественнонаучную проблематику; понимать основные особенности естествознания как формы человеческого познания; демонстрировать осведомленность в том, что естественные науки и технология оказывают влияние на материальную, интеллектуальную и культурную сферы общества; проявлять активную гражданскую позицию при рассмотрении проблем, связанных с естествознанием.

Программа международной оценки компетенции взрослых (PIAAC) - программа ОЭСР, целью которой является получение информации о состоянии ключевых компетенций взрослого населения и о применении ключевых навыков на рабочих местах и в повседневной жизни. Ключевые компетенции в целом опре- 
делены как грамотность - заинтересованность и умение людей пользоваться социально-культурными средствами, в том числе цифровыми технологиями и средствами коммуникации, для работы с информацией, формирования новых знаний и общения. Компонентами оценки являются грамотность в области чтения, математическая грамотность и решение задач в технологически насыщенной среде. Источник данных по зарубежным странам OECD Skills Outlook 2013 (http://www.oecd-ilibrary.org/education/ oecd-skills-outlook-2013_9789264204256-en). В рамках данного обследования используются следующие понятия:

- грамотность в области чтения - способность взрослого человека понимать, оценивать, использовать письменные тексты для участия в социальной жизни, реализации различных задач, получения знаний и развития собственного потенциала;

- математическая грамотность - способность взрослого человека оценивать, использовать, интерпретировать и передавать математическую информацию для решения широкого круга жизненных задач и ситуаций.

Данные об участии населения в непрерывном образовании представлены на основе репрезентативных опросов населения. Источник данных по европейским странам - Евростат (http://epp. eurostat.ec.europa.eu, результаты обследований «Adult Education Survey - AES», проведенных в 2007 и 2011 гг.), по России - Институт статистических исследований и экономики знаний НИУ ВШЭ (результаты обследований «Непрерывное образование», проведенных в 2006, 2008, 2012, 2014 и 2015 гг. совместно с Аналитическим центром Юрия Левады, опрошены соответственно 1138, 1135, 1179, 1189 и 1156 человек в возрасте 25-64 лет; а также результаты обследования «Георейтинг», проведенного в 2010 г. совместно с Фондом «Общественное мнение» (ФОМ), опрошены 29.2 тыс. человек в возрасте 25-64 лет). Обследование «Непрерывное образование - 2014» осуществлено в рамках проекта «Мониторинг инновационного поведения населения» Программы фундаментальных исследований НИУ ВШЭ.

Понятие непрерывное образование, или образование в течение всей жизни (lifelong learning) включает все целенаправленные виды образовательной деятельности - формальные или неформальные, осуществляемые на непрерывной основе с целью совершенствования знаний, навыков и умений.

Формальное образование включает образование разных уровней (общее, среднее профессиональное, высшее), которое проводится в организациях, осуществляющих образовательную деятельность, а также подготовку научных кадров в докторантуре. В международной практике используется показатель участия населения в формальном образовании, который учитывает долю лиц, обучавшихся на любых уровнях системы формального образования в течение последних 12 месяцев, среди населения в возрасте 25-64 лет.

Дополнительное образование включает организованные виды обучения, которые не являются частью программ формального образования, - курсы повышения квалификации, профессиональные и любительские курсы; лекции, семинары, тренинги (проводимые на рабочих местах на регулярной основе или разовые); программы дополнительного обучения (включая МВА). В международной практике используется показатель участия населения в дополнительном образовании, который учитывает 
долю лиц, получавших дополнительное образование в течение последних 12 месяцев, среди населения в возрасте 25-64 лет. Используется также показатель участия населения в формальном и (или) дополнительном образовании, который учитывает долю лиц среди населения в возрасте 25-64 лет, участвовавших во всех видах организованного обучения в течение последних 12 месяцев.

Самообразование - неформальное индивидуальное обучение, которое в отличие от формального образования и дополнительного образования не фиксируется получением диплома или иного документа, но вносит вклад в расширение знаний и умений. В международной практике используется показатель участия населения в самообразовании, который учитывает долю лиц среди населения в возрасте 25-64 лет, получавших в течение последних 12 месяцев знания и навыки самостоятельно с помощью печатных материалов (профессиональных книг, журналов и т.п.); технических средств (аудио- и видеозаписей, компьютеров, интернета); при посещении заведений, ориентированных на передачу знаний (библиотек, музеев, выставок, театров, кино и т.п.); при прослушивании учебных передач по радио, просмотре по телевидению; под руководством родственников, друзей, коллег по работе. 


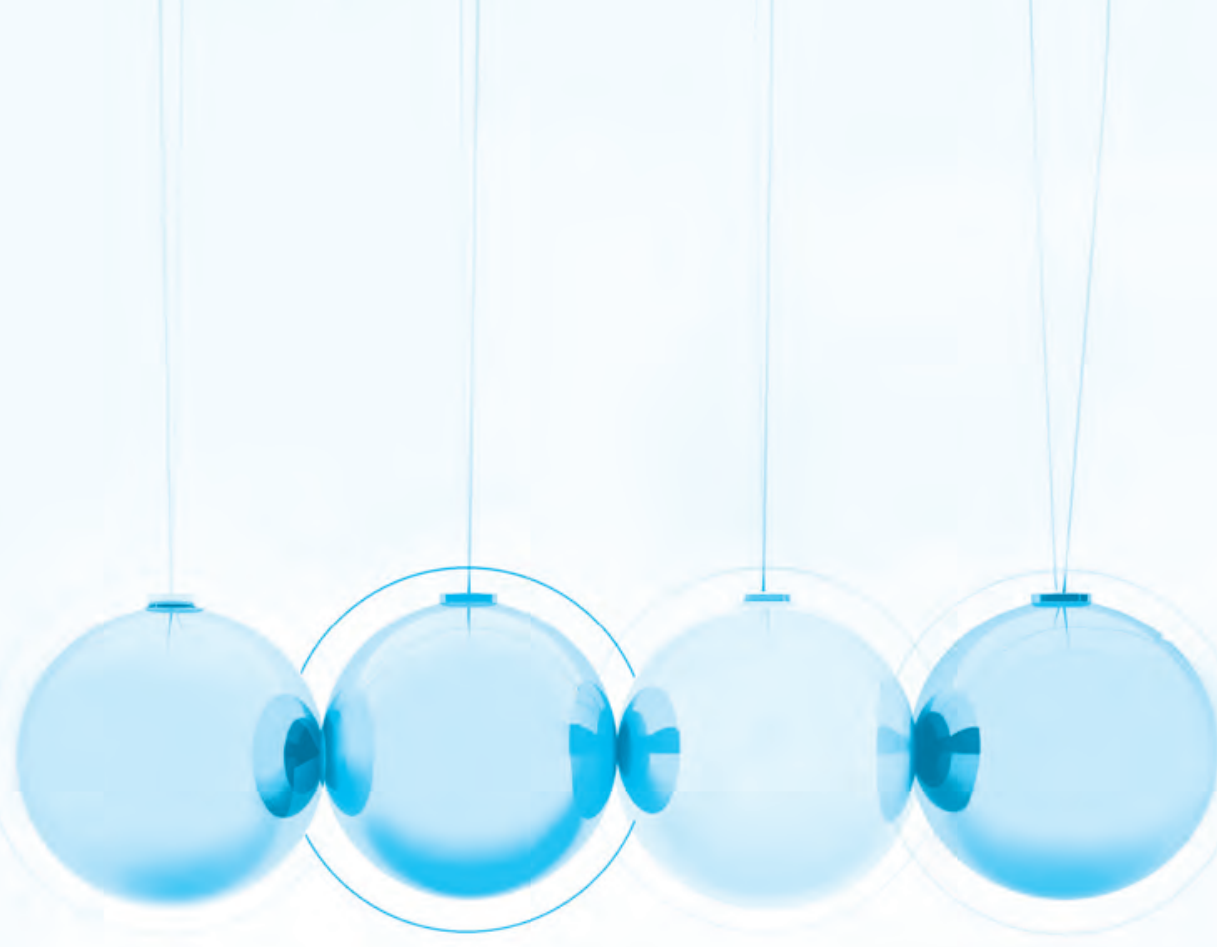

2. Образование и рынок труда 


\section{1. УРОВЕНЬ ЗАНЯТОСТИ И БЕЗРАБОТИЦЫ В ЗАВИСИМОСТИ ОТ УРОВНЯ ОБРАЗОВАНИЯ НАСЕЛЕНИЯ: 2015*}

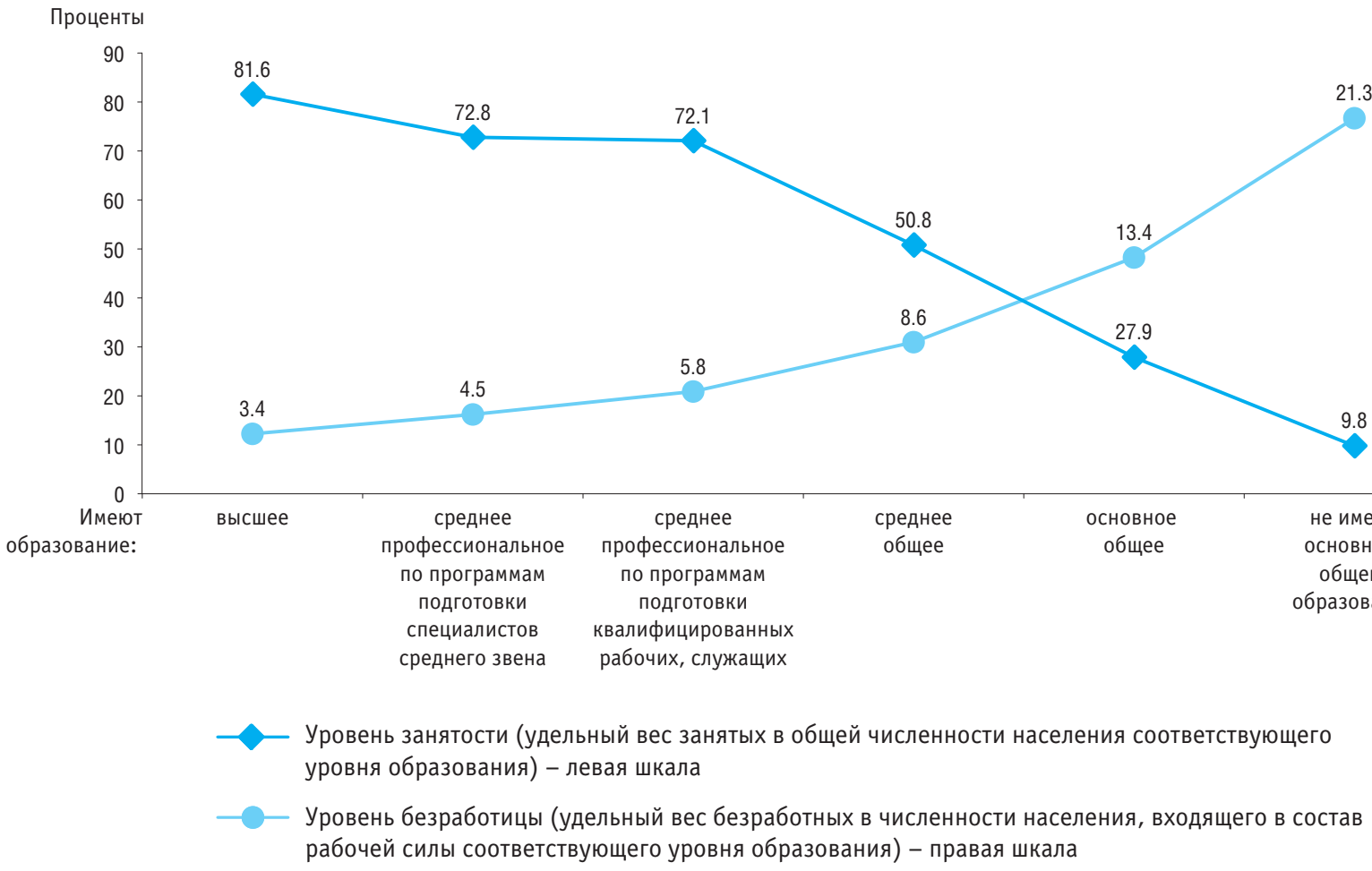

* Здесь и далее (табл. 2.2-2.5, 2.7-2.13, рис. 2.6) информация приведена по данным выборочных обследований рабочей силы. 


\section{2. ЗАНЯТЫЕ ПО УРОВНЮ ОБРАЗОВАНИЯ}

\begin{tabular}{|c|c|c|c|c|c|c|c|c|c|c|}
\hline & \multirow[t]{2}{*}{2000} & \multirow[t]{2}{*}{2005} & \multirow[t]{2}{*}{2010} & \multirow[t]{2}{*}{2011} & \multirow[t]{2}{*}{2012} & \multirow[t]{2}{*}{2013} & \multirow[t]{2}{*}{2014} & \multicolumn{3}{|c|}{2015} \\
\hline & & & & & & & & Всего & Мужчины & Женщины \\
\hline Численность занятых, тыс. чел. & 65070 & 68339 & 69934 & 70857 & 71545 & 71391 & 71539 & 72324 & 37136 & 35187 \\
\hline \multicolumn{11}{|l|}{ Имеют образование: } \\
\hline высшее & 13981 & 16646 & 20381 & 21129 & 21740 & 22616 & 23045 & 23847 & 10745 & 13102 \\
\hline неполное высшее профессиональное* & 2104 & 1290 & - & - & - & - & - & - & - & - \\
\hline \multicolumn{11}{|c|}{ среднее профессиональное по программам подготовки } \\
\hline специалистов среднего звена & 20118 & 17519 & 18960 & 19118 & 18748 & 18400 & 18486 & 18668 & 8145 & 10523 \\
\hline \multicolumn{11}{|c|}{ среднее профессиональное по программам подготовки } \\
\hline квалифицированных рабочих, служащих & 6603 & 12598 & 13683 & 13745 & 13955 & 13237 & 13618 & 13853 & 8764 & 5088 \\
\hline среднее общее & 15056 & 15446 & 13894 & 13907 & 14236 & 14446 & 13745 & 13322 & 7816 & 5507 \\
\hline основное общее & 5657 & 4367 & 2778 & 2730 & 2671 & 2511 & 2484 & 2485 & 1570 & 915 \\
\hline не имеют основного общего образования & 1551 & 474 & 237 & 228 & 196 & 181 & 160 & 147 & 96 & 52 \\
\hline \multicolumn{11}{|c|}{$\begin{array}{l}\text { Уровень занятости населения (удельный вес занятых } \\
\text { в общей численности населения соответствующего }\end{array}$} \\
\hline уровня образования; проценты) & 58.5 & 61.3 & 62.7 & 63.9 & 64.9 & 64.8 & 65.3 & 65.3 & 71.1 & 60.1 \\
\hline \multicolumn{11}{|l|}{ Имеют образование: } \\
\hline высшее & 79.0 & 81.3 & 81.2 & 81.6 & 82.4 & 81.8 & 82.2 & 81.6 & 86.6 & 77.8 \\
\hline неполное высшее профессиональное* & 49.3 & 40.4 & - & - & - & - & - & - & - & - \\
\hline \multicolumn{11}{|c|}{ среднее профессиональное по программам подготовки } \\
\hline специалистов среднего звена & 72.5 & 75.0 & 73.3 & 73.7 & 74.3 & 73.8 & 73.8 & 72.8 & 81.3 & 67.4 \\
\hline \multicolumn{11}{|c|}{ среднее профессиональное по программам подготовки } \\
\hline квалифицированных рабочих, служащих & 68.1 & 75.5 & 72.3 & 73.0 & 73.7 & 73.0 & 72.8 & 72.1 & 78.1 & 63.6 \\
\hline среднее общее & 56.4 & 52.9 & 48.7 & 49.5 & 50.0 & 50.4 & 51.3 & 50.8 & 59.3 & 42.2 \\
\hline основное общее & 34.1 & 28.7 & 25.4 & 26.7 & 28.1 & 27.3 & 26.8 & 27.9 & 34.0 & 21.3 \\
\hline не имеют основного общего образования & 18.3 & 13.9 & 11.1 & 11.6 & 11.6 & 11.1 & 9.5 & 9.8 & 12.6 & 6.9 \\
\hline
\end{tabular}

* С 2009 г. неполное высшее профессиональное образование учитывается по последнему полученному уровню образования. 
2.3. УРОВЕНЬ ЗАНЯТОСТИ НАСЕЛЕНИЯ ПО УРОВНЮ ОБРАЗОВАНИЯ И ВОЗРАСТНЫМ ГРУППАМ: 2015 (удельный вес занятых в общей численности населения соответствующего уровня образования и возрастной группы; проценты)

\begin{tabular}{|c|c|c|c|c|c|c|c|}
\hline & \multirow[t]{2}{*}{ Всего } & \multicolumn{6}{|c|}{ Имеют образование } \\
\hline & & высшее & $\begin{array}{c}\text { среднее профес- } \\
\text { сиональное } \\
\text { по программам } \\
\text { подготовки } \\
\text { специалистов } \\
\text { среднего звена }\end{array}$ & $\begin{array}{c}\text { среднее профес- } \\
\text { сиональное } \\
\text { по программам } \\
\text { подготовки ква- } \\
\text { лифицированных } \\
\text { рабочих, } \\
\text { служащих }\end{array}$ & $\begin{array}{l}\text { среднее } \\
\text { общее }\end{array}$ & $\begin{array}{c}\text { основное } \\
\text { общее }\end{array}$ & $\begin{array}{c}\text { не имеют } \\
\text { основного } \\
\text { общего } \\
\text { образования }\end{array}$ \\
\hline Занято & 65.3 & 81.6 & 72.8 & 72.1 & 50.8 & 27.9 & 9.8 \\
\hline \multicolumn{8}{|c|}{ Возраст, лет: } \\
\hline $15-19$ & 5.9 & 18.6 & 53.0 & 53.3 & 8.2 & 2.8 & 1.9 \\
\hline $20-24$ & 49.9 & 74.2 & 77.2 & 77.7 & 25.7 & 43.0 & 16.1 \\
\hline $25-29$ & 82.4 & 87.0 & 86.0 & 84.7 & 73.2 & 62.9 & 24.0 \\
\hline $30-34$ & 84.7 & 89.0 & 88.0 & 87.0 & 77.6 & 62.2 & 25.0 \\
\hline $35-39$ & 87.4 & 92.7 & 90.4 & 87.9 & 80.8 & 68.1 & 34.4 \\
\hline $40-44$ & 88.9 & 94.4 & 92.0 & 88.9 & 81.4 & 68.2 & 24.0 \\
\hline $45-49$ & 88.4 & 94.7 & 90.4 & 87.5 & 81.6 & 66.7 & 33.9 \\
\hline $50-54$ & 83.0 & 90.6 & 85.0 & 81.7 & 76.9 & 62.1 & 30.4 \\
\hline $55-59$ & 62.0 & 75.0 & 61.5 & 62.3 & 54.6 & 41.6 & 21.4 \\
\hline $60-64$ & 30.8 & 44.2 & 31.2 & 28.4 & 24.2 & 20.1 & 13.3 \\
\hline $65-72$ & 11.7 & 18.1 & 13.3 & 9.0 & 9.2 & 7.5 & 4.4 \\
\hline
\end{tabular}




\section{4. БЕЗРАБОТНЫЕ ПО УРОВНЮ ОБРАЗОВАНИЯ}

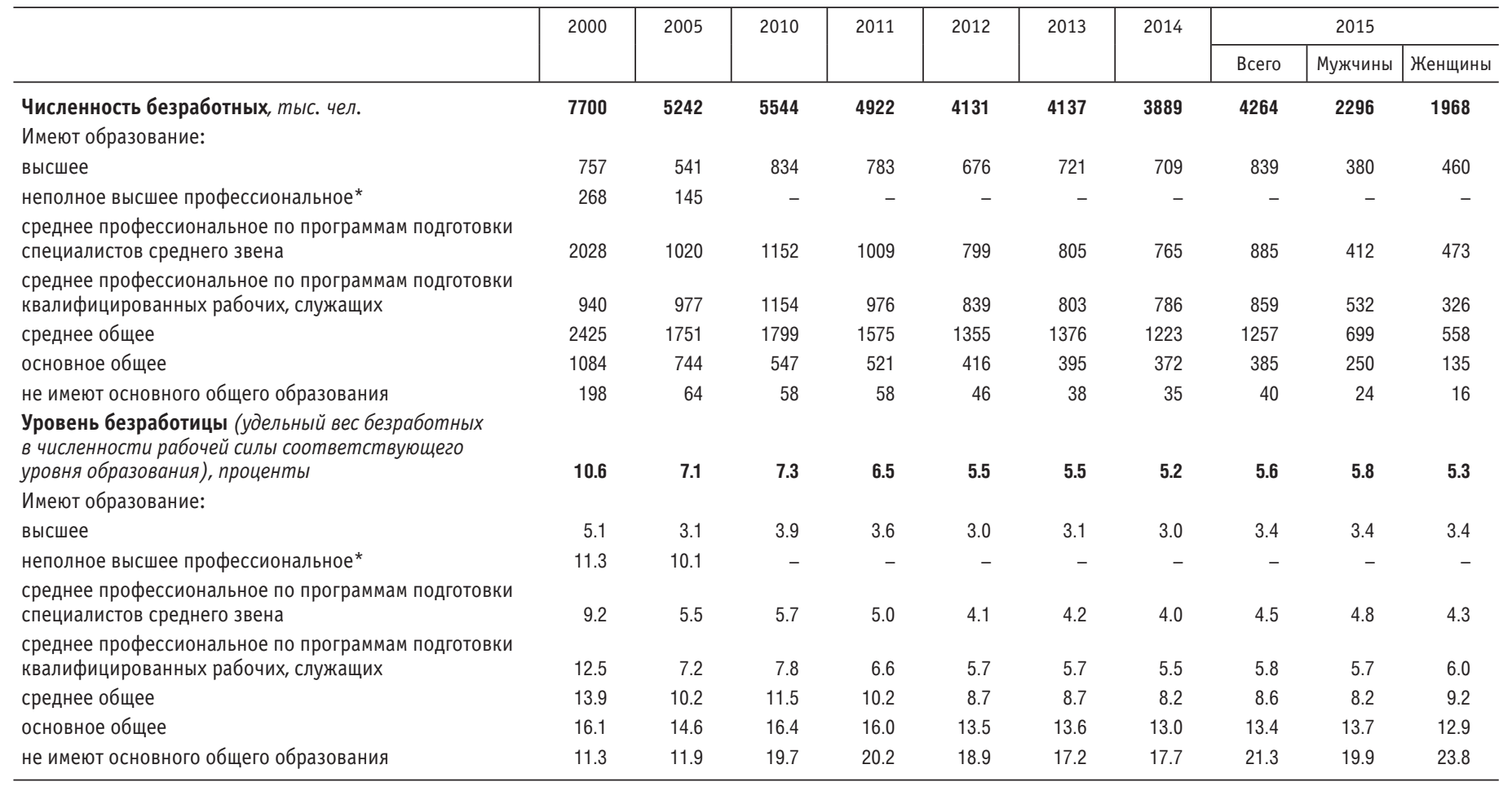

* С 2009 г. неполное высшее профессиональное образование учитывается по последнему полученному уровню образования. 


\section{5. УРОВЕНЬ БЕЗРАБОТИЦЫ ПО УРОВНЮ ОБРАЗОВАНИЯ И ВОЗРАСТНЫМ ГРУППАМ: 2015 \\ (удельный вес безработных в численности рабочей силы соответствующего уровня образования и возрастной группы; проценты)}

\begin{tabular}{|c|c|c|c|c|c|c|c|}
\hline & \multirow[t]{2}{*}{ Bcero } & \multicolumn{6}{|c|}{ Имеют образование } \\
\hline & & высшее & $\begin{array}{c}\text { среднее про- } \\
\text { фессиональное } \\
\text { по программам } \\
\text { подготовки } \\
\text { специалистов } \\
\text { среднего звена }\end{array}$ & $\begin{array}{c}\text { среднее про- } \\
\text { фессиональное } \\
\text { по программам } \\
\text { подготовки } \\
\text { квалифициро- } \\
\text { ванных рабочих, } \\
\text { служащих } \\
\end{array}$ & $\begin{array}{l}\text { среднее } \\
\text { общее }\end{array}$ & $\begin{array}{l}\text { основное } \\
\text { общее }\end{array}$ & $\begin{array}{c}\text { не имеют } \\
\text { основного } \\
\text { общего } \\
\text { образования }\end{array}$ \\
\hline Безработные & 5.6 & 3.4 & 4.5 & 5.8 & 8.6 & 13.4 & 21.3 \\
\hline \multicolumn{8}{|l|}{ Возраст, лет: } \\
\hline $15-19$ & 32.4 & 51.6 & 27.8 & 27.8 & 33.2 & 35.1 & 28.5 \\
\hline $20-24$ & 14.3 & 14.6 & 10.8 & 11.3 & 18.3 & 20.7 & 31.1 \\
\hline $25-29$ & 6.2 & 4.2 & 4.8 & 6.4 & 10.0 & 15.0 & 29.8 \\
\hline $30-34$ & 5.1 & 3.0 & 4.4 & 5.3 & 8.3 & 14.2 & 20.5 \\
\hline $35-39$ & 4.5 & 2.2 & 3.6 & 5.6 & 6.9 & 11.9 & 19.0 \\
\hline $40-44$ & 4.1 & 1.9 & 3.2 & 4.9 & 6.6 & 12.1 & 24.8 \\
\hline $45-49$ & 4.0 & 1.7 & 3.8 & 5.0 & 5.8 & 10.9 & 12.9 \\
\hline $50-54$ & 4.5 & 2.3 & 4.1 & 5.6 & 6.2 & 9.0 & 17.3 \\
\hline $55-59$ & 3.9 & 2.4 & 3.5 & 4.8 & 4.9 & 7.3 & 14.7 \\
\hline $60-64$ & 3.2 & 2.6 & 3.5 & 3.7 & 2.6 & 4.8 & 4.5 \\
\hline $65-72$ & 2.8 & 2.3 & 3.1 & 3.2 & 2.9 & 2.6 & 6.8 \\
\hline
\end{tabular}




\section{6. СРЕДНЯЯ ПРОДОЛЖИТЕЛЬНОСТЬ БЕЗРАБОТИЦЫ ПО УРОВНЮ ОБРАЗОВАНИЯ}

(среднее время поиска работы; месяцы)

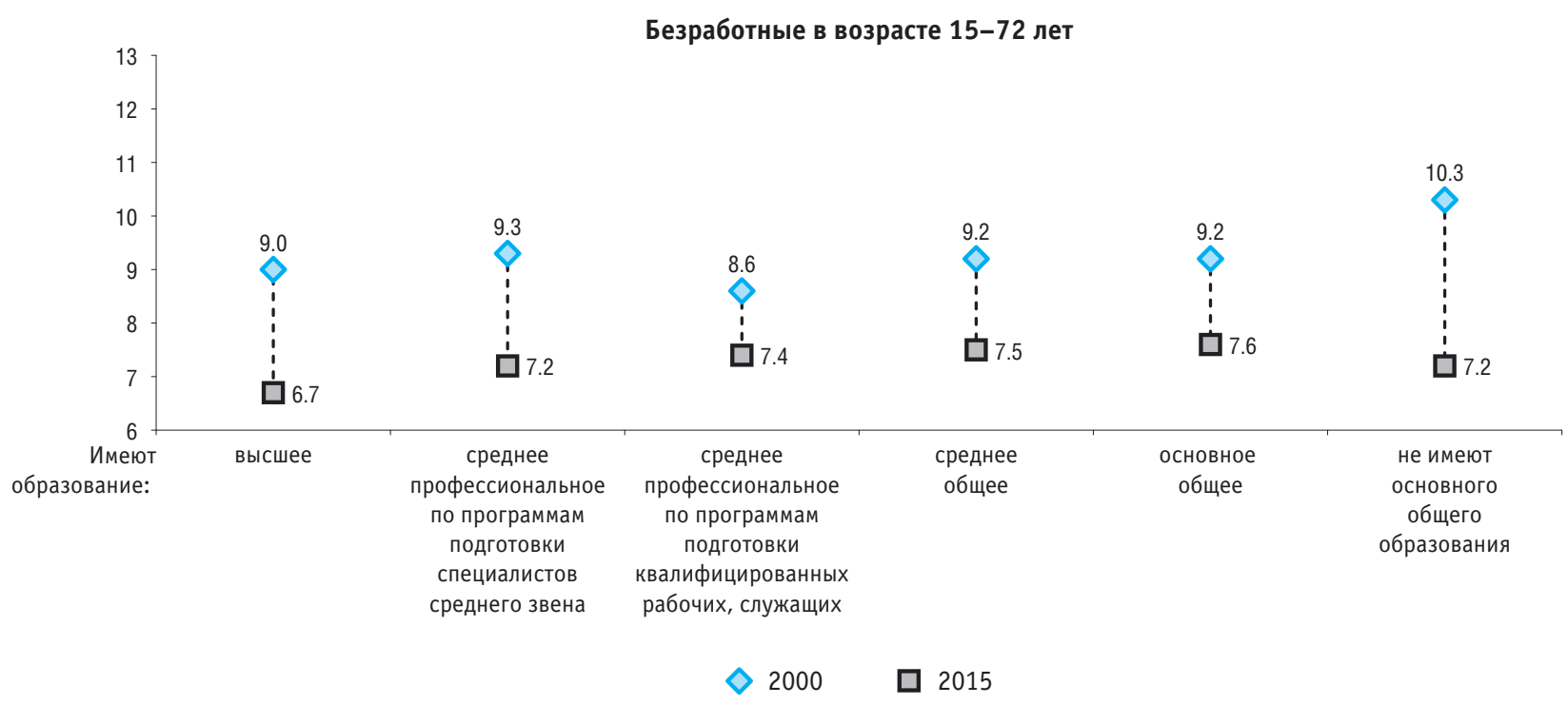


(окончание)

\section{Безработные в возрасте 25-34 лет}

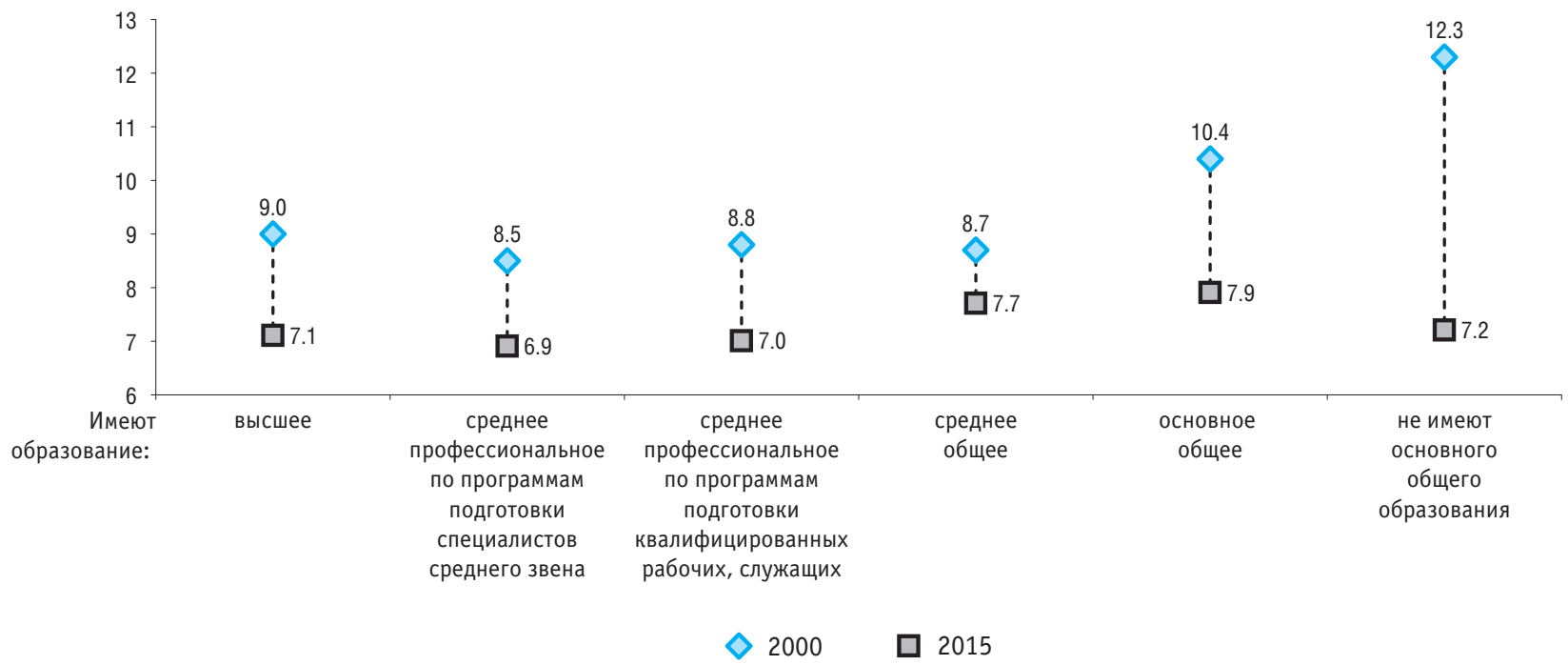




\section{7. ДЛИТЕЛЬНАЯ БЕЗРАБОТИЦА ПО УРОВНЮ ОБРАЗОВАНИЯ И ПОЛУ: 2015}

(удельный вес безработных, ищущих работу 12 месяцев и более, в общей численности безработных соответствующего уровня образования; проценты)

\begin{tabular}{|c|c|c|c|c|c|c|}
\hline & \multicolumn{3}{|c|}{ Безработные в возрасте 15-72 лет } & \multicolumn{3}{|c|}{ Безработные в возрасте 25-34 лет } \\
\hline & Bсего & Мужчины & Женщины & Bcero & Мужчины & Женщины \\
\hline Bcero & 27.3 & 26.7 & 28.0 & 27.0 & 25.6 & 28.6 \\
\hline Имеют образование: & & & & & & \\
\hline высшее & 22.7 & 22.5 & 22.8 & 24.3 & 23.7 & 24.8 \\
\hline $\begin{array}{l}\text { среднее профессиональное по программам подготовки } \\
\text { специалистов среднего звена }\end{array}$ & 25.9 & 23.4 & 28.0 & 24.4 & 21.2 & 27.4 \\
\hline $\begin{array}{l}\text { среднее профессиональное по программам подготовки } \\
\text { квалифицированных рабочих, служащих }\end{array}$ & 29.1 & 27.9 & 31.0 & 25.4 & 23.4 & 28.3 \\
\hline среднее общее & 28.9 & 28.6 & 29.3 & 30.6 & 28.6 & 32.8 \\
\hline основное общее & 31.3 & 30.2 & 33.3 & 32.0 & 31.3 & 33.2 \\
\hline не имеют основного общего образования & 29.9 & 32.8 & 25.5 & 27.9 & 31.0 & 21.9 \\
\hline
\end{tabular}




\section{8. УРОВЕНЬ УЧАСТИЯ В РАБОЧЕЙ СИЛЕ НАСЕЛЕНИЯ, ИМЕЮЩЕГО ВЫСШЕЕ ОБРАЗОВАНИЕ, ПО СПЕЦИАЛЬНОСТЯМ И НАПРАВЛЕНИЯМ ПОДГОТОВКИ ПО ДИПЛОМУ: 2015}

\begin{tabular}{|c|c|c|c|c|c|}
\hline & \multirow{2}{*}{$\begin{array}{c}\text { Рабочая сила, } \\
\text { тыс. чел. }\end{array}$} & \multicolumn{2}{|c|}{ В том числе } & \multirow{2}{*}{$\begin{array}{c}\text { Уровень } \\
\text { занятости, } \\
\text { проценты"* }\end{array}$} & \multirow{2}{*}{$\begin{array}{c}\text { Уровень } \\
\text { безработицы, } \\
\text { проценты* }\end{array}$} \\
\hline & & занятые & безработные & & \\
\hline Bсего & 24687 & 23847 & 839 & 81.6 & 3.4 \\
\hline \multicolumn{6}{|l|}{ Специальности и направления подготовки: } \\
\hline экономика и управление & 6646 & 6365 & 281 & 82.7 & 4.2 \\
\hline образование и педагогика & 4034 & 3921 & 112 & 78.4 & 2.8 \\
\hline гуманитарные науки & 3034 & 2910 & 124 & 83.4 & 4.1 \\
\hline здравоохранение & 1544 & 1526 & 18 & 84.3 & 1.1 \\
\hline архитектура и строительство & 1219 & 1178 & 41 & 80.9 & 3.3 \\
\hline \multicolumn{6}{|l|}{ энергетика, энергетическое машиностроение } \\
\hline и электротехника & 880 & 859 & 22 & 83.1 & 2.4 \\
\hline сельское и рыбное хозяйство & 744 & 715 & 29 & 77.1 & 3.9 \\
\hline металлургия, машиностроение и материалообработка & 820 & 796 & 24 & 79.2 & 2.9 \\
\hline информатика и вычислительная техника & 707 & 688 & 19 & 91.6 & 2.7 \\
\hline транспортные средства & 628 & 607 & 21 & 84.0 & 3.3 \\
\hline физико-математические специальности & 442 & 428 & 13 & 83.2 & 3.0 \\
\hline электронная техника, радиотехника и связь & 516 & 505 & 11 & 81.7 & 2.0 \\
\hline культура и искусство & 486 & 465 & 21 & 80.2 & 4.3 \\
\hline
\end{tabular}

* Удельный вес занятых в общей численности населения с высшим образованием соответствующей специальности (направления подготовки).

** Удельный вес безработных в численности населения с высшим образованием, входящего в состав рабочей силы, соответствующей специальности (направления подготовки). 


\section{9. УРОВЕНЬ УЧАСТИЯ В РАБОЧЕЙ СИЛЕ НАСЕЛЕНИЯ, ИМЕЮЩЕГО СРЕДНЕЕ ПРОФЕССИОНАЛЬНОЕ ОБРАЗОВАНИЕ ПО ПРОГРАММАМ ПОДГОТОВКИ СПЕЦИАЛИСТОВ СРЕДНЕГО ЗВЕНА, ПО СПЕЦИАЛЬНОСТЯМ ПО ДИПЛОМУ: 2015}

\begin{tabular}{|c|c|c|c|c|c|}
\hline & \multirow{2}{*}{$\begin{array}{c}\text { Рабочая сила, } \\
\text { тыс. чел. }\end{array}$} & \multicolumn{2}{|c|}{ В том числе } & \multirow{2}{*}{$\begin{array}{c}\text { Уровень } \\
\text { занятости, } \\
\text { проценты।* }\end{array}$} & \multirow{2}{*}{$\begin{array}{c}\text { Уровень } \\
\text { безработицы } \\
\text { проценты }\end{array}$} \\
\hline & & занятые & безработные & & \\
\hline Bcero & 19553 & 18668 & 885 & 72.8 & 4.5 \\
\hline \multicolumn{6}{|l|}{ Специальности: } \\
\hline экономика и управление & 3755 & 3557 & 198 & 68.3 & 5.3 \\
\hline здравоохранение & 2769 & 2700 & 68 & 74.6 & 2.5 \\
\hline транспортные средства & 1942 & 1857 & 85 & 81.8 & 4.4 \\
\hline образование и педагогика & 1744 & 1680 & 64 & 70.7 & 3.7 \\
\hline металлургия, машиностроение и материалообработка & 1069 & 1022 & 47 & 74.0 & 4.4 \\
\hline сельское и рыбное хозяйство & 1058 & 1003 & 55 & 69.8 & 5.2 \\
\hline \multicolumn{6}{|l|}{ энергетика, энергетическое машиностроение } \\
\hline и электротехника & 1025 & 983 & 43 & 76.8 & 4.2 \\
\hline архитектура и строительство & 1054 & 1001 & 53 & 73.4 & 5.0 \\
\hline \multicolumn{6}{|c|}{ технология продовольственных продуктов и потребительских } \\
\hline товаров & 1092 & 1029 & 63 & 66.1 & 5.8 \\
\hline гуманитарные науки & 680 & 637 & 42 & 79.8 & 6.2 \\
\hline электронная техника, радиотехника и связь & 516 & 492 & 24 & 72.6 & 4.6 \\
\hline культура и искусство & 465 & 439 & 27 & 68.9 & 5.8 \\
\hline информатика и вычислительная техника & 357 & 335 & 21 & 83.9 & 5.9 \\
\hline
\end{tabular}

* Удельный вес занятых в общей численности населения со средним профессиональным образованием по программам подготовки специалистов среднего звена соответствующей специальности.

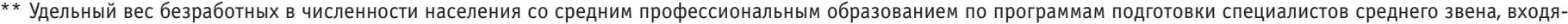
щего в состав рабочей силы, соответствующей специальности. 


\subsection{0. УРОВЕНЬ УЧАСТИЯ В РАБОЧЕЙ СИЛЕ НАСЕЛЕНИЯ, ИМЕЮЩЕГО СРЕДНЕЕ ПРОФЕССИОНАЛЬНОЕ ОБРАЗОВАНИЕ ПО ПРОГРАММАМ ПОДГОТОВКИ КВАЛИФИЦИРОВАННЫХ РАБОЧИХ, СЛУЖАЩИХ, ПО ПРОФЕССИЯМ ПО ДИПЛОМУ: 2015}

\begin{tabular}{|c|c|c|c|c|c|}
\hline & \multirow{2}{*}{$\begin{array}{c}\text { Рабочая сила, } \\
\text { тыс. чел. }\end{array}$} & \multicolumn{2}{|c|}{ В том числе } & \multirow{2}{*}{$\begin{array}{c}\text { Уровень } \\
\text { занятости, } \\
\text { проценты* }\end{array}$} & \multirow{2}{*}{$\begin{array}{c}\text { Уровень } \\
\text { безработицы } \\
\text { проценты } 1^{* *}\end{array}$} \\
\hline & & занятые & безработные & & \\
\hline Bcero & 14711 & 13853 & 859 & 72.1 & 5.8 \\
\hline \multicolumn{6}{|l|}{ Профессии: } \\
\hline металлообработка & 2780 & 2621 & 159 & 77.4 & 5.7 \\
\hline \multicolumn{6}{|l|}{ общественное питание, торговля и производство пищевой } \\
\hline продукции & 2776 & 2608 & 168 & 68.5 & 6.0 \\
\hline транспорт & 2616 & 2492 & 124 & 79.0 & 4.8 \\
\hline сельское хозяйство & 1132 & 1050 & 82 & 71.2 & 7.2 \\
\hline строительные, монтажные и ремонтно-строительные работы & 1352 & 1256 & 95 & 67.9 & 7.1 \\
\hline легкая промышленность & 978 & 923 & 55 & 61.8 & 5.6 \\
\hline должности служащих & 463 & 430 & 33 & 65.6 & 7.1 \\
\hline сфера обслуживания & 584 & 558 & 26 & 76.3 & 4.4 \\
\hline общие для всех видов экономической деятельности & 938 & 885 & 54 & 74.3 & 5.7 \\
\hline
\end{tabular}

* Удельный вес занятых в общей численности населения со средним профессиональным образованием по программам подготовки квалифицированных рабочих, служащих соответствующей профессии.

** Удельный вес безработных в численности населения со средним профессиональным образованием по программам подготовки квалифицированных рабочих, служащих, входящего в состав рабочей силы, соответствующей профессии. 
2.11. УРОВЕНЬ УЧАСТИЯ В РАБОЧЕЙ СИЛЕ ВЫПУСКНИКОВ, ОКОНЧИВШИХ ПРОФЕССИОНАЛЬНЫЕ ОБРАЗОВАТЕЛЬНЫЕ ОРГАНИЗАЦИИ И ОБРАЗОВАТЕЛЬНЫЕ ОРГАНИЗАЦИИ ВЫСШЕГО ОБРАЗОВАНИЯ В 2012-2014 ГГ.: 2015

\begin{tabular}{|c|c|c|c|c|c|}
\hline & \multirow{2}{*}{$\begin{array}{l}\text { Рабочая сила, } \\
\text { тыс. чел. }\end{array}$} & \multicolumn{2}{|c|}{ В том числе } & \multirow{2}{*}{$\begin{array}{c}\text { Уровень } \\
\text { занятости, } \\
\text { процентыь }\end{array}$} & \multirow{2}{*}{$\begin{array}{c}\text { Уровень } \\
\text { безработицы } \\
\text { проценты }{ }^{\star \star}\end{array}$} \\
\hline & & занятые & безработные & & \\
\hline Всего & 4908 & 4506 & 401 & 81.9 & 8.2 \\
\hline \multicolumn{6}{|l|}{ Имеют образование: } \\
\hline высшее & 3002 & 2810 & 192 & 84.8 & 6.4 \\
\hline $\begin{array}{l}\text { среднее профессиональное по программам подготовки } \\
\text { специалистов среднего звена }\end{array}$ & 1270 & 1146 & 123 & 79.2 & 9.7 \\
\hline $\begin{array}{l}\text { среднее профессиональное по программам подготовки } \\
\text { квалифицированных рабочих, служащих }\end{array}$ & 636 & 550 & 86 & 74.5 & 13.5 \\
\hline
\end{tabular}

* Удельный вес занятых в общей численности выпускников, получивших соответствующий уровень образования.

** Удельный вес безработных в численности выпускников, получивших соответствующий уровень образования и входящих в состав рабочей силы. 
2.12. СВЯЗЬ ОСНОВНОЙ РАБОТЫ С ПОЛУЧЕННОЙ ПРОФЕССИЕЙ (СПЕЦИАЛЬНОСТЬЮ) ЗАНЯТЫХ ПО УРОВНЮ ПРОФЕССИОНАЛЬНОГО ОБРАЗОВАНИЯ

\begin{tabular}{|c|c|c|c|}
\hline & 2013 & 2014 & 2015 \\
\hline Численность занятых, тыс. чел. & 71391 & 71539 & 72324 \\
\hline \multicolumn{4}{|l|}{$\begin{array}{l}\text { В том числе имеют работу, связанную с полученной профессией } \\
\text { (специальностью), проценты }\end{array}$} \\
\hline Всего & 54.2 & 55.3 & 54.8 \\
\hline \multicolumn{4}{|l|}{ Имеют образование: } \\
\hline высшее & 23.0 & 23.5 & 23.8 \\
\hline $\begin{array}{l}\text { среднее профессиональное по программам подготовки } \\
\text { специалистов среднего звена }\end{array}$ & 15.3 & 15.6 & 15.4 \\
\hline $\begin{array}{l}\text { среднее профессиональное по программам подготовки } \\
\text { квалифицированных рабочих, служащих }\end{array}$ & 10.3 & 10.9 & 10.7 \\
\hline
\end{tabular}




\subsection{3. ПОТЕНЦИАЛЬНАЯ РАБОЧАЯ СИЛА ПО УРОВНЮ ОБРАЗОВАНИЯ}

(тысячи человек)

\begin{tabular}{|c|c|c|c|c|c|c|c|c|}
\hline & \multirow[t]{2}{*}{2010} & \multirow[t]{2}{*}{2011} & \multirow[t]{2}{*}{2012} & \multirow[t]{2}{*}{2013} & \multirow[t]{2}{*}{2014} & \multicolumn{3}{|c|}{2015} \\
\hline & & & & & & Всего & Мужчины & Женщины \\
\hline $\begin{array}{l}\text { Численность потенциальной рабочей силы } \\
\text { Имеют образование: }\end{array}$ & 1731 & 1580 & 1401 & 1439 & 1338 & 1343 & 607 & 736 \\
\hline высшее & 166 & 157 & 139 & 162 & 155 & 150 & 53 & 97 \\
\hline $\begin{array}{l}\text { среднее профессиональное по программам подготовки } \\
\text { специалистов среднего звена }\end{array}$ & 304 & 284 & 259 & 271 & 259 & 278 & 90 & 188 \\
\hline $\begin{array}{l}\text { среднее профессиональное по программам подготовки } \\
\text { квалифицированных рабочих, служащих }\end{array}$ & 336 & 307 & 270 & 269 & 241 & 256 & 135 & 121 \\
\hline среднее общее & 585 & 520 & 472 & 493 & 437 & 436 & 207 & 230 \\
\hline основное общее & 297 & 274 & 227 & 214 & 213 & 197 & 106 & 91 \\
\hline не имеют основного общего образования & 44 & 38 & 33 & 29 & 33 & 26 & 17 & 9 \\
\hline
\end{tabular}




\subsection{4. СРЕДНЯЯ ЗАРАБОТНАЯ ПЛАТА РАБОТНИКОВ ПО УРОВНЮ ОБРАЗОВАНИЯ И ПОЛУ*} (рубли)

\begin{tabular}{|c|c|c|c|c|c|c|c|}
\hline & \multirow[t]{2}{*}{ Всего } & \multicolumn{6}{|c|}{ Имеют образование } \\
\hline & & высшее & $\begin{array}{c}\text { среднее про- } \\
\text { фессиональное } \\
\text { по программам } \\
\text { подготовки } \\
\text { специалистов } \\
\text { среднего звена }\end{array}$ & $\begin{array}{c}\text { среднее про- } \\
\text { фессиональное } \\
\text { по программам } \\
\text { подготовки } \\
\text { квалифициро- } \\
\text { ванных рабочих, } \\
\text { служащих }\end{array}$ & $\begin{array}{c}\text { среднее } \\
\text { общее }\end{array}$ & $\begin{array}{l}\text { основное } \\
\text { общее }\end{array}$ & $\begin{array}{c}\text { не имеют } \\
\text { основного } \\
\text { общего } \\
\text { образования }\end{array}$ \\
\hline \multicolumn{8}{|c|}{2005} \\
\hline Все работники & 8694 & 11383 & 7722 & 8123 & 7726 & 6418 & 5772 \\
\hline Мужчины & 10869 & 14307 & 10197 & 9842 & 9894 & 8119 & 7219 \\
\hline Женщины & 6926 & 9504 & 6320 & 5570 & 5260 & 4286 & 3972 \\
\hline \multicolumn{8}{|c|}{2011} \\
\hline Все работники & 22717 & 29927 & 18901 & 19746 & 18538 & 15970 & 14545 \\
\hline Мужчины & 27563 & 37457 & 23992 & 23449 & 22907 & 19942 & 17311 \\
\hline Женщины & 18718 & 25099 & 15714 & 13809 & 13180 & 10934 & 10908 \\
\hline \multicolumn{8}{|c|}{2013} \\
\hline Все работники & 28702 & 38233 & 23869 & 23926 & 22886 & 21622 & 19850 \\
\hline Мужчины & 33301 & 45952 & 28464 & 27947 & 27339 & 25769 & 23187 \\
\hline Женщины & 24721 & 33050 & 21093 & 18792 & 16898 & 16086 & 14809 \\
\hline \multicolumn{8}{|c|}{2015} \\
\hline Все работники & 32911 & 43362 & 26929 & 27128 & 25944 & 23724 & 23814 \\
\hline Мужчины & 38605 & 52829 & 32518 & 31731 & 31017 & 27984 & 27970 \\
\hline Женщины & 28021 & 36902 & 23369 & 20439 & 19522 & 17756 & 18185 \\
\hline
\end{tabular}

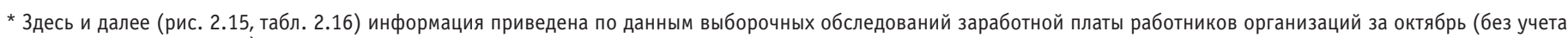
единовременных выплат). 


\subsection{5. СООТНОШЕНИЕ СРЕДНЕЙ ЗАРАБОТНОЙ ПЛАТЫ РАБОТНИКОВ ПО УРОВНЮ ОБРАЗОВАНИЯ}

(заработная плата работников со средним общим образованием =100\%)

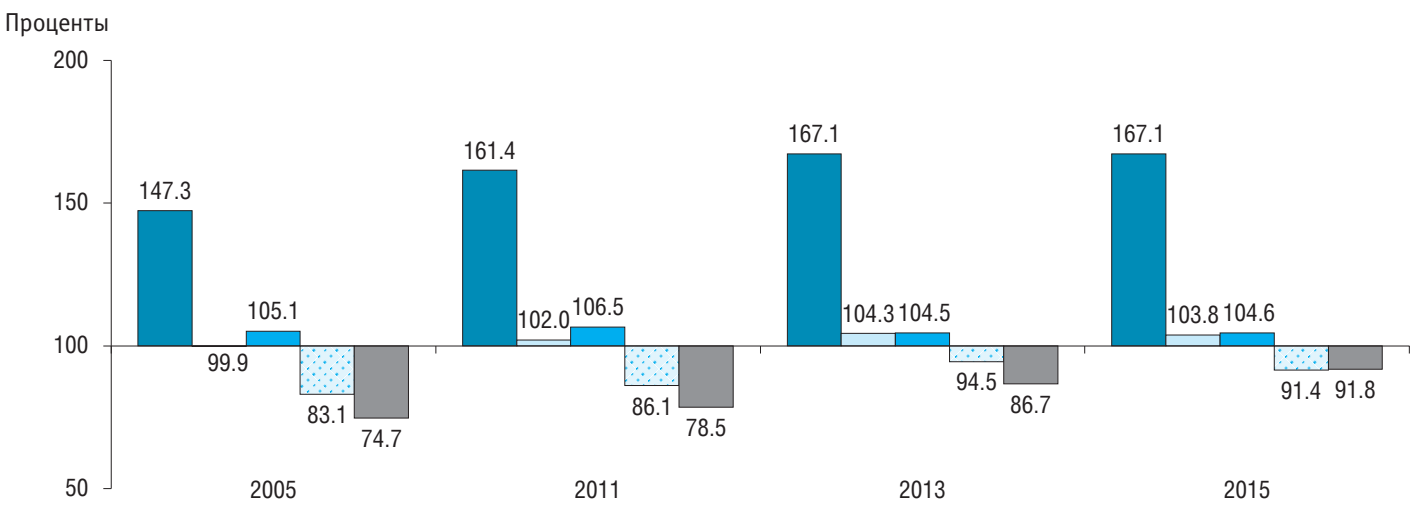

Имеют образование:

высшее

среднее профессиональное по программам подготовки специалистов среднего звена

$\square$ среднее профессиональное по программам подготовки квалифицированных рабочих, служащих основное общее

не имеют основного общего образования 


\subsection{6. СРЕДНЯЯ ЗАРАБОТНАЯ ПЛАТА РАБОТНИКОВ ПО ГРУППАМ ЗАНЯТИЙ И УРОВНЮ ОБРАЗОВАНИЯ: 2015 (рубли)}

\begin{tabular}{|c|c|c|c|c|c|c|c|}
\hline & \multirow[t]{2}{*}{ Всего } & \multicolumn{6}{|c|}{ Имеют образование } \\
\hline & & высшее & $\begin{array}{c}\text { среднее } \\
\text { профессио- } \\
\text { нальное по } \\
\text { программам } \\
\text { подготовки } \\
\text { специалистов } \\
\text { среднего } \\
\text { звена }\end{array}$ & $\begin{array}{c}\text { среднее } \\
\text { профессио- } \\
\text { нальное по } \\
\text { программам } \\
\text { подготовки } \\
\text { квалифици- } \\
\text { рованных } \\
\text { рабочих, } \\
\text { служащих }\end{array}$ & $\begin{array}{l}\text { среднее } \\
\text { общее }\end{array}$ & $\begin{array}{l}\text { основное } \\
\text { общее }\end{array}$ & $\begin{array}{c}\text { не имеют } \\
\text { основного } \\
\text { общего } \\
\text { образования }\end{array}$ \\
\hline Все работники & 32911 & 43362 & 26929 & 27128 & 25944 & 23724 & 23814 \\
\hline Руководители & 60719 & 65587 & 42022 & 39729 & 38239 & 39953 & 88225 \\
\hline Специалисты высшего уровня квалификации & 37023 & 39056 & 28345 & 28983 & 33099 & 29108 & 25764 \\
\hline Специалисты среднего уровня квалификации & 29492 & 37765 & 27334 & 25118 & 26056 & 24620 & 18806 \\
\hline Служащие, занятые подготовкой и оформлением & & & & & & & \\
\hline документации, учетом и обслуживанием & 22330 & 26041 & 21297 & 19032 & 20542 & 17113 & 14621 \\
\hline $\begin{array}{l}\text { Работники сферы обслуживания и торговли, охраны граждан } \\
\text { и собственности }\end{array}$ & 20235 & 27132 & 18696 & 19065 & 20140 & 19951 & 19589 \\
\hline $\begin{array}{l}\text { Квалифицированные работники сельского и лесного хозяйства, } \\
\text { рыбоводства и рыболовства }\end{array}$ & 20051 & 20435 & 20075 & 19932 & 20495 & 18668 & 19707 \\
\hline $\begin{array}{l}\text { Квалифицированные рабочие промышленности, строительства, } \\
\text { транспорт и рабочие родственных занятий }\end{array}$ & 32062 & 35077 & 31779 & 31916 & 31803 & 30819 & 31641 \\
\hline Операторы производственных установок и машин, сборщики & & & & & & & \\
\hline и водители & 32083 & 36624 & 30534 & 31935 & 32558 & 30757 & 31835 \\
\hline Неквалифицированные рабочие & 15529 & 17422 & 15221 & 15530 & 15771 & 14354 & 14955 \\
\hline
\end{tabular}




\subsection{7. ВЫПУСК КВАЛИФИЦИРОВАННЫХ РАБОЧИХ, СЛУЖАЩИХ \\ (ОЧНАЯ ФОРМА ОБУЧЕНИЯ)* \\ (тысячи человек)}

\begin{tabular}{|c|c|c|c|c|c|c|c|c|}
\hline & 2000 & 2005 & 2010 & 2011 & 2012 & 2013 & 2014 & 2015 \\
\hline Выпущено квалифицированных рабочих, служащих & 645.6 & 595.3 & 452.8 & 388.3 & 351.4 & 310.1 & 283.6 & 244.7 \\
\hline Получили направление на работу & 341.1 & 348.5 & 246.9 & 213.0 & 194.7 & 171.2 & 168.5 & 143.6 \\
\hline Продолжают обучение на следующем уровне & 67.7 & 70.2 & 57.0 & 48.4 & 42.4 & 34.6 & 26.3 & 22.2 \\
\hline Призваны в ряды Вооруженных Сил & 97.9 & 85.9 & 76.3 & 70.6 & 63.2 & 59.3 & 44.2 & 40.9 \\
\hline Предоставлено свободное трудоустройство & 135.1 & 84.0 & 52.4 & 38.3 & 34.0 & 30.6 & 30.4 & 26.4 \\
\hline \multicolumn{9}{|l|}{ В том числе: } \\
\hline $\begin{array}{l}\text { из-за несогласия выпускника с предложенными } \\
\text { условиями контракта работодателя }\end{array}$ & $\ldots$ & $\ldots$ & 2.9 & 3.5 & 2.4 & 1.8 & 2.0 & 2.3 \\
\hline из-за отсутствия рабочих мест & $\ldots$ & $\ldots$ & 5.7 & 4.1 & 4.1 & 4.8 & 4.2 & 3.1 \\
\hline Другие причины & 3.9 & 6.8 & 20.2 & 18.1 & 17.1 & 14.4 & 14.2 & 11.6 \\
\hline
\end{tabular}

* Без специальных учебно-воспитательных учреждений для обучающихся с девиантным (общественно опасным) поведением и профессиональных образовательных организаций ФСИН России. Данные с 2010 г. - включая обучавшихся на договорной основе, но без учета краткосрочно (менее 500 часов) обученных. 


\subsection{8. ВЫПУСК БАКАЛАВРОВ, СПЕЦИАЛИСТОВ, МАГИСТРОВ ГОСУДАРСТВЕННЫМИ И МУНИЦИПАЛЬНЫМИ ОБРАЗОВАТЕЛЬНЫМИ ОРГАНИЗАЦИЯМИ ВЫСШЕГО ОБРАЗОВАНИЯ (ОЧНАЯ ФОРМА ОБУЧЕНИЯ) * (тысячи человек)}

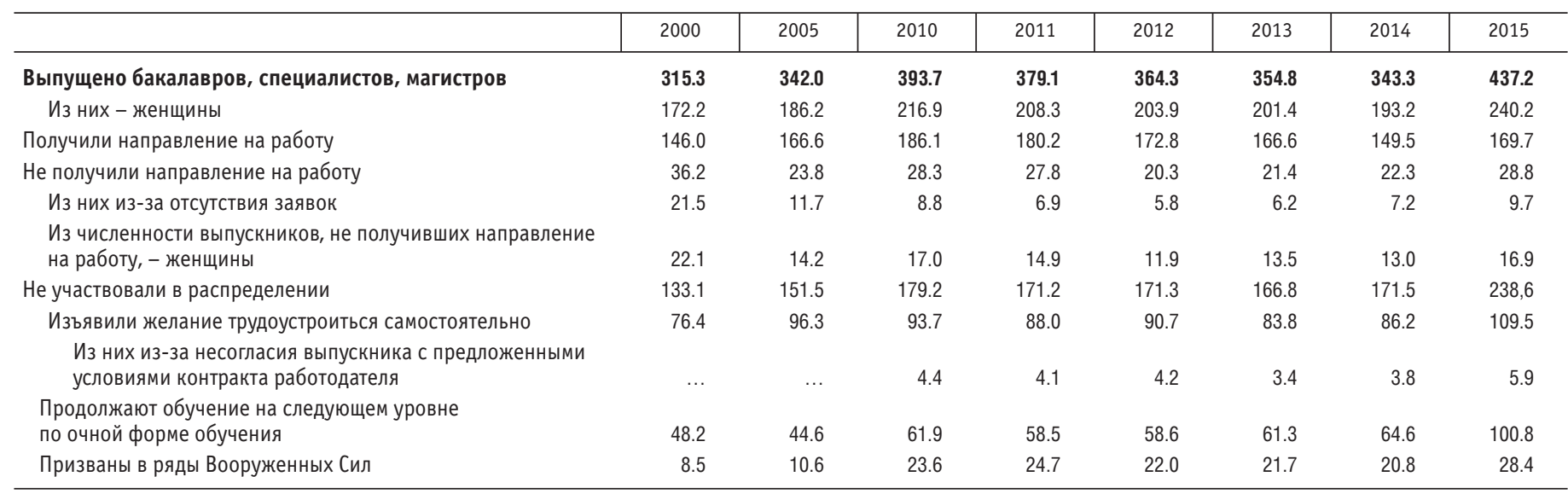

* Без учета численности лиц, обучавшихся за счет средств физических и (или) юридических лиц по договорам об оказании платных образовательных услуг. 


\subsection{9. ЧИСЛЕННОСТЬ ВЫПУСКНИКОВ ОБРАЗОВАТЕЛЬНЫХ ОРГАНИЗАЦИЙ, ЗАРЕГИСТРИРОВАННЫХ \\ В ОРГАНАХ ГОСУДАРСТВЕННОЙ СЛУЖБЫ ЗАНЯТОСТИ * \\ (на конец года; тысячи человек)}

\begin{tabular}{|c|c|c|c|c|c|c|c|c|}
\hline & 2000 & 2005 & 2010 & 2011 & 2012 & 2013 & 2014 & 2015 \\
\hline Численность безработных - всего & 1037.0 & 1830.1 & 1589.4 & 1285.6 & 1064.7 & 917.7 & 883.3 & 1001.1 \\
\hline Мужчины & 322.2 & 630.5 & 698.4 & 559.6 & 471.7 & 415.9 & 403.8 & 465.8 \\
\hline Женщины & 714.8 & 1199.5 & 891.0 & 725.9 & 593.0 & 501.8 & 479.5 & 535.4 \\
\hline \multicolumn{9}{|l|}{ Из них выпускники: } \\
\hline общеобразовательных организаций & 21.6 & 57.8 & $\ldots$ & $\ldots$ & $\ldots$ & $\ldots$ & 3.4 & 2.8 \\
\hline мужчины & 6.5 & 22.8 & $\ldots$ & $\ldots$ & $\ldots$ & $\ldots$ & 1.6 & 1.4 \\
\hline женщины & 15.1 & 34.9 & $\ldots$ & $\ldots$ & $\ldots$ & $\ldots$ & 1.8 & 1.5 \\
\hline профессиональных образовательных организаций & 44.7 & 87.9 & 34.4 & 16.7 & 12.9 & 11.1 & 9.1 & 10.6 \\
\hline мужчины & 35.8 & 28.5 & 14.3 & 6.5 & 5.0 & 4.4 & 3.6 & 4.3 \\
\hline женщины & 8.9 & 59.4 & 20.1 & 10.2 & 7.9 & 6.7 & 5.5 & 6.2 \\
\hline \multicolumn{9}{|l|}{$\begin{array}{l}\text { образовательных организаций высшего образования } \\
\text { (обучение по программам бакалавриата, специалитета, }\end{array}$} \\
\hline 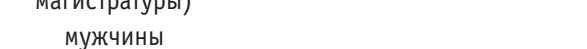 & $\begin{array}{l}9.5 \\
1.9\end{array}$ & $\begin{array}{r}24.7 \\
6.6\end{array}$ & $\begin{array}{r}15.5 \\
5.0\end{array}$ & $\begin{array}{r}10.2 \\
3.2\end{array}$ & $\begin{array}{l}7.4 \\
2.3\end{array}$ & $\begin{array}{l}5.9 \\
1.9\end{array}$ & $\begin{array}{l}4.5 \\
1.5\end{array}$ & $\begin{array}{l}8.7 \\
2.6\end{array}$ \\
\hline женщины & 7.6 & 18.1 & 10.5 & 7.0 & 5.1 & 4.0 & 3.1 & 6.2 \\
\hline
\end{tabular}

* По данным Федеральной службы по труду и занятости. 


\section{МЕТОДОЛОГИЧЕСКИЕ КОММЕНТАРИИ}

Информация о занятых, безработных подготовлена по материалам выборочных обследований рабочей силы, проводимых статистическими органами Российской Федерации. Единицами наблюдения являются домашние хозяйства и лица в возрасте 15-72 лет - члены этих хозяйств. Данные за 2000 и 2005 гг. сформированы без учета Чеченской Республики. Данные по всем показателям приведены в среднем за год. Показатели за 2005 и 2010 гг. пересчитаны с учетом итогов Всероссийской переписи населения 2010 г. Данные за 2014 г. приведены без учета сведений по Республике Крым и городу Севастополю.

Рабочая сила - лица в возрасте 15-72 лет, которые в рассматриваемый период считаются занятыми или безработными.

Занятые - лица в возрасте 15-72 лет, которые в рассматриваемый период осуществляли любую деятельность (хотя бы один час в неделю), связанную с производством товаров или оказанием услуг за плату или прибыль. В численность занятых включаются также лица, временно отсутствующие на рабочем месте в течение короткого промежутка времени и сохранившие связь с рабочим местом во время отсутствия.

Уровень занятости - отношение численности занятого населения к общей численности населения, рассчитанное в процентах.

Безработные - в соответствии со стандартами Международной Организации Труда (МОТ) - лица в возрасте 15-72 лет, которые в рассматриваемый период удовлетворяли одновременно следующим критериям:

- не имели работы (доходного занятия);

- занимались поиском работы, т.е. обращались в государ- ственную или коммерческую службы занятости, использовали или помещали объявления в СМИ и интернете, непосредственно обращались к администрации предприятия (работодателю), использовали личные связи или предпринимали шаги к организации собственного дела;

- были готовы приступить к работе в течение обследуемой недели.

Обучающиеся, пенсионеры и инвалиды учитывались в качестве безработных, если они не имели работы, занимались поиском работы и были готовы приступить к ней.

Уровень безработицы - отношение численности безработных к численности рабочей силы, рассчитанное в процентах.

Продолжительность безработицы (продолжительность поиска работы) - промежуток времени, в течение которого лицо, будучи незанятым, ищет работу, используя при этом любые способы.

Средняя продолжительность безработицы (среднее время поиска работы) рассчитывается как средневзвешенная величина для рассматриваемого состава безработных.

Потенциальная рабочая сила - незанятые лица, которые выражают заинтересованность в получении работы за оплату или прибыль, однако сложившиеся условия ограничивают их активные поиски работы или их готовность приступить к работе.

Информация о выпуске квалифицированных рабочих, служащих со средним профессиональным образованием приведена с учетом программ подготовки квалифицированных рабочих, служащих, реализуемых образовательными организациями высшего образования. 


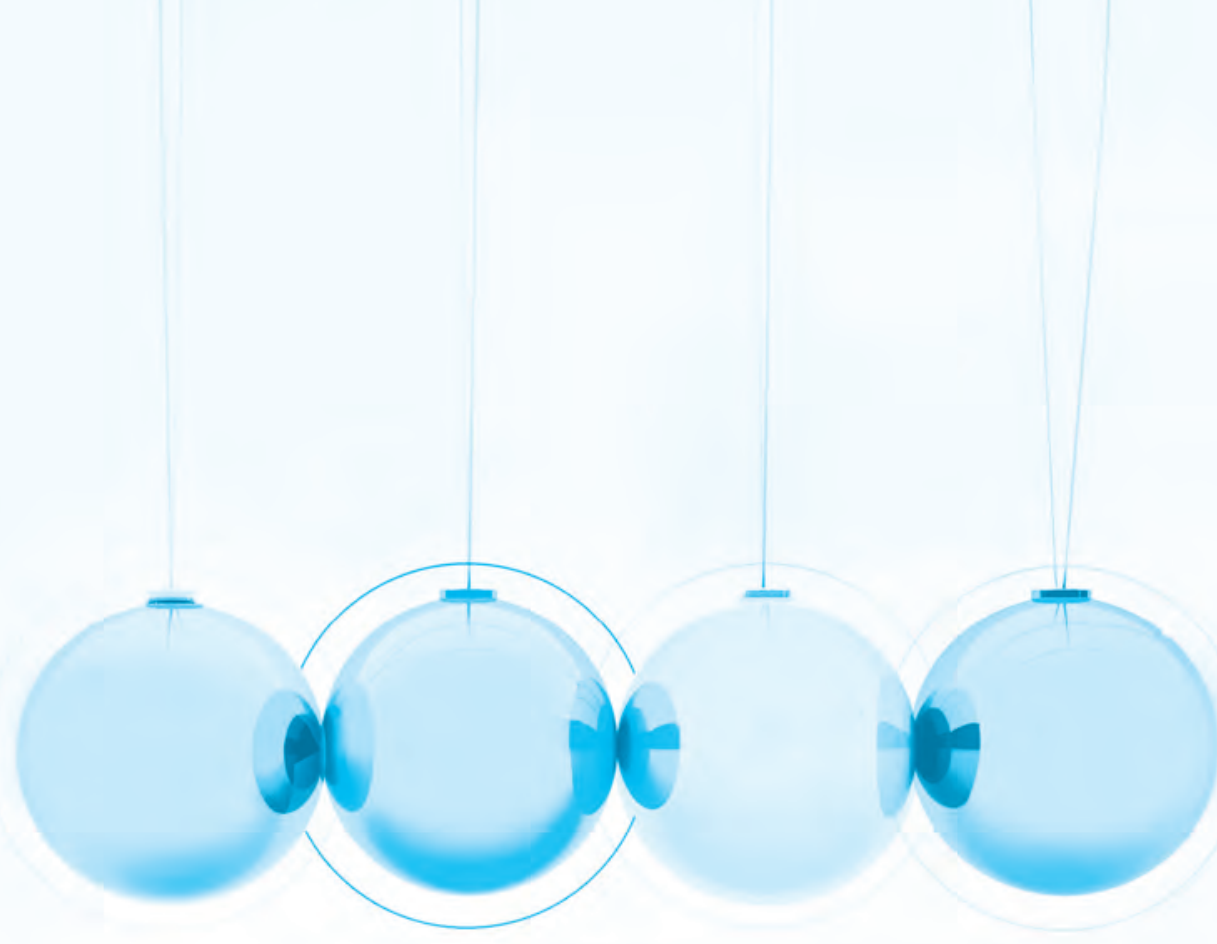

3. Финансирование образования 


\section{1. РАСХОДЫ НА ОБРАЗОВАНИЕ В РОССИЙСКОЙ ФЕДЕРАЦИИ*}

\section{В действующих ценах}

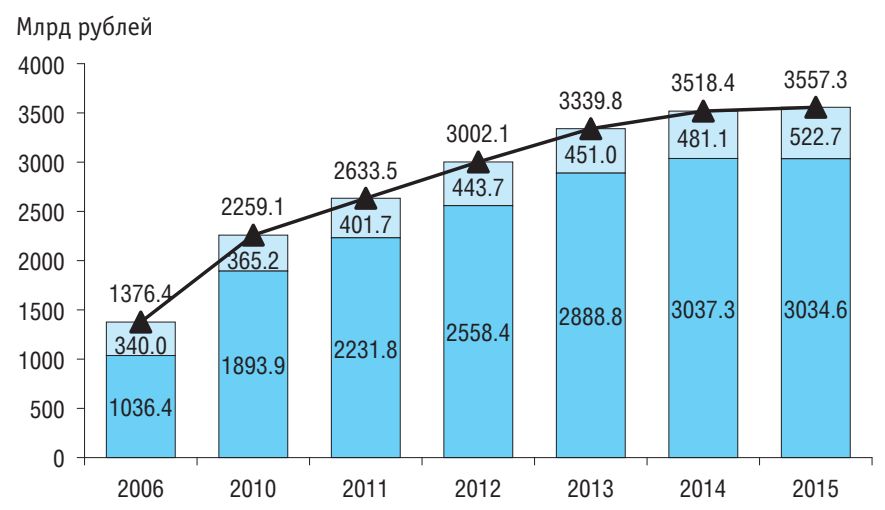

\section{В постоянных ценах} $2006=100 \%$

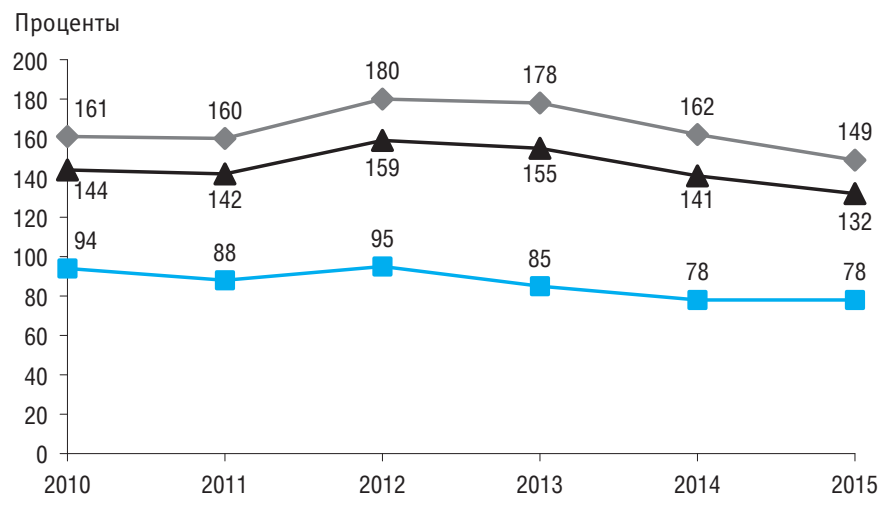

\section{$\boldsymbol{\sim}$ - Всего \\ $\square$ Государственные расходы}

$\leftarrow$ всего

- Государственные расходы

-_ Расходы за счет внебюджетных источников **

* Здесь и далее общие расходы на образование за счет всех источников финансирования приведены на основе оценки Национального исследовательского университета «Высшая школа экономики» (НИУ ВШЭ).

** Здесь и далее (рис. 3.2) - внебюджетные средства (с учетом собственных средств) дошкольных образовательных организаций, общеобразовательных организаций (включая средства, поступившие за оказание платных дополнительных образовательных услуг) и образовательных организаций профессионального образования (оценка НИУ ВШЭ по данным федерального статистического наблюдения). 


\section{2. РАСХОДЫ НА ОБРАЗОВАНИЕ В РОССИЙСКОЙ ФЕДЕРАЦИИ В ПРОЦЕНТАХ К ВАЛОВОМУ ВНУТРЕННЕМУ ПРОДУКТУ}

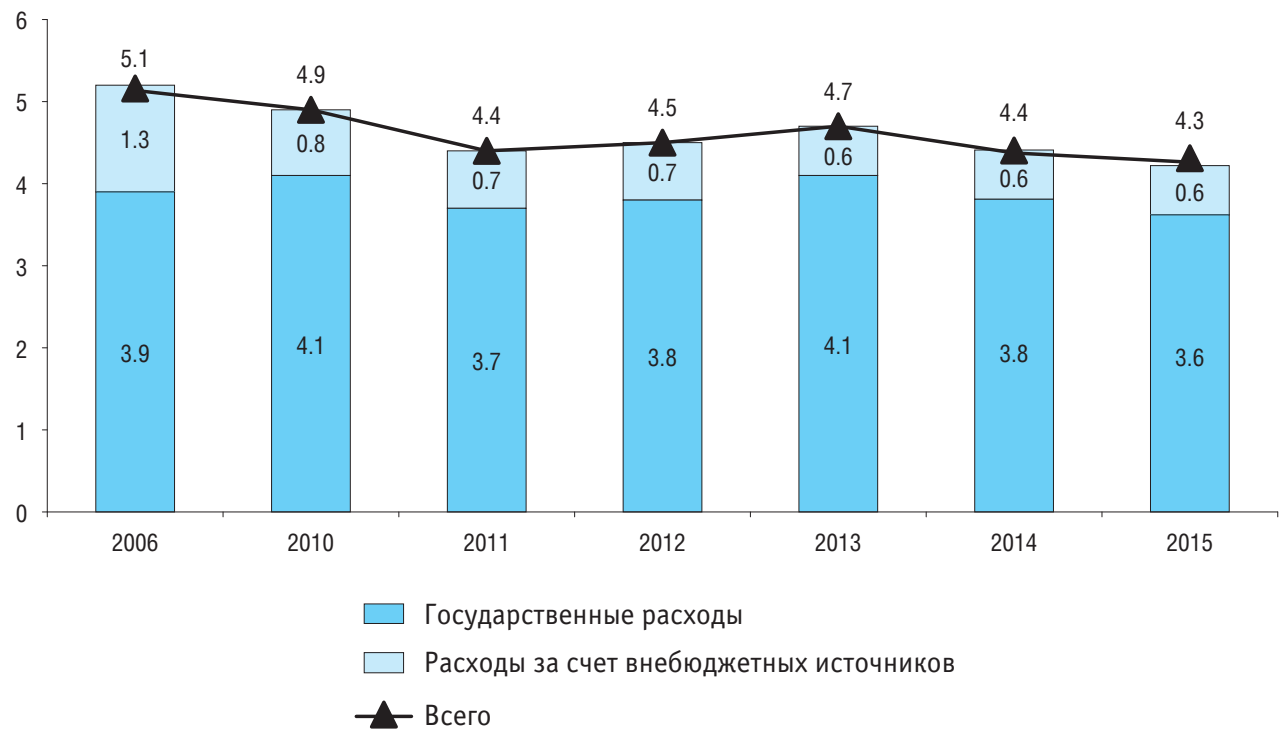




\section{3. ГОСУДАРСТВЕННЫЕ РАСХОДЫ НА ОБРАЗОВАНИЕ ПО УРОВНЯМ БЮДЖЕТНОЙ СИСТЕМЫ} (миллиарды рублей)

\begin{tabular}{|c|c|c|c|c|c|c|c|c|c|c|}
\hline & 2000 & 2005 & 2010 & 2011 & 2012 & 2013 & 2014 & 2015 & $2016^{* *}$ & $2017^{* * *}$ \\
\hline $\begin{array}{l}\text { Консолидированный бюджет Российской Федерации } \\
\text { и бюджеты государственных внебюджетных фондов* }\end{array}$ & 214.7 & 801.8 & 1893.9 & 2231.8 & 2558.4 & 2888.8 & 3037.3 & 3034.6 & $\ldots$ & $\ldots$ \\
\hline Федеральный бюджет & 38.1 & 162.1 & 442.8 & 553.4 & 603.8 & 672.3 & 638.3 & 610.6 & 603.9 & 595.0 \\
\hline $\begin{array}{l}\text { Бюджеты государственных внебюджетных фондов } \\
\text { Консолидированные бюджеты субъектов Российской }\end{array}$ & $\cdots$ & 11.0 & 0.1 & 0.1 & 0.1 & 0.2 & 0.2 & 0.2 & 0.3 & $\cdots$ \\
\hline Федерации & 176.6 & 628.6 & 1450.9 & 1728.4 & 2047.0 & 2333.8 & 2474.3 & 2472.5 & 2615.1 & $\ldots$ \\
\hline $\begin{array}{l}\text { Бюджеты территориальных государственных } \\
\text { внебюджетных фондов }\end{array}$ & $\ldots$ & 0.01 & 0.0 & 0.0 & 0.0 & 0.0 & 0.0 & 0.0 & $\ldots$ & $\ldots$ \\
\hline
\end{tabular}

* Здесь и далее данные за 2000 г. приведены без учета бюджетов государственных внебюджетных фондов.

** Годовые данные утверждены сводной бюджетной росписью с учетом внесенных изменений (отчет об исполнении консолидированного бюджета Российской Федерации и бюджетов государственных внебюджетных фондов по состоянию на 1 декабря 2016 г.).

*** В соответствии с Федеральным законом от 19.12.2016 № 415-Ф3 «0 федеральном бюджете на 2017 год и плановый период 2018 и 2019 годов». 


\section{4. ДИНАМИКА ГОСУДАРСТВЕННЫХ РАСХОДОВ НА ОБРАЗОВАНИЕ}

(в постоянных ценах)

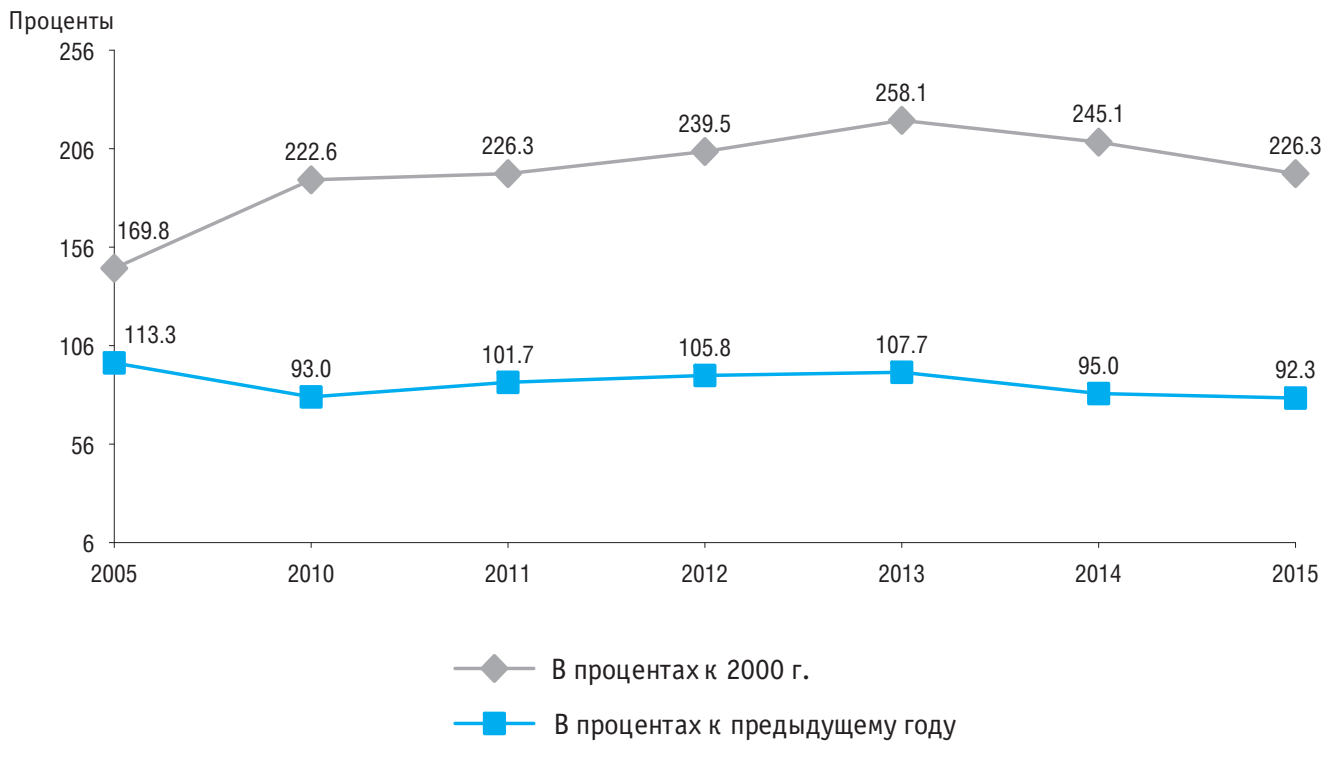




\section{6}

3.5. УДЕЛЬНЫЙ ВЕС РАСХОДОВ НА ОБРАЗОВАНИЕ В ОБЩИХ РАСХОДАХ КОНСОЛИДИРОВАННОГО БЮДЖЕТА РОССИЙСКОЙ ФЕДЕРАЦИИ И БЮДЖЕТОВ ГОСУДАРСТВЕННЫХ ВНЕБЮДЖЕТНЫХ ФОНДОВ

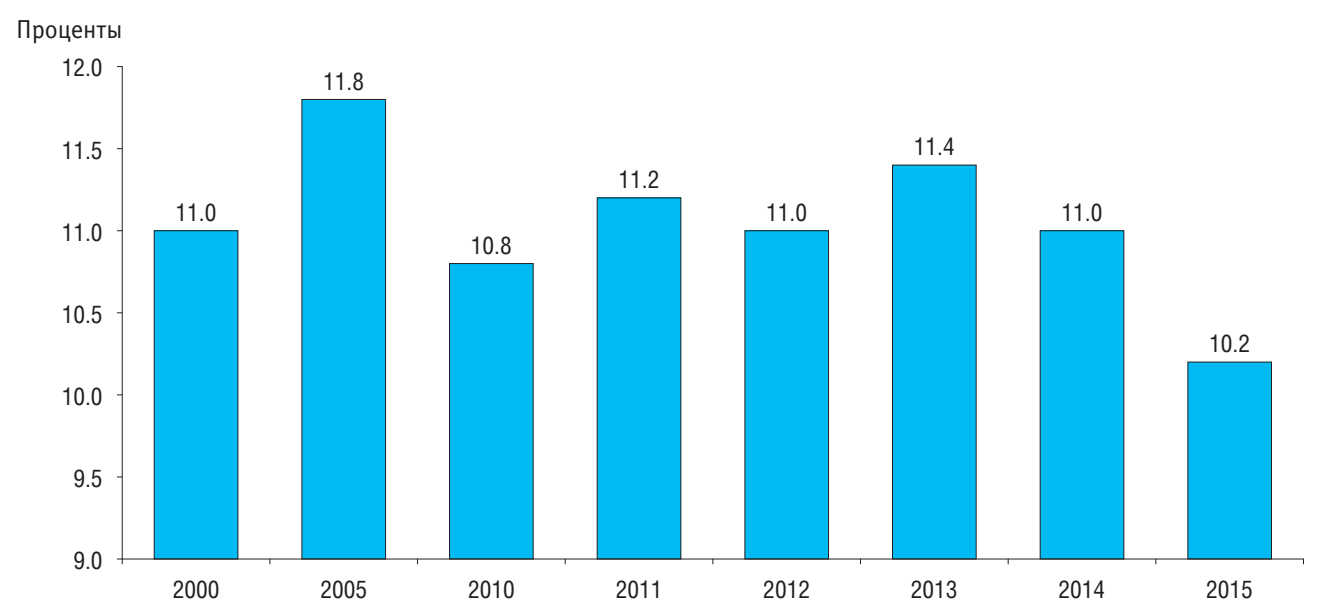


3.6. ГОСУДАРСТВЕННЫЕ РАСХОДЫ НА ОБРАЗОВАНИЕ В ПРОЦЕНТАХ К ВАЛОВОМУ ВНУТРЕННЕМУ ПРОДУКТУ ПО ОТДЕЛЬНЫМ УРОВНЯМ БЮДЖЕТНОЙ СИСТЕМЫ

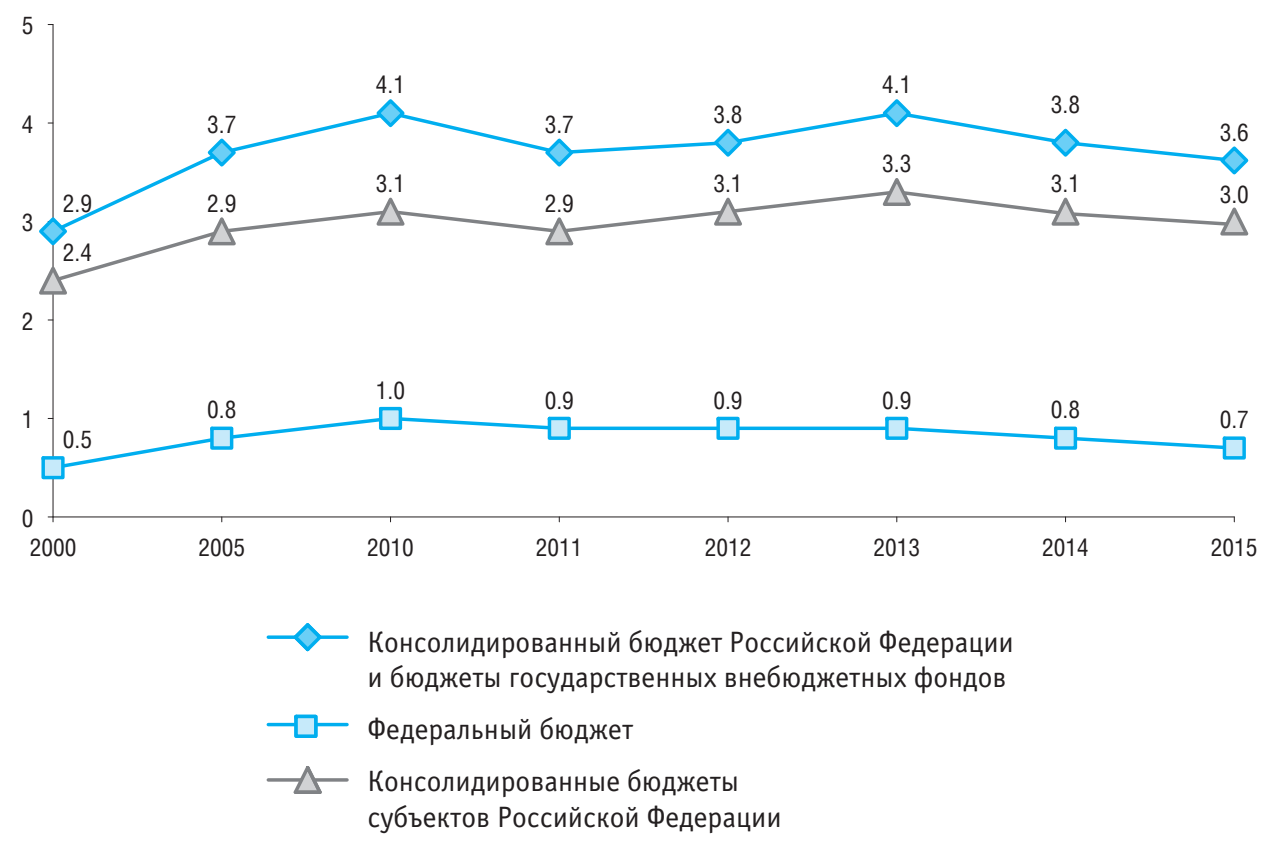




\section{7. ГОСУДАРСТВЕННЫЕ РАСХОДЫ НА ОБРАЗОВАНИЕ ПО ПОДРАЗДЕЛАМ КЛАССИФИКАЦИИ РАСХОДОВ БЮДЖЕТОВ} (миллиарды рублей)

\begin{tabular}{|c|c|c|c|c|c|c|c|c|}
\hline & 2000 & 2005 & 2010 & 2011 & 2012 & 2013 & 2014 & 2015 \\
\hline $\begin{array}{l}\text { Консолидированный бюджет Российской Федерации и бю } \\
\text { государственных внебюджетных фондов }\end{array}$ & 214.7 & 801.8 & 1893.9 & 2231.8 & 2558.4 & 2888.8 & 3037.3 & 3034.6 \\
\hline Дошкольное образование & 32.0 & 113.0 & 321.3 & 394.7 & 469.6 & 598.1 & 658.1 & 692.1 \\
\hline Общее образование & 107.9 & 356.0 & 827.4 & 989.7 & 1184.0 & 1329.2 & 1414.7 & 1405.9 \\
\hline Начальное профессиональное образование * & 13.4 & 39.4 & 61.7 & 62.4 & 58.4 & 52.5 & - & - \\
\hline Среднее профессиональное образование & 10.2 & 43.3 & 102.1 & 115.3 & 130.3 & 144.9 & 201.8 & 197.8 \\
\hline Высшее и послевузовское профессиональное образование** & 24.4 & 125.9 & 377.8 & 416.8 & 464.0 & 512.5 & 519.7 & 517.1 \\
\hline $\begin{array}{l}\text { Профессиональная подготовка, переподготовка и повышение } \\
\text { квалификации*** }\end{array}$ & 1.4 & 6.7 & 13.2 & 16.0 & 16.5 & 17.5 & 21.1 & 19.5 \\
\hline Молодежная политика и оздоровление детей & $\ldots$ & 24.8 & 49.5 & 57.3 & 62.9 & 62.5 & 62.0 & 58.4 \\
\hline Прикладные научные исследования в области образования & $\ldots$ & 1.8 & 15.7 & 20.2 & 13.7 & 8.8 & 15.5 & 13.4 \\
\hline Другие вопросы в области образования **** & 25.4 & 90.8 & 125.1 & 159.2 & 159.0 & 162.8 & 144.3 & 130.5 \\
\hline
\end{tabular}

* С 2014 г. учитывается по подразделу «Среднее профессиональное образование».

** В 2000 и 2005 гг. - «Высшее профессиональное образование».

*** В 2000 и 2005 гг. - «Переподготовка и повышение квалификации».

**** В 2000 г. - «Прочие расходы в области образования». 


\section{8. ГОСУДАРСТВЕННЫЕ РАСХОДЫ НА ОБРАЗОВАНИЕ В ПРОЦЕНТАХ К ВАЛОВОМУ ВНУТРЕННЕМУ ПРОДУКТУ}

ПО ПОДРАЗДЕЛАМ КЛАССИФИКАЦИИ РАСХОДОВ БЮДЖЕТОВ

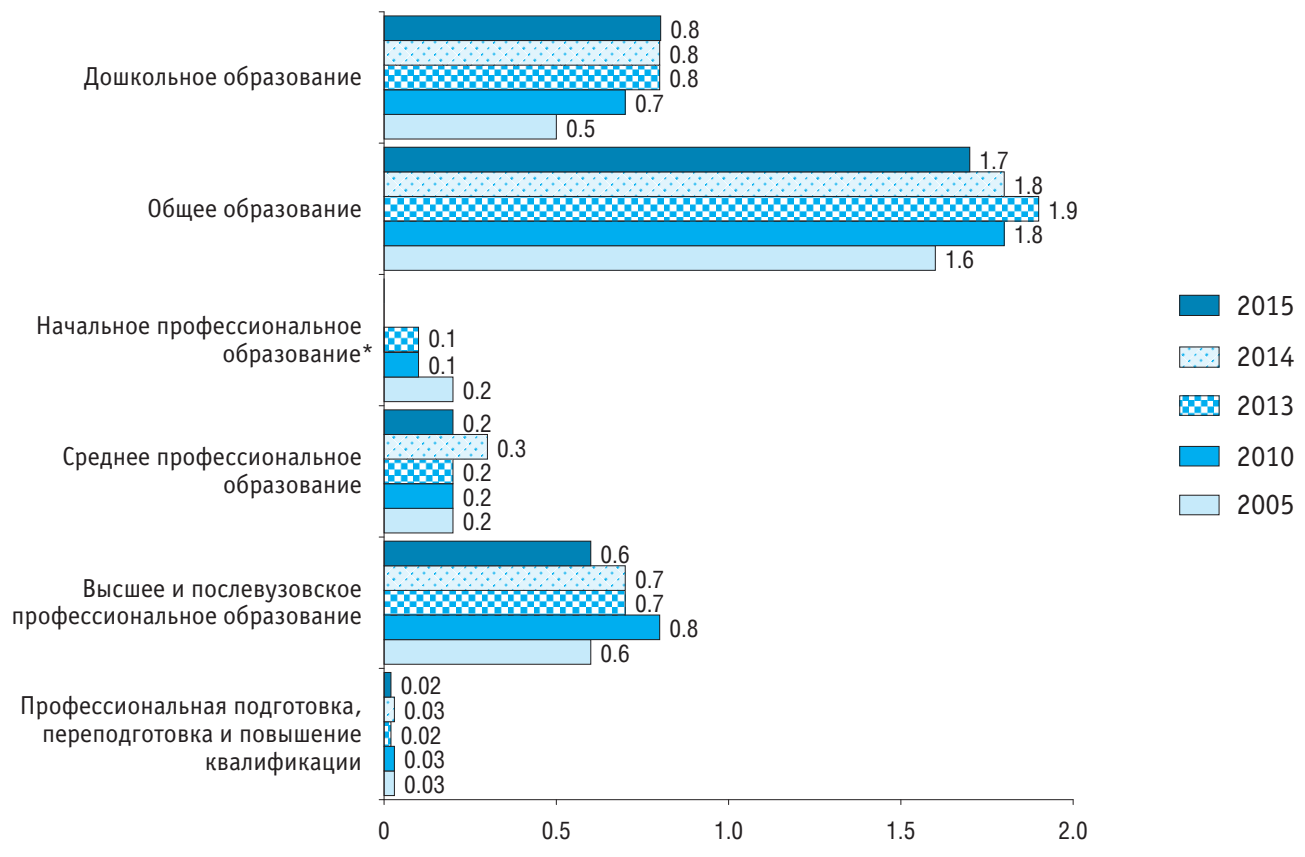

* C 2014 г. учитывается по подразделу «Среднее профессиональное образование». 


\section{9. ГОСУДАРСТВЕННЫЕ РАСХОДЫ НА ОБРАЗОВАНИЕ В РАСЧЕТЕ НА ОДНОГО ОБУЧАЮЩЕГОСЯ ПО ПОДРАЗДЕЛАМ КЛАССИФИКАЦИИ РАСХОДОВ БЮДЖЕТОВ}

\section{В фактических ценах}

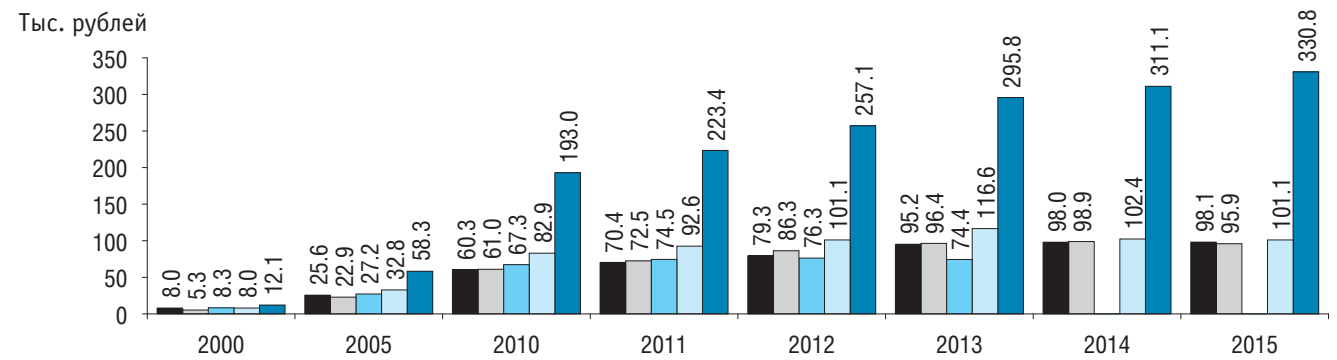

В постоянных ценах 2000 г.

Тыс. рублей

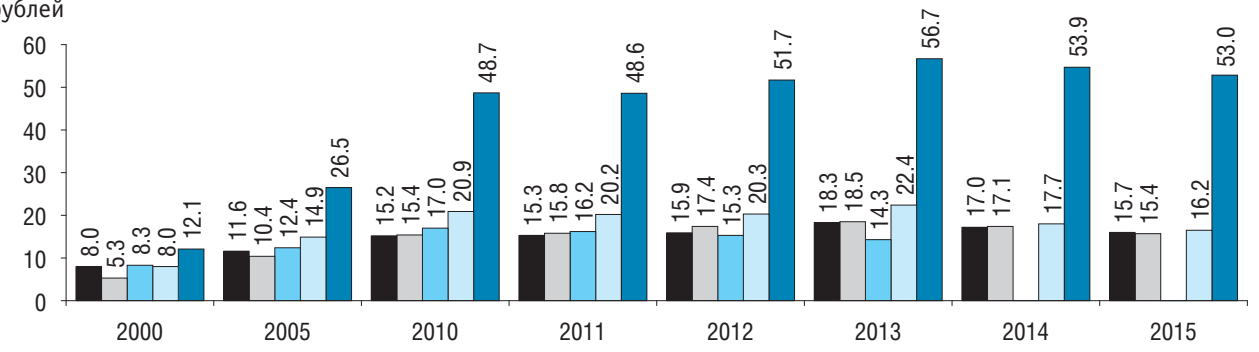

Расходы

на образование:

дошкольное

общее

начальное профессиональное*

среднее

профессиональное

высшее

и послевузовское

профессиональное

* С 2014 г. учитывается по подразделу «Среднее профессиональное образование». 


\subsection{0. ИНВЕСТИЦИИ В ОСНОВНОЙ КАПИТАЛ, НАПРАВЛЕННЫЕ НА РАЗВИТИЕ ОБРАЗОВАНИЯ*}

\begin{tabular}{|c|c|c|c|c|c|c|c|}
\hline & 2005 & 2010 & 2011 & 2012 & 2013 & 2014 & 2015 \\
\hline \multicolumn{8}{|l|}{ Инвестиции в основной капитал: } \\
\hline млн руб.; в фактических ценах & 68815 & 163687 & 198292 & 213337 & 228873 & 242687 & 239790 \\
\hline \multicolumn{8}{|l|}{ в процентах: } \\
\hline к предыдущему году, в сопоставимых ценах & 119.3 & 109.7 & 113.4 & 102.3 & 103.1 & $100.6^{* *}$ & 84.2 \\
\hline от общего объема инвестиций в основной капитал & 1.9 & 1.8 & 1.8 & 1.7 & 1.7 & 1.7 & 1.6 \\
\hline
\end{tabular}

* Данные за 2000 г. разработаны в соответствии со структурой ОКОНХ, с 2005 г. - со структурой ОКВЭД.

** В целях обеспечения статистической сопоставимости относительный показатель рассчитан без учета данных по Республике Крым и г. Севастополю.

\subsection{1. СТРУКТУРА ИНВЕСТИЦИЙ В ОСНОВНОЙ КАПИТАЛ, НАПРАВЛЕННЫХ НА РАЗВИТИЕ ОБРАЗОВАНИЯ, ПО ИСТОЧНИКАМ ФИНАНСИРОВАНИЯ*

$$
\text { (проценты) }
$$

\begin{tabular}{|c|c|c|c|c|c|c|c|}
\hline & 2005 & 2010 & 2011 & 2012 & 2013 & 2014 & 2015 \\
\hline Инвестиции в основной капитал & 100 & 100 & 100 & 100 & 100 & 100 & 100 \\
\hline Собственные средства организаций & 9.6 & 4.2 & 4.4 & 4.1 & 4.1 & 4.3 & 6.3 \\
\hline Привлеченные средства & 90.4 & 95.8 & 95.6 & 95.9 & 95.9 & 95.7 & 93.7 \\
\hline Из них бюджетные средства & 79.4 & 88.3 & 87.3 & 86.8 & 86.7 & 86.6 & 85.0 \\
\hline Федеральный бюджет & 21.8 & 40.5 & 42.9 & 34.3 & 32.5 & 32.8 & 34.2 \\
\hline Бюджеты субъектов Российской Федерации & 50.0 & 38.3 & 35.3 & 40.3 & 38.2 & 35.8 & 34.3 \\
\hline Местные бюджеты & $\ldots$ & $\ldots$ & $\ldots$ & 12.2 & 16.0 & 18.0 & 16.5 \\
\hline
\end{tabular}

* Без субъектов малого предпринимательства и объема инвестиций, не наблюдаемых прямыми статистическими методами. 
3.12. СТРУКТУРА ИНВЕСТИЦИЙ В ОСНОВНОЙ КАПИТАЛ, НАПРАВЛЕННЫХ НА РАЗВИТИЕ ОБРАЗОВАНИЯ, ПО ФОРМАМ СОБСТВЕННОСТИ*

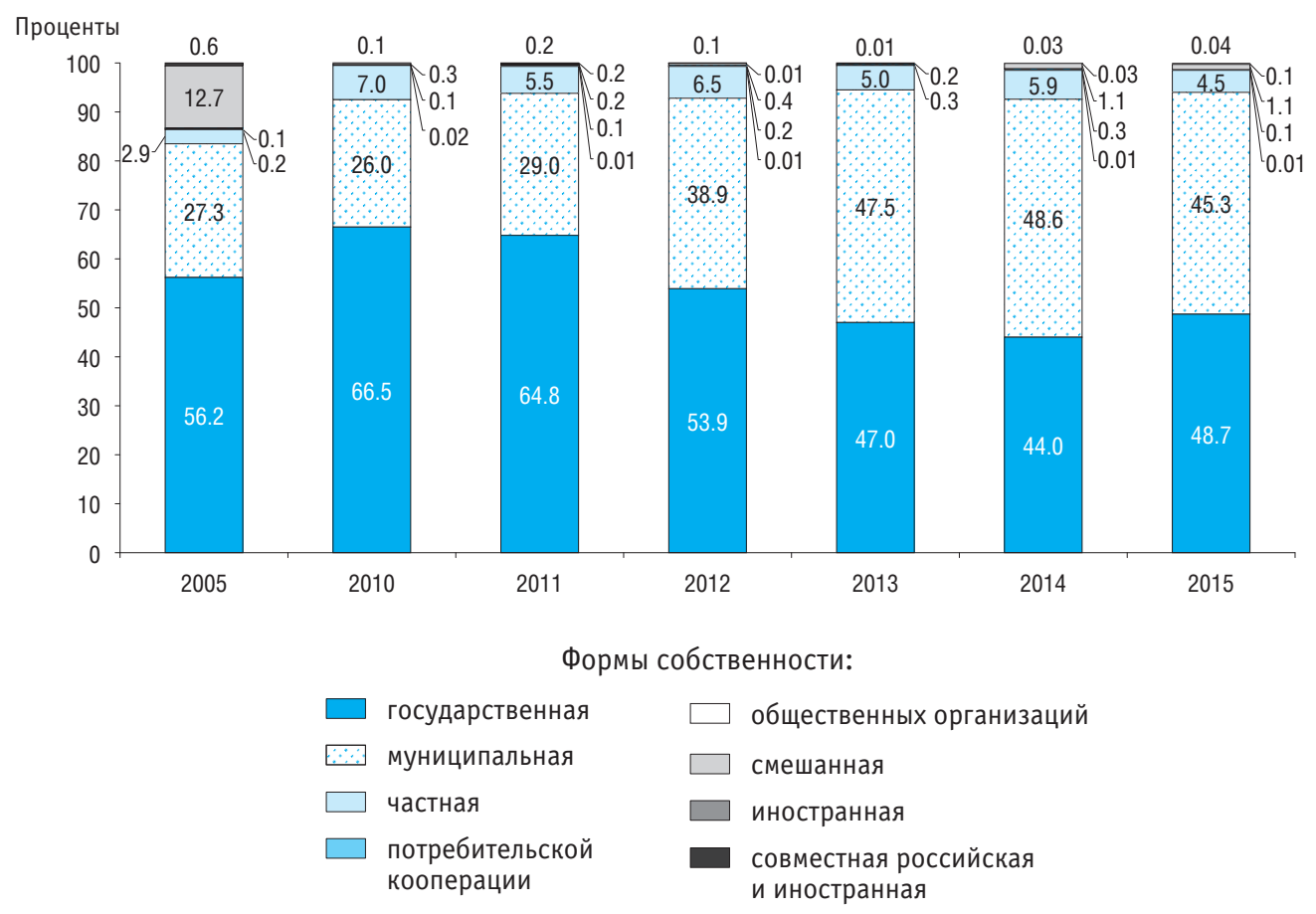

* Без субъектов малого предпринимательства и объема инвестиций, не наблюдаемых прямыми статистическими методами. 


\subsection{3. ОБЪЕМ ПЛАТНЫХ УСЛУГ НАСЕЛЕНИЮ В СИСТЕМЕ ОБРАЗОВАНИЯ}

\begin{tabular}{|c|c|c|c|c|c|c|c|c|}
\hline & 2000 & 2005 & 2010 & 2011 & 2012 & 2013 & 2014 & 2015 \\
\hline Млн рублей & 41530 & 152670 & 326100 & 347351 & 378931 & 449233 & 486543 & 539685 \\
\hline \multicolumn{9}{|l|}{ В процентах: } \\
\hline к предыдущему году, в сопоставимых ценах & 121.7 & 107.7 & 99.1 & 100.5 & 101.3 & 98.9 & $98.0^{*}$ & 96.8 \\
\hline к 2000 г., в сопоставимых ценах & 100 & 152.6 & 172.4 & 173.2 & 175.5 & 173.5 & $170.1^{*}$ & 164.6 \\
\hline от общего объема платных услуг населению & 6.9 & 6.7 & 6.6 & 6.3 & 6.3 & 6.5 & 6.5 & 6.7 \\
\hline Объем платных услуг на душу населения, руб. & 285.3 & 1063.8 & 2282.8 & 2429.7 & 2646.1 & 3130.4 & 3330.4 & 3686.2 \\
\hline
\end{tabular}

* В целях обеспечения статистической сопоставимости данных показатель рассчитан без учета сведений по Республике Крым и г. Севастополю.

\subsection{4. РАСХОДЫ ДОМАШНИХ ХОЗЯЙСТВ НА ОПЛАТУ УСЛУГ ОБРАЗОВАНИЯ *}

\begin{tabular}{|c|c|c|c|}
\hline & \multicolumn{3}{|c|}{ Расходы на оплату услуг образования } \\
\hline & $\begin{array}{c}\text { В расчете на } 1 \text { члена } \\
\text { домохозяйства в год, } \\
\text { руб. }\end{array}$ & $\begin{array}{c}\text { Удельный вес } \\
\text { в потребительских расходах, } \\
\text { проценты }\end{array}$ & $\begin{array}{c}\text { Удельный вес } \\
\text { в расходах на оплату } \\
\text { личных услуг, проценты }\end{array}$ \\
\hline 2000 & 137 & 1.0 & 7.2 \\
\hline 2005 & 931 & 1.8 & 7.8 \\
\hline 2010 & 1583 & 1.3 & 4.9 \\
\hline 2011 & 1616 & 1.2 & 4.5 \\
\hline 2012 & 1918 & 1.3 & 4.9 \\
\hline 2013 & 1604 & 1.0 & 3.7 \\
\hline $2014^{* *}$ & 1766 & 1.0 & 3.8 \\
\hline 2015 & 1573 & 0.9 & 3.3 \\
\hline
\end{tabular}

* По материалам выборочного обследования бюджетов домашних хозяйств.

** Без учета сведений по Республике Крым и г. Севастополю. 


\subsection{5. РАСХОДЫ ДОМАШНИХ ХОЗЯЙСТВ НА ОПЛАТУ УСЛУГ ОБРАЗОВАНИЯ ПО 10-ПРОЦЕНТНЫМ ГРУППАМ НАСЕЛЕНИЯ \\ С РАЗЛИЧНЫМ УРОВНЕМ СРЕДНЕДУШЕВЫХ ДОХОДОВ* \\ (в среднем на 1 члена домохозяйства в год; рубли)}

\begin{tabular}{|c|c|c|c|c|c|c|c|c|}
\hline & 2000 & 2005 & 2010 & 2011 & 2012 & 2013 & $2014^{* *}$ & 2015 \\
\hline Первая (с наименьшими доходами) & 16 & 96 & 211 & 303 & 265 & 251 & 275 & 282 \\
\hline Вторая & 22 & 162 & 426 & 488 & 463 & 497 & 463 & 400 \\
\hline Третья & 34 & 226 & 612 & 688 & 740 & 724 & 725 & 750 \\
\hline Четвертая & 50 & 375 & 1099 & 921 & 913 & 976 & 1055 & 852 \\
\hline Пятая & 80 & 548 & 1209 & 1178 & 1387 & 1411 & 1319 & 1607 \\
\hline Шестая & 110 & 1078 & 1507 & 1612 & 1588 & 1662 & 1756 & 1898 \\
\hline Седьмая & 130 & 1118 & 2348 & 3553 & 2622 & 2491 & 2798 & 2392 \\
\hline Восьмая & 217 & 1520 & 3339 & 2527 & 4251 & 2676 & 2790 & 2921 \\
\hline Девятая & 303 & 2069 & 3000 & 2632 & 3593 & 3297 & 3649 & 2528 \\
\hline Десятая (с наибольшими доходами) & 406 & 2109 & 2076 & 2259 & 3359 & 2057 & 2831 & 2096 \\
\hline
\end{tabular}

* По материалам выборочного обследования бюджетов домашних хозяйств.

** Без учета сведений по Республике Крым и г. Севастополю. 


\subsection{6. ОБЪЕМ СРЕДСТВ ДОШКОЛЬНЫХ ОБРАЗОВАТЕЛЬНЫХ ОРГАНИЗАЦИЙ}

ПО ИСТОЧНИКАМ ФИНАНСИРОВАНИЯ

\begin{tabular}{|c|c|c|c|c|c|c|c|}
\hline & 2009 & 2010 & 2011 & 2012 & 2013 & 2014 & 2015 \\
\hline \multicolumn{8}{|c|}{ Миллионы рублей } \\
\hline Объем средств - всего & 327851.5 & 338043.9 & 411416.6 & 480342.1 & 557518.7 & 653956.6 & 672498.3 \\
\hline Бюджетные средства & 277949.1 & 293930.0 & 362071.8 & 424905.1 & 492821.0 & 573147.3 & 574588.3 \\
\hline \multicolumn{8}{|l|}{ В том числе бюджетов: } \\
\hline федерального & 7957.3 & 6208.8 & 7668.4 & 6294.1 & 15464.1 & 19713.3 & 17542.4 \\
\hline субъектов Российской Федерации & 56894.7 & 65580.1 & 84310.5 & 115665.5 & 104576.9 & 305781.4 & 328612.1 \\
\hline местных & 213097.2 & 222141.1 & 270092.9 & 302945.6 & 372780.0 & 247652.6 & 228433.9 \\
\hline Средства организаций & 4597.6 & 4806.8 & 5321.2 & 5766.7 & 5560.5 & 5114.6 & 4968.9 \\
\hline Средства населения & 43592.1 & 37323.0 & 41663.3 & 47493.5 & 56498.5 & 73026.4 & 90192.6 \\
\hline Из них родительская плата & 41844.6 & 35437.9 & 39532.1 & 44958.3 & 53690.7 & 69823.6 & 86461.6 \\
\hline Внебюджетные фонды & 388.6 & 387.5 & 452.4 & 525.9 & 544.0 & 649.9 & 690.9 \\
\hline Иностранные источники & 1.0 & 1.6 & 0.1 & 2.1 & 3.7 & 0.2 & 3.8 \\
\hline Другие & 1323.0 & 1595.0 & 1907.8 & 1648.8 & 2091.0 & 2018.2 & 2053.8 \\
\hline \multicolumn{8}{|c|}{ Проценты } \\
\hline Объем средств - всего & 100 & 100 & 100 & 100 & 100 & 100 & 100 \\
\hline Бюджетные средства & 84.8 & 87.0 & 88.0 & 88.5 & 88.4 & 87.6 & 85.4 \\
\hline \multicolumn{8}{|l|}{ В том числе бюджетов: } \\
\hline федерального & 2.4 & 1.8 & 1.9 & 1.3 & 2.8 & 3.0 & 2.6 \\
\hline субъектов Российской Федерации & 17.4 & 19.4 & 20.5 & 24.1 & 18.8 & 46.8 & 48.9 \\
\hline местных & 65.0 & 65.7 & 65.6 & 63.1 & 66.9 & 37.9 & 34.0 \\
\hline Средства организаций & 1.4 & 1.4 & 1.3 & 1.2 & 1.0 & 0.8 & 0.7 \\
\hline Средства населения & 13.3 & 11.0 & 10.1 & 9.9 & 10.1 & 11.2 & 13.4 \\
\hline Из них родительская плата & 12.8 & 10.5 & 9.6 & 9.4 & 9.6 & 10.7 & 12.9 \\
\hline Внебюджетные фонды & 0.1 & 0.1 & 0.1 & 0.1 & 0.1 & 0.1 & 0.1 \\
\hline Иностранные источники & 0.0 & 0.0 & 0.0 & 0.0 & 0.0 & 0.0 & 0.0 \\
\hline Другие & 0.4 & 0.5 & 0.5 & 0.3 & 0.4 & 0.3 & 0.3 \\
\hline
\end{tabular}




\subsection{7. ОБЪЕМ СРЕДСТВ ОБЩЕОБРАЗОВАТЕЛЬНЫХ ОРГАНИЗАЦИЙ ПО ИСТОЧНИКАМ ФИНАНСИРОВАНИЯ}

\begin{tabular}{|c|c|c|c|c|c|c|c|c|c|c|c|c|}
\hline & \multicolumn{4}{|c|}{ Всего } & \multicolumn{4}{|c|}{$\begin{array}{c}\text { Государственные и муниципальные } \\
\text { организации }\end{array}$} & \multicolumn{4}{|c|}{ Частные организации } \\
\hline & 2012 & 2013 & 2014 & 2015 & 2012 & 2013 & 2014 & 2015 & 2012 & 2013 & 2014 & 2015 \\
\hline \multicolumn{13}{|c|}{ Миллионы рублей } \\
\hline Объем средств - всего & 944208.9 & 1093717.4 & 1195331.3 & 1231160.0 & 927953.3 & 1076080.5 & 1175218.1 & 1205958.3 & 16255.6 & 17636.9 & 20113.2 & 25201.7 \\
\hline $\begin{array}{l}\text { Бюджетные средства } \\
\text { В том числе бюджетов: }\end{array}$ & 909660.1 & 1053188.1 & 1145741.0 & 116970.2 & 905980.9 & 1049493.2 & 1141247.2 & 1164221.5 & 3679.2 & 3694.9 & 4493.9 & 4848.7 \\
\hline $\begin{array}{l}\text { федерального } \\
\text { субъектов Российской }\end{array}$ & 46929.8 & 41613.1 & 18099.8 & 9853.6 & 46787.4 & 41481.0 & 17886.8 & 9678.5 & 142.4 & 132.1 & 213.0 & 175.1 \\
\hline Федерации & 699265.8 & 841220.2 & 911993.3 & 947907.6 & 696063.4 & 838173.9 & 908097.0 & 943587.9 & 3202.4 & 3046.3 & 3896.3 & 4319.7 \\
\hline местных & 163464.5 & 170354.8 & 215647.9 & 211308.9 & 163130.0 & 169838.3 & 215263.4 & 210955.1 & 334.5 & 516.5 & 384.6 & 353.9 \\
\hline Средства организаций & 7345.9 & 7431.2 & 8104.3 & 8898.8 & 3572.1 & 4104.8 & 4619.7 & 4454.7 & 3773.8 & 3326.3 & 3484.6 & 4444.1 \\
\hline Средства населения & 25531.0 & 31281.4 & 39057.6 & 50767.0 & 17223.3 & 21143.5 & 27469.1 & 35446.4 & 8307.8 & 10138.0 & 11588.5 & 15320.6 \\
\hline Внебюджетные фонды & 1658.2 & 1795.5 & 2410.3 & 2387.4 & 1173.7 & 1332.8 & 1873.2 & 1832.1 & 484.5 & 462.7 & 537.1 & 555.3 \\
\hline Иностранные источники & 13.6 & 21.2 & 18.0 & 36.6 & 3.4 & 6.3 & 8.9 & 3.6 & 10,3 & 15.0 & 9.1 & 33.0 \\
\hline
\end{tabular}




\section{(окончание)}

\begin{tabular}{|c|c|c|c|c|c|c|c|c|c|c|c|c|}
\hline & \multicolumn{4}{|c|}{ Bсего } & \multicolumn{4}{|c|}{$\begin{array}{c}\text { Государственные и муниципальные } \\
\text { организации }\end{array}$} & \multicolumn{4}{|c|}{ Частные организации } \\
\hline & 2012 & 2013 & 2014 & 2015 & 2012 & 2013 & 2014 & 2015 & 2012 & 2013 & 2014 & 2015 \\
\hline \multicolumn{13}{|c|}{ Проценты } \\
\hline Объем средств - всего & 100 & 100 & 100 & 100 & 100 & 100 & 100 & 100 & 100 & 100 & 100 & 100 \\
\hline $\begin{array}{l}\text { Бюджетные средства } \\
\text { В том числе бюджетов: }\end{array}$ & 96.3 & 96.3 & 95.9 & 95.0 & 97.6 & 97.5 & 97.1 & 96.5 & 22.6 & 20.9 & 22.3 & 19.2 \\
\hline федерального & 5.0 & 3.8 & 1.5 & 0.8 & 5.0 & 3.9 & 1.5 & 0.8 & 0.9 & 0.7 & 1.1 & 0.7 \\
\hline Федерации & 74.1 & 76.9 & 76.3 & 77.0 & 75.0 & 77.9 & 77.3 & 78.2 & 19.7 & 17.3 & 19.4 & 17.1 \\
\hline местных & 17.3 & 15.6 & 18.0 & 17.2 & 17.6 & 15.8 & 18.3 & 17.5 & 2.1 & 2.9 & 1.9 & 1.4 \\
\hline Средства организаций & 0.8 & 0.7 & 0.7 & 0.7 & 0.4 & 0.4 & 0.4 & 0.4 & 23.2 & 18.9 & 17.3 & 17.6 \\
\hline Средства населения & 2.7 & 2.9 & 3.3 & 4.1 & 1.9 & 2.0 & 2.3 & 2.9 & 51.1 & 57.5 & 57.6 & 60.8 \\
\hline Внебюджетные фонды & 0.2 & 0.2 & 0.2 & 0.2 & 0.1 & 0.1 & 0.2 & 0.2 & 3.0 & 2.6 & 2.7 & 2.2 \\
\hline Иностранные источники & 0.0 & 0.0 & 0.0 & 0.0 & 0.0 & 0.0 & 0.0 & 0.0 & 0.1 & 0.1 & 0.0 & 0.1 \\
\hline
\end{tabular}




\subsection{8. ОБЪЕМ СРЕДСТВ ОБРАЗОВАТЕЛЬНЫХ ОРГАНИЗАЦИЙ ДОПОЛНИТЕЛЬНОГО ОБРАЗОВАНИЯ, РЕАЛИЗУЮЩИХ ДОПОЛНИТЕЛЬНЫЕ ОБЩЕОБРАЗОВАТЕЛЬНЫЕ ПРОГРАММЫ ДЛЯ ДЕТЕЙ,}

ПО ИСТОЧНИКАМ ФИНАНСИРОВАНИЯ *

\begin{tabular}{|c|c|c|c|c|c|}
\hline & 2011 & 2012 & 2013 & 2014 & 2015 \\
\hline \multicolumn{6}{|c|}{ Миллионы рублей } \\
\hline Объем средств - всего & 75765.4 & 95271.9 & 139104.5 & 253531.6 & 239867.6 \\
\hline Бюджетные средства & 71236.1 & 88465.7 & 128229.7 & 232772.9 & 217299.2 \\
\hline Остаток средств на начало года & 230.9 & 305.1 & 707.8 & 1891.7 & 1547.8 \\
\hline \multicolumn{6}{|l|}{ Доходы от реализации платных } \\
\hline дополнительных образовательных услуг & 2430.6 & 3802.3 & 6008.2 & 11289.4 & 12338.5 \\
\hline Доходы от производственной деятельности & 292.8 & 378.4 & 445.3 & 871.7 & 1308.9 \\
\hline Благотворительные средства & 437.8 & 600.5 & 1013.0 & 2524.5 & 2264.8 \\
\hline Другие & 1137.2 & 1720.0 & 2700.5 & 4181.4 & 5108.5 \\
\hline \multicolumn{6}{|c|}{ Проценты } \\
\hline Объем средств - всего & 100 & 100 & 100 & 100 & 100 \\
\hline Бюджетные средства & 94.0 & 92.9 & 92.2 & 91.8 & 90.6 \\
\hline Остаток средств на начало года & 0.3 & 0.3 & 0.5 & 0.7 & 0.6 \\
\hline $\begin{array}{l}\text { Доходы от реализации платных дополнитель } \\
\text { образовательных услуг }\end{array}$ & 3.2 & 4.0 & 4.3 & 4.5 & 5.1 \\
\hline Доходы от производственной деятельности & 0.4 & 0.4 & 0.3 & 0.3 & 0.5 \\
\hline Благотворительные средства & 0.6 & 0.6 & 0.7 & 1.0 & 0.5 \\
\hline Другие & 1.5 & 1.8 & 1.9 & 1.6 & 2.1 \\
\hline
\end{tabular}

* По данным Минобрнауки России. 


\subsection{9. ОБЪЕМ СРЕДСТВ ОБРАЗОВАТЕЛЬНЫХ ОРГАНИЗАЦИЙ, РЕАЛИЗУЮЩИХ ОБРАЗОВАТЕЛЬНЫЕ ПРОГРАММЫ СРЕДНЕГО ПРОФЕССИОНАЛЬНОГО ОБРАЗОВАНИЯ, ПО ИСТОЧНИКАМ ФИНАНСИРОВАНИЯ: 2015}

\begin{tabular}{|c|c|c|c|}
\hline & Bcero & $\begin{array}{c}\text { Государственные и муниципальные } \\
\text { организации }\end{array}$ & Частные организации \\
\hline \multicolumn{4}{|c|}{ Миллионы рублей } \\
\hline Объем средств - всего & 199814.8 & 194580.0 & 5234.8 \\
\hline Бюджетные средства & 167178.6 & 167140.9 & 37.7 \\
\hline \multicolumn{4}{|l|}{ В том числе бюджетов: } \\
\hline федерального & 14991.8 & 14986.0 & 5.8 \\
\hline субъектов Российской Федерации & 149307.2 & 149284.1 & 23.2 \\
\hline местных & 2879.5 & 2870.8 & 8.7 \\
\hline Средства организаций & 7750.3 & 5861.7 & 1888.6 \\
\hline Средства населения & 21706.1 & 18448.4 & 3257.8 \\
\hline Внебюджетные фонды & 3139.9 & 3089.4 & 50.6 \\
\hline Иностранные источники & 39.8 & 39.7 & 0.1 \\
\hline \multicolumn{4}{|c|}{ Проценты } \\
\hline Объем средств - всего & 100 & 100 & 100 \\
\hline Бюджетные средства & 83.7 & 85.9 & 0.7 \\
\hline \multicolumn{4}{|l|}{ В том числе бюджетов: } \\
\hline федерального & 7.5 & 7.7 & 0.1 \\
\hline субъектов Российской Федерации & 74.7 & 76.7 & 0.4 \\
\hline местных & 1.4 & 1.5 & 0.2 \\
\hline Средства организаций & 3.9 & 3.0 & 36.1 \\
\hline Средства населения & 10.9 & 9.5 & 62.2 \\
\hline Внебюджетные фонды & 1.6 & 1.6 & 1.0 \\
\hline Иностранные источники & 0.0 & 0.0 & 0.0 \\
\hline
\end{tabular}




\subsection{0. ОБЪЕМ СРЕДСТВ ОБРАЗОВАТЕЛЬНЫХ ОРГАНИЗАЦИЙ ВЫСШЕГО ОБРАЗОВАНИЯ} ПО ИСТОЧНИКАМ ФИНАНСИРОВАНИЯ

\begin{tabular}{|c|c|c|c|c|c|c|c|c|c|c|c|c|}
\hline & \multicolumn{4}{|c|}{ Bсего } & \multicolumn{4}{|c|}{$\begin{array}{c}\text { Государственные и муниципальные } \\
\text { организации }\end{array}$} & \multicolumn{4}{|c|}{ Частные организации } \\
\hline & 2012 & 2013 & 2014 & 2015 & 2012 & 2013 & 2014 & 2015 & 2012 & 2013 & 2014 & 2015 \\
\hline \multicolumn{13}{|c|}{ Миллионы рублей } \\
\hline Объем средств - всего & 695010.1 & 739134.2 & 781671.7 & 768246.8 & 650046.7 & 686931.3 & 728747.6 & 718172.8 & 44963.4 & 52202.9 & 52924.1 & 50074.0 \\
\hline $\begin{array}{l}\text { Бюджетные средства } \\
\text { В том числе бюджетов: }\end{array}$ & 397216.6 & 426461.7 & 460806.1 & 438103.9 & 396072.3 & 425266.0 & 459261.6 & 436626.8 & 1144.3 & 1195.6 & 1544.5 & 1477.1 \\
\hline $\begin{array}{l}\text { федерального } \\
\text { субъектов Российской }\end{array}$ & 381933.1 & 408942.7 & 438200.2 & 416297.2 & 381051.9 & 408053.2 & 437041.9 & 415075.2 & 881.2 & 889.5 & 1158.2 & 1222.1 \\
\hline Федерации & 14463.3 & 16939.5 & 20477.0 & 20467.3 & 14252.3 & 16656.7 & 20286.5 & 20331.1 & 211.0 & 282.9 & 190.6 & 136.2 \\
\hline местных & 820.2 & 579.4 & 2128.9 & 1339.3 & 768.1 & 556.2 & 1933.2 & 1220.5 & 52.1 & 23.2 & 195.7 & 118.8 \\
\hline Средства организаций & 98871.6 & 100176.0 & 91533.9 & 93971.4 & 94123.1 & 92451.4 & 83842.2 & 86653.3 & 4748.4 & 7724.6 & 7691.7 & 7318.1 \\
\hline Средства населения & 189483.8 & 201274.5 & 210915.1 & 212899.6 & 151244.5 & 159056.2 & 168245.9 & 173191.5 & 38239.4 & 42218.4 & 42669.2 & 39708.1 \\
\hline Внебюджетные фонды & 5181.7 & 4937.6 & 9981.6 & 12330.8 & 4972.7 & 4497.8 & 9580.4 & 11928.1 & 209.0 & 439.8 & 401.2 & 402.7 \\
\hline Иностранные источники & 4256.4 & 6284.4 & 8435.0 & 10941.2 & 3634.0 & 5659.9 & 7817.5 & 9773.2 & 622.3 & 624.5 & 617.4 & 1168.0 \\
\hline
\end{tabular}


(окончание)

\begin{tabular}{|c|c|c|c|c|c|c|c|c|c|c|c|c|}
\hline & \multicolumn{4}{|c|}{ Bсего } & \multicolumn{4}{|c|}{$\begin{array}{c}\text { Государственные и муниципальные } \\
\text { организации }\end{array}$} & \multicolumn{4}{|c|}{ Частные организации } \\
\hline & 2012 & 2013 & 2014 & 2015 & 2012 & 2013 & 2014 & 2015 & 2012 & 2013 & 2014 & 2015 \\
\hline \multicolumn{13}{|c|}{ Проценты } \\
\hline Объем средств - всего & 100 & 100 & 100 & 100 & 100 & 100 & 100 & 100 & 100 & 100 & 100 & 100 \\
\hline $\begin{array}{l}\text { Бюджетные средства } \\
\text { В том числе бюджетов: }\end{array}$ & 57.2 & 57.7 & 59.0 & 57.0 & 60.9 & 61.9 & 63.0 & 60.8 & 2.5 & 2.3 & 2.9 & 2.9 \\
\hline федерального & 55.0 & 55.3 & 56.1 & 54.2 & 58.6 & 59.4 & 60.0 & 57.8 & 2.0 & 1.7 & 2.2 & 2.4 \\
\hline $\begin{array}{l}\text { субъектов Российской } \\
\text { Федерации }\end{array}$ & 2.1 & 2.3 & 2.6 & 2.7 & 2.2 & 2.4 & 2.8 & 2.8 & 0.5 & 0.5 & 0.4 & 0.3 \\
\hline местных & 0.1 & 0.1 & 0.3 & 0.2 & 0.1 & 0.1 & 0.3 & 0.2 & 0.1 & 0.0 & 0.4 & 0.2 \\
\hline Средства организаций & 14.2 & 13.6 & 11.7 & 12.2 & 14.5 & 13.5 & 11.5 & 12.1 & 10.6 & 14.8 & 14.5 & 14.6 \\
\hline Средства населения & 27.3 & 27.2 & 27.0 & 27.7 & 23.3 & 23.2 & 23.1 & 24.1 & 85.0 & 80.9 & 80.6 & 79.3 \\
\hline Внебюджетные фонды & 0.7 & 0.7 & 1.3 & 1.6 & 0.8 & 0.7 & 1.3 & 1.7 & 0.5 & 0.8 & 0.8 & 0.8 \\
\hline Иностранные источники & 0.6 & 0.9 & 1.1 & 1.4 & 0.6 & 0.8 & 1.1 & 1.4 & 1.4 & 1.2 & 1.2 & 2.3 \\
\hline
\end{tabular}




\subsection{1. СРЕДНИЕ ПОТРЕБИТЕЛЬСКИЕ ЦЕНЫ НА ОТДЕЛЬНЫЕ ВИДЫ УСЛУГ ОБРАЗОВАНИЯ (на конец года; рубли)}

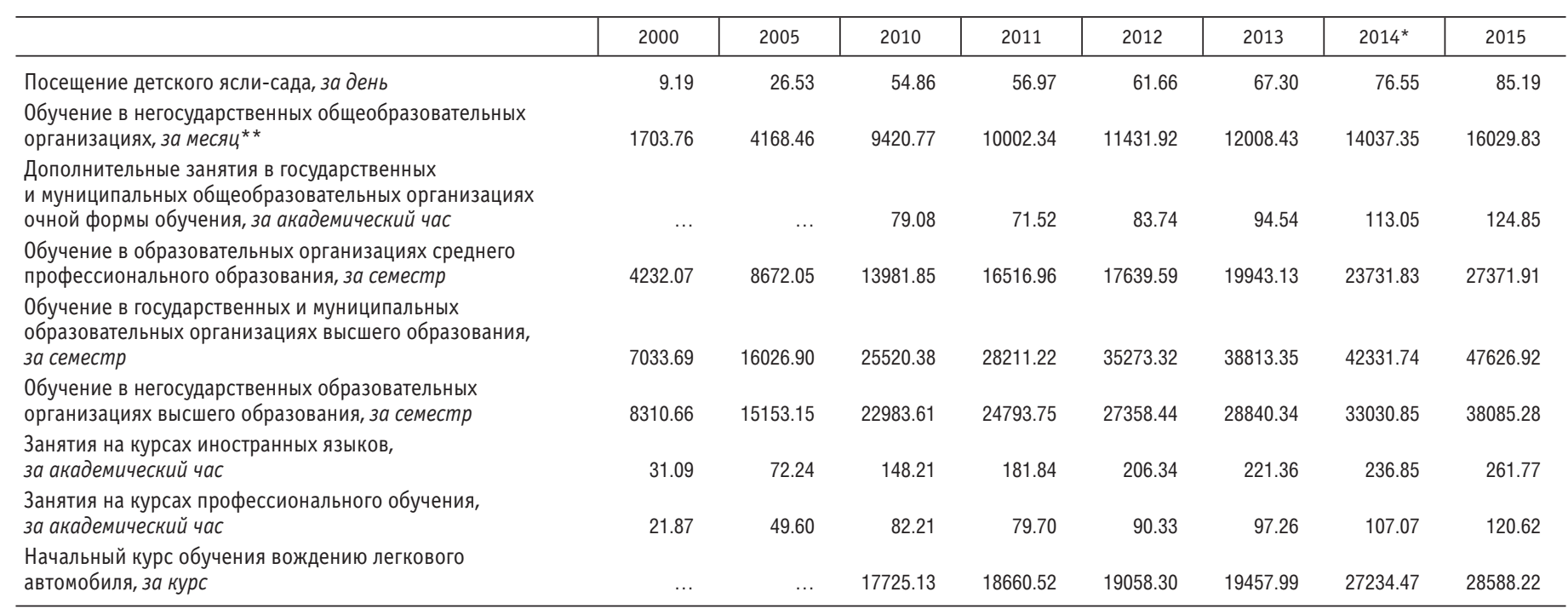

* В целях обеспечения статистической сопоставимости данных показатель рассчитан без учета сведений по Республике Крым и г. Севастополю.

** 2000, 2005 гг. - обучение в общеобразовательных средних учебных заведениях. 


\subsection{2. ИНДЕКСЫ ПОТРЕБИТЕЛЬСКИХ ЦЕН НА ОТДЕЛЬНЫЕ ВИДЫ УСЛУГ ОБРАЗОВАНИЯ}

(декабрь к декабрю предыдущего года)

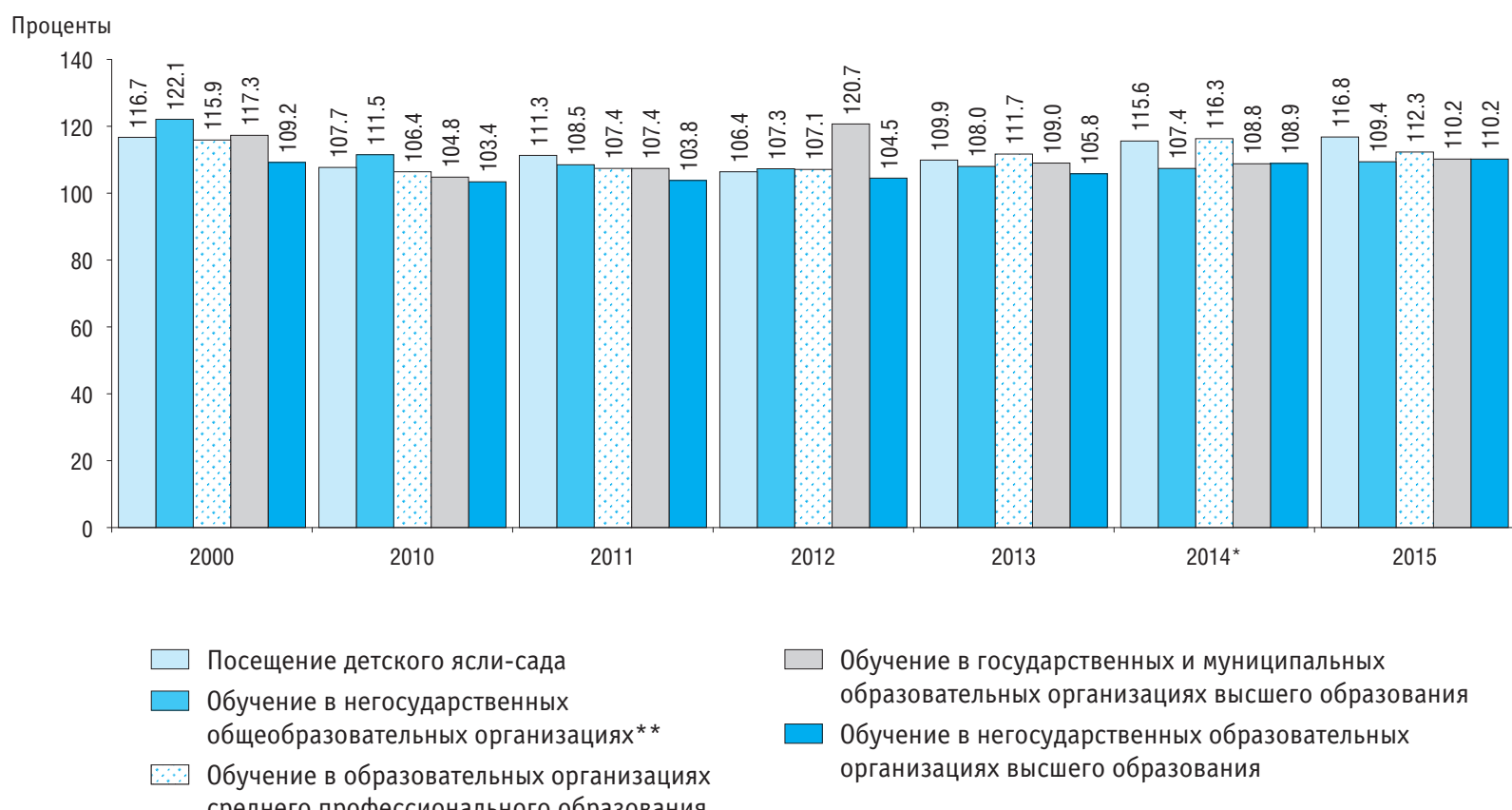

* В целях обеспечения статистической сопоставимости данных показатель рассчитан без учета сведений по Республике Крым и г. Севастополю.

** 2000 г. - обучение в общеобразовательных средних учебных заведениях. 


\subsection{3. ЧИСЛЕННОСТЬ СТУДЕНТОВ, ОБУЧАЮЩИХСЯ ПО ОБРАЗОВАТЕЛЬНЫМ ПРОГРАММАМ СРЕДНЕГО ПРОФЕССИОНАЛЬНОГО ОБРАЗОВАНИЯ - ПРОГРАММАМ ПОДГОТОВКИ КВАЛИФИЦИРОВАННЫХ РАБОЧИХ, СЛУЖАЩИХ, ПРИЕМ НА ОБУЧЕНИЕ И ВЫПУСК КВАЛИФИЦИРОВАННЫХ РАБОЧИХ, СЛУЖАЩИХ ПО ИСТОЧНИКАМ ФИНАНСИРОВАНИЯ (тысячи человек)}

\begin{tabular}{|c|c|c|c|c|c|c|}
\hline & \multicolumn{2}{|c|}{$\begin{array}{c}\text { Численность обучающихся, } \\
\text { на конец года }\end{array}$} & \multicolumn{2}{|c|}{ Принято на обучение } & \multicolumn{2}{|c|}{$\begin{array}{c}\text { Выпуск квалифицированных } \\
\text { рабочих, служащих }\end{array}$} \\
\hline & 2010 & 2015 & 2010 & 2015 & 2010 & 2015 \\
\hline Bcero & 1006.6 & 686.1 & 609.4 & 395.6 & 580.5 & 368.2 \\
\hline $\begin{array}{l}\text { Обучение за счет средств бюджета учредителя } \\
\text { образовательной организации }\end{array}$ & 964.7 & 670.0 & 508.6 & 371.4 & 484.2 & 346.6 \\
\hline Обучение по договорам & 41.9 & 16.1 & 100.8 & 24.2 & 96.3 & 21.7 \\
\hline За счет бюджетных ассигнований & 12.7 & 3.9 & 29.5 & 4.9 & 29.0 & 4.9 \\
\hline \multicolumn{7}{|l|}{ В том числе: } \\
\hline федерального бюджета & 1.9 & 0.1 & 10.9 & 0.8 & 11.4 & 0.9 \\
\hline бюджетов субъектов Российской Федерации & 10.2 & 3.8 & 16.4 & 3.7 & 15.0 & 3.7 \\
\hline местных бюджетов & 0.6 & 0.0 & 2.2 & 0.3 & 2.5 & 0.3 \\
\hline За счет средств организаций (работодателей) & 1.6 & 0.4 & 9.7 & 2.1 & 9.4 & 2.2 \\
\hline \multicolumn{7}{|l|}{ В том числе: } \\
\hline государственных & 0.7 & 0.1 & 4.1 & 1.1. & 4.3 & 1.1 \\
\hline негосударственных & 0.9 & 0.3 & 5.5 & 1.1 & 5.1 & 1.0 \\
\hline За счет средств обучающихся & 26.9 & 11.8 & 58.9 & 17.1 & 54.9 & 14.5 \\
\hline За счет средств других источников & 0.8 & 0.0 & 2.7 & 0.1 & 3.0 & 0.1 \\
\hline
\end{tabular}




\subsection{4. ЧИСЛЕННОСТЬ СТУДЕНТОВ, ОБУЧАЮЩИХСЯ ПО ОБРАЗОВАТЕЛЬНЫМ ПРОГРАММАМ СРЕДНЕГО ПРОФЕССИОНАЛЬНОГО ОБРАЗОВАНИЯ - ПРОГРАММАМ ПОДГОТОВКИ СПЕЦИАЛИСТОВ СРЕДНЕГО ЗВЕНА, ПРИЕМ НА ОБУЧЕНИЕ \\ И ВЫПУСК СПЕЦИАЛИСТОВ СРЕДНЕГО ЗВЕНА ПО ИСТОЧНИКАМ ФИНАНСИРОВАНИЯ}

(тысячи человек)

\begin{tabular}{|c|c|c|c|c|c|c|c|c|}
\hline & 2000 & 2005 & 2010 & 2011 & 2012 & 2013 & 2014 & 2015 \\
\hline Численность студентов, на начало учебного года & 2360.8 & 2590.7 & 2125.7 & 2081.7 & 2087.1 & 1984.3 & 2103.1 & 2180.2 \\
\hline \multicolumn{9}{|l|}{ В том числе обучающихся за счет: } \\
\hline бюджетных ассигнований & 1590.1 & 1603.9 & 1485.9 & 1492.4 & 1524.2 & 1452.4 & 1516.0 & 1533.3 \\
\hline в государственных и муниципальных организациях & 1590.1 & 1603.9 & 1485.7 & 1491.9 & 1523.4 & 1450.5 & 1514.7 & 1531.0 \\
\hline в частных организациях & $\ldots$ & $\ldots$ & 0.2 & 0.5 & 0.8 & 1.9 & 1.3 & 2.3 \\
\hline $\begin{array}{l}\text { физических и (или) юридических лиц по договорам } \\
\text { об оказании платных образовательных услуг }\end{array}$ & 770.7 & 986.8 & 639.8 & 589.3 & 562.9 & 532.0 & 587.2 & 646.9 \\
\hline в государственных и муниципальных организациях & 718.5 & 869.1 & 541.2 & 492.1 & 461.0 & 407.9 & 448.6 & 500.3 \\
\hline в частных организациях & 52.2 & 117.7 & 98.6 & 97.2 & 101.9 & 124.1 & 138.5 & 146.6 \\
\hline Прием студентов & 867.2 & 854.1 & 705.3 & 659.6 & 656.2 & 637.7 & 672.8 & 699.3 \\
\hline \multicolumn{9}{|l|}{ В том числе на обучение за счет: } \\
\hline в государственные и муниципальные организации & 516.5 & 500.5 & 489.7 & 479.9 & 481.2 & 447.9 & 455.1 & 454.7 \\
\hline в частные организации & $\ldots$ & $\cdots$ & 0.0 & 0.2 & 0.7 & 0.5 & 0.3 & 0.7 \\
\hline $\begin{array}{l}\text { физических и (или) юридических лиц по договорам } \\
\text { об оказании платных образовательных услуг }\end{array}$ & 350.7 & 353.6 & 215.5 & 179.5 & 174.3 & 189.3 & 217.5 & 243.9 \\
\hline в государственные и муниципальные организации & 325.9 & 310.4 & 182.1 & 148.9 & 139.6 & 143.4 & 163.3 & 185.1 \\
\hline в частные организации & 24.8 & 43.2 & 33.5 & 30.6 & 34.7 & 45.9 & 54.2 & 58.8 \\
\hline
\end{tabular}


3. Финансирование орразования

(окончание)

\begin{tabular}{|c|c|c|c|c|c|c|c|c|}
\hline & 2000 & 2005 & 2010 & 2011 & 2012 & 2013 & 2014 & 2015 \\
\hline Выпуск специалистов среднего звена & 579.3 & 684.4 & 572.1 & 518.0 & 486.3 & 439.0 & 451.0 & 446.0 \\
\hline \multicolumn{9}{|l|}{ В том числе обучавшихся за счет: } \\
\hline бюджетных ассигнований & 414.2 & 399.3 & 356.8 & 331.0 & 319.1 & 299.7 & 319.3 & 320.1 \\
\hline в государственных и муниципальных организациях & 414.2 & 399.3 & 356.8 & 330.9 & 319.0 & 299.4 & 319.3 & 319.4 \\
\hline в частных организациях & $\ldots$ & $\ldots$ & 0.0 & 0.1 & 0.0 & 0.4 & 0.1 & 0.7 \\
\hline $\begin{array}{l}\text { физических и (или) юридических лиц по договорам } \\
\text { об оказании платных образовательных услуг }\end{array}$ & 165.1 & 285.1 & 215.3 & 187.0 & 167.3 & 139.3 & 131.6 & 125.9 \\
\hline в государственных и муниципальных организациях & 153.5 & 252.1 & 178.9 & 153.3 & 135.9 & 104.6 & 98.7 & 91.6 \\
\hline в частных организациях & 11.6 & 33.0 & 36.4 & 33.7 & 31.4 & 34.7 & 32.9 & 34.3 \\
\hline
\end{tabular}


3.25. ЧИСЛЕННОСТЬ СТУДЕНТОВ, ОБУЧАЮЩИХСЯ ПО ОБРАЗОВАТЕЛЬНЫМ ПРОГРАММАМ ВЫСШЕГО ОБРАЗОВАНИЯ ПРОГРАММАМ БАКАЛАВРИАТА, ПРОГРАММАМ СПЕЦИАЛИТЕТА, ПРОГРАММАМ МАГИСТРАТУРЫ, ПРИЕМ НА ОБУЧЕНИЕ

И ВЫПУСК БАКАЛАВРОВ, СПЕЦИАЛИСТОВ, МАГИСТРОВ ПО ИСТОЧНИКАМ ФИНАНСИРОВАНИЯ

(тысячи человек)

\begin{tabular}{|c|c|c|c|c|c|c|c|}
\hline & 2000 & 2005 & 2010 & 2011 & 2012 & 2013 & 2015 \\
\hline Численность студентов, на начало учебного года & 4741.4 & 7064.6 & 7049.8 & 6490.0 & 6075.4 & 5646.7 & 4766.5 \\
\hline \multicolumn{8}{|l|}{ В том числе обучающихся за счет: } \\
\hline бюджетных ассигнований & 2802.0 & 3002.7 & 2619.8 & 2455.8 & 2338.0 & 2196.9 & 1933.6 \\
\hline в государственных и муниципальных организациях & 2802.0 & 3002.7 & 2619.3 & 2455.2 & 2332.9 & 2190.3 & 1923.6 \\
\hline в частных организациях & $\ldots$ & $\ldots$ & 0.5 & 0.6 & 5.1 & 6.6 & 10.0 \\
\hline $\begin{array}{l}\text { физических и (или) юридических лиц по договорам } \\
\text { об оказании платных образовательных услуг }\end{array}$ & 1939.4 & 4061.9 & 4430.1 & 4034.1 & 3737.3 & 3449.7 & 2832.9 \\
\hline в государственных и муниципальных организациях & 1468.8 & 2982.6 & 3229.5 & 2998.6 & 2812.3 & 2571.6 & 2137.8 \\
\hline в частных организациях & 470.6 & 1079.3 & 1200.6 & 1035.5 & 925.0 & 878.1 & 695.0 \\
\hline Прием студентов & 1292.5 & 1640.5 & 1399.5 & 1207.4 & 1298.2 & 1246.5 & 1221.8 \\
\hline \multicolumn{8}{|l|}{ В том числе на обучение за счет: } \\
\hline бюджетных ассигнований & 586.8 & 613.7 & 519.2 & 510.7 & 519.5 & 499.1 & 523.0 \\
\hline в государственные и муниципальные организации & 586.8 & 613.7 & 519.0 & 510.5 & 514.9 & 496.8 & 520.7 \\
\hline в частные организации & $\ldots$ & $\ldots$ & 0.2 & 0.2 & 4.6 & 2.3 & 2.3 \\
\hline $\begin{array}{l}\text { физических и (или) юридических лиц по договорам } \\
\text { об оказании платных образовательных услуг }\end{array}$ & 705.7 & 1026.8 & 880.2 & 696.6 & 778.7 & 747.4 & 698.8 \\
\hline в государственные и муниципальные организации & 553.5 & 758.8 & 676.4 & 547.2 & 596.7 & 569.9 & 528.8 \\
\hline в частные организации & 152.2 & 268.0 & 203.8 & 149.5 & 182.0 & 177.5 & 169.9 \\
\hline
\end{tabular}


З. Финансирование образования

(окончание)

\begin{tabular}{|c|c|c|c|c|c|c|c|}
\hline & 2000 & 2005 & 2010 & 2011 & 2012 & 2013 & 2015 \\
\hline Выпуск бакалавров, специалистов, магистров & 635.1 & 1151.7 & 1467.9 & 1442.9 & 1397.2 & 1291.0 & 1300.5 \\
\hline \multicolumn{8}{|l|}{ В том числе обучавшихся за счет: } \\
\hline бюджетных ассигнований & 451.8 & 517.2 & 546.7 & 521.3 & 496.8 & 473.4 & 536.1 \\
\hline в государственных и муниципальных организациях & 451.8 & 517.2 & 546.6 & 521.0 & 496.7 & 473.3 & 535.6 \\
\hline в частных организациях & $\ldots$ & $\ldots$ & 0.1 & 0.3 & 0.1 & 0.1 & 0.5 \\
\hline $\begin{array}{l}\text { физических и (или) юридических лиц по договорам } \\
\text { об оказании платных образовательных услуг }\end{array}$ & 183.3 & 634.5 & 921.2 & 921.6 & 900.5 & 817.6 & 764.4 \\
\hline в государственных и муниципальных организациях & 127.1 & 461.2 & 631.2 & 636.3 & 628.7 & 586.7 & 574.4 \\
\hline в частных организациях & 56.2 & 173.3 & 290.1 & 285.3 & 271.8 & 230.9 & 190.0 \\
\hline
\end{tabular}




\subsection{6. СРЕДНЕМЕСЯЧНАЯ НОМИНАЛЬНАЯ НАЧИСЛЕННАЯ ЗАРАБОТНАЯ ПЛАТА}

РАБОТНИКОВ ОБРАЗОВАНИЯ*

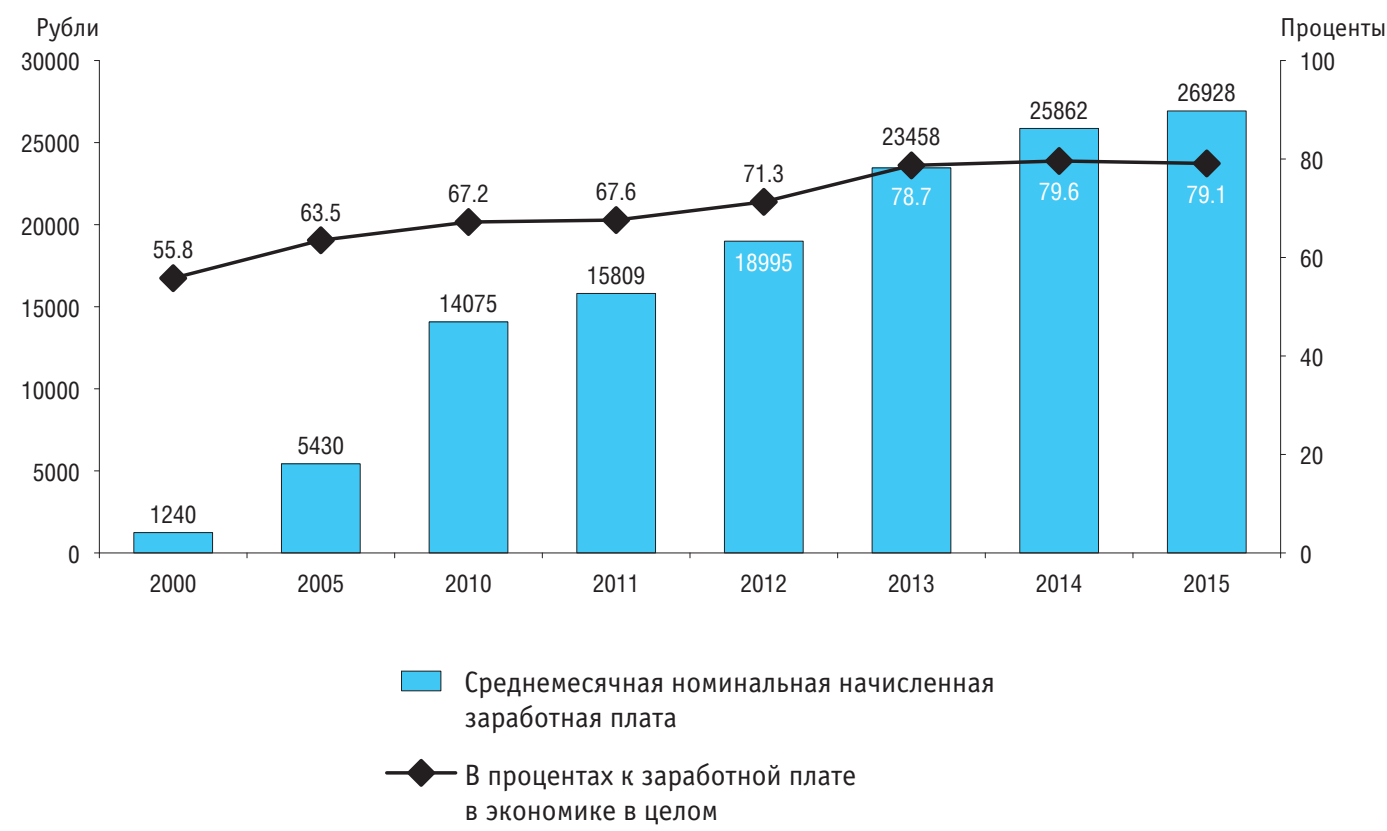

* Здесь и и далее (рис. 3.27, 3.30, 3.31, табл. 3.28, 3.29) данные за 2014 г. приведены без учета сведений по Республике Крым и г. Севастополю. 


\subsection{7. РЕАЛЬНАЯ НАЧИСЛЕННАЯ ЗАРАБОТНАЯ ПЛАТА В ОБРАЗОВАНИИ И ЭКОНОМИКЕ} (в процентах к предыдущему году)
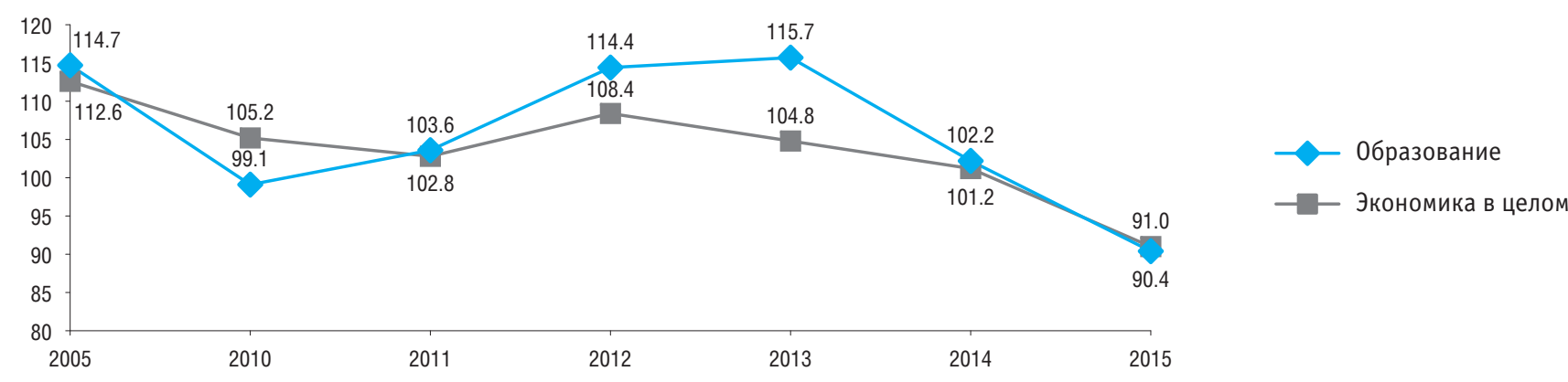

\subsection{8. СРЕДНЕМЕСЯЧНАЯ НОМИНАЛЬНАЯ НАЧИСЛЕННАЯ ЗАРАБОТНАЯ ПЛАТА РАБОТНИКОВ ОБРАЗОВАНИЯ ПО ФОРМАМ СОБСТВЕННОСТИ ОРГАНИЗАЦИЙ}

(рубли)

\begin{tabular}{|c|c|c|c|c|c|c|c|}
\hline & 2005 & 2010 & 2011 & 2012 & 2013 & 2014 & 2015 \\
\hline Всего & 5430 & 14075 & 15809 & 18995 & 23458 & 25862 & 26928 \\
\hline \multicolumn{8}{|l|}{ Формы собственности: } \\
\hline государственная & 7189 & 19974 & 22056 & 25707 & 30938 & 34406 & 36068 \\
\hline муниципальная & 4380 & 10682 & 12294 & 15258 & 19490 & 21665 & 22497 \\
\hline частная & 9527 & 21430 & 22191 & 23733 & 27832 & 26425 & 28692 \\
\hline общественных и религиозных организаций (объединений) & 7449 & 15715 & 16361 & 17504 & 18388 & 19903 & 20314 \\
\hline смешанная российская & 11075 & 22827 & 24698 & 27461 & 27513 & 29890 & 35812 \\
\hline иностранная, совместная российская и иностранная & 12758 & 33425 & 29006 & 35088 & 39260 & 39926 & 46102 \\
\hline
\end{tabular}




\subsection{9. СРЕДНЕМЕСЯЧНАЯ НОМИНАЛЬНАЯ НАЧИСЛЕННАЯ ЗАРАБОТНАЯ ПЛАТА РАБОТНИКОВ ОБРАЗОВАНИЯ}

(рубли)

\begin{tabular}{|c|c|c|c|c|c|c|c|}
\hline & 2005 & 2010 & 2011 & 2012 & 2013 & 2014 & 2015 \\
\hline Bcero & 5430 & 14075 & 15809 & 18995 & 23458 & 25862 & 26928 \\
\hline Дошкольное и начальное общее образование & 4235 & 10718 & 12103 & 14492 & 18577 & 20382 & 20958 \\
\hline Дошкольное образование & $\ldots$ & 10222 & 11562 & 13919 & 18008 & 19407 & 19718 \\
\hline Начальное общее образование & $\ldots$ & 10436 & 12115 & 15626 & 20000 & 21724 & 23454 \\
\hline Дополнительное образование детей & $\ldots$ & 12722 & 14250 & 16649 & 20664 & 24020 & 25433 \\
\hline \multicolumn{8}{|l|}{ Основное общее, среднее (полное) общее, начальное } \\
\hline и среднее профессиональное образование & 5238 & 13898 & 15890 & 19797 & 24479 & 27007 & 28037 \\
\hline Основное общее и среднее (полное) общее образование & $\ldots$ & 13566 & 15658 & 19735 & 24678 & 27162 & 28151 \\
\hline Основное общее образование & $\ldots$ & 11347 & 13062 & 16525 & 20988 & 23289 & 23971 \\
\hline Среднее (полное) общее образование & $\ldots$ & 13971 & 16129 & 20290 & 25298 & 27813 & 28838 \\
\hline Начальное и среднее профессиональное образование & $\ldots$ & 15266 & 16856 & 20061 & 23601 & 26285 & 27483 \\
\hline Начальное профессиональное образование & $\ldots$ & 12620 & 14139 & 16734 & 20060 & 22600 & 24745 \\
\hline Среднее профессиональное образование & $\ldots$ & 16702 & 18194 & 21453 & 24809 & 27144 & 27857 \\
\hline Образование для взрослых и прочие виды образования & 6394 & 16426 & 17786 & 19861 & 20898 & 21736 & 27621 \\
\hline
\end{tabular}


3.30. СРЕДНЕМЕСЯЧНАЯ НОМИНАЛЬНАЯ НАЧИСЛЕННАЯ ЗАРАБОТНАЯ ПЛАТА РАБОТНИКОВ ОБРАЗОВАНИЯ В ПРОЦЕНТАХ К ЗАРАБОТНОЙ ПЛАТЕ В ЭКОНОМИКЕ В ЦЕЛОМ

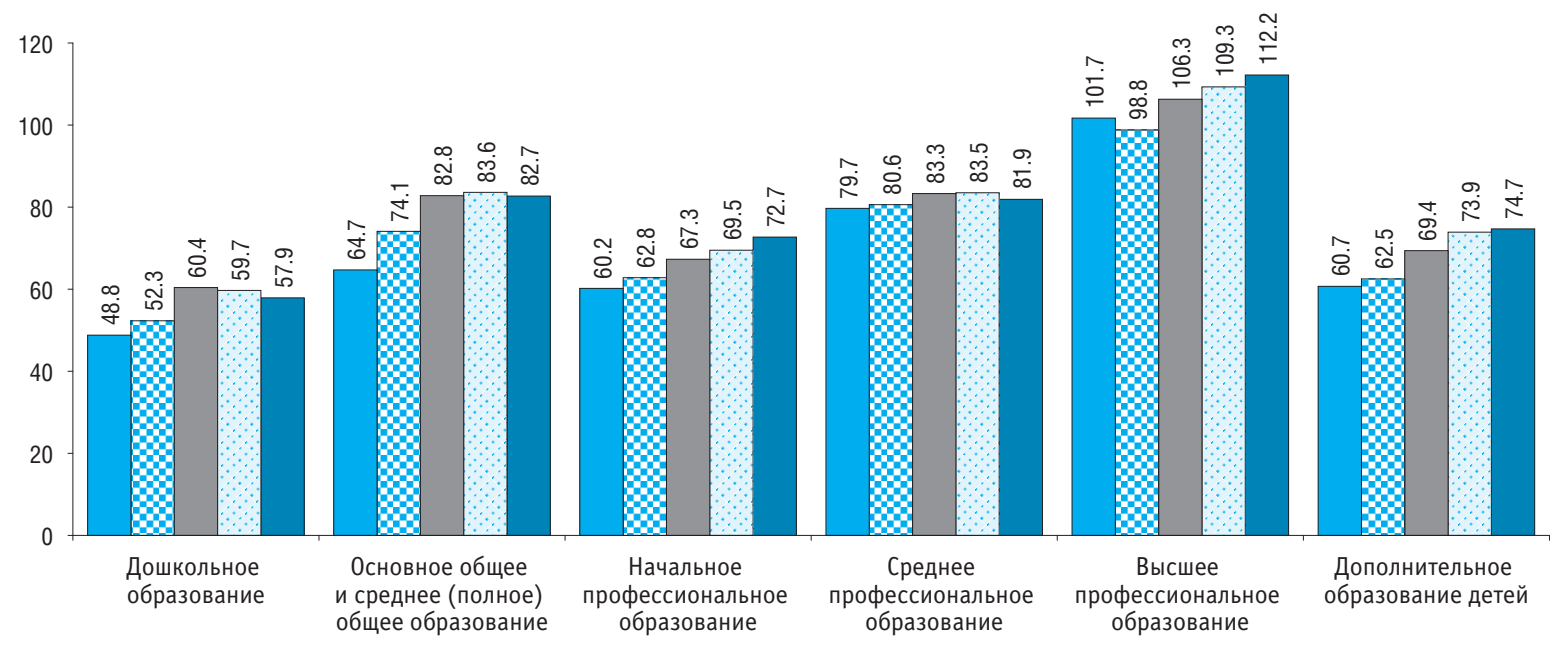




\subsection{1. СРЕДНЯЯ ЗАРАБОТНАЯ ПЛАТА ПЕДАГОГИЧЕСКИХ РАБОТНИКОВ ГОСУДАРСТВЕННЫХ И МУНИЦИПАЛЬНЫХ ОБРАЗОВАТЕЛЬНЫХ ОРГАНИЗАЦИЙ}

Рубли

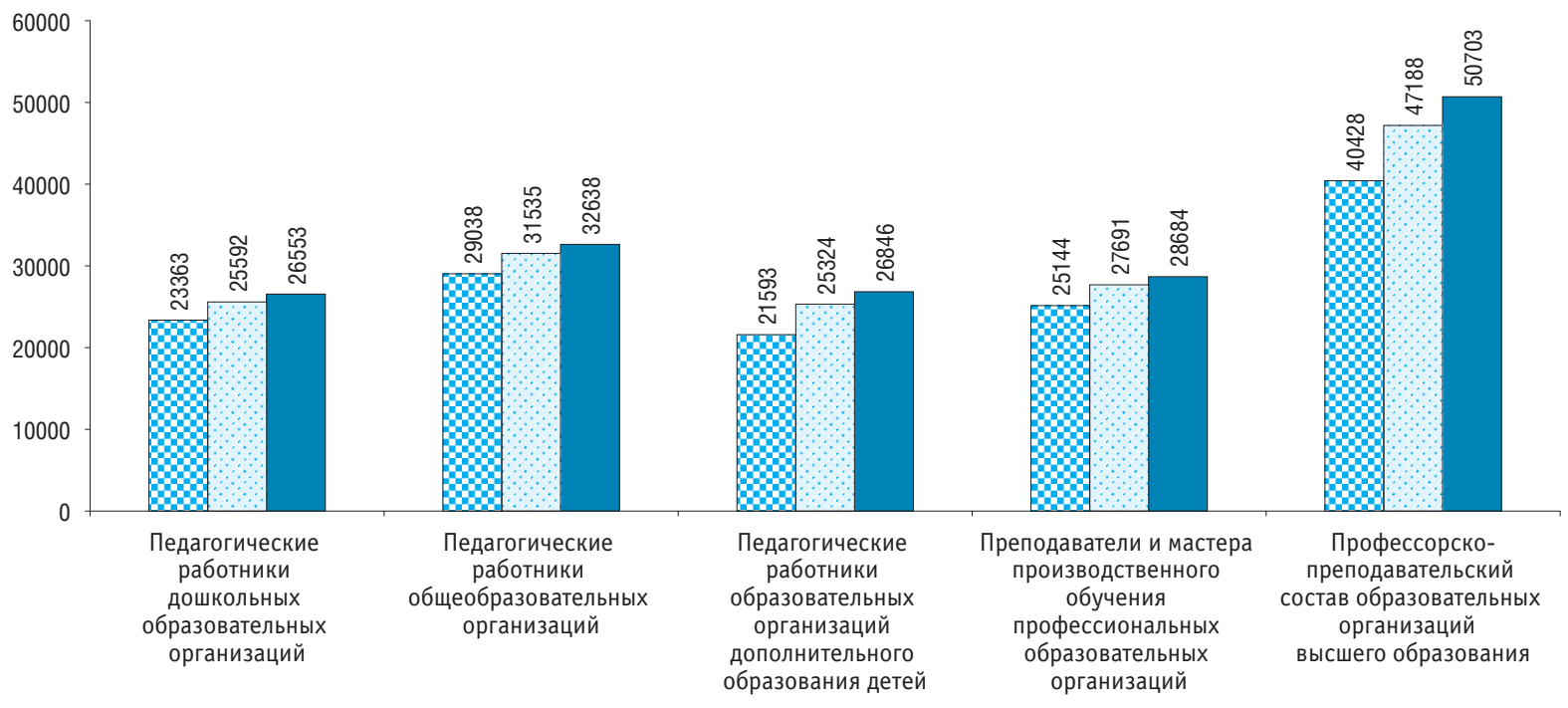

口2013 $2014 \square 2015$ 
(окончание)

В процентах к средней заработной плате в целом*

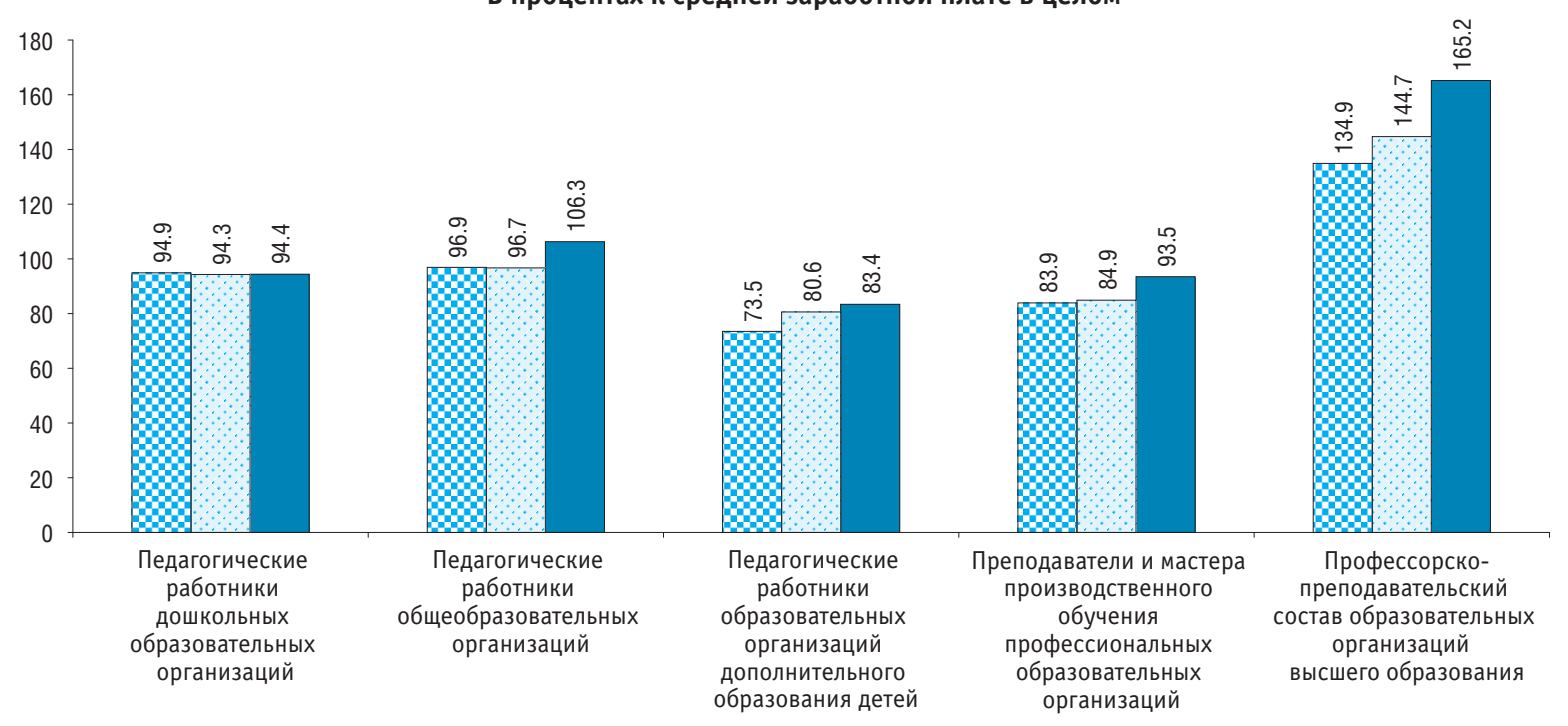

DD2013 $2014 \square 2015$

* C 2015 г. - среднемесячная заработная плата наемных работников в организациях, у индивидуальных предпринимателей и физических лиц (среднемесячный доход от трудовой деятельности). Заработная плата педагогических работников дошкольных образовательных организаций приведена в процентах к средней заработной плате в общем образовании, педагогических работников образовательных организаций дополнительного образования детей - к средней заработной плате учителей. 


\section{МЕТОДОЛОГИЧЕСКИЕ КОММЕНТАРИИ}

Консолидированный бюджет Российской Федерации образуют федеральный бюджет и свод консолидированных бюджетов субъектов Российской Федерации (без учета межбюджетных трансфертов между этими бюджетами).

Государственный внебюджетный фонд - фонд денежных средств, образуемых вне федерального бюджета и бюджетов субъектов Российской Федерации.

Федеральный бюджет предназначен для исполнения расходных обязательств Российской Федерации.

Консолидированный бюджет субъекта Российской Федерации образуют бюджет субъекта Российской Федерации и свод бюджетов муниципальных образований, входящих в состав субъекта Российской Федерации (без учета межбюджетных трансфертов между этими бюджетами).

Расходы бюджета - денежные средства, направляемые на финансовое обеспечение задач и функций государства и местного самоуправления.

Расходы бюджета Российской Федерации на образование (государственные расходы на образование) - денежные средства, направленные на финансовое обеспечение образования. Соответствующая информация основывается на годовых отчетах об исполнении консолидированного бюджета Российской Федерации и бюджетов государственных внебюджетных фондов по разделу 0700 «0бразование». Раздел 0700 «0бразование» состоит из восьми подразделов и аккумулирует расходы на целе- направленный процесс воспитания и обучения в интересах человека, общества, государства.

Темпы роста государственных расходов на образование в постоянных ценах показывают изменение объемов этих расходов в текущем году по сравнению с базисным в неизменных ценах. Для расчета государственных расходов на образование в постоянных ценах применен дефлятор элементов использования валового внутреннего продукта.

Государственные расходы на образование в расчете на одного обучающегося по подразделам классификации расходов определяются как отношение государственных расходов на соответствующий уровень образования к численности обучающихся за счет бюджетных ассигнований на этом уровне образования.

Инвестиции в основной капитал - совокупность затрат, направленных на реконструкцию (включая расширение и модернизацию) объектов, которые приводят к увеличению их первоначальной стоимости; приобретение машин, оборудования, транспортных средств и т.д. Начиная с 2013 г. в инвестиции в основной капитал включаются инвестиции в объекты интеллектуальной собственности: произведения науки, литературы и искусства; программное обеспечение и базы данных для ЭВМ, изобретения, полезные модели, промышленные образцы, селекционные достижения, произведенные нематериальные поисковые затраты, затраты на научно-исследовательские, опытноконструкторские и технологические работы и т.д. 
С 2001 г. инвестиции в основной капитал учитываются без налога на добавленную стоимость. Темпы роста инвестиций в основной капитал рассчитаны в сопоставимых ценах. В качестве сопоставимых цен приняты среднегодовые цены предыдущего периода.

Объем платных услуг населению в системе образования представляет собой денежный эквивалент оказанных населению услуг по содержанию детей в дошкольных образовательных организациях, обучению на платной основе в образовательных организациях всех форм собственности, на платных курсах, в секциях, кружках, студиях, находящихся при общеобразовательных организациях, услуг частных репетиторов, услуг лагерей дневного пребывания при образовательных организациях и других услуг, отнесенных в соответствии с Общероссийским классификатором услуг населению (0КУН) к подгруппе 11 «Услуги в системе образования». Этот показатель формируется на основании данных форм федерального статистического наблюдения и оценки ненаблюдаемой деятельности на рынке услуг (до 2012 г. включительно - по методике, утвержденной постановлением Госкомстата России от 25 февраля 2000 г. № 15, с 2013 г. - по методологии, утвержденной приказом Росстата от 26 июня 2013 г. № 234).

Темпы роста объема платных услуг населению в системе образования в сопоставимых ценах показывают изменение объемов этих услуг в текущем году по сравнению с базисным при исключении влияния динамики цен.

Обследование бюджетов домашних хозяйств проводится органами государственной статистики во всех субъектах Рос- сийской Федерации по выборочному методу, охватывает около 48.5 тыс. домашних хозяйств и строится на принципе их добровольного участия. Программа обследования основывается на ведении в домохозяйстве дневниковых записей о текущих расходах и опросе (интервьюировании) членов домохозяйства по окончании учетного периода обследования, охватывающего квартал.

С 2001 г. сбор и обработка статистической информации, характеризующей уровень и структуру потребительских расходов населения, при проведении бюджетного обследования производится с использованием Классификатора индивидуального потребления по целям (КИПЦ-ДХ). Классификатор разработан Росстатом на основе Международной статистической классификации индивидуального потребления по целям - Classification of Individual Consumption by Purpose (COICOP), которая является одной из функциональных классификаций СНС и служит средством стандартного группирования затрат домашних хозяйств на личное потребление.

Домашнее хозяйство (домохозяйство) представляет собой совокупность лиц, проживающих в одном жилом помещении или его части, как связанных, так и не связанных отношениями родства, совместно обеспечивающих себя всем необходимым для жизни, полностью или частично объединяя и расходуя свои средства. Домохозяйство может состоять из одного человека, проживающего самостоятельно.

Потребительские расходы домашних хозяйств являются частью денежных расходов, которые направляются на приобретение 
потребительских товаров и услуг. В их составе не учитываются расходы на покупку произведений искусства, антиквариата и ювелирных изделий, приобретаемых в качестве капиталовложений, оплату материалов и работ по строительству и капитальному ремонту жилых или подсобных помещений, являющиеся инвестициями.

Расходы домашних хозяйств на оплату услуг образования включают расходы: на дошкольное и начальное образование (плата за обучение в начальных школах, подготовительных группах детских садов и школ и т.п.); среднее общее образование (плата за обучение в средних школах, гимназиях, лицеях и других средних учебных заведениях, в том числе плата за услуги уборщиц, посещение группы продленного дня (без питания), охрану и т.п.), включая внешкольное среднее образование для молодежи и взрослых; среднее профессиональное образование (плата за обучение); высшее образование (плата за обучение), а также расходы на образование, не определенные по уровню (плата за получение образовательных услуг в области профессионально-технического обучения, не требующего предшествующего специального образования, а также на других направлениях обучения: компьютерные курсы, курсы иностранного языка, бухгалтерского учета и т.п.).

Средние потребительские цены (тарифы) по Российской Федерации определяются как средняя арифметическая величина из уровней цен по субъектам Российской Федерации, взвешенных на удельный вес численности населения субъектов Российской Федерации в общей численности населения Российской Федерации.
Индекс потребительских цен (тарифов) измеряет отношение стоимости фиксированного набора услуг в ценах текущего периода к его стоимости в ценах базисного периода и отражает изменение во времени общего уровня цен и тарифов на услуги, приобретаемые населением для непроизводственного потребления. Наблюдение за изменением цен (тарифов) проводится на территории всех субъектов Российской Федерации. Ценовая информация собирается в столицах республик, центрах краев, областей, автономной области, автономных округов, городах федерального значения и выборочно - в районных центрах.

Среднемесячная номинальная начисленная заработная плата за год исчисляется делением фонда начисленной заработной платы работников на среднесписочную численность работников и на 12. Пособия, получаемые работниками из государственных внебюджетных фондов, не включаются в фонд заработной платы и среднемесячную заработную плату.

Реальная начисленная заработная плата характеризует покупательную способность заработной платы в отчетном периоде в связи с изменением цен на потребительские товары и услуги по сравнению с базисным периодом. Для этого рассчитывается индекс реальной начисленной заработной платы путем деления индекса номинальной начисленной заработной платы на индекс потребительских цен за один и тот же временной период.

Средняя заработная плата педагогических работников государственных и муниципальных образовательных организаций исчисляется в отношении работников списочного состава по основной работе делением фонда начисленной заработной 


\section{8}

платы работников списочного состава (без фонда заработной платы внешних совместителей и фонда заработной платы по договорам гражданско-правового характера с лицами, не являющимися работниками организаций) на среднесписочную численность работников (без внешних совместителей и работающих по договорам гражданско-правового характера) и на количество месяцев в периоде. При этом в сумму начисленной заработной платы работников списочного состава по основной работе включается оплата труда по внутреннему совместительству, а также вознаграждения по договорам гражданско-правового характера, заключенным работниками списочного состава со своей организацией. 


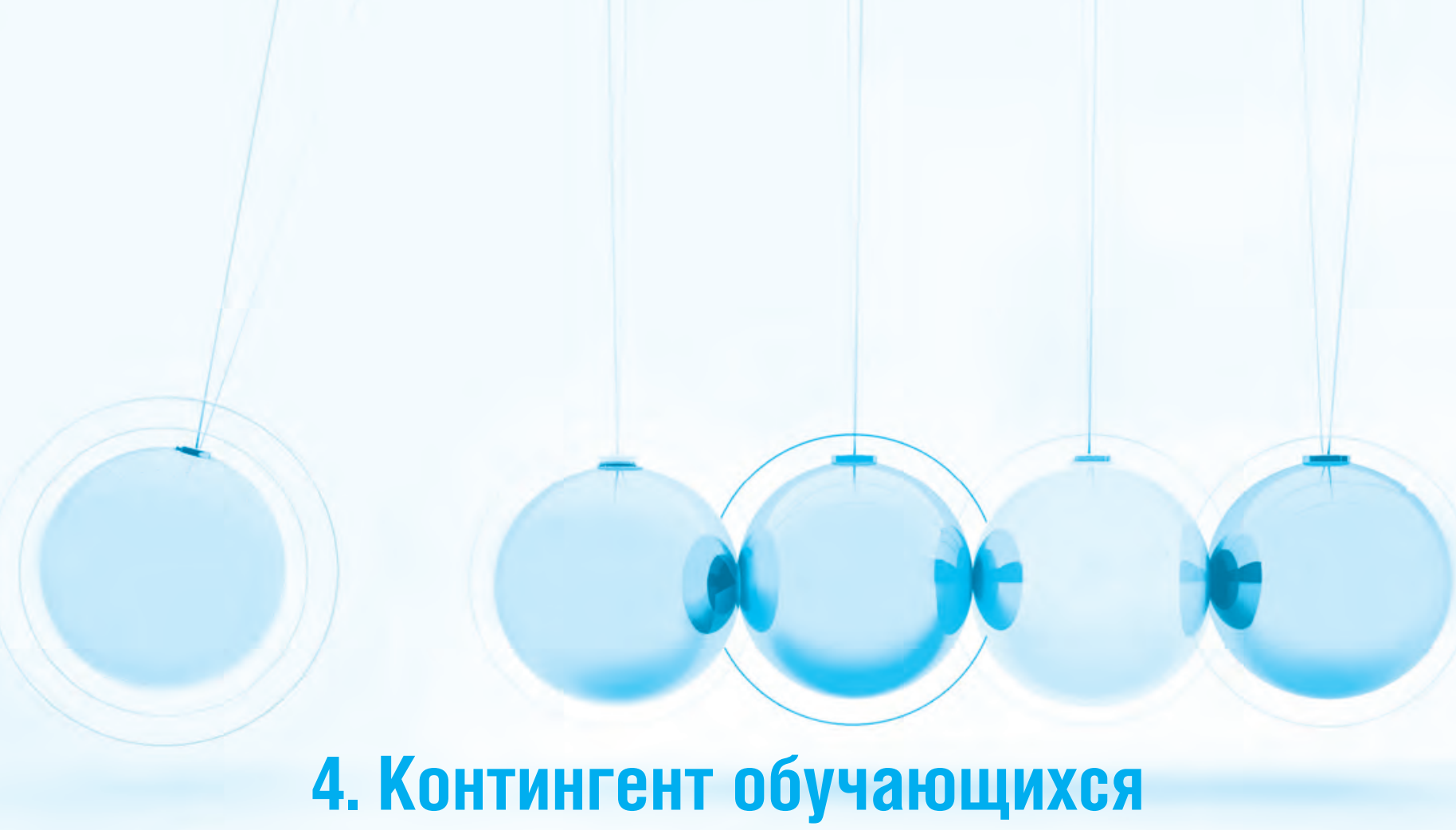




\section{1. ДИНАМИКА ЧИСЛЕННОСТИ ОБУЧАЮЩИХСЯ ПО ОТДЕЛЬНЫМ ОБРАЗОВАТЕЛЬНЫМ ПРОГРАММАМ}

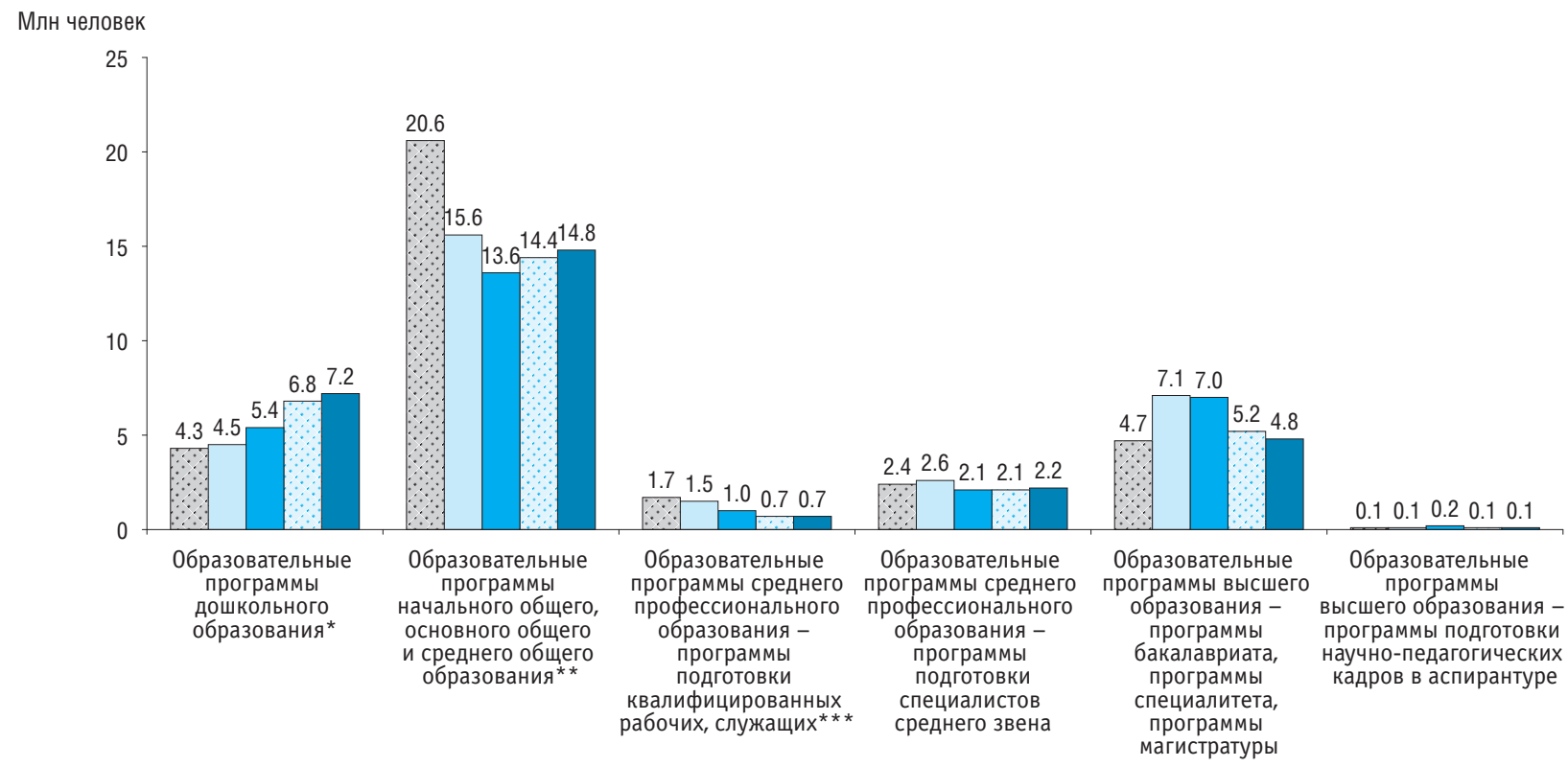

* Включая детей, в отношении которых осуществляются только присмотр и уход.

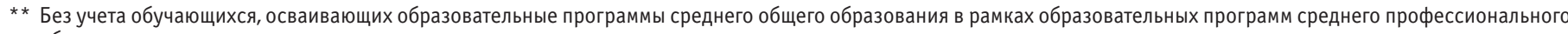
образования.

*** C 2010 г. - включая обучающихся на договорной основе, но без учета краткосрочно (менее 500 часов) обученных. 


\section{2. ЧИСЛЕННОСТЬ ВОСПИТАННИКОВ ОРГАНИЗАЦИЙ, ОСУЩЕСТВЛЯЮЩИХ ОБРАЗОВАТЕЛЬНУЮ ДЕЯТЕЛЬНОСТЬ ПО ОБРАЗОВАТЕЛЬНЫМ ПРОГРАММАМ ДОШКОЛЬНОГО ОБРАЗОВАНИЯ, ПРИСМОТР И УХОД ЗА ДЕТЬМИ*}

(на конец года)

\begin{tabular}{|c|c|c|c|c|c|c|c|c|}
\hline & 2000 & 2005 & 2010 & 2011 & 2012 & 2013 & 2014 & 2015 \\
\hline Численность воспитанников - всего, тыс. чел. ** & 4263.0 & 4530.4 & 5388.0 & 5661.1 & 5982.9 & 6347.3 & 6813.6 & 7151.6 \\
\hline Города и поселки городского типа & 3408.5 & 3611.0 & 4280.6 & 4502.4 & 4750.6 & 5037.1 & 5415.6 & 5693.8 \\
\hline Сельская местность & 854.5 & 919.4 & 1107.3 & 1158.8 & 1232.2 & 1310.2 & 1398.0 & 1457.7 \\
\hline $\begin{array}{l}\text { Охват детей дошкольным образованием, в процентах } \\
\text { от численности детей в возрасте 1-6 лет }\end{array}$ & 55.0 & 56.7 & 59.2 & 60.6 & 62.1 & 63.0 & 64.6 & 66.2 \\
\hline Города и поселки городского типа & 64.2 & 64.3 & 66.5 & 68.1 & 69.6 & 70.3 & 72.1 & 73.6 \\
\hline Сельская местность & 34.9 & 38.7 & 41.5 & 42.5 & 43.8 & 44.9 & 46.1 & 47.7 \\
\hline
\end{tabular}

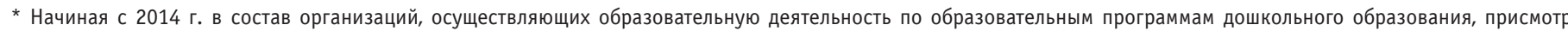

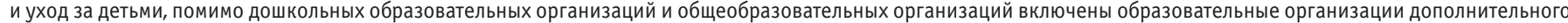
образования, профессиональные образовательные организации, организации высшего образования и иные организации.

* * Здесь и далее - включая детей, в отношении которых осуществляются только присмотр и уход. 
4.3. ЧИСЛЕННОСТЬ ВОСПИТАННИКОВ ОРГАНИЗАЦИЙ, ОСУЩЕСТВЛЯЮЩИХ ОБРАЗОВАТЕЛЬНУЮ ДЕЯТЕЛЬНОСТЬ ПО ОБРАЗОВАТЕЛЬНЫМ ПРОГРАММАМ ДОШКОЛЬНОГО ОБРАЗОВАНИЯ, ПРИСМОТР И УХОД ЗА ДЕТЬМИ, ПО ГРУППАМ: 2015

(на конец года)

\begin{tabular}{|c|c|c|c|}
\hline & \multirow[t]{2}{*}{ Всего, чел. } & \multicolumn{2}{|c|}{$\begin{array}{c}\text { В том числе дети } \\
\text { с ограниченными возможностями здоровья }\end{array}$} \\
\hline & & чел. & проценты \\
\hline Всего & 7151553 & 343591 & 100 \\
\hline Группы общеразвивающей направленности & 6327248 & 40793 & 11.9 \\
\hline Группы компенсирующей направленности & 411036 & 269946 & 78.6 \\
\hline \multicolumn{4}{|l|}{ В том числе для детей: } \\
\hline с нарушением слуха & 6062 & 4174 & 1.2 \\
\hline с нарушением речи & 292505 & 175290 & 51.0 \\
\hline с нарушением зрения & 34346 & 27125 & 7.9 \\
\hline с нарушением интеллекта & 6206 & 5891 & 1.7 \\
\hline с задержкой психического развития & 32099 & 28346 & 8.2 \\
\hline с нарушением опорно-двигательного аппарата & 26921 & 19653 & 5.7 \\
\hline со сложным дефектом & 5212 & 4750 & 1.4 \\
\hline другого профиля & 7685 & 4717 & 1.4 \\
\hline Группы оздоровительной направленности & 90791 & 4676 & 1.4 \\
\hline \multicolumn{4}{|l|}{ Из них для детей: } \\
\hline с туберкулезной интоксикацией & 26021 & 2841 & 0.8 \\
\hline часто болеющих & 33198 & 548 & 0.2 \\
\hline Группы комбинированной направленности & 130096 & 27200 & 7.9 \\
\hline Группы для детей раннего возраста & 142794 & 433 & 0.1 \\
\hline Группы по присмотру и уходу за детьми & 31114 & 253 & 0.1 \\
\hline Семейные дошкольные группы & 18474 & 290 & 0.1 \\
\hline
\end{tabular}


4.4. ЧИСЛЕННОСТЬ ВОСПИТАННИКОВ ОРГАНИЗАЦИЙ, ОСУЩЕСТВЛЯЮЩИХ ОБРАЗОВАТЕЛЬНУЮ ДЕЯТЕЛЬНОСТЬ ПО ОБРАЗОВАТЕЛЬНЫМ ПРОГРАММАМ ДОШКОЛЬНОГО ОБРАЗОВАНИЯ, ПРИСМОТР И УХОД ЗА ДЕТЬМИ, ПО ПОЛУ И ВОЗРАСТУ: 2015

(на конец года; число полных лет на 1 января; тысячи человек)

\begin{tabular}{|c|c|c|c|c|c|c|c|c|c|}
\hline & \multirow[t]{2}{*}{ Всего } & \multicolumn{8}{|c|}{ Возраст, лет } \\
\hline & & До 1 года & 1 & 2 & 3 & 4 & 5 & 6 & 7 и старше \\
\hline Всего & 7151.6 & 1.6 & 138.2 & 921.8 & 1518.0 & 1521.2 & 1531.5 & 1390.8 & 128.4 \\
\hline Мальчики & 3708.6 & 0.8 & 72.2 & 478.5 & 783.3 & 785.9 & 792.9 & 721.7 & 73.2 \\
\hline Девочки & 3442.9 & 0.8 & 66.0 & 443.3 & 734.7 & 735.4 & 738.6 & 669.0 & 55.2 \\
\hline
\end{tabular}

\section{5. ПОСЕЩАЕМОСТЬ ОРГАНИЗАЦИЙ, ОСУЩЕСТВЛЯЮЩИХ ОБРАЗОВАТЕЛЬНУЮ ДЕЯТЕЛЬНОСТЬ ПО ОБРАЗОВАТЕЛЬНЫМ ПРОГРАММАМ ДОШКОЛЬНОГО ОБРАЗОВАНИЯ, ПРИСМОТР И УХОД ЗА ДЕТЬМИ}

\begin{tabular}{|c|c|c|c|c|c|c|}
\hline & 2010 & 2011 & 2012 & 2013 & 2014 & 2015 \\
\hline $\begin{array}{l}\text { Число дней, проведенных воспитанниками в гр } \\
\text { миллионы дней }\end{array}$ & 835.5 & 882.2 & 900.4 & 996.7 & 1019.5 & 1082.8 \\
\hline $\begin{array}{l}\text { Число дней, пропущенных воспитанниками, } \\
\text { миллионы дней }\end{array}$ & 360.3 & 375.7 & 406.6 & 424.9 & 467.5 & 499.6 \\
\hline По болезни & 79.4 & 86.0 & 90.9 & 97.1 & 108.0 & 113.1 \\
\hline По другим причинам & 280.9 & 289.7 & 315.7 & 327.8 & 359.5 & 386.5 \\
\hline Пропущено дней по болезни одним ребенком & 15.6 & 15.8 & 15.8 & 16.0 & 17.0 & 15.9 \\
\hline Коэффициент посещаемости, проценты & 65.7 & 65.4 & 62.7 & 66.3 & 64.9 & 61.6 \\
\hline
\end{tabular}




\section{6. ЧИСЛЕННОСТЬ ВОСПИТАННИКОВ, ПОСЕЩАЮЩИХ ГРУППЫ КРАТКОВРЕМЕННОГО ПРЕБЫВАНИЯ} (на конец года)

Тыс. человек

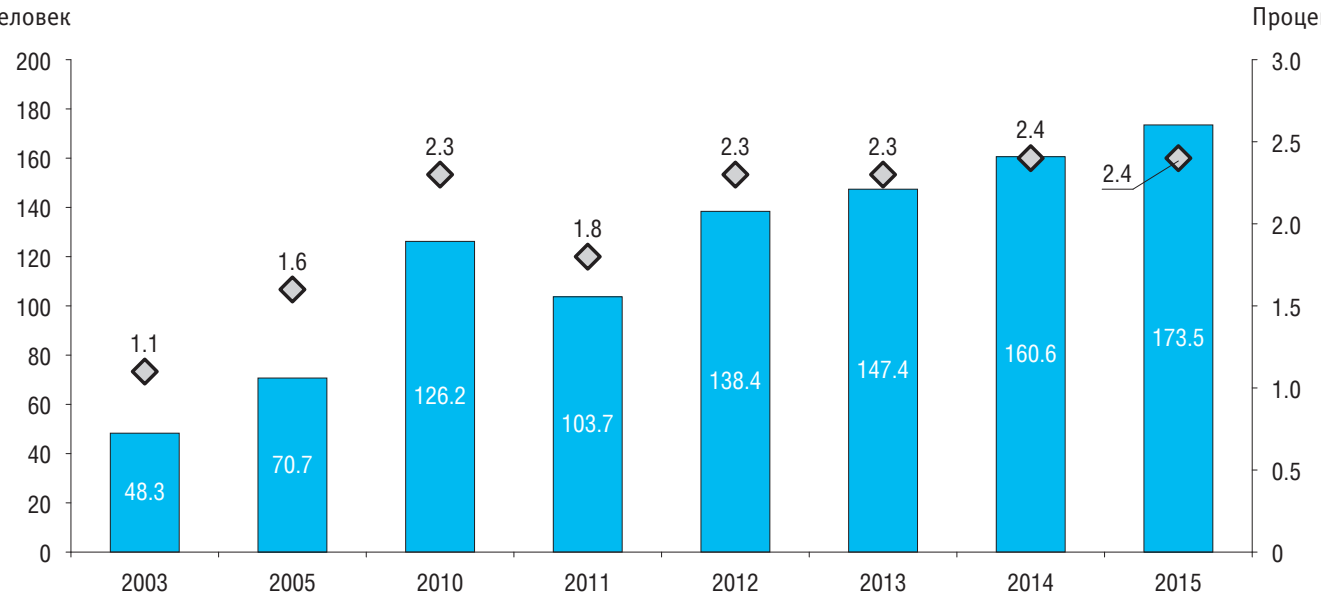

$\square$ Численность воспитанников, посещающих группы кратковременного пребывания

$\diamond$ В процентах от общей численности воспитанников организаций, осуществляющих образовательную деятельность по образовательным программам дошкольного образования, присмотр и уход за детьми 


\section{7. ЧИСЛЕННОСТЬ ОБУЧАЮЩИХСЯ В ОБЩЕОБРАЗОВАТЕЛЬНЫХ ОРГАНИЗАЦИЯХ}

(на начало учебного года; тысячи человек)

\begin{tabular}{|c|c|c|c|c|c|c|c|c|}
\hline & $2000 / 2001$ & $2005 / 2006$ & $2010 / 2011$ & $2011 / 2012$ & $2012 / 2013$ & $2013 / 2014$ & $2014 / 2015$ & $2015 / 2016$ \\
\hline Bcero & 20553.5 & 15630.9 & 13642.4 & 13737.8 & 13804.5 & 13877.4 & 14398.9 & 14770.4 \\
\hline $\begin{array}{l}\text { Общеобразовательные организации (без вечерних } \\
\text { (сменных) общеобразовательных организаций) }\end{array}$ & 20073.8 & 15185.1 & 13317.7 & 13445.8 & 13537.3 & 13643.2 & 14191.6 & 14596.3 \\
\hline Государственные и муниципальные & 20013.3 & 15112.8 & 13244.2 & 13362.3 & 13445.4 & 13548.3 & 14091.6 & 14491.8 \\
\hline Города и поселки городского типа & 13998.0 & 10496.8 & 9501.9 & 9689.8 & 9835.0 & 9980.0 & 10406.1 & 10765.7 \\
\hline Сельская местность & 6015.2 & 4615.9 & 3742.3 & 3672.4 & 3610.4 & 3568.3 & 3685.5 & 3726.1 \\
\hline Частные & 60.6 & 72.3 & 73.5 & 83.5 & 91.9 & 94.9 & 99.9 & 104.5 \\
\hline Города и поселки городского типа & $\ldots$ & $\ldots$ & 68.8 & 78.0 & 86.4 & 88.8 & 92.9 & 96.7 \\
\hline Сельская местность & $\ldots$ & $\ldots$ & 4.7 & 5.5 & 5.5 & 6.1 & 7.0 & 7.8 \\
\hline Вечерние (сменные) общеобразовательные & & & & & & & & \\
\hline организации & 479.6 & 445.8 & 324.7 & 292.0 & 267.2 & 234.3 & 207.3 & 174.1 \\
\hline Города и поселки городского типа & 391.1 & 347.9 & 259.4 & 232.8 & 211.1 & 187.7 & 168.7 & 145.3 \\
\hline Сельская местность & 88.6 & 97.8 & 65.3 & 59.2 & 56.1 & 46.6 & 38.6 & 28.7 \\
\hline
\end{tabular}


4.8. ОХВАТ ДЕТЕЙ И ПОДРОСТКОВ ОБРАЗОВАТЕЛЬНЫМИ ПРОГРАММАМИ НАЧАЛЬНОГО, ОСНОВНОГО И СРЕДНЕГО ОБЩЕГО ОБРАЗОВАНИЯ

(отношение численности обучающихся 1-11 (12) классов общеобразовательных организаций и численности студентов, осваивающих образовательные программы среднего общего образования в рамках образовательных программ среднего профессионального образования, к численности населения в возрасте 7-17 лет)

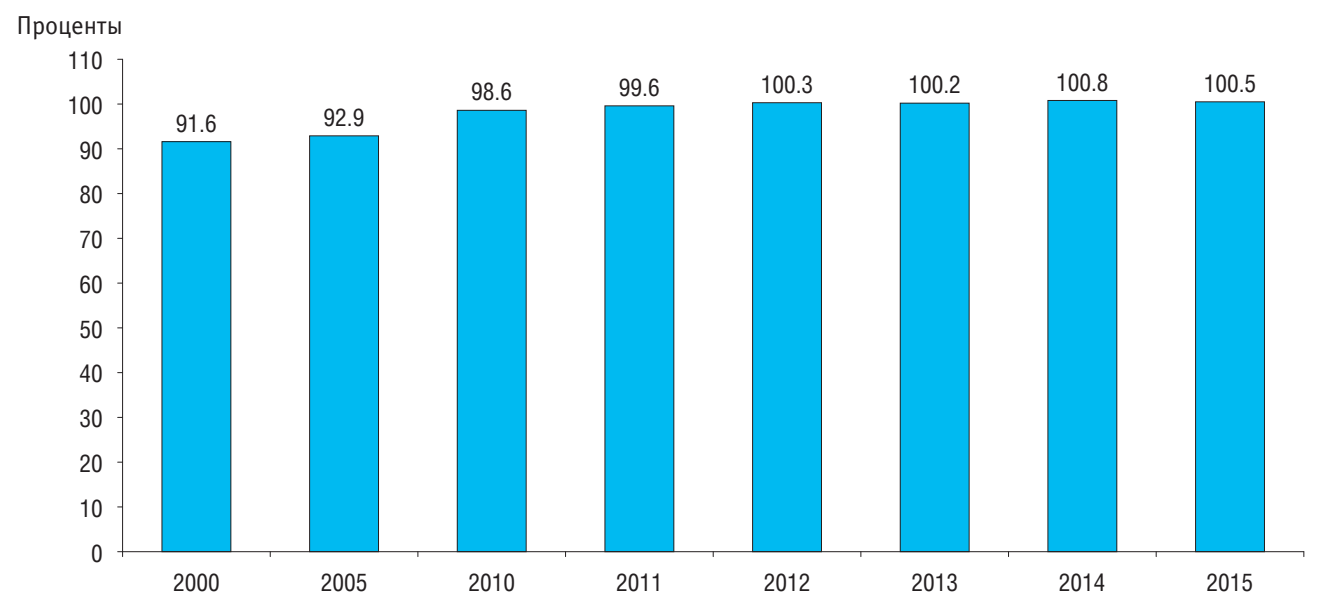




\section{9. ЧИСЛЕННОСТЬ ОБУЧАЮЩИХСЯ В ОБЩЕОБРАЗОВАТЕЛЬНЫХ ОРГАНИЗАЦИЯХ (БЕЗ ВЕЧЕРНИХ (СМЕННЫХ) \\ ОБЩЕОБРАЗОВАТЕЛЬНЫХ ОРГАНИЗАЦИЙ) ПО ПОЛУ И ВОЗРАСТУ: 2015/2016 *}

(на начало учебного года; число полных лет на 1 января; тысячи человек)

\begin{tabular}{|c|c|c|c|c|c|c|c|c|c|c|c|c|c|c|c|}
\hline & \multirow[t]{2}{*}{ Bсего } & \multicolumn{14}{|c|}{ Возраст, лет } \\
\hline & & 5 & 6 & 7 & 8 & 9 & 10 & 11 & 12 & 13 & 14 & 15 & 16 & 17 & $\begin{array}{c}18 \\
\text { и старше }\end{array}$ \\
\hline \multicolumn{16}{|c|}{ Всего } \\
\hline Всего & 14250.1 & 7.5 & 183.4 & 1567.9 & 1589.6 & 1458.9 & 1428.4 & 1467.3 & 1436.8 & 1375.9 & 1288.7 & 1165.4 & 713.0 & 523.7 & 43.5 \\
\hline Мальчики & 7184.3 & 3.6 & 88.1 & 794.6 & 812.2 & 742.9 & 725.8 & 746.7 & 731.0 & 699.7 & 655.4 & 589.1 & 335.3 & 238.4 & 21.6 \\
\hline Девочки & 7065.8 & 3.9 & 95.3 & 773.3 & 777.4 & 716.1 & 702.6 & 720.6 & 705.9 & 676.3 & 633.3 & 576.2 & 377.7 & 285.3 & 21.9 \\
\hline \multicolumn{16}{|c|}{ Государственные и муниципальные организации } \\
\hline Всего & 14145.7 & 7.2 & 180.8 & 1556.1 & 1577.1 & 1447.4 & 1417.6 & 1457.7 & 1427.6 & 1367.2 & 1280.3 & 1157.6 & 706.8 & 519.2 & 43.0 \\
\hline Мальчики & 7129.2 & 3.4 & 86.8 & 788.5 & 805.6 & 736.8 & 720.1 & 741.7 & 726.1 & 695.0 & 650.9 & 584.9 & 332.0 & 236.1 & 21.3 \\
\hline Девочки & 7016.5 & 3.8 & 94.0 & 767.5 & 771.5 & 710.6 & 697.5 & 716.0 & 701.5 & 672.2 & 629.4 & 572.6 & 374.9 & 283.1 & 21.7 \\
\hline \multicolumn{16}{|c|}{ Частные организации } \\
\hline Мальчики & 55.1 & 0.2 & 1.3 & 6.1 & 6.6 & 6.1 & 5.7 & 5.0 & 4.9 & 4.7 & 4.5 & 4.2 & 3.3 & 2.3 & 0.3 \\
\hline Девочки & 49.3 & 0.1 & 1.3 & 5.8 & 5.9 & 5.5 & 5.1 & 4.6 & 4.4 & 4.1 & 3.8 & 3.6 & 2.8 & 2.2 & 0.2 \\
\hline
\end{tabular}

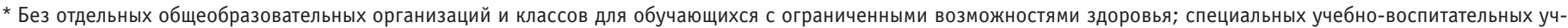

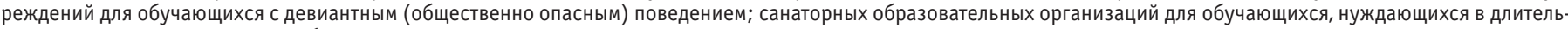
ном лечении; организаций для обучающихся, нуждающихся в психолого-педагогической, медицинской и со-циальной помощи. 


\subsection{0. ЧИСЛЕННОСТЬ ОБУЧАЮЩИХСЯ В ОБЩЕОБРАЗОВАТЕЛЬНЫХ ОРГАНИЗАЦИЯХ (БЕЗ ВЕЧЕРНИХ (СМЕННЫХ) ОБЩЕОБРАЗОВАТЕЛЬНЫХ ОРГАНИЗАЦИЙ) ПО ГРУППАМ КЛАССОВ * \\ (на начало учебного года; тысячи человек)}

\begin{tabular}{|c|c|c|c|c|c|c|c|c|}
\hline & $2000 / 2001$ & $2005 / 2006$ & $2010 / 2011$ & $2011 / 2012$ & $2012 / 2013$ & $2013 / 2014$ & $2014 / 2015$ & $2015 / 2016$ \\
\hline \multicolumn{9}{|c|}{ Всего } \\
\hline Всего & 19560.2 & 14755.4 & 12970.1 & 13104.2 & 13195.8 & 13303.4 & 13848.8 & 14250.1 \\
\hline \multicolumn{9}{|l|}{ Классы: } \\
\hline $1-4$ & 5702.3 & 5164.7 & 5318.3 & 5514.8 & 5651.7 & 5725.5 & 5982.6 & 6198.8 \\
\hline $5-9$ & 11076.5 & 7131.3 & 6205.5 & 6095.0 & 6119.6 & 6238.3 & 6548.8 & 6780.6 \\
\hline $10-11(12)$ & 2781.3 & 2459.4 & 1446.3 & 1494.3 & 1424.4 & 1339.6 & 1317.4 & 1270.7 \\
\hline \multicolumn{9}{|c|}{ Государственные и муниципальные организации } \\
\hline Bcero & 19499.7 & 14683.1 & 12896.6 & 13020.8 & 13104.1 & 13208.6 & 13748.9 & 14145.7 \\
\hline \multicolumn{9}{|l|}{ Классы: } \\
\hline $1-4$ & 5682.4 & 5136.1 & 5285.0 & 5477.4 & 5609.4 & 5681.4 & 5936.0 & 6149.6 \\
\hline $5-9$ & 11047.9 & 7102.1 & 6174.9 & 6060.6 & 6082.2 & 6199.2 & 6507.3 & 6737.2 \\
\hline $10-11(12)$ & 2769.4 & 2444.8 & 1436.7 & 1482.8 & 1412.5 & 1328.0 & 1305.7 & 1258.9 \\
\hline \multicolumn{9}{|c|}{ Частные организации } \\
\hline Bcero & 60.6 & 72.3 & 73.5 & 83.4 & 91.8 & 94.8 & 99.9 & 104.4 \\
\hline \multicolumn{9}{|l|}{ Классы: } \\
\hline $1-4$ & 20.0 & 28.6 & 33.3 & 37.4 & 42.4 & 44.1 & 46.6 & 49.2 \\
\hline $5-9$ & 28.7 & 29.1 & 30.6 & 34.5 & 37.4 & 39.1 & 41.5 & 43.4 \\
\hline $10-11(12)$ & 12.0 & 14.6 & 9.6 & 11.6 & 12.0 & 11.6 & 11.8 & 11.8 \\
\hline
\end{tabular}

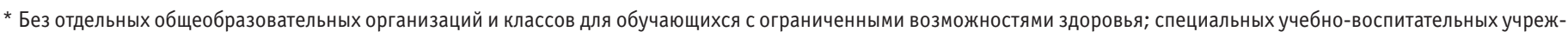

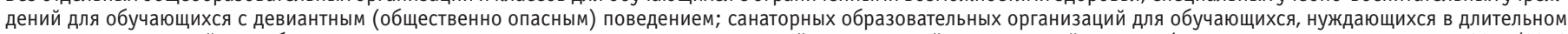

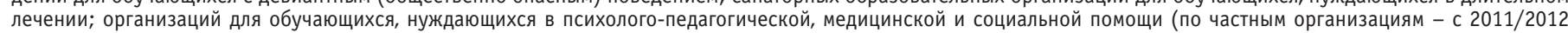
учебного года). 


\subsection{1. ЧИСЛЕННОСТЬ ЛИЦ С ОГРАНИЧЕННЫМИ ВОЗМОЖНОСТЯМИ ЗДОРОВЬЯ, ДЕТЕЙ-ИНВАЛИДОВ, ИНВАЛИДОВ, ОБУЧАЮЩИХСЯ В ОБЩЕОБРАЗОВАТЕЛЬНЫХ ОРГАНИЗАЦИЯХ}

(на начало учебного года)

\begin{tabular}{|c|c|c|c|c|c|c|c|c|c|c|c|c|}
\hline & \multicolumn{4}{|c|}{$2012 / 2013$} & \multicolumn{4}{|c|}{$2014 / 2015$} & \multicolumn{4}{|c|}{$2015 / 2016$} \\
\hline & \multicolumn{2}{|c|}{\begin{tabular}{|c|} 
Лица с ограниченными \\
возможностями \\
здоровья
\end{tabular}} & \multicolumn{2}{|c|}{$\begin{array}{c}\text { Дети-инвалиды, } \\
\text { инвалиды }\end{array}$} & \multicolumn{2}{|c|}{$\begin{array}{c}\text { Лица с ограниченными } \\
\text { возможностями } \\
\text { здоровья }\end{array}$} & \multicolumn{2}{|c|}{$\begin{array}{c}\text { Дети-инвалиды, } \\
\text { инвалиды }\end{array}$} & \multicolumn{2}{|c|}{$\begin{array}{c}\text { Лица с ограниченными } \\
\text { возможностями } \\
\text { здоровья }\end{array}$} & \multicolumn{2}{|c|}{$\begin{array}{c}\text { Дети-инвалиды, } \\
\text { инвалиды }\end{array}$} \\
\hline & Тыс. чел. & $\begin{array}{c}\text { В про- } \\
\text { центах } \\
\text { от общей } \\
\text { численно- } \\
\text { сти обуча- } \\
\text { ющихся }\end{array}$ & Тыс. чел. & $\begin{array}{c}\text { В про- } \\
\text { центах } \\
\text { от общей } \\
\text { численно- } \\
\text { сти обуча- } \\
\text { ющихся }\end{array}$ & Тыс. чел. & $\begin{array}{c}\text { В про- } \\
\text { центах } \\
\text { от общей } \\
\text { численно- } \\
\text { сти обуча- } \\
\text { ющихся }\end{array}$ & Тыс. чел. & $\begin{array}{c}\text { В про- } \\
\text { центах } \\
\text { от общей } \\
\text { численно- } \\
\text { сти обуча- } \\
\text { ющихся }\end{array}$ & Тыс. чел. & $\begin{array}{c}\text { В про- } \\
\text { центах } \\
\text { от общей } \\
\text { численно- } \\
\text { сти обуча- } \\
\text { ющихся }\end{array}$ & Тыс. чел. & $\begin{array}{c}\text { В про- } \\
\text { центах } \\
\text { от общей } \\
\text { численно- } \\
\text { сти обуча- } \\
\text { ющихся }\end{array}$ \\
\hline Всего & 407.4 & 3.0 & 225.8 & 1.6 & 455.5 & 3.2 & 235.5 & 1.6 & 507.1 & 3.4 & 250.5 & 1.7 \\
\hline $\begin{array}{l}\text { Общеобразовательные } \\
\text { организации (без вечерних } \\
\text { (сменных) общеобразовательных }\end{array}$ & & & & & & & & & & & & \\
\hline организаций) & 406.0 & 3.0 & 224.1 & 1.7 & 454.5 & 3.2 & 234.3 & 1.7 & 505.9 & 3.5 & 249.2 & 1.7 \\
\hline $\begin{array}{l}\text { Государственные и муници- } \\
\text { пальные }\end{array}$ & 405.5 & 3.0 & 223.3 & 1.7 & 453.9 & 3.2 & 233.7 & 1.7 & 505.3 & 3.5 & 248.3 & 1.7 \\
\hline Частные & 0.5 & 0.5 & 0.8 & 0.8 & 0.6 & 0.6 & 0.6 & 0.6 & 0.6 & 0.5 & 0.8 & 0.8 \\
\hline $\begin{array}{l}\text { Вечерние (сменные) общеобразо- } \\
\text { вательные организации }\end{array}$ & 1.5 & 0.6 & 1.7 & 0.6 & 1.0 & 0.5 & 1.2 & 0.6 & 1.2 & 0.7 & 1.4 & 0.8 \\
\hline
\end{tabular}




\subsection{2. ЧИСЛЕННОСТЬ ЛИЦ С ОГРАНИЧЕННЫМИ ВОЗМОЖНОСТЯМИ ЗДОРОВЬЯ, ДЕТЕЙ-ИНВАЛИДОВ, ИНВАЛИДОВ, ОБУЧАЮЩИХСЯ В КЛАССАХ ОБЩЕОБРАЗОВАТЕЛЬНЫХ ОРГАНИЗАЦИЙ (БЕЗ ВЕЧЕРНИХ (СМЕННЫХ) ОБЩЕОБРАЗОВАТЕЛЬНЫХ ОРГАНИЗАЦИЙ), НЕ ЯВЛЯЮЩИХСЯ ОТДЕЛЬНЫМИ КЛАССАМИ ДЛЯ ОБУЧАЮЩИХСЯ ПО АДАПТИРОВАННЫМ \\ ОСНОВНЫМ ОБЩЕОБРАЗОВАТЕЛЬНЫМ ПРОГРАММАМ* \\ (на начало учебного года)}

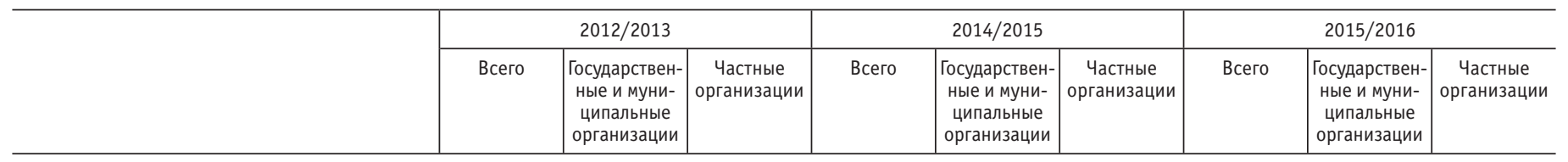

\section{Лица с ограниченными возможностями}

\section{здоровья:}

тыс. чел.

ороцентах от общей численности обучающихся с ограниченными возможностями здоровья

тыс. чел.

в процентах от общей численност

обучающихся детей-инвалидов,

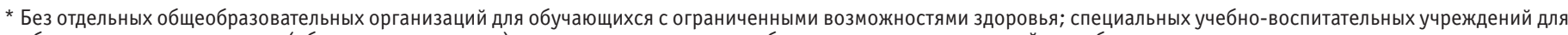

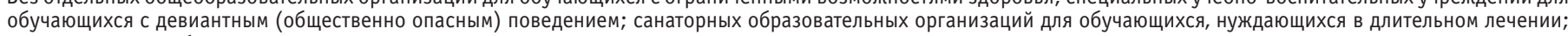
организаций для обучающихся, нуждающихся в психолого-педагогической, медицинской и социальной помощи. 


\subsection{3. ЧИСЛЕННОСТЬ ЛИЦ С ОГРАНИЧЕННЫМИ ВОЗМОЖНОСТЯМИ ЗДОРОВЬЯ, ДЕТЕЙ-ИНВАЛИДОВ, ИНВАЛИДОВ, ОБУЧАЮЩИХСЯ ИНДИВИДУАЛЬНО НА ДОМУ \\ (на начало учебного года; человек)}

\begin{tabular}{|c|c|c|c|c|c|c|}
\hline & \multicolumn{2}{|c|}{$2012 / 2013$} & \multicolumn{2}{|c|}{$2014 / 2015$} & \multicolumn{2}{|c|}{$2015 / 2016$} \\
\hline & Всего & $\begin{array}{c}\text { Из них с ис- } \\
\text { пользованием } \\
\text { дистанционных } \\
\text { технологий }\end{array}$ & Bсего & $\begin{array}{c}\text { Из них с ис- } \\
\text { пользованием } \\
\text { дистанционных } \\
\text { технологий }\end{array}$ & Bсего & $\begin{array}{c}\text { Из них сис- } \\
\text { пользованием } \\
\text { дистанционных } \\
\text { технологий }\end{array}$ \\
\hline \multicolumn{7}{|l|}{ Лица с ограниченными возможностями здоровья: } \\
\hline $\begin{array}{l}\text { общеобразовательные организации (без вечерних } \\
\text { (сменных) общеобразовательных организаций) }\end{array}$ & 43579 & 3709 & 49666 & 4174 & 52526 & 4286 \\
\hline государственные и муниципальные организации & 43550 & 3707 & 49636 & 4173 & 52499 & 4279 \\
\hline частные организации & 29 & 2 & 30 & 1 & 27 & 7 \\
\hline \multicolumn{7}{|l|}{ Дети-инвалиды, инвалиды: } \\
\hline $\begin{array}{l}\text { общеобразовательные организации (без вечерних } \\
\text { (сменных) общеобразовательных организаций) }\end{array}$ & 67985 & 13654 & 72605 & 14423 & 75172 & 13222 \\
\hline государственные и муниципальные организации & 67942 & 13648 & 72550 & 14414 & 75127 & 13216 \\
\hline частные организации & 43 & 6 & 55 & 9 & 45 & 6 \\
\hline
\end{tabular}




\subsection{4. ЧИСЛЕННОСТЬ ОБУЧАЮЩИХСЯ В ГОСУДАРСТВЕННЫХ И МУНИЦИПАЛЬНЫХ ОТДЕЛЬНЫХ ОБЩЕОБРАЗОВАТЕЛЬНЫХ ОРГАНИЗАЦИЯХ И КЛАССАХ ДЛЯ ОБУЧАЮЩИХСЯ С ОГРАНИЧЕННЫМИ ВОЗМОЖНОСТЯМИ ЗДОРОВЬЯ \\ (на начало учебного года; тысячи человек)}

\begin{tabular}{|c|c|c|c|c|c|c|c|c|}
\hline & $2000 / 2001$ & $2005 / 2006$ & $2010 / 2011$ & $2011 / 2012$ & $2012 / 2013$ & $2013 / 2014$ & $2014 / 2015$ & $2015 / 2016$ \\
\hline Отдельные общеобразовательные организации & 281.3 & 236.1 & 207.7 & 208.9 & 211.1 & 210.2 & 212.2 & 213.4 \\
\hline \multicolumn{9}{|l|}{ В том числе для детей: } \\
\hline умственно отсталых & 203.7 & 162.3 & 139.4 & 138.4 & 140.5 & 140.6 & 141.3 & 143.3 \\
\hline незрячих & 3.0 & 2.4 & 2.3 & 2.3 & 2.2 & 2.4 & 2.4 & 2.4 \\
\hline слабовидящих и поздноослепших & 10.3 & 10.8 & 11.1 & 11.1 & 11.4 & 11.1 & 11.2 & 11.6 \\
\hline неслышащих & 10.8 & 9.1 & 7.2 & 7.0 & 6.5 & 6.6 & 6.6 & 6.6 \\
\hline слабослышащих и позднооглохших & 10.5 & 9.9 & 9.0 & 9.7 & 9.9 & 10.1 & 10.2 & 10.1 \\
\hline с нарушениями опорно-двигательного аппарата & 9.3 & 9.0 & 8.0 & 8.0 & 7.8 & 7.2 & 7.6 & 8.0 \\
\hline с тяжелыми нарушениями речи & 11.5 & 10.6 & 9.6 & 9.6 & 9.9 & 10.0 & 11.0 & 10.0 \\
\hline с задержкой психического развития & 19.2 & 19.3 & 18.7 & 19.9 & 19.6 & 19.5 & 19.4 & 19.0 \\
\hline детей-инвалидов индивидуального обучения на дому & 3.0 & 2.8 & 2.3 & 2.8 & 3.1 & 2.7 & 2.6 & 2.6 \\
\hline $\begin{array}{l}\text { Отдельные классы, организованные при } \\
\text { общеобразовательных организациях }\end{array}$ & 228.7 & 188.8 & 119.8 & 111.7 & 109.4 & 110.2 & 110.3 & 114.1 \\
\hline \multicolumn{9}{|l|}{ Из них для детей: } \\
\hline умственно отсталых & 24.2 & 26.7 & 22.6 & 21.8 & 23.2 & 25.0 & 26.2 & 30.6 \\
\hline с задержкой психического развития & 202.2 & 149.0 & 86.8 & 80.2 & 76.2 & 75.5 & 74.0 & 72.1 \\
\hline
\end{tabular}




\subsection{5. ВЫПУСКНИКИ ОБЩЕОБРАЗОВАТЕЛЬНЫХ ОРГАНИЗАЦИЙ}

(тысячи человек)

\begin{tabular}{|c|c|c|c|c|c|c|c|c|}
\hline & 2000 & 2005 & 2010 & 2011 & 2012 & 2013 & 2014 & 2015 \\
\hline \multicolumn{9}{|c|}{ Выпускники, получившие аттестат об основном общем образовании } \\
\hline Всего & 2199.5 & 1944.1 & 1354.1 & 1321.8 & 1249.7 & 1220.3 & 1223.2 & 1198.3 \\
\hline $\begin{array}{l}\text { Общеобразовательные организации (без вечерних (сменных } \\
\text { общеобразовательных организаций) }\end{array}$ & 2132.7 & 1875.8 & 1308.3 & 1277.6 & 1207.7 & 1181.3 & 1196.3 & 1170.8 \\
\hline Государственные и муниципальные & 2128.0 & 1868.5 & 1302.8 & 1270.4 & 1200.5 & 1174.2 & 1188.9 & 1163.3 \\
\hline Города и поселки городского типа & 1529.0 & 1311.8 & 899.8 & 894.9 & 847.7 & 831.9 & 845.7 & 831.7 \\
\hline Сельская местность & 599.1 & 556.8 & 403.1 & 375.5 & 352.8 & 342.3 & 343.2 & 331.6 \\
\hline Частные & 4.7 & 7.3 & 5.5 & 7.2 & $7.2^{*}$ & $7.2^{*}$ & $7.4^{*}$ & $7.5^{\star}$ \\
\hline Вечерние (сменные) общеобразовательные организации ** & 66.8 & 68.3 & 45.8 & 44.2 & 42.1 & 39.0 & 26.9 & 27.4 \\
\hline \multicolumn{9}{|c|}{ Выпускники, получившие аттестат о среднем (полном) общем образовании } \\
\hline Всего & 1457.8 & 1466.0 & 789.3 & 702.7 & 765.8 & 735.2 & 701.4 & 647.8 \\
\hline $\begin{array}{l}\text { Общеобразовательные организации (без вечерних (сменных } \\
\text { общеобразовательных организаций) }\end{array}$ & 1322.0 & 1319.7 & 724.0 & 645.0 & 715.5 & 690.5 & 659.7 & 614.2 \\
\hline Государственные и муниципальные & 1317.2 & 1312.1 & 719.6 & 639.6 & 709.2 & 684.4 & 653.4 & 608.4 \\
\hline Города и поселки городского типа & 952.0 & 956.0 & 509.1 & 444.7 & 517.2 & 506.7 & 488.7 & 466.2 \\
\hline Сельская местность & 365.2 & 356.1 & 210.4 & 194.9 & 192.0 & 177.7 & 164.7 & 142.2 \\
\hline Частные & 4.8 & 7.6 & 4.5 & 5.4 & $6.3^{*}$ & $6.1^{*}$ & $6.3^{*}$ & $5.8^{*}$ \\
\hline Вечерние (сменные) общеобразовательные организации * & 135.8 & 146.3 & 65.2 & 57.7 & 50.3 & 44.7 & 41.7 & 33.6 \\
\hline
\end{tabular}

* Включая обучающихся, окончивших частные общеобразовательные организации экстерном.

** Включая обучающихся, окончивших государственные и муниципальные общеобразовательные организации экстерном. 


\subsection{6. ЧИСЛЕННОСТЬ ДЕТЕЙ И ПОДРОСТКОВ В ВОЗРАСТЕ 7-18 ЛЕТ, НЕ ОБУЧАЮЩИХСЯ В ОБРАЗОВАТЕЛЬНЫХ ОРГАНИЗАЦИЯХ ПО РАЗЛИЧНЫМ ПРИЧИНАМ* (на 1 октября)}

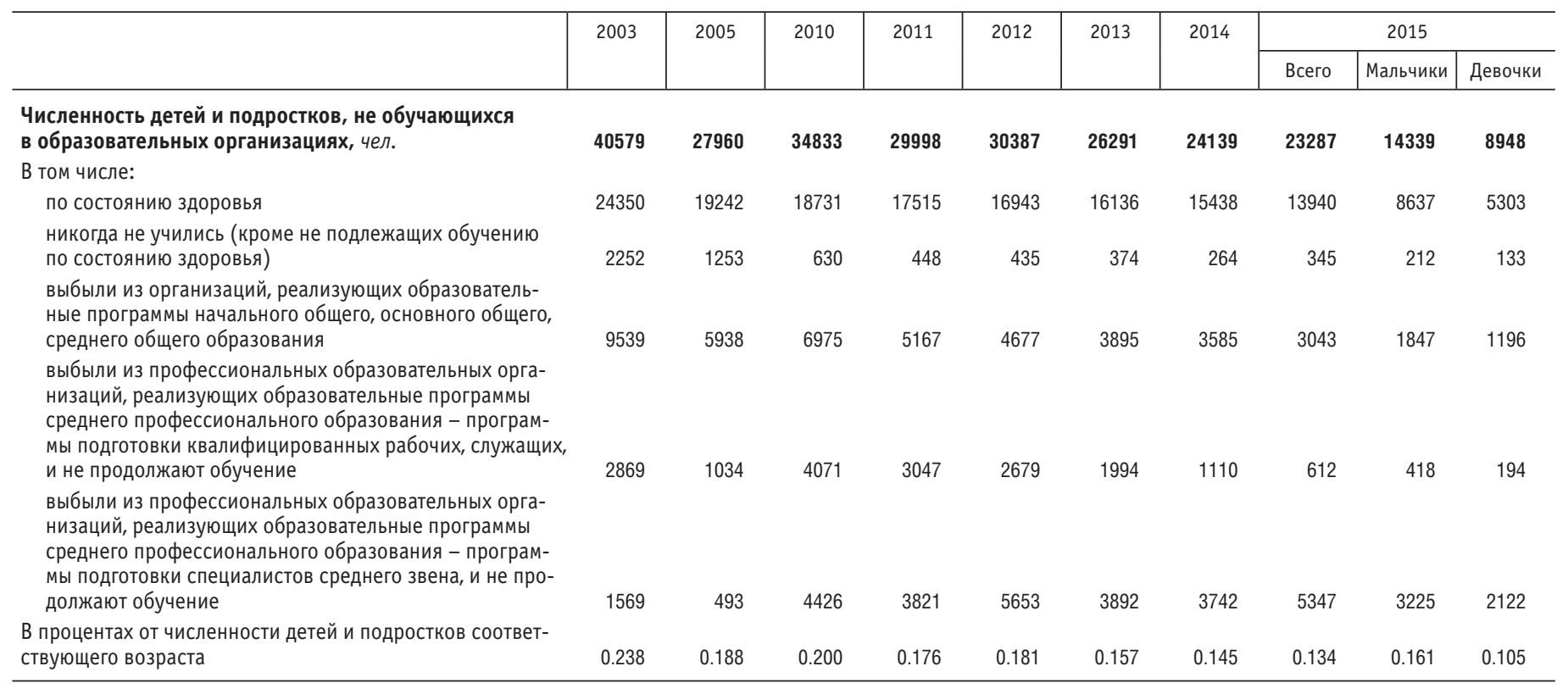

* Данные за 2003, 2005 гг. - по возрастной группе 7-15 лет. 
4.17. РАСПРЕДЕЛЕНИЕ ДЕТЕЙ И ПОДРОСТКОВ В ВОЗРАСТЕ 7-18 ЛЕТ, НЕ ОБУЧАЮЩИХСЯ В ОБРАЗОВАТЕЛЬНЫХ ОРГАНИЗАЦИЯХ, ПО ПОЛУ И ВОЗРАСТУ: 2015

(на 1 октября)

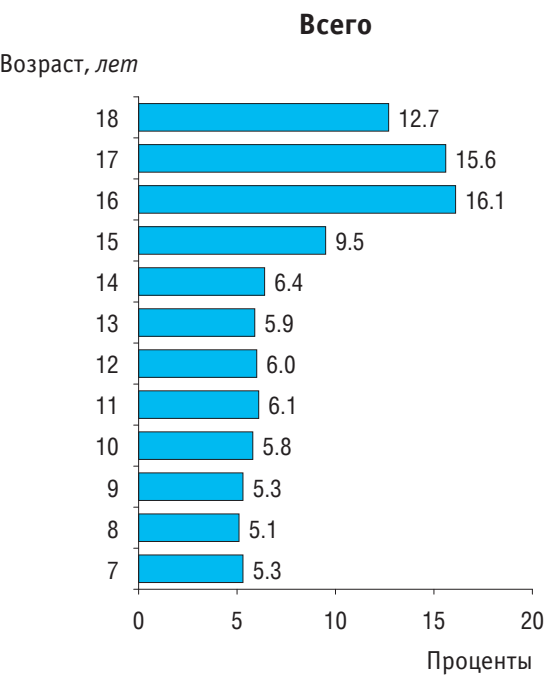

Мальчики

Возраст, лет

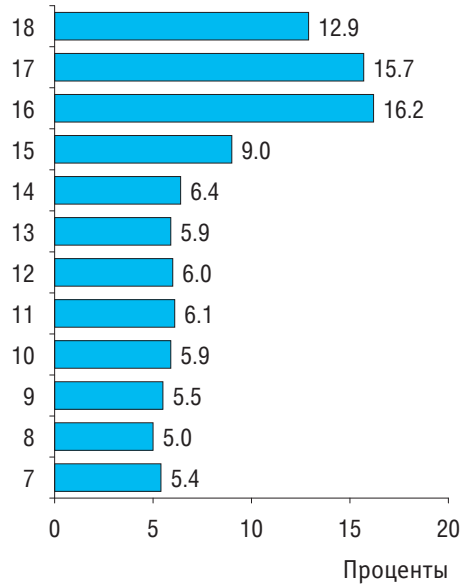

\section{Девочки}

Возраст, лет

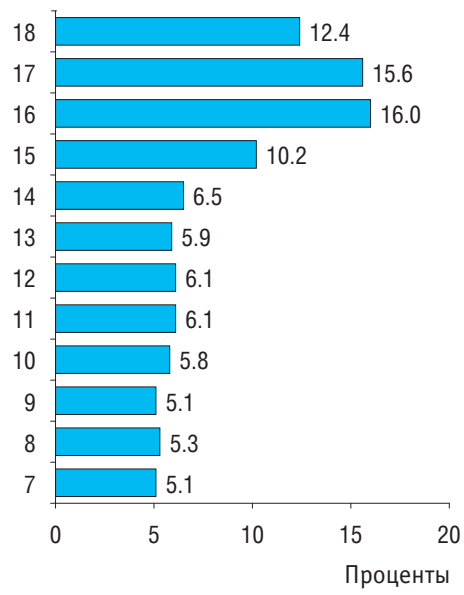




\subsection{8. ЧИСЛЕННОСТЬ УЧАЩИХСЯ ОБРАЗОВАТЕЛЬНЫХ ОРГАНИЗАЦИЙ ДОПОЛНИТЕЛЬНОГО ОБРАЗОВАНИЯ, РЕАЛИЗУЮЩИХ ДОПОЛНИТЕЛЬНЫЕ ОБЩЕОБРАЗОВАТЕЛЬНЫЕ ПРОГРАММЫ ДЛЯ ДЕТЕЙ}

(тысячи человек)

\begin{tabular}{|c|c|c|c|c|c|c|c|c|}
\hline & 2000 & 2005 & 2010 & 2011 & 2012 & 2013 & 2014 & 2015 \\
\hline $\begin{array}{l}\text { Численность учащихся образовательных организаций } \\
\text { дополнительного образования, реализующих дополнительные }\end{array}$ & & & & & & & & \\
\hline общеобразовательные программы для детей * & 7905.8 & 8443.7 & 8083.3 & 7853.4 & 7976.5 & 8881.6 & 9617.2 & 11010.0 \\
\hline Численность учащихся детско-юношеских спортивных школ * * & 866.2 & 1097.3 & 1455.7 & 1674.3 & 1782.4 & 1860.6 & 1981.3 & 2000.5 \\
\hline $\begin{array}{l}\text { Численность учащихся детских музыкальных, художественных, } \\
\text { хореографических школ и школ искусств*** }\end{array}$ & 1284.5 & 1280.9 & 1433.0 & 1446.6 & 1442.5 & 1458.6 & 1496.6 & 1533.4 \\
\hline
\end{tabular}

* По данным Минобрнауки России; с 2010 г. - включая детей, занимающихся в научных обществах.

** По данным Минспорта России.

*** По данным Минкультуры России; 2014 г. - без учета сведений по Республике Крым и г. Севастополю.

\subsection{9. ЧИСЛЕННОСТЬ СТУДЕНТОВ, ОБУЧАЮЩИХСЯ ПО ОБРАЗОВАТЕЛЬНЫМ ПРОГРАММАМ СРЕДНЕГО ПРОФЕССИОНАЛЬНОГО ОБРАЗОВАНИЯ - ПРОГРАММАМ ПОДГОТОВКИ КВАЛИФИЦИРОВАННЫХ РАБОЧИХ, СЛУЖАЩИХ*}

(на конец года)

\begin{tabular}{|c|c|c|c|c|c|c|c|c|}
\hline & 2000 & 2005 & 2010 & 2011 & 2012 & 2013 & 2014 & 2015 \\
\hline Всего, тыс. чел. & 1679.3 & 1509.4 & 1006.6 & 921.0 & 838.0 & 774.2 & 727.3 & 686.1 \\
\hline Из них женщины & 642.0 & 541.2 & 345.0 & 311.3 & 278.5 & 249.7 & 224.3 & 208.6 \\
\hline Численность студентов на 10000 человек населения, чел. & 115 & 105 & 70 & 64 & 58 & 54 & 50 & 47 \\
\hline
\end{tabular}

* Здесь и далее: с 2010 г. - включая студентов, обучающихся на договорной основе, но без учета краткосрочно (менее 500 часов) обученных. 
4.20. ОХВАТ МОЛОДЕЖИ ОБРАЗОВАТЕЛЬНЫМИ ПРОГРАММАМИ СРЕДНЕГО ПРОФЕССИОНАЛЬНОГО ОБРАЗОВАНИЯ ПРОГРАММАМИ ПОДГОТОВКИ КВАЛИФИЦИРОВАННЫХ РАБОЧИХ, СЛУЖАЩИХ

(отношение численности студентов, обучающихся по образовательным программам среднего профессионального образования - программам подготовки квалифицированных рабочих, служащих, к численности населения в возрасте 15-17 лет)

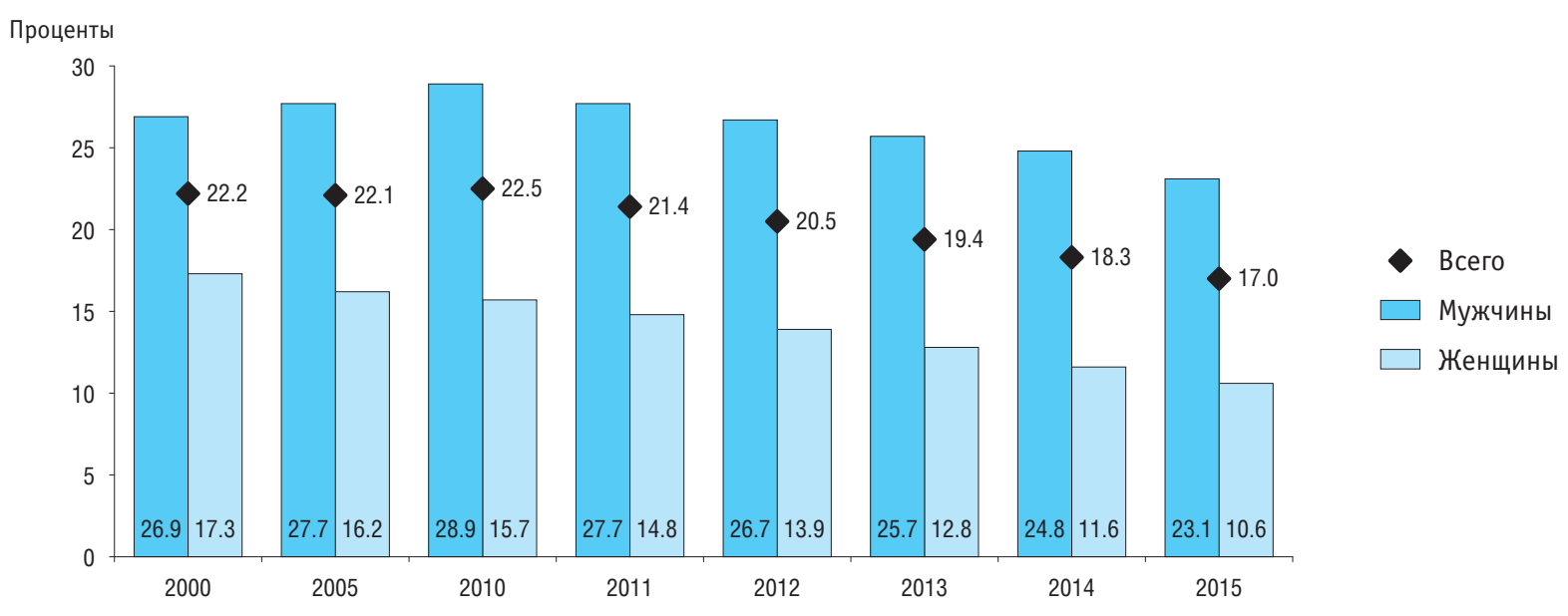




\subsection{1. ЧИСЛЕННОСТЬ СТУДЕНТОВ, ОБУЧАЮЩИХСЯ ПО ОБРАЗОВАТЕЛЬНЫМ ПРОГРАММАМ СРЕДНЕГО ПРОФЕССИОНАЛЬНОГО ОБРАЗОВАНИЯ - ПРОГРАММАМ ПОДГОТОВКИ КВАЛИФИЦИРОВАННЫХ РАБОЧИХ, СЛУЖАЩИХ, ПО ВОЗРАСТУ * (на конец года; человек)}

\begin{tabular}{|c|c|c|c|c|c|c|c|c|c|c|c|c|c|}
\hline & \multirow[t]{2}{*}{ Bсего } & \multicolumn{12}{|c|}{ Возраст, лет } \\
\hline & & $\begin{array}{c}14 \\
\text { и младше }\end{array}$ & 15 & 16 & 17 & 18 & 19 & 20 & 21 & 22 & 23 & $24-29$ & $\begin{array}{c}30 \\
\text { и старше }\end{array}$ \\
\hline \multicolumn{14}{|c|}{2011} \\
\hline Всего & 920959 & 2328 & 32726 & 162844 & 234233 & 198895 & 101098 & 52602 & 28662 & 17693 & 12752 & 33901 & 40983 \\
\hline \multicolumn{14}{|l|}{$\begin{array}{l}\text { В том числе } \\
\text { обучаются: }\end{array}$} \\
\hline \multicolumn{14}{|c|}{$\begin{array}{l}\text { за счет средств } \\
\text { бюджета }\end{array}$} \\
\hline учредителя & 892668 & 2309 & 32315 & 159723 & 229804 & 193843 & 98063 & 50052 & 26839 & 16323 & 11717 & 31193 & 38436 \\
\hline по договорам & 28291 & 19 & 411 & 3121 & 4429 & 5052 & 3035 & 2550 & 1823 & 1370 & 1035 & 2708 & 2547 \\
\hline \multicolumn{14}{|c|}{2015} \\
\hline Всего & 686120 & 913 & 21516 & 122871 & 172203 & 149206 & 68768 & 30215 & 19218 & 12581 & 9744 & 31882 & 44668 \\
\hline \multicolumn{14}{|l|}{$\begin{array}{l}\text { В том числе } \\
\text { обучаются: }\end{array}$} \\
\hline \multicolumn{14}{|l|}{$\begin{array}{l}\text { за счет средств } \\
\text { бюджета }\end{array}$} \\
\hline учредителя & 670028 & 897 & 21138 & 119961 & 168829 & 146531 & 67397 & 29341 & 18737 & 12146 & 9342 & 30437 & 43044 \\
\hline по договорам & 16094 & 16 & 378 & 2910 & 3374 & 2675 & 1371 & 874 & 481 & 435 & 402 & 1445 & 1624 \\
\hline
\end{tabular}

* Расхождение с суммой слагаемых за счет лиц, возраст которых не известен. 


\subsection{2. ЧИСЛЕННОСТЬ ЛИЦ С ОГРАНИЧЕННЫМИ ВОЗМОЖНОСТЯМИ ЗДОРОВЬЯ, ДЕТЕЙ-ИНВАЛИДОВ, ИНВАЛИДОВ, ОБУЧАЮЩИХСЯ ПО ПРОГРАММАМ СРЕДНЕГО ПРОФЕССИОНАЛЬНОГО ОБРАЗОВАНИЯ - ПРОГРАММАМ ПОДГОТОВКИ КВАЛИФИЦИРОВАННЫХ РАБОЧИХ, СЛУЖАЩИХ}

(на конец года)

\begin{tabular}{|c|c|c|c|}
\hline & \multirow[t]{2}{*}{ Bcero } & \multicolumn{2}{|c|}{ В том числе обучаются } \\
\hline & & $\begin{array}{c}\text { за счет средств } \\
\text { бюджета учредителя }\end{array}$ & по договорам \\
\hline \multicolumn{4}{|c|}{2011} \\
\hline \multicolumn{4}{|c|}{ Лица с ограниченными возможностями здоровья: } \\
\hline человек & 28913 & 28701 & 212 \\
\hline в процентах от общей численности & 3.1 & 3.2 & 0.7 \\
\hline \multicolumn{4}{|l|}{ Дети-инвалиды, инвалиды: } \\
\hline человек & 9417 & 9335 & 82 \\
\hline \multirow[t]{2}{*}{ в процентах от общей численности } & 1.0 & 1.0 & 0.3 \\
\hline & 2015 & & \\
\hline \multicolumn{4}{|c|}{ Лица с ограниченными возможностями здоровья: } \\
\hline человек & 27580 & 27508 & 72 \\
\hline в процентах от общей численности & 4.0 & 4.1 & 0.4 \\
\hline \multicolumn{4}{|l|}{ Дети-инвалиды, инвалиды: } \\
\hline человек & 9996 & 9950 & 46 \\
\hline в процентах от общей численности & 1.5 & 1.5 & 0.3 \\
\hline
\end{tabular}

\subsection{3. ПРИЕМ НА ОБУЧЕНИЕ ПО ОБРАЗОВАТЕЛЬНЫМ ПРОГРАММАМ СРЕДНЕГО ПРОФЕССИОНАЛЬНОГО ОБРАЗОВАНИЯ - ПРОГРАММАМ ПОДГОТОВКИ КВАЛИФИЦИРОВАННЫХ РАБОЧИХ, СЛУЖАЩИХ}

\begin{tabular}{|c|c|c|c|c|c|c|c|c|}
\hline & 2000 & 2005 & 2010 & 2011 & 2012 & 2013 & 2014 & 2015 \\
\hline Принято на обучение, тыс. чел. & 844.9 & 687.8 & 609.4 & 532.5 & 499.2 & 451.3 & 415.6 & 395.6 \\
\hline $\begin{array}{l}\text { В процентах от численности населения в возрасте } 15 \text { лет } \\
\text { (коэффициент приема) }\end{array}$ & 34.2 & 32.0 & 42.3 & 39.1 & 38.6 & 33.9 & 32.0 & 28.8 \\
\hline
\end{tabular}




\subsection{4. ВЫПУСК КВАЛИФИЦИРОВАННЫХ РАБОЧИХ, СЛУЖАЩИХ ПО ПРОФЕССИЯМ}

\begin{tabular}{|c|c|c|c|c|c|c|c|c|c|}
\hline & \multirow[t]{2}{*}{2001} & \multirow[t]{2}{*}{2005} & \multirow[t]{2}{*}{2010} & \multirow[t]{2}{*}{2011} & \multirow[t]{2}{*}{2012} & \multirow[t]{2}{*}{2013} & \multirow[t]{2}{*}{2014} & \multicolumn{2}{|c|}{2015} \\
\hline & & & & & & & & Тыс. чел. & Проценты \\
\hline Всего, тыс. чел. & 758.6 & 702.5 & 580.5 & 516.7 & 483.5 & 436.0 & 403.0 & 368.2 & 100 \\
\hline \multicolumn{10}{|l|}{ В том числе по профессиям: } \\
\hline промышленности & 230.9 & 214.0 & 174.8 & 160.0 & 152.6 & 138.3 & 127.3 & 119.8 & 32.5 \\
\hline \multicolumn{10}{|l|}{ из них: } \\
\hline производства черных и цветных металлов & 2.1 & 2.1 & 1.5 & 1.3 & 0.8 & 1.2 & 1.0 & 0.9 & 0.2 \\
\hline химического производства & 1.0 & 0.6 & 0.4 & 0.4 & 0.3 & 0.2 & 0.3 & 0.1 & 0.0 \\
\hline металлообработки & 117.7 & 115.5 & 95.9 & 82.9 & 75.8 & 66.0 & 59.2 & 54.9 & 14.9 \\
\hline \multicolumn{10}{|l|}{ лесозаготовительных работ, деревообрабатывающего } \\
\hline производства, производства целлюлозы, бумаги и картона & 12.1 & 16.4 & 17.2 & 17.6 & 16.5 & 15.7 & 13.9 & 13.9 & 3.8 \\
\hline производства строительных материалов & 0.3 & 0.2 & 0.6 & 0.4 & 0.5 & 0.7 & 0.7 & 0.5 & 0.1 \\
\hline легкой & 67.7 & 50.7 & 32.4 & 32.7 & 34.6 & 32.5 & 31.6 & 31.8 & 8.6 \\
\hline \multicolumn{10}{|l|}{ из них производства: } \\
\hline текстильного & 1.5 & 1.0 & 0.4 & 0.2 & 0.2 & 0.2 & 0.2 & 0.2 & 0.1 \\
\hline швейного & 62.4 & 46.2 & 29.5 & 30.0 & 32.0 & 30.2 & 29.6 & 29.4 & 8.0 \\
\hline обувного & 1.3 & 1.3 & 1.5 & 1.5 & 1.5 & 1.6 & 1.6 & 1.8 & 0.5 \\
\hline сельского хозяйства & 96.5 & 77.4 & 47.1 & 43.1 & 41.0 & 37.2 & 31.8 & 28.2 & 7.7 \\
\hline строительных, монтажных и ремонтно-строительных работ & 88.1 & 83.5 & 74.9 & 69.4 & 67.0 & 61.3 & 60.4 & 55.8 & 15.2 \\
\hline транспорта & 95.3 & 81.3 & 86.0 & 72.1 & 59.8 & 57.2 & 47.8 & 43.8 & 11.9 \\
\hline Связи & 4.1 & 3.9 & 3.1 & 2.6 & 2.4 & 2.0 & 2.1 & 1.7 & 0.5 \\
\hline \multicolumn{10}{|l|}{ общественного питания, торговли и производства пищевой } \\
\hline продукции & 109.2 & 109.6 & 80.8 & 71.9 & 76.5 & 67.2 & 66.6 & 60.7 & 16.5 \\
\hline сферы обслуживания & 14.8 & 17.3 & 22.0 & 19.0 & 17.8 & 15.2 & 14.4 & 13.5 & 3.7 \\
\hline общим для всех видов экономической деятельности & 61.2 & 62.1 & 56.5 & 47.6 & 43.0 & 39.8 & 36.9 & 33.9 & 9.2 \\
\hline другим & 58.6 & 53.4 & 35.5 & 30.9 & 23.4 & 17.8 & 15.8 & 10.7 & 2.9 \\
\hline
\end{tabular}




\subsection{5. ЧИСЛЕННОСТЬ СТУДЕНТОВ, ОБУЧАЮЩИХСЯ ПО ПРОГРАММАМ СРЕДНЕГО ПРОФЕССИОНАЛЬНОГО ОБРАЗОВАНИЯ -}

ПРОГРАММАМ ПОДГОТОВКИ СПЕЦИАЛИСТОВ СРЕДНЕГО ЗВЕНА

\begin{tabular}{|c|c|c|c|c|c|c|c|c|}
\hline & $2000 / 2001$ & $2005 / 2006$ & $2010 / 2011$ & $2011 / 2012$ & $2012 / 2013$ & $2013 / 2014$ & $2014 / 2015$ & $2015 / 2016$ \\
\hline Численность студентов, на начало учебного года; тыс. чел. & 2360.8 & 2590.7 & 2125.7 & 2081.7 & 2087.1 & 1984.3 & 2103.1 & 2180.2 \\
\hline Государственные и муниципальные организации & 2308.6 & 2473.0 & 2026.8 & 1984.0 & 1984.4 & 1858.4 & 1963.3 & 2031.3 \\
\hline Частные организации & 52.2 & 117.7 & 98.9 & 97.7 & 102.7 & 126.0 & 139.8 & 148.9 \\
\hline $\begin{array}{l}\text { Численность студентов на } 10000 \text { человек населения, чел. } \\
\text { Из общей численности - по формам обучения: }\end{array}$ & 161 & 181 & 149 & 146 & 146 & 138 & 144 & 149 \\
\hline очная & 1721.5 & 1960.3 & 1578.2 & 1569.1 & 1608.2 & 1557.5 & 1674.7 & 1746.9 \\
\hline очно-заочная & 93.4 & 70.7 & 54.3 & 53.1 & 48.3 & 45.9 & 45.8 & 48.6 \\
\hline заочная* & 545.9 & 559.7 & 493.2 & 459.5 & 430.6 & 380.9 & 382.6 & 384.7 \\
\hline \multicolumn{9}{|l|}{ Из общей численности - обучаются по программам на базе: } \\
\hline основного общего образования & 907.9 & 1095.6 & 1129.1 & 1212.3 & 1304.1 & 1310.6 & 1421.4 & 1493.9 \\
\hline среднего общего образования & 1452.9 & 1495.1 & 996.6 & 869.5 & 783.0 & 673.7 & 681.7 & 686.3 \\
\hline
\end{tabular}

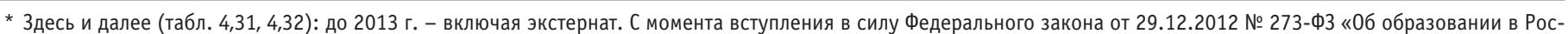
сийской Федерации» форма обучения «экстернат» упразднена. 
4.26. ОХВАТ МОЛОДЕЖИ ОБРАЗОВАТЕЛЬНЫМИ ПРОГРАММАМИ СРЕДНЕГО ПРОФЕССИОНАЛЬНОГО ОБРАЗОВАНИЯ ПРОГРАММАМИ ПОДГОТОВКИ СПЕЦИАЛИСТОВ СРЕДНЕГО ЗВЕНА ПО ПОЛУ

(отношение численности студентов, обучающихся по образовательным программам среднего профессионального образования - программам подготовки специалистов среднего звена, к численности населения в возрасте 15-19 лет)

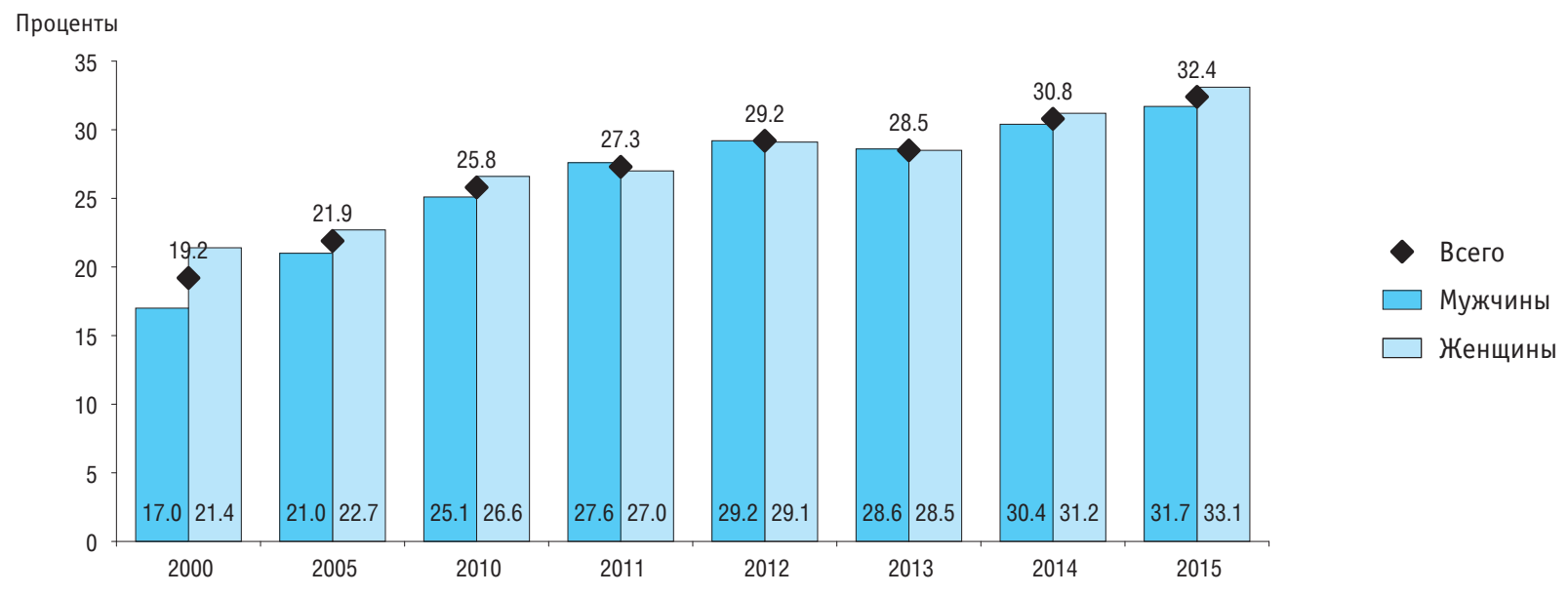




\subsection{7. ЧИСЛЕННОСТЬ СТУДЕНТОВ, ОБУЧАЮЩИХСЯ ПО ОБРАЗОВАТЕЛЬНЫМ ПРОГРАММАМ СРЕДНЕГО \\ ПРОФЕССИОНАЛЬНОГО ОБРАЗОВАНИЯ - ПРОГРАММАМ ПОДГОТОВКИ \\ СПЕЦИАЛИСТОВ СРЕДНЕГО ЗВЕНА, ПО ПОЛУ И ВОЗРАСТУ \\ (на начало учебного года; число полных лет на 1 января; человек)}

\begin{tabular}{|c|c|c|c|c|c|c|c|c|c|c|c|c|c|}
\hline & \multirow[t]{2}{*}{ Bcero } & \multicolumn{12}{|c|}{ Возраст, лет } \\
\hline & & $\begin{array}{c}15 \\
\text { и младше }\end{array}$ & 16 & 17 & 18 & 19 & 20 & 21 & 22 & 23 & 24 & 25 & $\begin{array}{c}26 \\
\text { и старше }\end{array}$ \\
\hline \multicolumn{14}{|c|}{$2010 / 2011$} \\
\hline Всего & 2125708 & 85699 & 277857 & 355219 & 396192 & 296912 & 167792 & 85332 & 56857 & 46781 & 39800 & 35375 & 281892 \\
\hline Мужчины & 1053896 & 46022 & 151748 & 184371 & 192782 & 138284 & 77462 & 39213 & 27649 & 23489 & 20567 & 18313 & 133966 \\
\hline Женщины & 1071812 & 39677 & 126109 & 170848 & 203410 & 158628 & 90330 & 46119 & 29208 & 23292 & 19233 & 17062 & 147896 \\
\hline \multicolumn{14}{|c|}{$2015 / 2016$} \\
\hline Всего & 2180205 & 90339 & 314659 & 406520 & 416835 & 304362 & 154234 & 83486 & 51303 & 38869 & 31584 & 28923 & 259091 \\
\hline Мужчины & 1091446 & 45400 & 163513 & 209345 & 208528 & 154909 & 74496 & 42029 & 26802 & 20305 & 16350 & 14907 & 114862 \\
\hline Женщины & 1088759 & 44939 & 151146 & 197175 & 208307 & 149453 & 79738 & 41457 & 24501 & 18564 & 15234 & 14016 & 144229 \\
\hline
\end{tabular}


4.28. СТРУКТУРА ЧИСЛЕННОСТИ СТУДЕНТОВ, ОБУЧАЮЩИХСЯ ПО ОБРАЗОВАТЕЛЬНЫМ ПРОГРАММАМ СРЕДНЕГО ПРОФЕССИОНАЛЬНОГО ОБРАЗОВАНИЯ - ПРОГРАММАМ ПОДГОТОВКИ СПЕЦИАЛИСТОВ СРЕДНЕГО ЗВЕНА, ПО ФОРМАМ ОБУЧЕНИЯ: 2015/2016

(на начало учебного года)

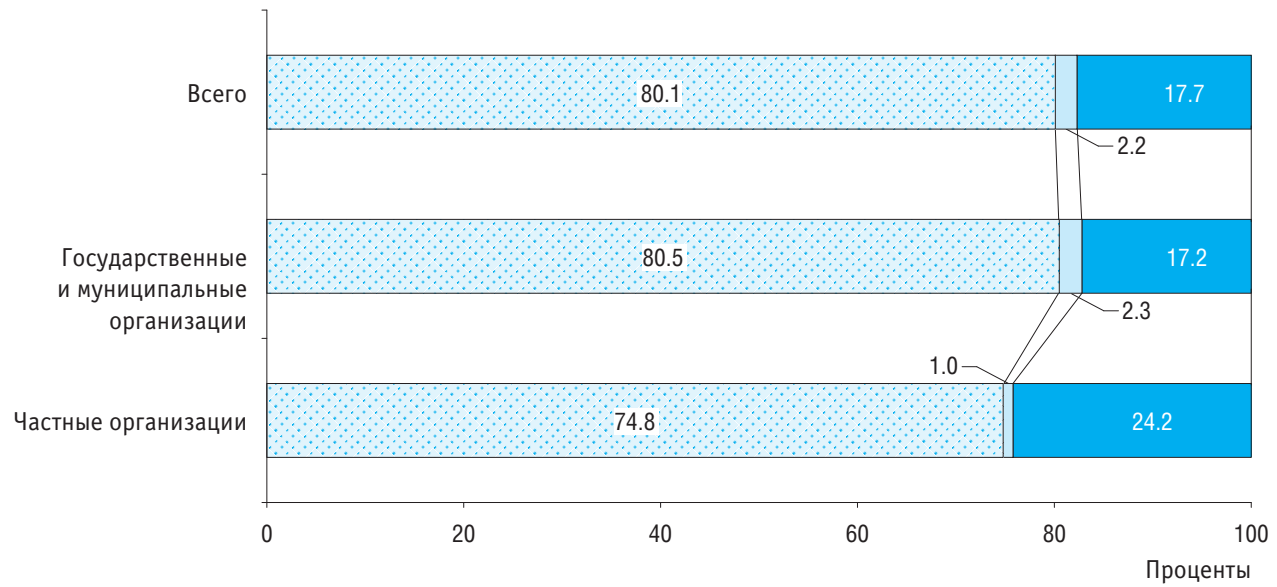

Формы обучения:

очная $\square$ очно-заочная

заочная 


\subsection{9. ЧИСЛЕННОСТЬ ЛИЦ С ОГРАНИЧЕННЫМИ ВОЗМОЖНОСТЯМИ ЗДОРОВЬЯ, ДЕТЕЙ-ИНВАЛИДОВ И ИНВАЛИДОВ, ОБУЧАЮЩИХСЯ ПО ОБРАЗОВАТЕЛЬНЫМ ПРОГРАММАМ СРЕДНЕГО ПРОФЕССИОНАЛЬНОГО ОБРАЗОВАНИЯ - \\ ПРОГРАММАМ ПОДГОТОВКИ СПЕЦИАЛИСТОВ СРЕДНЕГО ЗВЕНА: 2015/2016 \\ (на начало учебного года)}

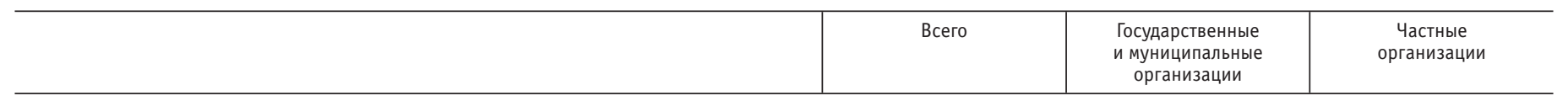

\section{Лица с ограниченными возможностями здоровья:}

чел.

в процентах от общей численности студентов

чел.

в процентах от общей численности обучающихся с ограниченными возможностями

здоровья

\section{Дети-инвалиды, инвалиды:}

чел.

в процентах от общей численности студентов

из них обучаются по адаптированным образовательным программам:

чел.

в процентах от общей численности обучающихся детей-инвалидов, инвалидов
5647

0.3

976

647

17.3

14788

0.7

2041

13.8
5576

0.3

969

17.4

14218

0.7

2030

14.3
71

0.0

9.9

570

0.4

11

1.9 


\subsection{0. ЧИСЛЕННОСТЬ ИНОСТРАННЫХ СТУДЕНТОВ, ОБУЧАЮЩИХСЯ ПО ОБРАЗОВАТЕЛЬНЫМ ПРОГРАММАМ СРЕДНЕГО ПРОФЕССИОНАЛЬНОГО ОБРАЗОВАНИЯ - ПРОГРАММАМ ПОДГОТОВКИ СПЕЦИАЛИСТОВ СРЕДНЕГО ЗВЕНА (на начало учебного года)}

\begin{tabular}{|c|c|c|c|c|c|c|c|}
\hline & $2000 / 2001$ & $2010 / 2011$ & $2011 / 2012$ & $2012 / 2013$ & $2013 / 2014$ & $2014 / 2015$ & $2015 / 2016$ \\
\hline \multicolumn{8}{|c|}{ Всего } \\
\hline Всего, чел. * & $\ldots$ & 12131 & 14153 & 16353 & 44111 & 36951 & 39377 \\
\hline \multicolumn{8}{|l|}{ В том числе граждане: } \\
\hline стран СНГ, Балтии, Грузии, Абхазии и Южной Осетии * & $\ldots$ & 10907 & 11947 & 14005 & 19031 & 24462 & 27110 \\
\hline из них обучаются на условиях общего приема & $\ldots$ & 10620 & 11741 & 13833 & 16452 & 21606 & 24093 \\
\hline стран дальнего зарубежья & $\ldots$ & 259 & 297 & 434 & 373 & 486 & 523 \\
\hline из них обучаются на условиях общего приема & $\ldots$ & - & - & - & 315 & 449 & 494 \\
\hline В процентах от общей численности студентов & $\cdots$ & 0.6 & 0.7 & 0.8 & 2.2 & 1.8 & 1.8 \\
\hline \multicolumn{8}{|c|}{ Государственные и муниципальные организации } \\
\hline Всего, чел. * & 5111 & 10839 & 12833 & 14817 & 37560 & 33145 & 35906 \\
\hline \multicolumn{8}{|l|}{ В том числе граждане: } \\
\hline стран СНГ, Балтии, Грузии, Абхазии и Южной Осетии * & 4922 & 9631 & 10650 & 12483 & 16098 & 22015 & 24466 \\
\hline из них обучаются на условиях общего приема & $\ldots$ & 9344 & 10445 & 12311 & 13536 & 19177 & 21463 \\
\hline стран дальнего зарубежья & 189 & 247 & 284 & 424 & 353 & 462 & 486 \\
\hline из них обучаются на условиях общего приема & - & - & - & - & 296 & 425 & 457 \\
\hline В процентах от общей численности студентов & 0.2 & 0.5 & 0.6 & 0.7 & 2.0 & 1.7 & 1.8 \\
\hline \multicolumn{8}{|c|}{ Частные организации } \\
\hline Всего, чел. * & $\ldots$ & 1292 & 1320 & 1536 & 6551 & 3806 & 3471 \\
\hline \multicolumn{8}{|l|}{ В том числе граждане: } \\
\hline стран СНГ, Балтии, Грузии, Абхазии и Южной Осетии * & $\ldots$ & 1276 & 1297 & 1522 & 2933 & 2447 & 2644 \\
\hline из них обучаются на условиях общего приема & $\ldots$ & 1276 & 1296 & 1522 & 2916 & 2429 & 2630 \\
\hline стран дальнего зарубежья & $\ldots$ & 12 & 13 & 10 & 20 & 24 & 37 \\
\hline из них обучаются на условиях общего приема & $\ldots$ & - & - & - & 19 & 24 & 37 \\
\hline В процентах от общей численности студентов & $\ldots$ & 1.3 & 1.4 & 1.5 & 5.2 & 2.7 & 2.3 \\
\hline
\end{tabular}

* С 2010/2011 учебного года - включая лиц без гражданства.

** До 2011/2012 учебного года - без учета граждан Абхазии и Южной Осетии. 
4.31. ПРИЕМ СТУДЕНТОВ НА ОБУЧЕНИЕ ПО ОБРАЗОВАТЕЛЬНЫМ ПРОГРАММАМ СРЕДНЕГО ПРОФЕССИОНАЛЬНОГО ОБРАЗОВАНИЯ ПРОГРАММАМ ПОДГОТОВКИ СПЕЦИАЛИСТОВ СРЕДНЕГО ЗВЕНА

\begin{tabular}{|c|c|c|c|c|c|c|c|c|}
\hline & 2000 & 2005 & 2010 & 2011 & 2012 & 2013 & 2014 & 2015 \\
\hline Всего, тыс. чел. & 867.2 & 854.1 & 705.3 & 659.6 & 656.2 & 637.7 & 672.8 & 699.3 \\
\hline Государственные и муниципальные организации & 842.4 & 810.9 & 671.8 & 628.8 & 620.8 & 591.3 & 618.4 & 639.8 \\
\hline Частные организации & 24.8 & 43.2 & 33.5 & 30.8 & 35.4 & 46.4 & 54.4 & 59.5 \\
\hline $\begin{array}{l}\text { В процентах от численности населения в возрасте } 15 \text { лет } \\
\text { (коэффициент приема) }\end{array}$ & 35.1 & 39.7 & 49.0 & 48.5 & 50.8 & 47.8 & 51.9 & 50.8 \\
\hline \multicolumn{9}{|l|}{ Из общей численности - по формам обучения: } \\
\hline очная & 625.1 & 662.0 & 537.9 & 515.2 & 518.6 & 507.8 & 544.8 & 567.7 \\
\hline очно-заочная & 35.5 & 20.9 & 19.2 & 17.0 & 15.8 & 16.1 & 15.3 & 16.9 \\
\hline заочная & 206.7 & 171.2 & 148.2 & 127.4 & 121.8 & 113.8 & 112.7 & 114.7 \\
\hline
\end{tabular}

\subsection{2. ВЫПУСК СПЕЦИАЛИСТОВ СРЕДНЕГО ЗВЕНА} (тысячи человек)

\begin{tabular}{|c|c|c|c|c|c|c|c|c|}
\hline & 2000 & 2005 & 2010 & 2011 & 2012 & 2013 & 2014 & 2015 \\
\hline Bcero & 579.3 & 684.4 & 572.1 & 518.0 & 486.3 & 439.0 & 451.0 & 446.0 \\
\hline Государственные и муниципальные организации & 567.7 & 651.4 & 535.7 & 484.2 & 454.9 & 404.0 & 418.0 & 410.9 \\
\hline Частные организации & 11.6 & 33.0 & 36.5 & 33.8 & 31.4 & 35.0 & 33.0 & 35.0 \\
\hline \multicolumn{9}{|l|}{ Из общей численности - по формам обучения: } \\
\hline очная & 426.4 & 493.4 & 418.0 & 372.7 & 349.2 & 323.5 & 348.9 & 354.4 \\
\hline очно-заочная & 25.7 & 22.7 & 15.2 & 13.4 & 12.9 & 11.0 & 10.6 & 9.8 \\
\hline заочная & 127.2 & 168.3 & 139.0 & 132.0 & 124.2 & 104.5 & 91.4 & 81.8 \\
\hline
\end{tabular}




\subsection{3. ВЫПУСК СПЕЦИАЛИСТОВ СРЕДНЕГО ЗВЕНА ПО УКРУПНЕННЫМ ГРУППАМ СПЕЦИАЛЬНОСТЕЙ: 2004-2013} (тысячи человек)

\begin{tabular}{|c|c|c|c|c|c|c|}
\hline & 2004 & 2005 & 2010 & 2011 & 2012 & 2013 \\
\hline Всего & 702.7 & 684.4 & 572.1 & 518.0 & 486.3 & 439.0 \\
\hline Физико-математические науки & 0.3 & - & - & - & - & - \\
\hline Естественные науки & 0.5 & 0.5 & 0.4 & 0.3 & 0.3 & 0.2 \\
\hline Гуманитарные науки & 72.3 & 72.1 & 50.6 & 44.3 & 42.0 & 34.7 \\
\hline Социальные науки & 1.0 & 1.1 & 1.0 & 1.2 & 1.2 & 1.5 \\
\hline Образование и педагогика & 58.6 & 54.9 & 45.6 & 40.5 & 38.2 & 33.5 \\
\hline Здравоохранение & 67.7 & 57.3 & 63.3 & 56.8 & 50.3 & 47.0 \\
\hline Культура и искусство & 18.3 & 18.3 & 18.1 & 17.4 & 17.3 & 14.9 \\
\hline Экономика и управление & 207.9 & 203.1 & 148.1 & 135.4 & 115.7 & 87.4 \\
\hline Информационная безопасность & - & - & 0.4 & 0.4 & 0.6 & 0.7 \\
\hline Сфера обслуживания & 9.0 & 10.0 & 14.7 & 15.1 & 14.8 & 20.9 \\
\hline Сельское и рыбное хозяйство & 28.6 & 28.4 & 17.6 & 15.3 & 14.9 & 15.7 \\
\hline Геодезия и землеустройство & 2.2 & 2.5 & 2.6 & 2.5 & 3.0 & 6.0 \\
\hline Геология, разведка и разработка полезных ископаемых & 7.6 & 7.5 & 8.4 & 8.2 & 8.8 & 8.0 \\
\hline Энергетика, энергетическое машиностроение и электротехника & 19.6 & 19.0 & 16.7 & 14.9 & 15.1 & 14.4 \\
\hline Металлургия, машиностроение и материалообработка & 30.6 & 30.2 & 22.6 & 19.7 & 18.5 & 17.6 \\
\hline Авиационная и ракетно-космическая техника & 2.2 & 2.0 & 2.0 & 1.6 & 1.7 & 1.8 \\
\hline Морская техника & 4.1 & 3.9 & 3.2 & 2.7 & 3.1 & 3.2 \\
\hline Транспортные средства & 51.0 & 50.5 & 44.6 & 40.4 & 40.2 & 39.6 \\
\hline Приборостроение и оптотехника & 1.7 & 1.7 & 1.3 & 0.9 & 0.9 & 0.8 \\
\hline Электронная техника, радиотехника и связь & 12.9 & 12.2 & 9.0 & 7.3 & 6.6 & 6.1 \\
\hline Автоматика и управление & 8.2 & 7.5 & 5.9 & 5.4 & 5.3 & 5.4 \\
\hline Информатика и вычислительная техника & 22.1 & 26.0 & 31.1 & 27.7 & 26.4 & 24.0 \\
\hline Химическая и биотехнологии & 5.5 & 5.4 & 3.8 & 3.3 & 3.2 & 3.1 \\
\hline Воспроизводство и переработка лесных ресурсов & 6.6 & 6.3 & 4.8 & 4.2 & 4.3 & 4.0 \\
\hline
\end{tabular}


(окончание)

\begin{tabular}{|c|c|c|c|c|c|c|}
\hline & 2004 & 2005 & 2010 & 2011 & 2012 & 2013 \\
\hline Технология продовольственных продуктов и потребительских товаров & 29.0 & 28.1 & 22.4 & 19.9 & 20.2 & 17.8 \\
\hline Архитектура и строительство & 32.6 & 33.0 & 31.7 & 30.5 & 31.4 & 28.1 \\
\hline $\begin{array}{l}\text { Безопасность жизнедеятельности, природообустройство } \\
\text { и защита окружающей среды }\end{array}$ & 2.5 & 2.9 & 2.4 & 2.0 & 2.3 & 2.6 \\
\hline
\end{tabular}

\subsection{4. ВЫПУСК СПЕЦИАЛИСТОВ СРЕДНЕГО ЗВЕНА ПО УКРУПНЕННЫМ ГРУППАМ СПЕЦИАЛЬНОСТЕЙ: 2014, 2015}

\begin{tabular}{|c|c|c|c|c|}
\hline & \multicolumn{2}{|c|}{2014} & \multicolumn{2}{|c|}{2015} \\
\hline & Чел. & Проценты & Чел. & Проценты \\
\hline Bcero & 450966 & 100 & 445960 & 100 \\
\hline Науки о Земле & 318 & 0.1 & 314 & 0.1 \\
\hline Архитектура & 1592 & 0.4 & 1696 & 0.4 \\
\hline Техника и технологии строительства & 27321 & 6.1 & 25597 & 5.7 \\
\hline Информационная безопасность & 629 & 0.1 & 1166 & 0.3 \\
\hline Электроника, радиотехника и системы связи & 6766 & 1.5 & 6289 & 1.4 \\
\hline \multicolumn{5}{|l|}{ Фотоника, приборостроение, оптические и биотехнические системы } \\
\hline и технологии & 368 & 0.1 & 482 & 0.1 \\
\hline Электро- и теплоэнергетика & 15534 & 3.4 & 15335 & 3.4 \\
\hline Ядерная энергетика и технологии & 234 & 0.1 & 1723 & 0.4 \\
\hline Машиностроение & 18530 & 4.1 & 15613 & 3.5 \\
\hline Промышленная экология и биотехнологии & 16065 & 3.6 & 16791 & 3.8 \\
\hline Техносферная безопасность и природообустройство & 3017 & 0.7 & 3467 & 0.8 \\
\hline Прикладная геология, горное дело, нефтегазовое дело и геодезия & 18806 & 4.2 & 17534 & 3.9 \\
\hline Технологии материалов & 4185 & 0.9 & 4363 & 1.0 \\
\hline
\end{tabular}


(окончание)

\begin{tabular}{|c|c|c|c|c|}
\hline & \multicolumn{2}{|c|}{2014} & \multicolumn{2}{|c|}{2015} \\
\hline & Чел. & Проценты & Чел. & Проценты \\
\hline Техника и технологии наземного транспорта & 40107 & 8.9 & 40606 & 9.1 \\
\hline Авиационная и ракетно-космическая техника & 664 & 0.1 & 764 & 0.2 \\
\hline Аэронавигация и эксплуатация авиационной и ракетно-космической техники & 1042 & 0.2 & 1654 & 0.4 \\
\hline Техника и технологии кораблестроения и водного транспорта & 5707 & 1.3 & 4742 & 1.1 \\
\hline Управление в технических системах & 2949 & 0.7 & 2495 & 0.6 \\
\hline Технологии легкой промышленности & 3002 & 0.7 & 2609 & 0.6 \\
\hline Клиническая медицина & 17851 & 4.0 & 16423 & 3.7 \\
\hline Науки о здоровье и профилактическая медицина & 100 & 0.0 & 134 & 0.0 \\
\hline Фармация & 6345 & 1.4 & 7426 & 1.7 \\
\hline Сестринское дело & 26477 & 5.9 & 26924 & 6.0 \\
\hline Сельское, лесное и рыбное хозяйство & 16960 & 3.8 & 15025 & 3.4 \\
\hline Ветеринария и зоотехния & 2808 & 0.6 & 2459 & 0.6 \\
\hline Экономика и управление & 79163 & 17.6 & 72486 & 16.3 \\
\hline Социология и социальная работа & 2262 & 0.5 & 1860 & 0.4 \\
\hline Юриспруденция & 27363 & 6.1 & 29937 & 6.7 \\
\hline Средства массовой информации и информационно-библиотечное дело & 1877 & 0.4 & 2279 & 0.5 \\
\hline Сервис и туризм & 17352 & 3.8 & 18556 & 4.2 \\
\hline Образование и педагогические науки & 25746 & 5.7 & 27137 & 6.1 \\
\hline История и археология & 3845 & 0.9 & 3354 & 0.8 \\
\hline Физическая культура и спорт & 4934 & 1.1 & 5939 & 1.3 \\
\hline Искусствознание & - & - & - & - \\
\hline Культуроведение и социокультурные проекты & 4691 & 1.0 & 4074 & 0.9 \\
\hline Сценические искусства и литературное творчество & 754 & 0.2 & 705 & 0.2 \\
\hline Музыкальное искусство & 6456 & 1.4 & 6554 & 1.5 \\
\hline Изобразительное и прикладные виды искусств & 7297 & 1.6 & 8666 & 1.9 \\
\hline Экранные искусства & 405 & 0.1 & 493 & 0.1 \\
\hline Обеспечение государственной безопасности & - & - & - & - \\
\hline
\end{tabular}


4.35. ЧИСЛЕННОСТЬ СТУДЕНТОВ, ОБУЧАЮЩИХСЯ ПО ОБРАЗОВАТЕЛЬНЫМ ПРОГРАММАМ ВЫСШЕГО ОБРАЗОВАНИЯ ПРОГРАММАМ БАКАЛАВРИАТА, ПРОГРАММАМ СПЕЦИАЛИТЕТА, ПРОГРАММАМ МАГИСТРАТУРЫ

\begin{tabular}{|c|c|c|c|c|c|c|c|c|}
\hline & $2000 / 2001$ & $2005 / 2006$ & $2010 / 2011$ & $2011 / 2012$ & $2012 / 2013$ & $2013 / 2014$ & $2014 / 2015$ & $2015 / 2016$ \\
\hline Численность студентов, на начало учебного года; тыс. чел. & 4741.4 & 7064.6 & 7049.8 & 6490.0 & 6075.4 & 5646.7 & 5209.0 & 4766.5 \\
\hline Государственные и муниципальные организации & 4270.8 & 5985.3 & 5848.7 & 5453.9 & 5145.3 & 4762.0 & 4405.5 & 4061.4 \\
\hline Частные организации & 470.6 & 1079.3 & 1201.1 & 1036.1 & 930.1 & 884.7 & 803.5 & 705.1 \\
\hline $\begin{array}{l}\text { Численность студентов на } 10000 \text { человек населения, чел. } \\
\text { Из общей численности - по формам обучения: }\end{array}$ & 324 & 493 & 493 & 454 & 424 & 393 & 356 & 325 \\
\hline очная & 2625.1 & 3508.0 & 3073.7 & 2847.7 & 2724.3 & 2618.8 & 2575.0 & 2379.6 \\
\hline очно-заочная & 302.2 & 371.2 & 304.7 & 263.4 & 229.7 & 189.2 & 158.5 & 149.1 \\
\hline заочная* & 1814.1 & 3185.4 & 3671.3 & 3378.9 & 3121.4 & 2838.6 & 2475.5 & 2237.8 \\
\hline
\end{tabular}

* Здесь и далее (табл. 4.43, 4.46): до 2014 г. - включая экстернат. С момента вступления в силу Федерального закона от 29.12.2012 № 273 -Ф3 «0б образовании в Российской Федерации» форма обучения «экстернат» упразднена. 
4.36. ОХВАТ МОЛОДЕЖИ ОБРАЗОВАТЕЛЬНЫМИ ПРОГРАММАМИ ВЫСШЕГО ОБРАЗОВАНИЯ - ПРОГРАММАМИ БАКАЛАВРИАТА, ПРОГРАММАМИ СПЕЦИАЛИТЕТА, ПРОГРАММАМИ МАГИСТРАТУРЫ ПО ПОЛУ

(отношение численности студентов, обучающихся по образовательным программам высшего образования программам бакалавриата, программам специалитета, программам магистратуры, к численности населения в возрасте 17-25 лет)

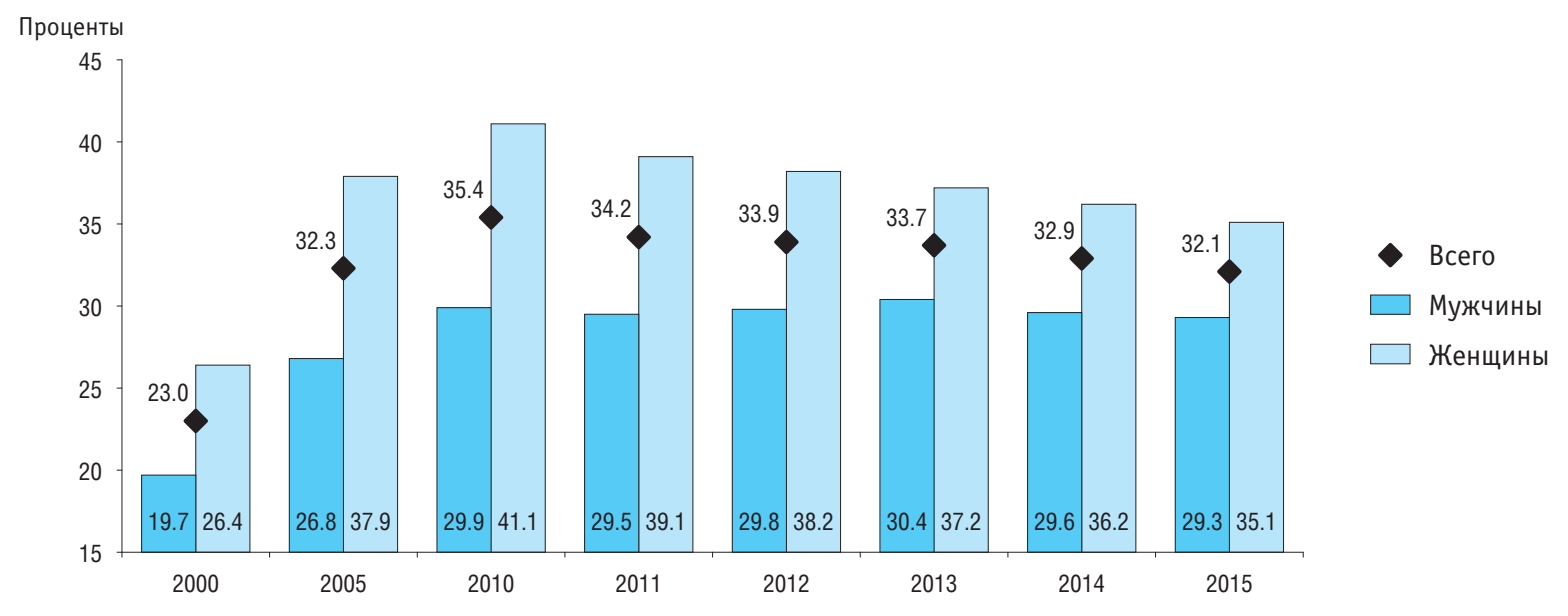


4.37. ЧИСЛЕННОСТЬ СТУДЕНТОВ, ОБУЧАЮЩИХСЯ ПО ОБРАЗОВАТЕЛЬНЫМ ПРОГРАММАМ ВЫСШЕГО ОБРАЗОВАНИЯ ПРОГРАММАМ БАКАЛАВРИАТА, ПРОГРАММАМ СПЕЦИАЛИТЕТА, ПРОГРАММАМ МАГИСТРАТУРЫ,

ПО ПОЛУ И ВОЗРАСТУ

(на начало учебного года; число полных лет на 1 января; человек)

\begin{tabular}{|c|c|c|c|c|c|c|c|c|c|c|c|}
\hline & \multirow[t]{2}{*}{ Всего } & \multicolumn{10}{|c|}{ Возраст, лет } \\
\hline & & $\begin{array}{c}17 \\
\text { и младше }\end{array}$ & 18 & 19 & 20 & 21 & 22 & 23 & 24 & 25 & $\begin{array}{c}26 \\
\text { и старше }\end{array}$ \\
\hline \multicolumn{12}{|c|}{$2010 / 2011$} \\
\hline Всего & 7049815 & 318444 & 617107 & 794153 & 906190 & 930911 & 719909 & 487230 & 360519 & 284754 & 1630598 \\
\hline Мужчины & 3019722 & 144419 & 270581 & 335345 & 377328 & 386551 & 303145 & 210584 & 159463 & 128524 & 703782 \\
\hline Женщины & 4030093 & 174025 & 346526 & 458808 & 528862 & 544360 & 416764 & 276646 & 201056 & 156230 & 926816 \\
\hline \multicolumn{12}{|c|}{$2015 / 2016$} \\
\hline Всего & 4766479 & 152900 & 431213 & 572761 & 646345 & 626237 & 463409 & 323174 & 231839 & 182967 & 1135634 \\
\hline Мужчины & 2217879 & 70768 & 194825 & 250300 & 285076 & 277193 & 209636 & 151889 & 116227 & 94018 & 567947 \\
\hline Женщины & 2548600 & 82132 & 236388 & 322461 & 361269 & 349044 & 253773 & 171285 & 115612 & 88949 & 567687 \\
\hline
\end{tabular}


4.38. ЧИСЛЕННОСТЬ СТУДЕНТОВ, ОБУЧАЮЩИХСЯ ПО ОБРАЗОВАТЕЛЬНЫМ ПРОГРАММАМ ВЫСШЕГО ОБРАЗОВАНИЯ (на начало учебного года; тысячи человек)

\begin{tabular}{|c|c|c|c|c|}
\hline & \multirow[t]{2}{*}{ Bcero } & \multicolumn{3}{|c|}{ В том числе по программам } \\
\hline & & бакалавриата & специалитета & магистратуры \\
\hline \multicolumn{5}{|c|}{ Bcero } \\
\hline $2011 / 2012$ & 6490.0 & 1425.4 & 4929.3 & 135.4 \\
\hline $2012 / 2013$ & 6075.4 & 2271.8 & 3634.8 & 168.8 \\
\hline $2013 / 2014$ & 5646.7 & 2994.8 & 2453.5 & 198.3 \\
\hline $2014 / 2015$ & 5209.0 & 3516.1 & 1465.9 & 227.0 \\
\hline $2015 / 2016$ & 4766.5 & 3530.9 & 904.9 & 330.7 \\
\hline \multicolumn{5}{|c|}{ Государственные и муниципальные организации } \\
\hline $2011 / 2012$ & 5453.9 & 1159.6 & 4166.8 & 127.5 \\
\hline $2012 / 2013$ & 5145.3 & 1875.6 & 3113.1 & 156.6 \\
\hline $2013 / 2014$ & 4762.0 & 2453.3 & 2125.8 & 182.9 \\
\hline $2014 / 2015$ & 4405.5 & 2893.0 & 1300.1 & 212.4 \\
\hline $2015 / 2016$ & 4061.4 & 2924.8 & 823.3 & 313.3 \\
\hline \multicolumn{5}{|c|}{ Частные организации } \\
\hline $2011 / 2012$ & 1036.1 & 265.8 & 762.5 & 7.9 \\
\hline $2012 / 2013$ & 930.1 & 396.2 & 521.7 & 12.2 \\
\hline $2013 / 2014$ & 884.7 & 541.5 & 327.8 & 15.5 \\
\hline $2014 / 2015$ & 803.5 & 623.1 & 165.8 & 14.6 \\
\hline $2015 / 2016$ & 705.1 & 606.1 & 81.6 & 17.4 \\
\hline
\end{tabular}




\subsection{9. СТРУКТУРА ЧИСЛЕННОСТИ СТУДЕНТОВ, ОБУЧАЮЩИХСЯ ПО ОБРАЗОВАТЕЛЬНЫМ ПРОГРАММАМ}

ВЫСШЕГО ОБРАЗОВАНИЯ - ПРОГРАММАМ БАКАЛАВРИАТА, ПРОГРАММАМ СПЕЦИАЛИТЕТА, ПРОГРАММАМ МАГИСТРАТУРЫ, ПО ФОРМАМ ОБУЧЕНИЯ: 2015/2016

(на начало учебного года)

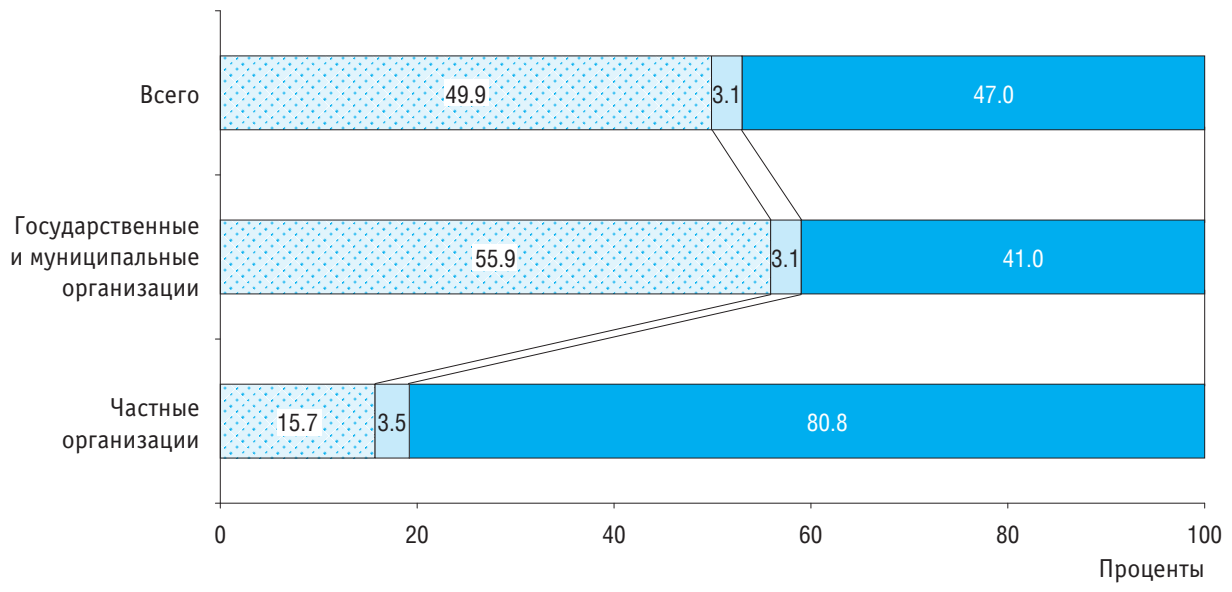

Формы обучения:

$\therefore$ очная $\square$ очно-заочная

заочная 
4.40. ЧИСЛЕННОСТЬ ЛИЦ С ОГРАНИЧЕННЫМИ ВОЗМОЖНОСТЯМИ ЗДОРОВЬЯ, ДЕТЕЙ-ИНВАЛИДОВ, ИНВАЛИДОВ, ОБУЧАЮЩИХСЯ ПО ОБРАЗОВАТЕЛЬНЫМ ПРОГРАММАМ ВЫСШЕГО ОБРАЗОВАНИЯ - ПРОГРАММАМ БАКАЛАВРИАТА,

ПРОГРАММАМ СПЕЦИАЛИТЕТА, ПРОГРАММАМ МАГИСТРАТУРЫ

(на начало учебного года)

\begin{tabular}{|c|c|c|c|c|c|c|}
\hline & \multicolumn{3}{|c|}{$2014 / 2015$} & \multicolumn{3}{|c|}{$2015 / 2016$} \\
\hline & Bcero & $\begin{array}{c}\text { Государственные } \\
\text { и муниципальные } \\
\text { организации }\end{array}$ & $\begin{array}{c}\text { Частные } \\
\text { организации }\end{array}$ & Bcero & $\begin{array}{c}\text { Государственные } \\
\text { и муниципальные } \\
\text { организации }\end{array}$ & $\begin{array}{c}\text { Частные } \\
\text { организации }\end{array}$ \\
\hline \multicolumn{7}{|c|}{ Лица с ограниченными возможностями здоровья: } \\
\hline чел. & 4052 & 3974 & 78 & 5730 & 5610 & 120 \\
\hline в процентах от общей численности студентов & 0.1 & 0.1 & 0.0 & 0.1 & 0.1 & 0.0 \\
\hline \multicolumn{7}{|l|}{$\begin{array}{l}\text { из них обучаются по адаптированным } \\
\text { образовательным программам: }\end{array}$} \\
\hline чел. & 555 & 525 & 30 & 755 & 722 & 33 \\
\hline \multicolumn{7}{|l|}{ в процентах от общей численности студентов } \\
\hline с ограниченными возможностями здоровья & 13.7 & 13.2 & 38.5 & 13.2 & 12.9 & 27.5 \\
\hline \multicolumn{7}{|l|}{ Дети-инвалиды, инвалиды: } \\
\hline чел. & 16768 & 16201 & 567 & 21222 & 21355 & 767 \\
\hline в процентах от общей численности студентов & 0.3 & 0.4 & 0.1 & 0.5 & 0.5 & 0.1 \\
\hline \multicolumn{7}{|l|}{$\begin{array}{l}\text { из них обучаются по адаптированным } \\
\text { образовательным программам: }\end{array}$} \\
\hline чел. & 1262 & 1227 & 35 & 1868 & 1835 & 33 \\
\hline \multicolumn{7}{|l|}{ в процентах от общей численности обучающихся } \\
\hline
\end{tabular}



ПРОГРАММАМ БАКАЛАВРИАТА, ПРОГРАММАМ СПЕЦИАЛИТЕТА, ПРОГРАММАМ МАГИСТРАТУРЫ

(на начало учебного года)

\begin{tabular}{|c|c|c|c|c|c|c|}
\hline & $2010 / 2011$ & $2011 / 2012$ & $2012 / 2013$ & $2013 / 2014$ & $2014 / 2015$ & $2015 / 2016$ \\
\hline \multicolumn{7}{|c|}{ Всего } \\
\hline Всего, тыс. чел. * & 160.9 & 159.5 & 171.6 & 205.7 & 224.6 & 242.5 \\
\hline \multicolumn{7}{|l|}{ В том числе граждане стран: } \\
\hline СНГ, Балтии, Грузии, Абхазии и Южной Осетии * & 116.7 & 121.8 & 127.5 & 156.3 & 175.5 & 188.1 \\
\hline их них обучаются на условиях общего приема & 105.3 & 108.2 & 110.2 & 137.7 & 154.6 & 169.6 \\
\hline дальнего зарубежья & 37.1 & 36.6 & 37.4 & 39.5 & 44.5 & 49.5 \\
\hline их них обучаются на условиях общего приема & - & - & - & 25.9 & 32.4 & 36.0 \\
\hline В процентах от общей численности студентов & 2.3 & 2.4 & 2.8 & 3.6 & 4.3 & 5.1 \\
\hline \multicolumn{7}{|c|}{ Государственные и муниципальные организации } \\
\hline Всего, тыс. чел. * & 130.6 & 126.9 & 139.4 & 160.3 & 178.6 & 195.6 \\
\hline \multicolumn{7}{|l|}{ В том числе граждане стран: } \\
\hline СНГ, Балтии, Грузии, Абхазии и Южной Осетии * * & 86.7 & 89.8 & 98.4 & 113.3 & 130.7 & 142.2 \\
\hline их них обучаются на условиях общего приема & 75.3 & 76.2 & 81.1 & 94.9 & 109.9 & 124.0 \\
\hline дальнего зарубежья & 36.8 & 36.5 & 37.1 & 39.1 & 43.9 & 48.6 \\
\hline их них обучаются на условиях общего приема & - & - & - & 25.5 & 31.8 & 35.2 \\
\hline В процентах от общей численности студентов & 2.2 & 2.3 & 2.7 & 3.3 & 4.0 & 4.8 \\
\hline \multicolumn{7}{|c|}{ Частные организации } \\
\hline Всего, тыс. чел. * & 30.3 & 32.6 & 32.2 & 45.4 & 45.9 & 46.9 \\
\hline \multicolumn{7}{|l|}{ В том числе граждане стран: } \\
\hline СНГ, Балтии, Грузии, Абхазии и Южной Осетии * * & 30.0 & 32.0 & 29.1 & 43.0 & 44.8 & 45.9 \\
\hline их них обучаются на условиях общего приема & 30.0 & 32.0 & 29.0 & 42.8 & 44.7 & 45.7 \\
\hline дальнего зарубежья & 0.2 & 0.1 & 0.2 & 0.4 & 0.6 & 0.9 \\
\hline их них обучаются на условиях общего приема & - & - & - & 0.4 & 0.6 & 0.8 \\
\hline В процентах от общей численности студентов & 2.5 & 3.1 & 3.5 & 5.1 & 5.7 & 6.7 \\
\hline
\end{tabular}

* Включая лиц без гражданства.

** 2010/2011 учебный год - без учета граждан Абхазии и Южной Осетии. 


\subsection{2. СТРУКТУРА ЧИСЛЕННОСТИ ИНОСТРАННЫХ СТУДЕНТОВ ИЗ СТРАН ДАЛЬНЕГО ЗАРУБЕЖЬЯ, ОБУЧАЮЩИХСЯ ПО ОБРАЗОВАТЕЛЬНЫМ ПРОГРАММАМ ВЫСШЕГО ОБРАЗОВАНИЯ - ПРОГРАММАМ БАКАЛАВРИАТА, ПРОГРАММАМ СПЕЦИАЛИТЕТА, ПРОГРАММАМ МАГИСТРАТУРЫ, ПО ГРАЖДАНСТВУ: 2015/2016}

(на начало учебного года; проченты)

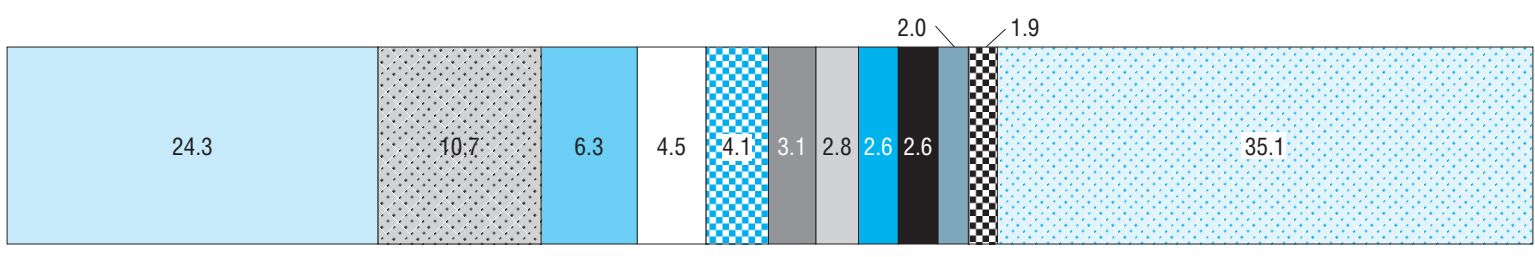

\section{Страны:}

$\begin{array}{ll}\square \text { Китай } & \square \text { Малайзия } \\ \therefore \text { Индия } & \square \text { Нигерия } \\ \square \text { Вьетнам } & \square \text { Марокко } \\ \square \text { Монголия } & \square \text { Сирийская Арабская Республика }\end{array}$

Ирак

$\square$ Турция

20 Ангола

$\therefore$ Другие страны 
4.43. ПРИЕМ СТУДЕНТОВ НА ОБУЧЕНИЕ ПО ОБРАЗОВАТЕЛЬНЫМ ПРОГРАММАМ ВЫСШЕГО ОБРАЗОВАНИЯ ПРОГРАММАМ БАКАЛАВРИАТА, ПРОГРАММАМ СПЕЦИАЛИТЕТА, ПРОГРАММАМ МАГИСТРАТУРЫ

\begin{tabular}{|c|c|c|c|c|c|c|c|c|}
\hline & 2000 & 2005 & 2010 & 2011 & 2012 & 2013 & 2014 & 2015 \\
\hline Принято, тыс. чел. & 1292.5 & 1640.5 & 1399.5 & 1207.4 & 1298.2 & 1246.5 & 1191.7 & 1221.8 \\
\hline Государственные и муниципальные организации & 1140.3 & 1372.5 & 1195.4 & 1057.7 & 1111.6 & 1066.8 & 1020.8 & 1049.6 \\
\hline Частные организации & 152.2 & 268.0 & 204.0 & 149.7 & 186.6 & 179.7 & 170.9 & 172.2 \\
\hline $\begin{array}{l}\text { В процентах от численности населения в возрасте } 17 \text { лет } \\
\text { (коэффициент приема) }\end{array}$ & 50.1 & 68.0 & 91.1 & 80.0 & 90.0 & 91.4 & 90.6 & 90.1 \\
\hline \multicolumn{9}{|l|}{ Из общей численности - по формам обучения: } \\
\hline очная & 687.5 & 830.7 & 659.6 & 628.0 & 673.4 & 664.5 & 653.7 & 676.2 \\
\hline очно-заочная & 81.9 & 86.1 & 52.4 & 40.4 & 40.8 & 34.6 & 32.4 & 36.3 \\
\hline заочная & 523.1 & 723.7 & 687.5 & 539.0 & 584.0 & 547.5 & 505.6 & 509.3 \\
\hline
\end{tabular}


4.44. ПРИЕМ СТУДЕНТОВ ПО ОБРАЗОВАТЕЛЬНЫМ ПРОГРАММАМ ВЫСШЕГО ОБРАЗОВАНИЯ (тысячи человек)

\begin{tabular}{|c|c|c|c|c|}
\hline & \multirow[t]{2}{*}{ Всего } & \multicolumn{3}{|c|}{ В том числе на обучение по программам } \\
\hline & & бакалавриата & специалитета & магистратуры \\
\hline \multicolumn{5}{|c|}{ Bcero } \\
\hline 2011 & 1207.4 & 987.9 & 143.1 & 76.3 \\
\hline 2012 & 1298.2 & 1061.9 & 143.5 & 92.9 \\
\hline 2013 & 1246.5 & 995.1 & 147.3 & 104.1 \\
\hline 2014 & 1191.7 & 930.9 & 142.0 & 118.8 \\
\hline 2015 & 1221.8 & 866.6 & 147.7 & 207.5 \\
\hline \multicolumn{5}{|c|}{ Государственные и муниципальные организации } \\
\hline 2011 & 1057.7 & 855.2 & 129.8 & 72.7 \\
\hline 2012 & 1111.6 & 887.6 & 137.3 & 86.7 \\
\hline 2013 & 1066.8 & 828.0 & 140.8 & 98.0 \\
\hline 2014 & 1020.8 & 773.7 & 134.2 & 112.9 \\
\hline 2015 & 1049.6 & 713.6 & 138.8 & 197.2 \\
\hline \multicolumn{5}{|c|}{ Частные организации } \\
\hline 2011 & 149.7 & 132.7 & 13.4 & 3.7 \\
\hline 2012 & 186.6 & 174.3 & 6.1 & 6.2 \\
\hline 2013 & 179.7 & 167.1 & 6.5 & 6.1 \\
\hline 2014 & 170.9 & 157.3 & 7.7 & 5.9 \\
\hline 2015 & 172.2 & 153.1 & 8.9 & 10.3 \\
\hline
\end{tabular}




\subsection{5. ПРИЕМ НА ОБУЧЕНИЕ ПО ОБРАЗОВАТЕЛЬНЫМ ПРОГРАММАМ ВЫСШЕГО ОБРАЗОВАНИЯ - ПРОГРАММАМ БАКАЛАВРИАТА, ПРОГРАММАМ СПЕЦИАЛИТЕТА, ПРОГРАММАМ МАГИСТРАТУРЫ ПО УКРУПНЕННЫМ ГРУППАМ СПЕЦИАЛЬНОСТЕЙ И НАПРАВЛЕНИЙ ПОДГОТОВКИ}

\begin{tabular}{|c|c|c|c|c|}
\hline & \multicolumn{2}{|c|}{2014} & \multicolumn{2}{|c|}{2015} \\
\hline & Тыс. чел. & Проценты & Тыс. чел. & Проценты \\
\hline Bcero & 1191.7 & 100 & 1221.8 & 100 \\
\hline Математика и механика & 10.7 & 0.9 & 12.4 & 1.0 \\
\hline Компьютерные и информационные науки & 4.8 & 0.4 & 5.1 & 0.4 \\
\hline Физика и астрономия & 6.9 & 0.6 & 7.9 & 0.6 \\
\hline Химия & 4.9 & 0.4 & 5.0 & 0.4 \\
\hline Науки о Земле & 11.0 & 0.9 & 11.4 & 0.9 \\
\hline Биологические науки & 7.7 & 0.6 & 7.6 & 0.6 \\
\hline Архитектура & 5.8 & 0.5 & 6.1 & 0.5 \\
\hline Техника и технологии строительства & 43.6 & 3.7 & 45.1 & 3.7 \\
\hline Информатика и вычислительная техника & 43.0 & 3.6 & 46.9 & 3.8 \\
\hline Информационная безопасность & 6.0 & 0.5 & 6.3 & 0.5 \\
\hline Электроника, радиотехника и системы связи & 16.2 & 1.4 & 18.6 & 1.5 \\
\hline Фотоника, приборостроение, оптические и биотехнические системы и технологии & 5.8 & 0.5 & 6.5 & 0.5 \\
\hline Электро- и теплоэнергетика & 31.1 & 2.6 & 33.5 & 2.7 \\
\hline Ядерная энергетика и технологии & 2.0 & 0.2 & 2.3 & 0.2 \\
\hline Машиностроение & 30.7 & 2.6 & 33.1 & 2.7 \\
\hline Физико-технические науки и технологии & 1.7 & 0.1 & 1.7 & 0.1 \\
\hline Оружие и системы вооружения & 0.7 & 0.1 & 0.8 & 0.1 \\
\hline Химические технологии & 11.5 & 1.0 & 13.4 & 1.1 \\
\hline Промышленная экология и биотехнологии & 12.8 & 1.1 & 12.9 & 1.1 \\
\hline Техносферная безопасность и природообустройство & 13.8 & 1.2 & 15.0 & 1.2 \\
\hline Прикладная геология, горное дело, нефтегазовое дело и геодезия & 29.4 & 2.5 & 30.4 & 2.5 \\
\hline Технологии материалов & 5.2 & 0.4 & 6.1 & 0.5 \\
\hline
\end{tabular}


(продолжение)

\begin{tabular}{|c|c|c|c|c|}
\hline & \multicolumn{2}{|c|}{2014} & \multicolumn{2}{|c|}{2015} \\
\hline & Тыс. чел. & Проценты & Тыс. чел. & Проценты \\
\hline Техника и технологии наземного транспорта & 35.5 & 3.0 & 38.4 & 3.1 \\
\hline Авиационная и ракетно-космическая техника & 4.6 & 0.4 & 5.1 & 0.4 \\
\hline Аэронавигация и эксплуатация авиационной и ракетно-космической техники & 3.2 & 0.3 & 3.1 & 0.3 \\
\hline Техника и технологии кораблестроения и водного транспорта & 7.0 & 0.6 & 7.2 & 0.6 \\
\hline Управление в технических системах & 13.2 & 1.1 & 14.8 & 1.2 \\
\hline Нанотехнологии и наноматериалы & 0.9 & 0.1 & 1.1 & 0.1 \\
\hline Технологии легкой промышленности & 3.3 & 0.3 & 3.3 & 0.3 \\
\hline Фундаментальная медицина & 0.7 & 0.1 & 0.8 & 0.1 \\
\hline Клиническая медицина & 43.8 & 3.7 & 45.4 & 3.7 \\
\hline Науки о здоровье и профилактическая медицина & 1.9 & 0.2 & 1.9 & 0.2 \\
\hline Фармация & 5.2 & 0.4 & 5.0 & 0.4 \\
\hline Сестринское дело & 1.4 & 0.1 & 1.2 & 0.1 \\
\hline Сельское, лесное и рыбное хозяйство & 33.4 & 2.8 & 34.0 & 2.8 \\
\hline Ветеринария и зоотехния & 12.1 & 1.0 & 11.9 & 1.0 \\
\hline Психологические науки & 21.1 & 1.8 & 20.3 & 1.7 \\
\hline Экономика и управление & 323.9 & 27.2 & 300.5 & 24.6 \\
\hline Социология и социальная работа & 12.9 & 1.1 & 12.9 & 1.1 \\
\hline Юриспруденция & 134.3 & 11.3 & 150.3 & 12.3 \\
\hline Политические науки и регионоведение & 9.9 & 0.8 & 11.4 & 0.9 \\
\hline Средства массовой информации и информационно-библиотечное дело & 16.2 & 1.4 & 17.1 & 1.4 \\
\hline Сервис и туризм & 16.1 & 1.4 & 14.8 & 1.2 \\
\hline Образование и педагогические науки & 113.0 & 9.5 & 114.8 & 9.4 \\
\hline Языкознание и литературоведение & 21.4 & 1.8 & 24.0 & 2.0 \\
\hline История и археология & 6.7 & 0.6 & 7.3 & 0.6 \\
\hline Философия, этика и религиоведение & 1.5 & 0.1 & 1.7 & 0.1 \\
\hline
\end{tabular}


(окончание)

\begin{tabular}{|c|c|c|c|c|}
\hline & \multicolumn{2}{|c|}{2014} & \multicolumn{2}{|c|}{2015} \\
\hline & Тыс. чел. & Проценты & Тыс. чел. & Проценты \\
\hline Теология & 1.1 & 0.1 & 1.3 & 0.1 \\
\hline Физическая культура и спорт & 13.4 & 1.1 & 13.6 & 1.1 \\
\hline Искусствознание & 1.3 & 0.1 & 1.7 & 0.1 \\
\hline Культуроведение и социокультурные проекты & 8.2 & 0.7 & 8.4 & 0.7 \\
\hline Сценические искусства и литературное творчество & 3.3 & 0.3 & 3.9 & 0.3 \\
\hline Музыкальное искусство & 5.1 & 0.4 & 5.9 & 0.5 \\
\hline Изобразительное и прикладные виды искусств & 9.6 & 0.8 & 9.2 & 0.8 \\
\hline Экранные искусства & 1.3 & 0.1 & 1.4 & 0.1 \\
\hline
\end{tabular}

4.46. ВЫПУСК БАКАЛАВРОВ, СПЕЦИАЛИСТОВ, МАГИСТРОВ

(тысячи человек)

\begin{tabular}{|c|c|c|c|c|c|c|c|c|}
\hline & 2000 & 2005 & 2010 & 2011 & 2012 & 2013 & 2014 & 2015 \\
\hline Всего & 635.1 & 1151.7 & 1467.9 & 1442.9 & 1397.2 & 1291.0 & 1226.2 & 1300.5 \\
\hline Государственные и муниципальные организации & 578.9 & 978.4 & 1177.8 & 1157.3 & 1125.4 & 1060.0 & 1017.7 & 1109.9 \\
\hline Частные организации & 56.2 & 173.3 & 290.1 & 285.6 & 271.9 & 231.0 & 208.4 & 190.5 \\
\hline \multicolumn{9}{|l|}{ Из общей численности - по формам обучения: } \\
\hline очная & 375.3 & 570.5 & 689.8 & 654.2 & 617.4 & 568.5 & 527.2 & 698.2 \\
\hline очно-заочная & 39.8 & 59.9 & 68.0 & 65.8 & 61.2 & 53.1 & 48.4 & 38.5 \\
\hline заочная & 220.0 & 521.3 & 710.0 & 722.8 & 718.8 & 669.3 & 650.6 & 563.8 \\
\hline
\end{tabular}




\section{4}

4.47. СТРУКТУРА ВЫПУСКА ПО УРОВНЮ ПОЛУЧЕННЫХ ДИПЛОМОВ

2000 (11.2

Получили диплом:

$\square$ бакалавра $\quad \square$ магистра
$\therefore$ специалиста $\quad \square$ онеполном высшем

профессиональном образовании




\subsection{8. ПОДГОТОВКА НАУЧНО-ПЕДАГОГИЧЕСКИХ КАДРОВ В АСПИРАНТУРЕ}

(человек)

\begin{tabular}{|c|c|c|c|c|c|c|}
\hline & $\begin{array}{c}\text { Численность } \\
\text { аспирантов, } \\
\text { на конец года }\end{array}$ & $\begin{array}{c}\text { В том числе } \\
\text { численность } \\
\text { аспирантов } \\
\text { иностранных } \\
\text { государств }\end{array}$ & $\begin{array}{c}\text { Прием } \\
\text { в аспирантуру }\end{array}$ & \begin{tabular}{|c|} 
В том числе \\
лица, окончившие \\
образовательные \\
организации выс- \\
шего образования \\
в отчетном году
\end{tabular} & $\begin{array}{c}\text { Выпуск } \\
\text { из аспирантуры }\end{array}$ & $\begin{array}{l}\text { В том числе } \\
\text { с защитой } \\
\text { диссертации }\end{array}$ \\
\hline 2000 & 117714 & $\ldots$ & 43100 & 26926 & 24828 & 7503 \\
\hline 2005 & 142899 & $\ldots$ & 46896 & 31211 & 33561 & 10650 \\
\hline 2010 & 157437 & 3471 & 54558 & 37528 & 33763 & 9611 \\
\hline 2011 & 156279 & 4035 & 50582 & 34326 & 33082 & 9635 \\
\hline 2012 & 146754 & 4423 & 45556 & 28411 & 35162 & 9195 \\
\hline 2013 & 132002 & 4831 & 38971 & 27736 & 34733 & 8979 \\
\hline 2014 & 119868 & 5497 & 32981 & 21720 & 28273 & 5189 \\
\hline \multicolumn{7}{|l|}{ 2015: } \\
\hline всего & 109936 & 6081 & 31647 & 20585 & 25826 & 4651 \\
\hline научно-исследовательские организации & 11528 & 149 & 3189 & 2005 & 2728 & 313 \\
\hline образовательные организации высшего образования & 97847 & 5923 & 28285 & 18572 & 22971 & 4318 \\
\hline $\begin{array}{l}\text { образовательные организации дополнительного } \\
\text { профессионального образования }\end{array}$ & 561 & 9 & 173 & 8 & 127 & 20 \\
\hline
\end{tabular}




\section{6}

4.49. ЧИСЛЕННОСТЬ АСПИРАНТОВ ПО ПОЛУ И ВОЗРАСТУ

(на конец года; человек)

\begin{tabular}{|c|c|c|c|c|c|c|c|c|c|c|c|c|}
\hline & \multirow[t]{2}{*}{ Всего } & \multicolumn{11}{|c|}{ Возраст, лет } \\
\hline & & $\begin{array}{c}22 \\
\text { и младше }\end{array}$ & 23 & 24 & 25 & 26 & 27 & 28 & 29 & $30-34$ & $35-39$ & $\begin{array}{c}40 \\
\text { и старше }\end{array}$ \\
\hline \multicolumn{13}{|c|}{2007} \\
\hline Всего & 147719 & 19713 & 29092 & 30021 & 20115 & 12172 & 7570 & 4950 & 4046 & 9300 & 5037 & 5703 \\
\hline Мужчины & 84399 & 12920 & 19094 & 19510 & 12125 & 6528 & 3338 & 1963 & 1595 & 3236 & 1844 & 2246 \\
\hline Женщины & 63320 & 6793 & 9998 & 10511 & 7990 & 5644 & 4232 & 2987 & 2451 & 6064 & 3193 & 3457 \\
\hline \multicolumn{13}{|c|}{2015} \\
\hline Всего & 109936 & 4815 & 13423 & 18420 & 17178 & 12838 & 8675 & 5920 & 4772 & 11457 & 6001 & 6437 \\
\hline Мужчины & 57372 & 2796 & 8050 & 10853 & 9642 & 6860 & 4101 & 2619 & 2120 & 4904 & 2608 & 2819 \\
\hline Женщины & 52564 & 2019 & 5373 & 7567 & 7536 & 5978 & 4574 & 3301 & 2652 & 6553 & 3393 & 3618 \\
\hline
\end{tabular}




\subsection{0. ВЫПУСК ИЗ АСПИРАНТУРЫ ПО ОТРАСЛЯМ НАУК}

(человек)

\begin{tabular}{|c|c|c|c|c|c|c|c|c|c|}
\hline & \multirow[t]{2}{*}{2000} & \multirow[t]{2}{*}{2005} & \multirow[t]{2}{*}{2010} & \multirow[t]{2}{*}{2011} & \multirow[t]{2}{*}{2012} & \multirow[t]{2}{*}{2013} & \multirow[t]{2}{*}{2014} & \multicolumn{2}{|c|}{2015} \\
\hline & & & & & & & & Всего & $\begin{array}{c}\text { В том числе } \\
\text { с защитой } \\
\text { диссертации }\end{array}$ \\
\hline Всего & 24828 & 33561 & 33763 & 33082 & 35162 & 34733 & 28273 & 25826 & 4651 \\
\hline \multicolumn{10}{|l|}{ Отрасли наук: } \\
\hline физико-математические & 1933 & 1843 & 1771 & 1910 & 2106 & 2069 & 1669 & 1230 & 272 \\
\hline химические & 725 & 823 & 878 & 806 & 935 & 919 & 694 & 497 & 146 \\
\hline биологические & 1354 & 1616 & 1680 & 1750 & 1763 & 1740 & 1371 & 1235 & 232 \\
\hline технические & 6279 & 7480 & 7761 & 7547 & 8491 & 8738 & 7282 & 6723 & 1093 \\
\hline сельскохозяйственные & 1047 & 1212 & 1078 & 1074 & 1188 & 1212 & 1024 & 1006 & 254 \\
\hline исторические и археология & 892 & 1219 & 1093 & 1003 & 1074 & 1072 & 932 & 855 & 127 \\
\hline филологические & 1320 & 1724 & 1573 & 1509 & 1516 & 1556 & 1323 & 1248 & 272 \\
\hline философские & 607 & 729 & 670 & 669 & 719 & 675 & 555 & 492 & 77 \\
\hline искусствоведение & 438 & 635 & 521 & 431 & 569 & 558 & 549 & 304 & 12 \\
\hline психологические & 483 & 694 & 770 & 735 & 854 & 718 & 621 & 544 & 69 \\
\hline экономические & 3807 & 6009 & 5887 & 5507 & 5800 & 5479 & 4040 & 3839 & 582 \\
\hline педагогические & 1414 & 2159 & 2179 & 2084 & 2202 & 2095 & 1800 & 1580 & 286 \\
\hline социологические & 391 & 634 & 548 & 633 & 634 & 571 & 460 & 423 & 68 \\
\hline юридические & 979 & 2222 & 2554 & 2494 & 2309 & 2270 & 1737 & 1461 & 205 \\
\hline политология & 199 & 360 & 466 & 497 & 456 & 458 & 393 & 392 & 48 \\
\hline медицинские & 1730 & 2707 & 2798 & 2865 & 2671 & 2883 & 2429 & 2611 & 722 \\
\hline науки о Земле & 971 & 1160 & 1159 & 1111 & 1422 & 1299 & 1103 & 1104 & 154 \\
\hline прочие & 259 & 335 & 377 & 457 & 453 & 421 & 291 & 282 & 32 \\
\hline
\end{tabular}


4.51. УДЕЛЬНЫЙ ВЕС ЛИЦ, ЗАЩИТИВШИХ ДИССЕРТАЦИИ В ПЕРИОД ПОДГОТОВКИ, В ОБЩЕМ ВЫПУСКЕ ИЗ АСПИРАНТУРЫ ПО ОТРАСЛЯМ НАУК: 2015

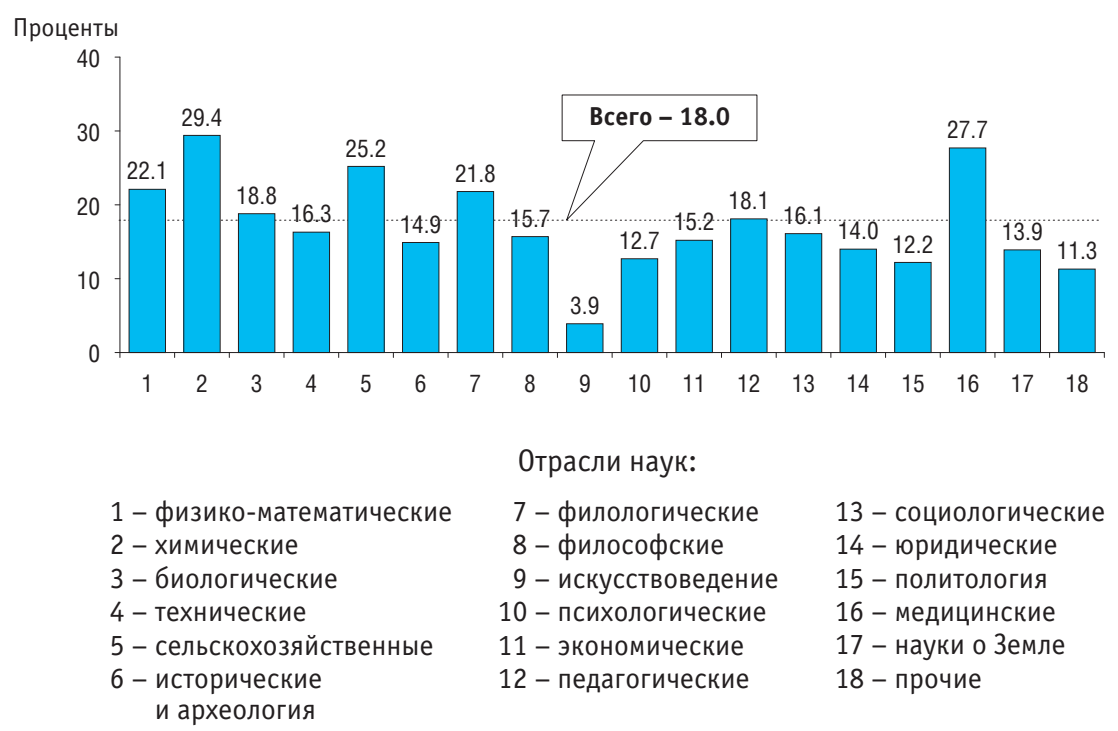




\section{МЕТОДОЛОГИЧЕСКИЕ КОММЕНТАРИИ}

Охват детей дошкольным образованием измеряется отношением численности детей, посещающих организации, осуществляющие образовательную деятельность по образовательным программам дошкольного образования, присмотр и уход за детьми, к численности детей в возрасте 1-6 лет, скорректированной на численность детей в возрасте 5-6 лет, обучающихся в общеобразовательных организациях.

Пропущено дней по болезни одним ребенком в год - отношение числа дней, пропущенных воспитанниками по болезни, к среднегодовой численности воспитанников.

Коэффициент посещаемости организаций, осуществляющих образовательную деятельность по образовательным программам дошкольного образования, присмотр и уход за детьми, исчисляется отношением среднего числа посещенных дней одним воспитанником к количеству рабочих дней в году, в процентах. При этом среднее число посещенных дней одним воспитанником определяется как отношение числа дней, проведенных в группах с детьми, к среднегодовой численности воспитанников.

Группы общеразвивающей направленности - группы, в которых осуществляется реализация образовательных программ дошкольного образования.

Группы компенсирующей направленности - группы, в которых осуществляется реализация адаптированной образовательной программы дошкольного образования для воспитанников с ограниченными возможностями здоровья с учетом их психофизического развития, индивидуальных возможностей, обеспечива- ющей коррекцию нарушений развития и социальную адаптацию воспитанников с ограниченными возможностями здоровья.

Группы оздоровительной направленности - группы, в которых осуществляется реализация образовательных программ дошкольного образования, а также комплекс санитарно-гигиенических, лечебно-оздоровительных и профилактических мероприятий и процедур. Создаются для воспитанников с туберкулезной интоксикацией, часто болеющих и других категорий детей, нуждающихся в длительном лечении и проведении для них необходимого комплекса специальных лечебно-оздоровительных мероприятий.

Группы комбинированной направленности - группы, в которых осуществляется совместное образование здоровых детей и детей с ограниченными возможностями здоровья в соответствии с образовательной программой дошкольного образования, адаптированной для воспитанников с ограниченными возможностями здоровья с учетом их психофизического развития, индивидуальных возможностей и обеспечивающей коррекцию нарушения развития и социальную адаптацию воспитанников с ограниченными возможностями здоровья.

Группы для детей раннего возраста - группы без реализации образовательной программы дошкольного образования, обеспечивающие развитие, присмотр, уход и оздоровление воспитанников в возрасте от 2 месяцев до 3 лет.

Группы по присмотру и уходу за детьми - группы без реализации образовательной программы дошкольного образования, 
в которых обеспечивается комплекс мер по организации питания и хозяйственно-бытового обслуживания детей, обеспечению соблюдения ими личной гигиены и режима дня.

Семейные дошкольные группы - группы, создаваемые с целью удовлетворения потребности населения в услугах дошкольного образования в семьях. Могут иметь общеразвивающую направленность или осуществлять присмотр и уход за детьми без реализации образовательной программы дошкольного образования.

Группы кратковременного пребывания детей - группы, функционирующие в режиме кратковременного, неполного (от трех до пяти часов в день), но систематического пребывания детей в организации, осуществляющей образовательную деятельность по образовательным программам дошкольного образования, присмотр и уход за детьми.

Численность детей и подростков, не обучающихся в образовательных организациях, - показатель численности лиц, подлежащих по возрасту обучению в общеобразовательных организациях, но не обучающихся в них и не получающих общего образования в иных образовательных организациях как по уважительным, так и по неуважительным причинам.

В общую численность студентов, обучающихся по образовательным программам среднего профессионального об- разования - программам подготовки специалистов среднего звена, программам высшего образования - программам бакалавриата, программам специалитета, программам магистратуры, а также в общую численность принятых на обучение и выпуск не включены иностранные граждане, лица без гражданства, обучающиеся в Российской Федерации по международным договорам.

Прием на обучение по программам среднего профессионального образования, высшего образования - программам бакалавриата, программам специалитета, программам магистратуры - показатель численности лиц, принятых на обучение. Осуществляется в соответствии с утвержденными правилами. В численность принятых на обучение не включаются второгодники и лица, восстановленные на обучение.

Аспирантом является лицо, имеющее образование не ниже высшего (специалитет или магистратура), обучающееся в аспирантуре по программе подготовки научно-педагогических кадров.

Численность аспирантов приводится на конец года, включая граждан из стран СНГ и других зарубежных стран.

В настоящем разделе итоги за 2014 (кроме табл. 4.18) и 2015 гг. приведены с учетом данных по Республике Крым и г. Севастополю. 


\section{5. Персонал образовательных организаций}




\section{1. СРЕДНЕГОДОВАЯ ЧИСЛЕННОСТЬ ЗАНЯТЫХ ПО ВИДАМ ЭКОНОМИЧЕСКОЙ ДЕЯТЕЛЬНОСТИ *} (тысячи человек)

\begin{tabular}{|c|c|c|c|c|c|c|c|c|}
\hline & 2000 & 2005 & 2010 & 2011 & 2012 & 2013 & 2014 & 2015 \\
\hline Занято в экономике & 64517 & 66683 & 67493 & 67644 & 67968 & 67901 & 67813 & 68389 \\
\hline Сельское хозяйство, охота и лесное хозяйство & 8996 & 7489 & 6622 & 6565 & 6467 & 6364 & 6247 & 6297 \\
\hline Рыболовство, рыбоводство & 138 & 138 & 138 & 144 & 142 & 139 & 139 & 146 \\
\hline Добыча полезных ископаемых & 1110 & 1122 & 1054 & 1062 & 1080 & 1075 & 1064 & 1082 \\
\hline Обрабатывающие производства & 12297 & 11631 & 10260 & 10272 & 10170 & 10065 & 9872 & 9840 \\
\hline \multicolumn{8}{|l|}{ Производство и распределение электроэнергии, } & 1923 \\
\hline Строительство & 4325 & 4986 & 5399 & 5479 & 5642 & 5712 & 5664 & 5652 \\
\hline \multicolumn{9}{|l|}{$\begin{array}{l}\text { Оптовая и розничная торговля; ремонт автотранспорт- } \\
\text { ных средств, мотоциклов, бытовых изделий и предме- }\end{array}$} \\
\hline тов личного пользования & 8806 & 11038 & 12073 & 12143 & 12292 & 12408 & 12695 & 12890 \\
\hline Гостиницы и рестораны & 948 & 1017 & 1181 & 1218 & 1250 & 1267 & 1272 & 1338 \\
\hline Транспорт и связь & 5056 & 5262 & 5336 & 5353 & 5430 & 5420 & 5409 & 5501 \\
\hline Финансовая деятельность & 657 & 865 & 1121 & 1182 & 1223 & 1309 & 1312 & 1278 \\
\hline $\begin{array}{l}\text { Операции с недвижимым имуществом, аренда } \\
\text { и предоставление услуг }\end{array}$ & 4490 & 4980 & 5374 & 5504 & 5709 & 5815 & 5889 & 6002 \\
\hline $\begin{array}{l}\text { Государственное управление и обеспечение военной } \\
\text { безопасности; социальное страхование }\end{array}$ & 3098 & 3367 & 3901 & 3801 & 3734 & 3711 & 3732 & 3730 \\
\hline Образование & 5979 & 6048 & 5897 & 5785 & 5697 & 5570 & 5520 & 5541 \\
\hline Здравоохранение и предоставление социальных услуг & 4408 & 4433 & 4617 & 4603 & 4573 & 4523 & 4496 & 4529 \\
\hline $\begin{array}{l}\text { Предоставление прочих коммунальных, социальных } \\
\text { и персональных услуг }\end{array}$ & 2313 & 2359 & 2524 & 2526 & 2547 & 2520 & 2513 & 2560 \\
\hline
\end{tabular}

* Данные за 2005, 2010-2015 гг. приведены по основному виду экономической деятельности. 


\section{2. УДЕЛЬНЫЙ ВЕС ЗАНЯТЫХ В ОБРАЗОВАНИИ В ОБЩЕЙ ЧИСЛЕННОСТИ ЗАНЯТЫХ В ЭКОНОМИКЕ*}

Проценты

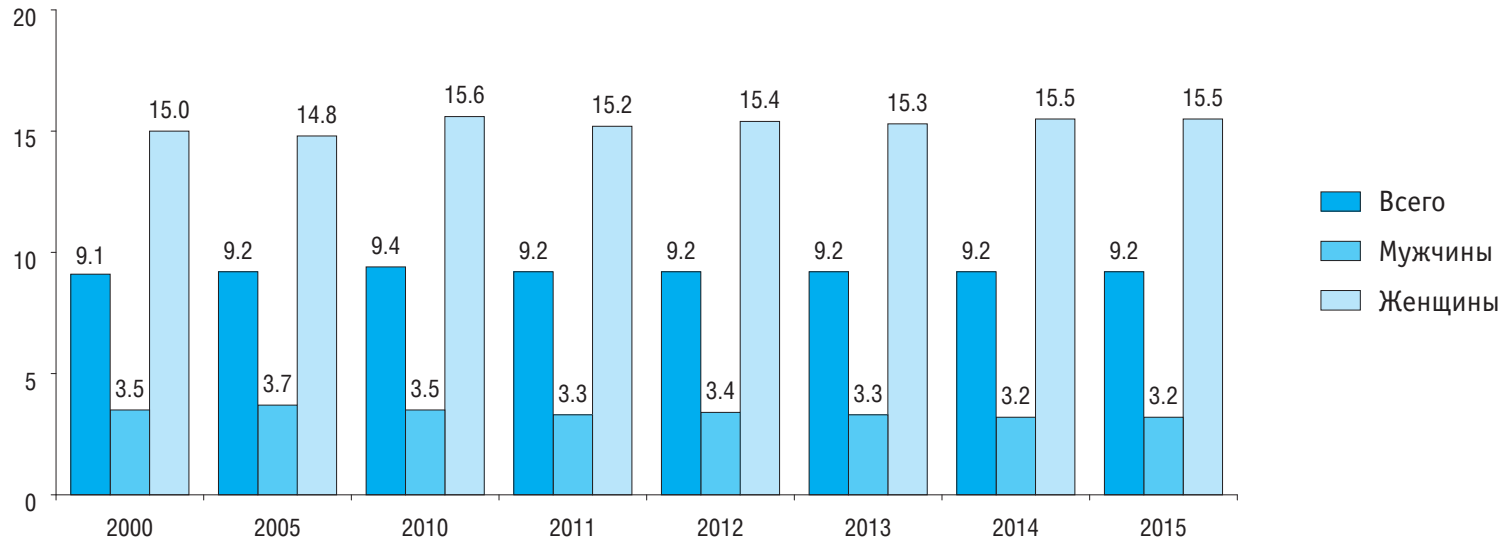

* Здесь и далее (рис. 5.3-5.5) - по материалам выборочных обследований рабочей силы. 
5.3. УДЕЛЬНЫЙ ВЕС ЖЕНЩИН В ОБЩЕЙ ЧИСЛЕННОСТИ ЗАНЯТЫХ В ЭКОНОМИКЕ И В ОБРАЗОВАНИИ

Проценть

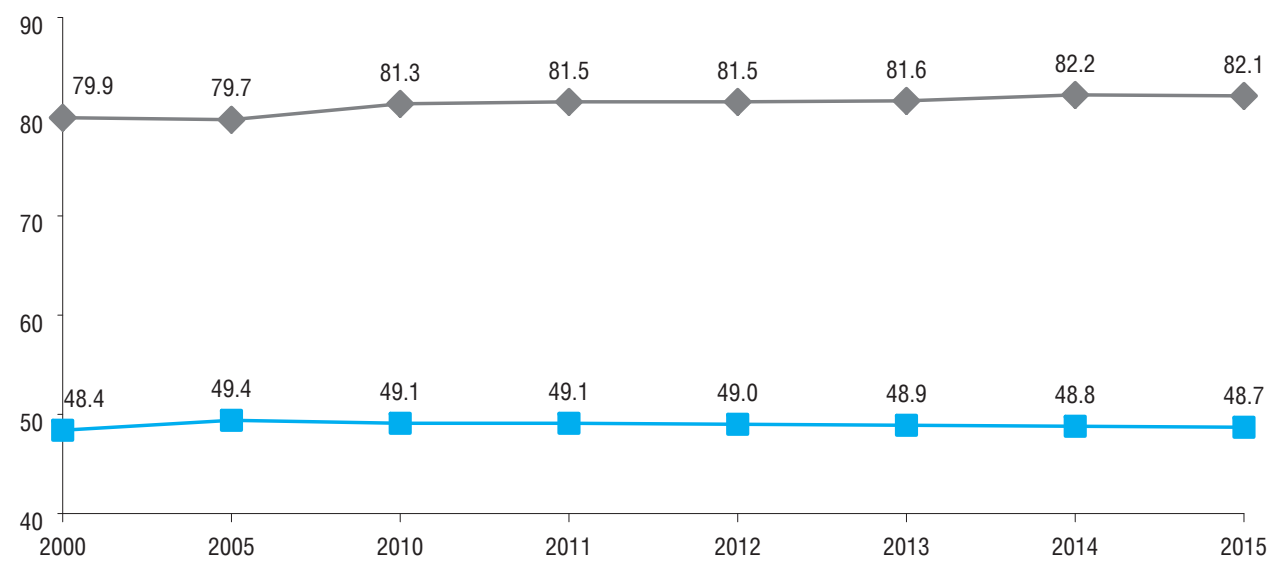




\section{4. РАСПРЕДЕЛЕНИЕ ЗАНЯТЫХ В ЭКОНОМИКЕ И В ОБРАЗОВАНИИ}

ПО УРОВНЮ ОБРАЗОВАНИЯ: 2015

Проценты

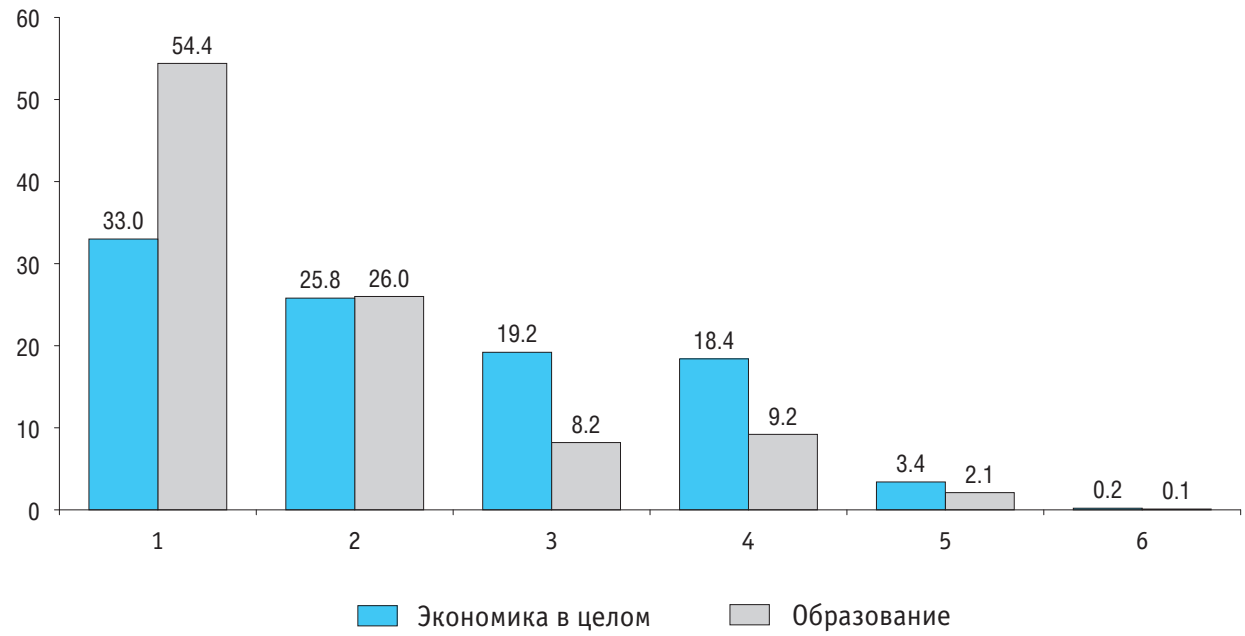

Уровень образования:

1 - высшее

2 - среднее профессиональное по программам подготовки специалистов среднего звена

3 - среднее профессиональное по программам подготовки квалифицированных рабочих, служащих

4 - среднее общее

5 - основное общее

6 - не имеют основного общего образования 
5.5. СРЕДНИЙ ВОЗРАСТ ЗАНЯТЫХ В ЭКОНОМИКЕ И В ОБРАЗОВАНИИ

Возраст, лет

43

42

41

40

39

38
41.2

39.2
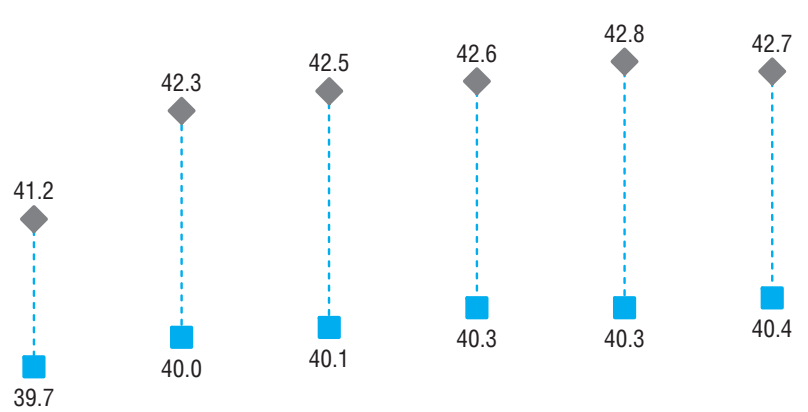

43.0

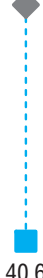

- - Экономика в целом

$\multimap$ Образование

\section{5}

2011

\section{2}

2013

2014

2015 


\section{6. СРЕДНЕГОДОВАЯ ЧИСЛЕННОСТЬ РАБОТНИКОВ ОБРАЗОВАНИЯ}

(тысячи человек)

\begin{tabular}{|c|c|c|c|c|c|c|c|}
\hline & 2005 & 2010 & 2011 & 2012 & 2013 & 2014 & 2015 \\
\hline Bcero & 5834 & 5523 & 5364 & 5268 & 5168 & 5098 & 5102 \\
\hline Дошкольное и начальное общее образование & 1737 & 1840 & 1828 & 1847 & 1840 & 1818 & 1840 \\
\hline Дошкольное образование & $\ldots$ & 1427 & 1421 & 1441 & 1434 & 1408 & 1424 \\
\hline Начальное общее образование & $\ldots$ & 53 & 50 & 47 & 47 & 51 & 49 \\
\hline Дополнительное образование детей & $\ldots$ & 360 & 357 & 359 & 359 & 359 & 368 \\
\hline \multicolumn{8}{|l|}{ Основное общее, среднее (полное) общее, начальное } \\
\hline и среднее профессиональное образование & 3186 & 2728 & 2607 & 2514 & 2461 & 2449 & 2466 \\
\hline Основное общее и среднее (полное) общее образование & $\ldots$ & 2196 & 2102 & 2035 & 2005 & 2017 & 2043 \\
\hline Основное общее образование & $\ldots$ & 339 & 322 & 300 & 289 & 280 & 288 \\
\hline Среднее (полное) общее образование & $\ldots$ & 1857 & 1780 & 1735 & 1717 & 1727 & 1755 \\
\hline Начальное и среднее профессиональное образование & $\ldots$ & 532 & 505 & 479 & 455 & 433 & 422 \\
\hline Начальное профессиональное образование & $\ldots$ & 187 & 167 & 141 & 116 & 82 & 51 \\
\hline Среднее профессиональное образование & $\ldots$ & 345 & 338 & 338 & 339 & 351 & 371 \\
\hline Образование для взрослых и прочие виды образования & 54 & 53 & 53 & 53 & 61 & 62 & 68 \\
\hline
\end{tabular}




\section{7. ЧИСЛЕННОСТЬ РАБОТНИКОВ ОРГАНИЗАЦИЙ, ОСУЩЕСТВЛЯЮЩИХ ОБРАЗОВАТЕЛЬНУЮ ДЕЯТЕЛЬНОСТЬ ПО ОБРАЗОВАТЕЛЬНЫМ ПРОГРАММАМ ДОШКОЛЬНОГО ОБРАЗОВАНИЯ, ПРИСМОТР И УХОД ЗА ДЕТЬМИ, ПО КАТЕГОРИЯМ *}

(без внешних совместителей и работавших по договорам гражданско-правового характера; на конец года; тысячи человек)

\begin{tabular}{|c|c|c|c|c|c|c|c|}
\hline & 2008 & 2010 & 2011 & 2012 & 2013 & 2014 & 2015 \\
\hline Всего & 1439.0 & 1477.5 & 1493.5 & 1513.6 & 1534.5 & 1499.7 & 1517.9 \\
\hline Административный персонал & 75.6 & 77.4 & 78.8 & 78.7 & 78.6 & 76.6 & 74.9 \\
\hline Педагогический персонал & 587.4 & 605.1 & 612.5 & 626.6 & 652.2 & 630.3 & 642.8 \\
\hline Младшие воспитатели & 163.8 & 174.5 & 177.7 & 181.4 & 181.6 & 180.1 & 184.7 \\
\hline Помощники воспитателей & 108.3 & 116.6 & 119.7 & 122.4 & 127.7 & 123.9 & 127.5 \\
\hline Медицинский персонал & 44.9 & 37.8 & 36.5 & 34.5 & 26.2 & 20.2 & 17.0 \\
\hline Обслуживающий персонал & 458.8 & 466.1 & 468.2 & 470.0 & 468.3 & 468.8 & 470.9 \\
\hline
\end{tabular}

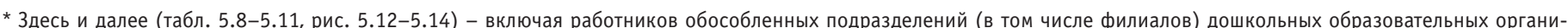

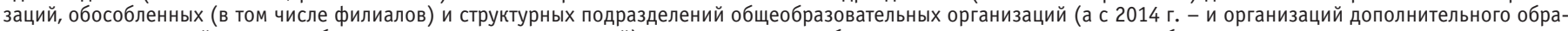

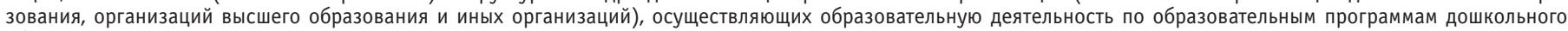
образования, присмотр и уход за детьми. 
5.8. ЧИСЛЕННОСТЬ ПЕДАГОГИЧЕСКИХ РАБОТНИКОВ ОРГАНИЗАЦИЙ, ОСУЩЕСТВЛЯЮЩИХ ОБРАЗОВАТЕЛЬНУЮ ДЕЯТЕЛЬНОСТЬ ПО ОБРАЗОВАТЕЛЬНЫМ ПРОГРАММАМ ДОШКОЛЬНОГО ОБРАЗОВАНИЯ, ПРИСМОТР И УХОД ЗА ДЕТЬМИ, ПО ДОЛЖНОСТЯМ

(на конец года; тысячи человек)

\begin{tabular}{|c|c|c|c|c|c|c|c|c|c|c|c|c|}
\hline & \multicolumn{6}{|c|}{$\begin{array}{c}\text { Численность работников (без внешних совместителей } \\
\text { и работавших по договорам гражданско-правового характера) }\end{array}$} & \multicolumn{6}{|c|}{ Численность внешних совместителей } \\
\hline & 2010 & 2011 & 2012 & 2013 & 2014 & 2015 & 2010 & 2011 & 2012 & 2013 & 2014 & 2015 \\
\hline Bcero & 605.1 & 612.5 & 626.6 & 652.2 & 630.3 & 642.8 & 21.2 & 21.8 & 21.9 & 21.1 & 19.2 & 18.4 \\
\hline \multicolumn{13}{|l|}{ Из них: } \\
\hline старшие воспитатели & 17.9 & 18.1 & 18.5 & 19.7 & 19.8 & 21.2 & 0.6 & 0.6 & 0.6 & 0.6 & 0.5 & 0.5 \\
\hline воспитатели & 467.3 & 475.2 & 487.1 & 507.1 & 491.1 & 500.2 & 2.6 & 2.8 & 3.0 & 2.8 & 2.4 & 2.2 \\
\hline музыкальные руководители & 43.2 & 42.9 & 43.1 & 44.4 & 43.3 & 44.0 & 8.3 & 8.6 & 9.1 & 8.6 & 8.1 & 7.8 \\
\hline инструкторы по физической культуре & 19.3 & 19.2 & 19.6 & 21.0 & 20.3 & 20.8 & 1.6 & 1.7 & 1.9 & 1.9 & 1.8 & 1.8 \\
\hline учителя-логопеды & 27.9 & 28.0 & 28.5 & 29.5 & 27.4 & 28.2 & 2.8 & 2.9 & 3.0 & 2.8 & 2.6 & 2.5 \\
\hline учителя-дефектологи & 4.9 & 4.9 & 4.9 & 4.9 & 4.5 & 4.5 & 0.3 & 0.2 & 0.3 & 0.2 & 0.2 & 0.2 \\
\hline педагоги-психологи & 14.9 & 14.8 & 14.8 & 15.3 & 14.4 & 14.7 & 1.7 & 1.7 & 1.8 & 1.8 & 1.6 & 1.5 \\
\hline социальные педагоги & 1.6 & 1.5 & 1.4 & 1.4 & 1.2 & 1.1 & 0.1 & 0.1 & 0.1 & 0.1 & 0.1 & 0.1 \\
\hline педагоги-организаторы & 0.4 & 0.3 & 0.3 & 0.3 & 0.2 & 0.2 & 0.2 & 0.2 & 0.1 & 0.1 & 0.0 & 0.0 \\
\hline педагоги дополнительного образования & 7.5 & 7.4 & 6.7 & 6.6 & 6.1 & 5.4 & 1.7 & 1.9 & 1.8 & 1.7 & 1.6 & 1.5 \\
\hline
\end{tabular}




\section{9. ЧИСЛЕННОСТЬ ЖЕНЩИН В СОСТАВЕ ПЕДАГОГИЧЕСКИХ РАБОТНИКОВ ОРГАНИЗАЦИЙ, ОСУЩЕСТВЛЯЮЩИХ ОБРАЗОВАТЕЛЬНУЮ ДЕЯТЕЛЬНОСТЬ ПО ОБРАЗОВАТЕЛЬНЫМ ПРОГРАММАМ ДОШКОЛЬНОГО ОБРАЗОВАНИЯ, \\ ПРИСМОТР И УХОД ЗА ДЕТЬМИ, ПО ДОЛЖНОСТЯМ}

(без внешних совместителей и работавших по договорам гражданско-правового характера; на конец года)

\begin{tabular}{|c|c|c|c|c|c|c|c|c|c|c|c|c|}
\hline & \multicolumn{6}{|c|}{ Всего, тыс. чел. } & \multicolumn{6}{|c|}{ В процентах от общей численности } \\
\hline & 2010 & 2011 & 2012 & 2013 & 2014 & 2015 & 2010 & 2011 & 2012 & 2013 & 2014 & 2015 \\
\hline Bcero & 602.5 & 609.8 & 623.2 & 648.2 & 626.8 & 638.7 & 99.6 & 99.5 & 99.5 & 99.4 & 99.5 & 99.3 \\
\hline \multicolumn{13}{|l|}{ Из них: } \\
\hline старшие воспитатели & 17.7 & 18.0 & 18.5 & 19.6 & 19.7 & 21.2 & 99.2 & 98.9 & 99.6 & 99.5 & 99.6 & 99.6 \\
\hline воспитатели & 465.5 & 472.9 & 486.1 & 505.8 & 490.2 & 498.9 & 99.6 & 99.5 & 99.8 & 99.8 & 99.8 & 99.7 \\
\hline музыкальные руководители & 41.8 & 41.5 & 42.0 & 43.3 & 42.2 & 43.0 & 96.8 & 96.7 & 97.4 & 97.5 & 97.6 & 97.6 \\
\hline инструкторы по физической культуре & 18.6 & 18.5 & 18.9 & 20.1 & 19.4 & 19.7 & 96.5 & 96.2 & 96.6 & 95.9 & 95.7 & 94.8 \\
\hline учителя-логопеды & 27.7 & 27.7 & 28.4 & 29.3 & 27.3 & 28.1 & 99.3 & 99.0 & 99.6 & 99.4 & 99.6 & 99.5 \\
\hline учителя-дефектологи & 4.8 & 4.9 & 4.9 & 4.9 & 4.4 & 4.5 & 99.5 & 99.5 & 99.7 & 99.7 & 99.6 & 99.8 \\
\hline педагоги-психологи & 14.7 & 14.5 & 14.6 & 15.1 & 14.3 & 14.6 & 98.4 & 98.1 & 99.0 & 98.8 & 99.1 & 99.0 \\
\hline социальные педагоги & 1.6 & 1.4 & 1.4 & 1.4 & 1.2 & 1.1 & 98.1 & 98.3 & 98.2 & 97.7 & 98.4 & 97.4 \\
\hline педагоги-организаторы & 0.4 & 0.3 & 0.3 & 0.3 & 0.2 & 0.2 & 94.9 & 94.5 & 96.8 & 96.5 & 96.5 & 95.8 \\
\hline педагоги дополнительного образования & 7.3 & 7.1 & 6.5 & 6.5 & 5.9 & 5.2 & 97.1 & 96.6 & 97.2 & 97.3 & 96.8 & 96.4 \\
\hline
\end{tabular}


5.10. УРОВЕНЬ ОБРАЗОВАНИЯ ПЕДАГОГИЧЕСКИХ РАБОТНИКОВ ОРГАНИЗАЦИЙ, ОСУЩЕСТВЛЯЮЩИХ ОБРАЗОВАТЕЛЬНУЮ ДЕЯТЕЛЬНОСТЬ ПО ОБРАЗОВАТЕЛЬНЫМ ПРОГРАММАМ ДОШКОЛЬНОГО ОБРАЗОВАНИЯ,

ПРИСМОТР И УХОД ЗА ДЕТЬМИ

(без внешних совместителей и работавших по договорам гражданско-правового характера;

на конец года; проценты)

\begin{tabular}{|c|c|c|c|c|c|c|c|}
\hline & 2008 & 2010 & 2011 & 2012 & 2013 & 2014 & 2015 \\
\hline Всего & 100 & 100 & 100 & 100 & 100 & 100 & 100 \\
\hline \multicolumn{8}{|l|}{ Имеют образование: } \\
\hline высшее & 37.5 & 41.5 & 43.7 & 45.3 & 47.5 & 48.7 & 50.7 \\
\hline из них педагогическое & 35.2 & 38.9 & 40.9 & 42.3 & 44.3 & 45.5 & 47.7 \\
\hline \multicolumn{8}{|l|}{ среднее профессиональное по программам } \\
\hline подготовки специалистов среднего звена & 57.5 & 53.9 & 54.2 & 52.8 & 50.6 & 49.5 & 47.7 \\
\hline из них педагогическое & 52.1 & 48.9 & 49.0 & 47.5 & 45.8 & 45.3 & 44.2 \\
\hline
\end{tabular}


5.11. УРОВЕНЬ ОБРАЗОВАНИЯ ПЕДАГОГИЧЕСКИХ РАБОТНИКОВ ОРГАНИЗАЦИЙ, ОСУЩЕСТВЛЯЮЩИХ ОБРАЗОВАТЕЛЬНУЮ ДЕЯТЕЛЬНОСТЬ ПО ОБРАЗОВАТЕЛЬНЫМ ПРОГРАММАМ ДОШКОЛЬНОГО ОБРАЗОВАНИЯ,

ПРИСМОТР И УХОД ЗА ДЕТЬМИ, ПО ДОЛЖНОСТЯМ: 2015

(без внешних совместителей и работавших по договорам гражданско-правового характера; на конец года; проценты)

\begin{tabular}{|c|c|c|c|c|c|}
\hline & \multirow[t]{2}{*}{ Bсего } & \multicolumn{4}{|c|}{ Имеют образование } \\
\hline & & высшее & $\begin{array}{c}\text { из них } \\
\text { педагогическое }\end{array}$ & $\begin{array}{c}\text { среднее } \\
\text { профессиональное } \\
\text { по программам } \\
\text { подготовки специалистов } \\
\text { среднего звена }\end{array}$ & $\begin{array}{c}\text { из них } \\
\text { педагогическое }\end{array}$ \\
\hline Всего & 100 & 50.7 & 47.7 & 47.7 & 44.2 \\
\hline \multicolumn{6}{|l|}{ Из них: } \\
\hline старшие воспитатели & 100 & 82.6 & 80.2 & 16.9 & 16.2 \\
\hline воспитатели & 100 & 44.7 & 41.8 & 53.5 & 49.7 \\
\hline музыкальные руководители & 100 & 44.6 & 40.5 & 54.3 & 48.4 \\
\hline инструкторы по физической культуре & 100 & 58.8 & 54.6 & 39.9 & 37.0 \\
\hline учителя-логопеды & 100 & 98.2 & 96.8 & 1.5 & 1.3 \\
\hline учителя-дефектологи & 100 & 98.6 & 97.9 & 1.2 & 1.1 \\
\hline педагоги-психологи & 100 & 96.9 & 93.5 & 2.7 & 2.3 \\
\hline социальные педагоги & 100 & 77.2 & 70.6 & 21.4 & 18.4 \\
\hline педагоги-организаторы & 100 & 64.1 & 57.3 & 32.8 & 22.9 \\
\hline педагоги дополнительного образования & 100 & 67.9 & 60.5 & 30.9 & 26.4 \\
\hline
\end{tabular}


5.12. СТРУКТУРА ЧИСЛЕННОСТИ ПЕДАГОГИЧЕСИХ РАБОТНИКОВ ОРГАНИЗАЦИЙ, ОСУЩЕСТВЛЯЮЩИХ ОБРАЗОВАТЕЛЬНУЮ ДЕЯТЕЛЬНОСТЬ ПО ОБРАЗОВАТЕЛЬНЫМ ПРОГРАММАМ ДОШКОЛЬНОГО ОБРАЗОВАНИЯ, ПРИСМОТР И УХОД ЗА ДЕТЬМИ,

ПО В0ЗРАСТНЫМ ГРУППАМ

(без внешних совместителей и работавщих по договорам гражданско-правового характера;

на конец года; число полных лет на 1 января)

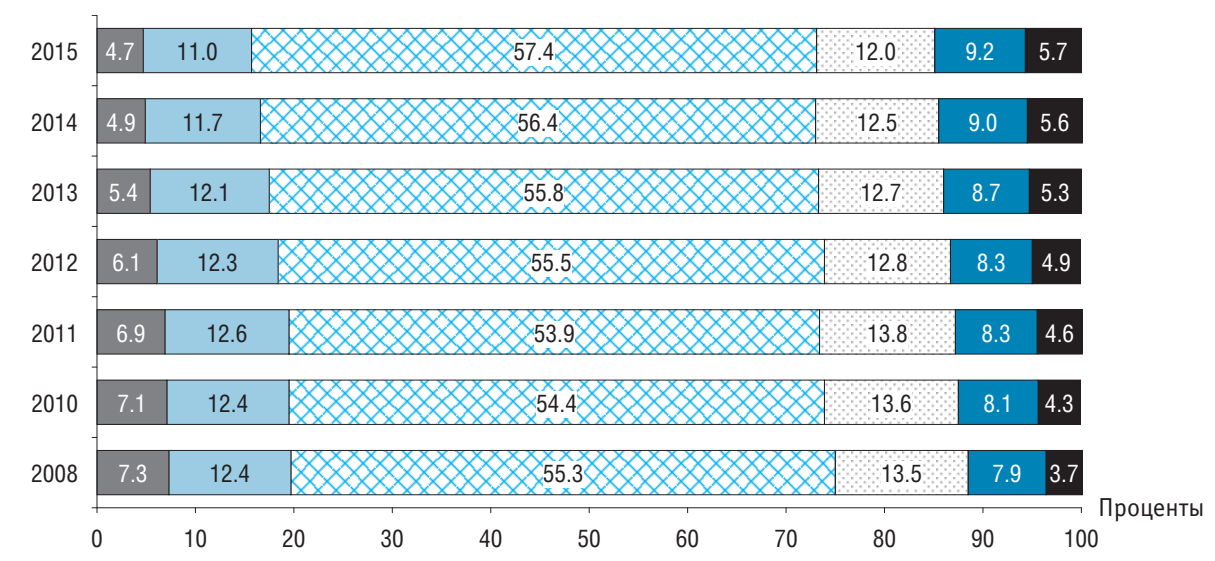

Возраст, лет:

$\begin{array}{lll}\square \text { до } 25 & \square 0-49 & 55-59 \\ \square & 35-29 & 60 \text { и старше }\end{array}$


5.13. СТРУКТУРА ПЕДАГОГИЧЕСКОГО ПЕРСОНАЛА ОРГАНИЗАЦИЙ, ОСУЩЕСТВЛЯЮЩИХ ОБРАЗОВАТЕЛЬНУЮ ДЕЯТЕЛЬНОСТЬ ПО ОБРАЗОВАТЕЛЬНЫМ ПРОГРАММАМ ДОШКОЛЬНОГО ОБРАЗОВАНИЯ, ПРИСМОТР И УХОД ЗА ДЕТЬМИ,

ПО ДОЛЖНОСТЯМ И В0ЗРАСТНЫМ ГРУППАМ: 2015

(без внешних совместителей и работавших по договорам гражданско-правового характера; на конец года; число полных лет на 1 января)

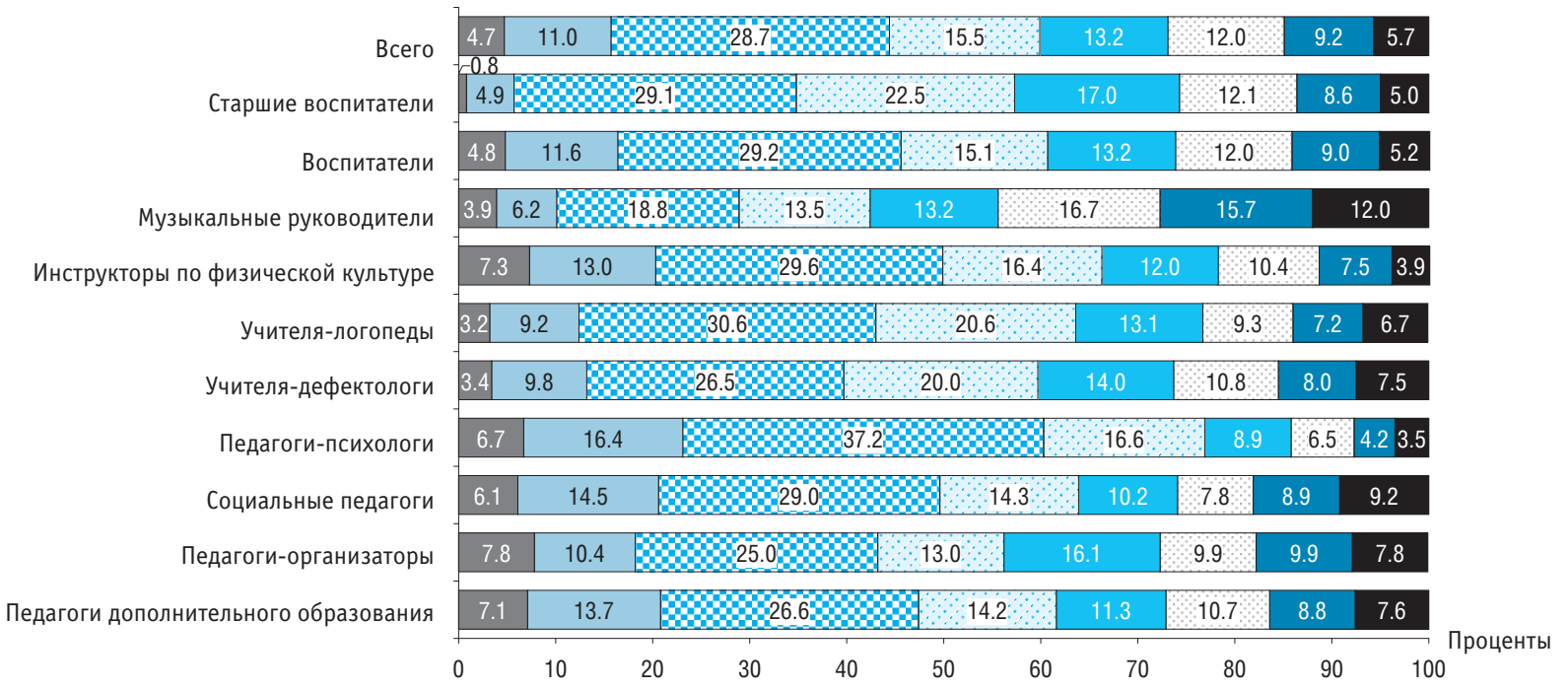

Возраст, лет:

\begin{tabular}{|c|c|c|c|}
\hline$\square$ до 25 & Bas $30-39$ & $\square \quad 45-49$ & $55-59$ \\
\hline $25-29$ & $\therefore 40-44$ & $50-54$ & 60 и старше \\
\hline
\end{tabular}


5.14. ЧИСЛЕННОСТЬ ВОСПИТАННИКОВ В ОРГАНИЗАЦИЯХ, ОСУЩЕСТВЛЯЮЩИХ ОБРАЗОВАТЕЛЬНУЮ ДЕЯТЕЛЬНОСТЬ ПО ОБРАЗОВАТЕЛЬНЫМ ПРОГРАММАМ ДОШКОЛЬНОГО ОБРАЗОВАНИЯ, ПРИСМОТР И УХОД ЗА ДЕТЬМИ,

В РАСЧЕТЕ НА ОДНОГО ВОСПИТАТЕЛЯ *

(на конец года)

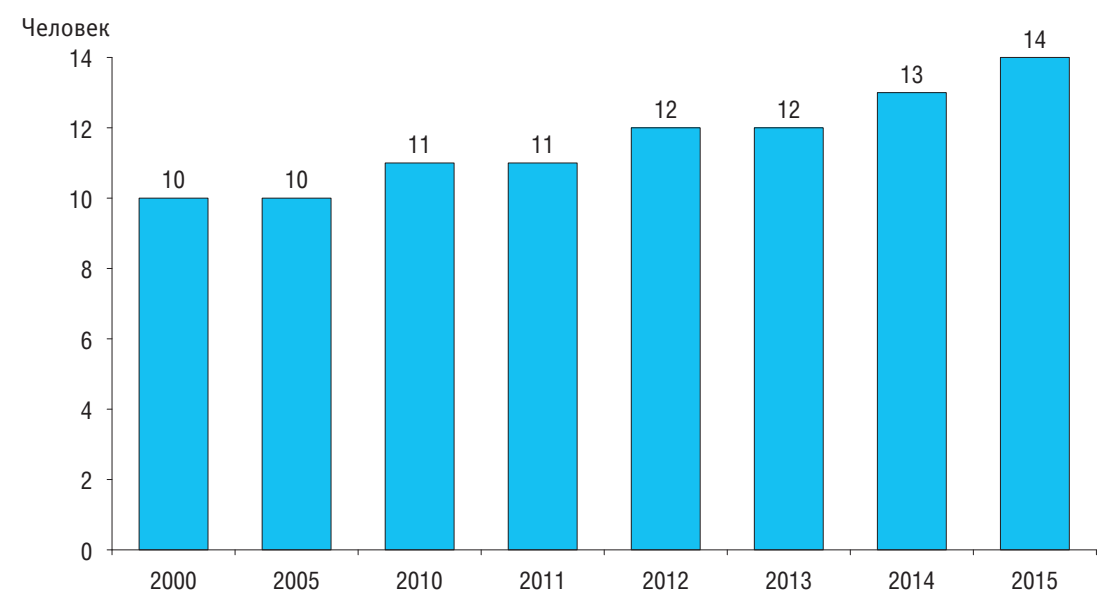

* Включая старших воспитателей. 
5.15. ЧИСЛЕННОСТЬ РАБОТНИКОВ ОБЩЕОБРАЗОВАТЕЛЬНЫХ ОРГАНИЗАЦИЙ ПО КАТЕГОРИЯМ* (на 20 сентября; тысячи человек)

\begin{tabular}{|c|c|c|c|c|c|c|c|c|c|c|}
\hline & \multicolumn{5}{|c|}{ Численность работников (без внешних совместителей) } & \multicolumn{5}{|c|}{ Численность внешних совместителей } \\
\hline & 2011 & 2012 & 2013 & 2014 & 2015 & 2011 & 2012 & 2013 & 2014 & 2015 \\
\hline \multicolumn{11}{|c|}{ Всего } \\
\hline Bcero & 2138.6 & 2130.3 & 2136.2 & 2215.8 & 2202.2 & 128.5 & 130.1 & 126.1 & 123.2 & 114.5 \\
\hline Руководящие работники & 188.6 & 184.0 & 178.5 & 175.2 & 165.9 & 2.0 & 2.0 & 2.0 & 2.0 & 1.9 \\
\hline Педагогические работники & 1248.2 & 1251.6 & 1265.5 & 1316.2 & 1321.0 & 84.5 & 85.0 & 80.0 & 76.5 & 70.7 \\
\hline Учебно-вспомогательный персонал & 105.4 & 110.1 & 113.4 & 128.0 & 130.2 & 7.0 & 7.3 & 7.6 & 8.0 & 7.4 \\
\hline Обслуживающий персонал & 596.5 & 584.6 & 578.9 & 596.4 & 585.0 & 35.0 & 35.8 & 36.4 & 36.7 & 34.5 \\
\hline \multicolumn{11}{|c|}{ 0бщеобразовательные организации (без вечерних (сменных) общеобразовательных организаций) } \\
\hline Всего & 2116.0 & 2109.4 & 2117.9 & 2199.9 & 2189.4 & 119.3 & 122.2 & 120.6 & 118.7 & 111.2 \\
\hline Руководящие работники & 185.4 & 180.9 & 175.8 & 172.9 & 164.1 & 1.9 & 1.9 & 1.9 & 1.9 & 1.8 \\
\hline Педагогические работники & 1234.9 & 1239.2 & 1254.6 & 1306.6 & 1313.1 & 76.3 & 78.0 & 75.4 & 72.7 & 67.8 \\
\hline Учебно-вспомогательный персонал & 104.2 & 109.0 & 112.5 & 127.1 & 129.6 & 6.8 & 7.1 & 7.5 & 7.9 & 7.4 \\
\hline Обслуживающий персонал & 591.5 & 580.2 & 575.1 & 593.2 & 582.6 & 34.3 & 35.2 & 35.8 & 36.2 & 34.2 \\
\hline \multicolumn{11}{|c|}{ Вечерние (сменные) общеобразовательные организации * * } \\
\hline Bcero & 22.6 & 20.9 & 18.4 & 15.9 & 12.8 & 9.2 & 7.9 & 5.4 & 4.4 & 3.3 \\
\hline Руководящие работники & 3.2 & 3.0 & 2.7 & 2.3 & 1.8 & 0.1 & 0.1 & 0.1 & 0.1 & 0.1 \\
\hline Педагогические работники & 13.3 & 12.4 & 10.9 & 9.6 & 7.9 & 8.2 & 6.9 & 4.6 & 3.8 & 2.8 \\
\hline Учебно-вспомогательный персонал & 1.1 & 1.1 & 0.9 & 0.8 & 0.7 & 0.2 & 0.2 & 0.1 & 0.1 & 0.1 \\
\hline Обслуживающий персонал & 4.9 & 4.4 & 3.8 & 3.2 & 2.4 & 0.7 & 0.7 & 0.6 & 0.5 & 0.3 \\
\hline
\end{tabular}

* Здесь и далее (табл. 5.16, 5.17, 5.19-5.24, 5.27, 5.29, 5.30, рис. 5.18, 5.25, 5.26, 5.28, 5.31) - включая работников обособленных подразделений (в том числе филиалов).

** На начало соответствующего учебного года. 


\subsection{6. ЧИСЛЕННОСТЬ РАБОТНИКОВ ОБЩЕОБРАЗОВАТЕЛЬНЫХ ОРГАНИЗАЦИЙ (БЕЗ ВЕЧЕРНИХ (СМЕННЫХ) ОБЩЕОБРАЗОВАТЕЛЬНЫХ ОРГАНИЗАЦИЙ) ПО КАТЕГОРИЯМ}

(на 20 сентября; тысячи человек)

\begin{tabular}{|c|c|c|c|c|c|c|c|c|c|c|c|c|}
\hline & \multicolumn{7}{|c|}{ Государственные и муниципальные организации* } & \multicolumn{5}{|c|}{ Частные организации } \\
\hline & 2009 & 2010 & 2011 & 2012 & 2013 & 2014 & 2015 & 2011 & 2012 & 2013 & 2014 & 2015 \\
\hline \multicolumn{13}{|c|}{ Численность работников (без внешних совместителей) } \\
\hline Всего & 2257.8 & 2159.5 & 2086.8 & 2079.1 & 2086.6 & 2166.9 & 2155.2 & 29.2 & 30.3 & 31.3 & 32.9 & 34.2 \\
\hline Руководящие работники & 193.5 & 188.2 & 182.1 & 177.5 & 172.3 & 169.3 & 160.4 & 3.3 & 3.4 & 3.5 & 3.6 & 3.8 \\
\hline Педагогические работники & 1286.4 & 1243.0 & 1217.1 & 1220.8 & 1235.5 & 1286.5 & 1292.4 & 17.8 & 18.4 & 19.1 & 20.2 & 20.7 \\
\hline Учебно-вспомогательный персонал & 108.4 & 105.8 & 102.8 & 107.5 & 110.9 & 125.5 & 127.7 & 1.5 & 1.6 & 1.6 & 1.7 & 1.8 \\
\hline Обслуживающий персонал & 669.6 & 622.4 & 584.8 & 573.3 & 567.9 & 585.7 & 574.7 & 6.7 & 6.9 & 7.2 & 7.5 & 7.9 \\
\hline \multicolumn{13}{|c|}{ Численность внешних совместителей } \\
\hline Bcero & 115.3 & 112.6 & 114.8 & 117.9 & 116.2 & 114.2 & 106.8 & 4.5 & 4.3 & 4.4 & 4.6 & 4.4 \\
\hline Руководящие работники & 1.6 & 1.8 & 1.7 & 1.8 & 1.7 & 1.7 & 1.6 & 0.2 & 0.2 & 0.2 & 0.2 & 0.2 \\
\hline Педагогические работники & 70.5 & 70.1 & 72.6 & 74.5 & 71.9 & 69.2 & 64.4 & 3.7 & 3.5 & 3.5 & 3.5 & 3.4 \\
\hline Учебно-вспомогательный персонал & 6.8 & 6.5 & 6.7 & 7.0 & 7.4 & 7.8 & 7.2 & 0.1 & 0.1 & 0.2 & 0.2 & 0.1 \\
\hline Обслуживающий персонал & 36.4 & 34.2 & 33.8 & 34.6 & 35.2 & 35.6 & 33.6 & 0.6 & 0.5 & 0.6 & 0.6 & 0.6 \\
\hline
\end{tabular}

* Данные за 2010 г. и ранее приведены по общеобразовательным организациям системы Минобрнауки России. 


\subsection{7. ЧИСЛЕННОСТЬ ПЕДАГОГИЧЕСКИХ РАБОТНИКОВ ОБЩЕОБРАЗОВАТЕЛЬНЫХ ОРГАНИЗАЦИЙ ПО ДОЛЖНОСТЯМ} (на 20 сентября; тысячи человек)

\begin{tabular}{|c|c|c|c|c|c|c|c|c|c|c|c|c|c|c|c|}
\hline & \multicolumn{5}{|c|}{ Всего } & \multicolumn{5}{|c|}{$\begin{array}{c}\text { Общеобразовательные организации } \\
\text { (без вечерних (сменных) } \\
\text { общеобразовательных организаций) }\end{array}$} & \multicolumn{5}{|c|}{$\begin{array}{c}\text { Вечерние (сменные) } \\
\text { общеобразовательные организации * }\end{array}$} \\
\hline & 2011 & 2012 & 2013 & 2014 & 2015 & 2011 & 2012 & 2013 & 2014 & 2015 & 2011 & 2012 & 2013 & 2014 & 2015 \\
\hline \multicolumn{16}{|c|}{ Численность работников (без внешних совместителей) } \\
\hline Всего & 1248.2 & 1251.6 & 1265.5 & 1316.2 & 1321.0 & 1234.9 & 1239.2 & 1254.6 & 1306.6 & 1313.1 & 13.3 & 12.4 & 10.9 & 9.6 & 7.9 \\
\hline Учителя & 1060.4 & 1054.8 & 1056.2 & 1076.2 & 1077.3 & 1048.2 & 1043.5 & 1046.2 & 1067.4 & 1070.0 & 12.1 & 11.3 & 10.0 & 8.8 & 7.2 \\
\hline Учителя-логопеды & 10.6 & 10.6 & 11.1 & 13.1 & 13.4 & 10.6 & 10.6 & 11.1 & 13.1 & 13.4 & 0.0 & 0.0 & 0.0 & 0.0 & 0.0 \\
\hline Мастера производственного обучения & 3.0 & 2.6 & 2.2 & 2.1 & 1.6 & 2.8 & 2.5 & 2.2 & 2.0 & 1.6 & 0.1 & 0.1 & 0.1 & 0.1 & 0.1 \\
\hline Педагоги-психологи & 20.4 & 20.4 & 20.9 & 22.6 & 23.0 & 20.2 & 20.1 & 20.7 & 22.4 & 22.9 & 0.3 & 0.2 & 0.2 & 0.2 & 0.1 \\
\hline Социальные педагоги & 17.9 & 17.5 & 17.7 & 17.9 & 17.6 & 17.5 & 17.2 & 17.5 & 17.7 & 17.4 & 0.4 & 0.3 & 0.3 & 0.2 & 0.2 \\
\hline Воспитатели & 86.6 & 91.3 & 98.5 & 115.4 & 114.2 & 86.6 & 91.3 & 98.5 & 115.4 & 114.2 & 0.0 & 0.0 & 0.0 & 0.0 & 0.0 \\
\hline Тьюторы & 0.3 & 0.4 & 0.6 & 1.0 & 1.4 & 0.3 & 0.4 & 0.6 & 1.0 & 1.4 & - & 0.0 & 0.0 & 0.0 & 0.0 \\
\hline Другие педагогические работники & 49.0 & 54.0 & 58.2 & 67.9 & 72.5 & 48.6 & 53.6 & 57.9 & 67.6 & 72.2 & 0.4 & 0.3 & 0.3 & 0.3 & 0.2 \\
\hline \multicolumn{16}{|c|}{ Численность внешних совместителей } \\
\hline Всего & 84.5 & 85.0 & 80.0 & 76.5 & 70.7 & 76.3 & 78.0 & 75.4 & 72.7 & 67.8 & 8.2 & 6.9 & 4.6 & 3.8 & 2.8 \\
\hline Учителя & 64.2 & 62.3 & 57.7 & 54.5 & 50.0 & 56.2 & 55.5 & 53.2 & 50.8 & 47.3 & 8.0 & 6.8 & 4.5 & 3.7 & 2.7 \\
\hline Учителя-логопеды & 1.2 & 1.2 & 1.2 & 1.2 & 1.0 & 1.2 & 1.2 & 1.2 & 1.2 & 1.0 & 0.0 & 0.0 & 0.0 & - & - \\
\hline Мастера производственного обучения & 0.3 & 0.3 & 0.2 & 0.2 & 0.2 & 0.3 & 0.2 & 0.2 & 0.2 & 0.1 & 0.0 & 0.0 & 0.0 & 0.0 & 0.0 \\
\hline Педагоги-психологи & 1.5 & 1.5 & 1.4 & 1.4 & 1.3 & 1.5 & 1.4 & 1.4 & 1.4 & 1.3 & 0.0 & 0.0 & 0.0 & 0.0 & 0.0 \\
\hline Социальные педагоги & 0.4 & 0.4 & 0.4 & 0.3 & 0.3 & 0.4 & 0.4 & 0.3 & 0.3 & 0.3 & 0.0 & 0.0 & 0.0 & 0.0 & 0.0 \\
\hline Воспитатели & 1.6 & 1.7 & 1.5 & 1.4 & 1.1 & 1.6 & 1.7 & 1.5 & 1.4 & 1.1 & 0.0 & 0.0 & 0.0 & 0.0 & 0.0 \\
\hline Тьюторы & 0.1 & 0.1 & 0.1 & 0.1 & 0.1 & 0.1 & 0.1 & 0.1 & 0.1 & 0.1 & 0.0 & 0.0 & 0.0 & 0.0 & 0.0 \\
\hline Другие педагогические работники & 15.3 & 17.7 & 17.5 & 17.4 & 16.7 & 15.2 & 17.6 & 17.4 & 17.4 & 16.6 & 0.1 & 0.1 & 0.1 & 0.0 & 0.1 \\
\hline
\end{tabular}

* На начало соответствующего учебного года. 


\subsection{8. УКОМПЛЕКТОВАННОСТЬ ШТАТОВ ПЕДАГОГИЧЕСКИХ РАБОТНИКОВ \\ ОБЩЕОБРАЗОВАТЕЛЬНЫХ ОРГАНИЗАЦИЙ: 2015 (на 20 сентября)}

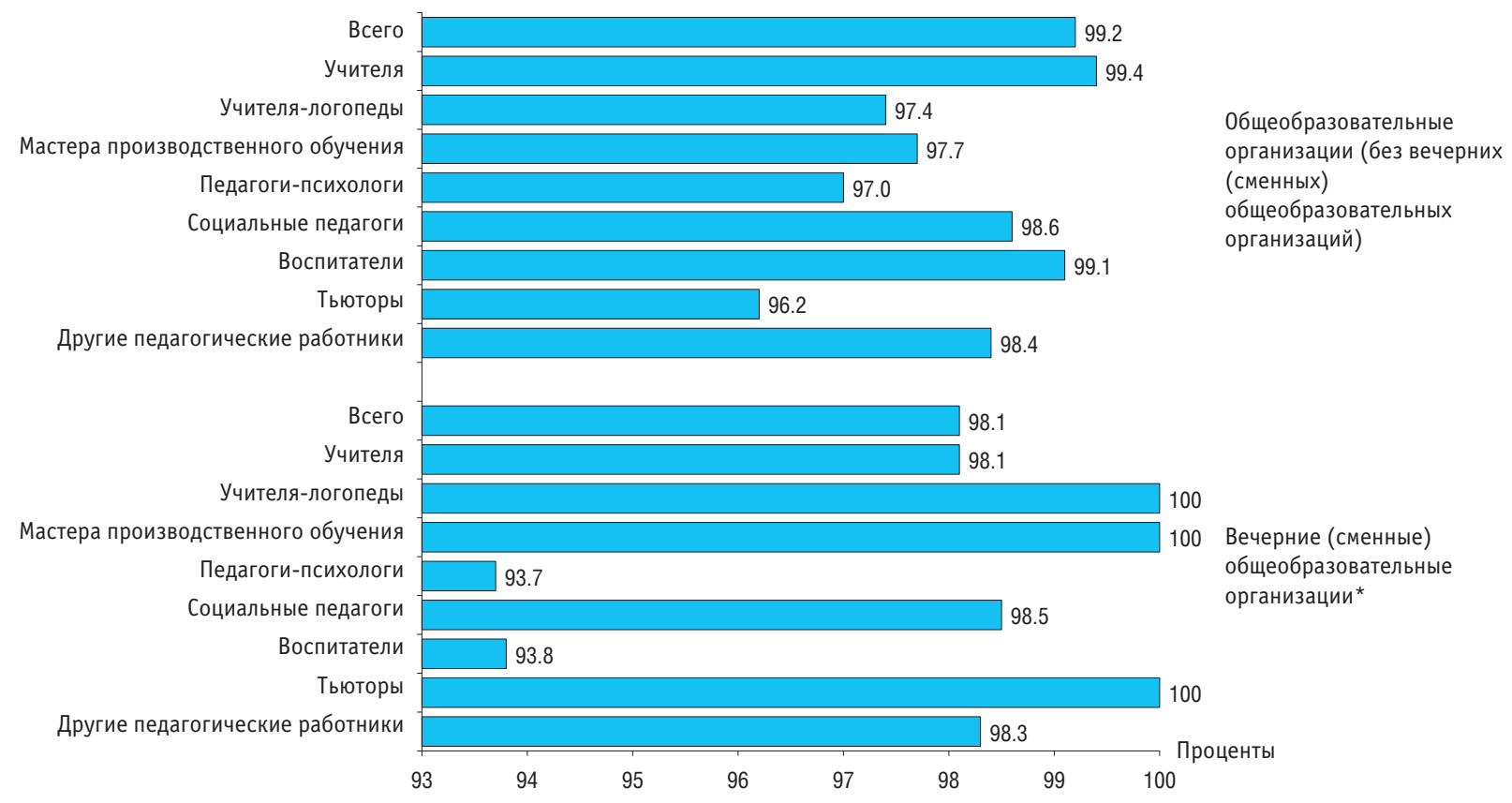

* На начало 2015/2016 учебного года. 


\subsection{9. ЧИСЛЕННОСТЬ ПЕДАГОГИЧЕСКИХ РАБОТНИКОВ ОБЩЕОБРАЗОВАТЕЛЬНЫХ ОРГАНИЗАЦИЙ (БЕЗ ВЕЧЕРНИХ (СМЕННЫХ) ОБЩЕОБРАЗОВАТЕЛЬНЫХ ОРГАНИЗАЦИЙ) ПО ДОЛЖНОСТЯМ (на 20 сентября; тысячи человек)}

\begin{tabular}{|c|c|c|c|c|c|c|c|c|c|c|c|c|}
\hline & \multicolumn{7}{|c|}{ Государственные и муниципальные организации * } & \multicolumn{5}{|c|}{ Частные организации } \\
\hline & 2009 & 2010 & 2011 & 2012 & 2013 & 2014 & 2015 & 2011 & 2012 & 2013 & 2014 & 2015 \\
\hline \multicolumn{13}{|c|}{ Численность работников (без внешних совместителей) } \\
\hline Всего & 1286.4 & 1243.0 & 1217.1 & 1220.8 & 1235.5 & 1286.5 & 1292.4 & 17.8 & 18.4 & 19.1 & 20.2 & 20.7 \\
\hline Учителя & 1086.5 & 1053.0 & 1034.5 & 1029.4 & 1031.7 & 1052.2 & 1054.6 & 13.7 & 14.1 & 14.5 & 15.2 & 15.5 \\
\hline Учителя-логопеды & 11.9 & 10.9 & 10.4 & 10.3 & 10.8 & 12.7 & 13.1 & 0.3 & 0.3 & 0.3 & 0.3 & 0.3 \\
\hline Мастера производственного обучения & 4.3 & 3.4 & 2.8 & 2.5 & 2.2 & 2.0 & 1.6 & 0.0 & 0.0 & 0.0 & 0.0 & 0.0 \\
\hline Педагоги-психологи & 21.9 & 20.9 & 19.7 & 19.6 & 20.2 & 21.9 & 22.3 & 0.5 & 0.5 & 0.5 & 0.5 & 0.6 \\
\hline Социальные педагоги & 19.6 & 18.3 & 17.5 & 17.2 & 17.4 & 17.6 & 17.3 & 0.1 & 0.1 & 0.1 & 0.1 & 0.1 \\
\hline Воспитатели & 93.7 & 89.0 & 84.1 & 88.6 & 95.7 & 112.6 & 111.5 & 2.5 & 2.7 & 2.7 & 2.8 & 2.7 \\
\hline Тьюторы & 0.2 & 0.2 & 0.3 & 0.3 & 0.5 & 0.9 & 1.3 & 0.0 & 0.0 & 0.0 & 0.0 & 0.1 \\
\hline Другие педагогические работники & 48.3 & 47.3 & 47.9 & 52.8 & 57.0 & 66.5 & 70.7 & 0.7 & 0.8 & 0.9 & 1.2 & 1.5 \\
\hline \multicolumn{13}{|c|}{ Численность внешних совместителей } \\
\hline Всего & 70.5 & 70.1 & 72.6 & 74.5 & 71.9 & 69.2 & 64.4 & 3.7 & 3.5 & 3.5 & 3.5 & 3.4 \\
\hline Учителя & 50.1 & 50.3 & 53.0 & 52.4 & 50.3 & 47.8 & 44.4 & 3.2 & 3.0 & 3.0 & 3.0 & 2.9 \\
\hline Учителя-логопеды & 1.2 & 1.2 & 1.1 & 1.1 & 1.1 & 1.1 & 1.0 & 0.1 & 0.1 & 0.1 & 0.1 & 0.1 \\
\hline Мастера производственного обучения & 0.4 & 0.3 & 0.3 & 0.2 & 0.2 & 0.2 & 0.1 & 0.0 & 0.0 & - & - & - \\
\hline Педагоги-психологи & 1.7 & 1.5 & 1.4 & 1.4 & 1.3 & 1.3 & 1.2 & 0.1 & 0.1 & 0.1 & 0.1 & 0.1 \\
\hline Социальные педагоги & 0.4 & 0.4 & 0.4 & 0.3 & 0.3 & 0.3 & 0.3 & 0.0 & 0.0 & 0.0 & 0.0 & 0.0 \\
\hline Воспитатели & 1.8 & 1.6 & 1.5 & 1.6 & 1.5 & 1.3 & 1.1 & 0.1 & 0.1 & 0.0 & 0.1 & 0.0 \\
\hline Тьюторы & 0.0 & 0.1 & 0.1 & 0.1 & 0.1 & 0.1 & 0.1 & 0.0 & 0.0 & 0.0 & 0.0 & 0.0 \\
\hline Другие педагогические работники & 14.8 & 14.8 & 14.9 & 17.3 & 17.1 & 17.0 & 16.3 & 0.3 & 0.3 & 0.3 & 0.4 & 0.4 \\
\hline
\end{tabular}

* Данные за 2010 г. и ранее приведены по общеобразовательным организациям системы Минобрнауки России. 

(без внешних совместителей; на 20 сентября)

\begin{tabular}{|c|c|c|c|c|c|c|c|c|c|c|c|c|c|c|c|}
\hline & \multicolumn{5}{|c|}{ Всего } & \multicolumn{5}{|c|}{$\begin{array}{c}\text { Общеобразовательные организации } \\
\text { (без вечерних (сменных) } \\
\text { общеобразовательных организаций) }\end{array}$} & \multicolumn{5}{|c|}{$\begin{array}{c}\text { Вечерние (сменные) } \\
\text { общеобразовательные организации* }\end{array}$} \\
\hline & 2011 & 2012 & 2013 & 2014 & 2015 & 2011 & 2012 & 2013 & 2014 & 2015 & 2011 & 2012 & 2013 & 2014 & 2015 \\
\hline \multicolumn{16}{|c|}{ Тысячи человек } \\
\hline Всего & 1098.9 & 1100.1 & 1112.3 & 1160.8 & 1165.7 & 1087.8 & 1089.8 & 1103.3 & 1153.0 & 1159.4 & 11.1 & 10.3 & 9.0 & 7.8 & 6.3 \\
\hline Учителя & 930.6 & 925.0 & 926.0 & 943.8 & 943.3 & 920.4 & 915.6 & 917.8 & 936.6 & 937.6 & 10.1 & 9.4 & 8.3 & 7.1 & 5.7 \\
\hline Учителя-логопеды & 10.5 & 10.5 & 10.9 & 12.9 & 13.3 & 10.5 & 10.5 & 10.9 & 12.9 & 13.3 & 0.0 & 0.0 & 0.0 & 0.0 & 0.0 \\
\hline Мастера производственного обучения & 0.5 & 0.5 & 0.4 & 0.4 & 0.4 & 0.5 & 0.4 & 0.4 & 0.4 & 0.3 & 0.1 & 0.0 & 0.0 & 0.0 & 0.0 \\
\hline Педагоги-психологи & 19.3 & 19.2 & 19.6 & 21.4 & 21.9 & 19.1 & 19.0 & 19.4 & 21.3 & 21.7 & 0.2 & 0.2 & 0.2 & 0.2 & 0.1 \\
\hline Социальные педагоги & 17.0 & 16.6 & 16.6 & 16.9 & 16.7 & 16.6 & 16.3 & 16.4 & 16.7 & 16.5 & 0.4 & 0.3 & 0.3 & 0.2 & 0.2 \\
\hline Воспитатели & 82.1 & 86.2 & 92.7 & 109.8 & 109.8 & 82.0 & 86.1 & 92.7 & 109.8 & 109.8 & 0.0 & 0.0 & 0.0 & 0.0 & 0.0 \\
\hline Тьюторы & 0.3 & 0.3 & 0.5 & 0.8 & 1.2 & 0.3 & 0.3 & 0.5 & 0.8 & 1.2 & - & 0.0 & 0.0 & 0.0 & 0.0 \\
\hline Другие педагогические работники & 38.6 & 41.8 & 45.6 & 54.7 & 59.1 & 38.4 & 41.6 & 45.3 & 54.5 & 59.0 & 0.3 & 0.2 & 0.2 & 0.2 & 0.2 \\
\hline \multicolumn{16}{|c|}{ В процентах от общей численности } \\
\hline Всего & 88.0 & 87.9 & 87.9 & 88.2 & 88.2 & 88.1 & 87.9 & 87.9 & 88.2 & 88.3 & 83.7 & 83.3 & 82.9 & 81.6 & 79.4 \\
\hline Учителя & 87.8 & 87.7 & 87.7 & 87.7 & 87.6 & 87.8 & 87.7 & 87.7 & 87.7 & 87.6 & 83.7 & 83.3 & 82.8 & 81.6 & 79.3 \\
\hline Учителя-логопеды & 98.6 & 98.7 & 98.5 & 98.7 & 98.9 & 98.6 & 98.7 & 98.5 & 98.7 & 98.9 & 100 & 100 & 100 & 100 & 100 \\
\hline Мастера производственного обучения & 18.3 & 17.8 & 18.7 & 21.0 & 21.9 & 17.0 & 16.6 & 17.8 & 20.1 & 21.3 & 46.0 & 49.5 & 42.4 & 41.6 & 34.8 \\
\hline Педагоги-психологи & 94.6 & 94.4 & 93.7 & 94.7 & 95.1 & 94.6 & 94.4 & 93.7 & 94.7 & 95.1 & 93.3 & 94.3 & 94.8 & 92.6 & 94.0 \\
\hline Социальные педагоги & 94.7 & 94.4 & 93.6 & 94.5 & 95.0 & 94.7 & 94.4 & 93.6 & 94.5 & 95.0 & 96.7 & 96.6 & 96.2 & 94.1 & 95.9 \\
\hline Воспитатели & 94.8 & 94.4 & 94.1 & 95.1 & 96.1 & 94.8 & 94.4 & 94.1 & 95.1 & 96.1 & 95.9 & 97.7 & 93.1 & 92.6 & 86.7 \\
\hline Тьюторы & 91.1 & 83.1 & 81.9 & 86.1 & 87.0 & 91.1 & 82.6 & 81.9 & 86.0 & 87.0 & - & 100 & 100 & 100 & 100 \\
\hline Другие педагогические работники & 78.8 & 77.5 & 78.3 & 80.6 & 81.6 & 78.9 & 77.5 & 78.3 & 80.6 & 81.6 & 72.9 & 69.5 & 76.0 & 75.3 & 70.7 \\
\hline
\end{tabular}

* На начало соответствующего учебного года. 


\subsection{1. ЧИСЛЕННОСТЬ ЖЕНЩИН В СОСТАВЕ ПЕДАГОГИЧЕСКИХ РАБОТНИКОВ ОБЩЕОБРАЗОВАТЕЛЬНЫХ ОРГАНИЗАЦИЙ (БЕЗ ВЕЧЕРНИХ (СМЕННЫХ) ОБЩЕОБРАЗОВАТЕЛЬНЫХ ОРГАНИЗАЦИЙ) ПО ДОЛЖНОСТЯМ}

(без внешних совместителей; на 20 сентября)

\begin{tabular}{|c|c|c|c|c|c|c|c|c|c|c|c|c|}
\hline & \multicolumn{7}{|c|}{ Государственные и муниципальные организации* } & \multicolumn{5}{|c|}{ Частные организации } \\
\hline & 2009 & 2010 & 2011 & 2012 & 2013 & 2014 & 2015 & 2011 & 2012 & 2013 & 2014 & 2015 \\
\hline \multicolumn{13}{|c|}{ Тысячи человек } \\
\hline Всего & 1129.6 & 1096.2 & 1071.9 & 1073.5 & 1086.4 & 1135.3 & 1141.2 & 15.8 & 16.3 & 16.9 & 17.7 & 18.2 \\
\hline Учителя & 950.7 & 925.1 & 908.4 & 903.3 & 905.2 & 923.5 & 924.3 & 12.0 & 12.2 & 12.6 & 13.2 & 13.3 \\
\hline Учителя-логопеды & 11.8 & 10.8 & 10.2 & 10.2 & 10.6 & 12.6 & 12.9 & 0.3 & 0.3 & 0.3 & 0.3 & 0.3 \\
\hline Мастера производственного обучения & 0.7 & 0.6 & 0.5 & 0.4 & 0.4 & 0.4 & 0.3 & 0.0 & - & 0.0 & - & - \\
\hline Педагоги-психологи & 20.8 & 19.8 & 18.6 & 18.5 & 19.0 & 20.8 & 21.2 & 0.4 & 0.5 & 0.5 & 0.5 & 0.5 \\
\hline Социальные педагоги & 18.5 & 17.4 & 16.5 & 16.2 & 16.3 & 16.6 & 16.5 & 0.1 & 0.1 & 0.1 & 0.1 & 0.1 \\
\hline Воспитатели & 88.3 & 84.7 & 79.6 & 83.6 & 90.0 & 107.0 & 107.1 & 2.4 & 2.5 & 2.7 & 2.7 & 2.6 \\
\hline Тьюторы & 0.2 & 0.2 & 0.3 & 0.3 & 0.4 & 0.8 & 1.1 & 0.0 & 0.0 & 0.0 & 0.0 & 0.1 \\
\hline Другие педагогические работники & 38.7 & 37.6 & 37.8 & 40.9 & 44.6 & 53.6 & 57.7 & 0.5 & 0.7 & 0.7 & 0.9 & 1.2 \\
\hline \multicolumn{13}{|c|}{ В процентах от общей численности } \\
\hline Всего & 87.8 & 88.2 & 88.1 & 87.9 & 87.9 & 88.2 & 88.3 & 88.8 & 88.2 & 88.2 & 87.9 & 87.8 \\
\hline Учителя & 87.5 & 87.9 & 87.8 & 87.7 & 87.7 & 87.8 & 87.6 & 87.4 & 87.1 & 87.0 & 86.5 & 86.3 \\
\hline Учителя-логопеды & 98.7 & 98.8 & 98.6 & 98.7 & 98.5 & 98.7 & 98.9 & 99.3 & 98.6 & 98.7 & 97.4 & 97.4 \\
\hline Мастера производственного обучения & 15.6 & 16.4 & 17.0 & 16.6 & 17.8 & 20.1 & 21.3 & 66.7 & - & 25.0 & - & - \\
\hline Педагоги-психологи & 95.2 & 95.0 & 94.7 & 94.5 & 93.8 & 94.8 & 95.3 & 92.4 & 91.5 & 90.6 & 91.4 & 89.3 \\
\hline Социальные педагоги & 94.3 & 95.0 & 94.7 & 94.4 & 93.6 & 94.5 & 95.0 & 96.3 & 89.6 & 86.7 & 84.6 & 92.4 \\
\hline Воспитатели & 94.2 & 95.1 & 94.7 & 94.4 & 94.0 & 95.1 & 96.1 & 97.7 & 95.0 & 97.0 & 97.1 & 97.3 \\
\hline Тьюторы & 93.0 & 87.8 & 90.9 & 83.6 & 81.5 & 85.7 & 86.4 & 92.7 & 73.0 & 86.5 & 93.3 & 97.1 \\
\hline Другие педагогические работники & 80.1 & 79.5 & 78.9 & 77.5 & 78.3 & 80.6 & 81.6 & 78.1 & 80.6 & 77.7 & 81.0 & 83.2 \\
\hline
\end{tabular}

* Данные за 2010 г. и ранее приведены по общеобразовательным организациям системы Минобрнауки России. 


\subsection{2. УРОВЕНЬ ОБРАЗОВАНИЯ ПЕДАГОГИЧЕСКИХ РАБОТНИКОВ ОБЩЕОБРАЗОВАТЕЛЬНЫХ ОРГАНИЗАЦИЙ}

(без внешних совместителей; на 20 сентября; проценты)

\begin{tabular}{|c|c|c|c|c|c|c|c|c|c|c|c|c|c|c|c|}
\hline & \multicolumn{5}{|c|}{ Всего } & \multicolumn{5}{|c|}{$\begin{array}{c}\text { Общеобразовательные организации } \\
\text { (без вечерних (сменных) } \\
\text { общеобразовательных организаций) }\end{array}$} & \multicolumn{5}{|c|}{$\begin{array}{c}\text { Вечерние (сменные) } \\
\text { общеобразовательные организации* }\end{array}$} \\
\hline & 2011 & 2012 & 2013 & 2014 & 2015 & 2011 & 2012 & 2013 & 2014 & 2015 & 2011 & 2012 & 2013 & 2014 & 2015 \\
\hline Bcero & 100 & 100 & 100 & 100 & 100 & 100 & 100 & 100 & 100 & 100 & 100 & 100 & 100 & 100 & 100 \\
\hline \multicolumn{16}{|l|}{ Имеют образование: } \\
\hline высшее & 80.9 & 81.2 & 81.6 & 82.0 & 82.7 & 80.7 & 81.1 & 81.5 & 81.9 & 82.6 & 94.1 & 94.8 & 95.0 & 94.7 & 94.8 \\
\hline из них педагогическое & 75.8 & 75.9 & 76.3 & 76.7 & 77.5 & 75.7 & 75.8 & 76.2 & 76.6 & 77.4 & 86.7 & 87.5 & 87.5 & 86.2 & 86.8 \\
\hline $\begin{array}{l}\text { среднее профессиональное по программам } \\
\text { подготовки специалистов среднего звена }\end{array}$ & 17.5 & 17.3 & 16.9 & 16.6 & 16.2 & 17.7 & 17.4 & 17.0 & 16.7 & 16.2 & 4.7 & 4.3 & 4.2 & 4.6 & 4.5 \\
\hline из них педагогическое & 14.8 & 14.7 & 14.4 & 14.2 & 14.0 & 15.0 & 14.8 & 14.5 & 14.3 & 14.1 & 2.9 & 2.7 & 2.5 & 2.7 & 3.0 \\
\hline
\end{tabular}

* На начало соответствующего учебного года. 


\subsection{3. УРОВЕНЬ ОБРАЗОВАНИЯ ПЕДАГОГИЧЕСКИХ РАБОТНИКОВ ОБЩЕОБРАЗОВАТЕЛЬНЫХ ОРГАНИЗАЦИЙ (БЕЗ ВЕЧЕРНИХ (СМЕННЫХ) ОБЩЕОБРАЗОВАТЕЛЬНЫХ ОРГАНИЗАЦИЙ) \\ (без внешних совместителей; на 20 сентября; проценты)}

\begin{tabular}{|c|c|c|c|c|c|c|c|c|c|c|c|c|}
\hline & \multicolumn{7}{|c|}{ Государственные и муниципальные организации* } & \multicolumn{5}{|c|}{ Частные организации } \\
\hline & 2009 & 2010 & 2011 & 2012 & 2013 & 2014 & 2015 & 2011 & 2012 & 2013 & 2014 & 2015 \\
\hline Всего & 100 & 100 & 100 & 100 & 100 & 100 & 100 & 100 & 100 & 100 & 100 & 100 \\
\hline \multicolumn{13}{|l|}{ Имеют образование: } \\
\hline высшее & 79.1 & 79.9 & 80.6 & 81.0 & 81.4 & 81.8 & 82.5 & 87.8 & 88.7 & 88.7 & 89.2 & 89.5 \\
\hline из них педагогическое & 74.2 & 74.8 & 75.6 & 75.7 & 76.2 & 76.6 & 77.4 & 78.3 & 79.7 & 79.9 & 80.5 & 80.5 \\
\hline \multicolumn{13}{|l|}{ среднее профессиональное по программам } \\
\hline подготовки специалистов среднего звена & 19.1 & 18.4 & 17.8 & 17.5 & 17.1 & 16.8 & 16.3 & 10.8 & 10.2 & 10.0 & 9.8 & 9.7 \\
\hline из них педагогическое & 16.2 & 15.6 & 15.1 & 14.9 & 14.6 & 14.4 & 14.2 & 8.2 & 7.8 & 7.9 & 7.8 & 7.8 \\
\hline
\end{tabular}

* Данные за 2010 г. и ранее приведены по общеобразовательным организациям системы Минобрнауки России. 


\subsection{4. УРОВЕНЬ ОБРАЗОВАНИЯ ПЕДАГОГИЧЕСКИХ РАБОТНИКОВ ОБЩЕОБРАЗОВАТЕЛЬНЫХ ОРГАНИЗАЦИЙ \\ ПО ДОЛЖНОСТяМ: 2015 \\ (без внешних совместителей; на 20 сентября; проценты)}

\begin{tabular}{|c|c|c|c|c|c|}
\hline & \multirow[t]{2}{*}{ Всего } & \multicolumn{4}{|c|}{ Имеют образование } \\
\hline & & высшее & $\begin{array}{c}\text { из них } \\
\text { педагогическое }\end{array}$ & $\begin{array}{c}\text { среднее } \\
\text { профессиональное } \\
\text { по программам } \\
\text { подготовки специалистов } \\
\text { среднего звена }\end{array}$ & $\begin{array}{c}\text { из них } \\
\text { педагогическое }\end{array}$ \\
\hline Bcero & 100 & 82.7 & 77.5 & 16.2 & 14.0 \\
\hline Учителя & 100 & 86.1 & 81.9 & 13.2 & 11.8 \\
\hline Учителя-логопеды & 100 & 97.6 & 95.1 & 2.1 & 1.7 \\
\hline Мастера производственного обучения & 100 & 43.1 & 23.1 & 40.0 & 9.4 \\
\hline Педагоги-психологи & 100 & 96.4 & 88.0 & 2.8 & 2.2 \\
\hline Социальные педагоги & 100 & 80.7 & 69.0 & 17.4 & 12.7 \\
\hline Воспитатели & 100 & 53.8 & 47.8 & 42.9 & 37.6 \\
\hline Тьюторы & 100 & 81.7 & 67.7 & 15.4 & 10.7 \\
\hline Другие педагогические работники & 100 & 71.3 & 55.5 & 24.6 & 15.7 \\
\hline
\end{tabular}




\section{6}

\subsection{5. СТРУКТУРА ЧИСЛЕННОСТИ ПЕДАГОГИЧЕСКИХ РАБОТНИКОВ ОБЩЕОБРАЗОВАТЕЛЬНЫХ ОРГАНИЗАЦИЙ}

ПО В0ЗРАСТНЫМ ГРУППАМ

(без внешних совместителей; на 20 сентября)

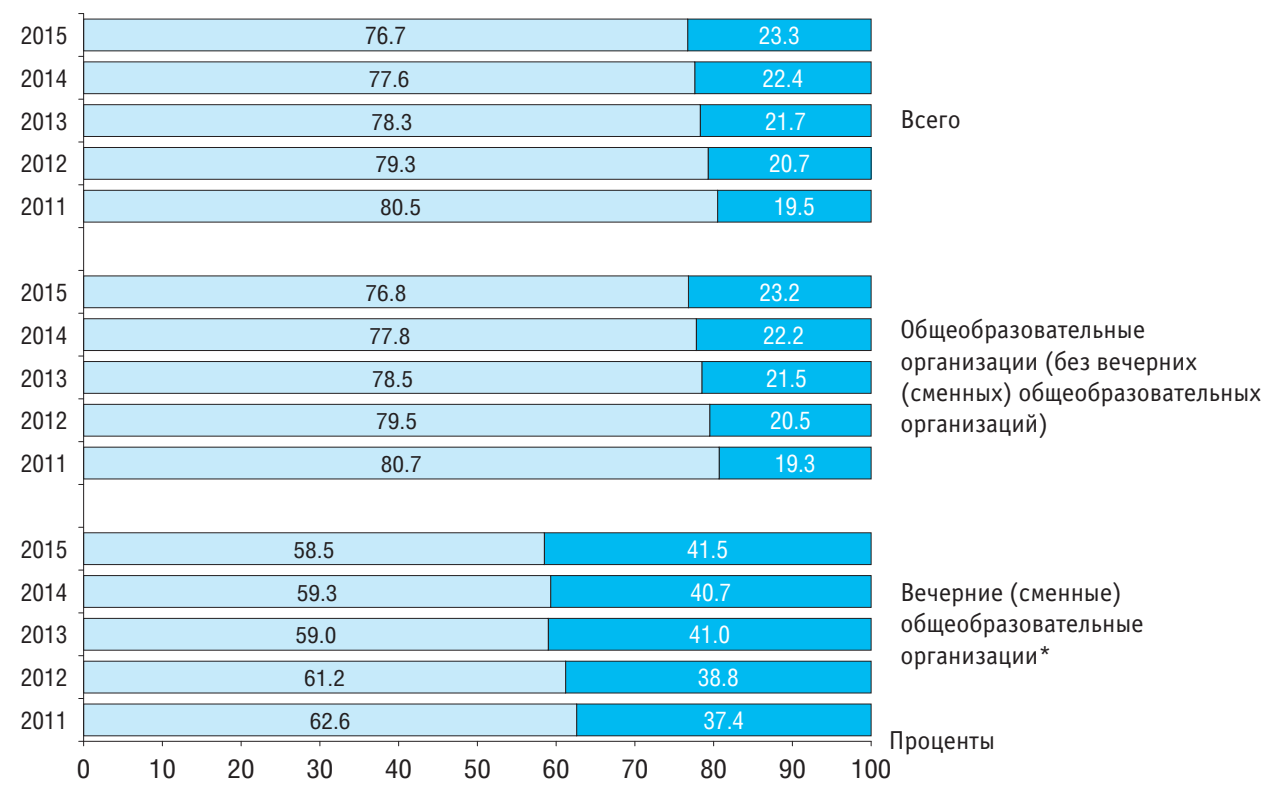

Возраст:

$\square$ трудоспособный $\square$ старше трудоспособного

* На начало соответствующего учебного года. 


\subsection{6. СТРУКТУРА ЧИСЛЕННОСТИ ПЕДАГОГИЧЕСКИХ РАБОТНИКОВ ОБЩЕОБРАЗОВАТЕЛЬНЫХ ОРГАНИЗАЦИЙ}

ПО ДОЛЖНОСТЯМ И ВОЗРАСТНЫМ ГРУППАМ: 2015

(без внешних совместителей; на 20 сентября)

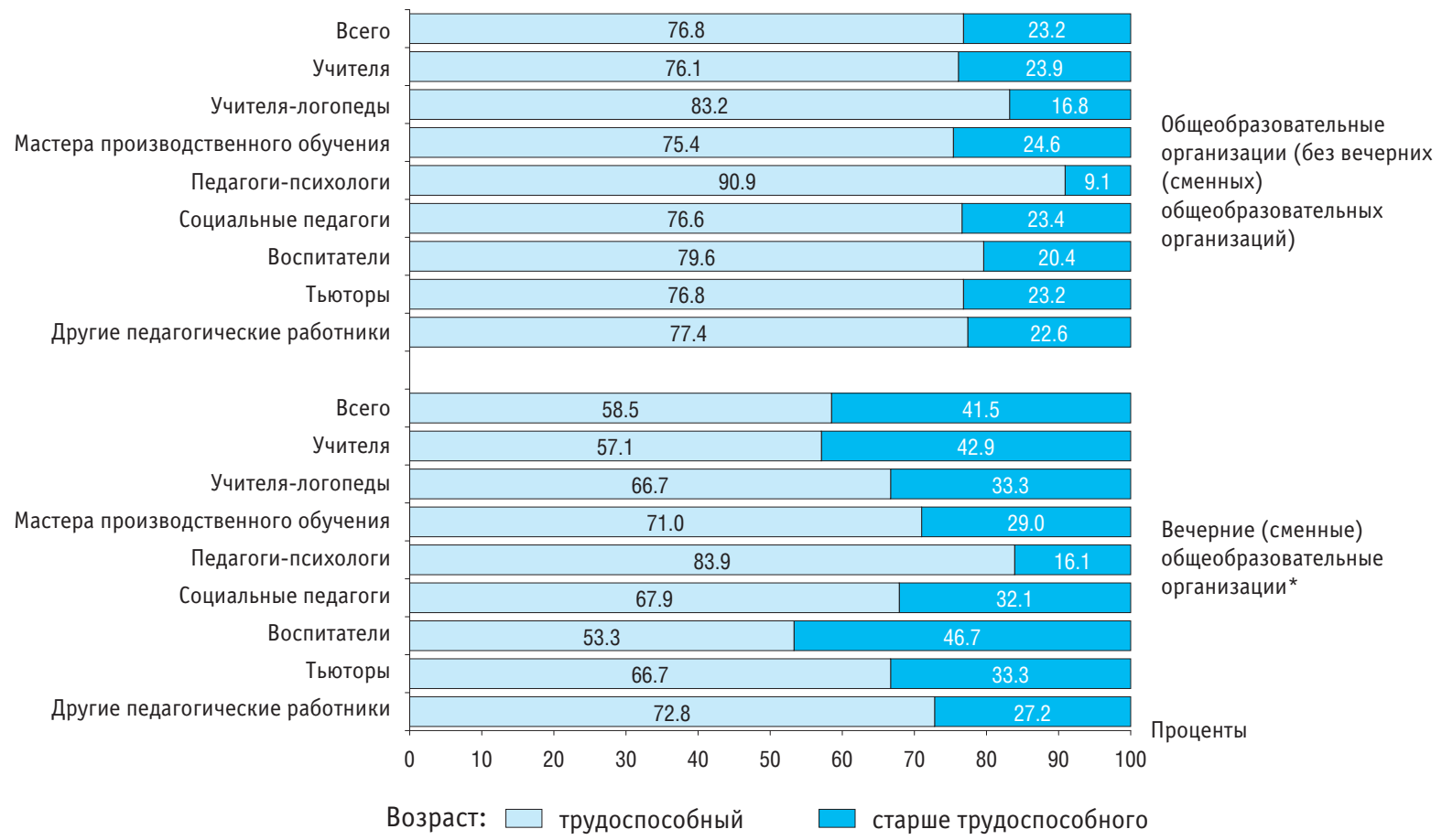

* На начало 2015/2016 учебного года. 


\subsection{7. ЧИСЛЕННОСТЬ УЧИТЕЛЕЙ ОБЩЕОБРАЗОВАТЕЛЬНЫХ ОРГАНИЗАЦИЙ ПО СПЕЦИАЛЬНОСТЯМ (на 20 сентября; тысячи человек)}

\begin{tabular}{|c|c|c|c|c|c|c|c|c|c|c|c|c|c|c|c|}
\hline & \multicolumn{5}{|c|}{ Всего } & \multicolumn{5}{|c|}{$\begin{array}{c}\text { Общеобразовательные организации } \\
\text { (без вечерних (сменных) } \\
\text { общеобразовательных организаций) }\end{array}$} & \multicolumn{5}{|c|}{$\begin{array}{c}\text { Вечерние (сменные) } \\
\text { общеобразовательные организации * }\end{array}$} \\
\hline & 2011 & 2012 & 2013 & 2014 & 2015 & 2011 & 2012 & 2013 & 2014 & 2015 & 2011 & 2012 & 2013 & 2014 & 2015 \\
\hline \multicolumn{16}{|c|}{ Численность учителей (без внешних совместителей) } \\
\hline Всего & 1060.4 & 1054.8 & 1056.2 & 1076.2 & 1077.3 & 1048.2 & 1043.5 & 1046.2 & 1067.4 & 1070.0 & 12.1 & 11.3 & 10.0 & 8.8 & 7.2 \\
\hline \multicolumn{16}{|l|}{ Учителя: } \\
\hline 1-4 классов & 278.9 & 282.1 & 286.2 & 294.1 & 298.0 & 278.9 & 282.1 & 286.2 & 294.1 & 298.0 & - & - & - & - & - \\
\hline русского языка и литературы & 128.5 & 126.9 & 126.3 & 128.1 & 127.2 & 125.8 & 124.5 & 124.2 & 126.2 & 125.7 & 2.7 & 2.5 & 2.1 & 1.8 & 1.5 \\
\hline нерусского языка и литературы & 19.5 & 19.3 & 19.3 & 20.1 & 19.3 & 19.4 & 19.2 & 19.2 & 20.0 & 19.2 & 0.1 & 0.1 & 0.1 & 0.1 & 0.1 \\
\hline $\begin{array}{l}\text { истории, права, обществознания, } \\
\text { экономики }\end{array}$ & 64.7 & 64.7 & 64.8 & 66.1 & 66.5 & 63.0 & 63.1 & 63.3 & 64.9 & 65.5 & 1.7 & 1.6 & 1.4 & 1.2 & 1.0 \\
\hline математики & 102.6 & 101.2 & 100.8 & 101.9 & 101.6 & 100.4 & 99.2 & 99.0 & 100.4 & 100.4 & 2.2 & 2.0 & 1.8 & 1.5 & 1.2 \\
\hline информатики & 30.1 & 29.9 & 29.9 & 30.2 & 29.8 & 29.8 & 29.6 & 29.5 & 29.9 & 29.6 & 0.3 & 0.4 & 0.3 & 0.3 & 0.2 \\
\hline физики & 35.9 & 35.1 & 34.4 & 34.5 & 34.0 & 34.8 & 34.1 & 33.5 & 33.7 & 33.3 & 1.1 & 1.0 & 0.9 & 0.8 & 0.6 \\
\hline химии & 29.7 & 28.8 & 28.2 & 28.0 & 27.2 & 28.6 & 27.8 & 27.3 & 27.2 & 26.6 & 1.1 & 1.0 & 0.9 & 0.7 & 0.6 \\
\hline географии & 33.8 & 33.1 & 32.6 & 32.9 & 32.6 & 33.2 & 32.5 & 32.1 & 32.4 & 32.3 & 0.7 & 0.6 & 0.5 & 0.5 & 0.4 \\
\hline биологии & 34.2 & 33.5 & 33.3 & 33.4 & 33.0 & 33.5 & 32.9 & 32.7 & 32.9 & 32.6 & 0.7 & 0.6 & 0.5 & 0.5 & 0.4 \\
\hline иностранных языков & 111.9 & 112.0 & 112.5 & 115.7 & 116,6 & 110.9 & 111.0 & 111.7 & 115.0 & 115.9 & 1.0 & 0.9 & 0.9 & 0.8 & 0.7 \\
\hline музыки и пения & 23.9 & 23.1 & 22.7 & 23.2 & 23.1 & 23.8 & 23.1 & 22.6 & 23.2 & 23.1 & 0.0 & 0.0 & 0.0 & 0.0 & 0.0 \\
\hline изобразительного искусства, черчения & 19.6 & 19.0 & 18.8 & 19.0 & 18.7 & 19.5 & 19.0 & 18.8 & 18.9 & 18.6 & 0.0 & 0.0 & 0.0 & 0.0 & 0.0 \\
\hline основ безопасности жизнедеятельности & 17.3 & 15.7 & 15.0 & 15.0 & 14.6 & 17.2 & 15.6 & 14.9 & 14.9 & 14.6 & 0.1 & 0.1 & 0.1 & 0.1 & 0.1 \\
\hline физической культуры & 69.4 & 71.5 & 73.3 & 76.3 & 77.5 & 69.2 & 71.4 & 73.2 & 76.2 & 77.3 & 0.1 & 0.1 & 0.1 & 0.1 & 0.1 \\
\hline трудового обучения & 48.8 & 46.8 & 46.1 & 45.9 & 45.2 & 48.7 & 46.7 & 46.0 & 45.8 & 45.1 & 0.2 & 0.1 & 0.1 & 0.1 & 0.1 \\
\hline прочих предметов & 11.6 & 11.9 & 12.0 & 12.0 & 12.4 & 11.4 & 11.8 & 11.8 & 11.8 & 12.2 & 0.2 & 0.2 & 0.2 & 0.2 & 0.1 \\
\hline
\end{tabular}


(окончание)

\begin{tabular}{|c|c|c|c|c|c|c|c|c|c|c|c|c|c|c|c|}
\hline & \multicolumn{5}{|c|}{ Bcero } & \multicolumn{5}{|c|}{$\begin{array}{c}\text { Общеобразовательные организации } \\
\text { (без вечерних (сменных) } \\
\text { общеобрразовательных организаций) }\end{array}$} & \multicolumn{5}{|c|}{$\begin{array}{c}\text { Вечерние (сменные) } \\
\text { общеобразовательные организации * }\end{array}$} \\
\hline & 2011 & 2012 & 2013 & 2014 & 2015 & 2011 & 2012 & 2013 & 2014 & 2015 & 2011 & 2012 & 2013 & 2014 & 2015 \\
\hline \multicolumn{16}{|c|}{ Численность внешних совместителей } \\
\hline Всего & 64.2 & 62.3 & 57.7 & 54.5 & 50.0 & 56.2 & 55.5 & 53.2 & 50.8 & 47.3 & 8.0 & 6.8 & 4.5 & 3.7 & 2.7 \\
\hline \multicolumn{16}{|l|}{ Учителя: } \\
\hline 1-4 классов & 2.6 & 2.9 & 2.9 & 2.9 & 2.7 & 2.6 & 2.9 & 2.9 & 2.9 & 2.7 & - & - & - & - & - \\
\hline русского языка и литературы & 4.4 & 4.1 & 3.7 & 3.6 & 3.0 & 3.0 & 3.0 & 3.0 & 3.0 & 2.6 & 1.4 & 1.1 & 0.7 & 0.6 & 0.4 \\
\hline нерусского языка и литературы & 0.6 & 0.6 & 0.6 & 0.5 & 0.5 & 0.4 & 0.5 & 0.5 & 0.5 & 0.4 & 0.1 & 0.1 & 0.1 & 0.1 & 0.1 \\
\hline \multicolumn{16}{|l|}{ истории, права, обществознания, } \\
\hline экономики & 5.2 & 5.0 & 4.5 & 4.0 & 3.7 & 4.1 & 4.1 & 3.9 & 3.5 & 3.4 & 1.1 & 0.9 & 0.6 & 0.5 & 0.3 \\
\hline математики & 4.4 & 4.2 & 3.7 & 3.4 & 3.1 & 3.2 & 3.1 & 3.1 & 2.9 & 2.7 & 1.2 & 1.0 & 0.6 & 0.5 & 0.3 \\
\hline информатики & 4.1 & 4.0 & 3.7 & 3.5 & 3.3 & 3.7 & 3.6 & 3.4 & 3.2 & 3.0 & 0.4 & 0.4 & 0.3 & 0.3 & 0.3 \\
\hline физики & 4.5 & 4.4 & 4.1 & 3.9 & 3.6 & 3.7 & 3.7 & 3.7 & 3.6 & 3.4 & 0.8 & 0.7 & 0.4 & 0.3 & 0.2 \\
\hline химии & 4.2 & 4.0 & 3.7 & 3.6 & 3.3 & 3.4 & 3.4 & 3.3 & 3.2 & 3.1 & 0.8 & 0.6 & 0.4 & 0.3 & 0.2 \\
\hline географии & 2.4 & 2.3 & 2.0 & 1.9 & 1.8 & 1.9 & 1.9 & 1.8 & 1.7 & 1.6 & 0.5 & 0.4 & 0.3 & 0.2 & 0.2 \\
\hline биологии & 2.5 & 2.3 & 2.1 & 2.0 & 1.9 & 2.0 & 1.9 & 1.9 & 1.8 & 1.7 & 0.5 & 0.5 & 0.3 & 0.2 & 0.1 \\
\hline иностранных языков & 6.9 & 6.7 & 6.2 & 5.7 & 5.3 & 6.1 & 5.9 & 5.6 & 5.2 & 5.0 & 0.8 & 0.8 & 0.6 & 0.5 & 0.3 \\
\hline музыки и пения & 6.0 & 5.7 & 5.3 & 5.0 & 4.6 & 6.0 & 5.6 & 5.3 & 5.0 & 4.6 & 0.0 & 0.0 & 0.0 & 0.0 & 0.0 \\
\hline изобразительного искусства, черчения & 2.1 & 2.0 & 1.9 & 1.8 & 1.5 & 2.1 & 2.0 & 1.8 & 1.7 & 1.5 & 0.0 & 0.0 & 0.0 & 0.0 & 0.0 \\
\hline основ безопасности жизнедеятельности & 1.2 & 1.2 & 1.1 & 1.0 & 1.0 & 1.2 & 1.1 & 1.0 & 1.0 & 0.9 & 0.1 & 0.1 & 0.1 & 0.1 & 0.0 \\
\hline физической культуры & 5.8 & 5.5 & 5.1 & 4.7 & 4.3 & 5.7 & 5.4 & 5.0 & 4.6 & 4.2 & 0.1 & 0.1 & 0.1 & 0.1 & 0.1 \\
\hline трудового обучения & 3.7 & 3.6 & 3.4 & 3.3 & 3.0 & 3.6 & 3.5 & 3.4 & 3.2 & 2.9 & 0.0 & 0.0 & 0.0 & 0.1 & 0.0 \\
\hline прочих предметов & 3.5 & 4.0 & 3.8 & 3.8 & 3.5 & 3.5 & 3.9 & 3.8 & 3.8 & 3.5 & 0.1 & 0.1 & 0.1 & 0.0 & 0.0 \\
\hline
\end{tabular}

* На начало соответствующего учебного года. 


\subsection{8. УКОМПЛЕКТОВАННОСТЬ ШТАТОВ ПЕДАГОГИЧЕСКИХ РАБОТНИКОВ ОБЩЕОБРАЗОВАТЕЛЬНЫХ ОРГАНИЗАЦИЙ УЧИТЕЛЯМИ ПО СПЕЦИАЛЬНОСТЯМ: 2015 (на 20 сентября)}

0бщеобразовательные организации (без вечерних (сменных) общеобразовательных организаций)

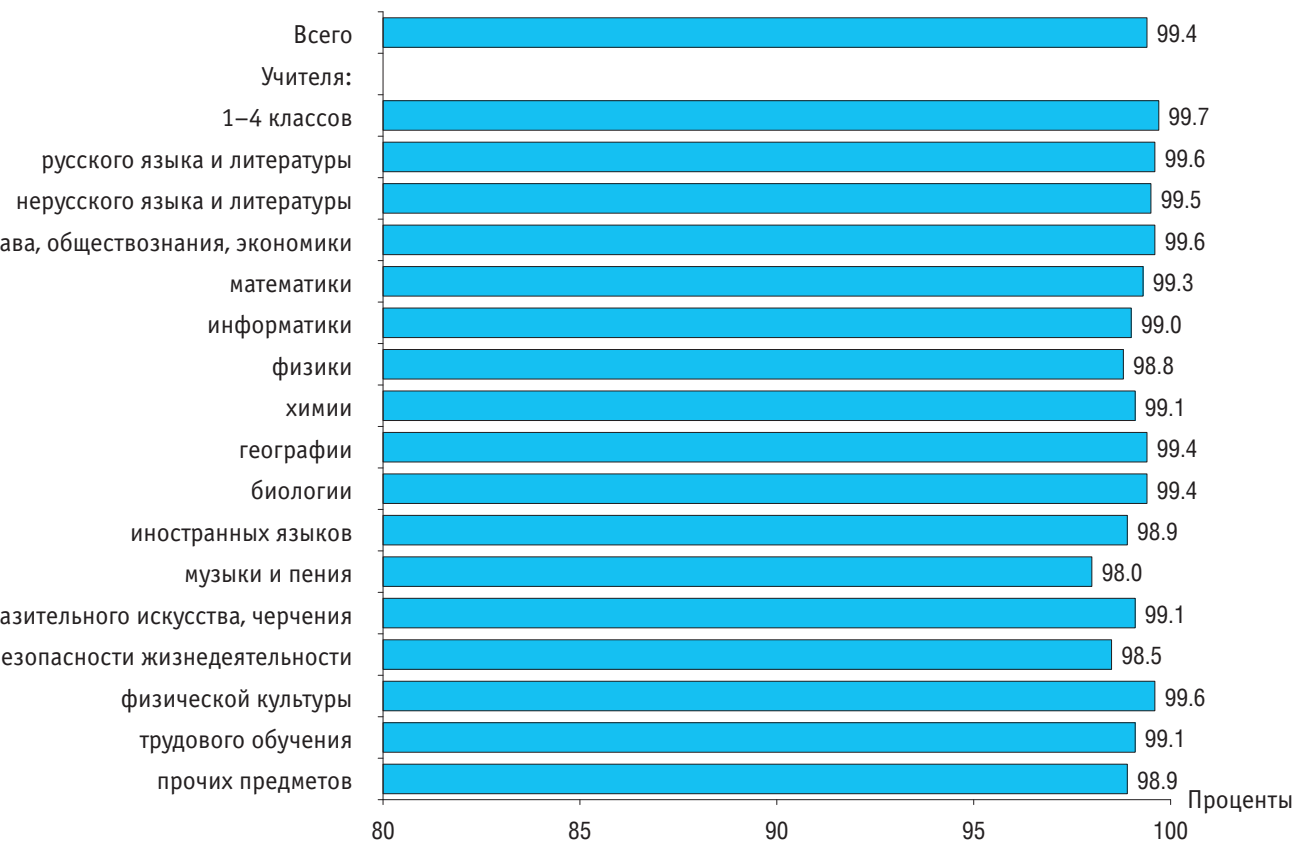

изобразительного искусства, черчения основ безопасности жизнедеятельности физической культуры рудового обучения 
Вечерние (сменные)

общеобразовательные организации *

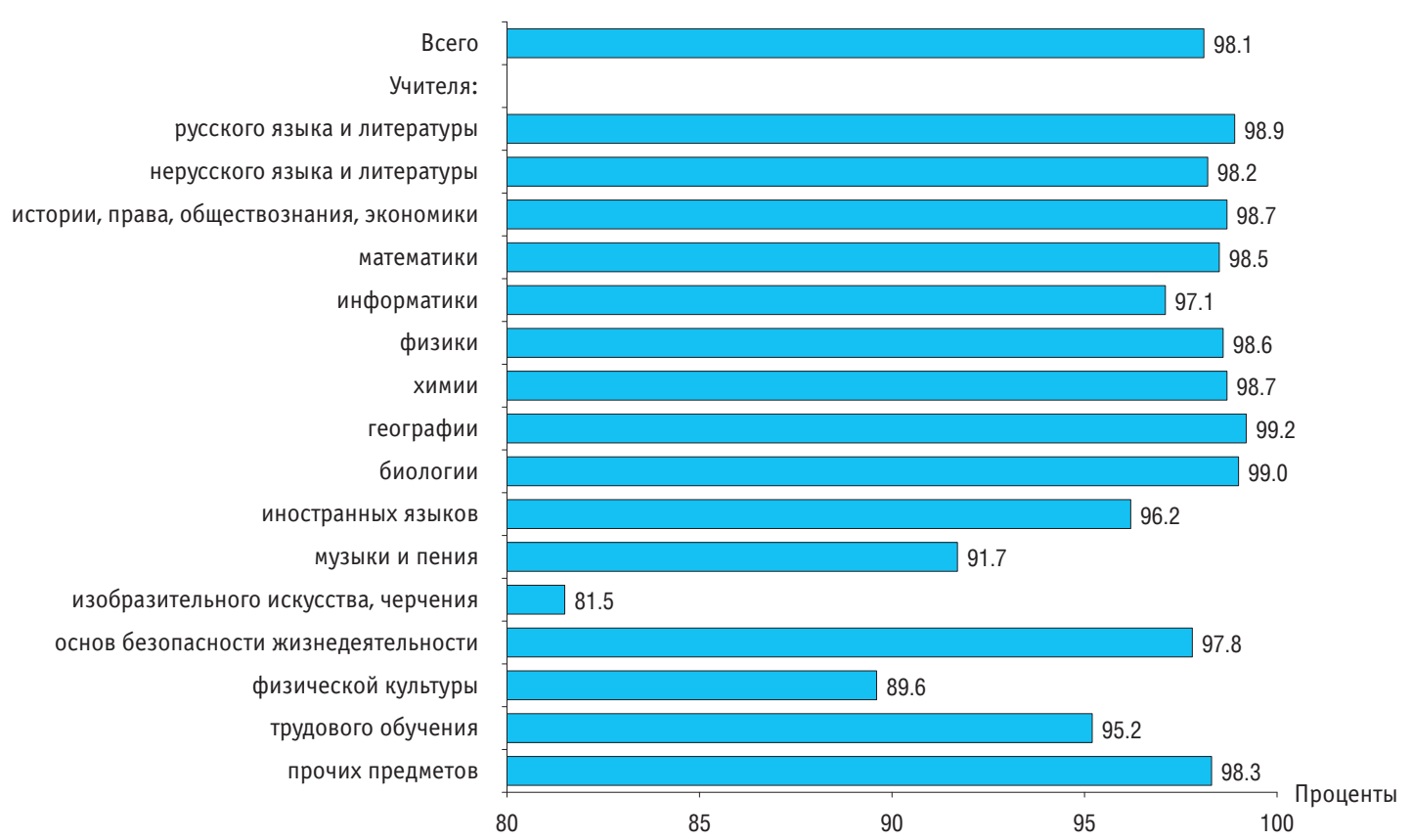

* На начало 2015/2016 учебного года. 


\subsection{9. ЧИСЛЕННОСТЬ ЖЕНЩИН В СОСТАВЕ УЧИТЕЛЕЙ ОБЩЕОБРАЗОВАТЕЛЬНЫХ ОРГАНИЗАЦИЙ ПО СПЕЦИАЛЬНОСТЯМ (на 20 сентября)}

\begin{tabular}{|c|c|c|c|c|c|c|c|c|c|c|c|c|c|c|c|}
\hline & \multicolumn{5}{|c|}{ Bcero } & \multicolumn{5}{|c|}{$\begin{array}{c}\text { Общеобразовательные организации } \\
\text { (без вечерних (сменных) } \\
\text { общеобразовательных организаций) }\end{array}$} & \multicolumn{5}{|c|}{$\begin{array}{c}\text { Вечерние (сменные) } \\
\text { общеобразовательные организации* }\end{array}$} \\
\hline & 2011 & 2012 & 2013 & 2014 & 2015 & 2011 & 2012 & 2013 & 2014 & 2015 & 2011 & 2012 & 2013 & 2014 & 2015 \\
\hline \multicolumn{16}{|c|}{ Тысячи человек } \\
\hline Всего & 930.6 & 925.0 & 926.0 & 943.8 & 943.3 & 920.4 & 915.6 & 917.8 & 936.6 & 937.6 & 10.1 & 9.4 & 8.3 & 7.1 & 5.7 \\
\hline \multicolumn{16}{|l|}{ Учителя: } \\
\hline 1-4 классов & 276.1 & 279.1 & 282.9 & 290.8 & 294.7 & 276.1 & 279.1 & 282.9 & 290.8 & 294.7 & - & - & - & - & - \\
\hline русского языка и литературы & 125.4 & 123.6 & 123.0 & 124.8 & 123.9 & 123.0 & 121.3 & 121.1 & 123.1 & 122.5 & 2.5 & 2.3 & 2.0 & 1.7 & 1.3 \\
\hline нерусского языка и литературы & 18.3 & 18.2 & 18.1 & 18.8 & 18.2 & 18.2 & 18.1 & 18.0 & 18.7 & 18.1 & 0.1 & 0.1 & 0.1 & 0.1 & 0.1 \\
\hline $\begin{array}{l}\text { истории, права, обществознания, } \\
\text { экономики }\end{array}$ & 52.9 & 52.7 & 52.7 & 53.7 & 53.6 & 51.7 & 51.5 & 51.7 & 52.8 & 52.9 & 1.2 & 1.1 & 1.0 & 0.9 & 0.7 \\
\hline математики & 96.6 & 94.9 & 94.6 & 95.4 & 94.7 & 94.7 & 93.2 & 93.0 & 94.1 & 93.7 & 1.9 & 1.7 & 1.6 & 1.3 & 1.0 \\
\hline информатики & 22.4 & 22.1 & 22.0 & 22.0 & 21.6 & 22.1 & 21.8 & 21.7 & 21.8 & 21.5 & 0.2 & 0.2 & 0.2 & 0.2 & 0.1 \\
\hline физики & 27.7 & 26.9 & 26.5 & 26.5 & 26.0 & 26.8 & 26.2 & 25.8 & 25.9 & 25.6 & 0.8 & 0.7 & 0.7 & 0.6 & 0.4 \\
\hline химии & 27.5 & 26.7 & 26.1 & 25.9 & 25.1 & 26.6 & 25.8 & 25.3 & 25.3 & 24.6 & 1.0 & 0.9 & 0.7 & 0.6 & 0.5 \\
\hline географии & 30.0 & 29.3 & 28.8 & 29.1 & 28.8 & 29.5 & 28.8 & 28.4 & 28.7 & 28.5 & 0.5 & 0.5 & 0.4 & 0.4 & 0.3 \\
\hline биологии & 32.0 & 31.3 & 31.1 & 31.2 & 30.8 & 31.4 & 30.8 & 30.6 & 30.8 & 30.4 & 0.6 & 0.6 & 0.5 & 0.4 & 0.3 \\
\hline иностранных языков & 107.8 & 107.6 & 107.9 & 111.0 & 111.5 & 106.9 & 106.8 & 107.1 & 110.3 & 111.0 & 0.9 & 0.8 & 0.7 & 0.7 & 0.6 \\
\hline музыки и пения & 21.1 & 20.6 & 20.3 & 20.8 & 20.8 & 21.1 & 20.6 & 20.3 & 20.8 & 20.7 & 0.0 & 0.0 & 0.0 & 0.0 & 0.0 \\
\hline изобразительного искусства, черчения & 17.4 & 17.1 & 16.9 & 17.2 & 16.9 & 17.4 & 17.1 & 16.9 & 17.1 & 16.9 & 0.0 & 0.0 & 0.0 & 0.0 & 0.0 \\
\hline основ безопасности жизнедеятельности & 4.1 & 3.8 & 3.6 & 3.7 & 3.6 & 4.1 & 3.8 & 3.6 & 3.7 & 3.6 & 0.0 & 0.0 & 0.0 & 0.0 & 0.0 \\
\hline физической культуры & 31.9 & 32.7 & 33.3 & 34.5 & 34.6 & 31.9 & 32.7 & 33.3 & 34.4 & 34.6 & 0.0 & 0.0 & 0.0 & 0.0 & 0.0 \\
\hline трудового обучения & 29.1 & 28.2 & 27.9 & 28.0 & 27.7 & 29.0 & 28.1 & 27.8 & 27.9 & 27.6 & 0.1 & 0.1 & 0.1 & 0.1 & 0.1 \\
\hline прочих предметов & 10.2 & 10.1 & 10.3 & 10.4 & 10.8 & 10.1 & 9.9 & 10.2 & 10.3 & 10.7 & 0.2 & 0.1 & 0.2 & 0.1 & 0.1 \\
\hline
\end{tabular}


(окончание)

\begin{tabular}{|c|c|c|c|c|c|c|c|c|c|c|c|c|c|c|c|}
\hline & \multicolumn{5}{|c|}{ Bcero } & \multicolumn{5}{|c|}{$\begin{array}{c}\text { Общеобразовательные организации } \\
\text { (без вечерних (сменных) } \\
\text { общеобрразовательных организаций) }\end{array}$} & \multicolumn{5}{|c|}{$\begin{array}{c}\text { Вечерние (сменные) } \\
\text { общеобразовательные организации* }\end{array}$} \\
\hline & 2011 & 2012 & 2013 & 2014 & 2015 & 2011 & 2012 & 2013 & 2014 & 2015 & 2011 & 2012 & 2013 & 2014 & 2015 \\
\hline \multicolumn{16}{|c|}{ В процентах от общей численности } \\
\hline Всего & 87.8 & 87.7 & 87.7 & 87.7 & 87.6 & 87.8 & 87.7 & 87.7 & 87.7 & 87.6 & 83.7 & 83.3 & 82.8 & 81.6 & 79.3 \\
\hline \multicolumn{16}{|l|}{ Учителя: } \\
\hline 1-4 классов & 99.0 & 98.9 & 98.8 & 98.9 & 98.9 & 99.0 & 98.9 & 98.8 & 98.9 & 98.9 & - & - & - & - & - \\
\hline русского языка и литературы & 97.6 & 97.3 & 97.4 & 97.4 & 97.4 & 97.7 & 97.4 & 97.5 & 97.5 & 97.5 & 92.7 & 92.3 & 92.3 & 91.1 & 89.3 \\
\hline нерусского языка и литературы & 93.9 & 94.0 & 93.7 & 93.8 & 94.2 & 94.0 & 94.0 & 93.8 & 93.9 & 94.4 & 80.8 & 80.0 & 77.3 & 80.5 & 70.9 \\
\hline \multicolumn{16}{|l|}{ истории, права, обществознания, } \\
\hline экономики & 81.7 & 81.4 & 81.3 & 81.1 & 80.5 & 82.0 & 81.6 & 81.6 & 81.4 & 80.7 & 71.0 & 71.0 & 71.1 & 69.8 & 67.7 \\
\hline математики & 94.1 & 93.8 & 93.9 & 93.6 & 93.3 & 94.3 & 93.9 & 94.0 & 93.7 & 93.4 & 87.1 & 86.9 & 88.1 & 86.7 & 85.6 \\
\hline информатики & 74.3 & 73.6 & 73.5 & 72.9 & 72.6 & 74.3 & 73.7 & 73.6 & 73.0 & 72.7 & 69.4 & 69.5 & 68.7 & 66.7 & 58.5 \\
\hline физики & 77.0 & 76.7 & 76.9 & 76.8 & 76.5 & 77.1 & 76.8 & 77.0 & 76.9 & 76.6 & 73.4 & 72.3 & 73.1 & 70.8 & 69.9 \\
\hline химии & 92.7 & 92.9 & 92.4 & 92.7 & 92.4 & 92.8 & 93.0 & 92.6 & 92.8 & 92.6 & 89.1 & 88.4 & 87.1 & 86.7 & 85.5 \\
\hline географии & 88.8 & 88.5 & 88.4 & 88.4 & 88.1 & 88.9 & 88.6 & 88.5 & 88.5 & 88.3 & 83.9 & 83.4 & 80.6 & 79.9 & 76.3 \\
\hline биологии & 93.6 & 93.5 & 93.4 & 93.5 & 93.2 & 93.6 & 93.6 & 93.5 & 93.6 & 93.3 & 91.3 & 89.8 & 89.3 & 88.3 & 85.4 \\
\hline иностранных языков & 96.3 & 96.1 & 95.9 & 95.9 & 95.7 & 96.3 & 96.1 & 96.0 & 96.0 & 95.7 & 91.9 & 91.1 & 91.2 & 88.8 & 86.9 \\
\hline музыки и пения & 88.5 & 89.2 & 89.7 & 89.8 & 89.8 & 88.5 & 89.2 & 89.7 & 89.8 & 89.8 & 75.0 & 72.7 & 85.7 & 93.8 & 90.9 \\
\hline изобразительного искусства, черчения & 89.1 & 90.1 & 90.1 & 90.5 & 90.8 & 89.1 & 90.1 & 90.1 & 90.5 & 90.8 & 89.7 & 90.9 & 100 & 86.4 & 95.5 \\
\hline основ безопасности жизнедеятельности & 23.9 & 24.3 & 24.0 & 24.9 & 24.7 & 23.8 & 24.2 & 23.9 & 24.8 & 24.6 & 40.9 & 40.7 & 40.9 & 36.8 & 33.0 \\
\hline физической культуры & 46.1 & 45.8 & 45.4 & 45.2 & 44.7 & 46.1 & 45.8 & 45.4 & 45.2 & 44.7 & 40.8 & 41.3 & 36.7 & 38.9 & 31.7 \\
\hline трудового обучения & 59.7 & 60.3 & 60.5 & 61.0 & 61.2 & 59.6 & 60.3 & 60.5 & 60.9 & 61.2 & 66.4 & 70.7 & 72.1 & 72.7 & 71.0 \\
\hline прочих предметов & 88.0 & 84.6 & 86.2 & 86.9 & 87.4 & 87.9 & 84.5 & 86.3 & 87.0 & 87.3 & 88.8 & 88.7 & 78.5 & 80.2 & 90.7 \\
\hline
\end{tabular}

* На начало соответствующего учебного года. 


\subsection{0. УРОВЕНЬ ОБРАЗОВАНИЯ И ВОЗРАСТНОЙ СОСТАВ УЧИТЕЛЕЙ ОБЩЕОБРАЗОВАТЕЛЬНЫХ ОРГАНИЗАЦИЙ \\ ПО СПЕЦИАЛЬНОСТЯМ: 2015 \\ (без внешних совместителей; на 20 сентября; проценты)}

\begin{tabular}{|c|c|c|c|c|c|c|c|}
\hline & \multirow[t]{2}{*}{ Всего } & \multicolumn{4}{|c|}{ Имеют образование } & \multicolumn{2}{|c|}{ Находятся в возрасте } \\
\hline & & высшее & $\begin{array}{c}\text { из них } \\
\text { педагогическое }\end{array}$ & $\begin{array}{c}\text { среднее про- } \\
\text { фессиональное } \\
\text { по программам } \\
\text { подготовки } \\
\text { специалистов } \\
\text { среднего звена }\end{array}$ & $\begin{array}{c}\text { из них } \\
\text { педагогическое }\end{array}$ & трудоспособном & $\begin{array}{c}\text { старше трудо- } \\
\text { способного }\end{array}$ \\
\hline Всего & 100 & 86.1 & 81.9 & 13.2 & 11.8 & 24.0 & 76.0 \\
\hline \multicolumn{8}{|l|}{ Учителя: } \\
\hline 1-4 классов & 100 & 74.3 & 72.8 & 25.2 & 24.7 & 19.3 & 80.7 \\
\hline русского языка и литературы & 100 & 96.8 & 95.5 & 2.8 & 2.6 & 30.1 & 69.9 \\
\hline нерусского языка и литературы & 100 & 91.4 & 90.0 & 8.1 & 7.8 & 19.3 & 80.7 \\
\hline истории, права, обществознания, экономики & 100 & 96.7 & 92.6 & 2.8 & 2.2 & 22.4 & 77.6 \\
\hline математики & 100 & 97.4 & 94.0 & 2.2 & 1.9 & 33.5 & 66.5 \\
\hline информатики & 100 & 91.9 & 76.7 & 7.2 & 5.2 & 11.3 & 88.7 \\
\hline химии & 100 & 98.6 & 92.8 & 0.9 & 0.6 & 34.2 & 65.8 \\
\hline географии & 100 & 96.2 & 92.3 & 3.2 & 2.7 & 27.9 & 72.1 \\
\hline биологии & 100 & 97.3 & 93.0 & 2.2 & 1.8 & 29.3 & 70.7 \\
\hline иностранных языков & 100 & 94.4 & 90.6 & 5.0 & 4.7 & 21.7 & 78.3 \\
\hline музыки и пения & 100 & 61.6 & 54.1 & 37.1 & 30.1 & 23.8 & 76.2 \\
\hline изобразительного искусства, черчения & 100 & 71.6 & 61.8 & 26.9 & 21.6 & 22.1 & 77.9 \\
\hline основ безопасности жизнедеятельности & 100 & 82.2 & 62.0 & 16.0 & 10.1 & 24.0 & 76.0 \\
\hline физической культуры & 100 & 77.8 & 72.9 & 20.7 & 18.5 & 15.6 & 84.4 \\
\hline трудового обучения & 100 & 69.1 & 55.9 & 28.0 & 16.7 & 29.5 & 70.5 \\
\hline прочих предметов & 100 & 81.8 & 71.9 & 16.2 & 12.5 & 29.0 & 71.0 \\
\hline
\end{tabular}




\subsection{1. ЧИСЛЕННОСТЬ ОБУЧАЮЩИХСЯ В ОБЩЕОБРАЗОВАТЕЛЬНЫХ ОРГАНИЗАЦИЯХ \\ В РАСЧЕТЕ НА ОДНОГО УЧИТЕЛЯ \\ (на начало учебного года)}

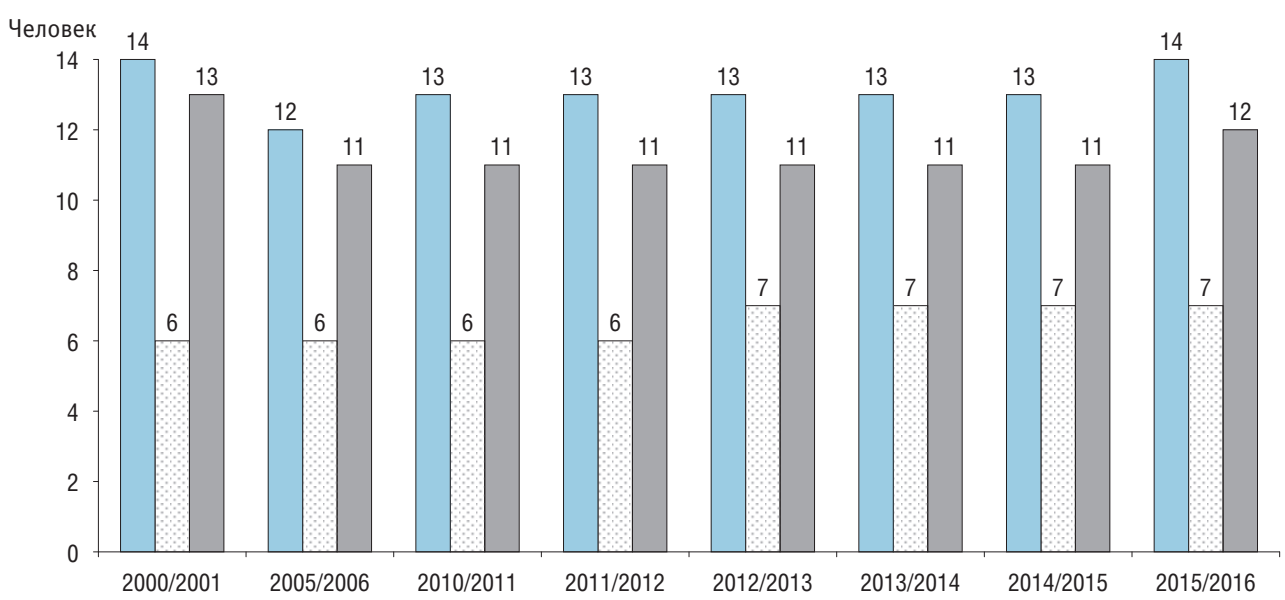

$\square$ Государственные и муниципальные общеобразовательные организации (без вечерних (сменных)

общеобразовательных организаций)
․․ Частные общеобразовательные организации (без вечерних (сменных) общеобразовательных организаций) $\square$ Вечерние (сменные) общеобразовательные организации 


\subsection{2. ОБЩАЯ ХАРАКТЕРИСТИКА УЧИТЕЛЕЙ И ДИРЕКТОРОВ* \\ (в процентах от численности опрошенных)}

\section{Директора}

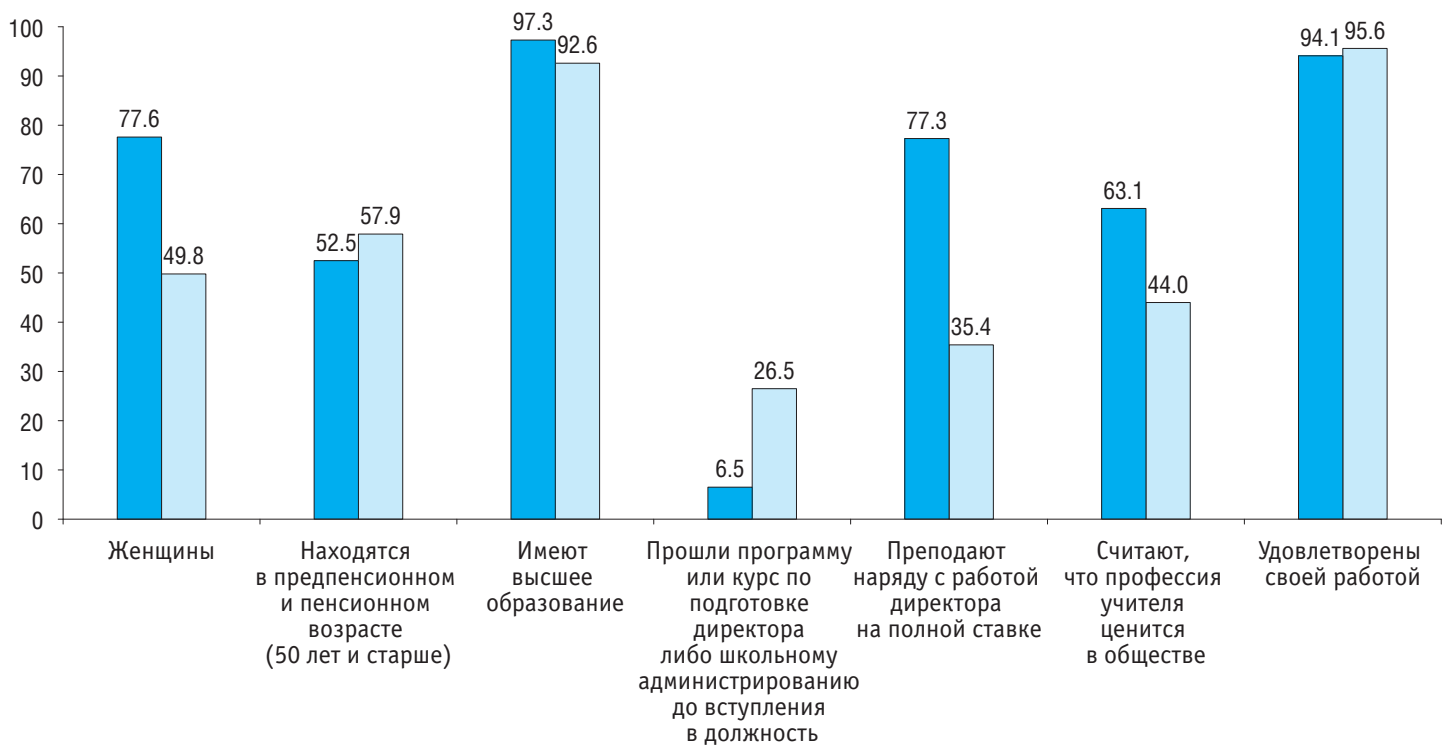

$\square$ Россия $\square$ MC

* Здесь и далее (рис. 5.33-5.38) - по результатам международного исследования учительского корпуса TALIS 2013; источник данных по международным средним показателям (МС), средним по странам ОЭСР (ОЭСР), девяти лидирующим странам (Н9) и восьми странам, устойчиво занимающим низкие позиции (L8) в международных сравнительных исследованиях в области образования, - OECD, TALIS 2013 International Database (https://data.oecd.org). 
(окончание)

\section{Учителя}

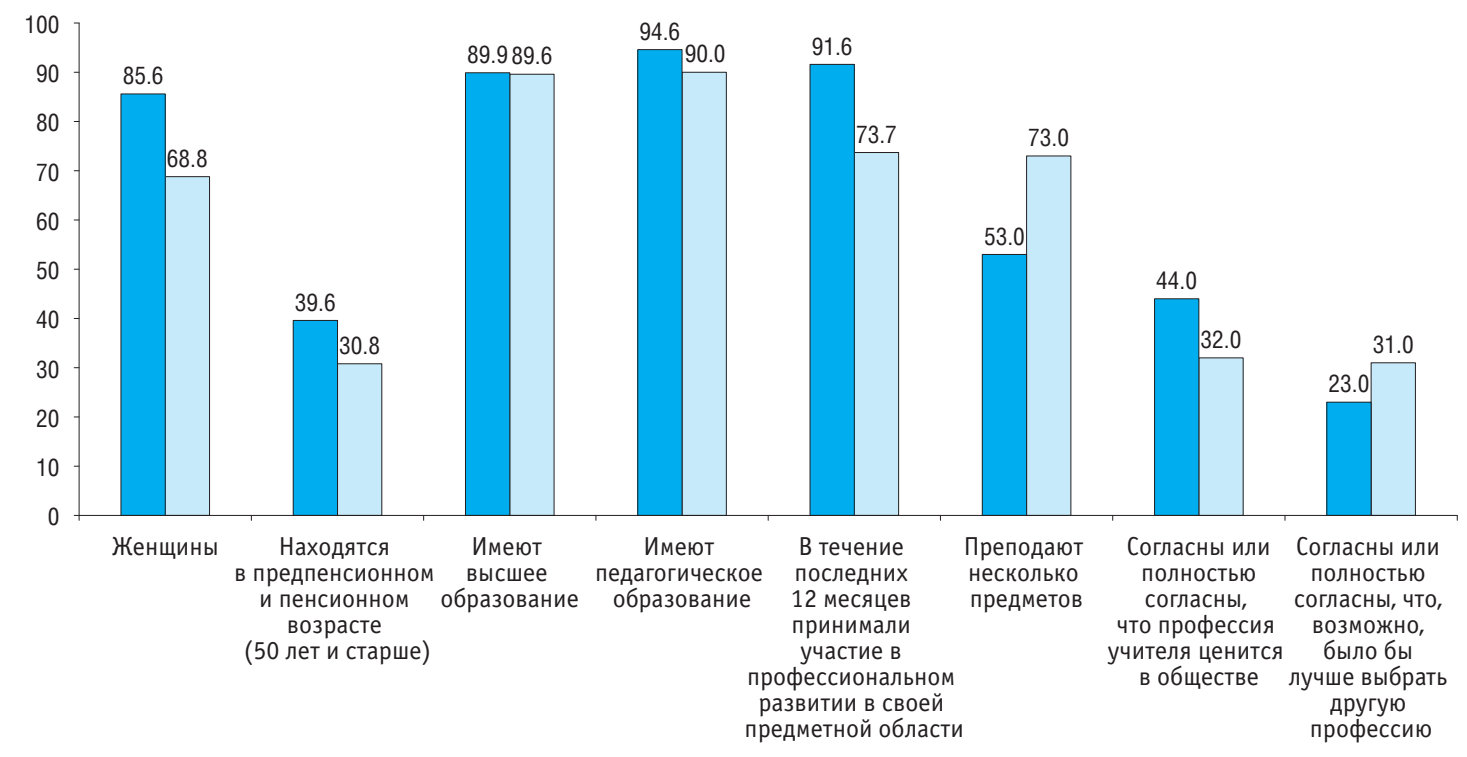


5.33. СРЕДНИЙ ВОЗРАСТ УЧИТЕЛЕЙ И ДИРЕКТОРОВ

(лет)

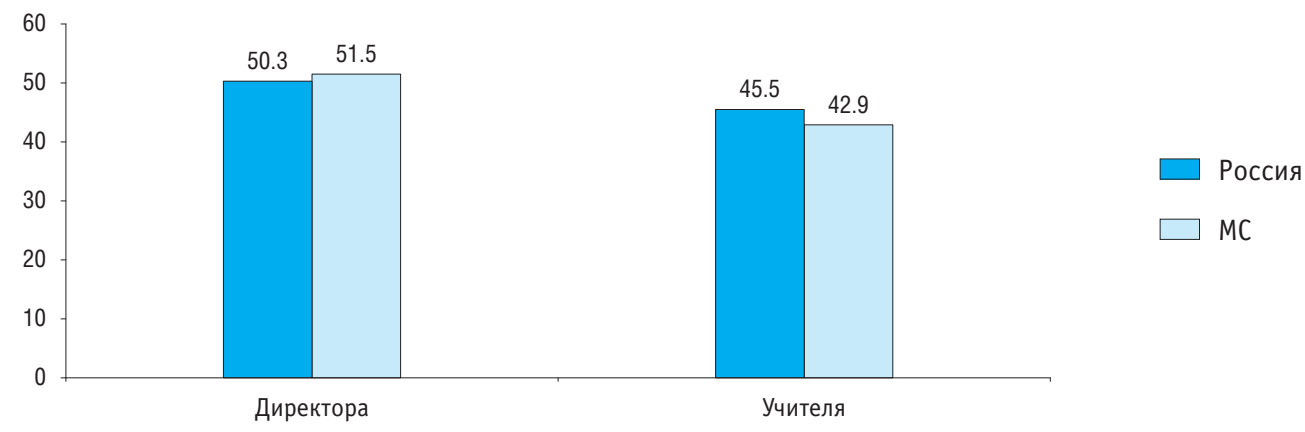

5.34. ОБЩАЯ НЕДЕЛЬНАЯ НАГРУЗКА УЧИТЕЛЕЙ

(количество часов, потраченных в течение одной рабочей недели)

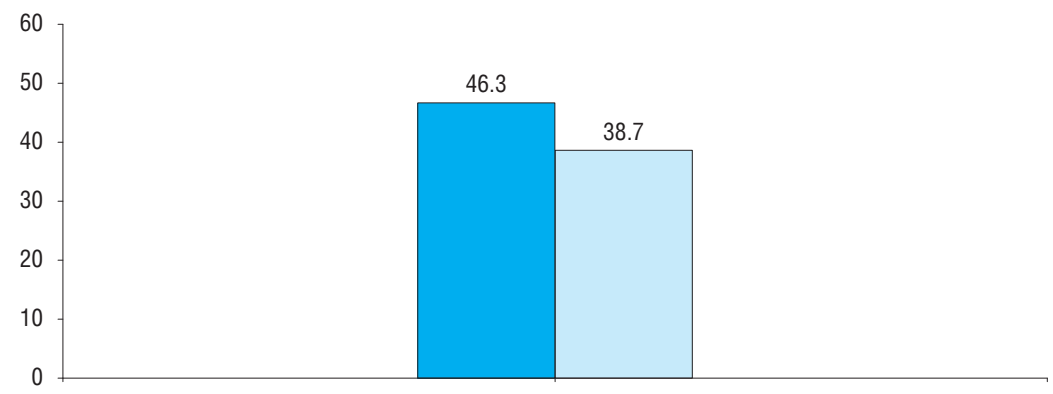

$\square$ Россия

$\square \mathrm{MC}$ 


\subsection{5. РАСПРЕДЕЛЕНИЕ ВРЕМЕНИ УЧИТЕЛЕЙ И ДИРЕКТОРОВ ПО ВИДАМ ДЕЯТЕЛЬНОСТИ}

(количество часов, потраченных в течение одной рабочей недели)

\section{Директора}

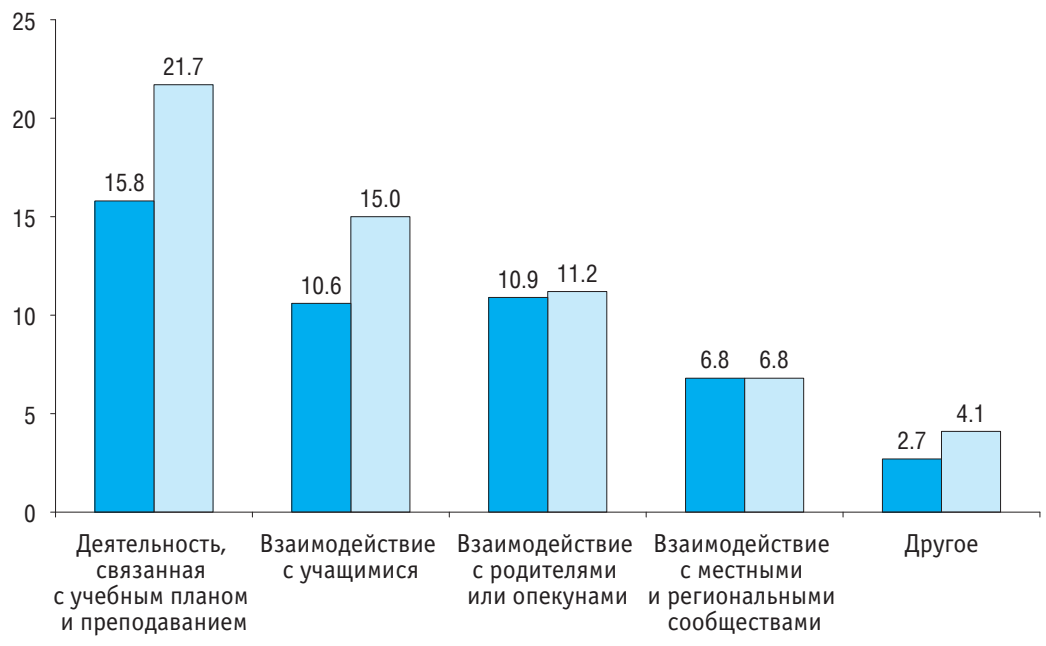

$\square$ Россия $\square$ MC 


\section{Учителя}

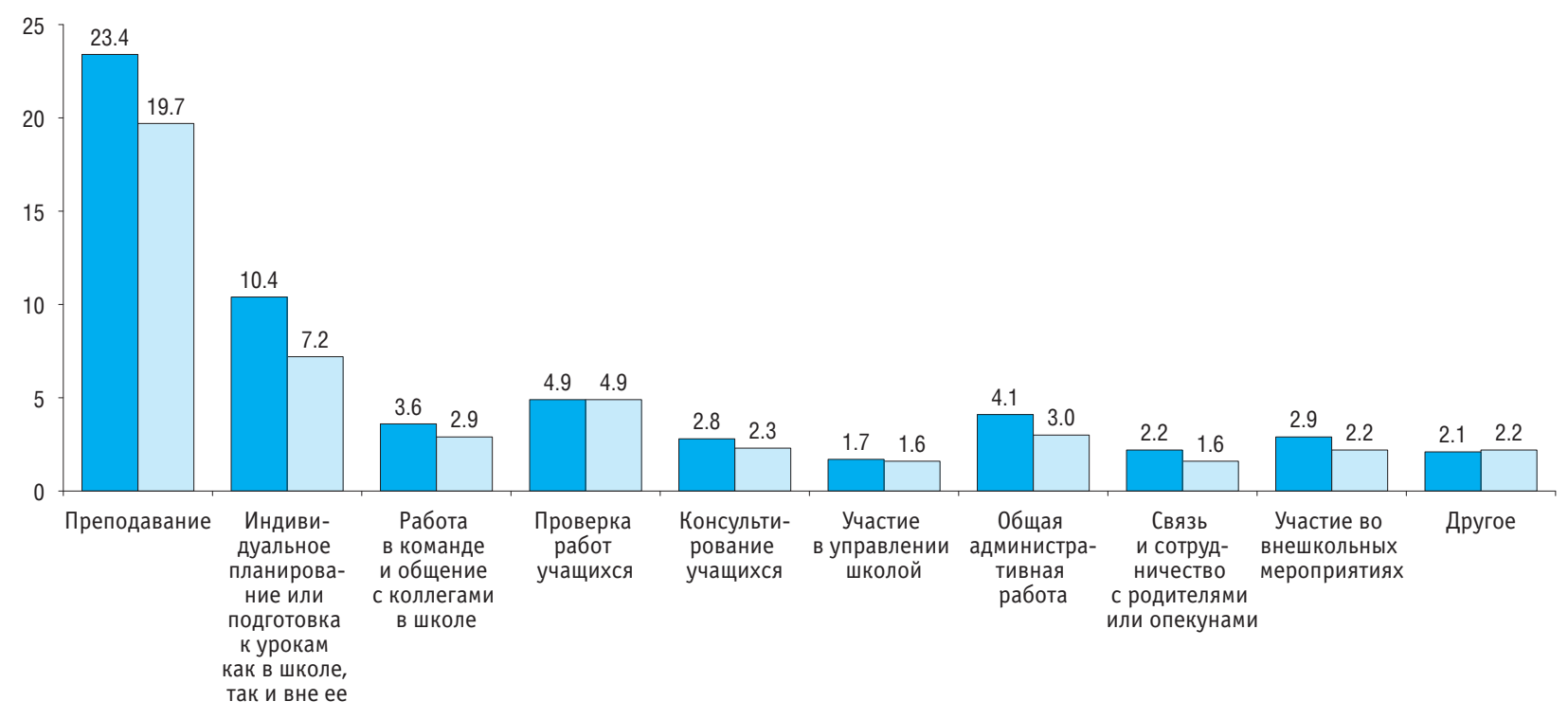

Россия $\quad \square$ MC 


\subsection{6. ПОТРЕБНОСТЬ УЧИТЕЛЕЙ В ПРОФЕССИОНАЛЬНОМ РАЗВИТИИ}

(доля оценивших потребность в том или ином виде профессионального развития как «среднюю» или «высокую» в общем числе опрощенных; проценты)

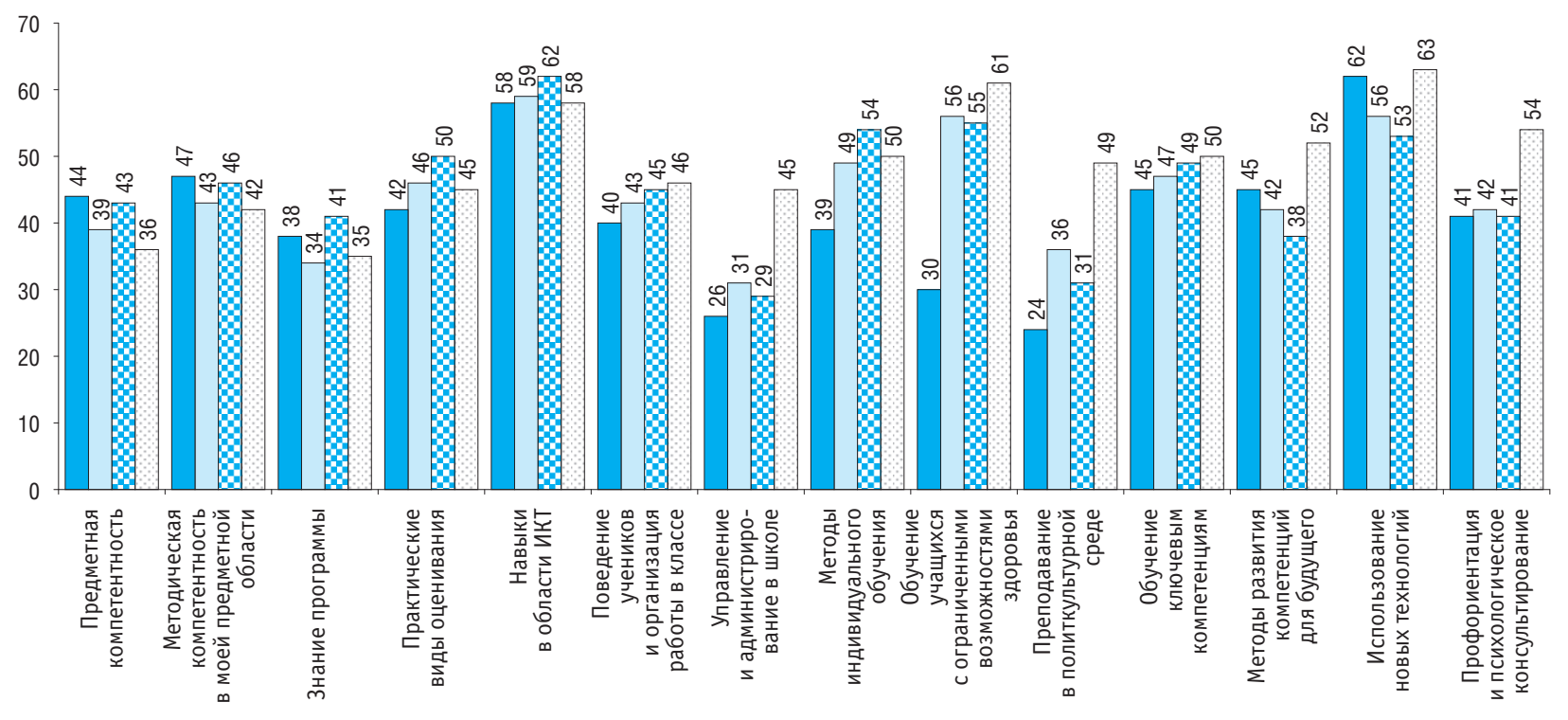

Россия

ОЭСР

DH9

L8 


\subsection{7. БАРЬЕРЫ ПРОФЕССИОНАЛЬНОГО РАЗВИТИЯ УЧИТЕЛЕЙ}

(доля согласных или абсолютно согласных, что указанные причины мешают их профессиональному развитию, в общем числе опрошенных; проценты)

Россия

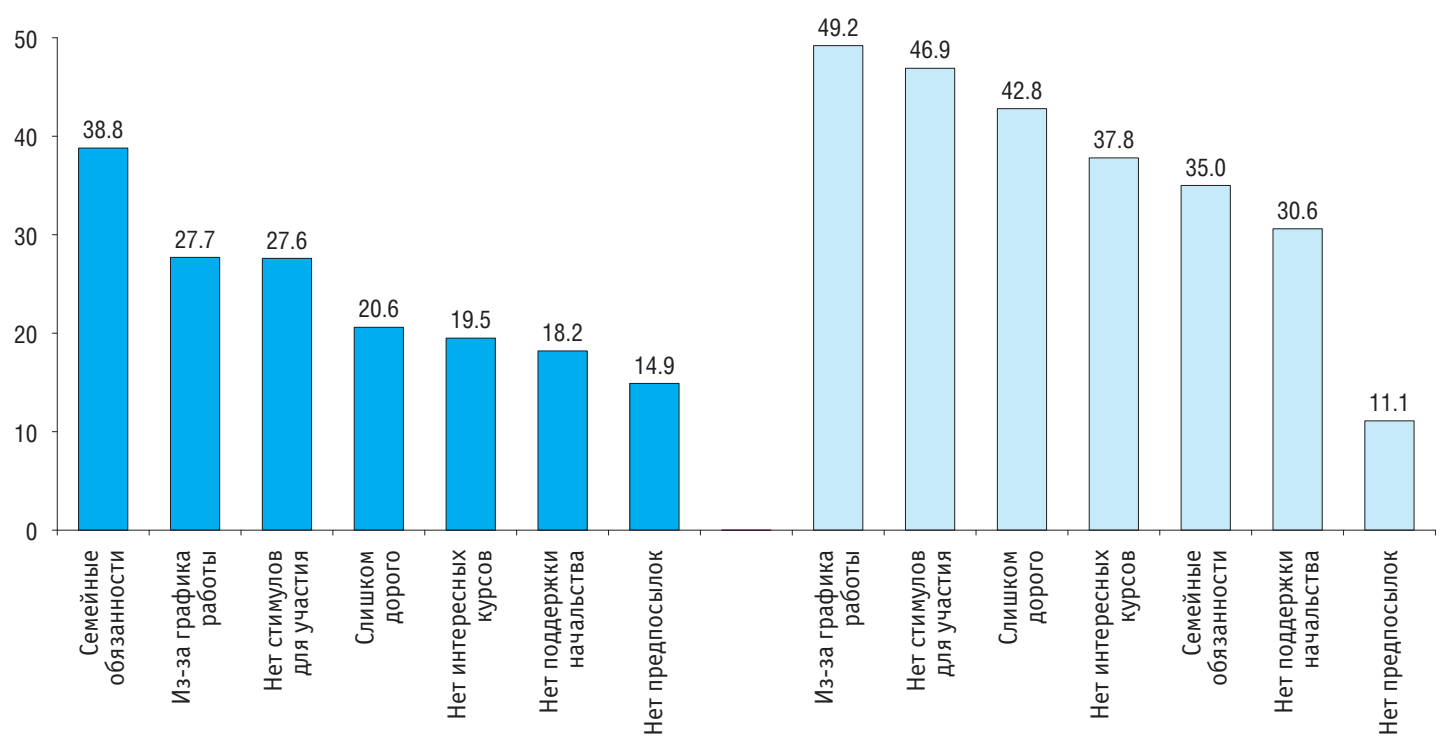




\subsection{8. ПОСЛЕДСТВИЯ ОЦЕНКИ КАЧЕСТВА РАБОТЫ УЧИТЕЛЕЙ}

(доля выбравших соответствующий ответ в общем числе опрошенных; проценты)

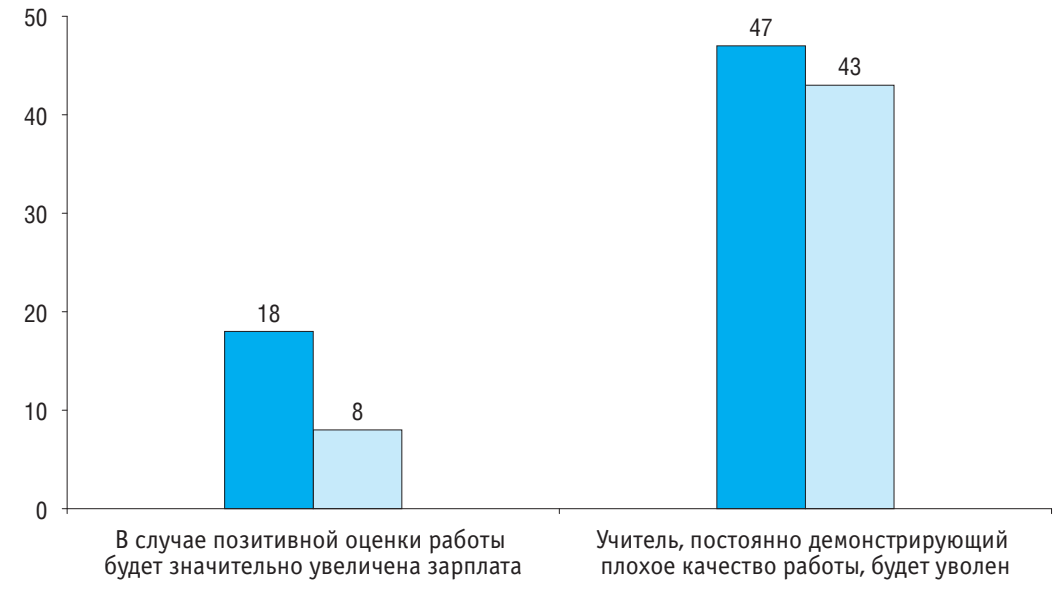

Россия $\square$ MC 


\subsection{9. ЧИСЛЕННОСТЬ РАБОТНИКОВ ОБРАЗОВАТЕЛЬНЫХ ОРГАНИЗАЦИЙ ДОПОЛНИТЕЛЬНОГО ОБРАЗОВАНИЯ, РЕАЛИЗУЮЩИХ ДОПОЛНИТЕЛЬНЫЕ ОБЩЕОБРАЗОВАТЕЛЬНЫЕ ПРОГРАММЫ ДЛЯ ДЕТЕЙ, ПО КАТЕГОРИЯМ}

(на конец года; тысячи человек)

\begin{tabular}{|c|c|c|c|c|c|c|c|c|c|c|c|c|c|c|}
\hline & \multicolumn{7}{|c|}{ Численность работников (без внешних совместителей) } & \multicolumn{7}{|c|}{ Численность внешних совместителей } \\
\hline & 2009 & 2010 & 2011 & 2012 & 2013 & 2014 & 2015 & 2009 & 2010 & 2011 & 2012 & 2013 & 2014 & 2015 \\
\hline Всего & 315.2 & 307.4 & 291.1 & 306.8 & 371.1 & 424.0 & 522.1 & 122.8 & 118.0 & 115.4 & 114.8 & 119.2 & 115.4 & 121.8 \\
\hline Руководящие работники & 30.4 & 30.4 & 29.0 & 31.0 & 36.3 & 40.1 & 47.7 & 0.6 & 0.6 & 0.6 & 0.7 & 0.7 & 0.8 & 0.9 \\
\hline Педагогические работники & 192.8 & 185.5 & 175.5 & 183.2 & 218.1 & 245.6 & 304.2 & 110.4 & 105.7 & 103.4 & 101.8 & 102.7 & 97.2 & 100.1 \\
\hline Учебно-вспомогательный персонал & 14.1 & 14.9 & 14.4 & 15.7 & 17.9 & 20.5 & 24.8 & 2.2 & 2.3 & 2.2 & 2.5 & 3.1 & 3.3 & 4.1 \\
\hline Обслуживающий персонал & 77.8 & 76.6 & 72.2 & 76.9 & 98.8 & 117.8 & 145.3 & 9.6 & 9.4 & 9.3 & 9.7 & 12.7 & 14.1 & 16.8 \\
\hline
\end{tabular}

\subsection{0. ЧИСЛЕННОСТЬ ПЕДАГОГИЧЕСКИХ РАБОТНИКОВ ОБРАЗОВАТЕЛЬНЫХ ОРГАНИЗАЦИЙ ДОПОЛНИТЕЛЬНОГО ОБРАЗОВАНИЯ, РЕАЛИЗУЮЩИХ ДОПОЛНИТЕЛЬНЫЕ ОБЩЕОБРАЗОВАТЕЛЬНЫЕ ПРОГРАММЫ ДЛЯ ДЕТЕЙ, ПО ДОЛЖНОСТЯМ}

(на конец года; тысячи человек)

\begin{tabular}{|c|c|c|c|c|c|c|c|c|c|c|c|c|c|c|}
\hline & \multicolumn{7}{|c|}{ Численность работников (без внешних совместителей) } & \multicolumn{7}{|c|}{ Численность внешних совместителей } \\
\hline & 2009 & 2010 & 2011 & 2012 & 2013 & 2014 & 2015 & 2009 & 2010 & 2011 & 2012 & 2013 & 2014 & 2015 \\
\hline Всего & 192.8 & 185.5 & 175.5 & 183.2 & 218.1 & 245.6 & 304.2 & 110.4 & 105.7 & 103.4 & 101.8 & 102.7 & 97.2 & 100.1 \\
\hline Учителя & 2.1 & 1.6 & 1.3 & 1.9 & 4.6 & 6.6 & 7.7 & 1.3 & 1.6 & 1.5 & 1.3 & 1.7 & 2.1 & 2.2 \\
\hline $\begin{array}{l}\text { Педагоги дополнительного } \\
\text { образования }\end{array}$ & 114.9 & 110.0 & 106.0 & 107.7 & 117.7 & 118.5 & 132.0 & 81.1 & 77.3 & 76.5 & 74.1 & 70.3 & 62.1 & 58.0 \\
\hline Педагоги-организаторы & 9.9 & 9.6 & 9.5 & 9.5 & 9.7 & 9.9 & 9.7 & 1.6 & 1.5 & 1.6 & 1.6 & 1.5 & 1.2 & 1.2 \\
\hline Социальные педагоги & 0.7 & 0.6 & 0.7 & 0.5 & 0.5 & 0.5 & 0.7 & 0.2 & 0.1 & 0.1 & 0.1 & 0.1 & 0.1 & 0.1 \\
\hline Тренеры-преподаватели & 41.0 & 39.1 & 34.9 & 37.5 & 49.1 & 57.5 & 72.9 & 19.9 & 18.9 & 17.5 & 17.6 & 20.2 & 21.0 & 23.2 \\
\hline Методисты & 13.0 & 12.7 & 12.1 & 11.9 & 13.3 & 14.2 & 15.5 & 2.0 & 2.0 & 1.9 & 1.9 & 2.1 & 1.8 & 1.8 \\
\hline Другие педагогические работники & 11.3 & 11.8 & 11.0 & 14.2 & 23.2 & 38.4 & 65.7 & 4.2 & 4.2 & 4.2 & 5.2 & 6.8 & 9.0 & 13.5 \\
\hline
\end{tabular}


5.41. УКОМПЛЕКТОВАННОСТЬ ШТАТОВ ПЕДАГОГИЧЕСКИХ РАБОТНИКОВ ОБРАЗОВАТЕЛЬНЫХ ОРГАНИЗАЦИЙ ДОПОЛНИТЕЛЬНОГО ОБРАЗОВАНИЯ, РЕАЛИЗУЮЩИХ ДОПОЛНИТЕЛЬНЫЕ ОБЩЕОБРАЗОВАТЕЛЬНЫЕ ПРОГРАММЫ ДЛЯ ДЕТЕЙ: 2015

(на конец года)

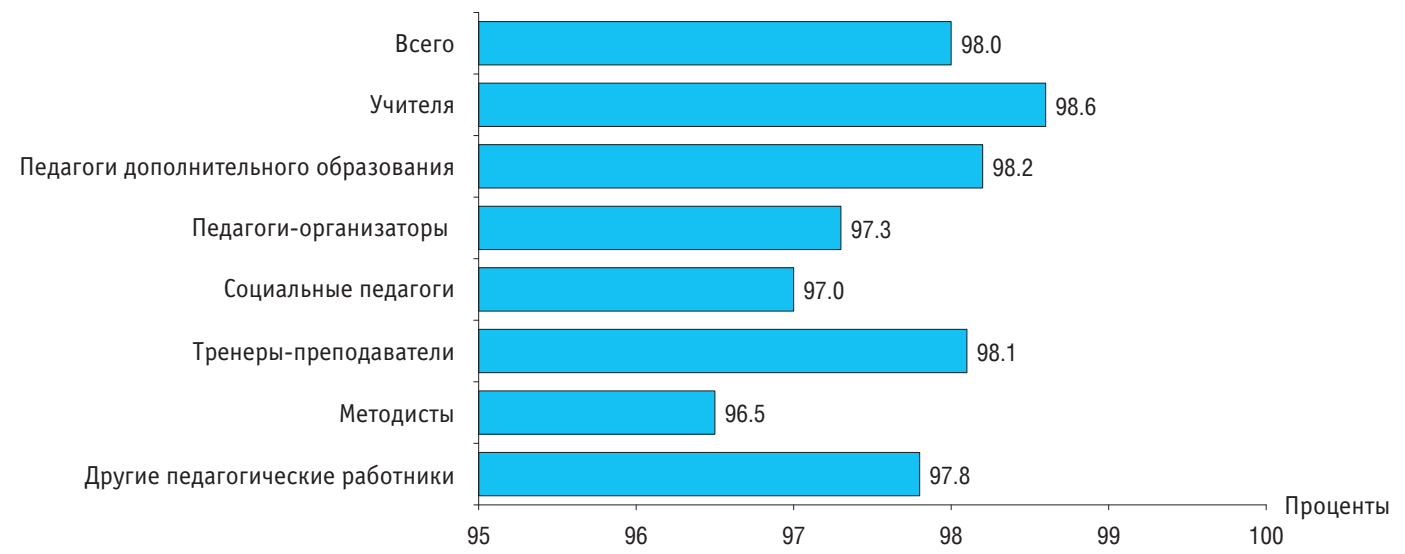




\subsection{2. ЧИСЛЕННОСТЬ ЖЕНЩИН В СОСТАВЕ ПЕДАГОГИЧЕСКИХ РАБОТНИКОВ ОБРАЗОВАТЕЛЬНЫХ ОРГАНИЗАЦИЙ ДОПОЛНИТЕЛЬНОГО ОБРАЗОВАНИЯ, РЕАЛИЗУЮЩИХ ДОПОЛНИТЕЛЬНЫЕ ОБЩЕОБРАЗОВАТЕЛЬНЫЕ ПРОГРАММЫ ДЛЯ ДЕТЕЙ, ПО ДОЛЖНОСТЯМ}

(без внешних совместителей; на конец года)

\begin{tabular}{|c|c|c|c|c|c|c|c|c|c|c|c|c|c|c|}
\hline & \multicolumn{7}{|c|}{ Всего, тыс. чел. } & \multicolumn{7}{|c|}{ В процентах от общей численности } \\
\hline & 2009 & 2010 & 2011 & 2012 & 2013 & 2014 & 2015 & 2009 & 2010 & 2011 & 2012 & 2013 & 2014 & 2015 \\
\hline Всего & 121.7 & 118.5 & 112.6 & 119.0 & 142.4 & 160.8 & 200.5 & 63.1 & 63.9 & 64.1 & 65.0 & 65.3 & 65.5 & 65.9 \\
\hline Учителя & 1.8 & 1.2 & 1.1 & 1.5 & 3.9 & 5.5 & 6.4 & 82.0 & 76.7 & 83.5 & 83.1 & 84.5 & 83.5 & 82.7 \\
\hline Педагоги дополнительного образования & 81.5 & 79.3 & 76.5 & 79.3 & 87.6 & 88.6 & 100.0 & 70.9 & 72.0 & 72.2 & 73.6 & 74.4 & 74.8 & 75.7 \\
\hline Педагоги-организаторы & 8.1 & 7.8 & 7.7 & 7.7 & 7.8 & 8.0 & 7.8 & 81.8 & 81.3 & 81.7 & 81.1 & 80.6 & 81.0 & 80.7 \\
\hline Социальные педагоги & 0.6 & 0.6 & 0.5 & 0.5 & 0.5 & 0.5 & 0.6 & 87.8 & 90.5 & 67.2 & 89.5 & 87.4 & 90.9 & 82.7 \\
\hline Тренеры-преподаватели & 11.5 & 10.9 & 9.1 & 9.9 & 14.1 & 16.0 & 21.1 & 28.1 & 27.9 & 25.9 & 26.4 & 28.8 & 27.8 & 29.0 \\
\hline Методисты & 10.6 & 10.5 & 9.9 & 9.7 & 10.9 & 11.5 & 12.6 & 81.9 & 82.3 & 82.0 & 81.9 & 81.4 & 81.5 & 81.3 \\
\hline Другие педагогические работники & 7.6 & 8.2 & 7.8 & 10.4 & 17.6 & 30.6 & 52.0 & 67.8 & 70.0 & 71.0 & 72.8 & 76.0 & 79.7 & 79.2 \\
\hline
\end{tabular}

\subsection{3. УРОВЕНЬ ОБРАЗОВАНИЯ ПЕДАГОГИЧЕСКИХ РАБОТНИКОВ ОБРАЗОВАТЕЛЬНЫХ ОРГАНИЗАЦИЙ ДОПОЛНИТЕЛЬНОГО ОБРАЗОВАНИЯ, РЕАЛИЗУЮЩИХ ДОПОЛНИТЕЛЬНЫЕ ОБЩЕОБРАЗОВАТЕЛЬНЫЕ ПРОГРАММЫ ДЛЯ ДЕТЕЙ (без внешних совместителей; на конец года; проценты)}

\begin{tabular}{|c|c|c|c|c|c|c|c|}
\hline & 2009 & 2010 & 2011 & 2012 & 2013 & 2014 & 2015 \\
\hline Всего & 100 & 100 & 100 & 100 & 100 & 100 & 100 \\
\hline \multicolumn{8}{|l|}{ Имеют образование: } \\
\hline высшее & 65.1 & 66.2 & 66.9 & 67.5 & 68.2 & 69.1 & 69.4 \\
\hline из них педагогическое & 50.9 & 51.3 & 51.8 & 52.1 & 53.4 & 53.9 & 55.5 \\
\hline \multicolumn{8}{|l|}{ среднее профессиональное по программам } \\
\hline подготовки специалистов среднего звена & 27.3 & 26.5 & 26.2 & 26.3 & 26.4 & 25.6 & 26.3 \\
\hline из них педагогическое & 16.6 & 16.1 & 15.8 & 16.4 & 17.6 & 17.4 & 19.3 \\
\hline
\end{tabular}




\subsection{4. УРОВЕНЬ ОБРАЗОВАНИЯ ПЕДАГОГИЧЕСКИХ РАБОТНИКОВ ОБРАЗОВАТЕЛЬНЫХ ОРГАНИЗАЦИЙ ДОПОЛНИТЕЛЬНОГО ОБРАЗОВАНИЯ, РЕАЛИЗУЮЩИХ ДОПОЛНИТЕЛЬНЫЕ ОБЩЕОБРАЗОВАТЕЛЬНЫЕ ПРОГРАММЫ ДЛЯ ДЕТЕЙ,}

ПО ДОЛЖНОСТЯМ: 2015

(без внешних совместителей; на конец года; проценты)

\begin{tabular}{|c|c|c|c|c|c|}
\hline & \multirow[t]{2}{*}{ Всего } & \multicolumn{4}{|c|}{ Имеют образование } \\
\hline & & высшее & $\begin{array}{c}\text { из них } \\
\text { педагогическое }\end{array}$ & $\begin{array}{c}\text { среднее } \\
\text { профессиональное } \\
\text { по программам } \\
\text { подготовки специалистов } \\
\text { среднего звена }\end{array}$ & $\begin{array}{c}\text { из них } \\
\text { педагогическое }\end{array}$ \\
\hline Всего & 100 & 69.4 & 55.5 & 26.3 & 19.3 \\
\hline Учителя & 100 & 68.4 & 60.7 & 30.6 & 26.4 \\
\hline Педагоги дополнительного образования & 100 & 66.0 & 51.7 & 30.3 & 21.5 \\
\hline Педагоги-организаторы & 100 & 70.9 & 47.1 & 23.3 & 12.3 \\
\hline Социальные педагоги & 100 & 76.8 & 61.2 & 17.6 & 13.1 \\
\hline Тренеры-преподаватели & 100 & 79.2 & 66.1 & 15.2 & 10.5 \\
\hline Методисты & 100 & 88.0 & 67.4 & 9.1 & 5.4 \\
\hline Другие педагогические работники & 100 & 60.9 & 49.2 & 34.4 & 28.4 \\
\hline
\end{tabular}


5.45. СТРУКТУРА ЧИСЛЕННОСТИ ПЕДАГОГИЧЕСКИХ РАБОТНИКОВ ОБРАЗОВАТЕЛЬНЫХ ОРГАНИЗАЦИЙ ДОПОЛНИТЕЛЬНОГО ОБРАЗОВАНИЯ, РЕАЛИЗУЮЩИХ ДОПОЛНИТЕЛЬНЫЕ ОБЩЕОБРАЗОВАТЕЛЬНЫЕ ПРОГРАММЫ ДЛЯ ДЕТЕЙ,

ПО ВОЗРАСТНЫМ ГРУППАМ

(без внешних совместителей; на конец года)

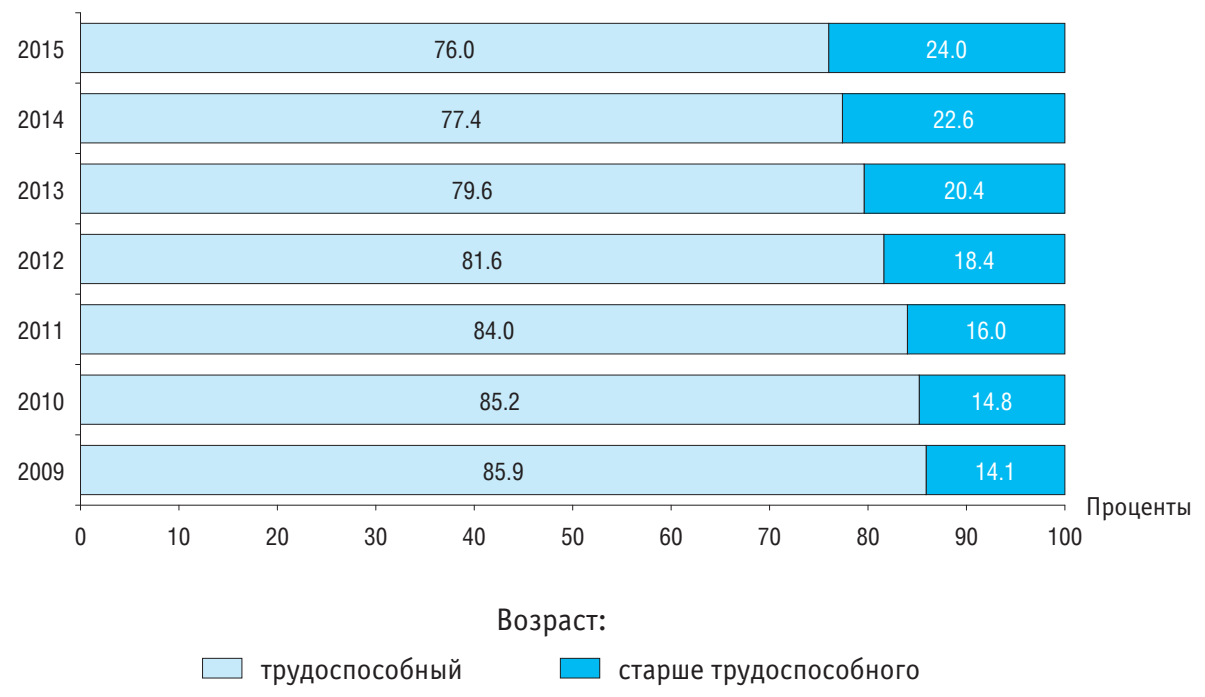


5.46. СТРУКТУРА ЧИСЛЕННОСТИ ПЕДАГОГИЧЕСКИХ РАБОТНИКОВ ОБРАЗОВАТЕЛЬНЫХ ОРГАНИЗАЦИЙ ДОПОЛНИТЕЛЬНОГО ОБРАЗОВАНИЯ, РЕАЛИЗУЮЩИХ ДОПОЛНИТЕЛЬНЫЕ ОБЩЕОБРАЗОВАТЕЛЬНЫЕ ПРОГРАММЫ ДЛЯ ДЕТЕЙ,

ПО ДОЛЖНОСТЯМ И В0ЗРАСТНЫМ ГРУППАМ: 2015

(без внешних совместителей; на конец года)

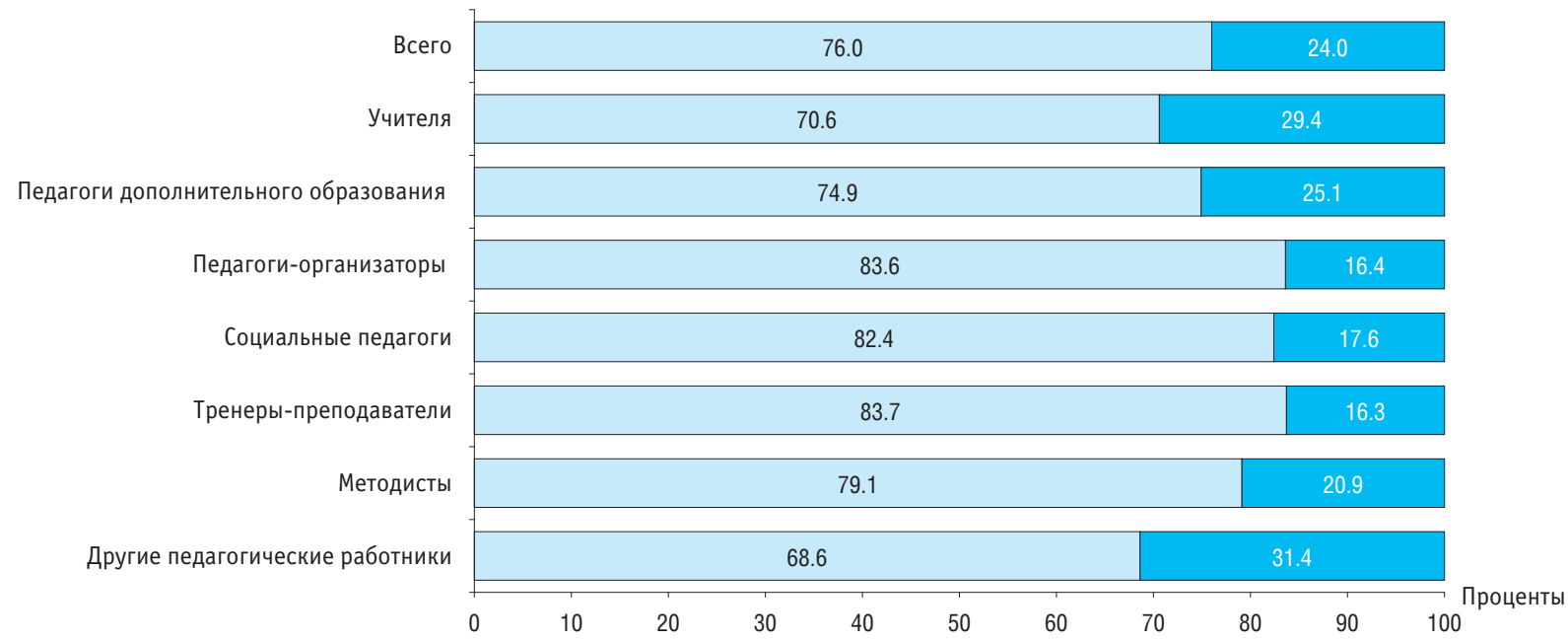

Возраст:

трудоспособный $\square$ старше трудоспособного 


\subsection{7. ЧИСЛЕННОСТЬ РАБОТНИКОВ ПРОФЕССИОНАЛЬНЫХ ОБРАЗОВАТЕЛЬНЫХ ОРГАНИЗАЦИЙ, РЕАЛИЗУЮЩИХ ОБРАЗОВАТЕЛЬНЫЕ ПРОГРАММЫ СРЕДНЕГО ПРОФЕССИОНАЛЬНОГО ОБРАЗОВАНИЯ - ПРОГРАММЫ ПОДГОТОВКИ КВАЛИФИЦИРОВАННЫХ РАБОЧИХ, СЛУЖАЩИХ, ПО КАТЕГОРИЯМ* \\ (на конец года; тысячи человек)}

\begin{tabular}{|c|c|c|c|c|c|c|c|c|c|c|c|c|c|c|}
\hline & \multicolumn{7}{|c|}{ Численность работников (без внешних совместителей) } & \multicolumn{7}{|c|}{ Численность внешних совместителей } \\
\hline & 2009 & 2010 & 2011 & 2012 & 2013 & 2014 & 2015 & 2009 & 2010 & 2011 & 2012 & 2013 & 2014 & 2015 \\
\hline Всего & 185.6 & 159.0 & 133.9 & 106.1 & 73.9 & 55.9 & 35.4 & 9.4 & 8.1 & 6.8 & 5.7 & 3.9 & 2.7 & 1.5 \\
\hline Руководящие работники & 19.1 & 16.3 & 13.9 & 11.1 & 8.0 & 6.0 & 4.0 & 0.1 & 0.1 & 0.1 & 0.0 & 0.0 & 0.0 & 0.0 \\
\hline Педагогические работники & 86.5 & 73.8 & 61.6 & 48.2 & 33.4 & 25.2 & 16.5 & 5.8 & 4.7 & 4.1 & 3.4 & 2.3 & 1.5 & 0.8 \\
\hline Учебно-вспомогательный персонал & 15.2 & 12.9 & 11.4 & 9.0 & 6.1 & 4.4 & 2.8 & 0.6 & 0.6 & 0.4 & 0.4 & 0.3 & 0.2 & 0.1 \\
\hline Обслуживающий персонал & 64.7 & 56.0 & 47.0 & 37.7 & 26.4 & 20.3 & 12.1 & 2.9 & 2.8 & 2.2 & 1.9 & 1.3 & 1.0 & 0.6 \\
\hline
\end{tabular}

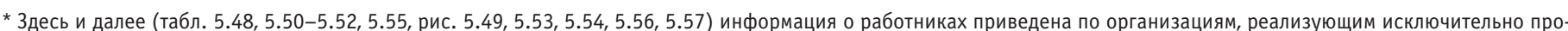

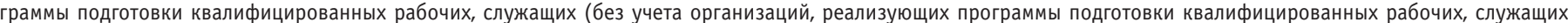
наряду с программами подготовки специалистов среднего звена). 
5.48. ЧИСЛЕННОСТЬ ПЕДАГОГИЧЕСКИХ РАБОТНИКОВ ПРОФЕССИОНАЛЬНЫХ ОБРАЗОВАТЕЛЬНЫХ ОРГАНИЗАЦИЙ, РЕАЛИЗУЮЩИХ ОБРАЗОВАТЕЛЬНЫЕ ПРОГРАММЫ СРЕДНЕГО ПРОФЕССИОНАЛЬНОГО ОБРАЗОВАНИЯ ПРОГРАММЫ ПОДГОТОВКИ КВАЛИФИЦИРОВАННЫХ РАБОЧИХ, СЛУЖАЩИХ, ПО ДОЛЖНОСТЯМ

(на конец года; тысячи человек)

\begin{tabular}{|c|c|c|c|c|c|c|c|c|c|c|c|c|c|c|}
\hline & \multicolumn{7}{|c|}{ Численность работников (без внешних совместителей) } & \multicolumn{7}{|c|}{ Численность внешних совместителей } \\
\hline & 2009 & 2010 & 2011 & 2012 & 2013 & 2014 & 2015 & 2009 & 2010 & 2011 & 2012 & 2013 & 2014 & 2015 \\
\hline Всего & 86.5 & 73.8 & 61.6 & 48.2 & 33.4 & 25.2 & 16.5 & 5.8 & 4.7 & 4.1 & 3.4 & 2.3 & 1.5 & 0.8 \\
\hline Преподаватели & 34.2 & 29.3 & 24.8 & 19.4 & 13.4 & 10.1 & 6.6 & 4.2 & 3.5 & 3.0 & 2.5 & 1.7 & 1.1 & 0.6 \\
\hline Мастера производственного обучения & 42.1 & 35.6 & 29.1 & 22.4 & 15.4 & 11.4 & 7.5 & 0.6 & 0.5 & 0.4 & 0.3 & 0.2 & 0.1 & 0.1 \\
\hline Воспитатели & 3.6 & 3.2 & 2.7 & 2.2 & 1.6 & 1.3 & 0.9 & 0.2 & 0.1 & 0.1 & 0.1 & 0.0 & 0.0 & 0.0 \\
\hline Социальные педагоги & 1.7 & 1.4 & 1.3 & 1.0 & 0.7 & 0.6 & 0.4 & 0.0 & 0.0 & 0.0 & 0.0 & 0.0 & 0.0 & 0.0 \\
\hline Психологи & 1.2 & 1.0 & 0.8 & 0.7 & 0.5 & 0.4 & 0.2 & 0.1 & 0.0 & 0.0 & 0.0 & 0.0 & 0.0 & 0.0 \\
\hline Методисты & 1.1 & 1.0 & 0.9 & 0.7 & 0.5 & 0.4 & 0.3 & 0.0 & 0.0 & 0.0 & 0.0 & 0,0 & 0.0 & 0.0 \\
\hline Другие педагогические работники & 2.6 & 2.3 & 2.0 & 1.8 & 1.2 & 1.0 & 0.6 & 0.7 & 0.6 & 0.5 & 0.4 & 0.3 & 0.2 & 0.1 \\
\hline
\end{tabular}


5.49. УКОМПЛЕКТОВАННОСТЬ ШТАТОВ ПЕДАГОГИЧЕСКИХ РАБОТНИКОВ ПРОФЕССИОНАЛЬНЫХ ОБРАЗОВАТЕЛЬНЫХ ОРГАНИЗАЦИЙ, РЕАЛИЗУЮЩИХ ОБРАЗОВАТЕЛЬНЫЕ ПРОГРАММЫ СРЕДНЕГО ПРОФЕССИОНАЛЬНОГО ОБРАЗОВАНИЯ ПРОГРАММЫ ПОДГОТОВКИ КВАЛИФИЦИРОВАННЫХ РАБОЧИХ, СЛУЖАЩИХ, ПО ДОЛЖНОСТЯМ: 2015 (на конец года)

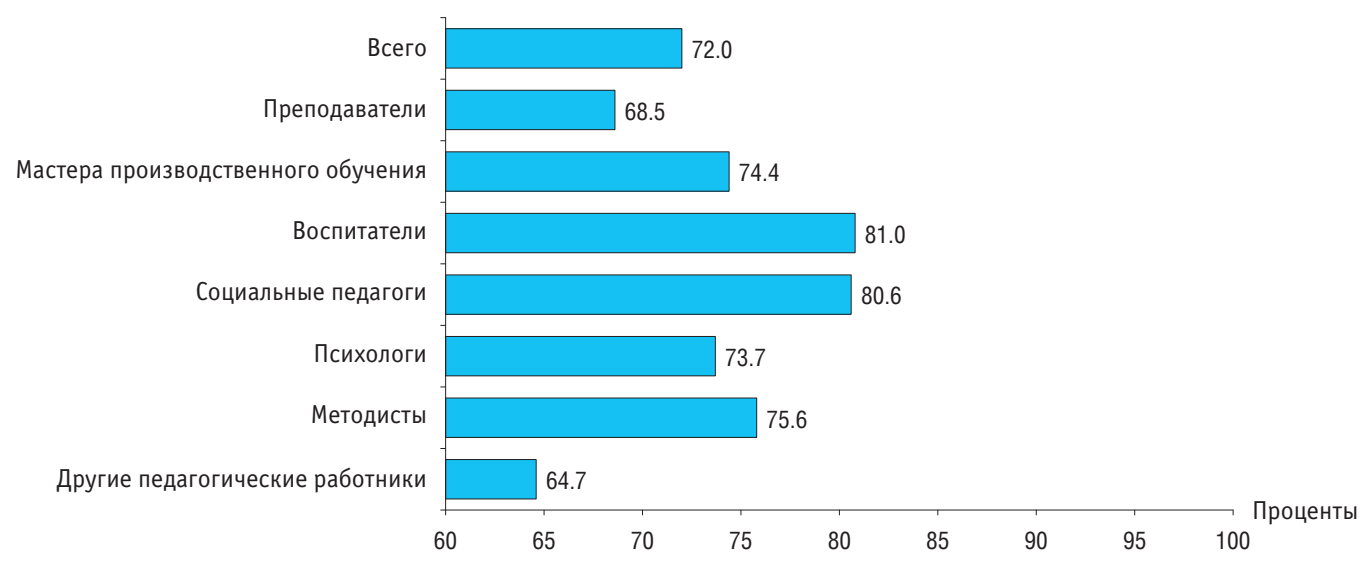


5.50. ЧИСЛЕННОСТЬ ЖЕНЩИН В СОСТАВЕ ПЕДАГОГИЧЕСКИХ РАБОТНИКОВ ПРОФЕССИОНАЛЬНЫХ ОБРАЗОВАТЕЛЬНЫХ ОРГАНИЗАЦИЙ, РЕАЛИЗУЮЩИХ ОБРАЗОВАТЕЛЬНЫЕ ПРОГРАММЫ СРЕДНЕГО ПРОФЕССИОНАЛЬНОГО ОБРАЗОВАНИЯ ПРОГРАММЫ ПОДГОТОВКИ КВАЛИФИЦИРОВАННЫХ РАБОЧИХ, СЛУЖАЩИХ, ПО ДОЛЖНОСТЯМ

(без внешних совместителей; на конец года)

\begin{tabular}{|c|c|c|c|c|c|c|c|c|c|c|c|c|c|c|}
\hline & \multicolumn{7}{|c|}{ Всего, тыс. чел. } & \multicolumn{7}{|c|}{ В процентах от общей численности } \\
\hline & 2009 & 2010 & 2011 & 2012 & 2013 & 2014 & 2015 & 2009 & 2010 & 2011 & 2012 & 2013 & 2014 & 2015 \\
\hline Всего & 55.6 & 46.9 & 39.3 & 30.3 & 20.4 & 15.1 & 9.4 & 64.2 & 63.5 & 63.8 & 62.9 & 61.1 & 59.9 & 56.8 \\
\hline Преподаватели & 23.9 & 20.1 & 17.3 & 13.4 & 9.2 & 7.0 & 4.4 & 69.8 & 68.7 & 69.7 & 69.3 & 68.9 & 68.6 & 66.1 \\
\hline Мастера производственного обучения & 23.0 & 19.3 & 15.6 & 11.7 & 7.4 & 5.2 & 3.0 & 54.7 & 54.3 & 53.5 & 52.0 & 47.8 & 45.6 & 40.8 \\
\hline Воспитатели & 3.3 & 2.9 & 2.4 & 1.9 & 1.4 & 1.1 & 0.7 & 90.5 & 90.3 & 89.3 & 86.6 & 87.5 & 82.9 & 81.4 \\
\hline Социальные педагоги & 1.6 & 1.4 & 1.2 & 1.0 & 0.7 & 0.6 & 0.3 & 95.2 & 96.2 & 96.4 & 96.2 & 96.4 & 95.7 & 95.8 \\
\hline Психологи & 1.1 & 0.9 & 0.8 & 0.6 & 0.5 & 0.3 & 0.2 & 94.1 & 95.7 & 95.9 & 95.4 & 95.2 & 93.6 & 94.3 \\
\hline Методисты & 1.0 & 0.9 & 0.8 & 0.6 & 0.4 & 0.4 & 0.3 & 91.9 & 93.3 & 92.8 & 92.2 & 90.6 & 91.0 & 87.6 \\
\hline Другие педагогические работники & 1.6 & 1.3 & 1.2 & 1.0 & 0.7 & 0.6 & 0.4 & 62.5 & 57.1 & 59.5 & 57.7 & 61.0 & 59.9 & 63.3 \\
\hline
\end{tabular}


5.51. УРОВЕНЬ ОБРАЗОВАНИЯ ПЕДАГОГИЧЕСКИХ РАБОТНИКОВ ПРОФЕССИОНАЛЬНЫХ ОБРАЗОВАТЕЛЬНЫХ ОРГАНИЗАЦИЙ, РЕАЛИЗУЮЩИХ ОБРАЗОВАТЕЛЬНЫЕ ПРОГРАММЫ СРЕДНЕГО ПРОФЕССИОНАЛЬНОГО ОБРАЗОВАНИЯ ПРОГРАММЫ ПОДГОТОВКИ КВАЛИФИЦИРОВАННЫХ РАБОЧИХ, СЛУЖАЩИХ

(без внешних совместителей; на конец года; проценты)

\begin{tabular}{|c|c|c|c|c|c|c|c|}
\hline & 2009 & 2010 & 2011 & 2012 & 2013 & 2014 & 2015 \\
\hline Всего & 100 & 100 & 100 & 100 & 100 & 100 & 100 \\
\hline \multicolumn{8}{|l|}{ Имеют образование: } \\
\hline высшее & 59.6 & 60.4 & 61.9 & 62.6 & 64.3 & 65.5 & 67.0 \\
\hline из них педагогическое & 35.0 & 35.7 & 37.0 & 37.0 & 37.7 & 38.0 & 37.6 \\
\hline \multicolumn{8}{|l|}{ среднее профессиональное по программам } \\
\hline подготовки специалистов среднего звена & 31.0 & 30.8 & 30.2 & 29.6 & 28.7 & 28.6 & 28.1 \\
\hline из них педагогическое & 8.9 & 9.0 & 8.7 & 8.7 & 8.5 & 8.4 & 8.2 \\
\hline
\end{tabular}




\subsection{2. УРОВЕНЬ ОБРАЗОВАНИЯ ПЕДАГОГИЧЕСКИХ РАБОТНИКОВ ПРОФЕССИОНАЛЬНЫХ ОБРАЗОВАТЕЛЬНЫХ ОРГАНИЗАЦИЙ, РЕАЛИЗУЮЩИХ ОБРАЗОВАТЕЛЬНЫЕ ПРОГРАММЫ СРЕДНЕГО ПРОФЕССИОНАЛЬНОГО ОБРАЗОВАНИЯ - ПРОГРАММЫ ПОДГОТОВКИ КВАЛИФИЦИРОВАННЫХ РАБОЧИХ, СЛУЖАЩИХ, ПО ДОЛЖНОСТЯМ: 2015}

(без внешних совместителей; на конец года; проценты)

\begin{tabular}{|c|c|c|c|c|c|}
\hline & \multirow[t]{2}{*}{ Всего } & \multicolumn{4}{|c|}{ Имеют образование } \\
\hline & & высшее & $\begin{array}{c}\text { из них } \\
\text { педагогическое }\end{array}$ & \begin{tabular}{|c} 
среднее \\
профессиональное \\
по программам \\
подготовки специалистов \\
среднего звена
\end{tabular} & $\begin{array}{c}\text { из них } \\
\text { педагогическое }\end{array}$ \\
\hline Всего & 100 & 67.0 & 37.6 & 28.1 & 8.2 \\
\hline Преподаватели & 100 & 89.0 & 59.9 & 9.8 & 3.5 \\
\hline Мастера производственного обучения & 100 & 46.6 & 15.2 & 45.5 & 11.6 \\
\hline Воспитатели & 100 & 55.1 & 38.0 & 35.9 & 18.9 \\
\hline Социальные педагоги & 100 & 77.6 & 52.9 & 19.3 & 8.1 \\
\hline Психологи & 100 & 95.2 & 70.0 & 4.4 & 1.3 \\
\hline Методисты & 100 & 92.4 & 56.7 & 6.2 & 0.7 \\
\hline Другие педагогические работники & 100 & 66.2 & 40.2 & 28.0 & 9.3 \\
\hline
\end{tabular}


5.53. СТРУКТУРА ЧИСЛЕННОСТИ ПЕДАГОГИЧЕСКИХ РАБОТНИКОВ ПРОФЕССИОНАЛЬНЫХ ОБРАЗОВАТЕЛЬНЫХ ОРГАНИЗАЦИЙ, РЕАЛИЗУЮЩИХ ОБРАЗОВАТЕЛЬНЫЕ ПРОГРАММЫ СРЕДНЕГО ПРОФЕССИОНАЛЬНОГО ОБРАЗОВАНИЯ - ПРОГРАММЫ ПОДГОТОВКИ КВАЛИФИЦИРОВАННЫХ РАБОЧИХ, СЛУЖАЩИХ, ПО ВОЗРАСТНЫМ ГРУППАМ (наконец года)

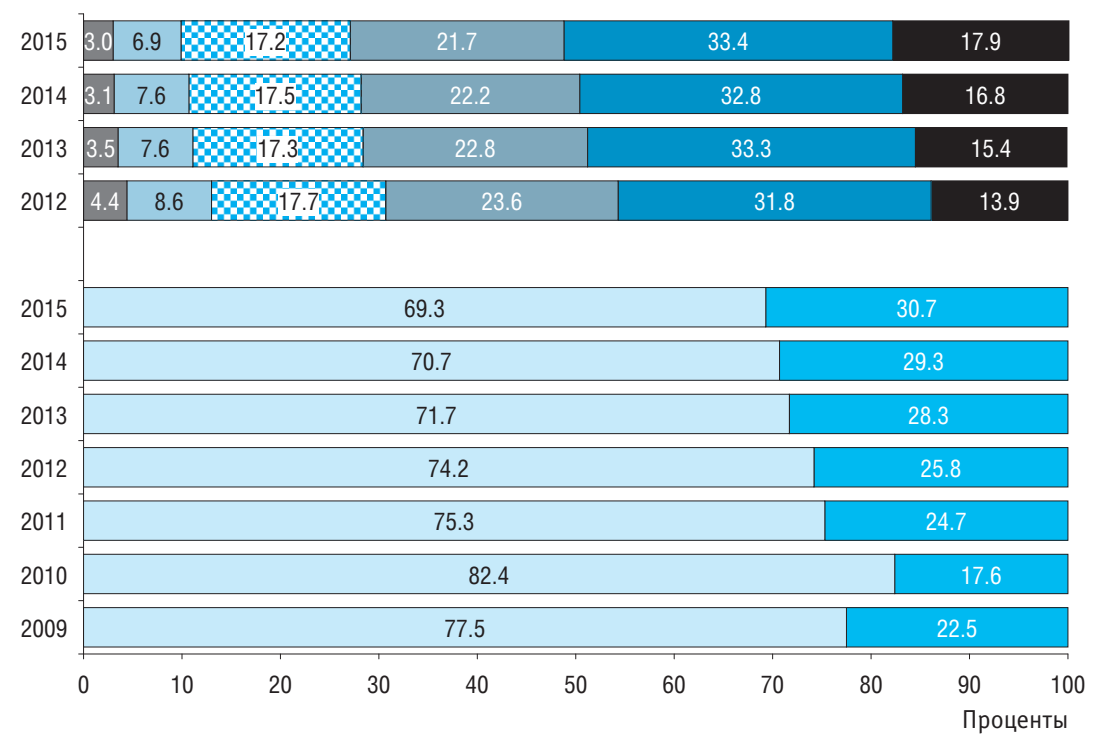

Возраст, лет:
$\square$ до 25
$\square$ 25-29
Ba 30-39
$\square 40-49$
$\square 0-59$
60 и старше

Возраст:

$\square$ трудоспособный

$\square$ старше трудоспособного 
5.54. СТРУКТУРА ЧИСЛЕННОСТИ ПЕДАГОГИЧЕСКИХ РАБОТНИКОВ ПРОФЕССИОНАЛЬНЫХ ОБРАЗОВАТЕЛЬНЫХ ОРГАНИЗАЦИЙ, РЕАЛИЗУЮЩИХ ОБРАЗОВАТЕЛЬНЫЕ ПРОГРАММЫ СРЕДНЕГО ПРОФЕССИОНАЛЬНОГО ОБРАЗОВАНИЯ - ПРОГРАММЫ ПОДГОТОВКИ КВАЛИФИЦИРОВАННЫХ РАБОЧИХ, СЛУЖАЩИХ, ПО ДОЛЖНОСТЯМ И ВОЗРАСТНЫМ ГРУППАМ: 2015 (без внешних совместителей; на конец года)

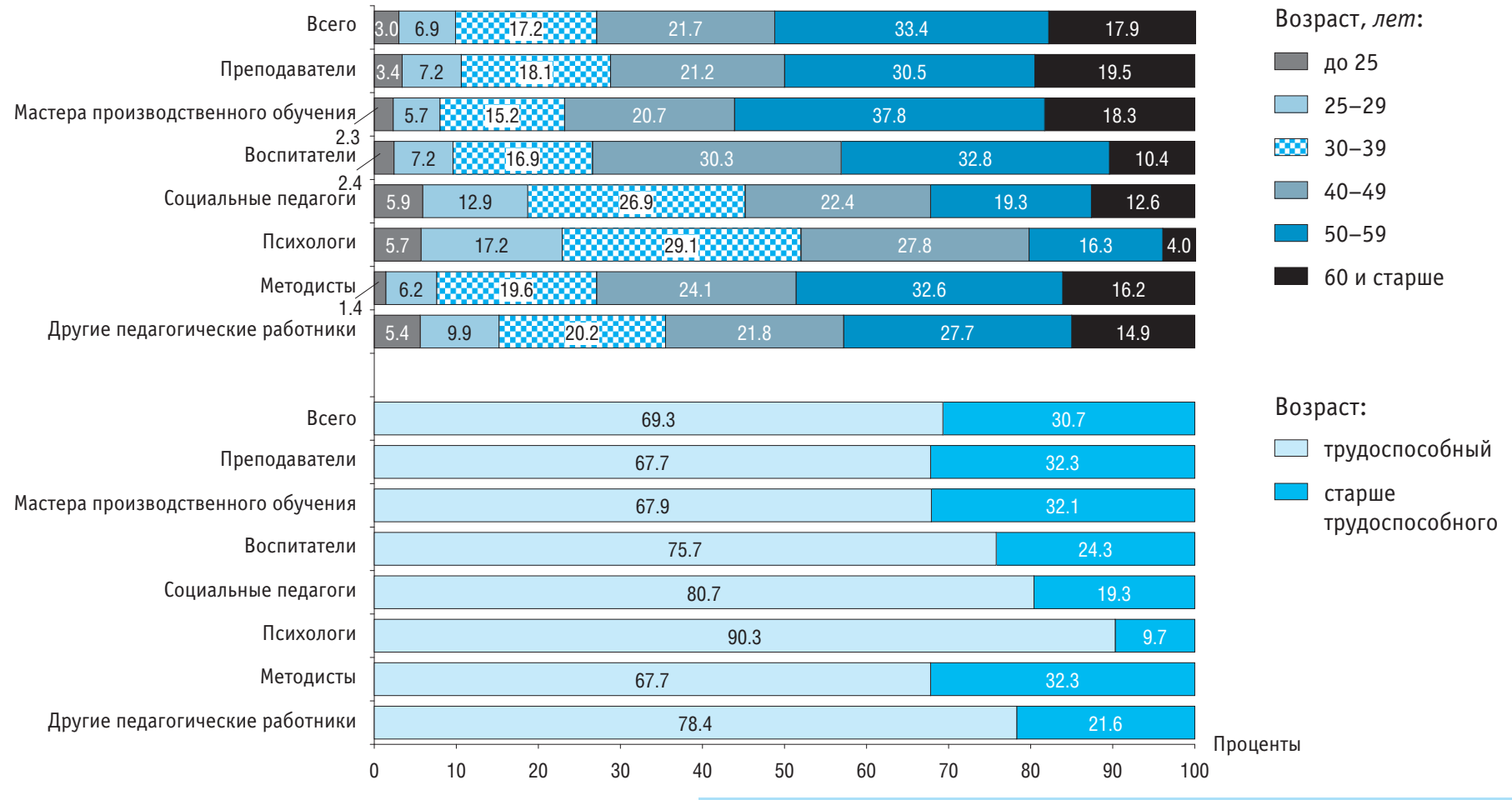




\subsection{5. ЧИСЛЕННОСТЬ ПРЕПОДАВАТЕЛЕЙ ПРОФЕССИОНАЛЬНЫХ ОБРАЗОВАТЕЛЬНЫХ ОРГАНИЗАЦИЙ, РЕАЛИЗУЮЩИХ ОБРАЗОВАТЕЛЬНЫЕ ПРОГРАММЫ СРЕДНЕГО ПРОФЕССИОНАЛЬНОГО ОБРАЗОВАНИЯ - ПРОГРАММЫ} ПОДГОТОВКИ КВАЛИФИЦИРОВАННЫХ РАБОЧИХ, СЛУЖАЩИХ

(без внешних совместителей; на конец года)

\begin{tabular}{|c|c|c|c|c|c|c|c|c|c|c|c|c|c|c|}
\hline & \multicolumn{7}{|c|}{ Численность преподавателей, тыс. чел. } & \multicolumn{7}{|c|}{ Из них - женщины, проценты } \\
\hline & 2009 & 2010 & 2011 & 2012 & 2013 & 2014 & 2015 & 2009 & 2010 & 2011 & 2012 & 2013 & 2014 & 2015 \\
\hline Всего & 34.2 & 29.3 & 24.8 & 19.4 & 13.4 & 10.1 & 6.6 & 69.8 & 68.7 & 69.7 & 69.3 & 68.9 & 68.6 & 66.1 \\
\hline \multicolumn{15}{|l|}{ Из них преподаватели дисциплин: } \\
\hline общественных & 3.7 & 2.9 & 2.3 & 1.7 & 1.1 & 0.8 & 0.5 & 81.0 & 79.8 & 81.5 & 78.8 & 79.3 & 79.7 & 76.0 \\
\hline общеобразовательных & 14.0 & 12.3 & 10.8 & 8.7 & 6.0 & 4.6 & 3.0 & 88.8 & 85.5 & 88.1 & 87.9 & 87.4 & 87.0 & 86.2 \\
\hline специальных и общетехнических & 12.2 & 10.4 & 8.6 & 6.6 & 4.7 & 3.5 & 2.5 & 59.5 & 57.8 & 57.3 & 56.3 & 54.6 & 53.8 & 47.6 \\
\hline $\begin{array}{l}\text { физического воспитания и основ } \\
\text { безопасности жизнедеятельности }\end{array}$ & 4.3 & 3.5 & 3.0 & 2.2 & 1.5 & 1.1 & 0.7 & 27.8 & 27.7 & 26.5 & 26.1 & 26.2 & 25.9 & 28.0 \\
\hline
\end{tabular}


5.56. ЧИСЛЕННОСТЬ МАСТЕРОВ ПРОИЗВОДСТВЕННОГО ОБУЧЕНИЯ ПРОФЕССИОНАЛЬНЫХ ОБРАЗОВАТЕЛЬНЫХ ОРГАНИЗАЦИЙ, РЕАЛИЗУЮЩИХ ОБРАЗОВАТЕЛЬНЫЕ ПРОГРАММЫ СРЕДНЕГО ПРОФЕССИОНАЛЬНОГО ОБРАЗОВАНИЯ - ПРОГРАММЫ ПОДГОТОВКИ КВАЛИФИЦИРОВАННЫХ РАБОЧИХ, СЛУЖАЩИХ, ИМЕЮЩИХ ПРОИЗВОДСТВЕННУЮ КВАЛИФИКАЦИЮ НА УРОВНЕ И ВЫШЕ УСТАНОВЛЕННОЙ ДЛЯ ВЫПУСКНИКОВ

(без внешних совместителей; на конец года)

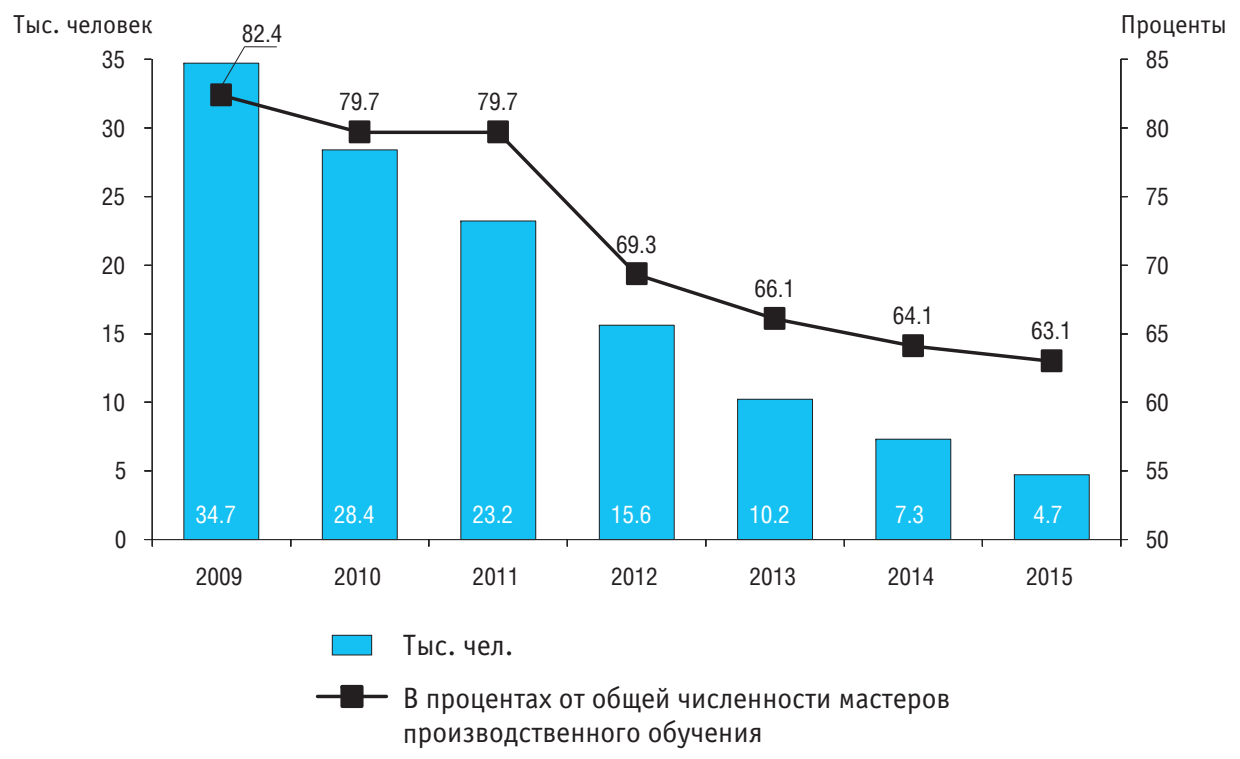




\subsection{7. ЧИСЛЕННОСТЬ СТУДЕНТОВ ПРОФЕССИОНАЛЬНЫХ ОБРАЗОВАТЕЛЬНЫХ ОРГАНИЗАЦИЙ, РЕАЛИЗУЮЩИХ ОБРАЗОВАТЕЛЬНЫЕ ПРОГРАММЫ СРЕДНЕГО ПРОФЕССИОНАЛЬНОГО ОБРАЗОВАНИЯ - ПРОГРАММЫ ПОДГОТОВКИ КВАЛИФИЦИРОВАННЫХ \\ РАБОЧИХ, СЛУЖАЩИХ, В РАСЧЕТЕ НА ОДНОГО ПРЕПОДАВАТЕЛЯ \\ (ВКЛЮЧАЯ МАСТЕРОВ ПРОИЗВОДСТВЕННОГО ОБУЧЕНИЯ) * \\ (на конец года)}

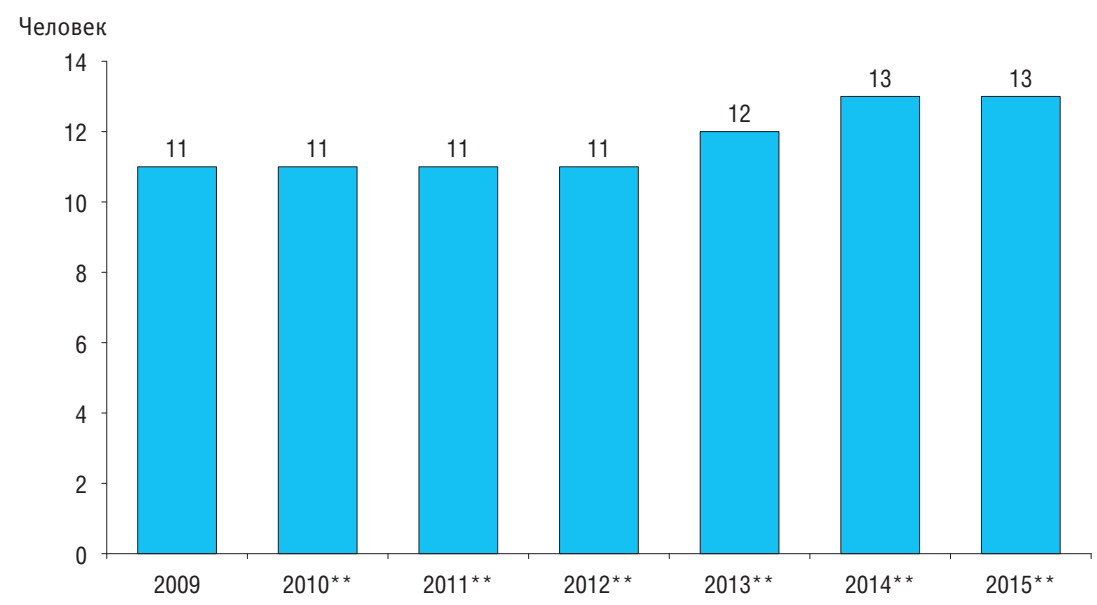

* Без внешних совместителей.

** Включая обучающихся на договорной основе, кроме краткосрочно (менее 500 часов) обученных. 


\subsection{8. ЧИСЛЕННОСТЬ РАБОТНИКОВ ОБРАЗОВАТЕЛЬНЫХ ОРГАНИЗАЦИЙ, РЕАЛИЗУЮЩИХ ОБРАЗОВАТЕЛЬНЫЕ ПРОГРАММЫ СРЕДНЕГО ПРОФЕССИОНАЛЬНОГО ОБРАЗОВАНИЯ - ПРОГРАММЫ ПОДГОТОВКИ СПЕЦИАЛИСТОВ СРЕДНЕГО ЗВЕНА, ПО КАТЕГОРИЯМ*}

(без внешних совместителей; на начало учебного года; тысячи человек)

\begin{tabular}{|c|c|c|c|c|c|c|}
\hline & $2010 / 2011$ & $2011 / 2012$ & $2012 / 2013$ & $2013 / 2014$ & $2014 / 2015$ & $2015 / 2016$ \\
\hline \multicolumn{7}{|c|}{ Всего } \\
\hline Всего & 335.4 & 338.5 & 346.6 & 330.0 & 350.2 & 356.7 \\
\hline Руководящие работники & 28.4 & 27.2 & 27.1 & 25.6 & 26.7 & 25.9 \\
\hline Педагогические работники & 154.8 & 156.5 & 161.3 & 153.5 & 164.9 & 172.3 \\
\hline Учебно-вспомогательный персонал & 51.9 & 44.8 & 43.1 & 39.5 & 41.9 & 41.3 \\
\hline Обслуживающий персонал & 100.3 & 109.9 & 115.0 & 111.5 & 116.7 & 117.2 \\
\hline \multicolumn{7}{|c|}{ Государственные и муниципальные организации } \\
\hline Всего & 326.7 & 329.7 & 337.7 & 317.6 & 337.6 & 344.1 \\
\hline Руководящие работники & 27.1 & 26.0 & 25.9 & 24.2 & 25.2 & 24.6 \\
\hline Педагогические работники & 149.8 & 151.3 & 156.0 & 146.7 & 157.8 & 165.2 \\
\hline Учебно-вспомогательный персонал & 50.8 & 43.8 & 42.1 & 37.9 & 40.3 & 39.8 \\
\hline Обслуживающий персонал & 99.0 & 108.5 & 113.6 & 108.9 & 114.2 & 114.6 \\
\hline \multicolumn{7}{|c|}{ Частные организации } \\
\hline Всего & 8.8 & 8.8 & 8.9 & 12.3 & 12.6 & 12.6 \\
\hline Руководящие работники & 1.2 & 1.2 & 1.2 & 1.4 & 1.5 & 1.3 \\
\hline Педагогические работники & 5.1 & 5.2 & 5.3 & 6.8 & 7.1 & 7.1 \\
\hline Учебно-вспомогательный персонал & 1.1 & 1.0 & 1.0 & 1.6 & 1.6 & 1.5 \\
\hline Обслуживающий персонал & 1.3 & 1.4 & 1.4 & 2.6 & 2.5 & 2.6 \\
\hline
\end{tabular}

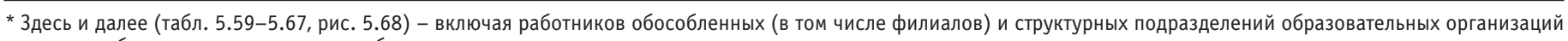
высшего образования, реализующих образовательные программы подготовки специалистов среднего звена. 


\subsection{9. ЧИСЛЕННОСТЬ ПЕДАГОГИЧЕСКИХ РАБОТНИКОВ ОБРАЗОВАТЕЛЬНЫХ ОРГАНИЗАЦИЙ, РЕАЛИЗУЮЩИХ ОБРАЗОВАТЕЛЬНЫЕ ПРОГРАММЫ СРЕДНЕГО ПРОФЕССИОНАЛЬНОГО ОБРАЗОВАНИЯ - \\ ПРОГРАММЫ ПОДГОТОВКИ СПЕЦИАЛИСТОВ СРЕДНЕГО ЗВЕНА, ПО ДОЛЖНОСТЯМ}

(без внешних совместителей; на начало учебного года; человек)

\begin{tabular}{|c|c|c|c|c|c|c|}
\hline & $2010 / 2011$ & $2011 / 2012$ & $2012 / 2013$ & $2013 / 2014$ & $2014 / 2015$ & $2015 / 2016$ \\
\hline \multicolumn{7}{|c|}{ Всего } \\
\hline Всего & 154828 & 156485 & 161302 & 153460 & 164901 & 172289 \\
\hline Преподаватели & 119950 & 118739 & 119662 & 112777 & 121069 & 126024 \\
\hline Мастера производственного обучения & 13594 & 15202 & 17167 & 17213 & 18568 & 19530 \\
\hline Социальные педагоги & 1423 & 1562 & 1842 & 1937 & 2182 & 2395 \\
\hline Педагоги-психологи & 1785 & 1793 & 1879 & 1824 & 1985 & 2103 \\
\hline Педагоги-организаторы & 1665 & 1722 & 1778 & 1744 & 1903 & 2033 \\
\hline $\begin{array}{l}\text { Преподаватели-организаторы основ } \\
\text { безопасности жизнедеятельности }\end{array}$ & 1926 & 2013 & 2127 & 1992 & 2030 & 2072 \\
\hline Руководители физического воспитания & 2510 & 2571 & 2622 & 2364 & 2412 & 2380 \\
\hline Методисты & 4594 & 4730 & 4853 & 4473 & 4874 & 4920 \\
\hline Тьюторы & 195 & 178 & 259 & 241 & 298 & 341 \\
\hline Прочие & 7186 & 7975 & 9113 & 8895 & 9580 & 10491 \\
\hline
\end{tabular}


(продолжение)

\begin{tabular}{|c|c|c|c|c|c|c|}
\hline & $2010 / 2011$ & $2011 / 2012$ & $2012 / 2013$ & $2013 / 2014$ & $2014 / 2015$ & $2015 / 2016$ \\
\hline \multicolumn{7}{|c|}{ Государственные и муниципальные организации } \\
\hline Всего & 149751 & 151326 & 156021 & 146683 & 157834 & 165165 \\
\hline Преподаватели & 115673 & 114383 & 115157 & 106828 & 114904 & 119838 \\
\hline Мастера производственного обучения & 13534 & 15137 & 17109 & 17138 & 18464 & 19465 \\
\hline Социальные педагоги & 1407 & 1546 & 1826 & 1922 & 2160 & 2366 \\
\hline Педагоги-психологи & 1723 & 1733 & 1830 & 1784 & 1935 & 2048 \\
\hline Педагоги-организаторы & 1617 & 1655 & 1722 & 1681 & 1845 & 1969 \\
\hline \multicolumn{7}{|l|}{ Преподаватели-организаторы основ } \\
\hline безопасности жизнедеятельности & 1832 & 1904 & 2024 & 1877 & 1912 & 1961 \\
\hline Руководители физического воспитания & 2389 & 2442 & 2505 & 2232 & 2281 & 2237 \\
\hline Методисты & 4311 & 4463 & 4596 & 4214 & 4641 & 4653 \\
\hline Тьюторы & 166 & 162 & 252 & 210 & 273 & 310 \\
\hline Прочие & 7099 & 7901 & 9000 & 8797 & 9419 & 10318 \\
\hline
\end{tabular}


(окончание)

\begin{tabular}{|c|c|c|c|c|c|c|}
\hline & $2010 / 2011$ & $2011 / 2012$ & $2012 / 2013$ & $2013 / 2014$ & $2014 / 2015$ & $2015 / 2016$ \\
\hline \multicolumn{7}{|c|}{ Частные организации } \\
\hline Bcero & 5077 & 5159 & 5281 & 6777 & 7067 & 7124 \\
\hline Преподаватели & 4277 & 4356 & 4505 & 5949 & 6165 & 6186 \\
\hline Мастера производственного обучения & 60 & 65 & 58 & 75 & 104 & 65 \\
\hline Социальные педагоги & 16 & 16 & 16 & 15 & 22 & 29 \\
\hline Педагоги-психологи & 62 & 60 & 49 & 40 & 50 & 55 \\
\hline Педагоги-организаторы & 48 & 67 & 56 & 63 & 58 & 64 \\
\hline $\begin{array}{l}\text { Преподаватели-организаторы основ } \\
\text { безопасности жизнедеятельности }\end{array}$ & 94 & 109 & 103 & 115 & 118 & 111 \\
\hline Руководители физического воспитания & 121 & 129 & 117 & 132 & 131 & 143 \\
\hline Методисты & 283 & 267 & 257 & 259 & 233 & 267 \\
\hline Тьюторы & 29 & 16 & 7 & 31 & 25 & 31 \\
\hline Прочие & 87 & 74 & 113 & 98 & 161 & 173 \\
\hline
\end{tabular}


5.60. ЧИСЛЕННОСТЬ ЖЕНЩИН В СОСТАВЕ ПЕДАГОГИЧЕСКИХ РАБОТНИКОВ ОБРАЗОВАТЕЛЬНЫХ ОРГАНИЗАЦИЙ, РЕАЛИЗУЮЩИХ ОБРАЗОВАТЕЛЬНЫЕ ПРОГРАММЫ СРЕДНЕГО ПРОФЕССИОНАЛЬНОГО ОБРАЗОВАНИЯ -

ПРОГРАММЫ ПОДГОТОВКИ СПЕЦИАЛИСТОВ СРЕДНЕГО ЗВЕНА

(без внешних совместителей; на начало учебного года)

\begin{tabular}{|c|c|c|c|c|c|c|}
\hline & $2010 / 2011$ & $2011 / 2012$ & $2012 / 2013$ & $2013 / 2014$ & $2014 / 2015$ & $2015 / 2016$ \\
\hline \multicolumn{7}{|c|}{ Тысячи человек } \\
\hline Всего & 117.7 & 118.0 & 121.0 & 112.8 & 121.1 & 128.4 \\
\hline Государственные и муниципальные организации & 113.9 & 114.2 & 117.1 & 108.0 & 115.9 & 123.1 \\
\hline Частные организации & 3.8 & 3.8 & 3.9 & 4.9 & 5.2 & 5.4 \\
\hline \multicolumn{7}{|c|}{ В процентах от общей численности } \\
\hline Всего & 76.0 & 75.4 & 75.0 & 73.5 & 73.4 & 74.5 \\
\hline Государственные и муниципальные организации & 76.1 & 75.5 & 75.1 & 73.6 & 73.5 & 74.5 \\
\hline Частные организации & 74.8 & 73.8 & 74.1 & 72.2 & 73.0 & 75.1 \\
\hline
\end{tabular}




\subsection{1. ЧИСЛЕННОСТЬ ЖЕНЩИН В СОСТАВЕ ПЕДАГОГИЧЕСКИХ РАБОТНИКОВ ОБРАЗОВАТЕЛЬНЫХ ОРГАНИЗАЦИЙ, РЕАЛИЗУЮЩИХ ОБРАЗОВАТЕЛЬНЫЕ ПРОГРАММЫ СРЕДНЕГО ПРОФЕССИОНАЛЬНОГО ОБРАЗОВАНИЯ - ПРОГРАММЫ ПОДГОТОВКИ СПЕЦИАЛИСТОВ СРЕДНЕГО ЗВЕНА, ПО ДОЛЖНОСТЯМ: 2015/2016}

(без внешних совместителей; на начало учебного года; человек)

\begin{tabular}{|c|c|c|c|c|c|c|}
\hline & \multicolumn{3}{|c|}{ Численность женщин, чел. } & \multicolumn{3}{|c|}{$\begin{array}{c}\text { В процентах от общей численности педагогических } \\
\text { работников по соответствующей должности }\end{array}$} \\
\hline & Всего & $\begin{array}{c}\text { Государственные } \\
\text { и муниципальные } \\
\text { организации }\end{array}$ & $\begin{array}{c}\text { Частные } \\
\text { организации }\end{array}$ & Всего & $\begin{array}{c}\text { Государственные } \\
\text { и муниципальные } \\
\text { организации }\end{array}$ & $\begin{array}{c}\text { Частные } \\
\text { организации }\end{array}$ \\
\hline Всего & 128416 & 123063 & 5353 & 74.5 & 74.5 & 75.1 \\
\hline Преподаватели & 98807 & 94074 & 4733 & 78.4 & 78.5 & 76.5 \\
\hline Мастера производственного обучения & 10159 & 10115 & 44 & 52.0 & 52.0 & 67.7 \\
\hline Социальные педагоги & 2235 & 2211 & 24 & 93.3 & 93.4 & 82.8 \\
\hline Педагоги-психологи & 1916 & 1865 & 51 & 91.1 & 91.1 & 92.7 \\
\hline Педагоги-организаторы & 1657 & 1604 & 53 & 81.5 & 81.5 & 82.8 \\
\hline $\begin{array}{l}\text { Преподаватели-организаторы основ без } \\
\text { жизнедеятельности }\end{array}$ & 277 & 243 & 34 & 13.4 & 12.4 & 30.6 \\
\hline Руководители физического воспитания & 717 & 669 & 48 & 30.1 & 29.9 & 33.6 \\
\hline Методисты & 4412 & 4190 & 222 & 89.7 & 90.0 & 83.1 \\
\hline Тьюторы & 282 & 262 & 20 & 82.7 & 84.5 & 64.5 \\
\hline Прочие & 7954 & 7830 & 124 & 75.8 & 75.9 & 71.7 \\
\hline
\end{tabular}




\subsection{2. УРОВЕНЬ ОБРАЗОВАНИЯ ПЕДАГОГИЧЕСКИХ РАБОТНИКОВ ОБРАЗОВАТЕЛЬНЫХ ОРГАНИЗАЦИЙ, РЕАЛИЗУЮЩИХ ОБРАЗОВАТЕЛЬНЫЕ ПРОГРАММЫ СРЕДНЕГО ПРОФЕССИОНАЛЬНОГО ОБРАЗОВАНИЯ - \\ ПРОГРАММЫ ПОДГОТОВКИ СПЕЦИАЛИСТОВ СРЕДНЕГО ЗВЕНА \\ (без внешних совместителей; на начало учебного года; проценты)}

\begin{tabular}{|c|c|c|c|c|c|c|}
\hline & $2010 / 2011$ & $2011 / 2012$ & $2012 / 2013$ & $2013 / 2014$ & $2014 / 2015$ & $2015 / 2016$ \\
\hline \multicolumn{7}{|c|}{ Всего } \\
\hline Всего & 100 & 100 & 100 & 100 & 100 & 100 \\
\hline \multicolumn{7}{|l|}{ Имеют образование: } \\
\hline высшее & 90.1 & 89.9 & 89.1 & 88.8 & 88.9 & 89.0 \\
\hline из них педагогическое & 53.2 & 53.8 & 53.3 & 52.3 & 52.8 & 53.1 \\
\hline $\begin{array}{l}\text { среднее профессиональное по программам } \\
\text { подготовки специалистов среднего звена }\end{array}$ & 8.4 & 8.5 & 9.1 & 8.4 & 8.4 & 8.4 \\
\hline \multicolumn{7}{|c|}{ Государственные и муниципальные организации } \\
\hline Bcero & 100 & 100 & 100 & 100 & 100 & 100 \\
\hline \multicolumn{7}{|l|}{ Имеют образование: } \\
\hline высшее & 89.9 & 89.6 & 88.9 & 88.3 & 88.5 & 88.6 \\
\hline из них педагогическое & 53.2 & 53.7 & 53.3 & 52.3 & 52.8 & 53.1 \\
\hline $\begin{array}{l}\text { среднее профессиональное по программам } \\
\text { подготовки специалистов среднего звена }\end{array}$ & 8.6 & 8.7 & 9.3 & 8.7 & 8.7 & 8.8 \\
\hline \multicolumn{7}{|c|}{ Частные организации } \\
\hline Bcero & 100 & 100 & 100 & 100 & 100 & 100 \\
\hline \multicolumn{7}{|l|}{ Имеют образование: } \\
\hline высшее & 96.5 & 97.2 & 97.2 & 97.7 & 97.3 & 98.0 \\
\hline из них педагогическое & 53.6 & 56.1 & 54.5 & 51.8 & 52.1 & 52.4 \\
\hline $\begin{array}{l}\text { среднее профессиональное по программам } \\
\text { подготовки специалистов среднего звена }\end{array}$ & 3.0 & 2.1 & 2.1 & 1.7 & 1.6 & 1.2 \\
\hline
\end{tabular}




\subsection{3. УРОВЕНЬ ОБРАЗОВАНИЯ ПЕДАГОГИЧЕСКИХ РАБОТНИКОВ ОБРАЗОВАТЕЛЬНЫХ ОРГАНИЗАЦИЙ, РЕАЛИЗУЮЩИХ ОБРАЗОВАТЕЛЬНЫЕ ПРОГРАММЫ СРЕДНЕГО ПРОФЕССИОНАЛЬНОГО ОБРАЗОВАНИЯ - ПРОГРАММЫ \\ ПОДГОТОВКИ СПЕЦИАЛИСТОВ СРЕДНЕГО ЗВЕНА, ПО ДОЛЖНОСТЯМ: 2015/2016}

(без внешних совместителей; на начало учебного года; проценты)

\begin{tabular}{|c|c|c|c|c|}
\hline & \multirow[t]{2}{*}{ Всего } & \multicolumn{3}{|c|}{ Имеют образование } \\
\hline & & высшее & $\begin{array}{c}\text { из них } \\
\text { педагогическое }\end{array}$ & $\begin{array}{c}\text { среднее профессиональное } \\
\text { по программам подготовки } \\
\text { специалистов среднего звена }\end{array}$ \\
\hline Bcero & 100 & 89.0 & 53.1 & 8.4 \\
\hline Преподаватели & 100 & 96.5 & 58.3 & 2.6 \\
\hline Мастера производственного обучения & 100 & 46.8 & 17.9 & 41.7 \\
\hline Социальные педагоги & 100 & 87.4 & 61.4 & 10.1 \\
\hline Педагоги-психологи & 100 & 97.8 & 75.8 & 1.0 \\
\hline Педагоги-организаторы & 100 & 80.3 & 46.6 & 15.0 \\
\hline $\begin{array}{l}\text { Преподаватели-организаторы основ } \\
\text { безопасности жизнедеятельности }\end{array}$ & 100 & 93.4 & 44.9 & 5.0 \\
\hline Руководители физического воспитания & 100 & 93.5 & 77.0 & 5.4 \\
\hline Методисты & 100 & 95.7 & 59.1 & 2.8 \\
\hline Тьюторы & 100 & 83.3 & 49.0 & 12.9 \\
\hline Прочие & 100 & 72.1 & 44.0 & 19.9 \\
\hline
\end{tabular}




\subsection{4. ЧИСЛЕННОСТЬ ПРЕПОДАВАТЕЛЕЙ ОБРАЗОВАТЕЛЬНЫХ ОРГАНИЗАЦИЙ, РЕАЛИЗУЮЩИХ ОБРАЗОВАТЕЛЬНЫЕ ПРОГРАММЫ СРЕДНЕГО ПРОФЕССИОНАЛЬНОГО ОБРАЗОВАНИЯ - ПРОГРАММЫ ПОДГОТОВКИ СПЕЦИАЛИСТОВ СРЕДНЕГО ЗВЕНА \\ (на начало учебного года)}

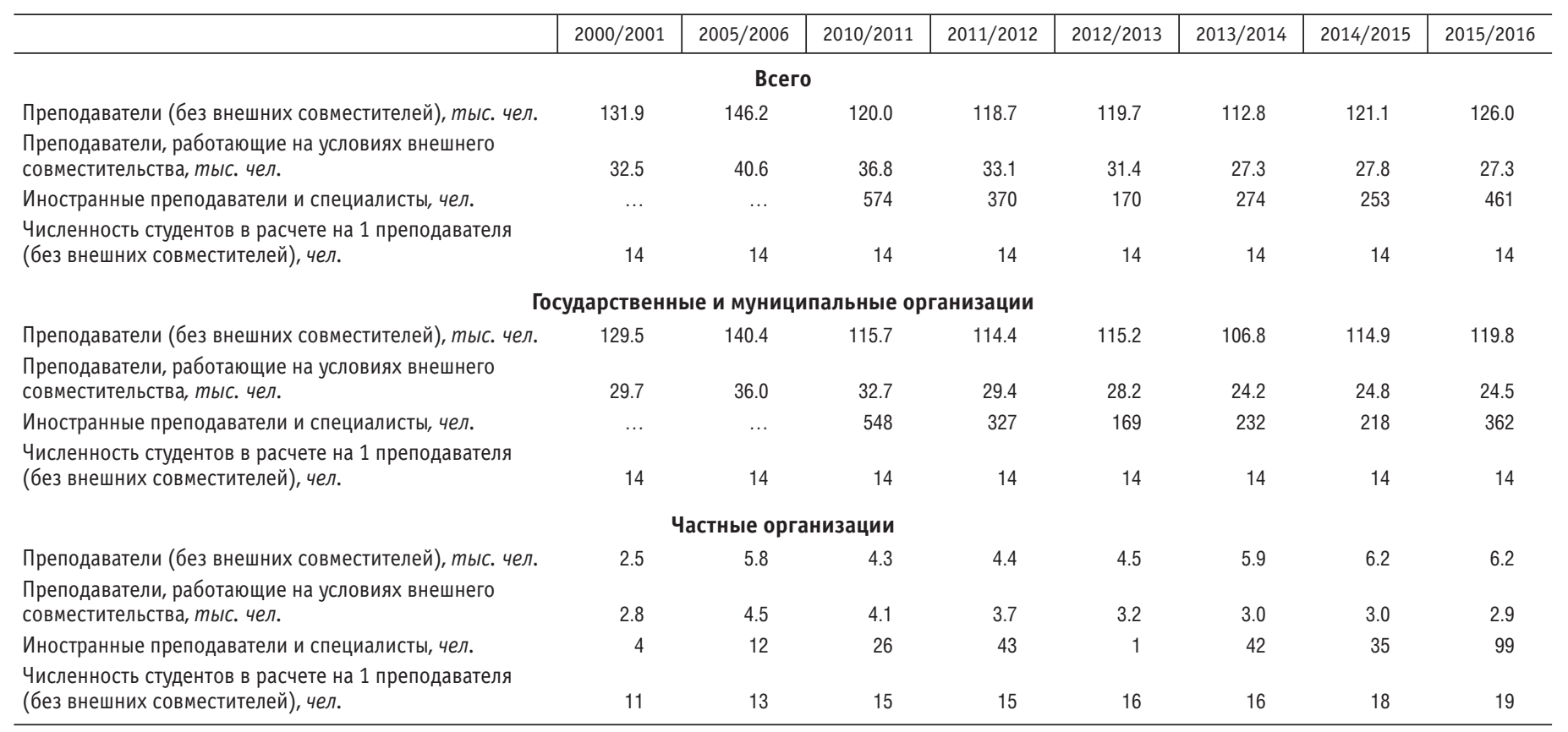


5.65. ЧИСЛЕННОСТЬ ЖЕНЩИН В СОСТАВЕ ПРЕПОДАВАТЕЛЕЙ ОБРАЗОВАТЕЛЬНЫХ ОРГАНИЗАЦИЙ, РЕАЛИЗУЮЩИХ ОБРАЗОВАТЕЛЬНЫЕ ПРОГРАММЫ СРЕДНЕГО ПРОФЕССИОНАЛЬНОГО ОБРАЗОВАНИЯ -

ПРОГРАММЫ ПОДГОТОВКИ СПЕЦИАЛИСТОВ СРЕДНЕГО ЗВЕНА

(без внешних совместителей; на начало учебного года)

\begin{tabular}{|c|c|c|c|c|c|c|c|c|}
\hline & $2000 / 2001$ & $2005 / 2006$ & $2010 / 2011$ & $2011 / 2012$ & $2012 / 2013$ & $2013 / 2014$ & $2014 / 2015$ & $2015 / 2016$ \\
\hline \multicolumn{9}{|c|}{ Тысячи человек } \\
\hline Всего & $\ldots$ & $\ldots$ & 95.7 & 94.3 & 94.8 & 87.4 & 93.5 & 98.8 \\
\hline Государственные и муниципальные организации & 96.9 & 107.4 & 92.4 & 91.0 & 91.4 & 83.0 & 88.9 & 94.1 \\
\hline Частные организации & $\ldots$ & $\ldots$ & 3.3 & 3.3 & 3.4 & 4.4 & 4.6 & 4.7 \\
\hline \multicolumn{9}{|c|}{ В процентах от общей численности преподавателей } \\
\hline Всего & $\ldots$ & $\ldots$ & 79.7 & 79.4 & 79.2 & 77.5 & 77.2 & 78.4 \\
\hline Государственные и муниципальные организации & 74.9 & 76.5 & 79.9 & 79.5 & 79.4 & 77.7 & 77.4 & 78.5 \\
\hline Частные организации & $\ldots$ & $\ldots$ & 76.1 & 76.6 & 76.0 & 73.5 & 74.4 & 76.5 \\
\hline
\end{tabular}


5.66. ЧИСЛЕННОСТЬ ПРЕПОДАВАТЕЛЕЙ ОБРАЗОВАТЕЛЬНЫХ ОРГАНИЗАЦИЙ, РЕАЛИЗУЮЩИХ ОБРАЗОВАТЕЛЬНЫЕ

ПРОГРАММЫ СРЕДНЕГО ПРОФЕССИОНАЛЬНОГО ОБРАЗОВАНИЯ - ПРОГРАММЫ ПОДГОТОВКИ

СПЕЦИАЛИСТОВ СРЕДНЕГО ЗВЕНА, ИМЕЮЩИХ УЧЕНУЮ СТЕПЕНЬ, УЧЕНОЕ ЗВАНИЕ

(без внешних совместителей; на начало учебного года; человек)

\begin{tabular}{|c|c|c|c|c|c|c|}
\hline & $2010 / 2011$ & $2011 / 2012$ & $2012 / 2013$ & $2013 / 2014$ & $2014 / 2015$ & $2015 / 2016$ \\
\hline \multicolumn{7}{|c|}{ Всего } \\
\hline \multicolumn{7}{|c|}{ Имеют ученую степень: } \\
\hline доктора наук & 169 & 141 & 178 & 339 & 314 & 255 \\
\hline кандидата наук & 3132 & 3410 & 3897 & 4703 & 5022 & 5203 \\
\hline \multicolumn{7}{|c|}{ Имеют ученое звание: } \\
\hline профессора & 138 & 150 & 173 & 285 & 259 & 185 \\
\hline доцента & 683 & 750 & 1069 & 1444 & 1439 & 1309 \\
\hline \multicolumn{7}{|c|}{ Государственные и муниципальные организации } \\
\hline \multicolumn{7}{|c|}{ Имеют ученую степень: } \\
\hline доктора наук & 96 & 74 & 122 & 185 & 179 & 131 \\
\hline кандидата наук & 2478 & 2715 & 3126 & 3399 & 3787 & 3933 \\
\hline \multicolumn{7}{|c|}{ Имеют ученое звание: } \\
\hline профессора & 76 & 83 & 120 & 166 & 155 & 109 \\
\hline доцента & 392 & 483 & 799 & 891 & 923 & 770 \\
\hline \multicolumn{7}{|c|}{ Частные организации } \\
\hline \multicolumn{7}{|c|}{ Имеют ученую степень: } \\
\hline доктора наук & 73 & 67 & 56 & 154 & 135 & 124 \\
\hline кандидата наук & 654 & 695 & 771 & 1304 & 1235 & 1270 \\
\hline \multicolumn{7}{|c|}{ Имеют ученое звание: } \\
\hline профессора & 62 & 67 & 53 & 119 & 104 & 76 \\
\hline доцента & 291 & 267 & 270 & 553 & 516 & 539 \\
\hline
\end{tabular}


5.67. ЧИСЛЕННОСТЬ ПРЕПОДАВАТЕЛЕЙ ОБРАЗОВАТЕЛЬНЫХ ОРГАНИЗАЦИЙ, РЕАЛИЗУЮЩИХ ОБРАЗОВАТЕЛЬНЫЕ ПРОГРАММЫ СРЕДНЕГО ПРОФЕССИОНАЛЬНОГО ОБРАЗОВАНИЯ - ПРОГРАММЫ ПОДГОТОВКИ СПЕЦИАЛИСТОВ СРЕДНЕГО ЗВЕНА, ПРОШЕДШИХ ПОВЫШЕНИЕ КВАЛИФИКАЦИИ И (ИЛИ) ПРОФЕССИОНАЛЬНУЮ ПЕРЕПОДГОТОВКУ

(без внешних совместителей; на начало учебного года)

\begin{tabular}{|c|c|c|c|c|c|c|}
\hline & $2010 / 2011$ & $2011 / 2012$ & $2012 / 2013$ & $2013 / 2014$ & $2014 / 2015$ & $2015 / 2016$ \\
\hline \multicolumn{7}{|c|}{ Тысячи человек } \\
\hline Всего & 33.1 & 32.7 & 31.8 & 29.8 & 33.6 & 35.6 \\
\hline Государственные и муниципальные организации & 32.0 & 31.7 & 30.7 & 28.1 & 31.8 & 33.7 \\
\hline Частные организации & 1.0 & 1.0 & 1.1 & 1.7 & 1.8 & 1.9 \\
\hline \multicolumn{7}{|c|}{ В процентах от общей численности преподавателей } \\
\hline Всего & 27.6 & 27.6 & 26.6 & 26.4 & 27.8 & 28.2 \\
\hline Государственные и муниципальные организации & 27.7 & 27.7 & 26.7 & 26.3 & 27.7 & 28.1 \\
\hline Частные организации & 24.1 & 23.9 & 24.9 & 29.0 & 29.6 & 29.9 \\
\hline
\end{tabular}




\subsection{8. СТРУКТУРА ЧИСЛЕННОСТИ ПРЕПОДАВАТЕЛЕЙ ОБРАЗОВАТЕЛЬНЫХ ОРГАНИЗАЦИЙ, РЕАЛИЗУЮЩИХ ОБРАЗОВАТЕЛЬНЫЕ ПРОГРАММЫ СРЕДНЕГО ПРОФЕССИОНАЛЬНОГО ОБРАЗОВАНИЯ - ПРОГРАММЫ \\ ПОДГОТОВКИ СПЕЦИАЛИСТОВ СРЕДНЕГО ЗВЕНА, ПО ВОЗРАСТНЫМ ГРУППАМ \\ (без внешних совместителей; на начало учебного года; число полных лет на 1 января)}

\begin{tabular}{|c|c|c|c|c|c|c|c|c|c|c|}
\hline $2015 / 2016$ & 4.0 & $9.1 \quad 010.2]$ & 11.2 & 10.5 & 9.7 & 11.8 & 13.2 & 10.3 & 10.0 & \multirow{6}{*}{ Всего } \\
\hline $2014 / 2015$ & 3.8 & $8.9 \quad \mathrm{~B} 10.2 \mathrm{P}$ & 11.1 & 102 & 9.8 & 12.7: & 13.2 & 10.4 & 9.9 & \\
\hline $2013 / 2014$ & 3.7 & $8.7 \quad 10.2 \mathrm{~m}$ & 10.8 & 99 & 10.0 & 13.2 & 13.4 & 10.6 & 9.5 & \\
\hline $2012 / 2013$ & 3.9 & $8.8 \quad 910.59$ & 10.6 & 94 & 10.3 & 13.3 & 13.4 & 10.8 & 9.1 & \\
\hline $2011 / 2012$ & 3.9 & $8.9 \quad \mathrm{~B} 10.6 \mathrm{~B}$ & 10.4 & 92 & 10.7 & 13.5 & 13.4 & 11.0 & 8.5 & \\
\hline $2010 / 2011$ & 4.2 & 9.1 bis & 9.9 & 90 & 11.2 & 13.5 & 13.3 & 11.1 & 8.1 & \\
\hline $2015 / 2016$ & 4.0 & $9.0 \quad \mathrm{~W} 10.0 \mathrm{~d}$ & 11.0 & 104 & 9.7 & 11.9 & 13.3 & 10.4 & 10.2 & \multirow{6}{*}{$\begin{array}{l}\text { Государственные } \\
\text { и муниципальные } \\
\text { организации }\end{array}$} \\
\hline $2014 / 2015$ & 3.8 & $8.7 \quad B=10.0 \%$ & 11.0 & $10 \%$ & 9.7 & 12.7 & 13.3 & 10.6 & 10.1 & \\
\hline $2013 / 2014$ & 3.7 & $8.5 \mathrm{Br} 10.0 \mathrm{H}$ & 10.7 & 98 & 9.9 & 13.2 & 13.6 & 10.8 & 9.7 & \\
\hline $2012 / 2013$ & 3.9 & $8.6 \quad 810.3$ & 10.4 & 9.3 & 10.3 & 13.4 & 13.5 & 11.0 & 9.3 & \\
\hline $2011 / 2012$ & 3.9 & $8.7 \quad \mathrm{~W}_{10} 10.5 \mathrm{H}$ & 10.2 & $9 \%$ & 10.7 & 13.6: & 13.6 & 11.1 & 8.6 & \\
\hline 2010/2011 & 4.1 & $8.9 \quad \mathrm{~B}=10.5 \mathrm{H}$ & 9.8 & 89 & 11.2 & 13.5 & 13.5 & 11.2 & 8.2 & \\
\hline $2015 / 2016$ & 4.8 & BQ13.0 & & 14.1 & 126 & 10.3 & 11.3 & 9.5 & 7.6 & \multirow{7}{*}{$\begin{array}{l}\text { Частные } \\
\text { организации }\end{array}$} \\
\hline $2014 / 2015$ & 4.0 & 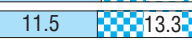 & & 13.3 & 126 & 11.1 & 11.4 & 10.1 & 7.0 & \\
\hline $2013 / 2014$ & 4.0 & $B 213.7^{\circ}$ & DI & 13.9 & 122 & 10.8 & 11.5 & 9.5 & \begin{tabular}{l|l}
7.0 & 5.7 \\
\end{tabular} & \\
\hline $2012 / 2013$ & 4.8 & 32 & 789 & 13.8 & $\because 118$ & 11.1 & 11.1 & 8.7 & \begin{tabular}{|l|l|}
5.9 & 4.6 \\
\end{tabular} & \\
\hline $2011 / 2012$ & 5.1 & Wain & 739 & 15.0 & $\quad 111$ & 10.3 & 10.4 & 8.9 & \begin{tabular}{|l|l|}
7.0 & 5.3 \\
\end{tabular} & \\
\hline $2010 / 2011$ & 5.2 & Pe1 & $4.8 \mathrm{PD}$ & 12.4 & 113 & 11.1 & 11.2 & 9.2 & \begin{tabular}{l|l|}
6.5 & 4.4 \\
\end{tabular} & \\
\hline & 0 & 10 & 30 & 40 & 50 & 60 & 70 & 80 & 90 & \\
\hline
\end{tabular}

Возраст, лет:

\begin{tabular}{|c|c|c|c|c|}
\hline$\square$ до 25 & 30-34 & $\therefore \quad 40-45$ & 50-54 & $\square$ 60-64 \\
\hline \begin{tabular}{|l}
$\square 25-29$ \\
\end{tabular} & $35-39$ & $46-49$ & $55-59$ & 65 и старше \\
\hline
\end{tabular}




\subsection{9. ЧИСЛЕННОСТЬ РАБОТНИКОВ ОБРАЗОВАТЕЛЬНЫХ ОРГАНИЗАЦИЙ ВЫСШЕГО ОБРАЗОВАНИЯ ПО КАТЕГОРИЯМ * (без внешних совместителей; на начало учебного года; тысячи человек)}

\begin{tabular}{|c|c|c|c|c|c|c|}
\hline & $2010 / 2011$ & $2011 / 2012$ & $2012 / 2013$ & $2013 / 2014$ & $2014 / 2015$ & $2015 / 2016$ \\
\hline \multicolumn{7}{|c|}{ Всего } \\
\hline Всего & 903.4 & 886.2 & 880.2 & 824.0 & 779.4 & 724.5 \\
\hline Руководящий персонал & 26.5 & 27.2 & 28.9 & 27.2 & 26.6 & 24.0 \\
\hline Профессорско-преподавательский состав & 356.8 & 348.2 & 342.0 & 319.3 & 299.8 & 279.8 \\
\hline Научные работники & 21.6 & 22.1 & 21.9 & 18.9 & 17.7 & 18.4 \\
\hline Инженерно-технический персонал & 47.2 & 49.7 & 49.3 & 48.1 & 48.4 & 46.7 \\
\hline Административно-хозяйственный персонал & 96.1 & 94.7 & 96.9 & 90.9 & 87.1 & 83.8 \\
\hline Производственный персонал & 16.1 & 14.6 & 13.0 & 13.1 & 14.0 & 11.7 \\
\hline Учебно-вспомогательный персонал & 163.4 & 157.8 & 154.9 & 141.8 & 130.5 & 121.8 \\
\hline Обслуживающий персонал & 175.6 & 172.0 & 173.2 & 164.6 & 155.4 & 138.3 \\
\hline \multicolumn{7}{|c|}{ Государственные и муниципальные организации } \\
\hline Всего & 837.4 & 826.3 & 820.4 & 764.6 & 723.2 & 676.1 \\
\hline Руководящий персонал & 22.9 & 23.6 & 25.1 & 23.6 & 23.1 & 21.1 \\
\hline Профессорско-преподавательский состав & 324.8 & 319.0 & 312.8 & 288.2 & 271.5 & 255.8 \\
\hline Научные работники & 21.3 & 21.8 & 21.6 & 18.5 & 17.0 & 17.7 \\
\hline Инженерно-технический персонал & 45.4 & 47.8 & 47.4 & 46.3 & 46.6 & 45.2 \\
\hline Административно-хозяйственный персонал & 88.2 & 87.5 & 90.3 & 85.3 & 81.1 & 78.2 \\
\hline Производственный персонал & 14.9 & 14.0 & 12.3 & 12.4 & 13.4 & 11.3 \\
\hline Учебно-вспомогательный персонал & 151.3 & 146.9 & 144.1 & 131.8 & 120.8 & 113.5 \\
\hline Обслуживающий персонал & 168.6 & 165.7 & 166.8 & 158.4 & 149.7 & 133.3 \\
\hline
\end{tabular}

* Здесь и далее (табл. 5.70-5.75, рис. 5.76) - включая работников обособленных подразделений (в том числе филиалов). 
(окончание)

\begin{tabular}{|c|c|c|c|c|c|c|}
\hline & $2010 / 2011$ & $2011 / 2012$ & $2012 / 2013$ & $2013 / 2014$ & $2014 / 2015$ & $2015 / 2016$ \\
\hline \multicolumn{7}{|c|}{ Частные организации } \\
\hline Bcero & 66.0 & 59.9 & 59.8 & 59.4 & 56.2 & 48.3 \\
\hline Руководящий персонал & 3.7 & 3.6 & 3.8 & 3.7 & 3.5 & 2.9 \\
\hline Профессорско-преподавательский состав & 32.0 & 29.2 & 29.2 & 31.1 & 28.2 & 23.9 \\
\hline Научные работники & 0.3 & 0.3 & 0.3 & 0.4 & 0.7 & 0.8 \\
\hline Инженерно-технический персонал & 1.8 & 1.8 & 1.9 & 1.7 & 1.8 & 1.5 \\
\hline Административно-хозяйственный персонал & 7.9 & 7.2 & 6.6 & 5.6 & 6.0 & 5.7 \\
\hline Производственный персонал & 1.2 & 0.6 & 0.6 & 0.7 & 0.5 & 0.4 \\
\hline Учебно-вспомогательный персонал & 12.1 & 10.9 & 10.9 & 10.0 & 9.7 & 8.2 \\
\hline Обслуживающий персонал & 7.0 & 6.3 & 6.5 & 6.2 & 5.7 & 5.0 \\
\hline
\end{tabular}




\subsection{0. ЧИСЛЕННОСТЬ ПРОФЕССОРСКО-ПРЕПОДАВАТЕЛЬСКОГО СОСТАВА ОБРАЗОВАТЕЛЬНЫХ ОРГАНИЗАЦИЙ ВЫСШЕГО ОБРАЗОВАНИЯ* (на начало учебного года)}

\begin{tabular}{|c|c|c|c|c|c|c|c|c|}
\hline & $2000 / 2001$ & $2005 / 2006$ & $2010 / 2011$ & $2011 / 2012$ & $2012 / 2013$ & $2013 / 2014$ & $2014 / 2015$ & $2015 / 2016$ \\
\hline \multicolumn{9}{|c|}{ Всего } \\
\hline $\begin{array}{l}\text { Профессорско-преподавательский состав (без внешних } \\
\text { совместителей), тыс. чел. }\end{array}$ & 279.6 & 358.9 & 356.8 & 348.2 & 342.0 & 319.3 & 299.8 & 279.8 \\
\hline Профессорско-преподавательский состав, работающий & & & & & & & & \\
\hline на условиях внешнего совместительства, тыс. чел. & 78.4 & 118.4 & 107.5 & 104.2 & 102.3 & 86.3 & 75.6 & 67.7 \\
\hline Иностранные преподаватели и специалисты, чел. & $\ldots$ & $\ldots$ & 1024 & 1304 & 1406 & 1996 & 1875 & 3204 \\
\hline $\begin{array}{l}\text { Численность студентов в расчете на } 1 \text { работника профессорско- } \\
\text { преподавательского состава (без внешних совместителей), чел. }\end{array}$ & 10 & 11 & 10 & 9 & 9 & 9 & 10 & 9 \\
\hline \multicolumn{9}{|c|}{ Государственные и муниципальные организации } \\
\hline $\begin{array}{l}\text { Профессорско-преподавательский состав (без внешних } \\
\text { совместителей), тыс. чел. }\end{array}$ & 265.2 & 322.1 & 324.8 & 319.0 & 312.8 & 288.2 & 271.5 & 255.8 \\
\hline Профессорско-преподавательский состав, работающий & & & & & & & & \\
\hline на условиях внешнего совместительства, тыс. чел. & 50.6 & 89.9 & 89.1 & 87.7 & 86.3 & 70.6 & 61.4 & 56.4 \\
\hline Иностранные преподаватели и специалисты, чел. & $\ldots$ & $\ldots$ & 923 & 1184 & 1244 & 1883 & 1685 & 3062 \\
\hline $\begin{array}{l}\text { Численность студентов в расчете на } 1 \text { работника профессорско- } \\
\text { преподавательского состава (без внешних совместителей), чел. }\end{array}$ & 10 & 11 & 10 & 9 & 9 & 10 & 10 & 10 \\
\hline \multicolumn{9}{|c|}{ Частные организации } \\
\hline $\begin{array}{l}\text { Профессорско-преподавательский состав (без внешних } \\
\text { совместителей), тыс. чел. } \\
\text { Профессорско-преподавательский состав, работающий }\end{array}$ & 14.4 & 36.7 & 32.0 & 29.2 & 29.2 & 31.1 & 28.2 & 23.9 \\
\hline на условиях внешнего совместительства, тыс. чел. & 27.8 & 28.5 & 18.4 & 16.5 & 16.0 & 15.7 & 14.2 & 11.3 \\
\hline Иностранные преподаватели и специалисты, чел. & 209 & 131 & 101 & 120 & 162 & 113 & 190 & 142 \\
\hline $\begin{array}{l}\text { Численность студентов в расчете на } 1 \text { работника профессорско- } \\
\text { преподавательского состава (без внешних совместителей), чел. }\end{array}$ & 15 & 11 & 10 & 9 & 8 & 7 & 7 & 7 \\
\hline
\end{tabular}

* Данные на начало 2000/2001 и 2005/2006 учебных годов - включая ректоров, проректоров, директоров филиалов. 


\subsection{1. ЧИСЛЕННОСТЬ ПРОФЕССОРСКО-ПРЕПОДАВАТЕЛЬСКОГО СОСТАВА ОБРАЗОВАТЕЛЬНЫХ \\ ОРГАНИЗАЦИЙ ВЫСШЕГО ОБРАЗОВАНИЯ ПО ДОЛЖНОСТЯМ \\ (без внешних совместителей; на начало учебного года)}

\begin{tabular}{|c|c|c|c|c|c|c|}
\hline & $2010 / 2011$ & $2011 / 2012$ & $2012 / 2013$ & $2013 / 2014$ & $2014 / 2015$ & $2015 / 2016$ \\
\hline \multicolumn{7}{|c|}{ Всего } \\
\hline Всего & 356.8 & 348.2 & 342.0 & 319.3 & 299.8 & 279.8 \\
\hline Деканы факультетов & 6.7 & 6.3 & 5.9 & 5.5 & 5.2 & 4.8 \\
\hline Заведующие кафедрами & 29.6 & 28.8 & 28.3 & 26.8 & 24.6 & 22.3 \\
\hline Профессора & 40.4 & 41.1 & 42.4 & 41.9 & 40.2 & 38.1 \\
\hline Доценты & 149.1 & 149.2 & 149.9 & 144.1 & 140.9 & 134.5 \\
\hline Старшие преподаватели & 76.5 & 72.9 & 69.4 & 61.5 & 55.2 & 50.3 \\
\hline Преподаватели, ассистенты & 54.6 & 49.9 & 46.2 & 39.6 & 33.7 & 29.8 \\
\hline \multicolumn{7}{|c|}{ Государственные и муниципальные организации } \\
\hline Всего & 324.8 & 319.0 & 312.8 & 288.2 & 271.5 & 255.8 \\
\hline Деканы факультетов & 5.5 & 5.2 & 4.9 & 4.6 & 4.3 & 4.1 \\
\hline Заведующие кафедрами & 25.4 & 24.8 & 24.1 & 22.3 & 20.4 & 19.0 \\
\hline Профессора & 36.2 & 36.9 & 37.9 & 36.2 & 35.4 & 34.0 \\
\hline Доценты & 137.5 & 138.6 & 139.1 & 132.0 & 129.1 & 123.8 \\
\hline Старшие преподаватели & 69.6 & 66.8 & 63.6 & 56.2 & 50.5 & 46.3 \\
\hline Преподаватели, ассистенты & 50.7 & 46.6 & 43.2 & 37.0 & 31.9 & 28.6 \\
\hline \multicolumn{7}{|c|}{ Частные организации } \\
\hline Всего & 32.0 & 29.2 & 29.2 & 31.1 & 28.2 & 23.9 \\
\hline Деканы факультетов & 1.2 & 1.1 & 1.0 & 0.9 & 0.8 & 0.7 \\
\hline Заведующие кафедрами & 4.1 & 4.0 & 4.1 & 4.6 & 4.2 & 3.4 \\
\hline Профессора & 4.2 & 4.1 & 4.5 & 5.7 & 4.8 & 4.0 \\
\hline Доценты & 11.6 & 10.5 & 10.8 & 12.2 & 11.8 & 10.7 \\
\hline Старшие преподаватели & 6.9 & 6.1 & 5.8 & 5.3 & 4.7 & 4.0 \\
\hline Преподаватели, ассистенты & 3.9 & 3.3 & 3.0 & 2.6 & 1.8 & 1.2 \\
\hline
\end{tabular}




\subsection{2. ЧИСЛЕННОСТЬ ЖЕНЩИН В СОСТАВЕ ПРОФЕССОРСКО-ПРЕПОДАВАТЕЛЬСКОГО СОСТАВА \\ ОБРАЗОВАТЕЛЬНЫХ ОРГАНИЗАЦИЙ ВЫСШЕГО ОБРАЗОВАНИЯ *}

(без внешних совместителей; на начало учебного года)

\begin{tabular}{|c|c|c|c|c|c|c|c|c|}
\hline & $2000 / 2001$ & $2005 / 2006$ & $2010 / 2011$ & $2011 / 2012$ & $2012 / 2013$ & $2013 / 2014$ & $2014 / 2015$ & $2015 / 2016$ \\
\hline \multicolumn{9}{|c|}{ Тысячи человек } \\
\hline Bcero & 138.5 & 191.5 & 200.8 & 196.1 & 193.2 & 180.9 & 170.3 & 159.5 \\
\hline Государственные и муниципальные организации & 130.3 & 171.7 & 182.4 & 179.3 & 176.5 & 163.6 & 154.6 & 146.3 \\
\hline Частные организации & 8.2 & 19.8 & 18.4 & 16.8 & 16.7 & 17.3 & 15.7 & 13.2 \\
\hline \multicolumn{9}{|c|}{ В процентах от общей численности } \\
\hline Всего & 49.5 & 53.4 & 56.3 & 56.3 & 56.5 & 56.6 & 56.8 & 57.0 \\
\hline Государственные и муниципальные организации & 49.1 & 53.3 & 56.1 & 56.2 & 56.4 & 56.8 & 56.9 & 57.2 \\
\hline Частные организации & 57.1 & 53.8 & 57.6 & 57.6 & 57.1 & 55.4 & 55.7 & 55.3 \\
\hline
\end{tabular}

* Данные на начало 2000/2001 и 2005/2006 учебных годов - включая ректоров, проректоров, директоров филиалов. 
5.73. ЧИСЛЕННОСТЬ ЖЕНЩИН В СОСТАВЕ ПРОФЕССОРСКО-ПРЕПОДАВАТЕЛЬСКОГО СОСТАВА ОБРАЗОВАТЕЛЬНЫХ ОРГАНИЗАЦИЙ ВЫСШЕГО ОБРАЗОВАНИЯ ПО ДОЛЖНОСТЯМ: 2015/2016

(без внешних совместителей; на начало учебного года)

\begin{tabular}{|c|c|c|c|c|c|c|}
\hline & \multicolumn{3}{|c|}{ Численность женщин, чел. } & \multicolumn{3}{|c|}{ В процентах от общей численности } \\
\hline & Всего & $\begin{array}{c}\text { Государственные } \\
\text { и муниципальные } \\
\text { организации }\end{array}$ & $\begin{array}{c}\text { Частные } \\
\text { организации }\end{array}$ & Всего & $\begin{array}{c}\text { Государственные } \\
\text { и муниципальные } \\
\text { организации }\end{array}$ & $\begin{array}{c}\text { Частные } \\
\text { организации }\end{array}$ \\
\hline Всего & 159.5 & 146.3 & 13.2 & 57.0 & 57.2 & 55.3 \\
\hline Деканы факультетов & 2.2 & 1.7 & 0.5 & 45.0 & 41.8 & 63.3 \\
\hline Заведующие кафедрами & 9.9 & 8.2 & 1.7 & 44.2 & 43.0 & 51.0 \\
\hline Профессора & 12.5 & 11.4 & 1.2 & 32.9 & 33.4 & 28.6 \\
\hline Доценты & 79.6 & 73.4 & 6.3 & 59.2 & 59.2 & 59.0 \\
\hline Старшие преподаватели & 35.4 & 32.6 & 2.8 & 70.4 & 70.4 & 70.5 \\
\hline Преподаватели, ассистенты & 19.9 & 19.1 & 0.8 & 66.9 & 66.8 & 69.6 \\
\hline
\end{tabular}




\subsection{4. ЧИСЛЕННОСТЬ ПРОФЕССОРСКО-ПРЕПОДАВАТЕЛЬСКОГО СОСТАВА ОБРАЗОВАТЕЛЬНЫХ ОРГАНИЗАЦИЙ ВЫСШЕГО ОБРАЗОВАНИЯ, ИМЕЮЩЕГО УЧЕНУЮ СТЕПЕНЬ, УЧЕНОЕ ЗВАНИЕ \\ (на начало учебного года; тысячи человек)}

\begin{tabular}{|c|c|c|c|c|c|c|c|c|}
\hline & $2000 / 2001$ & $2005 / 2006$ & $2010 / 2011$ & $2011 / 2012$ & $2012 / 2013$ & $2013 / 2014$ & $2014 / 2015$ & $2015 / 2016$ \\
\hline \multicolumn{9}{|c|}{ Всего } \\
\hline \multicolumn{9}{|c|}{ Имеют ученую степень: } \\
\hline доктора наук & 29.8 & 43.2 & 44.0 & 44.8 & 45.0 & 45.1 & 44.1 & 42.4 \\
\hline кандидата наук & 131.3 & 172.1 & 185.5 & 183.6 & 183.0 & 174.6 & 169.2 & 160.0 \\
\hline \multicolumn{9}{|c|}{ Имеют ученое звание: } \\
\hline профессора & 28.7 & 38.5 & 35.8 & 35.9 & 35.6 & 34.5 & 33.1 & 30.7 \\
\hline доцента & 94.2 & 112.7 & 115.7 & 115.7 & 115.2 & 109.4 & 106.7 & 100.3 \\
\hline \multicolumn{9}{|c|}{ Государственные и муниципальные организации } \\
\hline \multicolumn{9}{|c|}{ Имеют ученую степень: } \\
\hline доктора наук & 28.0 & 37.3 & 40.2 & 41.1 & 41.0 & 39.7 & 39.4 & 38.4 \\
\hline кандидата наук & 125.4 & 155.3 & 169.2 & 168.5 & 167.8 & 157.8 & 152.8 & 145.5 \\
\hline \multicolumn{9}{|c|}{ Имеют ученое звание: } \\
\hline профессора & 27.0 & 33.3 & 32.6 & 32.8 & 32.3 & 29.9 & 29.2 & 27.5 \\
\hline доцента & 89.8 & 102.2 & 106.7 & 107.3 & 106.6 & 100.0 & 97.4 & 92.2 \\
\hline \multicolumn{9}{|c|}{ Частные организации } \\
\hline \multicolumn{9}{|c|}{ Имеют ученую степень: } \\
\hline доктора наук & 1.7 & 5.9 & 3.8 & 3.7 & 4.0 & 5.3 & 4.7 & 4.0 \\
\hline кандидата наук & 5.9 & 16.8 & 16.3 & 15.0 & 15.2 & 16.8 & 16.3 & 14.4 \\
\hline \multicolumn{9}{|c|}{ Имеют ученое звание: } \\
\hline профессора & 1.8 & 5.2 & 3.2 & 3.1 & 3.3 & 4.6 & 3.9 & 3.2 \\
\hline доцента & 4.4 & 10.5 & 9.0 & 8.4 & 8.5 & 9.3 & 9.3 & 8.1 \\
\hline
\end{tabular}


5.75. ЧИСЛЕННОСТЬ ПРОФЕССОРСКО-ПРЕПОДАВАТЕЛЬСКОГО СОСТАВА ОБРАЗОВАТЕЛЬНЫХ ОРГАНИЗАЦИЙ

ВЫСШЕГО ОБРАЗОВАНИЯ, ПРОШЕДШЕГО ПОВЫШЕНИЕ КВАЛИФИКАЦИИ

И (ИЛИ) ПРОФЕССИОНАЛЬНУЮ ПЕРЕПОДГОТОВКУ

(без внешних совместителей; на начало учебного года)

\begin{tabular}{|c|c|c|c|c|c|c|}
\hline & $2010 / 2011$ & $2011 / 2012$ & $2012 / 2013$ & $2013 / 2014$ & $2014 / 2015$ & $2015 / 2016$ \\
\hline \multicolumn{7}{|c|}{ Тысячи человек } \\
\hline Всего & 78.0 & 77.5 & 81.9 & 87.6 & 87.0 & 90.5 \\
\hline Государственные и муниципальные организации & 70.0 & 70.7 & 74.8 & 79.0 & 73.6 & 81.8 \\
\hline Частные организации & 8.0 & 6.8 & 7.2 & 8.6 & 13.4 & 8.7 \\
\hline \multicolumn{7}{|c|}{ В процентах от общей численности } \\
\hline Всего & 21.8 & 22.2 & 24.0 & 27.4 & 29.0 & 32.3 \\
\hline Государственные и муниципальные организации & 21.5 & 22.2 & 23.9 & 27.4 & 27.1 & 32.0 \\
\hline Частные организации & 25.0 & 23.2 & 24.6 & 27.7 & 47.5 & 36.5 \\
\hline
\end{tabular}




\subsection{6. СТРУКТУРА ПРОФЕССОРСКО-ПРЕПОДАВАТЕЛЬСКОГО СОСТАВА ОБРАЗОВАТЕЛЬНЫХ ОРГАНИЗАЦИЙ ВЫСШЕГО ОБРАЗОВАНИЯ ПО ВОЗРАСТНЫМ ГРУППАМ \\ (без внешних совместителей; на начало учебного года; число полных лет на 1 января)}

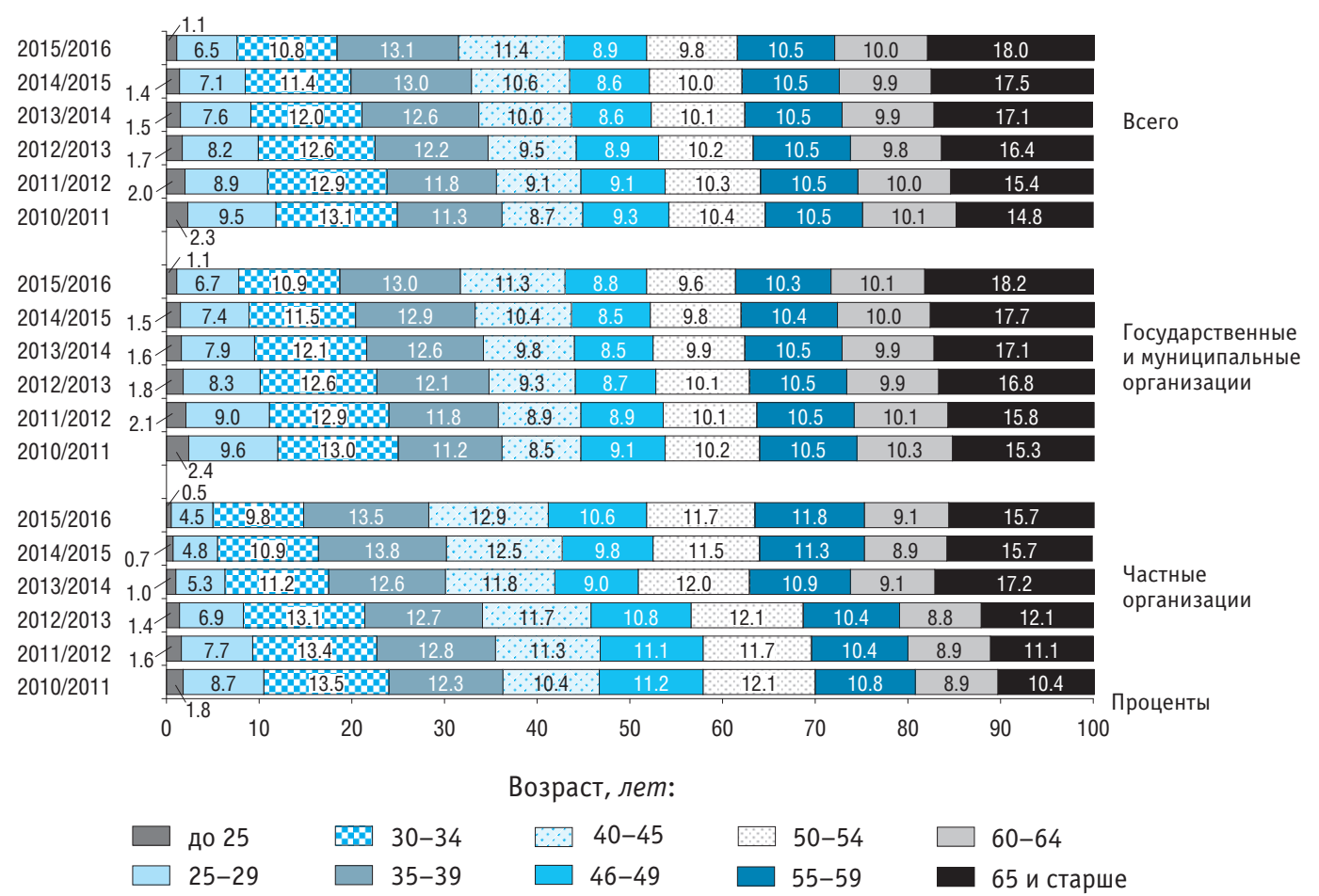




\section{МЕТОДОЛОГИЧЕСКИЕ КОММЕНТАРИИ}

Данные о среднегодовой численности занятых в экономике формируются по основной работе гражданского населения один раз в год при составлении баланса трудовых ресурсов на основе сведений организаций, материалов выборочного обследования рабочей силы, данных органов исполнительной власти. В среднегодовую численность занятых включаются работающие иностранные граждане, как постоянно проживающие, так и временно находящиеся на территории Российской Федерации. Данные за 2000, 2005 гг. сформированы без учета Чеченской Республики.

Среднесписочная численность работников образования за год определяется путем суммирования среднесписочной численности работников за все месяцы года и деления полученной суммы на 12.

Среднесписочная численность работников организаций за месяц исчисляется путем суммирования списочной численности работников за каждый календарный день месяца и деления полученной суммы на число календарных дней месяца. Женщины, находившиеся в отпусках по беременности, родам и уходу за ребенком, работники, обучающиеся в образовательных организациях и находившиеся в дополнительном отпуске без сохранения заработной платы, а также поступающие в образовательные организации, находившиеся в отпуске без сохранения заработной платы для сдачи вступительных испытаний, в среднесписочную численность работников не включаются. Работники, занятые неполный рабочий день или неполную ра- бочую неделю, учитываются в среднесписочной численности работников пропорционально отработанному времени.

В списочную численность работников организаций включаются работавшие по трудовому договору и выполнявшие постоянную, временную или сезонную работу один день и более, как фактически работавшие, так и отсутствовавшие на работе по каким-либо причинам (находившиеся в ежегодных, дополнительных, учебных отпусках; не явившиеся на работу по болезни; женщины, находившиеся в отпусках по беременности, родам, уходу за ребенком и др.).

Укомплектованность штатов - отношение числа занятых должностей к количеству ставок согласно штатному расписанию, в процентах.

Педагогический работник - физическое лицо, которое состоит в трудовых, служебных отношениях с организацией, осуществляющей образовательную деятельность, и выполняет обязанности по обучению, воспитанию обучающихся и (или) организации образовательной деятельности.

Преподаватель - работник образовательной организации, выполняющий учебную, научную, методическую, воспитательную и организационную деятельность (в общеобразовательной организации - учитель).

Численность обучающихся по образовательным программам в расчете на одного преподавателя - показатель, характеризующий численность обучающихся, приходящуюся на одного преподавателя. Определяется как отношение чис- 
ленности обучающихся в образовательных организациях к численности преподавателей (без учета внешних совместителей). Для общеобразовательных программ, реализуемых в вечерних (сменных) общеобразовательных организациях, программ среднего профессионального образования и программ высшего образования - программ бакалавриата, программ специалитета, программ магистратуры - используется расчетная численность обучающихся, определяемая исходя из численности обучающихся очной формы обучения плюс $25 \%$ от численности обучающихся очно-заочной формы обучения плюс $10 \%$ от численности обучающихся заочной формы обучения (по вечерним (сменным) общеобразовательным организациям - включая экстернов).

Международное исследование учительского корпуса (исследование преподавания и обучения) (TALIS) проводится 0ЭСР для сбора и сравнения информации об учителях и директорах в разных странах раз в пять лет. Исследование охватывает более 30 стран, не все из которых члены 0ЭСР. В 2013 г. Россия стала участником программы (основная часть исследования была проведена в 2014 г.). 0прос, проведенный в ходе TALIS 2013, охватил 4000 учителей, работающих на основной и старшей школьных ступенях, и 198 директоров из 200 школ 14 регионов Российской Федерации.

Система индикаторов TALIS позволяет собрать информацию, характеризующую состояние учительского корпуса:

- структурные характеристики кадров - гендерный и возрастной состав учительского и директорского корпуса; уровень профессиональной подготовки учителей и директоров; недельная нагрузка и распределение рабочего времени;

- профессиональные установки учителей - запросы на профессиональное развитие и особенности преподавания;

- мнения и взгляды учителей и директоров - удовлетворенность работой и профессией. Шкала «Удовлетворенность работой» построена на основании соответствующих блоков анкеты TALIS для всех стран, участвующих в исследовании. Шкала имеет среднее значение 10 и стандартное отклонение 2.

В настоящем разделе итоги за 2014 (за исключением табл. 5.1, 5.6, рис. 5.2-5.5) и 2015 гг. приведены с учетом сведений по Республике Крым и г. Севастополю. 


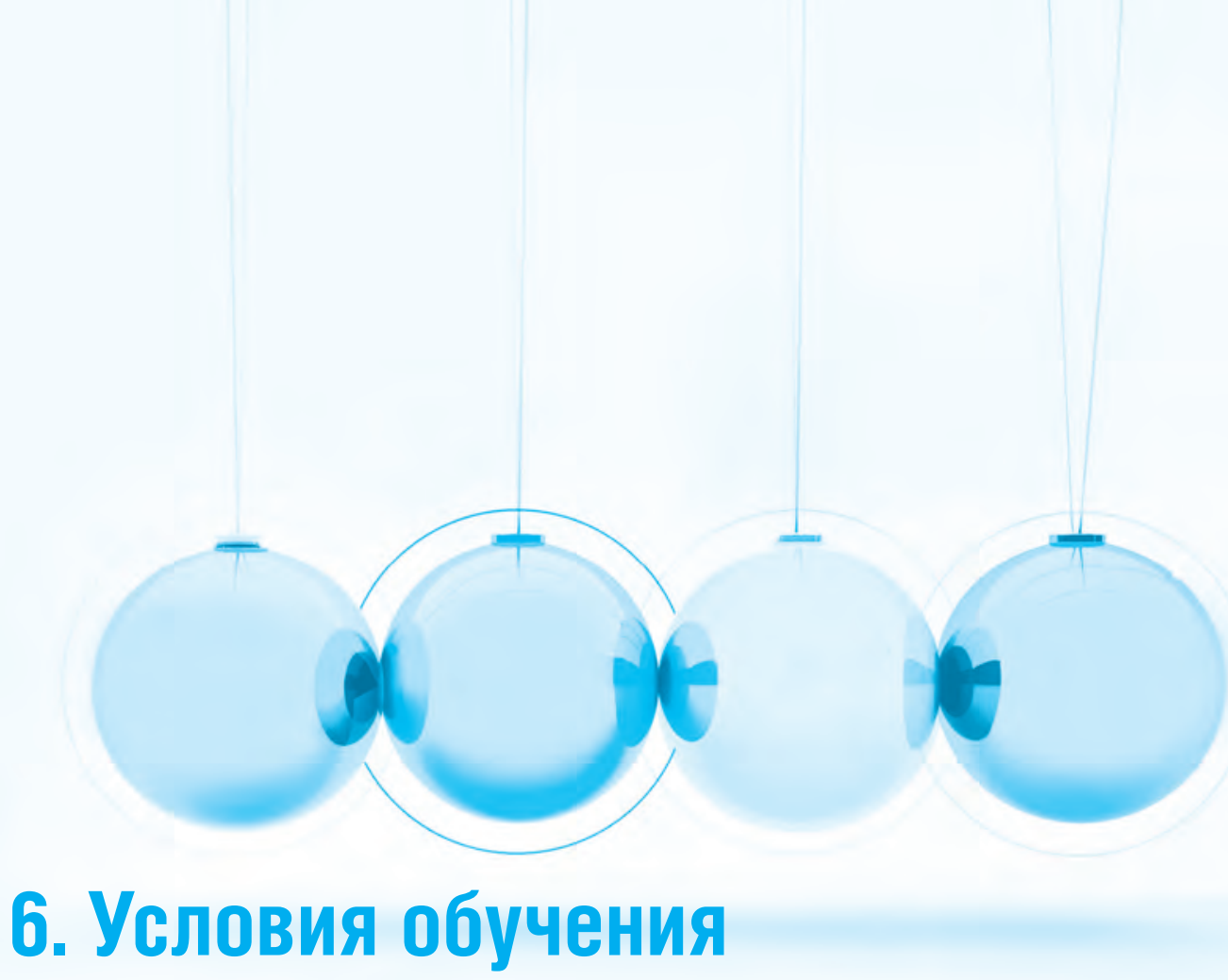




\section{1. ОСНОВНЫЕ ФОНДЫ ОБРАЗОВАНИЯ *} (на конец года)

\begin{tabular}{|c|c|c|c|c|c|c|c|c|}
\hline & 2000 & 2005 & 2010 & 2011 & 2012 & 2013 & 2014 & 2015 \\
\hline \multicolumn{9}{|l|}{ Основные фонды, по полной учетной стоимости: } \\
\hline млрд руб. & 472.8 & 1278.8 & 2700.0 & 2924.7 & 3266.8 & 3535.4 & 3807.1 & 4023.6 \\
\hline в процентах от общего объема основных фондов экономики & 2.7 & 3.1 & 2.9 & 2.7 & 2.7 & 2.6 & 2.6 & 2.5 \\
\hline Степень износа основных фондов, проценты & 34.9 & 43.8 & 53.2 & 54.3 & 54.3 & 53.9 & 52.5 & 48.0 \\
\hline
\end{tabular}

* Данные за 2000 г. приведены в соответствии со структурой ОКОНХ, начиная с 2005 г. - в соответствии со структурой ОКВЭД.

\section{2. ИНДЕКСЫ ФИЗИЧЕСКОГО ОБЪЕМА ОСНОВНЫХ ФОНДОВ ОБРАЗОВАНИЯ * (в сопоставимых ценах **; в процентах к концу предыдущего года)}

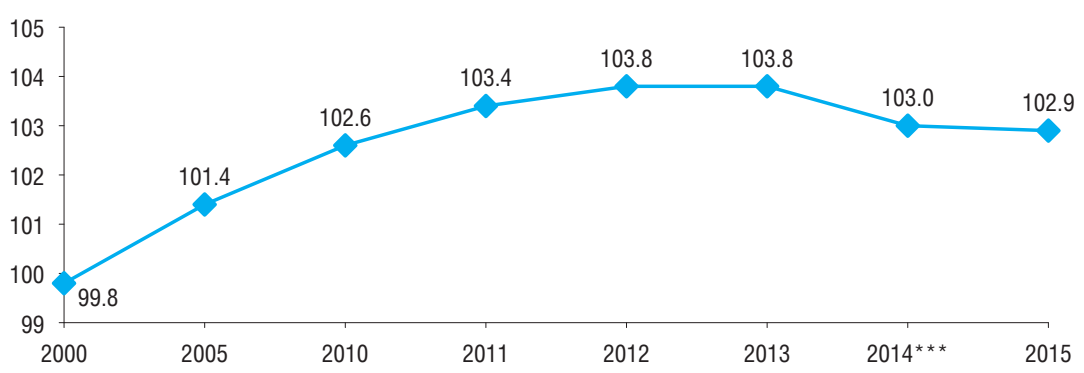

* Данные за 2000 г. приведены в соответствии со структурой ОКОНХ, начиная с 2005 г. - в соответствии со структурой ОКВЭД.

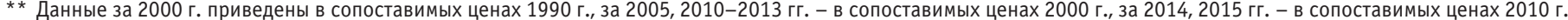
*** Без учета данных по Республике Крым и г. Севастополю. 


\section{3. ВВОД В ДЕЙСТВИЕ ОСНОВНЫХ ФОНДОВ ОБРАЗОВАНИЯ, КОЭФФИЦИЕНТЫ ИХ ОБНОВЛЕНИЯ И ВЫБЫТИЯ *}

\begin{tabular}{|c|c|c|c|c|c|c|c|c|}
\hline & 2000 & 2005 & 2010 & 2011 & 2012 & 2013 & 2014 & 2015 \\
\hline $\begin{array}{l}\text { Ввод в действие основных фондов, } \\
\text { в фактических ценах; млрд руб. }\end{array}$ & 14.0 & 58.9 & 138.1 & 164.3 & 231.0 & 277.4 & 236.7 & 240.6 \\
\hline $\begin{array}{l}\text { Коэффициент обновления основных фондов, } \\
\text { в сопоставимых ценах; проценты ** }\end{array}$ & 0.8 & 2.2 & 3.4 & 3.8 & 4.2 & 4.2 & $3.3^{\star \star * *}$ & 3.2 \\
\hline $\begin{array}{l}\text { Коэффициент выбытия основных фондов, } \\
\text { в сопоставимых ценах, проценты** }\end{array}$ & 1.0 & 0.9 & 0.8 & 0.7 & 0.8 & 0.7 & $0.6^{\star * *}$ & 0.6 \\
\hline
\end{tabular}

* Данные за 2000 г. приведены в соответствии со структурой ОКОНХ, начиная с 2005 г. - в соответствии со структурой ОКВЭД.

** Данные за 2000 г. приведены в сопоставимых ценах 1990 г., за 2005, 2010-2013 гг. - в сопоставимых ценах 2000 г., за 2014,2015 гг. - в сопоставимых ценах 2010 г. *** Без учета данных по Республике Крым и г. Севастополю.

\section{4. ВВОД В ДЕЙСТВИЕ МОЩНОСТЕЙ ОБРАЗОВАТЕЛЬНЫХ ОРГАНИЗАЦИЙ}

\begin{tabular}{|c|c|c|c|c|c|c|c|c|}
\hline & 2000 & 2005 & 2010 & 2011 & 2012 & 2013 & 2014 & 2015 \\
\hline Дошкольные образовательные организации, тыс. мест & 6.8 & 5.0 & 22.9 & 45.0 & 53.9 & 90.3 & 128.9 & 143.3 \\
\hline Общеобразовательные организации, тыс. ученических мест & 133.8 & 73.0 & 67.8 & 60.5 & 48.8 & 70.0 & 55.7 & 66.3 \\
\hline $\begin{array}{l}\text { Из них школы-интернаты для детей-сирот и детей, оставшихся } \\
\text { без попечения родителей, ученических мест }\end{array}$ & 20 & 426 & 510 & 518 & - & - & 74 & - \\
\hline $\begin{array}{l}\text { Профессиональные образовательные организации, реализующие } \\
\text { образовательные программы среднего профессионального обра- } \\
\text { зования - программы подготовки квалифицированных рабочих, } \\
\text { служащих, тыс. ученических мест }\end{array}$ & 0.6 & 0.3 & 1.2 & 3.5 & 2.0 & 0.3 & 1.4 & 0.5 \\
\hline $\begin{array}{l}\text { Профессиональные образовательные организации, реализующие } \\
\text { образовательные программы среднего профессионального образо- } \\
\text { вания - программы подготовки специалистов среднего звена, } \\
\text { тыс. кв. м общей площади учебно-лабораторных зданий }\end{array}$ & 18.2 & 11.5 & 60.4 & 10.8 & 36.7 & 7.2 & 16.1 & 8.9 \\
\hline $\begin{array}{l}\text { Образовательные организации высшего образования, } \\
\text { тыс. кв. м общей площади учебно-лабораторных зданий }\end{array}$ & 105.6 & 161.3 & 219.7 & 154.9 & 587.0 & 210.1 & 84.5 & 222.0 \\
\hline
\end{tabular}




\section{5. ДИНАМИКА ЧИСЛА ОБРАЗОВАТЕЛЬНЫХ ОРГАНИЗАЦИЙ}

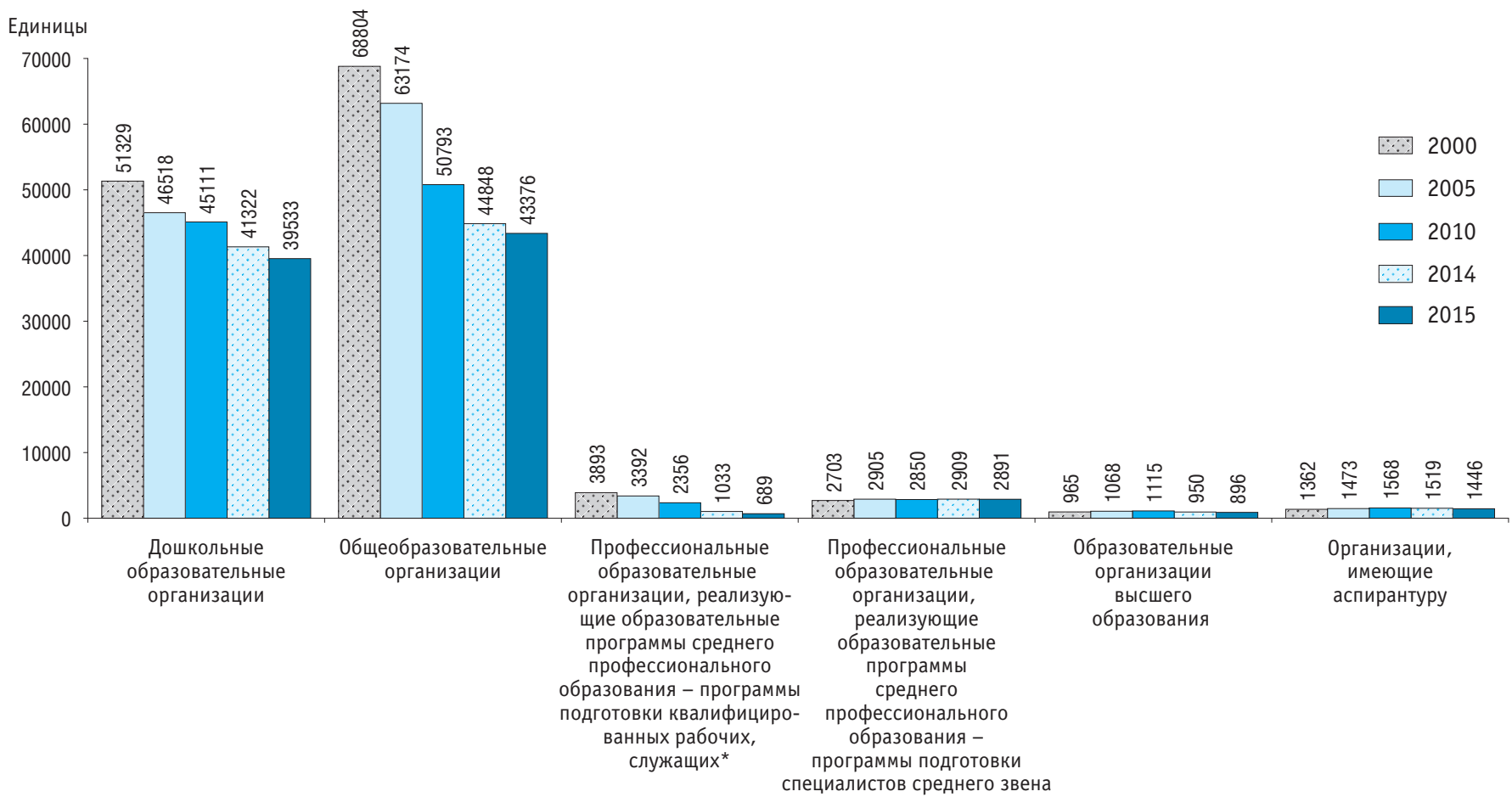

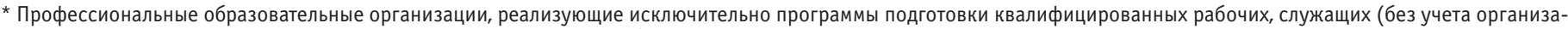
ций, реализующих программы подготовки квалифицированных рабочих, служащих наряду с реализацией программ подготовки специалистов среднего звена). 


\section{6. ЧИСЛО ОРГАНИЗАЦИЙ, ОСУЩЕСТВЛЯЮЩИХ ОБРАЗОВАТЕЛЬНУЮ ДЕЯТЕЛЬНОСТЬ ПО ОБРАЗОВАТЕЛЬНЫМ ПРОГРАММАМ ДОШКОЛЬНОГО ОБРАЗОВАНИЯ, ПРИСМОТР И УХОД ЗА ДЕТЬМИ * (на конец года)}

\begin{tabular}{|c|c|c|c|c|c|c|c|c|}
\hline & 2000 & 2005 & 2010 & 2011 & 2012 & 2013 & 2014 & 2015 \\
\hline Дошкольные образовательные организации & 51329 & 46518 & 45111 & 44884 & 44326 & 43187 & 41322 & 39533 \\
\hline Обособленные структурные подразделения (филиалы) & & & & & & & & \\
\hline дошкольных образовательных организаций & $\ldots$ & $\ldots$ & 401 & 577 & 620 & 795 & 1100 & 1148 \\
\hline $\begin{array}{l}\text { Обособленные структурные подразделения (филиалы) } \\
\text { общеобразовательных организаций }\end{array}$ & $\ldots$ & $\ldots$ & 1136 & 1211 & 1504 & 1581 & 1808 & 2065 \\
\hline $\begin{array}{l}\text { Обособленные структурные подразделения (филиалы) } \\
\text { профессиональных образовательных организаций } \\
\text { и образовательных организаций высшего образования }\end{array}$ & $\ldots$ & $\ldots$ & $\ldots$ & $\ldots$ & $\ldots$ & $\ldots$ & 15 & 18 \\
\hline \multicolumn{9}{|l|}{$\begin{array}{l}\text { Организации, имеющие подразделения (группы), } \\
\text { осуществляющие образовательную деятельность } \\
\text { по образовательным программам дошкольного образования, } \\
\text { присмотр и уход за детьми: }\end{array}$} \\
\hline общеобразовательные организации & $\ldots$ & 4073 & 6353 & 6689 & 7250 & 7924 & 9440 & 10333 \\
\hline $\begin{array}{l}\text { профессиональные образовательные организации } \\
\text { и образовательные организации высшего образования }\end{array}$ & $\ldots$ & $\ldots$ & $\ldots$ & $\ldots$ & $\ldots$ & $\ldots$ & 10 & 26 \\
\hline образовательные организации дополнительного образования & $\ldots$ & $\ldots$ & $\ldots$ & $\ldots$ & $\ldots$ & $\ldots$ & 87 & 91 \\
\hline иные организации & $\ldots$ & $\ldots$ & $\ldots$ & $\ldots$ & $\ldots$ & $\ldots$ & 120 & 132 \\
\hline
\end{tabular}

* Включая организации на капитальном ремонте. 
6.7. ЧИСЛО МЕСТ В ОРГАНИЗАЦИЯХ, ОСУЩЕСТВЛЯЮЩИХ ОБРАЗОВАТЕЛЬНУЮ ДЕЯТЕЛЬНОСТЬ ПО ОБРАЗОВАТЕЛЬНЫМ ПРОГРАММАМ ДОШКОЛЬНОГО ОБРАЗОВАНИЯ, ПРИСМОТР И УХОД ЗА ДЕТЬМИ

(на конец года)

\begin{tabular}{|c|c|c|c|c|c|c|c|c|}
\hline & 2000 & 2005 & 2010 & 2011 & 2012 & 2013 & 2014 & 2015 \\
\hline \multicolumn{9}{|c|}{ Всего } \\
\hline \multicolumn{9}{|c|}{$\begin{array}{l}\text { Число мест в организациях, осуществляющих образовательную } \\
\text { деятельность по реализации образовательных программ } \\
\text { дошкольного образования, присмотр и уход за детьми: }\end{array}$} \\
\hline тыс. & 5231.9 & 4765.5 & 5031.4 & 5322.8 & 5708.9 & 6046.1 & 6453.2 & 6764.4 \\
\hline в расчете на 1000 детей в возрасте 1-6 лет & 675 & 597 & 553 & 570 & 592 & 600 & 612 & 626 \\
\hline \multicolumn{9}{|c|}{ Города и поселки городского типа } \\
\hline \multicolumn{9}{|c|}{$\begin{array}{l}\text { Число мест в организациях, осуществляющих образовательную } \\
\text { деятельность по реализации образовательных программ } \\
\text { дошкольного образования, присмотр и уход за детьми: }\end{array}$} \\
\hline тыс. & 3862.2 & 3539.1 & 3796.2 & 4055.0 & 4366.9 & 4643.1 & 4960.1 & 5210.2 \\
\hline в расчете на 1000 детей в возрасте 1-6 лет & 727 & 630 & 590 & 614 & 640 & 648 & 660 & 673 \\
\hline \multicolumn{9}{|c|}{ Сельская местность } \\
\hline \multicolumn{9}{|c|}{$\begin{array}{l}\text { Число мест в организациях, осуществляющих образовательную } \\
\text { деятельность по реализации образовательных программ } \\
\text { дошкольного образования, присмотр и уход за детьми: }\end{array}$} \\
\hline тыс. & 1369.7 & 1226.4 & 1235.2 & 1267.8 & 1342.0 & 1403.0 & 1493.0 & 1554.2 \\
\hline в расчете на 1000 детей в возрасте 1-6 лет & 561 & 517 & 463 & 465 & 477 & 481 & 493 & 508 \\
\hline
\end{tabular}




\section{8. СРЕДНИЙ РАЗМЕР ГРУПП В ОРГАНИЗАЦИЯХ, ОСУЩЕСТВЛЯЮЩИХ ОБРАЗОВАТЕЛЬНУЮ ДЕЯТЕЛЬНОСТЬ ПО ОБРАЗОВАТЕЛЬНЫМ ПРОГРАММАМ ДОШКОЛЬНОГО ОБРАЗОВАНИЯ, ПРИСМОТР И УХОД ЗА ДЕТЬМИ: 2015}

(на конец года)

\begin{tabular}{|c|c|c|c|}
\hline & Всего & $\begin{array}{c}\text { Города и поселки } \\
\text { городского типа }\end{array}$ & Сельская местность \\
\hline Всего & 23 & 23 & 20 \\
\hline Группы общеразвивающей направленности & 23 & 25 & 20 \\
\hline Группы компенсирующей направленности & 16 & 16 & 15 \\
\hline \multicolumn{4}{|l|}{ В том числе для воспитанников: } \\
\hline с нарушением слуха & 11 & 11 & 12 \\
\hline с нарушением речи & 16 & 17 & 15 \\
\hline с нарушением зрения & 15 & 15 & 17 \\
\hline с нарушением интеллекта & 11 & 11 & 12 \\
\hline с задержкой психического развития & 13 & 13 & 13 \\
\hline с нарушением опорно-двигательного аппарата & 16 & 16 & 13 \\
\hline со сложным дефектом & 10 & 10 & 7 \\
\hline другого профиля & 16 & 16 & 14 \\
\hline Группы оздоровительной направленности & 20 & 20 & 18 \\
\hline \multicolumn{4}{|l|}{ Из них для воспитанников: } \\
\hline с туберкулезной интоксикацией & 18 & 18 & 15 \\
\hline часто болеющих & 21 & 21 & 19 \\
\hline Группы комбинированной направленности & 23 & 23 & 22 \\
\hline Группы для детей раннего возраста & 21 & 21 & 18 \\
\hline Группы по присмотру и уходу за детьми & 16 & 17 & 13 \\
\hline Семейные дошкольные группы & 7 & 5 & 15 \\
\hline
\end{tabular}




\section{9. ПЛОЩАДЬ ПОМЕЩЕНИЙ ДОШКОЛЬНЫХ ОБРАЗОВАТЕЛЬНЫХ ОРГАНИЗАЦИЙ *} (на конец года)

\begin{tabular}{|c|c|c|c|c|c|c|c|c|}
\hline & 2001 & 2004 & 2010 & 2011 & 2012 & 2013 & 2014 & 2015 \\
\hline Общая площадь всех помещений, млн кв. м & 59.3 & 55.7 & 58.5 & 59.9 & 61.1 & 64.0 & 61.6 & 63.5 \\
\hline $\begin{array}{l}\text { В том числе площадь помещений, использу } \\
\text { для нужд образовательной организации }\end{array}$ & $\ldots$ & $\ldots$ & 49.7 & 51.2 & 52.2 & 55.2 & 52.4 & 54.1 \\
\hline Из нее площадь групповых помещений & 33.2 & 31.2 & 31.3 & 32.0 & 32.6 & 33.2 & 32.6 & 33.1 \\
\hline \multicolumn{9}{|c|}{$\begin{array}{l}\text { Общая площадь всех помещений, используемых непосредственно } \\
\text { для нужд образовательной организации, в расчете }\end{array}$} \\
\hline на 1 воспитанника, кв. м & $\ldots$ & $\ldots$ & 9.2 & 9.0 & 8.7 & 8.7 & 8.6 & 8.5 \\
\hline Города и поселки городского типа & $\ldots$ & $\ldots$ & 9.0 & 8.8 & 8.5 & 8.5 & 8.2 & 8.2 \\
\hline Сельская местность & $\ldots$ & $\ldots$ & 10.0 & 9.8 & 9.5 & 9.4 & 10.3 & 10.0 \\
\hline
\end{tabular}

* Здесь и далее (рис. 6.10, 6.12, табл. 6.11) с 2010 г. (рис. 6.10 - с 2007 г.) сведения приведены с учетом обособленных подразделений (в том числе филиалов) дошкольных образовательных организаций и общеобразовательных организаций, а также профессиональных образовательных организаций (с 2015 г.) и образовательных организаций высшего образования (с 2014 г.), осуществляющих образовательную деятельность по образовательным программам дошкольного образования, присмотр и уход за детьми. 
6.10. УДЕЛЬНЫЙ ВЕС АРЕНДОВАННОЙ ПЛОЩАДИ В ОБЩЕЙ ПЛОЩАДИ ПОМЕЩЕНИЙ ДОШКОЛЬНЫХ ОБРАЗОВАТЕЛЬНЫХ ОРГАНИЗАЦИЙ

(на конец года)

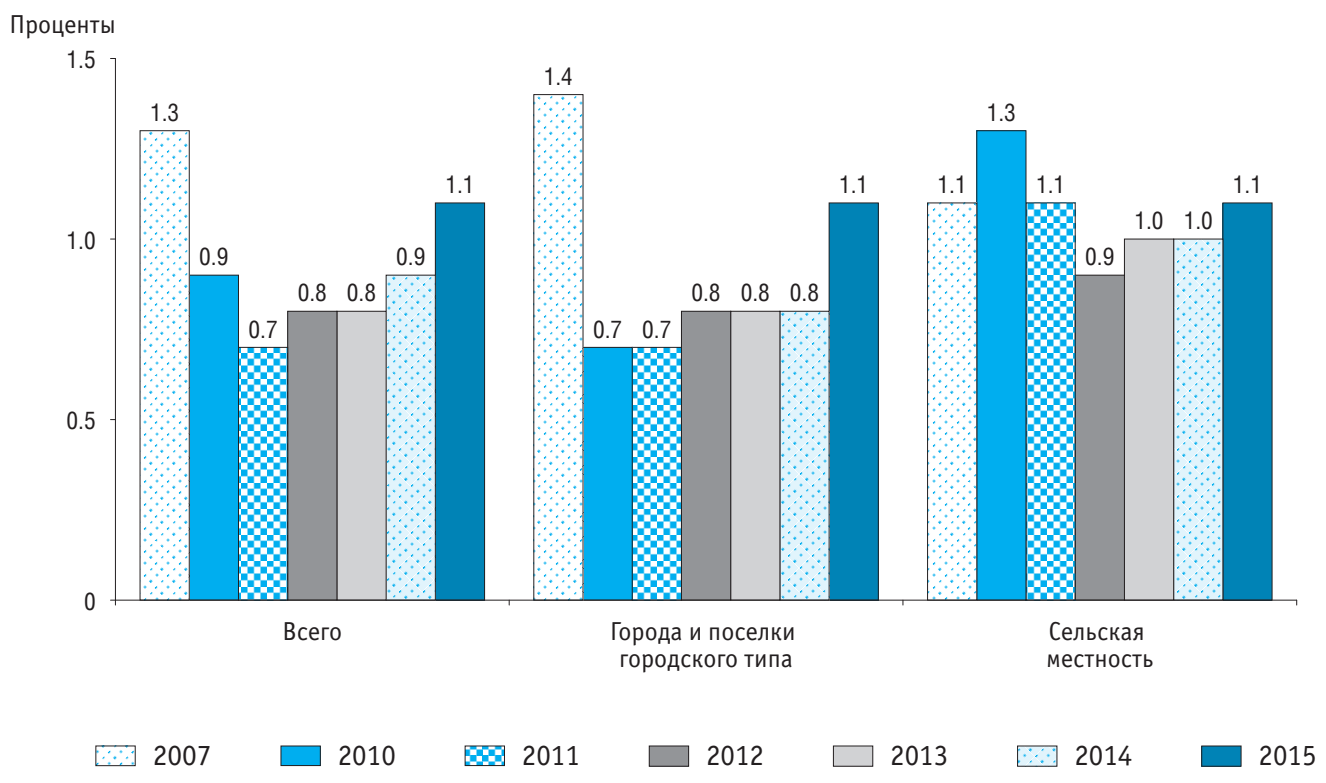




\subsection{1. ТЕХНИЧЕСКОЕ СОСТОЯНИЕ И БЛАГОУСТРОЙСТВО ЗДАНИЙ ДОШКОЛЬНЫХ ОБРАЗОВАТЕЛЬНЫХ ОРГАНИЗАЦИЙ} (на конец года)

\begin{tabular}{|c|c|c|c|c|c|c|c|c|}
\hline & 2001 & 2004 & 2010 & 2011 & 2012 & 2013 & 2014 & 2015 \\
\hline \multicolumn{9}{|c|}{ Дошкольные образовательные организации, здания которых: } \\
\hline требуют капитального ремонта, тыс. & 16392 & 14281 & 10335 & 6700 & 5372 & 4431 & 3791 & 3552 \\
\hline в процентах от общего числа организаций & 33.3 & 30.6 & 22.4 & 14.5 & 11.7 & 9.8 & 8.6 & 8.3 \\
\hline города и поселки городского типа & 29.6 & 27.3 & 19.5 & 12.3 & 9.9 & 8.2 & 7.2 & 7.3 \\
\hline сельская местность & 37.9 & 34.9 & 26.4 & 17.5 & 14.2 & 12.0 & 10.5 & 9.9 \\
\hline находятся в аварийном состоянии, тыс. & 626 & 444 & 527 & 252 & 92 & 67 & 127 & 150 \\
\hline в процентах от общего числа организаций & 1.3 & 1.0 & 1.1 & 0.5 & 0.2 & 0.1 & 0.3 & 0.4 \\
\hline города и поселки городского типа & 0.8 & 0.8 & 1.0 & 0.4 & 0.2 & 0.1 & 0.2 & 0.2 \\
\hline сельская местность & 1.9 & 1.2 & 1.4 & 0.8 & 0.3 & 0.2 & 0.5 & 0.5 \\
\hline имеют все виды благоустройства, тыс. & 39991 & 38139 & 40408 & 41170 & 41365 & 40847 & 40122 & 38568 \\
\hline в процентах от общего числа организаций & 81.2 & 81.7 & 87.5 & 89.1 & 89.8 & 90.3 & 91.1 & 90.5 \\
\hline города и поселки городского типа & 95.0 & 95.1 & 96.6 & 96.7 & 96.7 & 96.8 & 97.1 & 95.9 \\
\hline сельская местность & 63.7 & 64.2 & 75.1 & 78.4 & 80.2 & 81.5 & 82.8 & 82.7 \\
\hline
\end{tabular}




\subsection{2. ДОШКОЛЬНЫЕ ОБРАЗОВАТЕЛЬНЫЕ ОРГАНИЗАЦИИ, ИСПОЛЬЗУЮЩИЕ}

ПЕРСОНАЛЬНЫЕ КОМПЬЮТЕРЫ И ИНТЕРНЕТ: 2015

(на конец года; в процентах от общего числа организаций)

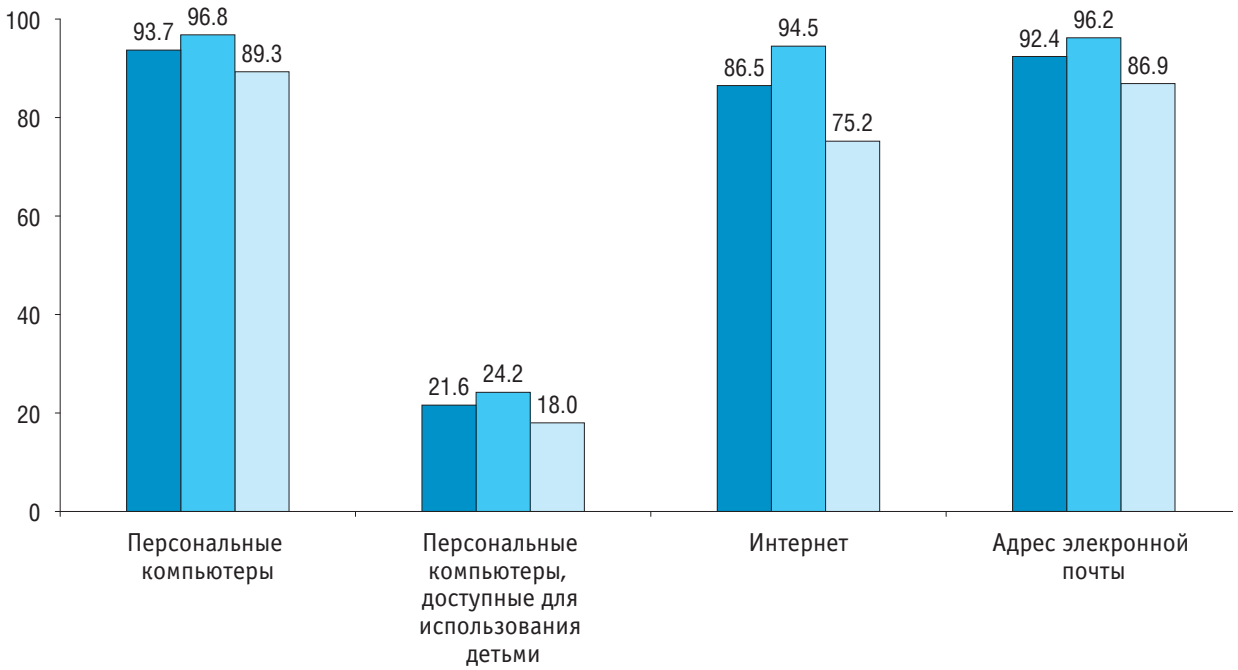

детьми 


\subsection{3. ОБЩЕОБРАЗОВАТЕЛЬНЫЕ ОРГАНИЗАЦИИ}

(на начало учебного года)

\begin{tabular}{|c|c|c|c|c|c|c|c|c|}
\hline & $2000 / 2001$ & $2005 / 2006$ & $2010 / 2011$ & $2011 / 2012$ & $2012 / 2013$ & $2013 / 2014$ & $2014 / 2015$ & $2015 / 2016$ \\
\hline Bcero & 68804 & 63174 & 50793 & 48342 & 46881 & 45419 & 44848 & 43376 \\
\hline $\begin{array}{l}\text { Общеобразовательные организации (без вечерних } \\
\text { (сменных) общеобразовательных организаций) }\end{array}$ & 67063 & 61497 & 49469 & 47146 & 45746 & 44436 & 43979 & 42687 \\
\hline Государственные и муниципальные* & 66428 & 60771 & 48804 & 46459 & 45031 & 43716 & 43228 & 41906 \\
\hline Города и поселки городского типа & 21271 & 20404 & 18478 & 18124 & 17900 & 17554 & 17285 & 16808 \\
\hline Сельская местность & 45157 & 40367 & 30326 & 28335 & 27131 & 26162 & 25943 & 25098 \\
\hline Частные & 635 & 726 & 665 & 687 & 715 & 720 & 751 & 781 \\
\hline Города и поселки городского типа & $\ldots$ & $\ldots$ & 620 & 634 & 663 & 668 & 692 & 718 \\
\hline Сельская местность & $\ldots$ & $\ldots$ & 45 & 53 & 52 & 52 & 59 & 63 \\
\hline $\begin{array}{l}\text { Вечерние (сменные) общеобразовательные } \\
\text { организации** }\end{array}$ & 1741 & 1677 & 1324 & 1196 & 1135 & 983 & 869 & 689 \\
\hline Города и поселки городского типа & 1423 & 1339 & 1027 & 918 & 859 & 764 & 673 & 531 \\
\hline Сельская местность & 318 & 338 & 297 & 278 & 276 & 219 & 196 & 158 \\
\hline
\end{tabular}

* Включая организации на капитальном ремонте.

** В 2013/2014 учебном году и ранее данные приведены без частных общеобразовательных организаций. 


\subsection{4. ОБЩЕОБРАЗОВАТЕЛЬНЫЕ ОРГАНИЗАЦИИ (БЕЗ ВЕЧЕРНИХ (СМЕННЫХ) ОБЩЕОБРАЗОВАТЕЛЬНЫХ ОРГАНИЗАЦИЙ) * (на начало учебного года)}

\begin{tabular}{|c|c|c|c|c|c|}
\hline & $2011 / 2012$ & $2012 / 2013$ & $2013 / 2014$ & $2014 / 2015$ & $2015 / 2016$ \\
\hline Bcero & 47146 & 45746 & 44436 & 43979 & 42687 \\
\hline \multicolumn{6}{|l|}{ Образовательные организации для детей дошкольного } \\
\hline и младшего школьного возраста & 1199 & 1102 & 964 & 829 & 716 \\
\hline Общеобразовательные организации и школы-интернаты & 43783 & 42503 & 41377 & 41066 & 40007 \\
\hline Начальные & 2510 & 1988 & 1651 & 1514 & 1334 \\
\hline Основные & 8643 & 8289 & 8038 & 7812 & 7542 \\
\hline Средние & 28655 & 28194 & 27657 & 27661 & 27375 \\
\hline С углубленным изучением отдельных предметов & 1305 & 1321 & 1304 & 1289 & 1121 \\
\hline Гимназии & 1554 & 1574 & 1588 & 1627 & 1519 \\
\hline Лицеи & 1116 & 1137 & 1139 & 1163 & 1116 \\
\hline Кадетские общеобразовательные организации & 156 & 174 & 178 & 178 & 152 \\
\hline $\begin{array}{l}\text { Общеобразовательные организации с первоначальной } \\
\text { летной подготовкой }\end{array}$ & 6 & 6 & 6 & 5 & 5 \\
\hline Общеобразовательные организации для обучающихся & & & & & \\
\hline с ограниченными возможностями здоровья * * & 1827 & 1793 & 1730 & 1709 & 1649 \\
\hline $\begin{array}{l}\text { Санаторные образовательные организации для обучающихся, } \\
\text { нуждающихся в длительном лечении }\end{array}$ & 103 & 100 & 101 & 115 & 96 \\
\hline $\begin{array}{l}\text { Организации для детей, нуждающихся в психолого- } \\
\text { педагогической и медико-социальной помощи }\end{array}$ & 72 & 68 & 80 & 77 & 62 \\
\hline
\end{tabular}

* Включая организации на капитальном ремонте.

** Включая специальные учебно-воспитательные учреждения для обучающихся с девиантным (общественно опасным) поведением. 
6.15. ВЕЧЕРНИЕ (СМЕННЫЕ) ОБЩЕОБРАЗОВАТЕЛЬНЫЕ ОРГАНИЗАЦИИ* (на начало учебного года)

\begin{tabular}{|c|c|c|c|c|c|c|c|c|}
\hline & $2000 / 2001$ & $2005 / 2006$ & $2010 / 2011$ & $2011 / 2012$ & $2012 / 2013$ & $2013 / 2014$ & $2014 / 2015$ & $2015 / 2016$ \\
\hline Всего & 1741 & 1677 & 1324 & 1196 & 1135 & 983 & 869 & 689 \\
\hline Вечерние (сменные) общеобразовательные школы & 1200 & 1074 & 771 & 692 & 614 & 500 & 431 & 342 \\
\hline \multicolumn{9}{|l|}{ Вечерние (сменные) общеобразовательные школы } \\
\hline при исправительных учреждениях & 189 & 206 & 223 & 212 & 254 & 249 & 237 & 189 \\
\hline Центры образования & 117 & 115 & 106 & 103 & 94 & 86 & 80 & 61 \\
\hline Открытые (сменные) общеобразовательные школы & 212 & 269 & 215 & 183 & 169 & 145 & 117 & 93 \\
\hline \multicolumn{9}{|l|}{ Общеобразовательные организации для обучающихся } \\
\hline с ограниченными возможностями здоровья & 23 & 13 & 9 & 6 & 4 & 3 & 4 & 4 \\
\hline
\end{tabular}

* В 2013/2014 учебном году и ранее данные приведены без частных общеобразовательных организаций. 


\subsection{6. СРЕДНИЙ РАЗМЕР КЛАССА В ОБЩЕОБРАЗОВАТЕЛЬНЫХ ОРГАНИЗАЦИЯХ (БЕЗ ВЕЧЕРНИХ (СМЕННЫХ) \\ ОБЩЕОБРАЗОВАТЕЛЬНЫХ ОРГАНИЗАЦИЙ) * \\ (на начало учебного года)}

\begin{tabular}{|c|c|c|c|c|c|c|c|c|}
\hline & $2000 / 2001$ & $2005 / 2006$ & $2010 / 2011$ & $2011 / 2012$ & $2012 / 2013$ & $2013 / 2014$ & $2014 / 2015$ & $2015 / 2016$ \\
\hline \multicolumn{9}{|c|}{ Всего } \\
\hline \multicolumn{9}{|l|}{ Классы: } \\
\hline $1-4$ & 18 & 18 & 20 & 20 & 20 & 20 & 21 & 21 \\
\hline $5-9$ & 21 & 18 & 18 & 18 & 18 & 19 & 19 & 19 \\
\hline $10-11(12)$ & 21 & 19 & 17 & 17 & 17 & 17 & 17 & 17 \\
\hline \multicolumn{9}{|c|}{ Государственные и муниципальные организации } \\
\hline \multicolumn{9}{|l|}{ Классы: } \\
\hline $1-4^{* *}$ & 18 & 18 & 20 & 20 & 20 & 21 & 21 & 21 \\
\hline города и поселки городского типа & 23 & 23 & 24 & 25 & 25 & 25 & 25 & 26 \\
\hline сельская местность & 13 & 12 & 13 & 13 & 13 & 14 & 14 & 14 \\
\hline $5-9$ & 21 & 18 & 18 & 18 & 19 & 19 & 19 & 19 \\
\hline города и поселки городского типа & 25 & 23 & 24 & 24 & 24 & 24 & 25 & 25 \\
\hline сельская местность & 15 & 13 & 12 & 12 & 12 & 12 & 12 & 12 \\
\hline $10-11(12)$ & 21 & 19 & 17 & 18 & 17 & 17 & 17 & 17 \\
\hline города и поселки городского типа & 24 & 23 & 22 & 23 & 22 & 22 & 22 & 22 \\
\hline сельская местность & 15 & 13 & 11 & 11 & 10 & 10 & 10 & 9 \\
\hline \multicolumn{9}{|c|}{ Частные организации } \\
\hline \multicolumn{9}{|l|}{ Классы: } \\
\hline $1-4^{* *}$ & 10 & 10 & 11 & 12 & 13 & 13 & 13 & 13 \\
\hline $5-9$ & 11 & 10 & 10 & 11 & 11 & 12 & 12 & 12 \\
\hline $10-11(12)$ & 12 & 11 & 9 & 10 & 10 & 10 & 10 & 10 \\
\hline
\end{tabular}

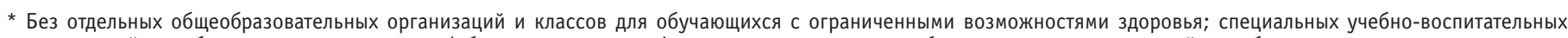

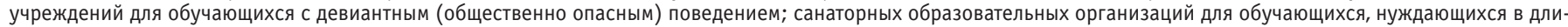

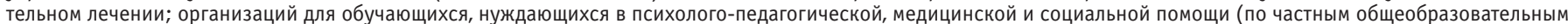
организациям - с 2011/2012 учебного года).

** Включая классы-комплекты (по частным общеобразовательным организациям - с 2011/2012 учебного года). 


\subsection{7. СМЕННОСТЬ ЗАНЯТИЙ В ОБЩЕОБРАЗОВАТЕЛЬНЫХ ОРГАНИЗАЦИЯХ (БЕЗ ВЕЧЕРНИХ (СМЕННЫХ) \\ ОБЩЕОБРАЗОВАТЕЛЬНЫХ ОРГАНИЗАЦИЙ)* \\ (на начало учебного года)}

\begin{tabular}{|c|c|c|c|c|c|c|c|c|}
\hline & $2000 / 2001$ & $2005 / 2006$ & $2010 / 2011$ & $2011 / 2012$ & $2012 / 2013$ & $2013 / 2014$ & $2014 / 2015$ & $2015 / 2016$ \\
\hline \multicolumn{9}{|l|}{ Численность обучающихся, тыс. чел.: } \\
\hline в одну смену & 15354.5 & 12456.1 & 11203.1 & 11300.0 & 11359.1 & 11442.9 & 11982.3 & 12355.9 \\
\hline в две-три смены & 4033.8 & 2191.2 & 1689.8 & 1801.8 & 1835.3 & 1859.6 & 1865.8 & 1893.5 \\
\hline в процентах от общей численности обучающихся & 20.8 & 15.0 & 13.1 & 13.8 & 13.9 & 14.0 & 13.5 & 13.3 \\
\hline города и поселки городского типа & 25.4 & 17.4 & 14.8 & 15.5 & 15.7 & 15.8 & 15.1 & 14.9 \\
\hline сельская местность & 10.2 & 9.6 & 8.8 & 9.1 & 9.1 & 9.0 & 8.9 & 8.7 \\
\hline
\end{tabular}

* Без отдельных общеобразовательных организаций и классов для обучающихся с ограниченными возможностями здоровья; специальных учебно-воспитательных учреждений для обучающихся с девиантным (общественно опасным) поведением; санаторных образовательных организаций для обучающихся, нуждающихся в длительном лечении; организаций для обучающихся, нуждающихся в психолого-педагогической, медицинской и социальной помощи; без 1-х классов, организованных в дошкольных образовательных организациях; в 2010/2011 учебном году и ранее - и без частных общеобразовательных организаций. 


\subsection{8. УДЕЛЬНЫЙ ВЕС ОБУЧАЮЩИХСЯ В ДВЕ-ТРИ СМЕНЫ В ОБЩЕЙ ЧИСЛЕННОСТИ ОБУЧАЮЩИХСЯ \\ В ОБЩЕОБРАЗОВАТЕЛЬНЫХ ОРГАНИЗАЦИЯХ (БЕЗ ВЕЧЕРНИХ (СМЕННЫХ) \\ ОБЩЕОБРАЗОВАТЕЛЬНЫХ ОРГАНИЗАЦИЙ) * \\ (на начало учебного года)}

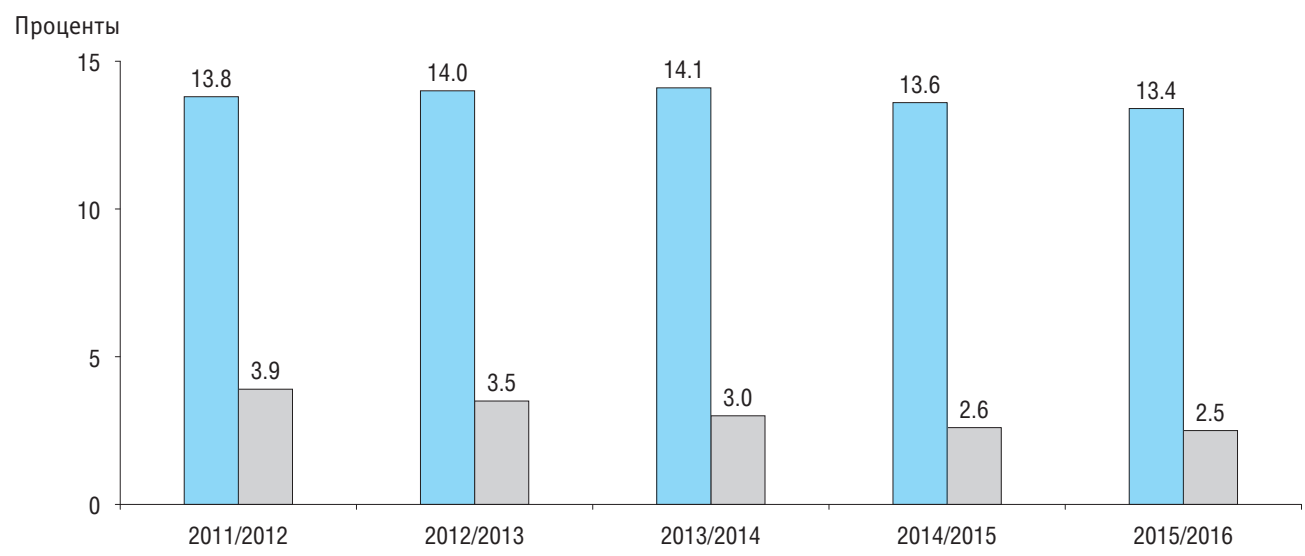

\section{Организации:}

государственные и муниципальные

частные

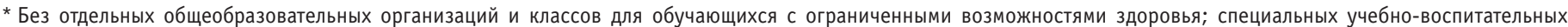

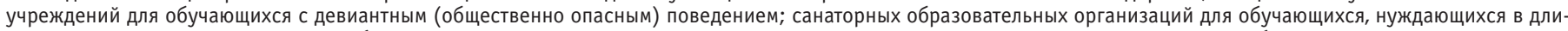

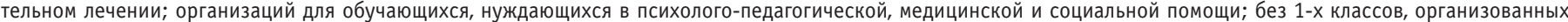
в дошкольных образовательных организациях. 


\subsection{9. ЧИСЛЕННОСТЬ ОБУЧАЮЩИХСЯ В ГОСУДАРСТВЕННЫХ И МУНИЦИПАЛЬНЫХ ОБЩЕОБРАЗОВАТЕЛЬНЫХ ОРГАНИЗАЦИЯХ В ГРУППАХ ПРОДЛЕННОГО ДНЯ (БЕЗ ВЕЧЕРНИХ (СМЕННЫХ) ОБЩЕОБРАЗОВАТЕЛЬНЫХ ОРГАНИЗАЦИЙ) * (на начало учебного года)}

\begin{tabular}{|c|c|c|c|c|c|c|c|c|}
\hline & $2000 / 2001$ & $2005 / 2006$ & $2010 / 2011$ & $2011 / 2012$ & $2012 / 2013$ & $2013 / 2014$ & $2014 / 2015$ & $2015 / 2016$ \\
\hline \multicolumn{9}{|c|}{ Численность обучающихся 1-9 классов в группах } \\
\hline продленного дня, тыс. чел. & 2491.6 & 2576.4 & 2056.1 & 1921.9 & 1908.5 & 1855.4 & 1706.6 & 1569.4 \\
\hline \multicolumn{9}{|c|}{ В процентах от общей численности обучающихся } \\
\hline $1-9$ классов & 15.1 & 21.3 & 18.1 & 16.8 & 16.4 & 15.7 & 13.8 & 12.2 \\
\hline Города и поселки городского типа & 16.0 & 22.7 & 19.3 & 17.8 & 17.3 & 16.4 & 14.4 & 12.9 \\
\hline Сельская местность & 13.1 & 18.0 & 15.0 & 13.8 & 13.9 & 13.7 & 11.9 & 10.3 \\
\hline \multicolumn{9}{|c|}{ Численность обучающихся 1-4 классов в группах } \\
\hline продленного дня, тыс. чел. & 1858.6 & 2004.0 & 1748.6 & 1665.4 & 1676.1 & 1634.9 & 1503.2 & 1389.3 \\
\hline \multicolumn{9}{|c|}{ В процентах от общей численности обучающихся } \\
\hline 1-4 классов & 33.6 & 39.5 & 33.2 & 30.5 & 30.0 & 28.9 & 25.4 & 22.7 \\
\hline Города и поселки городского типа & 37.7 & 43.0 & 36.0 & 32.9 & 32.1 & 30.7 & 27.1 & 24.4 \\
\hline Сельская местность & 25.8 & 31.5 & 25.9 & 23.8 & 24.0 & 23.3 & 20.4 & 17.6 \\
\hline
\end{tabular}

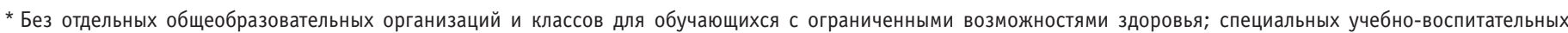

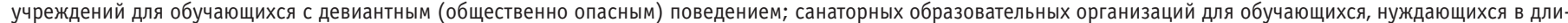

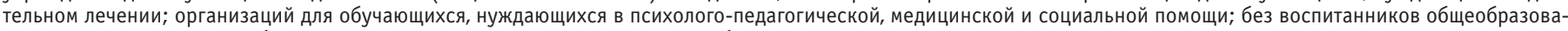
тельных школ-интернатов; без 1-х классов, организованных в дошкольных образовательных организациях 


\subsection{0. УЧЕБНАЯ ПЛОЩАДЬ ОБЩЕОБРАЗОВАТЕЛЬНЫХ ОРГАНИЗАЦИЙ (БЕЗ ВЕЧЕРНИХ (СМЕННЫХ) ОБЩЕОБРАЗОВАТЕЛЬНЫХ ОРГАНИЗАЦИЙ) * \\ (на начало учебного года)}

\begin{tabular}{|c|c|c|c|c|c|c|c|c|}
\hline & $2001 / 2002$ & $2005 / 2006$ & $2010 / 2011$ & $2011 / 2012$ & $2012 / 2013$ & $2013 / 2014$ & $2014 / 2015$ & $2015 / 2016$ \\
\hline Учебная площадь, млн кв. м & 59.9 & 59.2 & 57.6 & 57.1 & 64.1 & 63.6 & 63.8 & 58.5 \\
\hline $\begin{array}{l}\text { В процентах от общей площади помещений } \\
\text { общеобразовательных организаций }\end{array}$ & 38.4 & 32.4 & 34.5 & 33.9 & 34.3 & 33.8 & 33.6 & 33.2 \\
\hline В расчете на 1 обучающегося, кв. м & 4.0 & 4.8 & 5.0 & 4.9 & 5.5 & 5.4 & 5.2 & 4.6 \\
\hline Города и поселки городского типа & 3.4 & 4.0 & 4.1 & 4.0 & 4.8 & 4.8 & 4.4 & 3.8 \\
\hline Сельская местность & 5.2 & 6.4 & 7.0 & 7.1 & 7.1 & 7.0 & 7.2 & 6.7 \\
\hline
\end{tabular}

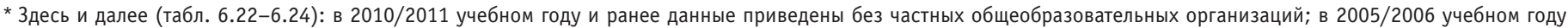

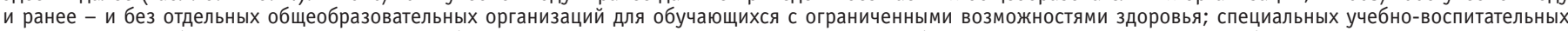

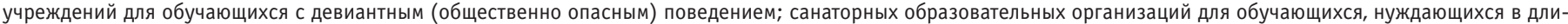

тельном лечении; организаций для обучающихся, нуждающихся в психолого-педагогической, медицинской и социальной помощи.

\subsection{1. УЧЕБНАЯ ПЛОЩАДЬ ОБЩЕОБРАЗОВАТЕЛЬНЫХ ОРГАНИЗАЦИЙ (БЕЗ ВЕЧЕРНИХ (СМЕННЫХ) ОБЩЕОБРАЗОВАТЕЛЬНЫХ ОРГАНИЗАЦИЙ) В РАСЧЕТЕ НА ОДНОГО ОБУЧАЮЩЕГОСЯ \\ (на начало учебного года)}

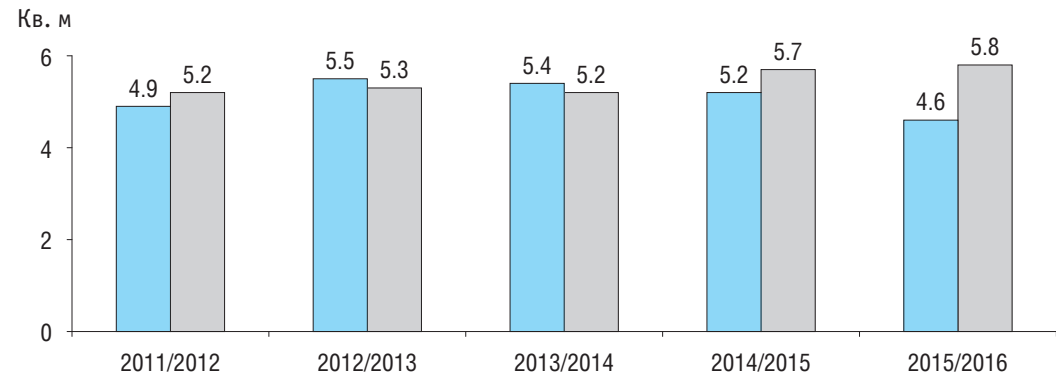

Организации:

$\square$ государственные

и муниципальные

$\square$ частные

\section{3}

Индикаторы образования: 2017 


\subsection{2. ТЕХНИЧЕСКОЕ СОСТОЯНИЕ ЗДАНИЙ ОБЩЕОБРАЗОВАТЕЛЬНЫХ ОРГАНИЗАЦИЙ (БЕЗ ВЕЧЕРНИХ (СМЕННЫХ) ОБЩЕОБРАЗОВАТЕЛЬНЫХ ОРГАНИЗАЦИЙ) \\ (на начало учебного года)}

\begin{tabular}{|c|c|c|c|c|c|c|c|c|}
\hline & $2001 / 2002$ & $2005 / 2006$ & $2010 / 2011$ & $2011 / 2012$ & $2012 / 2013$ & $2013 / 2014$ & $2014 / 2015$ & $2015 / 2016$ \\
\hline \multicolumn{9}{|l|}{ Общеобразовательные организации *, здания которых: } \\
\hline требуют капитального ремонта, тыс. & 23729 & 20629 & 10026 & 8808 & 7605 & 6281 & 6333 & 5837 \\
\hline в процентах от общего числа организаций & 37.0 & 35.2 & 19.0 & 17.1 & 15.0 & 12.7 & 13.0 & 12.3 \\
\hline города и поселки городского типа & 40.4 & 38.8 & 20.1 & 17.0 & 14.3 & 12.1 & 12.7 & 11.4 \\
\hline сельская местность & 35.5 & 33.4 & 18.4 & 17.1 & 15.4 & 13.1 & 13.1 & 12.8 \\
\hline находятся в аварийном состоянии, тыс. & 3265 & 1798 & 840 & 783 & 658 & 490 & 536 & 440 \\
\hline в процентах от общего числа организаций & 5.1 & 3.1 & 1.6 & 1.5 & 1.3 & 1.0 & 1.1 & 0.9 \\
\hline города и поселки городского типа & 4.2 & 2.0 & 1.0 & 1.0 & 0.9 & 0.6 & 0.7 & 0.6 \\
\hline сельская местность & 5.5 & 3.6 & 1.9 & 1.8 & 1.6 & 1.2 & 1.3 & 1.1 \\
\hline \multicolumn{9}{|l|}{$\begin{array}{l}\text { Численность обучающихся в общеобразовательных } \\
\text { организациях, здания которых: }\end{array}$} \\
\hline требуют капитального ремонта, тыс. чел. & 8045.3 & 6025.5 & 2576.9 & 2375.3 & 2005.7 & 1639.4 & 1831.7 & 1774.0 \\
\hline в процентах от общей численности обучающихся & 42.9 & 41.1 & 19.5 & 17.7 & 14.8 & 12.0 & 12.9 & 12.2 \\
\hline города и поселки городского типа & 40.5 & 39.3 & 18.0 & 15.9 & 13.0 & 10.6 & 11.9 & 10.9 \\
\hline сельская местность & 48.3 & 45.3 & 23.3 & 22.3 & 19.7 & 15.9 & 15.8 & 15.8 \\
\hline находятся в аварийном состоянии, тыс. чел. & 1003.7 & 435.7 & 206.1 & 201.3 & 169.4 & 130.4 & 146.4 & 115.6 \\
\hline в процентах от общей численности обучающихся & 5.4 & 3.0 & 1.6 & 1.5 & 1.3 & 1.0 & 1.0 & 0.8 \\
\hline города и поселки городского типа & 4.2 & 1.9 & 0.9 & 1.0 & 0.8 & 0.6 & 0.7 & 0.5 \\
\hline сельская местность & 7.9 & 5.3 & 3.1 & 2.7 & 2.6 & 1.9 & 2.0 & 1.7 \\
\hline
\end{tabular}

* Здесь и далее (табл. 6.23, 6.24): начиная с 2010/2011 учебного года - включая обособленные подразделения (в том числе филиалы). 


\subsection{3. БЛАГОУСТРОЙСТВО ЗДАНИЙ ОБЩЕОБРАЗОВАТЕЛЬНЫХ ОРГАНИЗАЦИЙ (БЕЗ ВЕЧЕРНИХ (СМЕННЫХ) ОБЩЕОБРАЗОВАТЕЛЬНЫХ ОРГАНИЗАЦИЙ) \\ (на начало учебного года)}

\begin{tabular}{|c|c|c|c|c|c|c|c|c|}
\hline & $2001 / 2002$ & $2005 / 2006$ & $2010 / 2011$ & $2011 / 2012$ & $2012 / 2013$ & $2013 / 2014$ & $2014 / 2015$ & $2015 / 2016$ \\
\hline \multicolumn{9}{|c|}{ Общеобразовательные организации, здания которых имеют } \\
\hline все виды благоустройства, тыс. & 33171 & 34047 & 38772 & 39161 & 40045 & 40057 & 40574 & 40537 \\
\hline В процентах от общего числа организаций & 51.8 & 58.0 & 73.4 & 75.8 & 79.2 & 81.0 & 83.0 & 85.2 \\
\hline Города и поселки городского типа & 89.4 & 92.5 & 96.2 & 95.7 & 96.6 & 96.8 & 97.1 & 97.9 \\
\hline Сельская местность & 35.1 & 41.8 & 61.0 & 64.3 & 68.9 & 71.7 & 74.7 & 77.7 \\
\hline \multicolumn{9}{|l|}{$\begin{array}{l}\text { Численность обучающихся в общеобразовательных } \\
\text { организациях, здания которых имеют все виды }\end{array}$} \\
\hline благоустройства, тыс. чел. & 15260.9 & 11924.4 & 11935.1 & 12138.5 & 12442.9 & 12644.8 & 13306.6 & 13843.9 \\
\hline В процентах от общей численности обучающихся & 81.4 & 81.4 & 90.1 & 90.3 & 91.9 & 92.7 & 93.8 & 94.8 \\
\hline Города и поселки городского типа & 94.4 & 93.3 & 96.7 & 96.0 & 96.8 & 96.9 & 97.5 & 98.1 \\
\hline Сельская местность & 52.1 & 54.6 & 73.5 & 75.0 & 78.4 & 80.9 & 83.1 & 85.4 \\
\hline
\end{tabular}




\subsection{4. ОБЕСПЕЧЕННОСТЬ ОБУЧАЮЩИХСЯ В ОБЩЕОБРАЗОВАТЕЛЬНЫХ ОРГАНИЗАЦИЯХ (БЕЗ ВЕЧЕРНИХ (СМЕННЫХ) ОБЩЕОБРАЗОВАТЕЛЬНЫХ ОРГАНИЗАЦИЙ) ГОРЯЧИМ ПИТАНИЕМ (на начало учебного года)}

\begin{tabular}{|c|c|c|c|c|c|c|c|c|}
\hline & $2001 / 2002$ & $2005 / 2006$ & $2010 / 2011$ & $2011 / 2012$ & $2012 / 2013$ & $2013 / 2014$ & $2014 / 2015$ & $2015 / 2016$ \\
\hline \multicolumn{9}{|l|}{ Общеобразовательные организации, имеющие } \\
\hline столовую или буфет, тыс. & 50580 & 49491 & 48617 & 47981 & 47313 & 46576 & 46460 & 45410 \\
\hline В процентах от общего числа организаций & 79.0 & 84.4 & 92.0 & 92.9 & 93.5 & 94.2 & 95.0 & 95.5 \\
\hline Города и поселки городского типа & 95.8 & 97.5 & 98.1 & 97.8 & 97.8 & 97.7 & 98.3 & 98.5 \\
\hline Сельская местность & 71.5 & 78.2 & 88.7 & 90.0 & 91.0 & 92.1 & 93.1 & 93.7 \\
\hline $\begin{array}{l}\text { Численность обучающихся, пользующихся горячим } \\
\text { питанием, тыс. чел. }\end{array}$ & 11300.3 & 9923.6 & 10175.5 & 10559.6 & 10782.0 & 11084.5 & 11540.0 & 11900.7 \\
\hline В процентах от общей численности обучающихся & 60.3 & 67.8 & 76.9 & 78.5 & 79.7 & 81.3 & 81.3 & 81.5 \\
\hline Города и поселки городского типа & 56.0 & 64.0 & 74.9 & 77.0 & 78.4 & 80.0 & 80.2 & 80.5 \\
\hline Сельская местность & 69.8 & 76.2 & 81.7 & 82.7 & 83.2 & 84.7 & 84.5 & 84.7 \\
\hline
\end{tabular}




\subsection{5. НАЛИЧИЕ ПЕРСОНАЛЬНЫХ КОМПЬЮТЕРОВ В ОБЩЕОБРАЗОВАТЕЛЬНЫХ ОРГАНИЗАЦИЯХ (БЕЗ ВЕЧЕРНИХ (СМЕННЫХ) ОБЩЕОБРАЗОВАТЕЛЬНЫХ ОРГАНИЗАЦИЙ) * \\ (на начало учебного года)}

\begin{tabular}{|c|c|c|c|c|c|c|c|}
\hline & $2009 / 2010$ & $2010 / 2011$ & $2011 / 2012$ & $2012 / 2013$ & $2013 / 2014$ & $2014 / 2015$ & $2015 / 2016$ \\
\hline \multicolumn{8}{|c|}{ Число компьютеров, тыс. ед. } \\
\hline Персональные компьютеры & 1057.0 & 1169.8 & 1380.1 & 1771.8 & 2053.0 & 2248.8 & 2325.1 \\
\hline \multicolumn{8}{|l|}{ Из них: } \\
\hline в составе локальных вычислительных сетей & 555.8 & 630.1 & 763.3 & 1008.7 & 1183.8 & 1334.2 & 1410.3 \\
\hline с доступом к интернету & 524.8 & 611.0 & 787.9 & 1084.0 & 1304.0 & 1497.8 & 1597.5 \\
\hline приобретенные в отчетном году & 191.5 & 128.1 & 199.1 & 386.0 & 353.9 & 225.8 & 121.0 \\
\hline используемые в учебных целях & 826.4 & 918.8 & 1088.1 & 1430.6 & 1689.4 & 1862.6 & 1932.4 \\
\hline \multicolumn{8}{|l|}{ из них в кабинетах основ информатики } \\
\hline \multirow[t]{2}{*}{ и вычислительной техники } & 522.8 & 533.3 & 541.9 & 610.6 & 591.8 & 606.1 & 609.3 \\
\hline & \multicolumn{7}{|c|}{ В расчете на 100 обучающихся, ед. } \\
\hline Персональные компьютеры & 8.0 & 8.8 & 10.3 & 13.1 & 15.0 & 15.8 & 15.9 \\
\hline \multicolumn{8}{|l|}{ Из них: } \\
\hline с доступом к интернету & 4.0 & 4.6 & 5.9 & 8.0 & 9.6 & 10.6 & 10.9 \\
\hline приобретенные в отчетном году & 1.4 & 1.0 & 1.5 & 2.9 & 2.6 & 1.6 & 0.8 \\
\hline используемые в учебных целях & 6.2 & 6.9 & 8.1 & 10.6 & 12.4 & 13.1 & 13.2 \\
\hline \multicolumn{8}{|l|}{ из них в кабинетах основ информатики } \\
\hline и вычислительной техники & 3.9 & 4.0 & 4.0 & 4.5 & 4.3 & 4.3 & 4.2 \\
\hline
\end{tabular}

* В 2009/2010 и 2010/2011 учебных годах - без частных общеобразовательных организаций. 


\section{8}

6.26. ЧИСЛО ПЕРСОНАЛЬНЫХ КОМПЬЮТЕРОВ, ИСПОЛЬЗУЕМЫХ В УЧЕБНЫХ ЦЕЛЯХ, В РАСЧЕТЕ НА 100 ОБУЧАЮЩИХСЯ В ОБЩЕОБРАЗОВАТЕЛЬНЫХ ОРГАНИЗАЦИЯХ

(БЕЗ ВЕЧЕРНИХ (СМЕННЫХ) ОБЩЕОБРАЗОВАТЕЛЬНЫХ ОРГАНИЗАЦИЙ)

(на начало учебного года)

Единицы

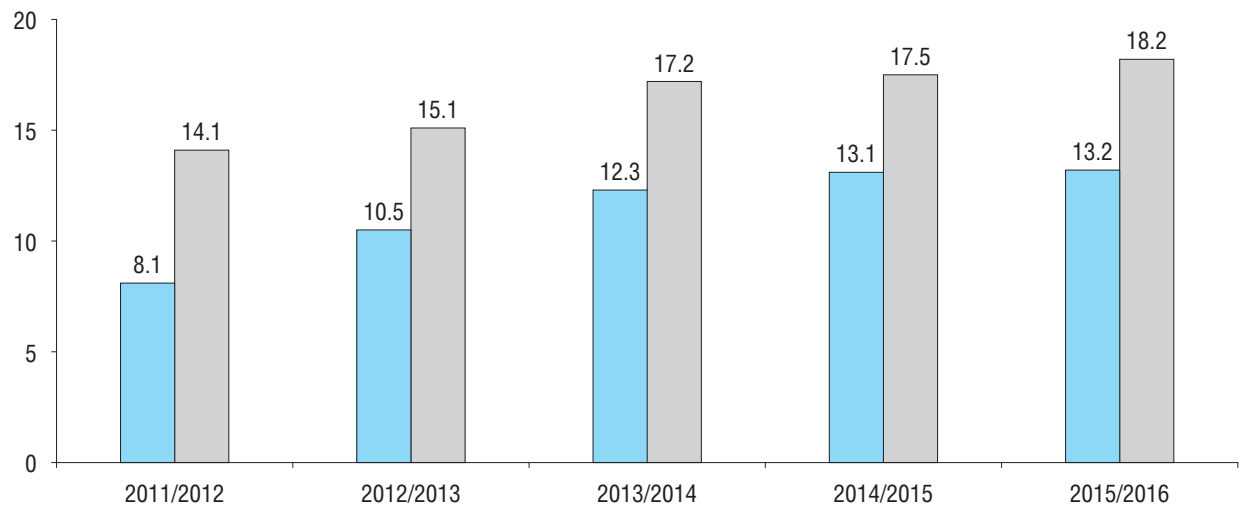

Организации:

$\square$ государственные и муниципальные

$\square$ частные 


\subsection{7. ОБЩЕОБРАЗОВАТЕЛЬНЫЕ ОРГАНИЗАЦИИ (БЕЗ ВЕЧЕРНИХ (СМЕННЫХ) ОБЩЕОБРАЗОВАТЕЛЬНЫХ ОРГАНИЗАЦИЙ), ИМЕЮЩИЕ ДОСТУП К ИНТЕРНЕТУ, АДРЕС ЭЛЕКТРОННОЙ ПОЧТЫ, ВЕБ-САЙТ* \\ (на начало учебного года)}

\begin{tabular}{|c|c|c|c|c|c|c|c|}
\hline & $2009 / 2010$ & $2010 / 2011$ & $2011 / 2012$ & $2012 / 2013$ & $2013 / 2014$ & $2014 / 2015$ & $2015 / 2016$ \\
\hline \multicolumn{8}{|l|}{ Общеобразовательные организации **, имеющие: } \\
\hline доступ к интернету, тыс. & 49915 & 49064 & 48591 & 48218 & 47214 & 46867 & 45805 \\
\hline в процентах от общего числа организаций & 90.7 & 92.8 & 94.1 & 95.3 & 95.5 & 95.8 & 96.3 \\
\hline города и поселки городского типа & 98.3 & 98.9 & 99.2 & 99.2 & 99.2 & 99.4 & 99.5 \\
\hline сельская местность & 86.7 & 89.5 & 91.1 & 93.1 & 93.3 & 93.8 & 94.4 \\
\hline адрес электронной почты, тыс. & 47585 & 47760 & 47855 & 47955 & 46940 & 46753 & 45685 \\
\hline в процентах от общего числа организаций & 86.4 & 90.4 & 92.6 & 94.8 & 94.9 & 95.6 & 96.1 \\
\hline города и поселки городского типа & 97.0 & 98.1 & 98.8 & 99.0 & 99.0 & 99.2 & 99.3 \\
\hline сельская местность & 80.9 & 86.2 & 89.1 & 92.3 & 92.5 & 93.5 & 94.1 \\
\hline веб-сайт & 32671 & 35520 & 41757 & 45590 & 45192 & 45109 & 44219 \\
\hline в процентах от общего числа организаций & 59.3 & 67.2 & 80.8 & 90.1 & 91.4 & 92.3 & 93.0 \\
\hline города и поселки городского типа & 78.0 & 84.2 & 92.5 & 96.9 & 98.3 & 98.6 & 99.1 \\
\hline сельская местность & 49.6 & 58.0 & 74.1 & 86.2 & 87.3 & 88.5 & 89.4 \\
\hline
\end{tabular}

* В 2009/2010 и 2010/2011 учебных годах - без частных общеобразовательных организаций.

** Включая обособленные структурные подразделения (филиалы). 


\subsection{8. ОБРАЗОВАТЕЛЬНЫЕ ОРГАНИЗАЦИИ ДОПОЛНИТЕЛЬНОГО ОБРАЗОВАНИЯ, РЕАЛИЗУЮЩИЕ ДОПОЛНИТЕЛЬНЫЕ ОБЩЕОБРАЗОВАТЕЛЬНЫЕ ПРОГРАММЫ ДЛЯ ДЕТЕЙ}

\begin{tabular}{|c|c|c|c|c|c|c|c|c|}
\hline & 2000 & 2005 & 2010 & 2011 & 2012 & 2013 & 2014 & 2015 \\
\hline \multicolumn{9}{|l|}{$\begin{array}{l}\text { Образовательные организации дополнительного образования, } \\
\text { реализующие дополнительные общеобразовательные программы }\end{array}$} \\
\hline для детей * & 8699 & 8876 & 8531 & 7902 & 8386 & 10462 & 11791 & 14359 \\
\hline \multicolumn{9}{|l|}{ В том числе: } \\
\hline работающие по всем видам образовательной деятельности & 3577 & 3654 & 3683 & 3392 & 3487 & 3631 & 3703 & 3782 \\
\hline художественные & 371 & 418 & 780 & 756 & 896 & 1909 & 2393 & 4375 \\
\hline эколого-биологические & 467 & 445 & 331 & 313 & 282 & 269 & 251 & 219 \\
\hline туристско-краеведческие & 335 & 331 & 256 & 247 & 232 & 210 & 209 & 185 \\
\hline технические & 570 & 536 & 327 & 305 & 287 & 261 & 245 & 217 \\
\hline спортивные & 2968 & 3072 & 2760 & 2480 & 2582 & 3245 & 3714 & 4445 \\
\hline военно-патриотические и спортивно-технические & 112 & 89 & 101 & 107 & 90 & 85 & 83 & 68 \\
\hline другие & 299 & 331 & 293 & 302 & 530 & 852 & 1193 & 1068 \\
\hline Детско-юношеские спортивные школы * & 1709 & 1839 & 2210 & 2449 & 2645 & 2746 & 2902 & 2809 \\
\hline \multicolumn{9}{|l|}{ Детские музыкальные, художественные, хореографические школы } \\
\hline и школы искусств*** & 5823 & 5555 & 5370 & 5328 & 5270 & 5223 & 5186 & 5108 \\
\hline
\end{tabular}

* По данным Минобрнауки России.

** По данным Минспорта России.

*** По данным Минкультуры России; итоги за 2014 г. приведены без учета данных по Республике Крым и г. Севастополю. 


\subsection{9. ТЕХНИЧЕСКОЕ СОСТОЯНИЕ И БЛАГОУСТРОЙСТВО ЗДАНИЙ ОРГАНИЗАЦИЙ ДОПОЛНИТЕЛЬНОГО ОБРАЗОВАНИЯ, РЕАЛИЗУЮЩИХ ДОПОЛНИТЕЛЬНЫЕ ОБЩЕОБРАЗОВАТЕЛЬНЫЕ ПРОГРАММЫ ДЛЯ ДЕТЕЙ *}

(на конец года)

\begin{tabular}{l|r|r|r|r|r|r|r}
\hline & 2001 & 2005 & 2010 & 2011 & 2012 & 2013 & 2014 \\
\hline
\end{tabular}

* По данным Минобрнауки России. 


\subsection{0. ПРОФЕССИОНАЛЬНЫЕ ОБРАЗОВАТЕЛЬНЫЕ ОРГАНИЗАЦИИ, РЕАЛИЗУЮЩИЕ ОБРАЗОВАТЕЛЬНЫЕ ПРОГРАММЫ СРЕДНЕГО ПРОФЕССИОНАЛЬНОГО ОБРАЗОВАНИЯ - ПРОГРАММЫ ПОДГОТОВКИ КВАЛИФИЦИРОВАННЫХ РАБОЧИХ, СЛУЖАЩИХ*}

(на конец года)

\begin{tabular}{|c|c|c|c|c|c|c|c|c|}
\hline & 2000 & 2005 & 2010 & 2011 & 2012 & 2013 & 2014 & 2015 \\
\hline Bcero & 3893 & 3392 & 2356 & 2040 & 1834 & 1319 & 1033 & 689 \\
\hline $\begin{array}{l}\text { Из них - профессиональные образовательные организации } \\
\text { Федеральной службы исполнения наказаний }\end{array}$ & 340 & 338 & 328 & 332 & 332 & 318 & 276 & 275 \\
\hline
\end{tabular}

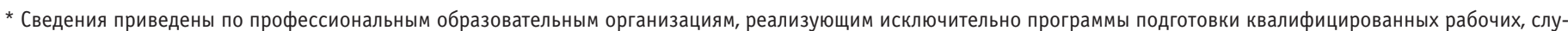

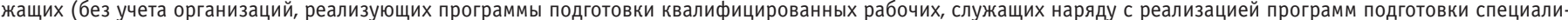
стов среднего звена).

\subsection{1. ПРОФЕССИОНАЛЬНЫЕ ОБРАЗОВАТЕЛЬНЫЕ ОРГАНИЗАЦИИ, РЕАЛИЗУЮЩИЕ ПРОГРАММЫ СРЕДНЕГО ПРОФЕССИОНАЛЬНОГО ОБРАЗОВАНИЯ - ПРОГРАММЫ ПОДГОТОВКИ СПЕЦИАЛИСТОВ СРЕДНЕГО ЗВЕНА (на начало учебного года)}

\begin{tabular}{|c|c|c|c|c|c|c|c|c|}
\hline & $2000 / 2001$ & $2005 / 2006$ & $2010 / 2011$ & $2011 / 2012$ & $2012 / 2013$ & $2013 / 2014$ & $2014 / 2015$ & $2015 / 2016$ \\
\hline Всего & 2703 & 2905 & 2850 & 2925 & 2981 & 2709 & 2909 & 2891 \\
\hline Государственные и муниципальные организации & 2589 & 2688 & 2586 & 2665 & 2725 & 2494 & 2665 & 2645 \\
\hline Частные организации & 114 & 217 & 264 & 260 & 256 & 215 & 244 & 246 \\
\hline
\end{tabular}




\subsection{2. ФИЛИАЛЫ ПРОФЕССИОНАЛЬНЫХ ОБРАЗОВАТЕЛЬНЫХ ОРГАНИЗАЦИЙ, РЕАЛИЗУЮЩИХ ПРОГРАММЫ СРЕДНЕГО ПРОФЕССИОНАЛЬНОГО ОБРАЗОВАНИЯ - ПРОГРАММЫ ПОДГОТОВКИ СПЕЦИАЛИСТОВ СРЕДНЕГО ЗВЕНА \\ (на начало учебного года)}

\begin{tabular}{|c|c|c|c|c|c|c|}
\hline & $2010 / 2011$ & $2011 / 2012$ & $2012 / 2013$ & $2013 / 2014$ & $2014 / 2015$ & $2015 / 2016$ \\
\hline Всего & 489 & 518 & 511 & 352 & 339 & 362 \\
\hline Государственные и муниципальные организации & 403 & 432 & 413 & 263 & 270 & 294 \\
\hline Частные организации & 86 & 86 & 98 & 89 & 69 & 68 \\
\hline В расчете на 1 профессиональную организацию & 0.2 & 0.2 & 0.2 & 0.1 & 0.1 & 0.1 \\
\hline Государственные и муниципальные организации & 0.2 & 0.2 & 0.2 & 0.1 & 0.1 & 0.1 \\
\hline Частные организации & 0.3 & 0.3 & 0.4 & 0.4 & 0.3 & 0.3 \\
\hline
\end{tabular}

\subsection{3. ПЛОЩАДЬ ЗДАНИЙ ПРОФЕССИОНАЛЬНЫХ ОБРАЗОВАТЕЛЬНЫХ ОРГАНИЗАЦИЙ, РЕАЛИЗУЮЩИХ ПРОГРАММЫ СРЕДНЕГО ПРОФЕССИОНАЛЬНОГО ОБРАЗОВАНИЯ: 2015*}

(на конец года; тыс. кв. м)

\begin{tabular}{|c|c|c|c|}
\hline & Всего & $\begin{array}{c}\text { Государственные и муниципальные } \\
\text { организации }\end{array}$ & Частные организации \\
\hline Общая площадь & 38046.2 & 37012.0 & 1034.2 \\
\hline Учебно-лабораторные здания & 26089.3 & 25268.0 & 821.3 \\
\hline Здания общежитий & 8765.1 & 8572.0 & 193.1 \\
\hline Прочие здания & 3191.7 & 3172.0 & 19.8 \\
\hline
\end{tabular}

* Здесь и далее (рис. 6.34, 6.36, 6.40, табл. 6.35, 6.37-6.39) - включая обособленные подразделения (в том числе филиалы) профессиональных образовательных организаций высшего образования, осуществляющие в качестве основной цели своей деятельности образовательную деятельность по реализации образовательных программ среднего профессионального образования. 
6.34. РАСПРЕДЕЛЕНИЕ ПЛОЩАДИ ЗДАНИЙ ПРОФЕССИОНАЛЬНЫХ ОБРАЗОВАТЕЛЬНЫХ ОРГАНИЗАЦИЙ, РЕАЛИЗУЮЩИХ ПРОГРАММЫ СРЕДНЕГО ПРОФЕССИОНАЛЬНОГО ОБРАЗОВАНИЯ, ПО ФОРМЕ ВЛАДЕНИЯ, ПОЛЬЗОВАНИЯ: 2015

(на конец года)

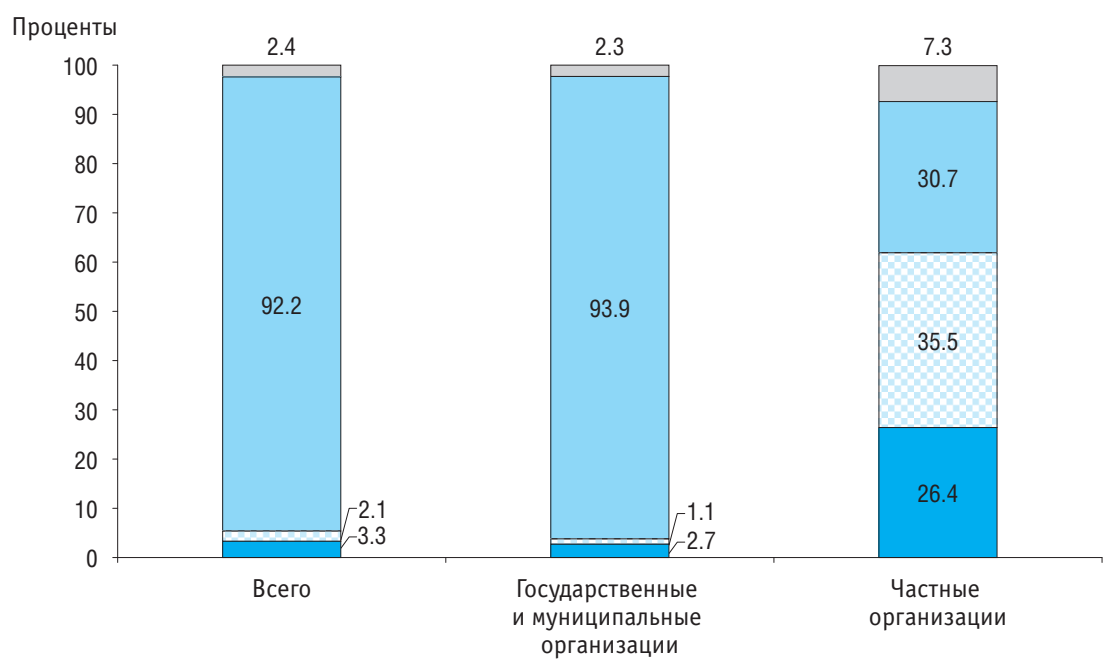

Форма владения, пользования:

$\square$ на правах собственности

аренда

$\square$ оперативное управление

другая 


\subsection{5. ТЕХНИЧЕСКОЕ СОСТОЯНИЕ ЗДАНИЙ ПРОФЕССИОНАЛЬНЫХ ОБРАЗОВАТЕЛЬНЫХ ОРГАНИЗАЦИЙ, РЕАЛИЗУЮЩИХ ПРОГРАММЫ СРЕДНЕГО ПРОФЕССИОНАЛЬНОГО ОБРАЗОВАНИЯ: 2015 \\ (на конец года; тыс. кв. м)}

\begin{tabular}{|c|c|c|c|c|c|c|}
\hline & \multicolumn{3}{|c|}{ Площадь, требующая капитального ремонта } & \multicolumn{3}{|c|}{ Площадь, находящаяся в аварийном состоянии } \\
\hline & Всего & $\begin{array}{c}\text { Государственные } \\
\text { и муниципальные } \\
\text { организации }\end{array}$ & $\begin{array}{c}\text { Частные } \\
\text { организации }\end{array}$ & Всего & $\begin{array}{c}\text { Государственные } \\
\text { и муниципальные } \\
\text { организации }\end{array}$ & $\begin{array}{c}\text { Частные } \\
\text { организации }\end{array}$ \\
\hline \multicolumn{7}{|c|}{ Тыс. кв. м } \\
\hline Общая площадь, тыс. кв. м & 4643.4 & 4633.0 & 10.3 & 449.5 & 449.5 & - \\
\hline Учебно-лабораторные здания & 2756.4 & 2747.3 & 9.1 & 237.9 & 237.9 & - \\
\hline Здания общежитий & 1582.6 & 1581.3 & 1.3 & 157.7 & 157.7 & - \\
\hline Прочие здания & 304.4 & 304.4 & - & 53.9 & 53.9 & - \\
\hline \multicolumn{7}{|c|}{ В процентах от общей площади } \\
\hline Общая площадь & 12.2 & 12.5 & 1.0 & 1.2 & 1.2 & - \\
\hline Учебно-лабораторные здания & 10.6 & 10.9 & 1.1 & 0.9 & 0.9 & - \\
\hline Здания общежитий & 18.1 & 18.4 & 0.6 & 1.8 & 1.8 & - \\
\hline
\end{tabular}


6.36. ИСПОЛЬЗОВАНИЕ ПЛОЩАДИ УЧЕБНО-ЛАБОРАТОРНЫХ ЗДАНИЙ ПРОФЕССИОНАЛЬНЫХ ОБРАЗОВАТЕЛЬНЫХ ОРГАНИЗАЦИЙ, РЕАЛИЗУЮЩИХ ПРОГРАММЫ СРЕДНЕГО ПРОФЕССИОНАЛЬНОГО ОБРАЗОВАНИЯ: 2015*

(на конец года)

Проценты

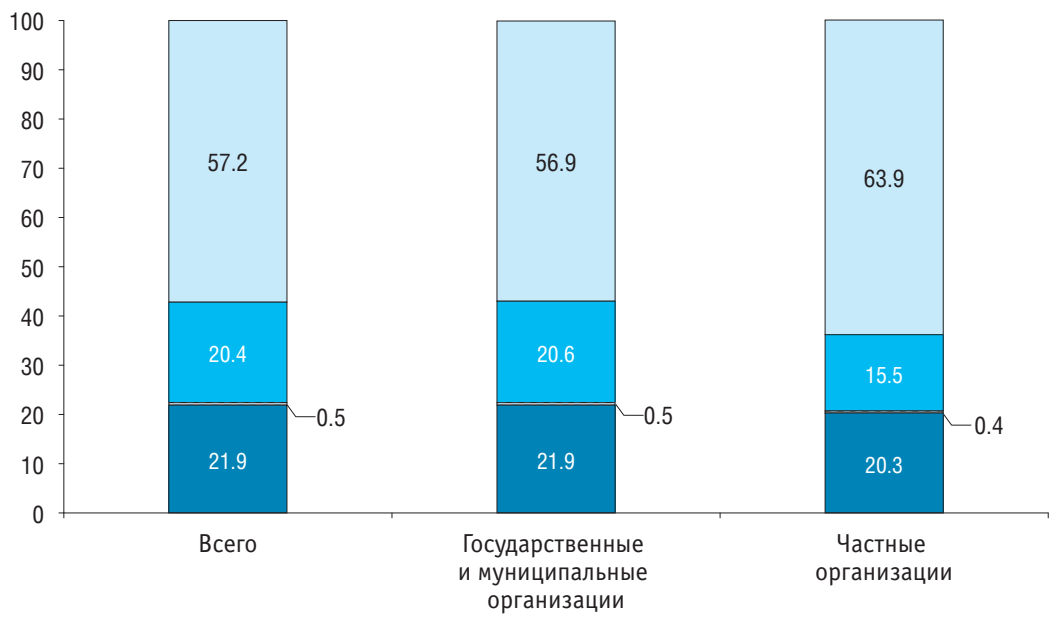

Площадь:

учебная

$\square$ учебно-вспомогательная $\square$ предназначенная для научно-исследовательских подразделений

подсобная

* Включая сданную в аренду или субаренду и находящуюся на капитальном ремонте. 


\subsection{7. ОБЕСПЕЧЕННОСТЬ ОБУЧАЮЩИХСЯ В ПРОФЕССИОНАЛЬНЫХ ОБРАЗОВАТЕЛЬНЫХ ОРГАНИЗАЦИЯХ, РЕАЛИЗУЮЩИХ ПРОГРАММЫ СРЕДНЕГО ПРОФЕССИОНАЛЬНОГО ОБРАЗОВАНИЯ, ОБЩЕЖИТИЯМИ: 2015}

(на конец года)

\begin{tabular}{|c|c|c|c|c|}
\hline & \multicolumn{2}{|c|}{$\begin{array}{c}\text { 0бразовательные программы среднего } \\
\text { профессионального образования }\end{array}$} & \multirow{2}{*}{$\begin{array}{c}\text { 0бразовательные } \\
\text { программы } \\
\text { профессионального } \\
\text { обучения* }\end{array}$} & \multirow{2}{*}{$\begin{array}{c}\text { Дополнительные } \\
\text { профессиональные } \\
\text { программы* }\end{array}$} \\
\hline & $\begin{array}{c}\text { программы подготовки } \\
\text { квалифицированных } \\
\text { рабочих, служащих }\end{array}$ & $\begin{array}{c}\text { программы подготовки } \\
\text { специалистов среднего } \\
\text { звена }\end{array}$ & & \\
\hline \multicolumn{5}{|c|}{ Всего } \\
\hline Численность обучающихся, нуждающихся в общежитиях, тыс. чел. & 101.7 & 253.5 & 32.3 & 3.7 \\
\hline В том числе в общежитиях сторонних организаций & 2.4 & 3.0 & 1.6 & 1.5 \\
\hline \multicolumn{5}{|c|}{ Государственные и муниципальные организации } \\
\hline Численность обучающихся, нуждающихся в общежитиях, тыс. чел. & 101.3 & 248.2 & 27.2 & 3.2 \\
\hline Из них проживают в общежитиях, проценты & 92.7 & 90.6 & 86.6 & 93.8 \\
\hline В том числе в общежитиях сторонних организаций & 2.4 & 2.8 & 1.7 & 1.7 \\
\hline Численность обучающихся, нуждающихся в общежитиях, тыс. чел. & 0.5 & 5.3 & 5.1 & 0.5 \\
\hline Из них проживают в общежитиях, проценты & 93.3 & 97.0 & 100 & 100 \\
\hline В том числе в общежитиях сторонних организаций & 5.4 & 12.1 & 0.7 & - \\
\hline
\end{tabular}

* 3a 2015 r. 


\subsection{8. ОБЕСПЕЧЕННОСТЬ СТУДЕНТОВ ПРОФЕССИОНАЛЬНЫХ ОБРАЗОВАТЕЛЬНЫХ ОРГАНИЗАЦИЙ, РЕАЛИЗУЮЩИХ ПРОГРАММЫ СРЕДНЕГО ПРОФЕССИОНАЛЬНОГО ОБРАЗОВАНИЯ, СЕТЬЮ ОБЩЕСТВЕННОГО ПИТАНИЯ: 2015}

(на конец года)

\begin{tabular}{|c|c|c|c|}
\hline & Всего & $\begin{array}{c}\text { Государственные и муниципальные } \\
\text { организации }\end{array}$ & Частные организации \\
\hline \multicolumn{4}{|c|}{ Число посадочных мест в предприятиях (подразделениях) } \\
\hline организаций, тыс. * & 378.0 & 361.3 & 16.8 \\
\hline В процентах от числа мест по норме & 137.9 & 136.9 & 163.3 \\
\hline
\end{tabular}

* Без учета предприятий общественного питания общежитий.

\subsection{9. НАЛИЧИЕ ПЕРСОНАЛЬНЫХ КОМПЬЮТЕРОВ, ИСПОЛЬЗУЕМЫХ В УЧЕБНЫХ ЦЕЛЯХ, В ПРОФЕССИОНАЛЬНЫХ ОБРАЗОВАТЕЛЬНЫХ ОРГАНИЗАЦИЯХ, РЕАЛИЗУЮЩИХ ПРОГРАММЫ СРЕДНЕГО ПРОФЕССИОНАЛЬНОГО ОБРАЗОВАНИЯ: 2015}

(на конец года)

\begin{tabular}{|c|c|c|c|c|c|c|}
\hline & \multicolumn{2}{|c|}{ Bcero } & \multicolumn{2}{|c|}{$\begin{array}{c}\text { Государственные и муниципальные } \\
\text { организации }\end{array}$} & \multicolumn{2}{|c|}{ Частные организации } \\
\hline & Тыс. ед. & $\begin{array}{l}\text { В процентах } \\
\text { к итогу }\end{array}$ & Тыс. ед. & $\begin{array}{l}\text { В процентах } \\
\text { к итогу }\end{array}$ & Тыс. ед. & $\begin{array}{l}\text { В процентах } \\
\text { к итогу }\end{array}$ \\
\hline Персональные компьютеры & 274.0 & 100 & 260.4 & 100 & 13.6 & 100 \\
\hline \multicolumn{7}{|l|}{ Из них: } \\
\hline в составе локальных вычислительных сетей & 205.0 & 74.8 & 194.0 & 74.5 & 11.0 & 81.0 \\
\hline с доступом к интернету & 210.3 & 76.8 & 198.8 & 76.3 & 11.5 & 85.0 \\
\hline приобретенные в отчетном году & 13.4 & 4.9 & 12.6 & 4.8 & 0.8 & 5.9 \\
\hline
\end{tabular}


6.40. ЧИСЛО ПЕРСОНАЛЬНЫХ КОМПЬЮТЕРОВ, ИСПОЛЬЗУЕМЫХ В УЧЕБНЫХ ЦЕЛЯХ, В ПРОФЕССИОНАЛЬНЫХ ОБРАЗОВАТЕЛЬНЫХ ОРГАНИЗАЦИЯХ, РЕАЛИЗУЮЩИХ ПРОГРАММЫ СРЕДНЕГО ПРОФЕССИОНАЛЬНОГО ОБРАЗОВАНИЯ,

В РАСЧЕТЕ НА 100 СТУДЕНТОВ

(на конец года)

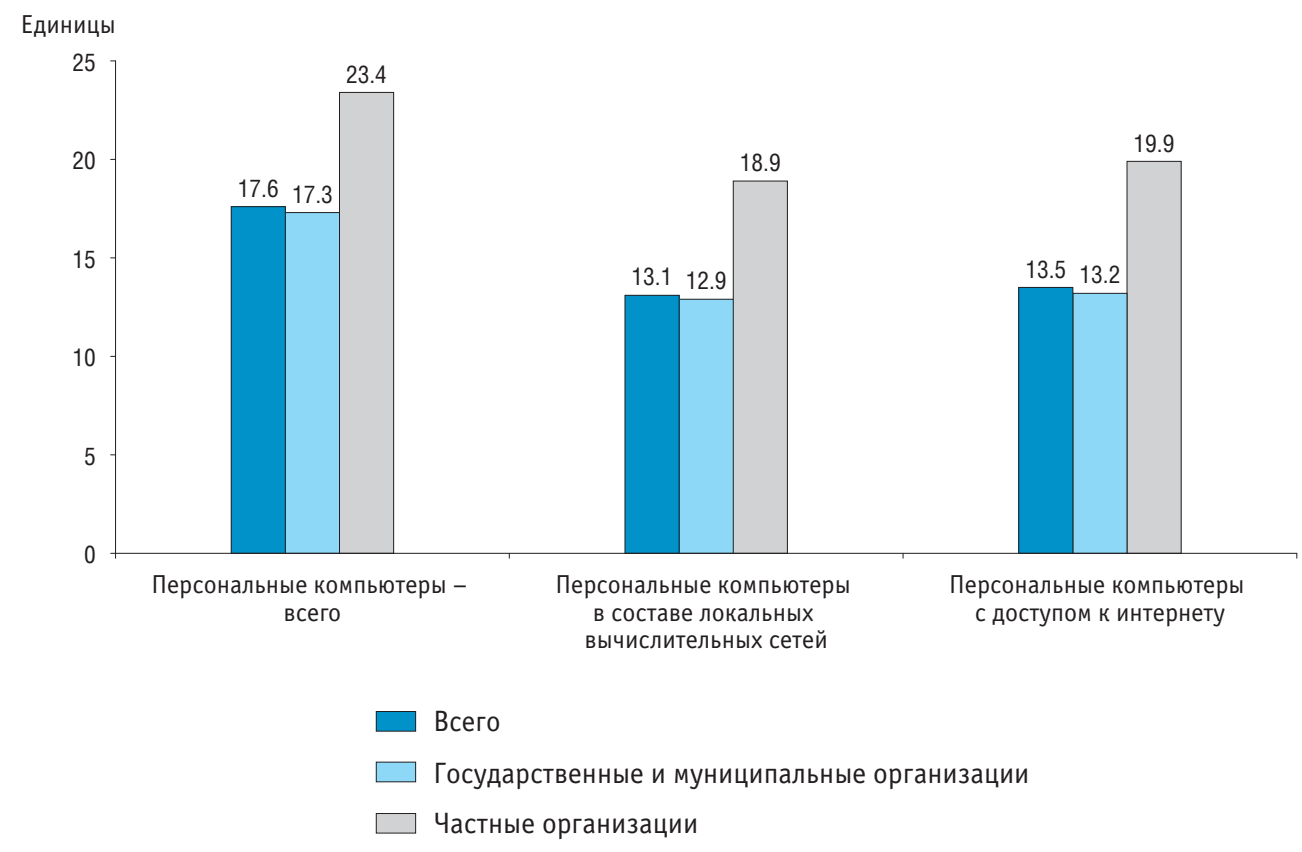

* В расчете использована приведенная численность студентов (Чп), определяемая по формуле: Чп = Чд + 0.25 Чв + 0.10 Чз, где Чд - численность студентов очной формы обучения, Чв - очно-заочной, Чз - заочной. 
6.41. ОБРАЗОВАТЕЛЬНЫЕ ОРГАНИЗАЦИИ ВЫСШЕГО ОБРАЗОВАНИЯ (на начало учебного года)

\begin{tabular}{|c|c|c|c|c|c|c|c|c|}
\hline & $2000 / 2001$ & $2005 / 2006$ & $2010 / 2011$ & $2011 / 2012$ & $2012 / 2013$ & $2013 / 2014$ & $2014 / 2015$ & $2015 / 2016$ \\
\hline Bcero & 965 & 1068 & 1115 & 1080 & 1046 & 969 & 950 & 896 \\
\hline Государственные и муниципальные организации & 607 & 655 & 653 & 634 & 609 & 578 & 548 & 530 \\
\hline Частные организации & 358 & 413 & 462 & 446 & 437 & 391 & 402 & 366 \\
\hline
\end{tabular}

\subsection{2. ФИЛИАЛЫ ОБРАЗОВАТЕЛЬНЫХ ОРГАНИЗАЦИЙ ВЫСШЕГО ОБРАЗОВАНИЯ, РЕАЛИЗУЮЩИЕ ПРОГРАММЫ БАКАЛАВРИАТА, СПЕЦИАЛИТЕТА, МАГИСТРАТУРЫ}

(на начало учебного года)

\begin{tabular}{|c|c|c|c|c|c|c|c|}
\hline & $2005 / 2006$ & $2010 / 2011$ & $2011 / 2012$ & $2012 / 2013$ & $2013 / 2014$ & $2014 / 2015$ & $2015 / 2016$ \\
\hline Bcero & 1621 & 1668 & 1639 & 1603 & 1482 & 1319 & 1079 \\
\hline Государственные и муниципальные организации & 1102 & 1069 & 1045 & 1013 & 949 & 843 & 727 \\
\hline Частные организации & 519 & 599 & 594 & 590 & 533 & 476 & 352 \\
\hline \multicolumn{8}{|l|}{ В расчете на 1 образовательную организацию } \\
\hline высшего образования & 1.5 & 1.5 & 1.5 & 1.5 & 1.5 & 1.4 & 1.2 \\
\hline Государственные и муниципальные организации & 1.7 & 1.6 & 1.6 & 1.7 & 1.6 & 1.5 & 1.4 \\
\hline Частные организации & 1.3 & 1.3 & 1.3 & 1.4 & 1.4 & 1.2 & 1.0 \\
\hline
\end{tabular}




\subsection{3. ПЛОЩАДЬ ЗДАНИЙ ОБРАЗОВАТЕЛЬНЫХ ОРГАНИЗАЦИЙ ВЫСШЕГО ОБРАЗОВАНИЯ*}

(на конец года; тыс. кв. м)

\begin{tabular}{|c|c|c|c|c|c|c|c|}
\hline & 2009 & 2010 & 2011 & 2012 & 2013 & 2014 & 2015 \\
\hline \multicolumn{8}{|c|}{ Всего } \\
\hline Общая площадь & 66538.2 & 67270.1 & 65930.9 & 65933.4 & 66557.5 & 69253.7 & 65206.1 \\
\hline Учебно-лабораторные здания & 49205.7 & 49624.5 & 47835.8 & 47117.5 & 47689.7 & 48960.9 & 45202.2 \\
\hline Здания общежитий & 13502.6 & 13799.0 & 14109.0 & 14544.5 & 14563.7 & 15471.1 & 15085.6 \\
\hline Прочие здания & 3829.9 & 3846.6 & 3986.0 & 4271.4 & 4304.1 & 4821.7 & 4918.2 \\
\hline \multicolumn{8}{|c|}{ Государственные и муниципальные организации } \\
\hline Общая площадь & 61132.8 & 62025.8 & 61168.1 & 61428.3 & 62067.1 & 65148.7 & 61911.0 \\
\hline Учебно-лабораторные здания & 44052.0 & 44582.3 & 43317.0 & 42947.5 & 43516.0 & 45157.2 & 42205.9 \\
\hline Здания общежитий & 13357.2 & 13658.0 & 13955.7 & 14330.1 & 14362.4 & 15292.2 & 14920.3 \\
\hline Прочие здания & 3723.7 & 3785.4 & 3895.4 & 4150.7 & 4188.8 & 4699.2 & 4784.9 \\
\hline \multicolumn{8}{|c|}{ Частные организации } \\
\hline Общая площадь & 5405.4 & 5244.3 & 4762.8 & 4505.2 & 4490.3 & 4105.0 & 3295.0 \\
\hline Учебно-лабораторные здания & 5153.7 & 5042.2 & 4518.8 & 4170.0 & 4173.7 & 3803.7 & 2996.3 \\
\hline Здания общежитий & 145.4 & 141.0 & 153.4 & 214.4 & 201.3 & 178.8 & 165.4 \\
\hline Прочие здания & 106.2 & 61.2 & 90.6 & 120.8 & 115.3 & 122.5 & 133.3 \\
\hline
\end{tabular}

* Здесь и далее (рис. 6.44, 6.46, 6.50, табл. 6.45, 6.47-6.49) - включая обособленные подразделения (в том числе филиалы) организаций высшего образования, осуществляющие в качестве основной цели своей деятельности образовательную деятельность по реализации образовательных программ высшего образования - программ бакалавриата, специалитета, магистратуры. 


\subsection{4. РАСПРЕДЕЛЕНИЕ ПЛОЩАДИ ЗДАНИЙ ОБРАЗОВАТЕЛЬНЫХ ОРГАНИЗАЦИЙ ВЫСШЕГО ОБРАЗОВАНИЯ} ПО ФОРМЕ ВЛАДЕНИЯ, ПОЛЬЗОВАНИЯ: 2015

(на конец года)

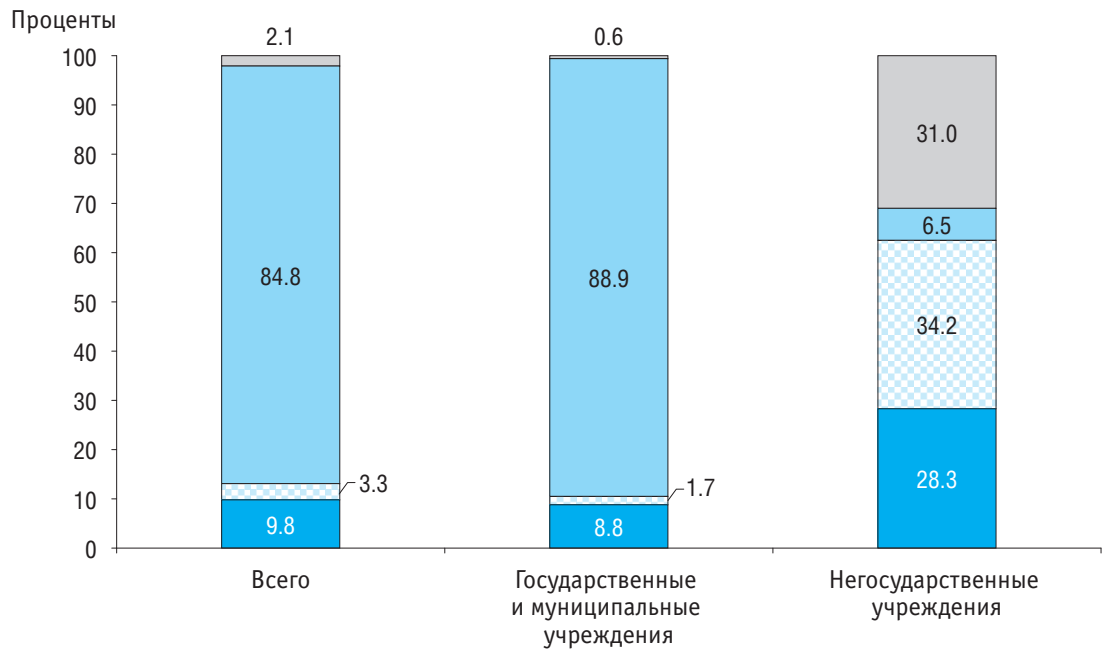

Форма владения, пользования:
$\square$ аренда

оперативное управление

другая 


\subsection{5. ТЕХНИЧЕСКОЕ СОСТОЯНИЕ ЗДАНИЙ ОБРАЗОВАТЕЛЬНЫХ ОРГАНИЗАЦИЙ ВЫСШЕГО ОБРАЗОВАНИЯ}

(на конец года)

\begin{tabular}{|c|c|c|c|c|c|c|c|c|c|c|c|c|c|c|}
\hline & \multicolumn{7}{|c|}{ Площадь, требующая капитального ремонта } & \multicolumn{7}{|c|}{ Площадь, находящаяся в аварийном состоянии } \\
\hline & 2009 & 2010 & 2011 & 2012 & 2013 & 2014 & 2015 & 2009 & 2010 & 2011 & 2012 & 2013 & 2014 & 2015 \\
\hline \multicolumn{15}{|c|}{ Тыс. кв. м } \\
\hline Общая площадь, тыс. кв. м & 6143.3 & 6319.1 & 7700.3 & 8052.3 & 8042.6 & 9023.4 & 8582.0 & 456.9 & 396.1 & 493.7 & 496.2 & 467.0 & 567.3 & 602.6 \\
\hline Учебно-лабораторные здания & 3748.7 & 3929.6 & 4526.4 & 4725.1 & 4563.1 & 5293.5 & 5097.0 & 273.5 & 226.5 & 321.9 & 297.1 & 242.4 & 268.4 & 317.0 \\
\hline Здания общежитий & 2183.3 & 2202.8 & 2899.6 & 3009.4 & 3082.2 & 3337.5 & 3061.1 & 163.8 & 151.5 & 150.9 & 166.0 & 148.7 & 191.2 & 189.2 \\
\hline \multicolumn{15}{|c|}{ В процентах от общей площади } \\
\hline 0бщая площадь & 9.2 & 9.4 & 11.7 & 12.2 & 12.1 & 13.0 & 13.2 & 0.7 & 0.6 & 0.7 & 0.8 & 0.7 & 0.8 & 0.9 \\
\hline Государственные и муниципальные & & & & & & & & & & & & & & \\
\hline организации & 10.0 & 10.1 & 12.5 & 13.1 & 13.0 & 13.8 & 13.8 & 0.7 & 0.6 & 0.8 & 0.8 & 0.8 & 0.9 & 1.0 \\
\hline Частные организации & 0.4 & 0.5 & 0.6 & 0.4 & 0.1 & 0.7 & 0.4 & 0.0 & 0.0 & 0.1 & 0.0 & - & - & - \\
\hline Учебно-лабораторные здания & 7.6 & 7.9 & 9.5 & 10.0 & 9.6 & 10.8 & 11.3 & 0.6 & 0.5 & 0.7 & 0.6 & 0.5 & 0.5 & 0.7 \\
\hline организации & 8.5 & 8.8 & 10.4 & 11.0 & 10.5 & 11.7 & 12.0 & 0.6 & 0.5 & 0.7 & 0.7 & 0.6 & 0.6 & 0.8 \\
\hline Частные организации & 0.4 & 0.5 & 0.5 & 0.2 & 0.1 & 0.8 & 0.4 & 0.0 & 0.0 & 0.1 & - & - & - & - \\
\hline Здания общежитий & 16.2 & 16.0 & 20.6 & 20.7 & 21.2 & 21.6 & 20.3 & 1.2 & 1.1 & 1.1 & 1.1 & 1.0 & 1.2 & 1.3 \\
\hline Государственные и муниципальные & & & & & & & & & & & & & & \\
\hline организации & 16.3 & 16.1 & 20.8 & 20.9 & 21.5 & 21.8 & 20.5 & 1.2 & 1.1 & 1.1 & 1.2 & 1.0 & 1.3 & 1.3 \\
\hline Частные организации & - & 1.1 & 2.0 & 3.7 & - & - & - & - & - & 0.3 & - & - & - & - \\
\hline Прочие здания & 5.5 & 4.9 & 6.9 & 7.4 & 9.2 & 8.1 & 8.6 & 0.5 & 0.5 & 0.5 & 0.8 & 1.8 & 2.2 & 2.0 \\
\hline
\end{tabular}


6.46. ИСПОЛЬЗОВАНИЕ ПЛОЩАДИ УЧЕБНО-ЛАБОРАТОРНЫХ ЗДАНИЙ ОБРАЗОВАТЕЛЬНЫХ ОРГАНИЗАЦИЙ ВЫСШЕГО ОБРАЗОВАНИЯ* (на конец года)

\section{Bсего}

Проценты

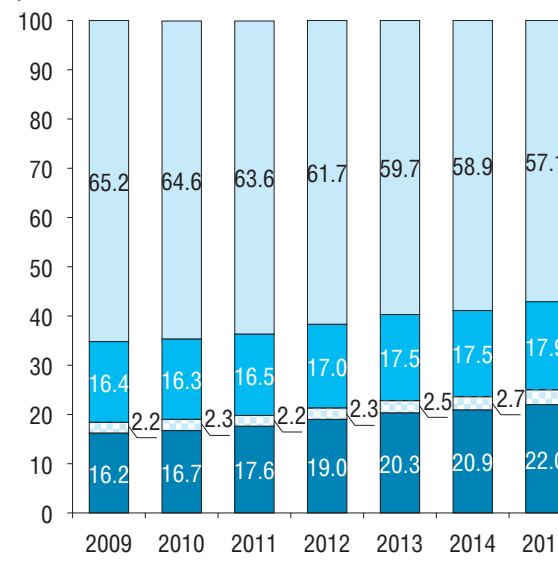

\section{Государственные и муниципальные организации}
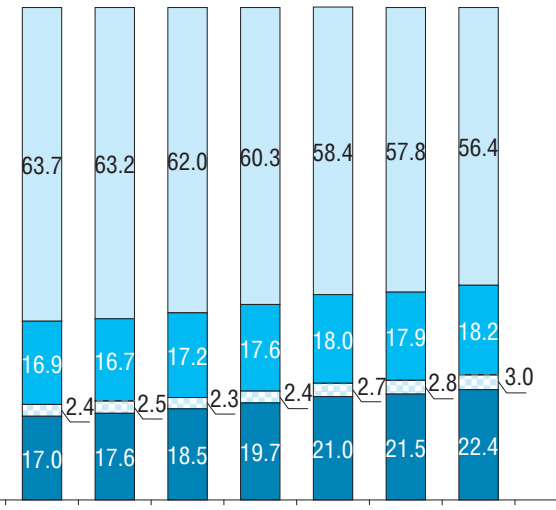

$20092010 \quad 20112012 \quad 2013 \quad 2014 \quad 2015$
Частные организации

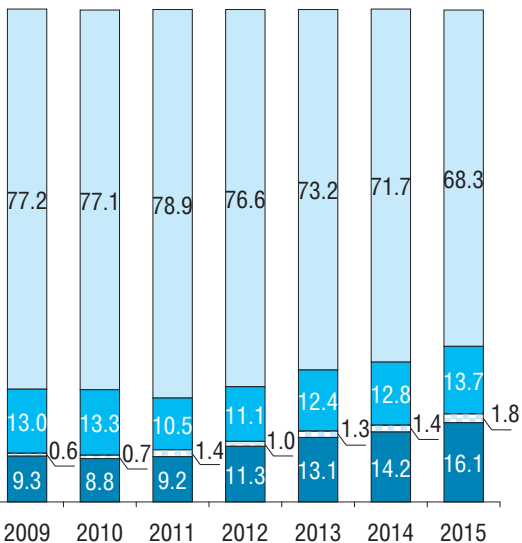

Площадь:

$\square$ учебная $\square$ учебно-вспомогательная $\square$ предназначенная
для научно-исследовательских
подразделений

* Включая сданную в аренду или субаренду и находящуюся на капитальном ремонте. 

(на конец года)

\begin{tabular}{|c|c|c|c|c|c|c|}
\hline & \multicolumn{2}{|c|}{$\begin{array}{c}\text { Образовательные программы } \\
\text { высшего образования }\end{array}$} & \multicolumn{2}{|c|}{$\begin{array}{c}\text { 0бразовательные программы среднего } \\
\text { профессионального образования }\end{array}$} & \multirow{2}{*}{$\begin{array}{c}\text { 0бразовательные } \\
\text { программы } \\
\text { профес- } \\
\text { сионального } \\
\text { обучения* }\end{array}$} & \multirow{2}{*}{$\begin{array}{c}\text { Дополнительные } \\
\text { профессиональные } \\
\text { программы* }\end{array}$} \\
\hline & $\begin{array}{c}\text { программы } \\
\text { бакалавриата, } \\
\text { программы } \\
\text { специалитета, } \\
\text { программы } \\
\text { магистратуры }\end{array}$ & $\begin{array}{c}\text { программы подго- } \\
\text { товки научно- } \\
\text { педагогических } \\
\text { кадров } \\
\text { в аспирантуре, } \\
\text { программы } \\
\text { ординатуры, } \\
\text { программы } \\
\text { ассистентуры- } \\
\text { стажировки }\end{array}$ & $\begin{array}{c}\text { программы } \\
\text { подготовки } \\
\text { квалифициро- } \\
\text { ванных рабочих, } \\
\text { служащих }\end{array}$ & $\begin{array}{c}\text { программы } \\
\text { подготовки } \\
\text { специалистов } \\
\text { среднего звена }\end{array}$ & & \\
\hline \multicolumn{7}{|c|}{ Всего } \\
\hline \multicolumn{7}{|l|}{ Численность обучающихся, нуждающихся } \\
\hline Из них проживают в общежитиях, проценты & 86.7 & 87.2 & 95.5 & 91.3 & 100 & 70.7 \\
\hline \multicolumn{7}{|c|}{ Государственные и муниципальные организации } \\
\hline \multicolumn{6}{|l|}{ Численность обучающихся, нуждающихся } & 15.4 \\
\hline Из них проживают в общежитиях, проценты & 86.6 & 87.2 & 95.5 & 91.2 & 100 & 70.3 \\
\hline В том числе в общежитиях сторонних организаций & 1.9 & 0.9 & - & 2.9 & - & 0.9 \\
\hline \multicolumn{7}{|c|}{ Частные организации } \\
\hline \multicolumn{7}{|l|}{ Численность обучающихся, нуждающихся } \\
\hline в общежитиях, тыс. чел. & 10.7 & 0.0 & - & 1.2 & 0.0 & 0.2 \\
\hline Из них проживают в общежитиях, проценты & 93.3 & 100 & - & 98.6 & 100 & 100 \\
\hline В том числе в общежитиях сторонних организаций & 30.2 & 10.2 & - & 31.7 & - & 44.8 \\
\hline
\end{tabular}

*3a 2015 г. 


\subsection{8. ОБЕСПЕЧЕННОСТЬ СТУДЕНТОВ ОБРАЗОВАТЕЛЬНЫХ ОРГАНИЗАЦИЙ ВЫСШЕГО ОБРАЗОВАНИЯ}

СЕТЬЮ ОБЩЕСТВЕННОГО ПИТАНИЯ

(на конец года)

\begin{tabular}{|c|c|c|c|c|c|c|c|}
\hline & 2009 & 2010 & 2011 & 2012 & 2013 & 2014 & 2015 \\
\hline \multicolumn{8}{|c|}{ Всего } \\
\hline \multicolumn{8}{|l|}{ Число посадочных мест в предприятиях (подразделениях) } \\
\hline В процентах от числа мест по норме & 51.1 & 57.8 & 60.4 & 63.3 & 62.8 & 60.5 & 57.0 \\
\hline \multicolumn{8}{|c|}{ Государственные и муниципальные организации } \\
\hline \multicolumn{8}{|l|}{ Число посадочных мест в предприятиях (подразделениях) } \\
\hline В процентах от числа мест по норме & 48.9 & 54.7 & 56.2 & 57.8 & 56.4 & 54.8 & 52.9 \\
\hline \multicolumn{8}{|c|}{ Частные организации } \\
\hline $\begin{array}{l}\text { Число посадочных мест в предприятиях (подразделениях) } \\
\text { общественного питания образовательных организаций, тыс. * }\end{array}$ & 49.9 & 52.9 & 51.5 & 58.8 & 62.5 & 55.5 & 41.5 \\
\hline В процентах от числа мест по норме & 69.8 & 86.5 & 111.1 & 127.5 & 136.1 & 137.9 & 108.9 \\
\hline
\end{tabular}

* Без учета предприятий общественного питания общежитий. 


\subsection{9. НАЛИЧИЕ ПЕРСОНАЛЬНЫХ КОМПЬЮТЕРОВ, ИСПОЛЬЗУЕМЫХ В УЧЕБНЫХ ЦЕЛЯХ \\ В ОБРАЗОВАТЕЛЬНЫХ ОРГАНИЗАЦИЯХ ВЫСШЕГО ОБРАЗОВАНИЯ}

(на конец года)

\begin{tabular}{|c|c|c|c|c|c|c|c|c|c|c|c|c|c|c|}
\hline & \multicolumn{7}{|c|}{ Всего, тыс. ед. } & \multicolumn{7}{|c|}{ В процентах к итогу } \\
\hline & 2009 & 2010 & 2011 & 2012 & 2013 & 2014 & 2015 & 2009 & 2010 & 2011 & 2012 & 2013 & 2014 & 2015 \\
\hline \multicolumn{15}{|c|}{ Всего } \\
\hline $\begin{array}{l}\text { Персональные компьютеры } \\
\text { Из них: }\end{array}$ & 626.2 & 643.3 & 689.1 & 700.2 & 733.8 & 744.0 & 712.4 & 100 & 100 & 100 & 100 & 100 & 100 & 100 \\
\hline в составе локальных вычислительных сетей & 520.5 & 548.0 & 586.6 & 613.2 & 652.6 & 674.0 & 631.1 & 83.1 & 85.2 & 85.1 & 87.6 & 88.9 & 90.6 & 88.6 \\
\hline с доступом к интернету & 488.0 & 504.2 & 562.0 & 598.1 & 645.6 & 668.9 & 639.3 & 77.9 & 78.4 & 81.6 & 85.4 & 88.0 & 89.9 & 89.7 \\
\hline приобретенные в отчетном году & 52.6 & 46.3 & 59.4 & 57.4 & 57.2 & 50.8 & 43.4 & 8.4 & 7.2 & 8.6 & 8.2 & 7.8 & 6.8 & 6.1 \\
\hline \multicolumn{15}{|c|}{ Государственные и муниципальные организации } \\
\hline $\begin{array}{l}\text { Персональные компьютеры } \\
\text { Из них: }\end{array}$ & 563.8 & 580.9 & 629.2 & 640.8 & 664.9 & 679.6 & 652.9 & 100 & 100 & 100 & 100 & 100 & 100 & 100 \\
\hline в составе локальных вычислительных сетей & 463.5 & 490.3 & 530.4 & 557.5 & 587.4 & 612.8 & 582.2 & 82.2 & 84.4 & 84.3 & 87.0 & 88.4 & 90.2 & 89.2 \\
\hline с доступом к интернету & 437.1 & 452.6 & 509.6 & 543.1 & 579.9 & 606.3 & 581.5 & 77.5 & 77.9 & 81.0 & 84.7 & 87.2 & 89.2 & 89.1 \\
\hline приобретенные в отчетном году & 46.8 & 40.9 & 55.4 & 52.1 & 49.8 & 44.6 & 35.4 & 8.3 & 7.0 & 8.8 & 8.1 & 7.5 & 6.6 & 5.4 \\
\hline \multicolumn{15}{|c|}{ Частные организации } \\
\hline $\begin{array}{l}\text { Персональные компьютеры } \\
\text { Из них: }\end{array}$ & 62.4 & 62.4 & 60.0 & 59.4 & 68.9 & 64.5 & 59.6 & 100 & 100 & 100 & 100 & 100 & 100 & 100 \\
\hline в составе локальных вычислительных сетей & 57.0 & 57.7 & 56.2 & 55.7 & 65.1 & 61.2 & 48.9 & 91.3 & 92.5 & 93.7 & 93.8 & 94.5 & 95.0 & 82.1 \\
\hline с доступом к интернету & 50.9 & 51.6 & 52.5 & 55.0 & 65.8 & 62.7 & 57.8 & 81.5 & 82.7 & 87.5 & 92.6 & 95.4 & 97.2 & 97.1 \\
\hline приобретенные в отчетном году & 5.7 & 5.4 & 4.0 & 5.3 & 7.3 & 6.2 & 7.9 & 9.2 & 8.7 & 6.7 & 9.0 & 10.7 & 9.6 & 13.3 \\
\hline
\end{tabular}




\section{8}

\subsection{0. ЧИСЛО ПЕРСОНАЛЬНЫХ КОМПЬЮТЕРОВ, ИСПОЛ ЬЗУЕМЫХ В УЧЕБНЫХ ЦЕЛЯХ, В РАСЧЕТЕ НА 100 СТУДЕНТОВ} (на конец года)

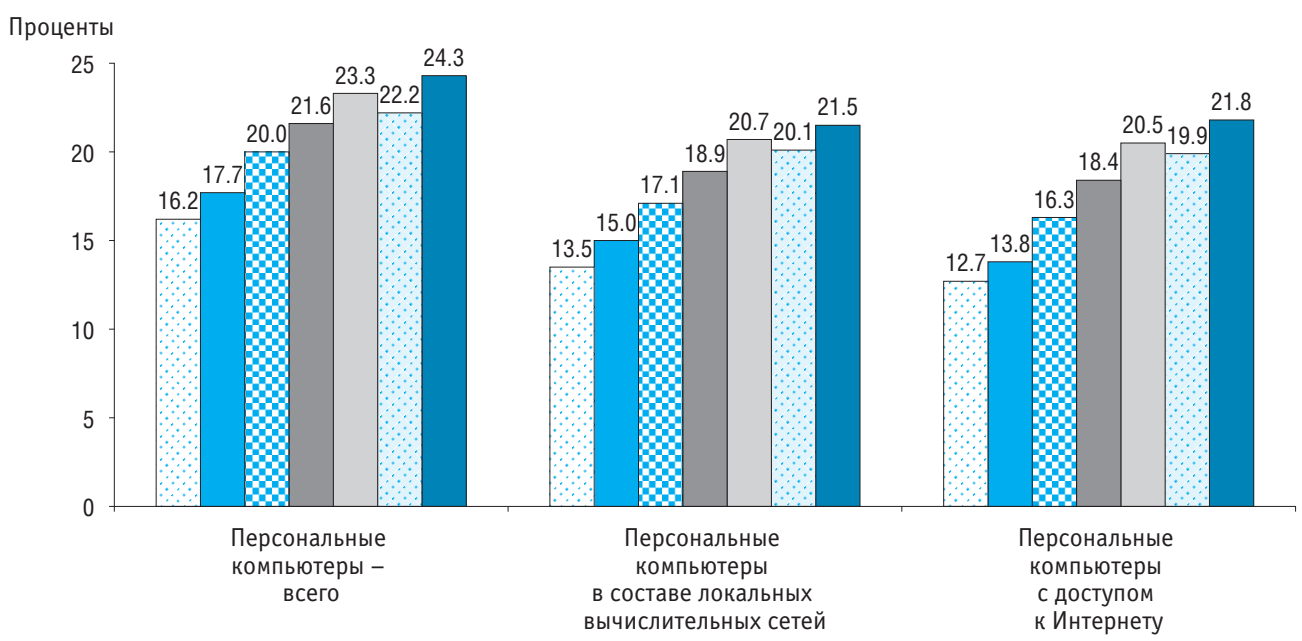




\subsection{1. ОРГАНИЗАЦИИ, ОСУЩЕСТВЛЯЮЩИЕ ПОДГОТОВКУ НАУЧНО-ПЕДАГОГИЧЕСКИХ}

КАДРОВ В АСПИРАНТУРЕ

(на конец года)

\begin{tabular}{|c|c|c|c|c|c|c|c|c|}
\hline & 2000 & 2005 & 2010 & 2011 & 2012 & 2013 & 2014 & 2015 \\
\hline Всего & 1362 & 1473 & 1568 & 1570 & 1575 & 1557 & 1519 & 1446 \\
\hline Научно-исследовательские организации & 797 & 833 & 809 & 805 & 820 & 818 & 805 & 771 \\
\hline $\begin{array}{l}\text { Образовательные организации высшего } \\
\text { образования }\end{array}$ & 565 & 640 & 748 & 750 & 740 & 724 & 698 & 661 \\
\hline $\begin{array}{l}\text { Образовательные организации дополнительного } \\
\text { профессионального образования }\end{array}$ & $\ldots$ & $\ldots$ & 11 & 15 & 15 & 15 & 16 & 14 \\
\hline
\end{tabular}




\section{МЕТОДОЛОГИЧЕСКИЕ КОММЕНТАРИИ}

Основные фонды представляют собой произведенные активы, подлежащие использованию неоднократно или постоянно в течение длительного периода, но не менее одного года, для производства товаров, оказания рыночных и нерыночных услуг, для управленческих нужд либо для предоставления другим организациям за плату во временное владение и пользование или во временное пользование. К ним относятся здания, сооружения, машины и оборудование, транспортные средства, рабочий и продуктивный скот, многолетние насаждения, другие виды основных фондов.

Полная учетная стоимость основных фондов равна сумме учитываемых в бухгалтерских балансах организаций остаточной балансовой стоимости основных фондов и величины накопленного износа. Эта стоимость отражает наличие основных фондов без учета постепенной утраты их потребительских свойств в процессе эксплуатации.

Остаточная балансовая стоимость основных фондов, учитываемая в бухгалтерских балансах организаций, отражает постепенную утрату их потребительских свойств в размере накопленного износа.

Полная учетная и остаточная балансовая стоимость основных фондов учитываются, как правило, в смешанных ценах, так как часть инвентарных объектов отражается в балансах организаций по восстановительной стоимости на момент последней проведенной переоценки, а другая часть, не проходившая переоценок, - в ценах приобретения.
Износ основных фондов - частичная или полная утрата основными фондами потребительских свойств и стоимости в процессе эксплуатации, под воздействием сил природы и вследствие технического прогресса. Нормы и методы начисления износа определяются порядком бухгалтерского, налогового и статистического учета.

Степень износа основных фондов - отношение накопленного к определенной дате износа имеющихся основных фондов (разницы их полной учетной и остаточной балансовой стоимости) к полной учетной стоимости этих основных фондов на ту же дату, в процентах.

Ввод в действие основных фондов - стоимость законченных строительством и принятых в эксплуатацию в установленном порядке объектов строительства - зданий, сооружений, пусковых комплексов, их очередей, а также оборудования, инструмента, инвентаря, многолетних насаждений, рабочего и продуктивного скота и других видов основных фондов. В формах статистического наблюдения ввод в действие основных фондов отражается одновременно с вводом в действие производственных мощностей и объектов жилищно-гражданского назначения на основании актов приемки законченных строительством объектов и документов, подтверждающих государственную регистрацию (по видам объектов, по которым предусмотрена такая регистрация).

Коэффициент обновления основных фондов - отношение основных фондов, введенных в действие в течение года, к их на- 
личию на конец года по полной учетной стоимости, в процентах. Этот показатель отражает удельный вес новых (введенных за год) основных фондов в их общем объеме.

Коэффициент выбытия основных фондов - отношение ликвидированных за год основных фондов к их наличию на начало года по полной учетной стоимости, в процентах. Данный показатель наряду с коэффициентом обновления характеризует интенсивность процесса обновления основных фондов.

Образовательная организация - некоммерческая организация, осуществляющая на основании лицензии образовательную деятельность в качестве основного вида деятельности в соответствии с целями, ради достижения которых такая организация создана. В Российской Федерации устанавливаются следующие типы образовательных организаций, реализующих: основные образовательные программы - дошкольная образовательная организация, общеобразовательная организация, профессиональная образовательная организация, образовательная организация высшего образования; дополнительные образовательные программы - организация дополнительного образования, организация дополнительного профессионального образования.

Организация, осуществляющая обучение, - юридическое лицо, осуществляющее на основании лицензии наряду с основной деятельностью образовательную деятельность в качестве дополнительного вида деятельности.

Организации, осуществляющие образовательную деятельность, - образовательные организации, а также организации, осуществляющие обучение.
Число мест в дошкольных образовательных организациях в расчете на 1000 детей в возрасте 1-6 лет - отношение числа мест в дошкольных образовательных организациях к общей численности детей в возрасте 1-6 лет, скорректированной на численность детей в возрасте 5 и 6 лет, обучающихся в общеобразовательных организациях, умноженное на 1000.

0бщая площадь здания - сумма площадей всех этажей здания (включая технические, мансардные, цокольные и подвальные), измеренных в пределах внутренних поверхностей наружных стен, а также площадей балконов и лоджий.

Учебная площадь - площадь помещений, в которых проходит учебный процесс: групповые помещения, классные комнаты, аудитории, учебные лаборатории, учебные кабинеты, чертежные залы курсового и дипломного проектирования, учебные мастерские, демонстрационные, монтажные и испытательные залы, закрытые спортивные сооружения (спортивные залы всех видов, крытый бассейн для плавания).

Учебно-вспомогательная площадь - площадь помещений, в которых производится работа, вспомогательная по отношению к учебному (воспитательному) процессу: преподавательские комнаты, кабинеты заведующих отделениями, административные помещения, помещения общественных организаций, библиотечные помещения (читальные залы, книгохранилища), служебнопроизводственные помещения, комнаты для отдыха сотрудников, кабинеты руководителей, архивы, виварии, вычислительный центр, помещения актового зала (актовый зал, комнаты для самодеятельных коллективов, киноаппаратная, радиоузел, кладовая для инвентаря). 
Средний размер группы (наполняемость групп) - отношение численности воспитанников (включая детей, в отношении которых осуществляется только присмотр и уход), состоящих в списках групп дошкольных образовательных организаций, к числу групп.

Средний размер класса (наполняемость класса) - отношение численности обучающихся в определенной группе классов к числу классов в этой группе, при этом класс-комплект (коллектив обучающихся двух или более классов, занимающихся с одним учителем в малокомплектной школе) приравнивается к классу.

Обеспеченность студентов профессиональных образовательных организаций и образовательных организаций высшего образования сетью общественного питания - отноше- ние числа посадочных мест в предприятиях (подразделениях) общественного питания образовательных организаций к числу посадочных мест по норме. Число посадочных мест по норме вычисляется путем умножения расчетной численности студентов на 200 и деления на 1000, так как по действующим в настоящее время нормам на 1000 студентов должно приходиться 200 мест в предприятиях общественного питания образовательной организации. Расчетная численность студентов равняется численности студентов очной формы обучения и 10\% студентов заочного обучения, умноженной на явочный коэффициент, равный 0.9.

В настоящем разделе за исключением специально оговоренных случаев (рис. 6.2, табл. 6.3, 6.28, ) итоги за 2014, 2015 гг. приведены с учетом данных по Республике Крым и г. Севастополю. 


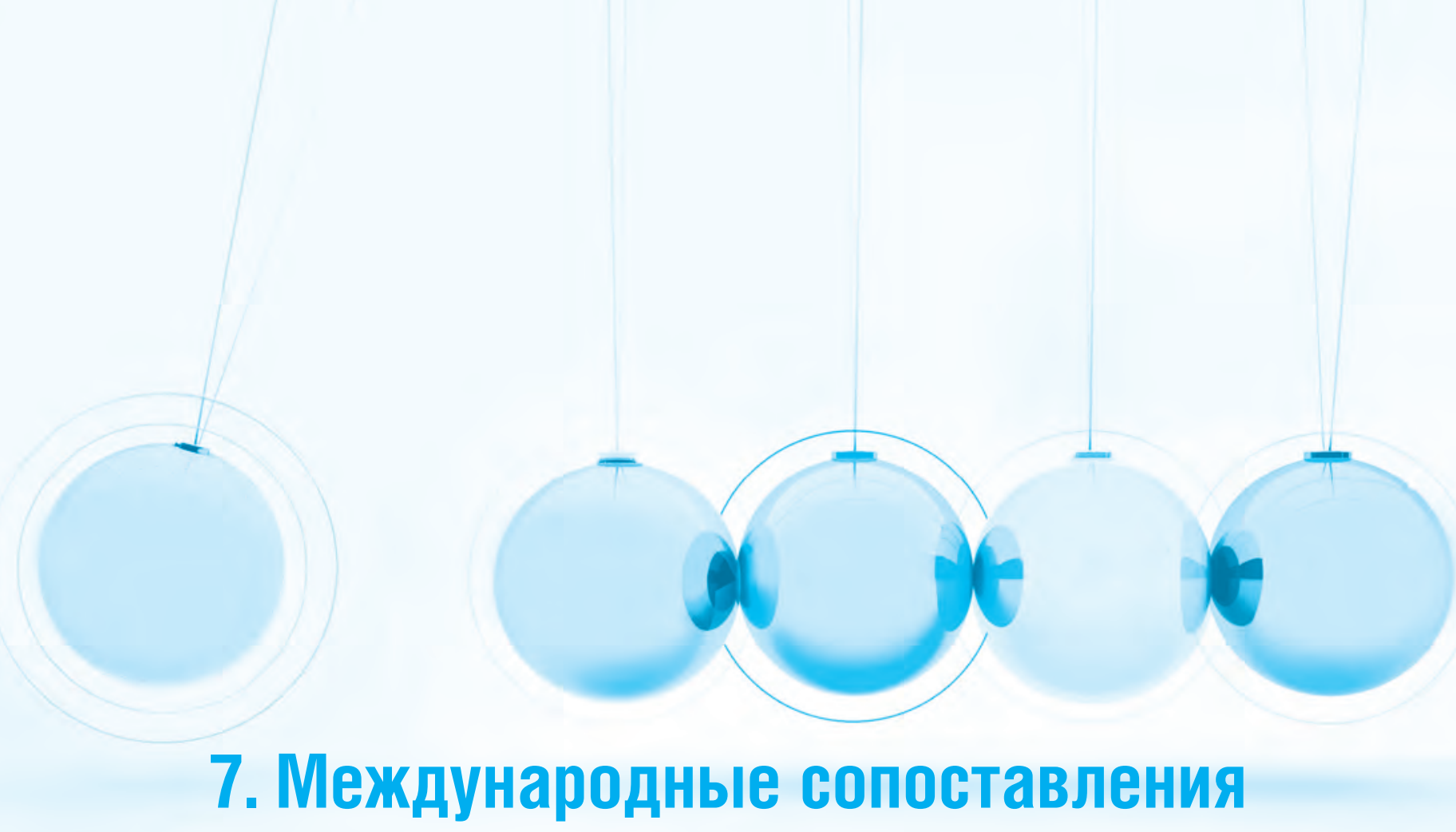


7.1. УРОВЕНЬ ОБРАЗОВАНИЯ ВЗРОСЛОГО НАСЕЛЕНИЯ В РОССИИ И СТРАНАХ ОЭСР: 2015* (в возрасте 25-64 лет; в процентах от общей численности населения соответствующей возрастной группы)

\begin{tabular}{|c|c|c|c|c|c|}
\hline & \multirow[t]{2}{*}{ Bсего } & \multicolumn{4}{|c|}{ Имеют образование } \\
\hline & & $\begin{array}{c}\text { основное общее } \\
\text { и ниже } \\
\text { (МСКО 0, } 1 \text { и 2) }\end{array}$ & $\begin{array}{c}\text { среднее общее, среднее } \\
\text { профессиональное по } \\
\text { программам подготовки } \\
\text { квалифицированных рабочих, } \\
\text { служащих (МСКО } 3 \text { и 4) }\end{array}$ & $\begin{array}{c}\text { среднее } \\
\text { профессиональное } \\
\text { по программам подготовки } \\
\text { специалистов среднего звена } \\
\text { (МСКО 5) }\end{array}$ & $\begin{array}{c}\text { высшее } \\
\text { (МСК0 6, } 7 \text { и 8) }\end{array}$ \\
\hline & (1) & $(2)$ & (3) & $(4)$ & $(5)$ \\
\hline Россия & 100 & 5.8 & 26.8 & 34.5 & 30.2 \\
\hline Австралия & 100 & 21.0 & 36.1 & 11.1 & 31.8 \\
\hline Австрия & 100 & 15.4 & 54.1 & 15.1 & 15.4 \\
\hline Бельгия & 100 & 25.3 & 37.8 & 0.4 & 36.5 \\
\hline Великобритания & 100 & 20.9 & 35.6 & 10.1 & 33.4 \\
\hline Венгрия & 100 & 16.8 & 59.0 & 1.3 & 22.9 \\
\hline Германия & 100 & 13.2 & 59.2 & 0.6 & 27.0 \\
\hline Греция & 100 & 29.8 & 41.2 & 1.6 & 27.4 \\
\hline Дания & 100 & 19.6 & 43.3 & 4.4 & 32.7 \\
\hline Израиль & 100 & 14.5 & 36.7 & 13.8 & 35.0 \\
\hline Ирландия & 100 & 20.2 & 37.0 & 13.0 & 29.8 \\
\hline Исландия & 100 & 25.3 & 35.9 & 4.1 & 34.8 \\
\hline Испания & 100 & 42.6 & 22.4 & 11.0 & 24.1 \\
\hline Италия & 100 & 40.1 & 42.3 & 0.0 & 17.5 \\
\hline Канада & 100 & 9.6 & 35.2 & 25.7 & 29.5 \\
\hline Латвия & 100 & 12.2 & 56.2 & 2.4 & 29.2 \\
\hline Люксембург & 100 & 25.4 & 34.8 & 7.0 & 32.8 \\
\hline Мексика & 100 & 64.5 & 19.2 & 0.5 & 15.8 \\
\hline Нидерланды & 100 & 23.6 & 41.1 & 2.3 & 33.0 \\
\hline Новая Зеландия & 100 & 25.3 & 40.7 & 4.1 & 30.0 \\
\hline
\end{tabular}


(окончание)

\begin{tabular}{|c|c|c|c|c|c|}
\hline & \multirow[t]{2}{*}{ Всего } & \multicolumn{4}{|c|}{ Имеют образование } \\
\hline & & $\begin{array}{c}\text { основное общее } \\
\text { и ниже } \\
\text { (МСКО 0, } 1 \text { и 2) }\end{array}$ & \begin{tabular}{|c|} 
среднее общее, среднее \\
профессиональное по \\
программам подготовки \\
квалифицированных рабочих, \\
служащих (МСК0 3 и 4)
\end{tabular} & $\begin{array}{c}\text { среднее } \\
\text { профессиональное } \\
\text { по программам подготовки } \\
\text { специалистов среднего звена } \\
\text { (МСК0 5) }\end{array}$ & $\begin{array}{c}\text { высшее } \\
\text { (МСК0 6, } 7 \text { и 8) }\end{array}$ \\
\hline & (1) & (2) & (3) & (4) & (5) \\
\hline Норвегия & 100 & 17.6 & 39.7 & 12.3 & 30.4 \\
\hline Польша & 100 & 9.2 & 63.0 & 0.1 & 27.6 \\
\hline Португалия & 100 & 54.9 & 22.3 & - & 22.9 \\
\hline Республика Корея & 100 & 14.2 & 40.3 & 13.1 & 32.4 \\
\hline Словакия & 100 & 8.7 & 70.1 & 0.3 & 20.8 \\
\hline Словения & 100 & 13.2 & 56.6 & 7.5 & 22.7 \\
\hline США & 100 & 10.5 & 44.9 & 10.5 & 34.1 \\
\hline Турция & 100 & 63.0 & 19.0 & 5.2 & 12.8 \\
\hline Финляндия & 100 & 12.8 & 44.4 & 12.1 & 30.7 \\
\hline Франция & 100 & 22.7 & 43.8 & 14.6 & 19.0 \\
\hline Чешская Республика & 100 & 6.8 & 71.0 & 0.2 & 22.0 \\
\hline Чили & 100 & 38.6 & 40.3 & 7.2 & 13.9 \\
\hline Швейцария & 100 & 11.8 & 46.5 & $n(5)^{\star \star}$ & 41.7 \\
\hline Швеция & 100 & 18.0 & 42.2 & 9.9 & 29.9 \\
\hline Эстония & 100 & 9.1 & 52.9 & 7.1 & 30.9 \\
\hline Япония & 100 & $n(3)$ & $50.5^{\star \star *}$ & $20.6^{* * *}$ & 28.9 \\
\hline
\end{tabular}

* По зарубежным странам - данные за 2015 г. или ближайшие годы; по России - данные микропереписи населения 2015 г.

** Здесь и далее символ «п» в какой-либо графе означает, что данные включены в другую графу, номер которой указан в скобках после «п».

*** Численность лиц, имеющих уровень образования МСКО 4, исключена из графы 3 и включена в графу 4. 


\section{2. УДЕЛЬНЫЙ ВЕС ВЗРОСЛОГО НАСЕЛЕНИЯ, ИМЕЮЩЕГО ВЫСШЕЕ ОБРАЗОВАНИЕ (МСКО 6, 7 И 8), В ЕГО ОБЩЕЙ ЧИСЛЕННОСТИ В РОССИИ И СТРАНАХ ОЭСР ПО ВОЗРАСТНЫМ ГРУППАМ: 2015* \\ (в процентах от общей численности населения соответствующей возрастной группы)}

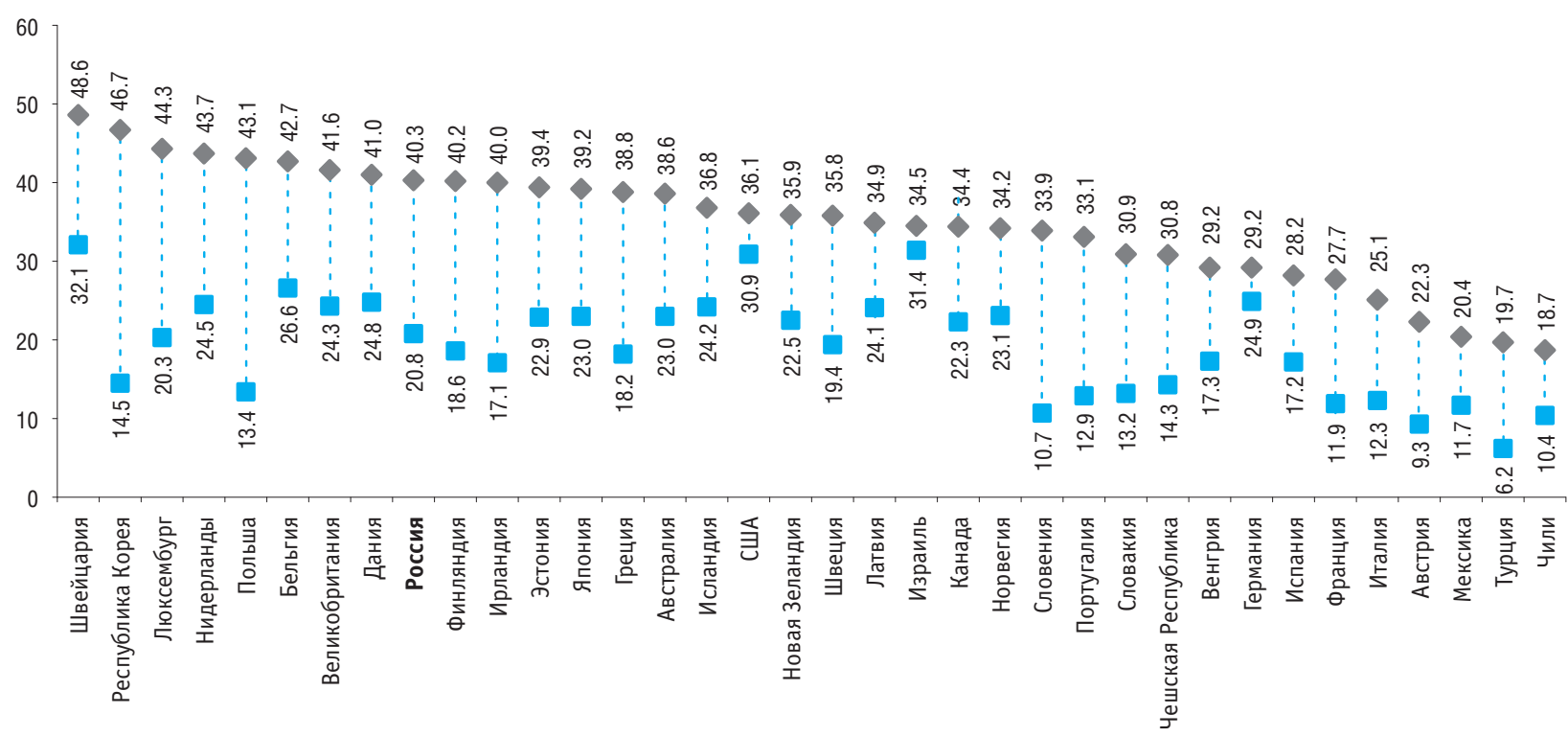

Возраст, лет:

- 25-34 55-64

* По зарубежным странам - данные за 2015 г. или ближайшие годы; по России - данные микропереписи населения 2015 г. 
7.3. УДЕЛЬНЫЙ ВЕС ВЗРОСЛОГО НАСЕЛЕНИЯ, ИМЕЮЩЕГО ОСНОВНОЕ ОБЩЕЕ ОБРАЗОВАНИЕ И НИЖЕ (МСКО 0,1 И 2), В ЕГО ОБЩЕЙ ЧИСЛЕННОСТИ В РОССИИ И СТРАНАХ ОЭСР ПО ВОЗРАСТНЫМ ГРУППАМ: 2015*

(в процентах от общей численности населения соответствующей возрастной группы)

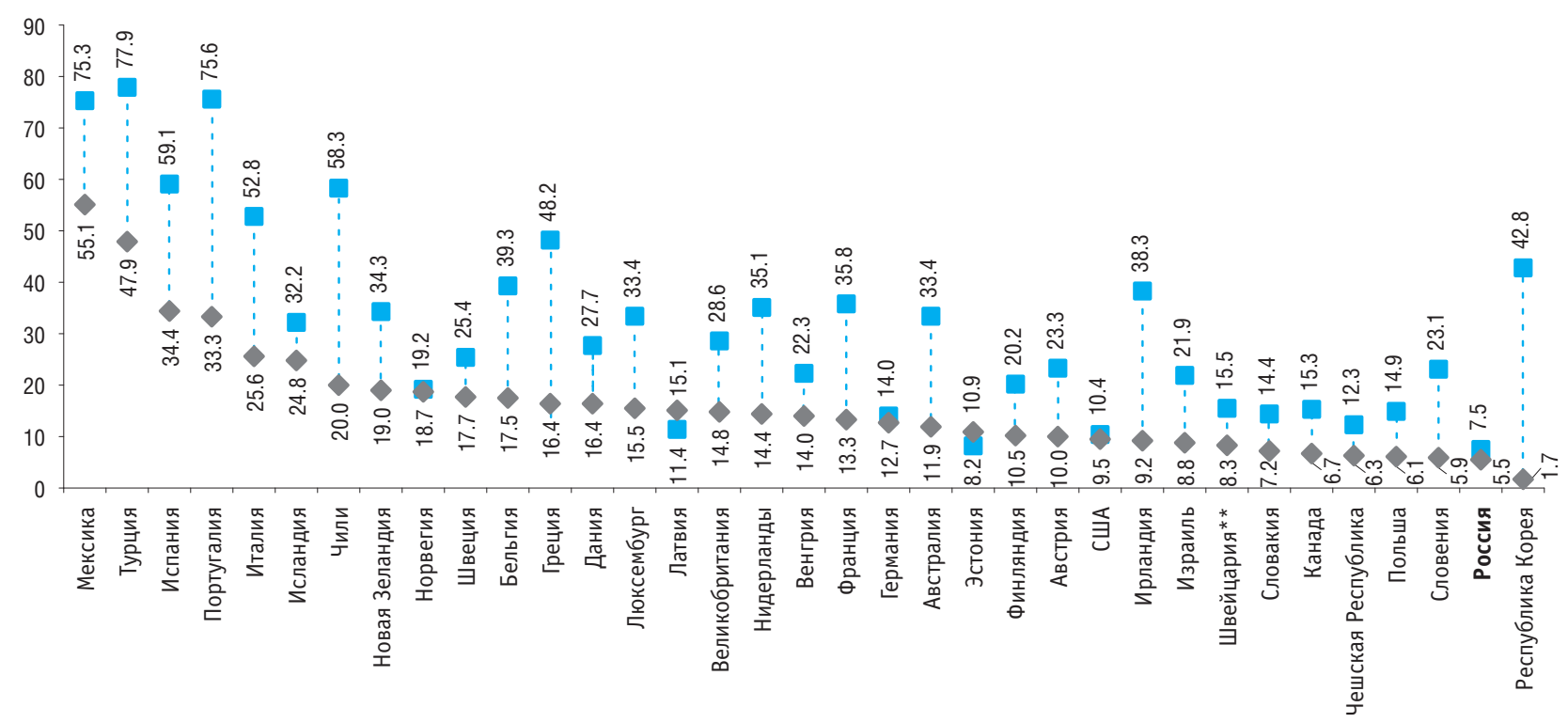

Возраст, лет:

- 25-34 55-64

* По зарубежным странам - данные за 2015 г. или ближайшие годы; по России - данные микропереписи населения 2015 г.

** Включая численность лиц, имеющих уровень образования МСКО 5. 


\section{4. ЗАНЯТОСТЬ И БЕЗРАБОТИЦА ПО ОБРАЗОВАНИЮ В РОССИИ И СТРАНАХ ОЭСР: 2015*}

(в возрасте 25-64 лет; проценты)

\begin{tabular}{|c|c|c|c|c|c|c|}
\hline & \multicolumn{3}{|c|}{$\begin{array}{c}\text { Уровень занятости по образованию (удельный вес занятых } \\
\text { в общей численности населения соответствующего } \\
\text { уровня образования) }\end{array}$} & \multicolumn{3}{|c|}{$\begin{array}{c}\text { Уровень безработицы по образованию (удельный вес безработных } \\
\text { в численности рабочей силы соответствующего } \\
\text { уровня образования) }\end{array}$} \\
\hline & $\begin{array}{l}\text { Основное общее и ниже } \\
\text { (МСКО 0, } 1 \text { и 2) }\end{array}$ & \begin{tabular}{|} 
Среднее общее, среднее \\
профессиональное по \\
программам подготовки \\
квалифицированных \\
рабочих, служащих \\
(МСК0 3 и 4)
\end{tabular} & $\begin{array}{c}\text { Среднее } \\
\text { профессиональное по } \\
\text { программам подготовки } \\
\text { специалистов среднего } \\
\text { звена, высшее } \\
\text { (МСКО 5, 6, } 7 \text { и 8) }\end{array}$ & $\begin{array}{l}\text { Основное общее и ниже } \\
\text { (МСКО 0, } 1 \text { и 2) }\end{array}$ & \begin{tabular}{|c|} 
Среднее общее, среднее \\
профессиональное по \\
программам подготовки \\
квалифицированных \\
рабочих, служащих \\
$($ МСК0 3 и 4)
\end{tabular} & $\begin{array}{c}\text { Среднее } \\
\text { профессиональное по } \\
\text { программам подготовки } \\
\text { специалистов среднего } \\
\text { 3вена, высшее } \\
\text { (МСКО 5, 6, 7 и 8) }\end{array}$ \\
\hline Россия** & 51.0 & 72.4 & 82.2 & 12.0 & 6.1 & 3.2 \\
\hline Австралия & 58.5 & 78.0 & 83.1 & 8.0 & 4.7 & 3.6 \\
\hline Австрия & 52.9 & 75.7 & 85.4 & 10.6 & 4.9 & 3.6 \\
\hline Бельгия & 46.6 & 72.2 & 84.6 & 14.8 & 7.5 & 4.1 \\
\hline Великобритания & 58.6 & 80.7 & 85.9 & 6.8 & 3.6 & 2.7 \\
\hline Венгрия & 48.1 & 73.7 & 83.0 & 15.5 & 5.7 & 2.2 \\
\hline Германия & 58.7 & 79.9 & 88.1 & 11.4 & 4.3 & 2.3 \\
\hline Греция & 48.5 & 56.4 & 68.7 & 26.3 & 25.5 & 19.0 \\
\hline Дания & 60.5 & 80.3 & 85.9 & 8.5 & 4.7 & 4.8 \\
\hline Израиль & 48.6 & 73.4 & 86.5 & 6.5 & 5.4 & 3.6 \\
\hline Ирландия & 48.8 & 68.9 & 82.1 & 15.9 & 9.9 & 5.1 \\
\hline Исландия & 78.4 & 88.1 & 91.8 & 4.0 & 3.1 & 2.8 \\
\hline Испания & 51.6 & 67.7 & 78.5 & 28.9 & 19.2 & 12.4 \\
\hline Италия & 50.2 & 70.1 & 78.6 & 14.2 & 8.9 & 6.8 \\
\hline Канада & 55.2 & 73.5 & 81.8 & 10.4 & 6.8 & 4.7 \\
\hline Латвия & 56.4 & 71.8 & 85.8 & 19.6 & 10.7 & 4.5 \\
\hline Люксембург & 62.3 & 71.8 & 84.8 & 8.3 & 5.4 & 4.6 \\
\hline Мексика & 64.3 & 70.6 & 80.1 & 3.1 & 4.0 & 4.2 \\
\hline Нидерланды & 60.0 & 78.2 & 88.2 & 9.3 & 6.8 & 3.7 \\
\hline
\end{tabular}


(окончание)

\begin{tabular}{|c|c|c|c|c|c|c|}
\hline & \multicolumn{3}{|c|}{$\begin{array}{c}\text { Уровень занятости по образованию (удельный вес занятых } \\
\text { в общей численности населения соответствующего } \\
\text { уровня образования) }\end{array}$} & \multicolumn{3}{|c|}{$\begin{array}{c}\text { Уровень безработицы по образованию (удельный вес безработных } \\
\text { в численности рабочей силы соответствующего } \\
\text { уровня образования) }\end{array}$} \\
\hline & $\begin{array}{c}\text { Основное общее и ниже } \\
\text { (МСКО 0,1 и 2) }\end{array}$ & $\begin{array}{c}\text { Среднее общее, среднее } \\
\text { профессиональное по } \\
\text { программам подготовки } \\
\text { квалифицированных } \\
\text { рабочих, служащих } \\
\text { (МСК0 } 3 \text { и 4) }\end{array}$ & $\begin{array}{c}\text { Среднее } \\
\text { профессиональное по } \\
\text { программам подготовки } \\
\text { специалистов среднего } \\
\text { звена, высшее } \\
\text { (МСК0 5, 6, } 7 \text { и 8) }\end{array}$ & $\begin{array}{c}\text { Основное общее и ниже } \\
\text { (МСКО 0, } 1 \text { и 2) }\end{array}$ & $\begin{array}{c}\text { Среднее общее, среднее } \\
\text { профессиональное по } \\
\text { программам подготовки } \\
\text { квалифицированных } \\
\text { рабочих, служащих } \\
\text { (МСК0 } 3 \text { и 4) }\end{array}$ & $\begin{array}{c}\text { Среднее } \\
\text { профессиональное по } \\
\text { программам подготовки } \\
\text { специалистов среднего } \\
\text { звена, высшее } \\
\text { (МСКО 5, 6, } 7 \text { и 8) }\end{array}$ \\
\hline Новая Зеландия & 69.1 & 81.3 & 87.5 & 6.2 & 4.8 & 2.8 \\
\hline Норвегия & 61.0 & 80.5 & 89.2 & 7.7 & 3.3 & 2.5 \\
\hline Польша & 40.8 & 67.2 & 87.1 & 15.5 & 7.1 & 3.5 \\
\hline Португалия & 64.3 & 78.7 & 83.7 & 13.0 & 11.4 & 8.2 \\
\hline Республика Корея & 65.8 & 72.4 & 77.4 & 2.7 & 3.3 & 3.2 \\
\hline Словакия & 34.5 & 72.6 & 80.3 & 34.2 & 9.9 & 5.6 \\
\hline США & 54.7 & 68.6 & 81.2 & 9.2 & 6.0 & 2.7 \\
\hline Турция & 50.9 & 62.1 & 76.2 & 9.1 & 9.2 & 8.4 \\
\hline Финляндия & 53.4 & 72.8 & 82.7 & 12.1 & 8.2 & 6.4 \\
\hline Франция & 54.1 & 72.7 & 83.8 & 14.0 & 8.8 & 5.7 \\
\hline Чешская Республика & 41.9 & 78.9 & 84.8 & 20.7 & 4.4 & 2.2 \\
\hline Чили & 61.3 & 71.6 & 84.0 & 5.2 & 5.6 & 4.9 \\
\hline Швейцария & 68.8 & 83.2 & 89.2 & 9.6 & 3.6 & 3.2 \\
\hline Швеция & 65.9 & 85.1 & 89.3 & 13.1 & 4.6 & 4.0 \\
\hline Эстония & 57.3 & 76.8 & 85.7 & 12.5 & 6.2 & 3.8 \\
\hline Япония & $\ldots$ & $\ldots$ & $\ldots$ & $\ldots$ & $\ldots$ & $\ldots$ \\
\hline
\end{tabular}

* По зарубежным странам - данные за 2015 г. или ближайшие годы.

** По данным выборочного обследования населения по проблемам занятости. 


\section{5. УРОВЕНЬ ЗАНЯТОСТИ ЛИЦ, ИМЕЮЩИХ СРЕДНЕЕ ПРОФЕССИОНАЛЬНОЕ ОБРАЗОВАНИЕ ПО ПРОГРАММАМ ПОДГОТОВКИ СПЕЦИАЛИСТОВ СРЕДНЕГО ЗВЕНА И ВЫСШЕЕ ОБРАЗОВАНИЕ (МСКО 5, 6, 7 И 8), \\ В РОССИИ И СТРАНАХ ОЭСР ПО ПРЕДМЕТНЫМ ОБЛАСТЯМ: 2012* \\ (в возрасте 25-64 лет; без учета лии, обучающихся на момент обследования; проценты)}

\begin{tabular}{|c|c|c|c|c|c|c|c|}
\hline & $\begin{array}{c}\text { Образование } \\
\text { и педагогические } \\
\text { науки }\end{array}$ & $\begin{array}{c}\text { Искусство } \\
\text { и гуманитарные } \\
\text { науки }\end{array}$ & $\begin{array}{c}\text { Социальные науки. } \\
\text { Экономика } \\
\text { и право }\end{array}$ & $\begin{array}{c}\text { Физико- } \\
\text { математические } \\
\text { и естественные } \\
\text { науки }\end{array}$ & $\begin{array}{c}\text { Инженерное дело, } \\
\text { технологии } \\
\text { и технические } \\
\text { науки }\end{array}$ & Здравоохранение & Всего \\
\hline Россия & 72.5 & 64.4 & 69.5 & 60.8 & 74.8 & 70.7 & 68.1 \\
\hline Австралия & 81.4 & 79.1 & 87.3 & 86.2 & 88.5 & 85.4 & 85.2 \\
\hline Австрия & 84.3 & 84.1 & 91.4 & 87.5 & 86.7 & 94.2 & 87.3 \\
\hline Германия & 84.4 & 84.7 & 89.9 & 90.5 & 92.9 & 89.9 & 89.5 \\
\hline Греция & 56.9 & 72.1 & 70.9 & 73.8 & 71.2 & 74.9 & 68.1 \\
\hline Дания & 84.4 & 87.8 & 90.8 & 90.9 & 89.6 & 87.3 & 88.1 \\
\hline Израиль & 77.5 & 84.0 & 87.9 & 88.6 & 90.6 & 90.0 & 85.8 \\
\hline Ирландия & 80.8 & 77.7 & 80.6 & 88.2 & 78.1 & 92.6 & 83.0 \\
\hline Испания & 75.5 & 71.8 & 82.5 & 83.0 & 84.0 & 81.8 & 80.0 \\
\hline Италия & $\ldots$ & 69.5 & 90.4 & 77.9 & 93.2 & 85.1 & 82.9 \\
\hline Канада & 85.4 & 82.1 & 84.0 & 88.7 & 91.4 & 85.4 & 86.0 \\
\hline Нидерланды & 85.7 & 87.2 & 89.9 & 89.1 & 88.1 & 87.3 & 88.3 \\
\hline Новая Зеландия & 86.3 & 82.2 & 87.9 & 90.8 & 89.5 & 86.5 & 87.2 \\
\hline Норвегия & 92.3 & 90.8 & 91.1 & 94.4 & 92.6 & 93.2 & 92.4 \\
\hline Польша & 87.2 & 82.9 & 88.8 & 85.3 & 93.2 & 94.2 & 88.2 \\
\hline Республика Корея & 72.9 & 70.2 & 83.1 & 81.6 & 84.9 & 79.0 & 79.4 \\
\hline Словакия & 77.0 & 83.3 & 93.3 & 91.1 & 85.1 & 89.6 & 86.8 \\
\hline Словения & 76.8 & 87.3 & 81.3 & 83.8 & 86.1 & 85.3 & 82.8 \\
\hline США & 82.4 & 87.6 & 88.0 & 81.6 & 86.4 & 86.5 & 85.5 \\
\hline
\end{tabular}


(окончание)

\begin{tabular}{l|c|c|c|c|c|c|c}
\hline & $\begin{array}{c}\text { Образование } \\
\text { и педагогические } \\
\text { науки }\end{array}$ & $\begin{array}{c}\text { Искусство } \\
\text { и гуманитарные } \\
\text { науки }\end{array}$ & $\begin{array}{c}\text { Социальные науки. } \\
\text { Экономика } \\
\text { и право }\end{array}$ & $\begin{array}{c}\text { Физико- } \\
\text { математические } \\
\text { и естественные } \\
\text { науки }\end{array}$ & $\begin{array}{c}\text { Инженерное дело, } \\
\text { технологии } \\
\text { и технические } \\
\text { науки }\end{array}$ & $\begin{array}{c}\text { Здравоохранение } \\
\text { Всего }\end{array}$ \\
\hline Турция & 71.6 & $\ldots$ & 67.8 & 68.5 & 74.1 & 63.0 \\
Финляндия & 90.1 & 84.3 & 87.7 & 90.4 & 88.6 & 89.6 \\
Франция & 84.2 & 84.0 & 84.8 & 83.9 & 87.8 & 86.9 \\
Чешская Республика & 88.2 & 87.6 & 81.9 & 93.0 & 84.8 & 80.6 \\
Чили & 92.4 & 80.9 & 92.1 & 91.0 & 93.1 & 92.1 \\
Швеция & 90.0 & 88.8 & 91.9 & 91.8 & 95.0 & 93.2 \\
Эстония & 88.4 & 93.4 & 86.2 & 88.2 & 85.1 & 90.3 \\
Япония & 70.4 & 65.7 & 84.5 & 90.7 & 92.5 & 92.5 \\
\hline
\end{tabular}

*По данным обследования компетенций взрослого населения (РІААС). В Чили, Греции, Израиле, Новой Зеландии, Словении и Турции обследование проходило в 2015 г., в остальных странах - в 2012 г. 


\section{6. ГОСУДАРСТВЕННЫЕ РАСХОДЫ НА ОБРАЗОВАНИЕ В РОССИИ И СТРАНАХ ОЭСР \\ В ПРОЦЕНТАХ К ВАЛОВОМУ ВНУТРЕННЕМУ ПРОДУКТУ: 2015*}

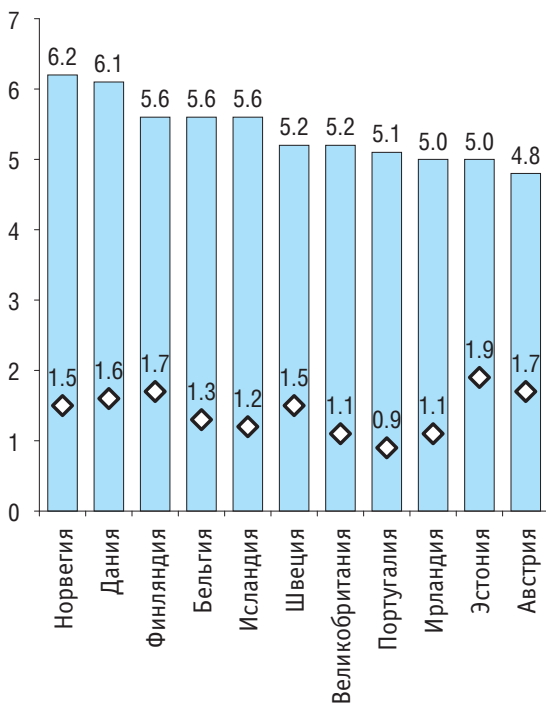

Расходы на образование:

$\diamond$ высшее образование (МСК0 6, 7 и 8)**

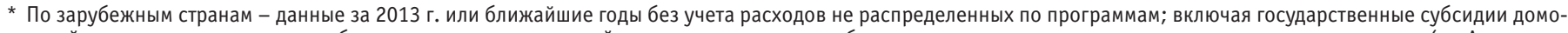

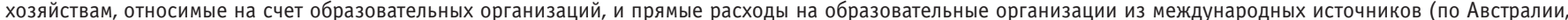

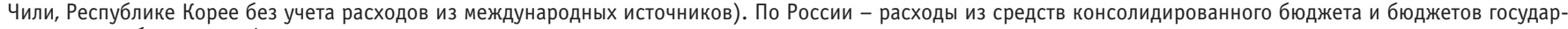
ственных внебюджетных фондов.

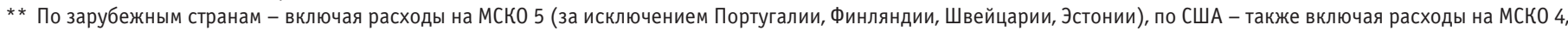
по Португалии и Японии - частично расходы на МСКО 4. 


\section{7. ГОСУДАРСТВЕННЫЕ РАСХОДЫ НА ОБРАЗОВАНИЕ В РОССИИ И СТРАНАХ ОЭСР В ПРОЦЕНТАХ ОТ ОБЩИХ ГОСУДАРСТВЕННЫХ РАСХОДОВ: 2015*}

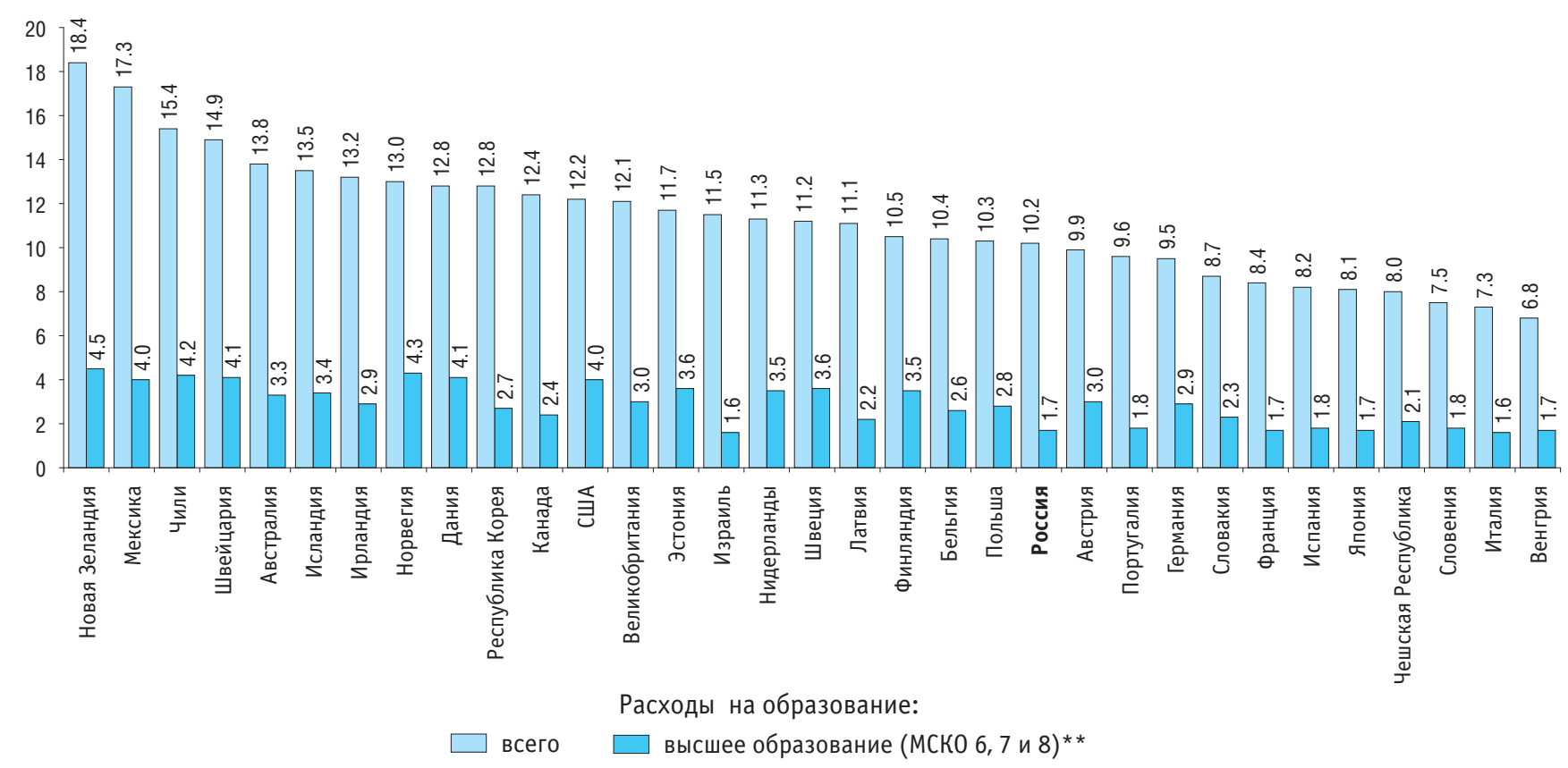

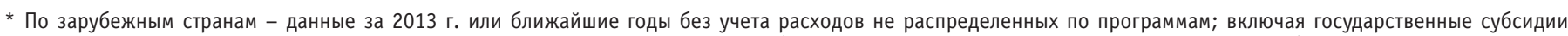

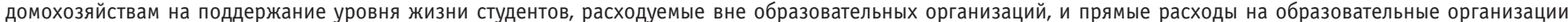
из международных источников; по России - расходы из средств консолидированного бюджета и бюджетов государственных внебюджетных фондов.

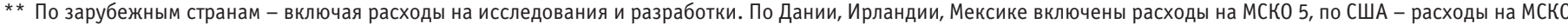
4 и 5, по Португалии и Японии - частично расходы на МСКО 4. 
7.8. ОХВАТ ОБРАЗОВАНИЕМ НАСЕЛЕНИЯ В ВОЗРАСТЕ 5-29 ЛЕТ В РОССИИ И СТРАНАХ ОЭСР: 2015* (проченты)

\begin{tabular}{|c|c|c|c|c|}
\hline & \multicolumn{4}{|c|}{ 0хват образованием населения в возрасте, лет } \\
\hline & \multirow[t]{2}{*}{$5-14$} & \multirow[t]{2}{*}{$15-19$} & \multicolumn{2}{|c|}{$20-29$} \\
\hline & & & $\begin{array}{c}\text { Среднее общее, среднее } \\
\text { профессиональное } \\
\text { по программам подготовки } \\
\text { квалифицированных рабочих, } \\
\text { служащих (МСКО } 3 \text { и 4) }\end{array}$ & $\begin{array}{c}\text { Среднее профессиональное } \\
\text { по программам подготовки } \\
\text { специалистов среднего } \\
\text { звена, высшее } \\
\text { (МСКО 5, 6, 7 и 8) }\end{array}$ \\
\hline Россия** & 97.8 & 87.2 & 0.6 & 17.2 \\
\hline Австралия & 100 & 86.8 & 9.4 & 23.4 \\
\hline Австрия & 98.4 & 79.6 & 3.2 & 23.0 \\
\hline Бельгия & 98.0 & 92.4 & 6.0 & 21.5 \\
\hline Великобритания & 98.8 & 84.6 & 6.0 & 15.3 \\
\hline Венгрия & 96.6 & 86.4 & 6.2 & 18.8 \\
\hline Германия & 99.1 & 89.7 & 11.6 & 22.8 \\
\hline Греция & 96.1 & 83.3 & 2.1 & 26.0 \\
\hline Дания & 99.3 & 87.0 & 13.6 & 31.5 \\
\hline Израиль & 97.8 & 65.5 & 1.4 & 21.0 \\
\hline Ирландия & 100 & 94.8 & 5.6 & 20.6 \\
\hline Исландия & $\ldots$ & $\ldots$ & $\ldots$ & $\ldots$ \\
\hline Испания & 97.2 & 87.2 & 5.0 & 23.9 \\
\hline Италия & 98.2 & 77.4 & 1.8 & 22.4 \\
\hline Канада*** & 90.6 & 73.1 & 2.8 & 19.2 \\
\hline Латвия & 97.7 & 91.9 & 5.2 & 23.2 \\
\hline Люксембург & 97.1 & 76.3 & 5.7 & 7.0 \\
\hline Мексика & 100 & 55.6 & 1.3 & 11.0 \\
\hline Нидерланды & 99.4 & 92.1 & 7.7 & 24.0 \\
\hline Новая Зеландия & 98.5 & 82.2 & 7.1 & 22.3 \\
\hline
\end{tabular}


(окончание)

\begin{tabular}{|c|c|c|c|c|}
\hline & \multicolumn{4}{|c|}{ Охват образованием населения в возрасте, лет } \\
\hline & \multirow[t]{2}{*}{$5-14$} & \multirow[t]{2}{*}{$15-19$} & \multicolumn{2}{|c|}{$20-29$} \\
\hline & & & $\begin{array}{c}\text { Среднее общее, среднее } \\
\text { профессиональное } \\
\text { по программам подготовки } \\
\text { квалифицированных рабочих, } \\
\text { служащих (МСКО } 3 \text { и 4) }\end{array}$ & $\begin{array}{c}\text { Среднее профессиональное } \\
\text { по программам подготовки } \\
\text { специалистов среднего } \\
\text { звена, высшее } \\
\text { (МСКО 5, 6, 7 и 8) }\end{array}$ \\
\hline Норвегия & 99.4 & 87.0 & 5.5 & 25.2 \\
\hline Польша & 95.6 & 89.3 & 5.9 & 24.9 \\
\hline Португалия & 99.7 & 89.2 & 4.3 & 19.5 \\
\hline Республика Корея & 98.5 & 87.2 & 0.0 & 31.3 \\
\hline Словакия & 93.7 & 84.7 & 1.8 & 18.6 \\
\hline Словения & 97.0 & 93.2 & 4.0 & 27.9 \\
\hline США & 97.2 & 81.6 & 1.3 & 24.2 \\
\hline Турция & 95.9 & 72.2 & 4.6 & 28.5 \\
\hline Финляндия & 96.7 & 86.0 & 12.7 & 28.4 \\
\hline Франция & 99.3 & 85.1 & 1.9 & 19.3 \\
\hline Чешская Республика & 97.7 & 90.4 & $\ldots$ & 22.9 \\
\hline Чили & 97.5 & 79.6 & 1.3 & 27.3 \\
\hline Швейцария & 99.8 & 85.5 & 6.6 & 20.1 \\
\hline Швеция & 98.2 & 85.3 & 9.0 & 21.3 \\
\hline Эстония & 73.1 & 89.7 & 6.1 & 22.9 \\
\hline Япония & 100 & 94.1 & $\ldots$ & \\
\hline
\end{tabular}

* По зарубежным странам - данные за 2014 г. или ближайшие годы. Несоответствие между данными о численности населения и об обучающихся может приводить как к заниженному, так и к завышенному результату (например, если большая часть населения страны обучается в других странах; при несоответствии временных характеристик показателей, используемых в расчете, и т.п.). Для стран, в которых показатель превышает 100\%, указано значение 100.

** Оценка Института статистических исследований и экономики знаний ниУ Вшэ.

*** Исключая программы МСКО 010 и 4. 


\section{9. УДЕЛЬНЫЙ ВЕС ИНОСТРАННЫХ СТУДЕНТОВ И АСПИРАНТОВ В ИХ ОБЩЕЙ ЧИСЛЕННОСТИ В РОССИИ И СТРАНАХ ОЭСР: СРЕДНЕЕ ПРОФЕССИОНАЛЬНОЕ ПО ПРОГРАММАМ ПОДГОТОВКИ СПЕЦИАЛИСТОВ СРЕДНЕГО ЗВЕНА}

И ВЫСШЕЕ ОБРАЗОВАНИЕ (МСКО 5, 6, 7 И 8), 2015*

Проценты

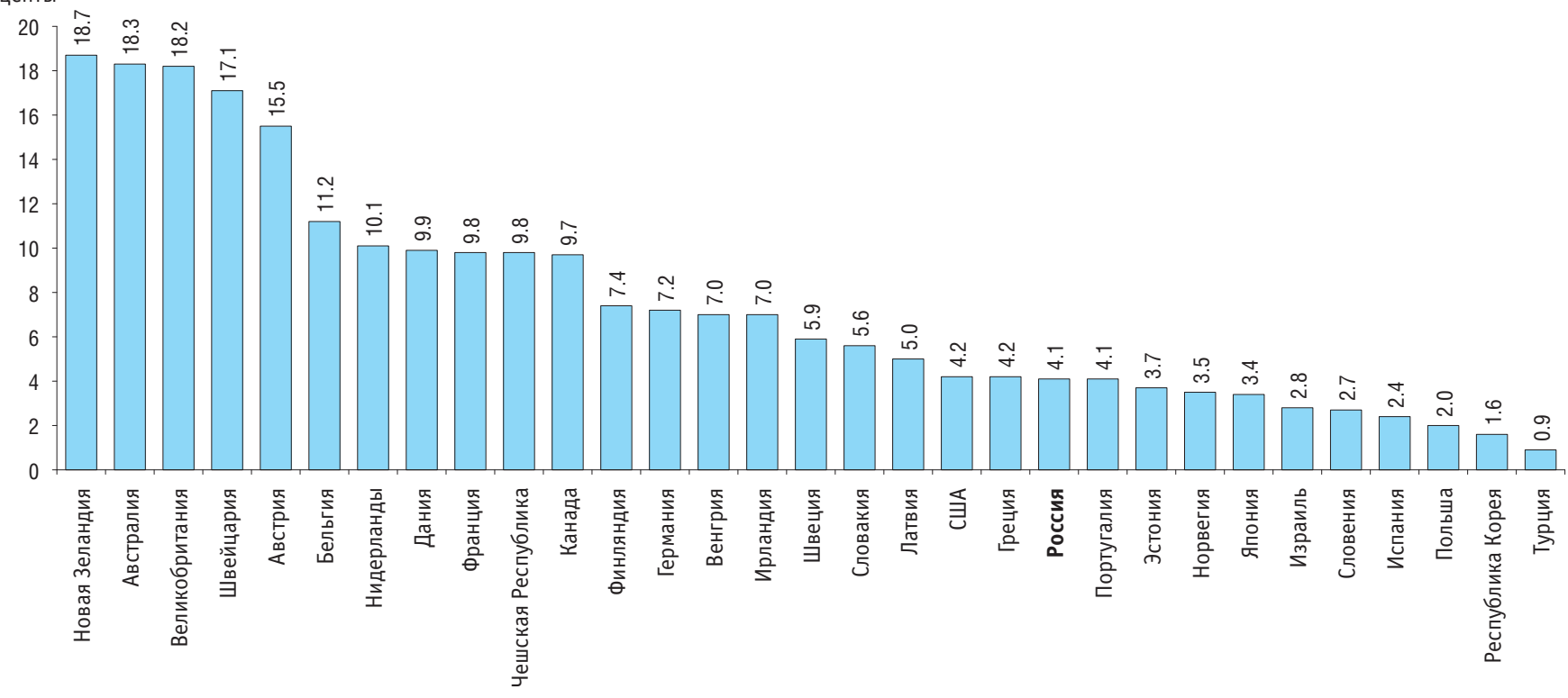

* По зарубежным странам - данные за 2014 г. или ближайшие годы. 
7.10. РАСПРЕДЕЛЕНИЕ ВЫПУСКНИКОВ, ПОЛУЧИВШИХ СРЕДНЕЕ ПРОФЕССИОНАЛЬНОЕ ОБРАЗОВАНИЕ ПО ПРОГРАММАМ ПОДГОТОВКИ СПЕЦИАЛИСТОВ СРЕДНЕГО ЗВЕНА И ВЫСШЕЕ ОБРАЗОВАНИЕ ВПЕРВЫЕ,

В РОССИИ И СТРАНАХ ОЭСР ПО УРОВНЮ ОБРАЗОВАНИЯ: 2015*

(проценты)

\begin{tabular}{|c|c|c|c|}
\hline & $\begin{array}{c}\text { Среднее профессиональное } \\
\text { образование по программам } \\
\text { подготовки специалистов } \\
\text { среднего звена } \\
\text { (МСКО 5) }\end{array}$ & $\begin{array}{c}\text { Высшее образование } \\
\text { по программам бакалавриата } \\
\text { (МСКО 6) }\end{array}$ & $\begin{array}{c}\text { Высшее образование } \\
\text { по программам магистратуры } \\
\text { и специалитета } \\
\text { (МСКО 7) }\end{array}$ \\
\hline Россия & 26.1 & 32.7 & 41.2 \\
\hline Австралия & 6.4 & 75.9 & 17.7 \\
\hline Австрия & 48.6 & 31.7 & 19.7 \\
\hline Бельгия & $\ldots$ & $\ldots$ & $\ldots$ \\
\hline Великобритания & 9.3 & 88.5 & 2.1 \\
\hline Венгрия & 19.2 & 68.8 & 12.0 \\
\hline Германия & 0.1 & 79.7 & 20.3 \\
\hline Греция & $\ldots$ & $\ldots$ & $\ldots$ \\
\hline Дания & 18.0 & 75.2 & 6.8 \\
\hline Израиль & $\ldots$ & $\ldots$ & $\ldots$ \\
\hline Ирландия & $\ldots$ & $\ldots$ & $\ldots$ \\
\hline Исландия & 3.0 & 95.4 & 1.6 \\
\hline Испания & 35.3 & 38.7 & 26.0 \\
\hline Италия & 0.5 & 81.5 & 18.0 \\
\hline Канада & $\ldots$ & $\ldots$ & $\ldots$ \\
\hline Латвия & 27.3 & 68.9 & 3.9 \\
\hline Люксембург & 17.6 & 34.8 & 47.5 \\
\hline Мексика & 8.2 & 91.8 & - \\
\hline Нидерланды & 1.4 & 90.9 & 7.7 \\
\hline
\end{tabular}


(окончание)

\begin{tabular}{|c|c|c|c|}
\hline & $\begin{array}{c}\text { Среднее профессиональное } \\
\text { образование по программам } \\
\text { подготовки специалистов } \\
\text { среднего звена } \\
\text { (МСКО 5) }\end{array}$ & $\begin{array}{c}\text { Высшее образование } \\
\text { по программам бакалавриата } \\
\text { (МСКО 6) }\end{array}$ & $\begin{array}{c}\text { Высшее образование } \\
\text { по программам магистратуры } \\
\text { и специалитета } \\
\text { (МСКО 7) }\end{array}$ \\
\hline Новая Зеландия & 31.1 & 65.9 & 2.9 \\
\hline Норвегия & 9.0 & 81.4 & 9.6 \\
\hline Польша & $\ldots$ & $\ldots$ & $\ldots$ \\
\hline Португалия & - & 84.2 & 15.8 \\
\hline Республика Корея & $\ldots$ & $\ldots$ & $\ldots$ \\
\hline Словакия & 2.6 & 92.9 & 4.5 \\
\hline Словения & 15.1 & 63.2 & 21.8 \\
\hline США & 41.3 & 58.7 & - \\
\hline Турция & 41.9 & 56.7 & 1.4 \\
\hline Финляндия & - & 88.7 & 11.3 \\
\hline Франция & $\ldots$ & $\ldots$ & $\ldots$ \\
\hline Чешская Республика & 0.6 & 89.0 & 10.4 \\
\hline Чили & 41.8 & 56.0 & 2.2 \\
\hline Швейцария & 3.5 & 96.1 & 0.4 \\
\hline Швеция & 3.2 & 63.3 & 33.5 \\
\hline Эстония & $\ldots$ & $\ldots$ & $\ldots$ \\
\hline Япония & 34.3 & 63.4 & 2.3 \\
\hline
\end{tabular}

* По зарубежным странам - данные за 2014 г. или ближайшие годы. 
7.11. УДЕЛЬНЫЙ ВЕС ЖЕНЩИН В ОБЩЕЙ ЧИСЛЕННОСТИ УЧИТЕЛЕЙ (ПРЕПОДАВАТЕЛЕЙ) В РОССИИ И СТРАНАХ ОЭСР: 2015* (проченты)

\begin{tabular}{|c|c|c|c|c|}
\hline & $\begin{array}{l}\text { Начальное общее } \\
\text { образование } \\
\text { (МСКО 1) }\end{array}$ & $\begin{array}{c}\text { Основное общее } \\
\text { образование } \\
\text { (МСКО 2) }\end{array}$ & $\begin{array}{c}\text { Среднее общее } \\
\text { образование } \\
(\text { (МСК0 3)** }\end{array}$ & $\begin{array}{c}\text { Среднее профессиональное } \\
\text { образование - программы } \\
\text { подготовки специалистов } \\
\text { среднего звена, высшее } \\
\text { образование } \\
\text { (МСК0 5, 6, } 7 \text { и 8) }\end{array}$ \\
\hline & (1) & (2) & (3) & (4) \\
\hline Россия & 98.9 & $n(3)$ & 83.3 & 63.7 \\
\hline Австралия & $\ldots$ & $\ldots$ & $\ldots$ & $44.5^{\star \star \star}$ \\
\hline Австрия & 91.4 & 72.0 & 62.8 & 42.6 \\
\hline Бельгия & 81.7 & 63.2 & 62.6 & 48.2 \\
\hline Великобритания & 84.1 & 58.8 & 61.9 & 44.3 \\
\hline Венгрия & 97.0 & 77.6 & 68.6 & 43.3 \\
\hline Германия & 86.8 & 66.1 & 54.7 & 38.0 \\
\hline Греция & 70.2 & 66.0 & 54.1 & 32.7 \\
\hline Дания & 69.1 & 64.3 & 50.8 & 41.2 \\
\hline Израиль & 85.3 & 78.9 & 70.0 & $\ldots$ \\
\hline Ирландия & 86.9 & $n(3)$ & 71.0 & 44.0 \\
\hline Исландия & $\ldots$ & $\ldots$ & $\ldots$ & $\ldots$ \\
\hline Испания & 76.0 & 59.2 & 56.2 & 41.7 \\
\hline Италия & 95.9 & 77.9 & 71.9 & 37.5 \\
\hline Канада & $73.6^{\star * * *}$ & $\mathrm{n}(1)$ & 73.6 & 49.4 \\
\hline Латвия & 92.8 & 84.3 & 84.5 & 55.7 \\
\hline Люксембург & 74.5 & 58.5 & 54.1 & 38.4 \\
\hline Мексика & 67.6 & 52.4 & 47.2 & $\ldots$ \\
\hline Нидерланды & 85.9 & 51.3 & 51.3 & 43.5 \\
\hline Новая Зеландия & 83.8 & 65.6 & 60.4 & 49.1 \\
\hline Норвегия & 74.8 & 74.8 & $52.1^{\star \star * \star *}$ & $45.2^{\star \star *}$ \\
\hline
\end{tabular}


(окончание)

\begin{tabular}{|c|c|c|c|c|}
\hline & $\begin{array}{l}\text { Начальное общее } \\
\text { образование } \\
\text { (МСКО 1) }\end{array}$ & $\begin{array}{c}\text { Основное общее } \\
\text { образование } \\
\text { (МСКО 2) }\end{array}$ & $\begin{array}{c}\text { Среднее общее } \\
\text { образование } \\
(\text { МСКО 3)** }\end{array}$ & $\begin{array}{c}\text { Среднее профессиональное } \\
\text { образование - программы } \\
\text { подготовки специалистов } \\
\text { среднего звена, высшее } \\
\text { образование } \\
\text { (МСК0 5, 6, } 7 \text { и 8) }\end{array}$ \\
\hline & (1) & (2) & (3) & (4) \\
\hline Польша & 85.3 & 73.7 & 70.4 & 44.2 \\
\hline Португалия & 79.8 & 71.6 & $67.8^{\star \star \star \star \star}$ & $44.0^{\star \star \star \star \star}$ \\
\hline Республика Корея & 78.6 & 69.2 & 51.0 & 34.7 \\
\hline Словакия & 90.0 & 77.8 & 74.2 & 44.9 \\
\hline Словения & 96.9 & 79.5 & 70.0 & 38.8 \\
\hline США & 87.2 & 66.8 & 57.0 & $49.1^{\star \star \star \star \star}$ \\
\hline Турция & 58.2 & 53.2 & 45.7 & 42.8 \\
\hline Финляндия & 79.5 & 72.4 & 69.8 & 50.3 \\
\hline Франция & 83.1 & 64.6 & 55.6 & $39.9^{\star \star \star \star *}$ \\
\hline Чешская Республика & 92.8 & 76.9 & 59.2 & 39.9 \\
\hline Чили & 81.0 & 68.2 & 57.4 & $\ldots$ \\
\hline Швейцария & 82.0 & 53.9 & 46.0 & 34.0 \\
\hline Швеция & 77.2 & 77.1 & 52.6 & 43.9 \\
\hline Эстония & 91.6 & 82.1 & 78.3 & 48.9 \\
\hline Япония & 64.8 & 42.4 & $30.0 * * * \star *$ & $26.8^{\star \star \star \star *}$ \\
\hline
\end{tabular}

* По зарубежным странам - данные за 2014 г. или ближайшие годы; по Израилю, Ирландии, Нидерландам, Швейцарии - только по государственным организациям. По России - данные по штатному персоналу учителей общеобразовательных организаций (без вечерних (сменных) общеобразовательных организаций) (МСК0 1, 2 и 3), штатному персоналу преподавателей образовательных организаций, реализующих образовательные программы среднего профессионального образования программы подготовки специалистов среднего звена, и профессорско-преподавательскому составу образовательных организаций высшего образования (МСК0 5, 6 и 7).

** По зарубежным странам - общие программы МСК0 3; по Израилю, Канаде, Мексике, Норвегии, Португалии, США, Швеции и Японии - все программы (общие и профессионально-технические).

*** Исключая программы МСКО 5.

**** Включая программы МСКО 0.

***** Включая программы МСКО 4; по Норвегии - включая и программы МСКО 5. 
7.12. ЧИСЛЕННОСТЬ ОБУЧАЮЩИХСЯ В РАСЧЕТЕ НА ОДНОГО УЧИТЕЛЯ (ПРЕПОДАВАТЕЛЯ) В РОССИИ И СТРАНАХ ОЭСР: 2015* (человек)

\begin{tabular}{|c|c|c|c|c|}
\hline & $\begin{array}{c}\text { Начальное общее } \\
\text { образование } \\
\text { (МСКО 1) }\end{array}$ & $\begin{array}{l}\text { Основное общее } \\
\text { образование } \\
\text { (МСКО 2) }\end{array}$ & $\begin{array}{c}\text { Среднее общее } \\
\text { образование } \\
(\text { (МСК0 3)** }\end{array}$ & $\begin{array}{c}\text { Среднее профессиональное } \\
\text { образование - программы } \\
\text { подготовки специалистов } \\
\text { среднего звена, высшее } \\
\text { образование } \\
\text { (МСКО 5, 6, } 7 \text { и 8) }\end{array}$ \\
\hline & (1) & (2) & (3) & (4) \\
\hline Россия & $n(3)$ & $\mathrm{n}(3)$ & 14 & 11 \\
\hline Австралия & 16 & $n(3)$ & 12 & $15^{\star \star *}$ \\
\hline Австрия & 12 & 9 & 10 & 15 \\
\hline Бельгия & 13 & 9 & 10 & 22 \\
\hline Великобритания & 20 & 15 & 15 & 17 \\
\hline Венгрия & 11 & 11 & 12 & 15 \\
\hline Германия & 15 & 13 & 13 & 12 \\
\hline Греция & 9 & 8 & $\ldots$ & 45 \\
\hline Дания & 12 & 11 & 11 & 14 \\
\hline Израиль & 15 & 12 & 11 & $\ldots$ \\
\hline Ирландия & 16 & $n(3)$ & 14 & 20 \\
\hline Исландия & $\ldots$ & $\ldots$ & $\ldots$ & $\ldots$ \\
\hline Испания & 14 & 12 & 12 & 13 \\
\hline Италия & 12 & 12 & 13 & 19 \\
\hline Канада & $16^{\star * \star *}$ & $n(1)$ & 14 & $\ldots$ \\
\hline Латвия & 11 & 8 & 8 & 19 \\
\hline Люксембург & 9 & 11 & 8 & $\ldots$ \\
\hline Мексика & 27 & 33 & 21 & 16 \\
\hline Нидерланды & 17 & 16 & 16 & 16 \\
\hline Новая Зеландия & 16 & 16 & 12 & 17 \\
\hline Норвегия & 10 & 10 & $10^{\star \star \star \star \star *}$ & $10^{* \star *}$ \\
\hline
\end{tabular}


(окончание)

\begin{tabular}{|c|c|c|c|c|}
\hline & $\begin{array}{c}\text { Начальное общее } \\
\text { образование } \\
\text { (МСКО 1) }\end{array}$ & $\begin{array}{c}\text { Основное общее } \\
\text { образование } \\
\text { (МСКО 2) }\end{array}$ & $\begin{array}{l}\text { Среднее общее } \\
\text { образование } \\
(\text { (МСК0 3) }\end{array}$ & $\begin{array}{c}\text { Среднее профессионально } \\
\text { образование - программы } \\
\text { подготовки специалистов } \\
\text { среднего звена, высшее } \\
\text { образование } \\
\text { (МСК0 5, 6,7 и 8) }\end{array}$ \\
\hline & (1) & (2) & (3) & (4) \\
\hline Польша & 11 & 10 & 13 & 15 \\
\hline Португалия & 14 & 10 & $9^{\star \star \star \star \star}$ & 14 \\
\hline Республика Корея & 17 & 17 & 15 & 21 \\
\hline Словакия & 17 & 12 & 14 & 14 \\
\hline Словения & 16 & 8 & 13 & 17 \\
\hline США & 15 & 15 & 15 & $15^{\star \star * \star *}$ \\
\hline Турция & 19 & 18 & 16 & 20 \\
\hline Финляндия & 13 & 9 & 14 & 14 \\
\hline Франция & 19 & 15 & 9 & $18^{\star \star \star \star *}$ \\
\hline Чешская Республика & 19 & 12 & 12 & 22 \\
\hline Чили & 21 & 23 & 24 & $\ldots$ \\
\hline Швейцария & 15 & 12 & 11 & $\cdots$ \\
\hline Швеция & 13 & 12 & 14 & 11 \\
\hline Эстония & 13 & 10 & 13 & 15 \\
\hline Япония & 17 & 14 & $12^{* * * * *}$ & $\ldots$ \\
\hline
\end{tabular}

* По зарубежным странам - данные за 2014 г. или ближайшие годы в эквиваленте полной занятости; по Израилю (лишь в отношении программ Мск0 3), Ирландии, Нидерландам и Швейцарии - только по государственным организациям. По России - данные по штатному персоналу учителей общеобразовательных организаций (без вечерних (сменных) общеобразовательных организаций) (МСКО 1, 2 и 3), штатному персоналу преподавателей образовательных организаций, реализующих образовательные программы среднего профессионального образования - программы подготовки специалистов среднего звена, и профессорскопреподавательскому составу образовательных организаций высшего образования (МСКО 5, 6 и 7).

** По зарубежным странам - общие программы МСКО 3; по Израилю, Канаде, Мексике, Норвегии, Португалии, США, Швеции и Японии - все программы (общие и профессионально-технические).

*** Исключая программы МСКО 5.

**** Включая программы МСКО 0.

***** Включая программы МСКО 4; по Норвегии - включая и программы МСКО 5. 
7.13. СРЕДНИЙ РАЗМЕР КЛАССА В РОССИИ И СТРАНАХ ОЭСР: 2015*

(человек)

\begin{tabular}{|c|c|c|c|c|c|c|}
\hline & \multicolumn{3}{|c|}{ Начальное общее образование (МСК0 1) } & \multicolumn{3}{|c|}{ Основное общее образование (МСКО 2) } \\
\hline & Всего & $\begin{array}{c}\text { Государственные } \\
\text { и муниципальные } \\
\text { организации }\end{array}$ & $\begin{array}{c}\text { Частные } \\
\text { организации }\end{array}$ & Bcero & $\begin{array}{c}\text { Государственные } \\
\text { и муниципальные } \\
\text { организации }\end{array}$ & $\begin{array}{c}\text { Частные } \\
\text { организации }\end{array}$ \\
\hline Россия & 21 & 21 & 13 & 19 & 19 & 12 \\
\hline Австралия & 24 & 23 & 25 & 24 & 23 & 25 \\
\hline Австрия & 18 & 18 & 19 & 21 & 21 & 21 \\
\hline Бельгия & $\ldots$ & $\ldots$ & $\ldots$ & $\ldots$ & $\ldots$ & $\ldots$ \\
\hline Великобритания & 25 & 26 & 21 & 19 & 20 & 18 \\
\hline Венгрия & 21 & 21 & 20 & 21 & 21 & 21 \\
\hline Германия & 21 & 21 & 21 & 24 & 24 & 24 \\
\hline Греция & $\ldots$ & $\ldots$ & $\ldots$ & $\ldots$ & $\ldots$ & $\ldots$ \\
\hline Дания & $\ldots$ & $\ldots$ & $\ldots$ & $\ldots$ & $\ldots$ & $\ldots$ \\
\hline Израиль & 27 & 28 & 24 & 28 & 29 & 24 \\
\hline Ирландия & $\ldots$ & 25 & $\ldots$ & $\ldots$ & $\ldots$ & $\ldots$ \\
\hline Исландия & 19 & 19 & 13 & 20 & 20 & 11 \\
\hline Испания & 22 & 21 & 24 & 25 & 25 & 26 \\
\hline Италия & 20 & 20 & 20 & 21 & 21 & 21 \\
\hline Канада & $\ldots$ & $\ldots$ & $\ldots$ & $\ldots$ & $\ldots$ & $\ldots$ \\
\hline Латвия & 16 & 16 & 9 & 15 & 15 & 10 \\
\hline Люксембург & 16 & 15 & 21 & 19 & 19 & 19 \\
\hline Мексика & 19 & 19 & 19 & 28 & 28 & 24 \\
\hline Нидерланды & 23 & $23^{\star *}$ & $\ldots$ & $\ldots$ & $\ldots$ & $\ldots$ \\
\hline Новая Зеландия & $\ldots$ & $\ldots$ & $\ldots$ & 25 & 25 & 21 \\
\hline Норвегия & $\ldots$ & $\ldots$ & $\ldots$ & $\ldots$ & $\ldots$ & $\ldots$ \\
\hline Польша & 18 & 19 & 11 & 22 & 23 & 17 \\
\hline
\end{tabular}


(окончание)

\begin{tabular}{|c|c|c|c|c|c|c|}
\hline & \multicolumn{3}{|c|}{ Начальное общее образование (МСКО 1) } & \multicolumn{3}{|c|}{ Основное общее образование (МСК0 2) } \\
\hline & Всего & $\begin{array}{c}\text { Государственные } \\
\text { и муниципальные } \\
\text { организации }\end{array}$ & $\begin{array}{c}\text { Частные } \\
\text { организации }\end{array}$ & Всего & $\begin{array}{c}\text { Государственные } \\
\text { и муниципальные } \\
\text { организации }\end{array}$ & $\begin{array}{c}\text { Частные } \\
\text { организации }\end{array}$ \\
\hline Португалия & 21 & 21 & 21 & 23 & 23 & 24 \\
\hline Республика Корея & 24 & 24 & 28 & 32 & 32 & 31 \\
\hline Словакия & 18 & 18 & 17 & 19 & 19 & 18 \\
\hline Словения & 19 & 19 & 20 & 20 & 20 & 21 \\
\hline США & 21 & 22 & 18 & 27 & 28 & 20 \\
\hline Турция & 23 & 23 & 19 & 28 & 28 & 19 \\
\hline Финляндия & 19 & 19 & 17 & 20 & 20 & 20 \\
\hline Франция & 23 & 23 & 23 & 25 & 25 & 26 \\
\hline Чешская Республика & 21 & 21 & 15 & 22 & 22 & 19 \\
\hline Чили & 30 & 29 & 31 & 31 & 30 & 31 \\
\hline Швейцария & $\ldots$ & $\ldots$ & $\ldots$ & $\ldots$ & $\ldots$ & $\ldots$ \\
\hline Швеция & 18 & 18 & 16 & 20 & 20 & 21 \\
\hline Эстония & 17 & 17 & 16 & 15 & 15 & 13 \\
\hline Япония & 27 & 27 & 29 & 32 & 32 & 33 \\
\hline
\end{tabular}

* По зарубежным странам - данные за 2014 г. По России - данные на начало 2015/2016 учебного года по общеобразовательным организациям без вечерних (сменных) общеобразовательных организаций; отдельных общеобразовательных организаций и классов для обучающихся с ограниченными возможностями здоровья; специальных учебно-воспитательных учреждений для обучающихся с девиантным (общественно опасным) поведением; санаторных образовательных организаций для обучающихся, нуждающихся в длительном лечении; организаций для обучающихся, нуждающихся в психолого-педагогической и медико-социальной помощи.

** Включая зависимые от государства частные организации. 


\section{МЕТОДОЛОГИЧЕСКИЕ КОММЕНТАРИИ}

Статистические данные по зарубежным странам базируются на источниках: Education at a Glance 2016. OECD Indicators (http://www.oecd.org/edu/education-at-a-glance-19991487. htm); OECD Online Education Database (Organisation for Economic Co-operation and Development; http://stats.oecd.org/).
При межстрановых сопоставлениях российская система образования представлена в соответствии со ступенями образования Международной стандартной классификации образования (МСКО 2011), применяемой для получения сопоставимых данных о ключевых параметрах систем образования различных стран.

\section{Соотношение ступеней образования в Международной стандартной классификации образования и российской системе образования}

\section{МСКО О - ОБРАЗОВАНИЕ ДЕТЕЙ МЛАДШЕГО ВОЗРАСТА} (ISCED 0 - Early childhood education)

Программы имеют образовательную направленность и, как правило, разрабатываются на основе комплексного подхода для поддержания познавательного, физического, социального и эмоционального развития и для знакомства детей младшего возраста с организованным обучением в отрыве от семейной обстановки; рассчитаны на детей, не достигших возраста для поступления на уровень МСКО 1.

Выделяются программы развития детей младшего возраста (МСК0 010) и программы дошкольного образования (МСКО 020). Первые имеют

образовательный компонент, ориентированный на детей в возрасте 0-2 лет, вторые разработаны для детей от 3 лет и до поступления на уровень МСКО 1.

Программы обычно реализуются на базе учреждения/организации для группы детей. Продолжительность программ составляет не менее 2 часов в день в течение 100 дней в году

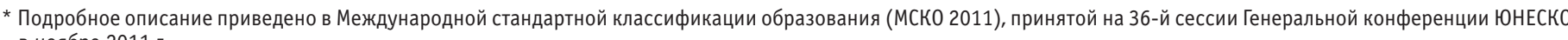
в ноябре 2011 г.
}

Дошкольное образование - программы дошкольного образования (включая присмотр и уход за детьми без реализации образовательных программ дошкольного образования) 


\section{МСКО 1 - НАЧАЛЬНОЕ ОБРАЗОВАНИЕ (ISCED 1 - Primary education)}

Программы, как правило, направлены на обучение основным навыкам чтения, письма и математики (т.е. грамотность и счет) и на создание серьезной основы для изучения и понимания основных областей знаний, развития личности и социального развития, подготовки к обучению на уровне МСКО 2. Обучение направлено на получение образования на основном уровне сложности с минимальной специализацией, если таковая имеется. Требование к поступлению - достижение типичного или установленного законом возраста (в большинстве стран - не менее 5 лет и не более 7 лет). Продолжительность обучения составляет 6 лет, однако может варьировать от 4 до 7 лет.

Обычно учебный процесс обеспечивает один учитель

\section{МСКО 2 - ПЕРВЫЙ ЭТАП СРЕДНЕГО ОБРАЗОВАНИЯ (ISCED 2 - Lower secondary education)}

Соответствующие программы, как правило, основываются на учебных результатах предыдущего уровня. Обычно цель образования заключается в том, чтобы заложить основы для обучения в течение всей жизни и развития личности. На уровне МСКО 2 особое значение придается предметноориентированному обучению.

Этот уровень требует завершения уровня МСКО 1 или способности осваивать содержание уровня путем сочетания уже полученного образования с жизненным и трудовым опытом.

Обучение на уровне МСКО 2 заканчивается спустя 8-11 лет с начала обучения на уровне МСКО 1, и его совокупная продолжительность составляет, как правило, 9 лет

\section{Основное общее образование}

\section{Начальное общее образование}


(продолжение)

\section{МСКО 3 - ВТОРОЙ ЭТАП СРЕДНЕГО ОБРАЗОВАНИЯ}

\section{(ISCED 3 - Upper secondary education)}

Программы уровня, как правило, рассчитаны на завершение среднего образования, обеспечивающего подготовку к третичному образованию или обучению навыкам, позволяющим найти работу, либо и то и другое.

Уровень МСКО 3 представлен программами общего образования и профессионально-технического образования.

Обучение на втором этапе среднего образования обычно составляет 11-13 лет с начала обучения на уровне МСК0 1. Требуется завершение первого этапа среднего образования (уровень МСКО 2) или способность изучать программы уровня МСКО 3 путем сочетания как уже полученного образования, так и жизненного и трудового опыта

\section{МСКО 4 - ПОСЛЕСРЕДНЕЕ НЕТРЕТИЧНОЕ ОБРАЗОВАНИЕ} (ISCED 4 - Post-secondary non-tertiary education)

Послесреднее нетретичное образование направлено на приобретение учебного опыта обучающимися на базе среднего образования и на подготовку к выходу на рынок труда, а также на получение третичного образования. Оно обеспечивает индивидуальное приобретение знаний, навыков и компетенций на уровне ниже третичного. Соответствующие программы, как правило, разрабатываются для обучения лиц, завершивших обучение на уровне МСКО 3 и получивших квалификации, обеспечивающие доступ к третичному образованию или трудоустройство, если квалификация уровня МСКО 3 не дает такого доступа.

Программы уровня МСКО 4 не рассматриваются как третичное образование и, как правило, имеют профессионально-техническую направленность или ориентированы непосредственно на рынок труда.

Для поступления на программы данного уровня требуется завершение программ уровня МСКО 3.

Программы уровня МСКО 4 несколько сложнее, чем программы уровня МСКО 3, но их содержание более специализировано или детализировано. Вместе с тем эти программы менее сложные по сравнению с программами третичного уровня.
Среднее общее образование; среднее профессиональное образование программы подготовки квалифицированных рабочих, служащих на базе основного общего образования (как с получением среднего общего образования, так и без получения среднего общего образования); профессиональное обучение - программы профессиональной подготовки по профессиям рабочих, должностям служащих (для лиц, не имеющих среднего общего образования)

Среднее профессиональное образование - программы подготовки квалифицированных рабочих, служащих на базе среднего общего образования; профессиональное обучение - программы профессиональной подготовки по профессиям рабочих, должностям служащих; программы переподготовки рабочих, служащих; программы повышения квалификации рабочих, служащих (для лиц, имеющих образование не ниже среднего общего) 


\section{УРОВЕНЬ МСКО 5 - КОРОТКИЙ ЦИКЛ ТРЕТИЧНОГО ОБРАЗОВАНИЯ} (ISCED 5 - Short-cycle tertiary education)

Программы уровня предназначены для предоставления участникам профессиональных знаний и развития профессиональных навыков и компетенций. Как правило, они связаны с практикой, профессиональной ориентацией и подготовкой обучающихся к выходу на рынок труда,

но также открывают путь к другим программам третичного образования. Академические программы третичного образования, которые ниже программ бакалавриата или равнозначны им, также относятся к уровню МСКО 5. Для поступления на программы данного уровня требуется успешное завершение уровней МСКО 3 и 4, обеспечивающих доступ к третичному образованию.

Минимальная продолжительность данного уровня - 2 года, но не более 3 лет

\section{МСКО 6 - БАКАЛАВРИАТ ИЛИ ЕГО ЭКВИВАЛЕНТ}

(ISCED 6 - Bachelor's or equivalent level)

Программы уровня часто предназначены для получения участниками академических и/или профессиональных знаний, навыков и компетенций, обеспечивающих получение ими первой степени или равнозначной квалификации. Программы этого уровня, как правило, имеют теоретическую основу, но могут включать практические компоненты и характеризуются высоким уровнем исследований и/или имеют лучшую профессиональную практику.

Обычно для поступления на программы этого уровня требуется успешное завершение программ уровней МСКО 3 или 4, обеспечивающих доступ к третичному образованию.

Продолжительность программ составляет от 3 до 4 лет очного обучения. Программы этого уровня, как правило, ведут к присвоению первых степеней и равнозначных квалификаций третичного образования
Среднее профессиональное образование - программы подготовки специалистов среднего звена (включая программы на базе основного общего образования)

\section{Высшее образование - программы бакалавриата}


(окончание)

\section{МСКО 7 - МАГИСТРАТУРА ИЛИ ЕЕ ЭКВИВАЛЕНТ}

(ISCED 7 - Master's or equivalent level)

Программы уровня часто предназначены для предоставления участникам расширенных академических и/или профессиональных знаний, развития навыков и компетенций, обеспечивающих получение второй степени третичного образования или равнозначной квалификации. Программы этого уровня могут иметь существенную исследовательскую составляющую, но еще не ведут к присвоению квалификации доктора наук (PhD). Для поступления обычно требуется успешное завершение программ уровней МсКо 6 или 7

\section{МСКО 8 - ДОКТОРАНТУРА ИЛИ ЕЕ ЭКВИВАЛЕНТ}

\section{(ISCED 8 - Doctoral or equivalent level)}

Программы уровня разработаны для обеспечения продвинутой

квалификации в области научных исследований. Они рассчитаны

на проведение углубленного самостоятельного исследования и завершаются после представления и защиты диссертации или равнозначной письменной работы, заслуживающей публикации и представляющей значительный вклад в расширение знаний в соответствующей области.

Поступление на такие программы обычно требует успешного завершения программ МСКО 7.

Продолжительность составляет не менее 3 лет в эквиваленте очного обучения при совокупной продолжительности очного обучения по программам третичного образования не менее 7 лет

\section{Высшее образование - программы специалитета, программы} магистратуры

Высшее образование - программы подготовки научно-педагогических кадров в аспирантуре (адъюнктуре), программы ординатуры, ассистентуры-стажировки 


\title{
ИНДИКАТОРЫ ОБРАЗОВАНИЯ: 2017
}

Статистический сборник

\author{
Редактор М. Ю. Соколова
}

Художник П.А. Шелегеда

Компьютерный макет В.Г. Паршина

Подписано в печать 05.04.2017. Формат 60×90 1/16. Бумага офсетная.

Уч.-изд. л. 14.3. Печ. л. 20. Тираж 300 экз. Заказ № 999.

Национальный исследовательский университет

«Высшая школа экономики»

Отпечатано в 000 «Типография ИРМ-1»

140000, Московская область, г. Люберцы, Инициативная ул., 38

По вопросам приобретения сборника обращаться

в Институт статистических исследований

и экономики знаний НИУ ВШЭ:

101000, Москва, Мясницкая ул., 20

Тел.: +7 (495) 621-28-73

http://issek.hse.ru, E-mail: issek@hse.ru 